\author{
PROGRAMA DE DOCTORADO EN \\ PATRIMONIO CULTURAL Y NATURAL. \\ HISTORIA. ARTE Y TERRITORIO
}

TESIS DOCTORAL:

\title{
LAS ARTES PLÁSTICAS DEL SIGLO XVI EN LA ACTUAL PROVINCIA DE SORIA Y SU RELACIÓN CON EL GRABADO
}

\author{
Presentada por \\ VIRGINIA PÉREZ DE GRACIA RODRÍGUEZ
}

Para optar al grado de

Doctor/a por la Universidad de Valladolid

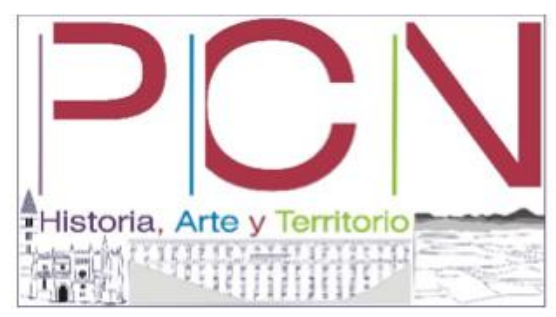

\section{Dirigida por:}

MARÍA JosÉ REDONDO CANTERA 


\section{ÍNDICE}

1. ELECCIÓN DEL TEMA.

3. REUNIÓN DEL CORPUS DE ESTUDIO Y MÉTODO DE TRABAJO .

4. EL MARCO ESPACIO-TEMPORAL

4.1. EL MECENAZGO ARTÍSTICO EN LAS DIÓCESIS QUE FORMARON LA ACTUAL

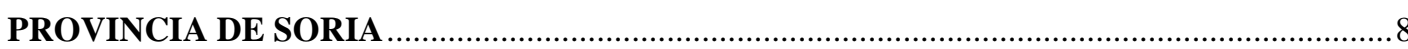

4.2. EL SIGLO XVI Y EL COMIENZO DEL RENACIMIENTO EN SORIA ............................15

5. LA IMPRENTA, LOS GRABADOS Y LOS ARTISTAS

5.1. EL NACIMIENTO DE LA IMPRENTA Y SU CONTRIBUCIÓN A LA DIFUSIÓN DE

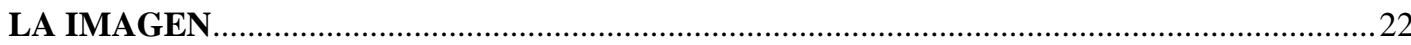

5.2 PRINCIPALES IMPRENTAS EN EUROPA Y SU PRODUCCIÓN DE GRABADOS .......24

5.3. EL GRABADO EN ESPAÑA. PRINCIPALES IMPRENTAS ESPAÑOLAS. ...................29

5.4. GRABADORES MÁS UTILIZADOS EN LA PROVINCIA DE SORIA. ..............................36

5.5. ACCESO DE LOS ARTISTAS A LOS GRABADOS..........................................................5

5.6. PRINCIPALES ARTISTAS ACTIVOS EN TIERRAS SORIANAS QUE UTILIZARON GRABADOS

6. RELACIÓN DE OBRAS DE PRODUCCIÓN LOCAL O NACIONAL ……………………….......73

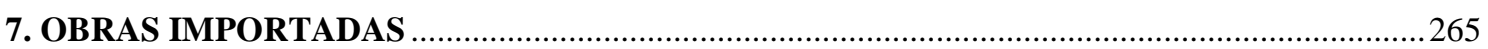

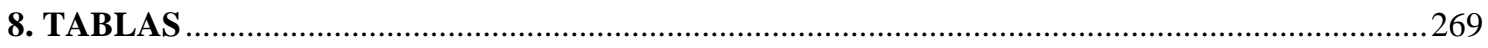

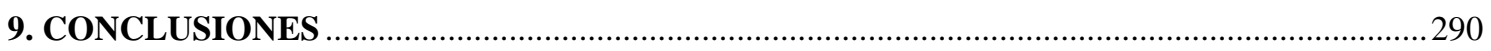

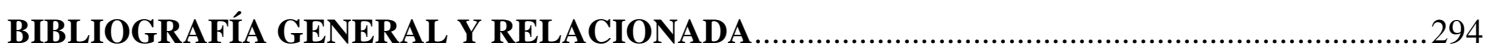

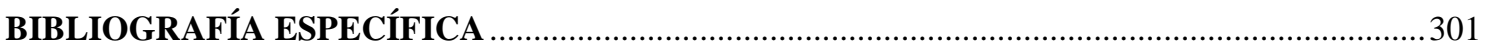

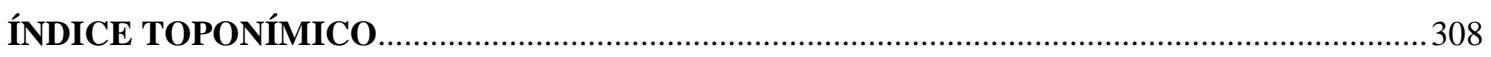

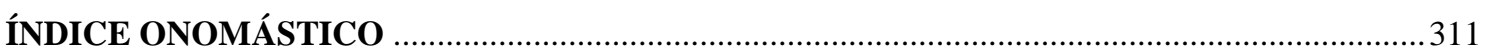




\section{ELECCIÓN DEL TEMA}

Mi interés por el objeto de estudio de esta Tesis Doctoral deriva del escaso desarrollo del conocimiento sobre el periodo artístico del Renacimiento en el territorio que abarca la actual provincia de Soria, en comparación con otros estilos artísticos como el Románico o el Gótico. Asimismo, son también poco numerosas las investigaciones sobre la influencia foránea en el patrimonio artístico soriano de dicha época.

Otra razón es que la mayoría de estas manifestaciones artísticas son pictóricas, arte por el cual siento predilección, además de la curiosidad que despierta el hecho de modelos tan lejanos de la provincia, como puedan ser Italia o Alemania, hayan podido influir de alguna manera en dichas obras. Mi Tesis se ha centrado en el influjo de grabados extranjeros en el arte soriano durante el siglo XVI.

La provincia de Soria se encontraba durante el Renacimiento dividida principalmente en cuatro diócesis: Osma, Tarazona, Sigüenza y Calahorra. Debido a ello este territorio recibió influencias diversas, procedentes de ciertos focos con capacidad de irradiación artística, dependiendo de cuál de dichas diócesis se encontrase más cerca. Por lo tanto, otra razón para estudiar el tema sería la heterogeneidad de las influencias en las manifestaciones artísticas sorianas realizadas durante el siglo XVI.

La dispersión espacial de muchas de estas obras de arte y -con gran frecuenciasu mal estado, debido al abandono, dificultan un estudio sistemático de dichas pinturas y esculturas. Gran parte de ellas apenas era conocida o han sido ignoradas por encontrarse en lugares poco visibles o recónditos, como las sacristías de algunas iglesias, lo que constituye otro motivo para su estudio.

$\mathrm{Su}$ calidad es muy variable y oscila desde obras muy originales, avanzadas para su época, a otras mediocres que se limitan a la mala imitación de un estilo por parte de otros pintores o escultores de menor formación o capacidad creativa.

Por último, es interesante identificar el modo en que los diversos artistas traspasaron el grabado a la pintura o la escultura, así como comprobar cuáles fueron las estampas más utilizados e intentar explicar el motivo de ello. 


\section{ESTADO DE LA CUESTIÓN}

El origen del interés por las estampas y su influjo en el arte español se encuentra ya en el siglo XIX en la obra de Ceán Bermúdez ${ }^{1}$, aunque este estudioso se manifestó críticamente sobre ello, pues denostó este uso de las estampas, ya que lo consideraba como un plagio que disminuía la calidad artística de las obras.

No fue hasta el último cuarto del siglo XX cuando el estudio del grabado empezó a interesar en la historiografía artística española.

Como tema de Tesis Doctoral fue pionera la de García Vega, El grabado del libro español (siglos XV-XVI-XVII), defendida en 1982 y publicada en 1984, que se realizó sobre los fondos de las bibliotecas históricas de la ciudad de Valladolid. En ella se reunió un considerable volumen de estampas que fueron adscritas a diversas imprentas que habían surgido en España desde el siglo XVI².

De amplio alcance nacional fue El grabado en España: siglos XV al XVIII, cuyo autor, Carrete Parrondo ${ }^{3}$ realizó el primer estudio general y exhaustivo de las imprentas surgidas en España a partir del Renacimiento. Además de ser una completa obra recopilatoria sobre la historia de las estampas en España, en ella queda claramente resaltada la importancia de los impresores foráneos, sobre todo alemanes, italianos o franceses, para el desarrollo de esta actividad en España.

También fue de interés y utilidad para el estudio de las estampas la compilación de La Real Colección de Estampas de San Lorenzo del Escorial (1992) ${ }^{4}$, realizada por González de Zárate, con prólogo de Santiago Sebastián. Además de publican este amplio repertorio de grabados, en la introducción se examinó la afición del rey Felipe II a las estampas, así como su relación con Arias Montano (1527-1598) y con algunos de los impresores más importantes de la época.

\footnotetext{
${ }^{1}$ CEÁN BERMÚDEZ, J. A., Colección lithográphica de cuadros del Rey de España el Señor Don Fernando VII: obra dedicada a S: M. lithographiada por hábiles artistas bajo la dirección de D. José de Madrazo, Madrid, 1826, I, lám. 32.

${ }^{2}$ GARCÍA VEGA, B., El grabado del libro español (siglos XV-XVI-XVII), 2 vols. Valladolid, Instituto Simancas, 1982.

${ }^{3}$ CARRETE PARRONDO, J., El grabado en España: siglos XV al XVII, col. Summa Artis, t. XXXI, Madrid, Espasa Calpe, 1987.

${ }^{4}$ VV. AA., La Real Colección de Estampas de San Lorenzo del Escorial, 10 vols., Vitoria-Gasteiz, Instituto de Estudios Ephialte, 1992-1996.
} 
En El largo siglo XVI. Los usos artísticos del Renacimiento español (1989) Fernando Marías se ocupó de algunos artistas en relación con este tema e hizo hincapié en el uso más o menos explícito de los grabados ${ }^{5}$.

Como modelo de estudio en el que se abordó la influencia de las estampas en un período y una zona determinada, destacó la obra de Benito Navarrete La pintura andaluza del siglo XVII y sus fuentes grabadas ${ }^{6}$, publicada en 1998. El autor estudió tanto la influencia concreta de algunas estampas en pinturas del Barroco andaluz, como en ciertos textos de eruditos de la época, que indicaban ya la llegada, el conocimiento y el uso de este tipo de obras. Para ello se basó sobre todo en el seguimiento de las estampas de Alberto Durero (1471-1528), Cornelis Cort (1533-1578), Hendrick Goltzius (1558-1617) y Bartholomeus Spranger (1546-1611), del siglo XVI; y de las realizadas por Abraham Bloemaert (1566-1651), Rubens (1577-1640) y Van Dyck (1599-1641), durante el siglo XVII. En Andalucía influyeron más los grabadores alemanes y flamencos que los italianos. Cabe señalar que muchas de estas estampas eran copias fraudulentas de estampas originales de los artistas más famosos ${ }^{7}$.

Otras aportaciones destacadas para el estudio de la influencia del grabado en el arte español del Renacimiento son dos artículos de Ana Ávila: "Influencia de la estampa en la obra de Juan Soreda", , publicado en1981, e "Influencia de Rafael en la pintura y escultura españolas del siglo XVI a través de estampas", , aparecido en 1984. En ambos se hace un análisis exhaustivo de la influencia de estos grabados en muchas obras del Renacimiento español, incluyendo algunas sorianas, como son las pinturas de la Concatedral de San Pedro en Soria o las del Monasterio de Santa María de Huerta, ambas obras de Juan Soreda (ca. 1506-1537). Respecto a Soreda y en referencia, aunque sea vagamente, al influjo de estas estampas, se encuentra el libro Juan Soreda y la pintura del Renacimiento en Sigüenza ${ }^{10}$, de Francisco Ramos Gómez, del año 2004. Se hace referencia en él a la influencia de las estampas en obras, tanto de Soreda como de

\footnotetext{
5 MARÍAS FRANCO, F., El largo siglo XVI. Los usos artísticos del Renacimiento español, Madrid, Taurus, 1989, pp. 217 y 313.

6 NAVARRETE PRIETO, B., La pintura andaluza del siglo XVII y sus fuentes grabadas, Madrid, Fundación de Apoyo a la Historia del Arte Hispánico, 1998.

${ }^{7}$ ID., op. cit., 1998, p. 4.

8 ÁVILA PADRÓN, A., "Influencia de la estampa en la obra de Juan Soreda", Boletín del Museo e Instituto Camón Aznar, no 6 y 7, 1981, pp. 81-93.

9 ID., "Influencia de Rafael en la pintura y escultura españolas del siglo XVI a través de estampas", Archivo Español de Arte, t. 57, no 225, 1984, pp. 58-88.

${ }^{10}$ RAMOS GÓMEZ, F. J., Juan Soreda y la pintura del Renacimiento en Sigüenza, Guadalajara, Diputación Provincial de Guadalajara, 2004.
} 
otros pintores menores que trabajaron para la diócesis seguntina, como, por ejemplo, Diego de Madrid (doc. 1532-1571).

Aunque Soreda ha sido el autor sobre el que más se ha escrito al respecto, también son de gran utilidad otros estudios sobre ciertos artistas de la época activos en tierras sorianas, como los abordados, por ejemplo, en varios artículos de Collar de Cáceres. En "Diego de Urbina (1516-1595). Pintura y mecenazgo antes de 1570", publicado en 2010, se analizaron algunas obras de este pintor entre las que destaca, por su interés para este tema de las estampas, el Velo de Pasión de la Catedral de El Burgo de Osma, debido a su evidente influencia de grabados de origen italiano. De Collar de Cáceres también es de resaltar "El tríptico de Leoni y otras obras de Gregorio Martínez"12, de 2014, en el que igualmente se muestra la influencia de las estampas en la obra de este pintor vallisoletano.

El retablo de San Miguel de Ágreda (Soria). Historia y restauración ${ }^{13}$, publicado en 1997, es una obra colectiva que analiza las diversas escenas que lo componen y sus fuentes grabadas, además de contener datos de interés sobre Pedro de Aponte (ca. 1507-1530) y el doctor García Fernández de Carrascón (ca. 1470-1533). Sobre Pedro de Aponte también trata La pintura aragonesa del Renacimiento en el contexto hispánico europeo, de Carmen Morte García $^{14}$, quien se ha interesado especialmente en las influencias foráneas sobre los pintores aragoneses desde los albores del Renacimiento hasta su final. En referencia a la relevancia de la localidad de Ágreda, el libro de Verónica Cardona, La pintura gótica en Ágreda (siglo XV), aparecido en 2006, que trata fundamentalmente de obras del siglo XV, hace también referencia a algunas obras que datan de principios del siglo XVI, para las que se hizo uso de estampas. Ejemplos de ello son el Retablo de San Lorenzo, en la iglesia de Nuestra Señora de los Milagros (Ágreda), o la predela con escenas de la Vida de la Virgen, de la iglesia de Nuestra Señora de la Virgen de la Peña (Ágreda) ${ }^{15}$.

\footnotetext{
${ }^{11}$ COLLAR DE CÁCERES, F., "Diego de Urbina (1516-1595). Pintura y mecenazgo antes de 1570", Anuario del Departamento de Historia y Teoría del Arte, vol. 22, 2010, pp. 103-136.

${ }^{12}$ ID., "El tríptico de Leoni y otras obras de Gregorio Martínez", Goya. Revista de arte, n 348, 2014, pp. 183-207.

${ }^{13}$ VV. AA., El retablo de San Miguel de Ágreda (Soria). Historia y restauración, Valladolid, Caja Salamanca y Soria, 1997.

${ }^{14}$ MORTE GARCÍA, C., "La pintura aragonesa del Renacimiento en el contexto hispánico europeo", en III Coloquio de Arte Aragonés (El arte aragonés y sus relaciones con el hispánico e internacional), vol. 2, 1985, pp. 277-302.

${ }^{15}$ CARDONA JIMÉNEZ, V., La pintura gótica en Ágreda (siglo XV), Valladolid, Junta de Castilla y León, 2006.
} 
Aunque con menos frecuencia que en la pintura, las estampas también influyeron en muchas esculturas, ya fueran relieves o de bulto redondo. Es más difícil identificarlas, pues para pasar una estampa a la escultura se llevan a cabo muchos cambios en cuanto al volumen de las figuras y al espacio. En el caso de los retablos, el escultor tenía que ceñirse a un espacio en muchas ocasiones reducido, lo que le obligaba a adoptar formas más simples para sus figuras. Por otro lado, en los obradores de imaginería con frecuencia se utilizaban como modelos gráficos estampas o dibujos preparatorios antes de ejecutar una talla o relieve ${ }^{16}$. Dentro de este campo destaca la escultura de Juan de Juni (1506-1577), que se inspiró a menudo en grabados italianos, pero los adaptó a su estilo particular. El artículo de Arias Martínez, "A propósito de Juan de Juni y las estampas de Baccio Bandinelli"17 analiza esta influencia en varias obras del escultor, en particular en el ámbito leonés.

\footnotetext{
${ }^{16}$ ECHEVERRÍA GOÑI, P. L. y PAYO HERNANZ, R., “Aportaciones al conocimiento de la escultura castellana en los años centrales del siglo XVI. Juan de Carranza I y el retablo mayor de la iglesia de Santa María la Mayor de Soria”, Anales de Historia del Arte, vol. 26, 2016, pp. 73-101.

${ }^{17}$ ARIAS MARTÍNEZ, M., "A propósito de Juan de Juni y las estampas de Baccio Bandinelli”, Boletín de la Real Academia de Bellas Artes de la Purísima Concepción de Valladolid, nº 48, 2013, pp. 27-34.
} 


\section{REUNIÓN DEL CORPUS DE ESTUDIO Y MÉTODO DE TRABAJO}

A partir del conocimiento en detalle de las obras de escultura y pintura del Renacimiento que se encuentran en tierras sorianas, en esta Tesis doctoral se ha reunido un nutrido conjunto de piezas, unos ochenta ejemplos, en los que se puede identificar la influencia de las estampas foráneas sobre el arte del siglo XVI.

A partir de la creación de dos bases de datos, creadas con el programa Access, de grabados, por un lado, y de pinturas y esculturas, por otro, he realizado un estudio comparativo formal entre las obras y las estampas más utilizadas durante la época. Esto me ha facilitado el estudio de las semejanzas y también de las diferencias existentes entre dichos ejemplos. Mis análisis se han basado no sólo en las figuras principales o en la composición, sino también en detalles, como el emplazamiento arquitectónico de la escena, el paisaje, las vestimentas o algunos objetos decorativos. Además de ello, he manejado otros recursos para realizar mi investigación.

En primer lugar, la consulta bibliográfica, centrada en estudios sobre grabados en general, obras más concretas sobre el tema de la influencia de las estampas en la provincia soriana, así como catálogos sobre conjuntos de grabados, como podría ser $L a$ Real Colección de Estampas de San Lorenzo del Escorial o los repertorios reunidos en diversos volúmenes publicados por Bartsch.

En segundo lugar, he acudido con frecuencia a las bibliotecas, entre las que destaca la Biblioteca Nacional, en cuya "Sala Goya" y en la Sección de Bellas Artes se encuentran numerosos catálogos de gran variedad de grabados. Aunque en su mayoría se trata de estampas españolas, también encontramos un importante fondo de imágenes alemanas, flamencas, italianas, francesas, etc. En cuanto a la temática responden a diversas temáticas: religión, mitología, historia, vistas de ciudades y paisajes, arquitecturas, retratos, etc. También en la sección local de la Biblioteca Pública de Soria se han consultado libros específicos sobre algunas de las parroquias objeto de investigación de esta Tesis.

Otro recurso utilizado han sido las fuentes documentales que se conservan en los archivos sorianos. En el Archivo Diocesano de El Burgo de Osma, he realizado investigaciones sobre las obras o la vida de algunos de los artistas que realizaron las piezas aquí estudiadas, a través de los libros parroquiales y de fábrica. He visitado también el Archivo Histórico Provincial de Soria, en particular en la Sección de los 
Protocolos Notariales, para investigar sobre encargos, pagos o almonedas en los cuales hubieran podido participar dichos artistas

Por último, se encuentra como herramienta de gran utilidad la webgrafía. A través de Internet es posible consultar algunos repertorios de grabados, como por ejemplo los de la Biblioteca Nacional de Madrid, del British Museum de Londres o del Metropolitan Museum de Nueva York. 


\section{EL MARCO ESPACIO-TEMPORAL}

Hasta noviembre de 1955, la diócesis de Osma-Soria compartió la titularidad del territorio actual de la provincia de Soria con las de Calahorra-La Calzada, Tarazona y Sigüenza (fig. 1). A su vez estas tierras recibían influencias diversas procedentes del Norte (Calahorra y Burgos), del Este (Aragón y Cataluña), del Oeste (Valladolid y diócesis de Osma) o del Sur (Sigüenza, Segovia y Madrid). En la comarca de Ágreda, por ejemplo, se hacía más evidente la presencia de lo aragonés y en las tierras de Yanguas, la riojana. Se trataba por lo tanto de una encrucijada de diversas influencias, a veces de claras consecuencias artísticas.

A su vez, la propia diócesis oxomense abarcaba zonas de las actuales provincias de Burgos y Soria ${ }^{18}$.

\subsection{EL MECENAZGO ARTÍSTICO EN LAS DIÓCESIS QUE FORMARON LA ACTUAL PROVINCIA DE SORIA}

Los obispos tuvieron un importante papel en la promoción de la cultura de sus respectivas diócesis. Durante el siglo XVI muchos destacaron por ser importantes humanistas y algunos de ellos fueron además auténticos mecenas de las artes.

\section{Diócesis de Osma}

El siglo XVI fue, desde el punto de vista cultural, el período más brillante de la diócesis de Osma, ya que se produjo una verdadera eclosión de la creatividad en las Letras y las Artes.

Su cercanía a las tierras de Burgos y Valladolid motivó que recibiera un mayor influjo de dichas zonas y que muchos artistas como, por ejemplo Juan de Juni, fueran llamados para realizar obras en la ciudad de El Burgo de Osma. Esta alcanzó durante el Renacimiento un gran esplendor cultural y artístico, gracias a la obra de algunos obispos humanistas como don Pedro Álvarez de Acosta.

\footnotetext{
${ }^{18}$ ARRANZ ARRANZ, J., El Renacimiento en la diócesis de Osma-Soria, Burgo de Osma (Soria), Obispado de Osma-Soria, 1979, p. 17.
} 


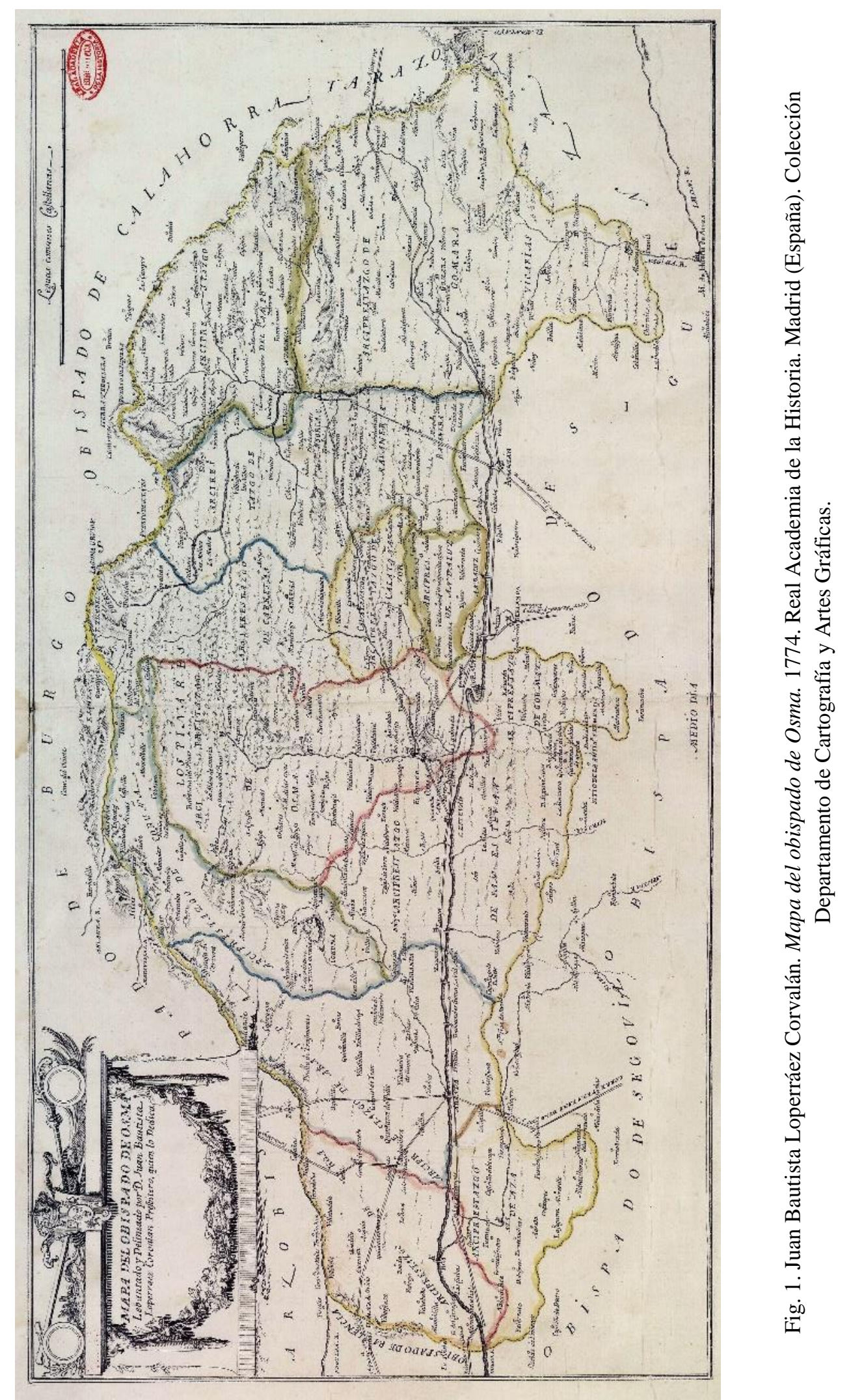




\section{Obispos destacados en la diócesis oxomense}

Obispo de Osma entre los años 1539 y 1563, Acosta fue el verdadero introductor del Renacimiento en la diócesis oxomense ${ }^{19}$. En 1550 creó, con su propio patrimonio, el colegio universitario de Santa Catalina en El Burgo de Osma ${ }^{20}$. Allí, estudiantes sin recursos podían adquirir cultura y formación universitaria. Iniciativa suya fue también la creación de una imprenta dentro de la sede episcopal. La obra artística más representativa de su mandato fue el retablo mayor de la Catedral de Burgo de Osma, obra de Juan de Juni ${ }^{21}$ y Juan Picardo ${ }^{22}$.

Tras Pedro Álvarez de Acosta llegó al obispado Honorato Juan (1564-1566), quien fue preceptor del príncipe Carlos, el hijo de Felipe II $^{23}$. De formación humanista y activo reformista de Trento, durante su mandato se llevaron a cabo obras de importancia, como el retablo de la iglesia de Peñalba de San Esteban, realizado por

${ }^{19}$ NÚNEEZ MARQUÉS, V., Guía de la catedral de Burgo de Osma y breve historia del obispado de Osma, Madrid, Gráficas Onofre Alonso Tetuán, 1949, pp. 143-149.

${ }^{20}$ LOPERRAEZ CORVALÁN, J., Descripción histórica del obispado de Osma, Madrid, Imprenta Real, 1788, pp. 418-419; NÚÑEZ MARQUÉS, V., op. cit., 1949, pp. 149-156; GARCÍA CHICO, E., "Artistas que trabajaron en la catedral de Burgo de Osma (siglo XVI)", Celtiberia, no 11, 1956, pp. 7-18; "Los grandes imagineros de Castilla: Juan Picardo", Boletín del Seminario de Estudios de Arte y Arqueología. $B S A A$, t. XXIII, 1957, pp. 41-53; ALCOLEA BLANCH, S., op. cit., 1964, p. 160; WETHEY, H. A., "Escaleras del primer Renacimiento español", Archivo Español de Arte, t. XXXVII, no 148, 1964, pp. 295-306; MARÍAS FRANCO, F., "La arquitectura del siglo XVI en la provincia de Soria", Celtiberia, $\mathrm{n}^{\circ}$ 50, 1975, pp. 175-206; BARTOLOMÉ MARTÍNEZ, B., "Retablo Histórico de la Diócesis de Osma", en Las Edades del Hombre. La ciudad de seis pisos, Las Edades del Hombre, s. 1., 1997, p. 51; MUNTADA TORRELLAS, A., "Claves para una lectura iconográfica del retablo mayor de la S. I. Catedral del Burgo de Osma", en Llena de Gracia. Iconografía de la Inmaculada en la Diócesis de Osma-Soria, Editorial Ochoa, El Burgo de Osma (Soria), 2005, pp. 76-119; ID., "Abraham dormido" y "Santa Catalina de Alejandría, en Paisaje interior. Las Edades del Hombre, Valladolid, Fundación Las Edades del Hombre, 2009, nº 22 y 116, pp. 259-261 y 442-445; ARIAS MARTÍNEZ, M. y HERNÁNDEZ REDONDO, J. I., Juan Picardo (1506 - c. 1576), Medina del Campo, Fundación Museo de las Ferias, 2016, pp. 3-12; CAPILLA DE BLAS, J. M., “Abraham dormido", en Reconciliare. Las Edades del Hombre, Valladolid, Fundación Edades del Hombre, 2017, n 27, p. 200.

${ }^{21}$ GARCÍA CHICO, E., Juan de Juni, Valladolid, Ediciones de la Escuela de Artes y Oficios Artísticos de Valladolid, 1949; MARTIN GONZÁLEZ, J. J., Juan de Juni, Instituto Diego de Velázquez del Consejo Superior de Investigaciones Científicas, Madrid, 1954; ID., Juan de Juni. Vida y obra, Madrid, Ministerio de Cultura, 1974; Juan de Juni y su época, exposición conmemorativa del IV centenario de la muerte de Juan de Juni, Valladolid-Madrid, Ministerio de Educación y Ciencia, 1977; ORICHETA GARCÍA, A., "Grabados alemanes y flamencos: los modelos de Juan de Juni y su escuela en León", Academia. Boletín de la Real Academia de Bellas Artes de San Fernando, 1996, nº 83, pp. 316-358; ARIAS MARTÍNEZ, M., "Revisando a Juan de Juni en San Marcos de León. Fuentes y modelos", Boletín de la Real Academia de la Purísima Concepción, $\mathrm{n}^{\circ}$ 43, 2008, pp. 9-34; FERNÁNDEZ DEL HOYO, M. A., "El escultor Juan de Juni", en Conocer Valladolid: II curso de patrimonio cultural (coord. DELIBES DE CASTRO, G.,), 2009, 109-120; MARTÍN GONZÁLEZ, J. J., "Retablo mayor”, en Paisaje interior..., $\mathrm{n}^{\circ}$ 154, pp. 268-271; FERNÁNDEZ DEL HOYO, M. A., Juan de Juni, escultor, Valladolid, Universidad de Valladolid, 2012; ARIAS MARTÍNEZ, M., “A propósito de Juan de Juni...”, pp. 27-34.

${ }^{22}$ ARRANZ ARRANZ, J., La escultura romanista..., p. 24. FRÍAS BALSA, J. V., "Nuevos datos sobre el escultor Juan Picardo, autor de la Magdalena del Trascoro de la Catedral de Osma (Soria)", Celtiberia, año n ${ }^{\circ}$ 54, no 98,2004 , pp. 267-284;

${ }^{23}$ NÚÑ̃Z MARQUÉS, V., op. cit., p. 157; BARTOLOMÉ MARTÍNEZ, B., op. cit., p. 51. 
Francisco de Logroño ${ }^{24}$. Su biblioteca alcanzó gran fama por la relevancia y variedad de manuscritos y libros impresos ${ }^{25}$. Lamentablemente una parte de la biblioteca desapareció tras su muerte, en 1566, vendiéndose en la almoneda. Afortunadamente, algunos de los que sobrevivieron se guardan en la biblioteca del Real Monasterio de San Lorenzo del Escorial; otros fueron adquiridos por importantes personajes de la época, como Diego Hurtado de Mendoza, quien luego los legaría a Felipe II. Aunque no hay constancia de que el obispo poseyera libros de grabados o estampas, sí que le interesaban los tratados de Arquitectura. Su biblioteca contaba con libros de Vitrubio, Durero (De Condensis Urbis) o Alberti. De hecho, regaló a Felipe II un ejemplar de los tratados de Geometría y Dibujo de Durero ${ }^{26}$. Nombrado obispo en 1564 , ya casi al final de su vida, se trasladó a Burgo de Osma con toda su biblioteca ${ }^{27}$.

El siguiente obispo fue don Francisco Tello Sandoval (1567-1578) ${ }^{28}$ que prosiguió con las reformas de los anteriores y bajo cuyo mandato se llevaron a cabo obras como el retablo de la Concatedral de San Pedro en Soria.

Respecto al arte desarrollado durante esta época se podría dividir el periodo renacentista en la diócesis de Osma en tres etapas que en líneas generales corresponden con la estructura habitual del Renacimiento español. En primer lugar tendríamos un periodo de introducción de las formas renacentistas (desde finales del siglo XV hasta el segundo tercio del siglo XVI). Después se avanzó hacia una etapa de asimilación del Renacimiento, representada en la figura del obispo Acosta y cuyos ejemplos primordiales serían el retablo de la Catedral de El Burgo de Osma de Juni y Picardo. Esta obra actúa como foco de influencia para el resto de la diócesis y su efecto se prolonga durante el segundo tercio del siglo XVI.

Por último, durante el último tercio del siglo XVI y hasta el segundo tercio del siglo XVII se desarrolló el periodo romanista y contrarreformista en el cual se abandonaron muchos de los excesos anteriores ${ }^{29}$.

\footnotetext{
${ }^{24}$ AZCÁRATE, J. M., Escultura del siglo XVI, Ars Hispaniae. vol. 13, Madrid, Plus-Ultra, p. 167 y 287; PORTELA SANDOVAL, F. J., La escultura del siglo XVI en Palencia, Palencia, Diputación de Palencia, 1977, p. 356; MARTÍN GONZÁLEZ, J. M., Juan de Juni. Vida y obra, Madrid, Madrid, Ministerio de Cultura, 1974, pp. 301-303.

${ }^{25}$ GONZALO SÁNCHEZ-MOLERO, J. L., "La Biblioteca de Honorato Juan (1507-1566), Maestro de Príncipes y Obispo de Osma”, Pliegos de Bibliofilia, n 9, primer trimestre 2000, p. 3.

${ }^{26} I d$., p. 14 .

${ }^{27} I d .$, , p. 23.

${ }^{28}$ NÚNNEZ MARQUÉS, V., op. cit., pp. 158-162.

${ }^{29}$ REDONDO LAGÜERA, J. P., "El arte del Renacimiento en la diócesis de Osma", en Arte e Historia en la Diócesis de Osma, El Burgo de Osma, Ayuntamiento de El Burgo de Osma, 1998, p. 93.
} 


\section{Diócesis de Tarazona}

Durante el siglo XVI se incrementó considerablemente el patrimonio artístico de la ciudad de Tarazona. Se completaron las obras de la Catedral con la culminación de la torre y la construcción del cimborrio, del pórtico y el claustro ${ }^{30}$. En el interior se colocaron ricos retablos escultóricos y pictóricos cuyas escenas fueron enmarcadas por relieves platerescos. Otras obras importantes son la construcción del convento de la Concepción y de San Miguel, así como la renovación estructural de la iglesia de la Magdalena y la finalización de su torre ${ }^{31}$. Respecto a la arquitectura civil destacan el Palacio de Eguarás y la Lonja (actual Ayuntamiento).

La diócesis de Tarazona incluía la zona este de la actual provincia de Soria. Entre las poblaciones sorianas que formaban parte de esta diócesis figuraban Ágreda y Ólvega. En esta zona, y a partir de la segunda mitad del siglo XV fue frecuente el uso de grabados de origen nórdico como punto de partida en las composiciones pictóricas. Sus medios de difusión eran los comercios de venta de estampas y los talleres de impresores como los hermanos Hurus ${ }^{32}$.

Destaca por su importancia e ubicación la localidad de Ágreda, situada en la frontera entre Aragón y Castilla $^{33}$. Durante el siglo XVI se unificó su casco urbano (1531) y se construyó un Palacio Municipal siguiendo el estilo renacentista ${ }^{34}$.

La diócesis contaba con la presencia de una importante figura dentro del mundo cultural y político de la época, el doctor García Fernández de Carrascón (ca. 14701533), promotor y mecenas de la obra de ampliación de la capilla y nave principal de la iglesia de San Miguel de Ágreda, así como del retablo mayor, pintado por Pedro de Aponte. Fue un personaje relevante por su promoción del arte renacentista y por sus relaciones con Italia ${ }^{35}$. En concreto, viajó a Roma en 1522 para la coronación de Adriano de Utrech como pontífice. Allí fue confirmado como arcipreste de Ágreda y jefe del Cabildo de la Villa. El contrato del retablo de Ágreda se llevó a cabo poco

\footnotetext{
${ }^{30}$ TORRALBA, F., Catedral de Tarazona, Zaragoza: Institución Fernando el Católico, 1974; AGUERRI, F., La Catedral de Tarazona. Plan director y restauración: catálogo de la exposición semipermanente en el claustro, Tarazona, Fundación Tarazona Monumental, 2012, pp. 46-48.

31 GARGALlO SANJOAQUÍN, M., Breve historia de Tarazona, Tarazona, Centro de Estudios Turiasonense de la Institución Fernando el Católico, 1979, pp. 29-31.

${ }^{32}$ LACARRA DUCAY, M. C., "Tendencia europea en la pintura altoaragonesa de la segunda mitad del siglo XV”, Serrablo, no 100, 1996, p. 74.

${ }^{33}$ Fue una importante zona de comercio entre ambos reinos desde finales del siglo XV. DIAGO HERNANDO, M., "Relaciones comerciales entre Castilla y Aragón en el ámbito fronterizo soriano a fines de la Edad Media", Aragón en la Edad Media, n 9, 1991, pp. 179-202.

${ }^{34}$ ALCALDE CRESPO, G., Ágreda, Soria, Ayuntamiento de Ágreda, 2005, p. 41.

${ }^{35}$ VV. AA., El retablo de San Miguel de Ágreda..., p. 65.
} 
después de 1523, cuando Carrascón estaba "resident en curia romana". Carmen Morte señaló que probablemente Carrascón trajera de Roma muchos de los grabados italianos en los cuales Pedro de Aponte se inspiró para crear las escenas de su retablo ${ }^{36}$.

\section{Diócesis de Sigüenza}

Muchos de los arciprestazgos que la conformaban con anterioridad a 1955 actualmente forman parte de la diócesis de Osma, como por ejemplo, los de Almazán, Medinaceli, Berlanga de Duero, Baraona o Caracena. También otras localidades que antes formaban parte de la diócesis de Sigüenza se incluyen ahora en la de Osma, como Liceras o Caltojar.

La diócesis de Siguienza llegó a ser la cuarta sede en España durante los siglos XV y XVI, tras Toledo, Sevilla y Santiago de Compostela. Símbolo de este esplendor cultural y artístico fue la creación de la Universidad de Sigüenza, promovida por la Iglesia seguntina y por el sacerdote Juan López de Medina.

Durante el siglo XVI destacaron especialmente los obispos Bernardino López de Carvajal, Fadrique de Portugal, Fernando de Valdés, Diego de Espinosa y Pedro Pacheco. Entre ellos interesan para el tema de este estudio sobre todo Bernardino López de Carvajal (1456-1523) y Fadrique de Portugal (ca. 1465-1539), que actuó como promotor de las obras de Juan Soreda.

López de Carvajal residió en Roma largas temporadas, apartado de la diócesis. A pesar de ello llevó a cabo importantes renovaciones y ampliaciones tanto de la ciudad como de la Catedral ${ }^{37}$. A su interés se deben obras como el ensanche o la construcción de una nueva muralla. El claustro de la Catedral también fue una de las magníficas obras llevadas a cabo durante su gobierno.

Durante el gobierno de Fadrique de Portugal se llevaron a cabo construcciones relevantes, entre las que destaca especialmente la Capilla de Santa Librada en la Catedral de Sigüenza. El culto a dicha santa estaba muy vinculado a don Fadrique, teniendo en cuenta que se trataba de una santa lusitana y que la capilla debía guardar sus reliquias. La capilla constituyó también el lugar de enterramiento del obispo, que colocó su suntuoso mausoleo junto al altar de la santa. Entre sus encargos destacan el retablo

\footnotetext{
${ }^{36}$ Ibídem.

${ }^{37}$ MINGHELlA y ARNEDO DE LAS MERCEDES, T., Historia de la Diócesis de Sigüenza y sus obispos, Madrid, Tipografía de la Revista de Archivos, Bibliotecas y Museos, Vol. II: desde principios del siglo XIV hasta comienzos del siglo XVII, 1912, p. 200.
} 
pintado por Juan Soreda entre 1525 y 1528, labrado en piedra caliza y decorado con imaginería a lo romano, y la urna sepulcral que guarda las reliquias de la santa ${ }^{38}$. Otras de las obras promovidas por Fadrique en Sigüenza fueron la rehabilitación de la torre de San Pedro (Catedral de Sigüenza) y de la iglesia de la Pelegrina.

La vinculación de ambos prelados con algunos importantes pintores de la época, como Juan Soreda, ha sido ratificada por autores como Ramos Gómez ${ }^{39}$. Ambos tuvieron también relación con Italia, en especial Bernardino de Carvajal.

\section{Diócesis De Calahorra-La Calzada-Logroño}

Ciudades fundamentales de esta diócesis fueron en un principio Calahorra, la cual durante la primera mitad del siglo XVI acogió a importantes personajes intelectuales como el Deán Ortuño. A finales del siglo XVI, tras perder su carácter de lugar fronterizo y militar, fue sustituida por Logroño ${ }^{40}$ en su papel de principal ciudad de la diócesis. En el siglo XVI se realizaron importantes construcciones en la ciudad, como fue la expansión más allá de sus murallas medievales o las reformas realizadas en la Catedral (1548-1640) ${ }^{41}$. También en las iglesias de San Andrés o la de Santiago se emprendieron a obras de renovación. Es importante resaltar que la ciudad fue sede del Tribunal de la Inquisición hasta 1570, año en que se trasladó la sede a Logroño ${ }^{42}$.

En Logroño fueron frecuentes durante el siglo XVI los intercambios comerciales con Flandes. Como se puede comprobar por el contenido descrito en muchos inventarios, fue abundante la presencia de cuadros procedentes de esa zona ${ }^{43}$. Además, también vivían algunos importantes artistas e ingenieros de origen francés e italiano ${ }^{44}$.

La localidad soriana de Yanguas formaba parte durante el Renacimiento y hasta mediados del siglo XX de la diócesis de Calahorra. Esto se debía a que en el siglo XVI la diócesis incluía, además de territorios que forman actualmente parte de otras regiones fronterizas, tierras de la Corona de Castilla (de Soria y Burgos). Esta diócesis es la que mayor densidad parroquial presenta durante la Edad Moderna. En el caso de Yanguas

\footnotetext{
${ }^{38}$ Ídem., pp. 218-219.

${ }^{39}$ RAMOS GÓMEZ, F. J., Juan Soreda ..., p. 99.

${ }^{40}$ IBÁÑEZ RODRÍGUEZ, S., "La Diócesis de Calahorra a mediados del siglo XVI según el libro de visita del Licenciado Martín Gil”, Brocar, no 21, 1998, p. 149.

${ }^{41}$ CASTILLÓN, J. F., La Catedral de Calahorra, un baptisterio para un martirio, Trobajo del Camino, Edilesa, 2000, p. 27.

${ }^{42}$ ÁLVAREZ CLAVIJO, M. T., Logroño en el siglo XVI. Arquitectura y urbanismo, t. II, Logroño, Instituto de Estudios Riojanos, 2003, p. 45.

${ }^{43}$ Ídem, p. 42.

${ }^{44}$ Ídem, p. 43.
} 
eran parroquias matrices que actuaban como sufragáneas o anejas de otras. La mayoría de dichas parroquias estaban dedicadas a la Virgen ${ }^{45}$. Ejemplo de ello es la parroquia de Santa María en Yanguas.

El arte de esta zona está muy influenciado por los modelos nórdicos. Dicho influjo supuso el preludio del Renacimiento en la región ${ }^{46}$. Algunos de los obispos que dirigieron la diócesis a principios del siglo XVI apenas estuvieron presentes en la misma y muchos de ellos fueron importantes defensores de la Reforma ${ }^{47}$.

\subsection{EL SIGLO XVI Y EL COMIENZO DEL RENACIMIENTO EN SORIA}

Durante el siglo XVI se produjo una revitalización de la vida urbana, aunque no se levantaron muchos templos de nueva construcción, ya que las iglesias románicas y góticas seguían en buen estado. Pero sí se enriquecieron los interiores mediante suntuosos retablos y otros ornamentos. Algunos de estos retablos, realizados en madera labrada y recubiertos de oro, alcanzaron proporciones casi arquitectónicas. Estas obras fueron iniciativa de las cofradías y asociaciones religiosas o de los obispos ${ }^{48}$. En el siglo XVI surgieron fuertes personalidades como la del obispo Pedro Álvarez de Acosta (1484-1563).

En general, la característica que definió el arte del Renacimiento soriano fue su arcaísmo $^{49}$. Esto se puede comprobar especialmente en la pintura, donde hasta bien entrado el siglo XVI se encuentran obras de fuerte influencia gótica o medieval, más propias del siglo XV. El caso de la escultura es similar. Se realizaron nuevos trípticos platerescos, que crecieron en dimensiones y se ensamblan con decoración renacentista; pero persistió un fuerte sustrato gótico. La distancia de los grandes centros creadores y la ausencia de una promoción artística generalizada explican claramente esa inercia y la resistencia que encontró el Renacimiento para introducirse en la provincia soriana, al igual de su prolongación hasta bien entrado el siglo XVII.

En cuanto a la temática, predominó la habitual de las representaciones religiosas, como las escenas del Nuevo Testamento vinculadas a la Pasión de Cristo, la Maternidad

\footnotetext{
${ }^{45}$ IBÁÑEZ RODRÍGUEZ, S., op. cit., p. 147.

46 ÁlvareZ ClAVIJO, M. T., "El siglo XVI", en Historia del Arte en la Rioja (coord. por ARRÚE UGARTE, B.), t. III, Logroño, Fundación Caja Rioja, 2005-2011, p. 25.

${ }^{47}$ ÁLVAREZ CLAVIJO, M. T., op. cit., t. III, pp. 21-22.

${ }^{48}$ TARACENA Y AGUIRRE, B. y TUDELA DE LA ORDEN, J., Guía artística de Soria y su provincia, Soria, Diputación Provincial de Soria, 1962, pp. 52-53.

49 PÉREZ RIOJA, J. A., “Arte II” en Castilla y León. Soria (dir. AGERO, J.), Madrid, Editorial Mediterráneo, 1994, p. 134.
} 
y Asunción de la Virgen. Entre los santos más representados destacaron San Francisco de Asís y San Miguel. En el último tercio del siglo se desarrolló el culto a la Virgen del Rosario y a Santo Domingo de Guzmán ${ }^{50}$.

En ciertos núcleos se puede identificar la actividad de ciertos talleres artísticos, en particular escultóricos.

El taller de El Burgo de Osma fue el más relevante. Desde allí se trasladaron gran número de obras hasta todas las iglesias de la diócesis. Fue sede residencial de todo tipo de artistas, incluyendo los arquitectos y entalladores de las grandes obras realizadas en la Catedral durante la primera mitad del siglo XVI: el claustro y la portada-retablo de la capilla de San Pedro de Osma (esta última terminada con la colaboración del obispo Acosta).

Respecto al taller de Soria, existió una patente escasez de fondos eclesiásticos, por lo que en muchos casos fue la nobleza la que fomentó la renovación del arte sagrado en iglesias como San Juan de Rabanera, Santa María la Mayor o el Salvador. Figura importante dentro de este taller fue la de Gabriel de Pinedo.

El taller de Berlanga de Duero conoció una gran prosperidad durante el siglo XVI. La construcción de la Colegiata marcó el punto de arranque de este nuevo Renacimiento artístico, que abarcó todas las manifestaciones, desde la escultura a la pintura. Los artistas que trabajaron en él contrataron también obras para la comarca. Otros talleres importantes fueron los de Villar del Río y Magaña, Sigüenza (Morón de Almazán) o Tarazona (Matalebreras) ${ }^{51}$.

\section{Pintura}

Al igual que el resto del arte de la provincia, la producción pictórica soriana dependió mucho del influjo de otras zonas, como fueron los focos artísticos de Burgos, Palencia o Valladolid. Además, muestra influencia también de la zona aragonesa navarra de Tarazona y Tudela y de la seguntina y toledana ${ }^{52}$.

Los primeros atisbos de pintura renacentista en Soria comenzaron a tener sus primeras manifestaciones a principios del XVI, dada la fuerte implantación del Gótico. Se trataba de pinturas de carácter gótico que aún mantenían la influencia de algunos de

\footnotetext{
50 ARRANZ ARRANZ, J., La escultura romanista en la diócesis de Osma-Soria, Burlada (Navarra), I. G., Castuera, 1986.p. 36.

${ }^{51}$ Ibíd, pp. 36-37.

52 BRASAS EGIDO, J. C., "La pintura en la diócesis de Osma-Soria", en Arte e Historia en la Diócesis de Osma. X Curso Universitario de Verano, Burgo de Osma, Ayuntamiento de Burgo de Osma, 1998, p. 187.
} 
los maestros de la escuela aragonesa-navarra (Tarazona, Zaragoza, Tudela, y Calatayud $)^{53}$. Maestros fundamentales de una primera etapa de transición hacia el Renacimiento fueron Miguel Ximénez (doc. 1462-1505) ${ }^{54}$, que trabajó en la zona oriental de Soria (Ágreda), el Maestro de Osma ${ }^{55}$ o el Maestro de Sedano (doc. 1486$1533)^{56}$. Estos pintores mostraron una gran dependencia en sus composiciones de las estampas nórdicas que se difundieron por España a finales del siglo XV, como las de Schongauer (1448-1491). En algunos casos continuaron con un amplio uso de los dorados para los fondos y las vestimentas. Mostraron poco o nulo interés en los problemas del espacio y la perspectiva, y con frecuencia representaron sus figuras sobre

\footnotetext{
${ }^{53}$ BRASAS EGIDO, J. C., "La pintura en la diócesis...", p. 192; ID., "Pintura", en VV. AA., Historia del Arte de Castilla y León, t. V: Renacimiento y Clasicismo, Valladolid: Consejería de Cultura y Turismo, 1996, pp. 289-290.

${ }^{54}$ SERRANO Y SANZ, M., "Documentos relativos a la pintura en Aragón durante los siglos XIV y XV", Revista de Archivos, Bibliotecas y Museos, XXXI, 1914, pp. 433-458; POST, Ch. R., A History of Spanish Painting, t. XIII, Milwood, Kraus Reprint, 1966; GUDIOL RICART, J., Pintura medieval en Aragón, Institución Fernando el Católico, Zaragoza, 1971; MORTE GARCÍA, C., Aportaciones al estudio de la pintura de Aragón durante el siglo XVI, Tesis Doctoral inédita defendida en la Universidad de Zaragoza, 1981; ÁVILA PADRON, A., "Influencia de Rafael en la pintura y escultura españolas del siglo XVI...", 1984, pp. 58-88; LACARRA DUCAY, C., "Influencia de Martin Schongauer en los primitivos aragoneses", Boletín del Museo e Instituto Camón Aznar, n 17, 1984, pp. 15-39; MORTE GARCÍA, C., La pintura aragonesa del Renacimiento..., vol. 2, 1985; MORTE GARCÍA, C., Aragón y la pintura del Renacimiento: (exposición), Zaragoza, Caja de Ahorros y Monte de Piedad de Zaragoza, Aragón y Rioja, 1990; YARZA LUACES, J., Los Reyes Católicos. Paisaje artístico de una monarquía, Madrid: Nerea, 1993, p. 115; LACARRA DUCAY, M. C., “Tendencia europea en la pintura..."pp. 7475; MORTE GARCÍA, C., "La colección de pinturas, tapices, dibujos, estampas y esculturas de Miguel Climent Gurrea, protonotario del consejo Supremo de Aragón y otros inventarios del siglo XVI", Boletín del Museo e Instituto Camón Aznar, no 65, 1996, pp. 131-164; LACARRA DUCAY, M. C., “Anunciación, Visitación, Nacimiento, Epifanía, Presentación en el templo y Piedad”, en Las Edades del Hombre. La ciudad de seis pisos, Burgo de Osma, Las Edades del Hombre, s. 1., 1997, nº 98, pp. 186-188; CARDONA JIMÉNEZ, V., La pintura gótica...; ORTIZ VALERO, N., "Una tabla dedicada a Santa Bárbara. Taller del pintor Miguel Jiménez (1462-1505)", Ars \& Renovatio, n ${ }^{\circ}$ 1, 2013, pp. 267-279; VELASCO GONZÁLEZ, A., “Aportaciones a los catálogos de pinturas de Miguel Ximénez (doc. 14621505) y Martín Bernat (doc. 1450-1505), pintores de Zaragoza”, Ars \& Renovatio, n 3, 2015, pp. 192232.

${ }^{55}$ POST, Ch. R., op. cit., vol. IX, pp. 669-674; GUDIOL RICART, J., Pintura gótica, Ars Hispaniae, vol IX, Madrid, Plus-Ultra, 1955, p. 352; ALCOLEA, S., Soria y su provincia, Barcelona, Aries, 1964; CAMÓN AZNAR, J., La pintura española del siglo XVI, Summa Artis, vol. XXIV, Madrid, Espasa Calpe, 1970; AZCÁRATE, J. M., Arte gótico en España, Ediciones Cátedra: Madrid, 1990; ARA GIL, C. J., en La música en la iglesia de Castilla y León. Las Edades del Hombre, Valladolid, Gráficas Andrés Martín, 1991, p. 144; PARRADO DEL OLMO, J. M., “Cantoral música gregoriana”, Ídem, 1991, pp. 102-103; YARZA LUACES, J., Los Reyes Católicos: paisaje artístico de una monarquía, Madrid: Nerea, 1993; PARRADO DEL OLMO, J. M., "Cantoral. Música gregoriana”, en Vlaanderen en Castilla y León. Op de drempel van Europa, Valladolid, Las Edades del Hombre, 1995, p. 304; MUNTADA TORREllAS, A., Cantorales del Monasterio de San Jerónimo de Espeja. Catedral del Burgo de Osma, Catedral del Burgo de Osma, Cabildo s. 1., 2003.

56 GUDIOL RICART, J., Pintura gótica..., pp. 370-371; CAMÓN AZNAR, J., Pintura medieval española, Summa Artis, vol. XXII, Madrid, Plus-Ultra, 1970, p. 604; SILVA MAROTO, P., Pintura hispanoflamenca castellana. Burgos y Palencia, t. III, Valladolid, Consejería de Cultura y Bienestar Social, 1990, pp. 738-739; SILVA MAROTO, P., "Retablo de la Virgen", en Paisaje interior..., $\mathrm{n}^{\circ}$ 70, pp. 360-361.
} 
simples fondos dorados. Lo más destacable es el uso de tipos humanos más individualizados y una mayor variedad cromática.

De esta tónica se apartó al Maestro de Sedano, quien comenzó a ubicar sus escenas en fondos arquitectónicos, quizá por influencia del arte italiano. Más adelante, durante el primer tercio del siglo XVI, se empezó a emplear en nuevo sistema de representación renacentista, que renovó la figuración de la anatomía o el espacio. Sin embargo, su asimilación fue tan solo superficial, sin comprender realmente los sistemas por los que operaban los maestros italianos o nórdicos. Dentro de esta etapa predominan también los maestros procedentes de los focos aragonés y navarro ${ }^{57}$. Artistas como Pedro de Aponte ${ }^{58}$ o Juan Soreda ${ }^{59}$, que mostraron ya un dominio del nuevo lenguaje, recurrieron con frecuencia al uso de grabados tanto italianos, como Marcantonio Raimondi (ca. 1480-ca. 1534) o Marco Dente (ca. 1490-1527), así como nórdicos (fundamentalmente de Durero). Soreda dependió también frecuentemente de la pintura anterior a través de las obras de Juan de Borgoña (act. ¿1494?-1536). En la obra de Pedro de Aponte predominaron los tipos caricaturescos, deformes y expresionistas derivados de la pintura nórdica y de las estampas de Durero.

\footnotetext{
${ }^{57}$ BRASAS EGIDO, J. C., "La pintura en la diócesis...”, p. 192.

58 ARCO GARAY, R., "El pintor cuatrocentrista Pedro de Aponte", Arte Español, no 3, 1914, pp. 106125; "Pedro del Ponte o Aponte, pintor del Rey Católico", Boletín del Seminario de Estudios de Arte y Arqueología, no 9, 1942-43, pp. 59-77; BALAGUER SÁNCHEZ, F., "Pintores zaragozanos, en protocolos notariales de Huesca", Seminario de Arte Aragonés, n 6, 1954, pp. 77-89; ANGULO IÑÍGUEZ, D., Pintura del Renacimiento, col. Ars Hispaniae, vol. XIII, Madrid, Plus-Ultra, 1954, pp. 7375; POST, Ch. R., op. cit., t. XIII, 1966; MORTE GARCÍA, C., "Huella de Durero en un retablo aragonés del siglo XVI", Seminario de Arte Aragonés, no 27-28, 1978, pp. 55-63; "La personalidad artística de Pedro de Aponte a partir del retablo de San Miguel de Ágreda (Soria)", en Actas del Primer Coloquio de Arte Aragonés, Teruel, 1978, pp. 219-231; Aportaciones al estudio de la pintura de Aragón durante el siglo XVI, Tesis Doctoral inédita defendida en la Universidad de Zaragoza, 1981; "La pintura aragonesa del Renacimiento en el contexto hispánico y europeo", en III Coloquio de Arte Aragonés, Teruel, vol. 2, 1985; "La obra del pintor Pedro de Aponte o del Ponte en Navarra: los retablos de Santa María la Real de Olite y de San Juan Bautista de Cintruénigo", Príncipe de Viana. Anejo., Anejo no 2, 1986; Aragón y la pintura del Renacimiento..., pp. 66-78; "Las artes figurativas del Renacimiento aragonés: revisión historiográfica y nuevas perspectivas", Actes del I, II i III coloquis sobre art i cultura a l'epoca del Renaixement a la Corona d'Aragó, Tortosa, 1996-1999, pp. 33-72; Damián Forment, escultor del Renacimiento, Zaragoza, Caja Inmaculada D. L., 2009; "Los artistas de Aragón y sus patronos en el Renacimiento: los proyectos figurativos", en El esplendor del Renacimiento en Aragón, Museo de Bellas Artes de Bilbao y Museo de Zaragoza, 2009, pp. 54-79; MARÍAS FRANCO, F., El largo siglo XVI...; GAETA, L., Juan de Borgoña e gli altri: relazioni artistiche tra Italia e Spagna nel'400, Galatina, Mario Congedo, 2012; NAVAL MAS, A., Pedro del Ponte (Aponte), memoria de Licenciatura leída el 12 de diciembre de 1975 en la Universidad Complutense de Madrid, publicada en el Sitio de Antonio Naval Mas el 4 de noviembre de 2016. URL: http://www.antonionavalmas.net/spip.php?article88. VV. AA., El retablo de San Miguel de Ágreda...,.

59 MAYER, A., La pintura española, Barcelona, Labor, 1929. POST, Ch. R., op. cit., t. IX, XIII; CAMÓN AZNAR, J., La pintura española del siglo XVI..., ÁVILA, A., "El pintor Juan Soreda...”, pp. 136-145 y "Juan Soreda y no Juan Pereda. Nuevas noticias documentales e iconográficas", Archivo Español de Arte, LII, no 208, 1979, pp. 405-424; NAVARRO TALEGÓN, J., Pintura de Toro. Obras restauradas, Toro (Zamora), Diputación provincial, 1985; MARÍAS FRANCO, F., El largo siglo XVI...; RAMOS GÓMEZ, F. J., Juan Soreda...
} 
Desde 1530 hasta finales del siglo XVI podemos hablar de una asimilación generalizada del Renacimiento. Predominó la influencia de modelos derivados de Rafael y Miguel Ángel. Y partir de 1550 se introdujo cierto Manierismo, con figuras alargadas y poses imposibles, de anatomía muy marcada. Este estilo se hizo patente a través de las obras de artistas como Diego de Urbina ${ }^{60}$. Como punto de partida predominó el uso de grabados italianos, tanto de Marcantonio Raimondi, como de modelos más modernos como el Parmigianino (ca. 1503-1540) o Schiavone (ca. 1520ca. 1583).

Ejemplo de este interés por el arte italiano fue el prior de la catedral de El Burgo de Osma, don Pedro Sarmiento, que trajo de Roma una serie de pinturas muy influidas por el arte de Rafael (1483-1520) y Miguel Ángel (1475-1564), que fueron encargadas para decorar la capilla de Santiago el Mayor, inaugurada en $1551^{61}$.

\section{Escultura}

Hasta el segundo tercio del siglo XVI no se empezaron a sustituir los retablos góticos por otros renacentistas o romanistas más acordes con el gusto imperante en la época. El aumento del amueblamiento artístico de los templos se debió a la mejora de las condiciones económicas (ganadería y agricultura), pero sobre todo a la promoción de algunos obispos como don Pedro Álvarez de Acosta. Como uno de los primeros ejemplos de escultura renacentista podemos considerar los retablos de la Capilla mayor y del Trascoro de la Catedral de El Burgo de Osma, obra de Juan de Juni y de Juan Picardo $^{62}$.

Hasta mediados del siglo XVI predominaron los retablos escultóricos de corte más clásico y con decoración plateresca, como el de la iglesia de Santa María la Mayor

\footnotetext{
60 DE ANTONIO-SAENZ, T., Pintura española del último tercio del siglo XVI en Madrid. Juan Fernández de Navarrete, Luis de Carvajal y Diego de Urbina, Madrid, Universidad Complutense de Madrid, 1987, pp. 588-589; "Diego de Urbina, pintor de Felipe II", Anales de Historia del Arte, n 1, 1989, pp. 141-151; URREA, J., "La lapidación de San Esteban”, en La ciudad de seis pisos. Las Edades del Hombre, El Burgo de Osma, Soria, s. 1., 1997, n 131, pp. 238-239; MUNTADA I TORRELLAS, A., "Velo de Pasión del obispo Pedro Álvarez da Costa", en Paisaje interior. Las Edades del Hombre, Fundación Las Edades del Hombre, 2009, n 136, pp. 482-486; COLLAR DE CÁCERES, F., "Diego de Urbina...", pp. 103-136.

${ }^{61}$ Entre ellas destaca la pintura del Abrazo ante la puerta dorada, que muestra una posible influencia de grabados italianos en algunas de sus figuras. NÚÑEZ MARQUÉS, V., op. cit., pp. 33-34; ARRANZ ARRANZ, J., El Renacimiento en la diócesis..., p. 26; DOMINGUEZ CASAS, R. Y FIZ FUERTES, I., "Retablo de la Concepción de Nuestra Señora", en Remembranza, Las Edades del Hombre, Fundación Las Edades del Hombre, 2001, nº 8, pp. 546-549.

${ }^{62}$ NÚÑ̃Z MARQUÉS, V., op. cit., pp. 30-32; 39-43; MARTÍN GONZÁLEZ, J. J., Juan de Juni: vida ..., p. 205; MARTÍN GONZÁLEZ, J. J., "Retablo mayor”, pp. 268-271.
} 
(Soria), obra de Juan de Carranza ${ }^{63}$. En la decoración de este tipo de retablos se empezaron a incorporar motivos clásicos, obtenidos de monedas, bustos o de las estampas de Marcantonio Raimondi, basadas en la Antigua Roma o en pinturas de Rafael.

Después, y hasta finales de siglo, predominaron los retablos más romanistas, caracterizados por la monumentalidad de sus figuras y la exageración de sus poses. Durante las últimas décadas del siglo XVI se produjo una auténtica eclosión de los retablos romanistas, como los de Ólvega, Pozalmuro, Monteagudo de las Vicarías o el de la iglesia de San Nicolás en Soria. Algunos de los escultores más importantes de esta época fueron Gabriel de Pinedo ${ }^{64}$ o Pedro del Cerro ${ }^{65}$. Muchos de estos retablos muestran diversas influencias debido a las distintas diócesis y talleres a los que pertenecían ${ }^{66}$. Algunos escultores como Martín de Vandoma ${ }^{67}$ o Juan de Carranza I muestran una mayor influencia de maestros burgaleses como Siloe (ca. 1495-1563) o Felipe Bigarny ( $c a .1475-1543)^{68}$. Durante esta etapa, como en el caso de la pintura, predominó la influencia de las estampas que difundían los modelos del Manierismo italiano muchas veces basados en el estilo de Miguel Ángel, Parmigianino o Tiziano, sin que por ello disminuyera la presencia de lo nórdico. Criado Mainar señala, refiriéndose al retablo de Ólvega, que la decoración de esta época aúna el carácter fantástico del

\footnotetext{
${ }^{63}$ ECHEVERRÍA GOÑI, P. L., "Los Ocio y su patronazgo artístico en el siglo XVI. Juan Carranza I y el retablo de la Anunciación de Treviana (La Rioja)", en BSSA arte, t. 77, 2011, pp. 69-92; PAYO HERNANZ, R., "Bernal Sánchez y la escultura burgalesa de los años centrales del siglo XVI. Entre la tradición siloesco-vigarniana y el influjo berruguetesco", en FERNÁNDEZ GRACIA, R. (coord.), PVLCHRVM. Scripta varia in honorem $M^{a}$ Concepción García Gainza, Pamplona, 2011, pp. 624-632; PAYO HERNANZ, R. y ECHEVERRÍA GOÑI, P. L., "Los Ocio y su patronazgo artístico...", pp. 80-82.

${ }^{64}$ LASSO DE LA VEGA Y LÓPEZ DE TEJADA (MARQUÉS DEL SALTILLO), M., Artistas y artífices sorianos de los siglos XVI y XVII: (1509-1699), Madrid, Imprenta y editorial Maestre, 1948; CAMÓN AZNAR, La escultura y rejería españolas, Summa Artis, vol. 18, Madrid, Espasa Calpe, 1976, p. 360; BARRIO LOZA, J. A., Escultura romanista en la Rioja, Madrid: Ministerio de Cultura, 1981; MARTÍNEZ FRÍAS, J. M., "Gabriel de Pinedo, escultor y tracista", BSAA, t. XILX, 1983, pp. 331- 343; MANRIQUE MAYOR, M. A., Las artes en Soria durante el siglo XVII. Estudio documental y artístico, Tesis Doctoral inédita, Universidad de Zaragoza, 1987.

${ }^{65}$ LASSO DE LA VEGA Y LÓPEZ DE TEJADA (MARQUÉS DEL SALTILLO), M., op. cit., pp. 115117; ARRANZ ARRANZ, J. La escultura...., 1986, p. 87; PÉREZ DE CASTRO, R., "Coronación de la Virgen", en Paisaje interior, Las Edades del Hombre, 2009, n 154, p. 520; "Sacrificio de Isaac", en Angeli, Las Edades del Hombre, 2019, pp. 56-57.

${ }^{66}$ PARRADO DEL OLMO, J. M. "Escultura", en VV. AA., op. cit., pp. 240-241. PÉREZ DE CASTRO, R., "Coronación de la Virgen", pp. 519-520.

${ }^{67}$ PÉREZ VILLAMIL, J., La catedral de Sigüenza erigida en el siglo XII: con noticias nuevas para la historia del arte en España, sacadas de documentos de su archivo, Madrid: Tip: Herres, 1899; "El Renacimiento español: Martín de Vandoma y su escuela", Arte Español. Revista de la Sociedad de Amigos del Arte, t. III, no 3, segundo cuatrimestre, 1916, pp. 193-216; AZCÁRATE, J. M., Escultura del siglo XVI..., p. 240; MARTÍNEZ FRÍAS, J. M., "Resurrección", en Kyrios. Las Edades del Hombre, Fundación de las Edades del Hombre, 2006, n 187, pp. 395-397.

${ }^{68}$ CASTRO SANTAMARÍA, A., "Resurrección", en Paisaje interior, Fundación Las Edades del Hombre, 2009, nº 150, p. 514.
} 
Manierismo romano y las estampas de la escuela de Fontainebleau, con un vocabulario escultórico contrarreformista que queda reducido a roleos vegetales, niños, bichas y pájaros $^{69}$.

En otras manifestaciones artísticas, como las artes aplicadas, es indudable el influjo que algunas estampas ejercieron sobre ellas ${ }^{70}$. Ejemplos de ello son el Velo de Pasión de la Catedral de El Burgo de Osma o las miniaturas en manuscritos y libros ilustrados del Monasterio de la Espeja, influenciados por grabados de Schongauer $^{71}$.

${ }^{69}$ Basándose en la etapa de transición definida por Pedro Echeverría para Navarra. ECHEVERRÍA GOÑI, P. L., Policromía del Renacimiento en Navarra, Gobierno Navarro, Departamento de Educación y Cultura: Pamplona, 1990, p. 224. CRIADO MAINAR, J., "Juan de Varaiz y la pintura de Tarazona en el último cuarto del siglo XVI", Turiaso, vol. XVIII, 2005-2007, p. 74.

${ }^{70}$ SÁNCHEZ RIVERA, J. A., "La huella y la forma. Influencia del grabado en el arte español de la Edad Moderna", Grabado y Edición II, n 26, 2010, p. 11.

71 VILLASEÑOR SEBASTIÁN, F., "Préstamos e influencias extranjeras en la miniatura hispanoflamenca castellana: 1450-1500", en El arte foráneo en España: presencia e influencia (coord. CABAÑAS BRAVO, M.), Madrid: 22-26 de noviembre de 2004, Departamento de Historia del Arte, Instituto de Historia, CSIC, Madrid, 2005, p. 232. 


\section{LA IMPRENTA, LOS GRABADOS Y LOS ARTISTAS}

\subsection{EL NACIMIENTO DE LA IMPRENTA Y SU CONTRIBUCIÓN A LA DIFUSIÓN DE LA IMAGEN}

La cultura del libro que surgió ya desde el Humanismo, en el siglo $\mathrm{XV}$, se manifestó en su concepción del hombre como "hombre de los libros", de la lectura. En paralelo el pensamiento conoció un proceso de secularización, lo que no implicó que se excluyera la religión, pero ya no importó sólo lo sagrado. Cobraron entonces gran importancia los libros que no eran de temática religiosa, sino que se encuadraban dentro de otros saberes o disciplinas, como la filosofía moral o la literatura, bien fuera la procedente de la cultura medieval, o de la clásica; en el caso de esta última, frecuentemente implicaba un contenido mitológico.

El auge del libro implicó su conversión en un objeto autónomo. Se empezó a cualificar estéticamente al libro, en cuanto a su tipografía, encuadernación o ilustraciones.

El origen de la imprenta supuso no sólo la difusión de la palabra escrita, sino también de la cultura visual ${ }^{72}$. El paso de la Edad Media al Renacimiento se acompañó de una preponderancia de la cultura visual sobre la oral en la comunicación del $\operatorname{saber}^{73}$. A partir de este momento la imagen fue objeto de utilización por todo tipo de instancias e instituciones: las monarquías, las élites políticas y eclesiásticas, los centros culturales (academias y universidades) y, por último, la cultura popular.

En contraposición al mencionado proceso de secularización y para evitar los peligros que suponía, la Iglesia se vio obligada a llevar a cabo un control ideológico de los libros impresos, lo que se puso de manifiesto en el pensamiento de la Contrarreforma y en la institución de la Inquisición ${ }^{74}$. A pesar de ello, la Iglesia también se benefició del invento de la imprenta. La multiplicación de los libros y las ilustraciones que estos contenían propiciaban la evangelización, como la de los pueblos americanos, y la difusión de la religión en general, actuando como un medio propagador de la ortodoxia. Y para los eruditos del siglo XVI, la estampa posibilitó una acumulación metódica de conocimientos, lo que fue de gran interés.

\footnotetext{
${ }^{72}$ CARRETE PARRONDO, J., op. cit., p. 11.

${ }^{73}$ NAVARRETE PRIETO, B., op. cit., p. 7.

${ }^{74}$ GRIFFIN, C., Oficiales de imprenta, herejía e Inquisición en la España del siglo XVI, Madrid: Ollero y Ramos, 2009, p. 25; CASTILLEJO BENAVENTE, A., La imprenta en Sevilla en el siglo XVI: (15211600), Sevilla, Editorial Universidad de Sevilla, 2019, pp. 30-32.
} 
La fina hoja en la cual se imprimía la estampa favorecía la recopilación y la colección de las mismas. La estampa, como el dibujo, es un objeto acumulable, conservable, autónomo y flexible. Estas características permitían distribuirlas y acumularlas; haciendo de ellas objetos fáciles de transportar e individualmente apropiables, distinguiéndose así de otros objetos como los retablos o los frescos. Otra peculiaridad era su carácter de objeto de sustitución, lo que puede tener un aspecto negativo, pues la estampa siempre será la copia de un arquetipo. La reproductibilidad era otra de sus virtudes: se trataba de un objeto multiplicable, distribuible e intercambiable.

La posibilidad de la repetición de las imágenes supuso una nueva época para la ilustración y la tipografía. La difusión de la imagen no sólo tenía un sentido dogmático, sino también estético. Ejemplos de artistas como Alberto Durero demostraron la capacidad de comunicación y difusión de las imágenes por medio de este nuevo arte. Durero siguió los pasos de Michel Wolgemut (ca. 1434-1519) y Schongauer (ca. 14481491), estableciendo nuevos caminos de la imagen grabada, como el inicio de su uso político a través de la exaltación de Maximiliano I, con un contenido simbólico y propagandístico $^{75}$.

El grabado se convirtió además en un medio de transmisión entre las artes mayores y las menores, aunque siempre se vinculó más a la Pintura en la lucha que existía en la época entre Artes Liberales y Mecánicas, y en su paragone con la Escultura. Otro factor importante fue el de las estampas como difusoras de las obras de arte. En este sentido destacó la actividad de Marcantonio Raimondi (ca. 1480-ca. 1534) como difusor de las obras de Rafael. Y es que uno de los aspectos más productivos de la estampa, que favorecía a la vez el seguimiento de una tradición y un sentido académico, es que siguió proporcionando modelos y fue un auténtico medio de codificación de imágenes ${ }^{76}$.

Esta nueva disciplina suponía graves problemas para algunos artistas ya que debían ejercer su control sobre una obra que, debido a su reproductibilidad, se independizaba de ellos, ya que la tirada se hacía en talleres, generalmente la comercialización era ajena a ellos y su distribución diversificaba su uso y ubicación. El

\footnotetext{
${ }^{75}$ HUIDOBRO, C., Durero grabador, Madrid, Electa, 1999, p. 11; GÓNZALEZ DE ZÁRATE, J. M., "Durero y los Hyerogliphica. Tres estampas y una pintura, Némesis (La Gran Fortuna), la Justicia, Melancolía I, Cristo ante los doctores", Archivo Español de Arte, LXXIX, 313, 2006, pp. 7, 8.

${ }^{76}$ MELOT, M., "Naturaleza y significado de la estampa", en El grabado. Historia de un arte, Barcelona, Carroggio, 1981, pp. 30-32.
} 
hecho de que para su confección participaran varias personas en una especie de equipo de ayudantes o discípulos hace difícil concebir la estampa como obra autónoma de autoría única. Generalmente el entallador se dedicaba a copiar imágenes ajenas, incluso de artistas extranjeros, así como a inspirarse en los motivos arquitectónicos, la pintura mural, las vidrieras y en obras de canteros o tallistas ${ }^{77}$.

La estampa, que surgió en la segunda mitad del siglo XV, aunaba el sentido práctico con el estético y el artesano. Se contrapusieron dos modos de comprender el arte del grabado. Por un lado, la concepción de la estampa como obra de arte al mismo nivel que la pintura, representada por artistas como Durero (1471-1528) o Holbein (ca. 1497-1543). Por otro, los talleres de impresores, auténticos centros de producción múltiple, que repetían la misma imagen en diversos contextos y países. Durero aunó el dominio de la técnica del artesano orfebre con la ambición del artista pintor que quería darse a conocer a través de la estampa. Prueba de ello es la marca del autor, símbolo de su individualidad y del carácter artístico de su labor.

Así pues, aunque debe diferenciarse entre la figura del "inventor", que ideaba la estampa, y la del entallador, que era el artesano que traspasaba a la plancha el diseño, aunque debe tenerse en cuenta también que, a veces, el dueño del taller fue el mismo artista.

\subsection{PRINCIPALES IMPRENTAS EN EUROPA Y SU PRODUCCIÓN DE GRABADOS}

En primer lugar, deben destacarse la decisiva contribución de los talleres situados en los distintos territorios y estados de Alemania, donde surgió la imprenta a mediados del siglo XV y se localizaron los focos impresores más activos (Nuremberg, Augsburgo, Colonia, Wittenberg y Estrasburgo).

Hacia 1439 su creador, Guttenberg (ca. 1400-1468) inició sus experimentos en Maguncia y Estrasburgo, estampando libros xilográficos sobre planchas. Más tarde, en 1457, sus socios Fust (ca. 1400-1466) y Schöffer (ca. 1425-1502), industrializaron el invento. En 1465 se introdujeron por primera vez los libros impresos con caracteres móviles y poco después se incluyeron las primeras estampas en libros, aprovechando los

\footnotetext{
77 VEGA GONZÁLEZ, J., La imprenta en Toledo. Estampas del Renacimiento, 1500-1550, Madrid, Ollero y Ramos Editores, 2010, p. 83.
} 
espacios de los márgenes, y se crearon los primeros frontispicios impresos, incluyendo en algunos casos retratos de los autores.

Pfiser fue el primer grabador-tipógrafo alemán conocido. Entre los primitivos autores del grabado en cobre destacaron el Maestro de los Juegos de Cartas (doc. 14251450), el Maestro de 1464 o de las Banderolas y el Maestro de 1466 también conocido con el nombre de Maestro E. S. (ca. 1420-ca.1468). Éste último destacó por la originalidad de sus composiciones. Más tarde, en las últimas décadas del siglo apareció Schongauer (ca. 1448-1491).

A finales del XV y comienzos del siglo XVI empezó a significarse la imprenta de Nuremberg, por su importante comercio con los países nórdicos y su vinculación con la ruta veneciana. Antonio Koburger, introductor de la imprenta en esta ciudad, es uno de los primeros impresores importantes de Europa. Ejemplo del esplendor de la imprenta en Nuremberg son también las obras de Michael Wolgemut y Wilhelm Pleidenwurff (doc.1460-1494), innovadores en la técnica de la xilografía a través del uso del claroscuro. De hecho, ambos influyeron posteriormente en la obra de Alberto Durero. Otras personalidades importantes dentro del grabado alemán del Renacimiento fueron Hans Holbein el Joven (ca. 1497-1543), Lucas Cranach (1472-1553), Albrecht Aldofer (1480-1538), Aldegrever (1502-1555-1561), etc.

En Francia la imprenta más desarrollada fue la de Lyon, por su ventajosa situación geográfica, entre Alemania, Suiza e Italia. La mayoría de los grabadores que trabajaron en esta imprenta eran de origen alemán, probablemente debido a las persecuciones religiosas provocadas por el Electorado de Maguncia. A finales del siglo XV predominó la xilografía y destacaron los Libros de Horas, decorados con minúsculas e imaginativas imágenes. Posteriormente, en el siglo XVI, la madera y el metal convivieron con igual importancia. Un foco destacable se situó en Fontainebleau, a donde acudieron grabadores franceses, italianos y flamencos ${ }^{78}$.

Al ser el comercio una actividad esencial en la economía flamenca, la realización y la venta de estampas adquirió una gran relevancia como parte de los intercambios mercantiles. Los flamencos fueron pioneros en el arte de la xilografía como demuestran dos impresiones realizadas en Harlem. También fueron relevantes los primeros grabados flamencos en metal vinculados a los nombres de Jacob Cornelisz ( $c a$. 1470-1533) y de Jean Walter Van Assen.

\footnotetext{
${ }^{78}$ ESTEVE BOTEY, F., Historia del grabado, Madrid, Clan, 1993, pp. 198-200
} 
En Flandes, las imprentas más importantes se ubicaron en Lovaina y Amberes. Esta última ciudad se convirtió durante el siglo XVI en una importante capital desde el punto de vista artístico, acogiendo a más de trescientos artistas y conformando uno de los primeros grandes mercados artísticos de Europa. Entre los grabadores más relevantes se encuentran Hyeronimus Cock ( $c a$. 1510-1570), grabador, pintor y humanista conocido por ser el fundador de la editorial Aux Quatre Vents entre cuyos miembros más célebres se encontraban grabadores como Cornelis Cort (ca. 1533-1578) ${ }^{79}$. Otro de los talleres importantes ubicados en Flandes es el llamado In de Witte Lelie cuyo miembro más importante fue Philippe Galle (1537-1612). Galle y Cock proporcionaron al resto de Europa gran número de composiciones realizadas por los singulares grabadores flamencos ${ }^{80}$.

Uno de los personajes más importantes dentro de la imprenta flamenca fue Cristóbal Plantino (ca. 1520-1581) ${ }^{81}$, propietario de uno de los talleres más activos de la zona. Su estrecha relación con Arias Montano (1527-1598) y su colaboración con Felipe II supervisando su proyecto de la Biblia Poliglota figuran entre sus aportaciones más destacables. Posiblemente la formación de la propia Colección de Estampas de El Escorial se debiera también a la influencia de Cristóbal Plantino ya que la mayoría de los grabados del monasterio son de origen flamenco.

En Italia las ciudades más importantes en cuanto a la producción de estampas fueron Roma, Venecia y Florencia. En el siglo XVI fueron los artistas italianos los que dictaron las pautas iconográficas y estilísticas tanto en el ámbito sacro como en el profano. En los inicios de este arte, el grabado xilográfico no tuvo tanta importancia como en otros países. Predominó el uso de grabado en metal, iniciado por los niellatori, que realizaron su actividad en Florencia y el Norte de Italia a finales del siglo XV. Durante los primeros años del siglo XVI destacaron las imprentas venecianas a través de personalidades como la de Mantegna (ca. 1431-1506) o más adelante artistas como Tiziano (?-1576). En Florencia gran parte de sus grabadores se trasladaron a Francia, a la Escuela de Fontainebleau.

Respecto a la Escuela Romana, destaca la figura de Marcantonio Raimondi, que si bien se formó en Bolonia y en Venecia, fue en Roma donde desarrolló gran parte de

\footnotetext{
${ }^{79}$ VV. AA., Real Colección de Estampas..., t. I, p. 18

${ }^{80}$ Ibídem.

${ }^{81}$ MARTÍN, M. A., "Un campo de entendimiento y colaboración: la espiritualidad”, en Vlaanderen en Castilla y León: Op de drempel van Europa, Las Edades del Hombre, 1995, pp. 70-71; STOLS, E., Y THOMAS, W., "Flandes y Castilla: dos siglos de caminos paralelos" en Ídem, 1995, p. 40.
} 
su obra ${ }^{82}$. Allí también fue relevante la figura de Antonio de Salamanca (1479-1562), editor de origen español que estuvo en la ciudad entre 1538 y 1563 . Fue uno de los primeros empresarios romanos en esta actividad, con obras fechadas en torno a 1540. Durante mucho tiempo trabajó junto a otro de los editores más famosos de la época, Antonio Lafreri (1512-1577). Salamanca se dedicó a editar gran número de estampas tanto de artistas contemporáneos suyos como de otros ya fallecidos. El negocio de los grabados prosperó enseguida, aunque provocó muchas veces que el valor artístico de las estampas decayera ${ }^{83}$. Además de editar, Salamanca también se dedicó a realizar él mismo algunas estampas, aunque son pocas las que se conservan.

\section{Técnicas}

Respecto a las técnicas, las xilografías o entalladuras se realizaron en madera tallada. Fue el método más antiguo de estampación. Esta técnica se difundió en Europa desde finales del siglo XIV y alcanzó su esplendor en Alemania. Sobre la madera tallada se aplicaba el dibujo, para más adelante reforzar el contorno del mismo con un cuchillo $^{84}$. Las zonas en relieve se dejaban para entintar mientras que las partes rebajadas con gubias se dejaban en blanco. Después se tintaba la superficie a través con rodillo y se realizaba la estampación, manualmente o con una prensa mecánica, en ambos casos sobre papel húmedo.

Los grabados en cobre se llevaron a cabo siguiendo dos de las técnicas principales sobre metal: el aguafuerte (manera húmeda) o la manera seca, realizada a través de buril. ${ }^{85} \mathrm{El}$ buril fue uno de los métodos más aprovechados en el grabado en hueco o calcografía. El instrumento consta de un mango redondo y de una barra de acero, habitualmente de forma cuadrangular con forma de rombo afilado con el cual se corta el metal.

\section{Conflictos religiosos y censura de los grabados}

Desde que surgieron los primeros centros impresores los poderes públicos se encargaron de dar permiso o veto a su establecimiento. Muestra de la relevancia de estos centros para las monarquías europeas era la protección físcal que los Reyes

\footnotetext{
${ }^{82}$ ESTEVE BOTEY, F., op. cit., pp. 148-149.

${ }^{83}$ GONZÁLEZ DE ZÁRATE, J. M., Artistas grabadores en la Edad del Humanismo, Pamplona, Liber Ediciones, 1999, p. 148.

${ }^{84}$ FUGA, A., Técnicas y materiales del arte, Electa, Barcelona, 2006, p. 56.

${ }^{85}$ Ibídem.
} 
Católicos dieron al libro impreso, en un principio sólo a título particular y más adelante a todos los mercaderes de libros. En el lado contrario estarían las leyes restrictivas, como las persecuciones de libros desde finales del siglo $\mathrm{XV}$, las quemas y la obligación de poseer una licencia real para imprimir. El miedo al Islam y al protestantismo estuvieron muy relacionados con estas prohibiciones.

En el mundo protestante las estampas se utilizaron en muchas ocasiones como una expresión de su crítica hacia la Iglesia Católica, sus fieles y sus manifestaciones $\operatorname{artísticas~}^{86}$. De hecho, muchos impresores eran partidarios de la Reforma y por ello se negaron a imprimir grabados contrarios a la misma. En el mundo católico se aplicó la censura y la limpieza de las obras publicadas que no fueran consideradas ortodoxas ${ }^{87}$.

Así mismo, la obra de algunos pensadores críticos con el catolicismo como Erasmo de Rotterdam, influirá en los grabados de maestros tan famosos como Durero o Hans Holbein el Joven (ca. 1497-1543). Esta tendencia se difundió con bastante frecuencia en Alemania, mientras que, en otros lugares como los Países Bajos, sometidos al control del Imperio de Carlos V, se perseguían los documentos contrarios a la fe católica. Hubo también artistas como Lucas Cranach el Viejo (1472-1553) o Durero que trabajaron a la vez para católicos y protestantes.

El Concilio de Trento, que comenzó en el año 1545, promovió los movimientos contrarreformistas y el aumento del número de estampas de la religiosidad católica. Durante ese mismo periodo la Reforma aumentó el número de grabados costumbristas, históricos, alegóricos o antológicos. Tras la aprobación del Concilio de Trento en 1563 muchos artistas españoles tuvieron que adaptar las estampas tanto flamencas como italianas a un sentido de decoro en consonancia con la ideología imperante. A la Iglesia española le parecía indecorosa la libertad con la que se representaban algunos temas religiosos, sobre todo de origen italiano, así como la presencia de desnudos en algunas composiciones $^{88}$.

\footnotetext{
${ }^{86}$ EISENSTEIN, E., La revolución de la imprenta en la Edad Moderna europea, Madrid, Akal Ediciones, 1994, p. 46.

${ }^{87}$ HUIDOBRO, C., "El grabado en la Europa de Erasmo: Un arte nuevo", en Erasmo en España: la recepción del Humanismo en el primer Renacimiento español, Madrid, Seacex, D. L., 2002, p. 54.

${ }^{88}$ NAVARRETE PRIETO, B., op. cit., p. 44.
} 


\subsection{EL GRABADO EN ESPAÑA. PRINCIPALES IMPRENTAS ESPAÑOLAS.}

La adaptación de ciertas ideas compositivas o iconográficas recibidas a través de los grabados nórdicos e italianos a las pinturas y esculturas del arte español, al igual que el de otros lugares, no se debe interpretar como una falta de creatividad, sino como un medio a través del cual los artistas creaban un lenguaje propio, a menudo ecléctico, donde se mezclaba el estilo del Gótico tardío que había caracterizado los primeros años del siglo XVI español con la llegada de nuevas ideas procedentes del Norte y del Sur de Europa.

Como señala en su tesis Navarrete Prieto, la originalidad de un artista muchas veces dependió de su capacidad para usar y transformar otros modelos. El artista usaría las estampas de forma más habitual durante su periodo de aprendizaje, y pasaría más tarde al estudio del natural ${ }^{89}$. Autores como Palomino (1655-1726) ${ }^{90}$ o Pacheco (1564$1644)^{91}$ a su vez reivindicaron su uso como medio de estudio y no como mero descanso frente al trabajo duro que supone la inventiva.

Los grabados no dependían de un texto y, sobre todo, permitían reproducir obras de arte muchísimas veces, además de ofrecer la posibilidad de conocer las nuevas formas a los artistas que no podían viajar a otros países. Es importante también el factor económico de la difusión de la cultura, resaltado por el impresor alemán Pablo Hurus (doc. 1475-1500) ${ }^{92}$ y creador de algunos de los mejores incunables del siglo XV en Zaragoza. Su precio asequible facilitaba su difusión entre las diversas clases sociales.

Como ya se ha dicho, el estudio de estampas en los talleres era una etapa importante dentro de la carrera de un joven artista. A veces los propios comitentes proporcionaban los grabados a los artistas, encargando pinturas o esculturas de acuerdo con los nuevos gustos.

Los modos de copia de lo ajeno, como ya señalaran Pacheco ${ }^{93}$ y Palomino ${ }^{94}$, serían tres: las copias literales, sobre todo por parte de artistas sin personalidad o debido a requerimientos del comitente; las copias de algunos elementos parciales, que se

\footnotetext{
${ }^{89}$ Ídem, p. 26.

${ }^{90}$ PALOMINO, A., El Museo Pictórico y Escala Óptica, Madrid, Aguilar, 1988, p. 189.

${ }^{91}$ PACHECO, F., El Arte de la Pintura, Madrid, Cátedra, 1990, p. 434-435. Esta clasificación de los modelos de copia de lo ajeno ha sido especialmente investigada en algunos artículos como el de ECHEVERRÍA GOÑI, P. L., y VÉLEZ CHAURRI, J. J., "Las fuentes gráficas de las pinturas barrocas de los padres de la iglesia de Mendiguren (Álava) y la Cerca (Burgos). Fortuna de una invención de Pieter de Witte", Brocar, no 38, 2014, p. 165.

${ }^{92}$ CARRETE PARRONDO, J., op. cit., p. 27.

${ }^{93}$ PACHECO, F., op. cit., pp. 434-435.

${ }^{94}$ PALOMINO, A., op. cit., p. 189.
} 
podían usar en composiciones diversas con las que no tienen ninguna relación temática (por ejemplo la arquitectura, un gesto o los ropajes de un personaje); y por último, las composiciones propias que se crean inspirándose en la disposición general de masas y luces del modelo. Cuando se copiaba fielmente, como en algunas representaciones religiosas, se solía reproducir casi todas las figuras de la composición. En las utilizaciones parciales de estampas, se mezclaban diversos modelos, tomando de ellos sólo algún gesto o postura, mientras que lo demás se dejaba a la imaginación del artista. En ocasiones se invertían las posturas de las figuras. En opinión de Ana Ávila, el artista español se interesaba principalmente por la composición, adaptando algunas figuras y su distribución en el espacio ${ }^{95}$.

\section{Tipos de estampas}

Se comenzó por la importación y producción local de hojas sueltas grabadas, pero desgraciadamente sólo se conservan los grabados procedentes de fondos bibliográficos. Se sabe que se importaban con frecuencia estampas sueltas, como objetos de devoción, materiales de trabajo y documentación, que fueron usados ya desde el periodo gótico por parte de pintores y miniaturistas. De esta época destacan especialmente los grabados de Martin Schongauer, utilizadas por artistas de toda España y por xilógrafos españoles. Durante el siglo XV predominó la influencia de los grabadores germánicos, por el favor que los reyes españoles otorgaron a aquellos estados $^{96}$. Otro tipo de estampas fueron los llamados pliegos sueltos o remiendos. Son obras a medio camino entre la estampa suelta y el libro y a menudo estuvieron vinculadas a lo literario. Al igual que sucede con las primeras se conservan muy pocos ejemplares ${ }^{97}$.

A partir del siglo XVI, proliferaron los grabados en libros: bien libros extranjeros (libros españoles editados en Europa o libros europeos en latín) o bien producidos en España. El Renacimiento y sus innovaciones tardaron bastante en penetrar en la Península. La xilografía se mantuvo en las primeras décadas del siglo ${ }^{98}$.

A partir del segundo cuarto del siglo XVI destacaron los grabadores e impresores franceses e italianos, que establecieron contacto con los artistas y editores locales. A pesar de ello se observa una mayor influencia de grabados alemanes que

\footnotetext{
95 ÁVILA PADRON, A., "Influencia de Rafael en la pintura...," p. 61.

${ }^{96}$ GARCÍA VEGA, B., op. cit., t. I, pp. 14-15.

${ }^{97}$ GALLEGO, A., Historia del grabado en España, Madrid, Cátedra, 1979, p. 65.

${ }^{98}$ ESTEVE BOTEY, F., op. cit., p. 60.
} 
italianos. Las estampas extranjeras que circularon por la Península a partir de entonces aumentó de modo significativo ${ }^{99}$.

En cuanto a la función de los grabados dentro de los libros impresos se podría dividir en decorativa, decorativa-informativa o como complemento del texto escrito ${ }^{100}$.

\section{Imprentas españolas}

En España los impresores extranjeros representaron un tercio de la población total dedicada a la tipografía ${ }^{101}$. La primera imprenta establecida en España fue la de Segovia, que tuvo un papel de primer orden. Fue fundada en 1471 por un impresor alemán, Juan Porix de Heidelberge. Más tarde surgieron las de Valencia, Barcelona y Zaragoza. En todas ellas se publicaron los primeros libros impresos, pero aún sin estampas. Hasta bien entrado el siglo XVI predominaron los grabados aún influenciados por el estilo del siglo anterior, principal elemento que diferenciaba a la imprenta española de las de otros países europeos y que marcó su carácter conservador ${ }^{102}$.

Se debe subrayar que muchos de estos primeros impresores eran de origen extranjero, fundamentalmente italianos y alemanes. Esto se explica por las estrechas relaciones existentes en primer lugar entre España e Italia. Esta influencia italiana se dejó sentir sobre todo en las ciudades del Reino de Aragón, más próximas a Italia.

En segundo lugar estuvieron las imprentas de Sevilla, por aquel entonces un importante centro comercial, en el que la más relevante fue la influencia alemana, de modo que se distinguían dos núcleos: uno español y el otro alemán. En el español destacaron Segura, Del Puerto y Antón Martínez. Y en el alemán, fundado en 1490, Thomas Glockner, Paulo de Colonia, Magno Herbst y Juan Peguitzer, que juntos formaron el grupo de los Cuatro Compañeros Alemanes. Pero los mejores libros producidos en Sevilla salíeron del taller de Meinardo Unout y Stanislao Polono, que más tarde fundaron la imprenta de Alcalá de Henares (1502), también de gran relevancia para la época.

Destacables fueron también las imprentas de Valencia, propiedad de Lope de la Roca, Nicolás Spindelerg y Cristophus Hoffmann, así como las de Barcelona,

\footnotetext{
${ }^{99}$ GALLEGO, A., op. cit., pp. 100-103.

${ }^{100}$ VEGA GONZÁLEZ, J., op. cit., p. 61.

${ }^{101}$ DUPLESSIS, G., Histoire de la gravure en Italie, en Espagne, en Allemagne, dans le Pays-Bas, en Angleterre et en France, París, Librairie Hachette, 1880, pp. 123-128; AINAUD, J., Grabado y encuadernación, Ars Hispaniae, vol. XVIII, Madrid, Plus Ultra, 1954; GARCÍA VEGA, B., op. cit., t. I., 1982, p. 70;

${ }^{102}$ VEGA GONZÁLEZ, J., op. cit., p. 59.
} 
encabezadas por Juan Rosenbach (doc. 1490-1530), Pedro Pose, Pedro Miguel y Pedro Trinxer, en las cuales predominó la influencia italiana, aunque muchos de sus impresores fueran en realidad de origen alemán. En Valencia el panorama artístico fue mucho más variado y cambiante, aunque hay que destacar la importancia que tuvieron los mercaderes italianos en la sociedad de la época. La ciudad llegó a contar con una treintena de incunables salidos de sus imprentas ${ }^{103}$.

\section{Imprentas en relación con la zona soriana}

La imprenta de Zaragoza tuvo un carácter humanista ${ }^{104}$, relevante sobre todo para el estudio de la influencia del grabado en Soria debido a su proximidad. Destacó desde el siglo $\mathrm{XV}$ por sus impresiones de incunables, y más tarde por sus libros ilustrados realizados por los hermanos Hurus ${ }^{105}$. Dentro de esta familia sobresale la figura de Pablo Hurus, oriundo de Constanza (Suiza), que hasta 1475 se encontraba en Barcelona y un año después viajó a Zaragoza, donde se dedicó a la edición hasta 1500. Entre los años 1485 y 1490 abandonó su actividad en España para ir a Alemania en busca de nuevas técnicas con las que renovar la imprenta española ${ }^{106}$. Poseía tacos alemanes como el Viaje a Tierra Sancta (1489 de Bernard Von Breiden Bach), o adaptaciones de escenas de la Pasión de Martin Schongauer. Una de sus mejores xilografías fue el Gran Calvario de Theodoro de la Pasión de Andrés de Li (1494). Hans Hurus, probablemente pariente suyo, trabajó en Zaragoza entre 1488 y 1490 e imprimió obras españolas típicamente germánicas. En 1499 dejó su taller en manos de tres seguidores suyos: Jorge Coci (?-1546), Leonardo de Hutz y Wolf Appenteger. Los libros de Hurus son los más ricos en estampas de la época y eran muchas veces adaptaciones de otros modelos grabados alemanes, con frecuencia de escenas de la Pasión de Schongauer ${ }^{107}$.

\footnotetext{
${ }^{103}$ CARRETE PARRONDO, J., op. cit., pp. 27-28; BOSCH CANTALLOPS, M., Contribución al estudio de la imprenta en Valencia en el siglo XVI, Tesis Doctoral inédita defendida en la Universidad Complutense, 1989, pp. 9-10.

${ }^{104}$ GARCÍA VEGA, B., op. cit., t. I., p. 64; MORTE GARCÍA, C., “Huella de Durero...”, pp. 55-63.

${ }^{105}$ JANKE, R. S., "Algunos documentos sobre Pablo Hurus y el comercio de libros a fines del siglo XV", Príncipe de Viana. Anejo. Año XLVII, Anejo 2, 1986, p. 335; STOLS, E., Y THOMAS, W., op. cit., p. 38; PEDRAZA GRACIA, M. J., "El traspaso de la imprenta de Pablo Hurus: aportación documental para el estudio de la imprenta incunable zaragozana", Boletín del Museo e Instituto Camón Aznar, nº 68, 1997, p. 132; PALLARÉS JIMÉNEZ, M. A., La imprenta de los incunables de Zaragoza en el comercio internacional del libro en el último tercio del siglo XV, Zaragoza, Institución Fernando el Católico, 2008, pp. 61-62.

${ }_{106}$ GARCÍA VEGA, B., op. cit., t. I., p. 80.

${ }^{107}$ Ídem, t. II., pp. 147-148.
} 
Otras imprentas importantes serían las de Navarra y Castilla. Ciudades como Pamplona donde Arnao Guillén de Brocar (ca. 1460-1523) produjo obras desde 1492 hasta el comienzo del Renacimiento ${ }^{108}$; Salamanca, que fue un centro muy importante, aunque no destacó por el número y calidad de sus ilustraciones; Valladolid (de carácter más modesto); Toledo (con orígenes tempranos pero de limitado alcance y donde se estableció Pablo Hagenbach) o Burgos, que produjo algunos de los incunables españoles más bellos. Además, por su cercanía a Soria, destaca la de Logroño, una de las primeras en surgir en España, y famosa también por las impresiones del francés Guillén de Brocar.

En cuanto a la imprenta de Sigüenza, su origen parece remontarse a finales del siglo XV, pero no hay evidencias documentales hasta $1561^{109}$. Su fundación aparece también vinculada a sus obispos, por ser Sigüenza ciudad episcopal. Fue una de las más cercanas a la provincia de Soria, sobre todo si se tiene en cuenta que algunas de las localidades sorianas actuales formaban parte entonces de la diócesis de Sigüenza. Entre estos obispos destacables por su interés por la imprenta estaban don Pedro Pacheco y don Pedro la Gasca, ambos promotores del Breviario Seguntino ${ }^{110}$.

Dentro de la actual provincia de Soria la imprenta fundamental fue la de El Burgo de Osma fundada durante el mandato del obispo don Pedro Álvarez Acosta en colaboración con Diego Fernández de Córdoba (1517-1589). Fernández de Córdoba estuvo vinculado con un impresor conocido como Alonso Fernández de Córdoba, que llegó a España desde Italia en compañía de otros impresores y que más tarde se asentó en Valencia en 1478. Alonso fue uno de los introductores de la imprenta en España y podría ser el padre de Diego Fernández de Córdoba ${ }^{111}$.

Este último fue el sucesor de Pedro de Castro en Valladolid y continuó utilizando la misma marca de este último, la flor de lis con las iniciales P. C., aunque la familia Fernández de Córdoba también contó con su propia marca. Había comenzado a trabajar entre los años 1535 y 1536 en Palencia, de donde pasó a Valladolid, ciudad en la que aparece documentado en 1538. Diego y su hermano Francisco formaron una compañía y trabajaron juntos entre los años 1545 y 1548 hasta la muerte de Francisco. Vivió en Medina del Campo entre los años 1550 y 1551 y más tarde pasó de nuevo por

\footnotetext{
${ }^{108}$ CARRETE PARRONDO, J., op. cit., p. 29.

109 SANCHEZ DONCEL, G, "La imprenta, en Sigüenza", Anales Seguntinos, Revista de Estudios Seguntinos, vol. I, $\mathrm{n}^{\circ} \mathrm{I}, 1984$, p. 109.

${ }^{110}$ PECES RATA, F. G., "Obispos de Sigüenza, mecenas de la imprenta seguntina", Memoria Ecclesiae, no 33, pp. 301-306.

${ }^{111}$ GARCÍA VEGA, B., op. cit., t. II, pp. 63-64.
} 
Valladolid (1552), para instalarse posteriormente en Berlanga de Duero (1565) y El Burgo de Osma (1570). Poco después se documenta su presencia en Palencia (1572), en Medina de Rioseco (1575) y otra vez en El Burgo de Osma en 1586. Entre los años 1586 y 1589 aparece otra vez en Valladolid, primero asociado a su supuesto hermano Alonso Fernández de Córdoba y después imprimiendo solo.

Durante su estancia en El Burgo de Osma, en la época del obispo Álvarez de Acosta (1539-1563), Diego Fernández de Córdoba contribuyó a la creación de la imprenta en la misma ciudad, que se dedicándose a la publicación de libros litúrgicos. En concreto se encuentra documentado en el Burgo de Osma entre los años 1555 y 1570. Sin embargo parece que el impresor y el obispo ya estaban vinculados desde 1538, ya que en ese año Acosta le encargó la impresión de las Compilaciones Sinodales antiguas y nuevas del obispado de Osma. Más tarde, a partir de los años 50 comenzó a realizar otros encargos para el obispo: Breviarium (1555), Missale secundum (1561), Passionarium (1562), Cathechismus (1565) y Vergel de Música (1570) ${ }^{112}$. En el Missale encontramos varias estampas y orlas de tema litúrgico, como la Crucifixión (fig. 2) ${ }^{113}$, la Oración en el Huerto, el Descendimiento y el Sepelio. Se considera una de las obras litúrgicas más raras debido a la abundancia de grabados que contiene. Se encuentra un ejemplar en la Biblioteca del Cabildo de la Catedral de Burgo Osma, otro en la Biblioteca Nacional y otros dos en el Seminario Conciliar de la Catedral de El Burgo de Osma. También trabaja para la imprenta de Berlanga de Duero como demuestra la impresión de Ratio Acentuum (1565). Por último, en 1586 aparece de nuevo imprimiendo en El Burgo de Osma, con la edición de Las Constituciones Sinodales de Sebastián Pérez, y la Doctrina Cristiana del obispo Pedro Álvarez de Acosta.

\footnotetext{
112 ZAMORA LUCAS, F., "La imprenta en Burgo de Osma (1561-1570)", Revista de Archivos, Bibliotecas y Museos, t. XII, $\mathrm{n}^{\circ}$ 2, Madrid, 1956, p. 430.

113 Imagen procedente de la página web de la Biblioteca Nacional: URL: $\underline{\text { http://bdh- }}$ rd.bne.es/viewer.vm?id=0000187819\&page $=1$
} 


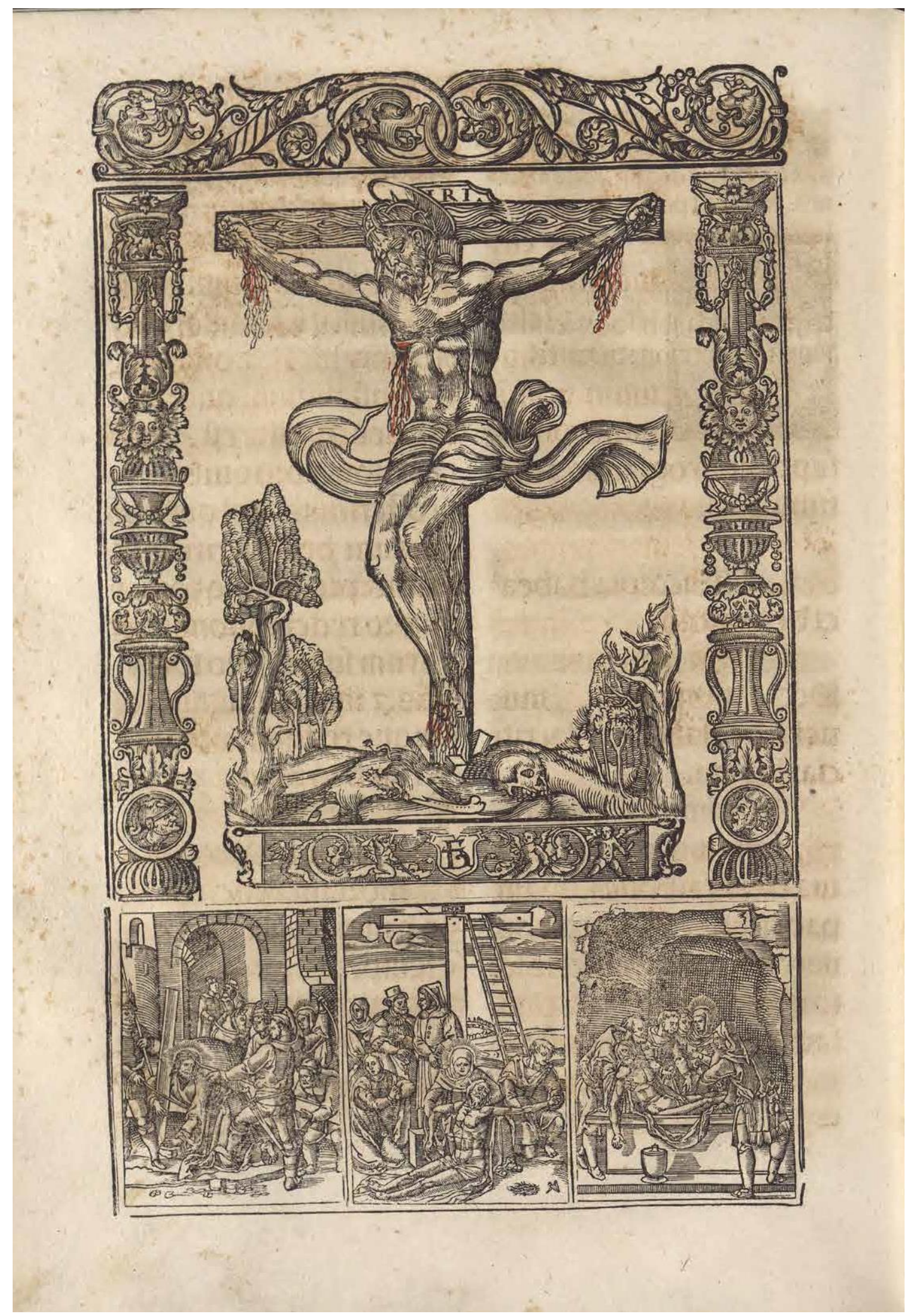

2. Diego Fernández de Córdoba. Missale secundum. 1561. p. 177. Biblioteca Nacional. 


\subsection{GRABADORES MÁS UTILIZADOS EN LA PROVINCIA DE SORIA.}

En general, los grabados más habituales que utilizaron los artistas fueron los de Schongauer, Alberto Durero y Marcantonio Raimondi.

Schongauer fue uno de los grabadores más influyentes en la pintura europea de las últimas del siglo XV y del siglo XVI. Se ha propuesto una estancia en algunos lugares de la Corona de Aragón ${ }^{114}$, pero no existe certeza de ello, al menos por el momento. Su estampa de la Huída a Egipto es uno de los más seguidos tanto dentro como fuera de Alemania. Las estampas de Schongauer llegaron a España relativamente pronto y fueron manejadas tanto por pintores como escultores o miniaturistas ${ }^{115}$.

Más adelante destacaron los grabados de Alberto Durero, que llegaron a España debido al aumento del comercio ${ }^{116}$. Su influjo en el arte español comienza desde los primeros decenios del siglo XVI como denotan las obras de artistas tan cercanos como Pedro de Aponte ${ }^{117}$.

Respecto a Raimondi, su obra fue un vehículo de difusión de la obra de Rafael y del arte clásico e influyó a muchos artistas desde la segunda década del siglo XVI abarcando también el siglo XVII.

Además de los grabados realizados por estos tres grandes artistas, se usan estampas de otros grabadores menores para algunas composiciones concretas, pero de manera más excepcional. En la nómina de grabadores cuya obra se refleja en pinturas o esculturas que se conservan en la provincia de Soria se puede distinguir claramente entre los de procedencia nórdica (alemanes y flamencos) e italiana. También se pueden dividir entre los del siglo XV, los de la primera mitad del siglo XVI y los de la segunda mitad del mismo, sobre todo en el caso de las estampas flamencas y alemanas. Respecto a los grabadores italianos, se considerarán separados a los pertenecientes al Quattrocento y al Cinquecento.

\footnotetext{
${ }^{114}$ FLECHSIG, E., Schongauer, Strasboug, Heitz, 1944, p. 120.

115 MATEO GÓMEZ, I., "Panorama de la pintura española del Renacimiento. Influencia del grabado alemán en España”, en Grabados Alemanes de la Biblioteca Nacional (siglos XV-XVI), t. I, Madrid, Biblioteca Nacional, Ministerio de Educación y Cultura, 1997, p. 18.

116 MATEO GÓMEZ, I., op. cit., t. I, p. 19.

${ }^{117}$ MORTE GARCÍA, C., "Los artistas de Aragón y sus patronos en el Renacimiento...", p. 56.
} 


\section{Grabadores nórdicos: Alemania y Flandes}

\subsubsection{Grabadores alemanes}

Dentro de este primer grupo destacan especialmente las estampas del grabador conocido como Maestro E. S., Martin Schongauer, Alberto Durero o Altdorfer entre $\operatorname{otros}^{118}$. Los grabados alemanes parecen haber influido de manera más evidente en la zona este de la actual provincia soriana, probablemente debido a su proximidad con los talleres de los hermanos Hurus.

\section{Maestro E. S. (ca. 1420- $c$. 1468)}

También conocido con el nombre de Maestro de $1466^{119}$. Este grabador alemán aparece ligado a las primeras tallas dulces realizadas en Alemania. Fue un importante grabador de talla en buril. Aunque el número de sus estampas ascendería a trescientas, en realidad sólo dieciocho aparecen firmadas con su monograma. Son características de su obra sus figuras extremadamente delgadas con cabezas grandes y desproporcionadas ${ }^{120}$. Otros detalles de importancia son la subordinación del dibujo a la expresión del sentimiento, elemento que proviene del arte gótico, así como el uso de pliegues duros y angulosos para las vestimentas.

Sus grabados son fundamentalmente de tema religioso e ilustran escenas bíblicas y hagiográficas. Una de las más utilizadas dentro de la provincia soriana es la Anunciación que sirvió de inspiración a los artistas, tanto para la Virgen, que aparece arrodillada en pose humilde y luciendo una larga cabellera, como por el ángel de grandes alas y ampulosas vestimentas. También sus interiores de carácter burgués, tan propios de mundo nórdico despertaron el interés de los artistas que trabajaron en Soria, en especial la cama de grandes doseles o el suelo ajedrezado formando dibujos geométricos.

Otra de sus obras más difundidas es la Lamentación ante el cuerpo de Cristo, datado entre 1450 y 1465 . De ella toman los pintores poses y expresiones dramáticas, aunque no solían adoptar la extraordinaria dureza con la que Maestro E.S. plasmó las complicadas vestimentas.

\footnotetext{
118 GÓNZALEZ DE ZÁRATE, J. M., Artistas grabadores..., pp. 61-87.

${ }^{119}$ BARTSCH, A., Le peintre graveur, vol. 6, Viena, J. V. Degen, 1808, pp. 1-3.

${ }^{120}$ GONZÁLEZ DE ZÁRATE, J. M., Artistas grabadores..., p. 64.
} 
Muchas veces se inspiran también en la ambientación de las escenas como es caso de la Natividad, datada entre 1450 y 1465. La arquitectura lignaria propia de las ciudades nórdicas servirá de modelo para muchas escenas de la Vida de Cristo, que pasaron a España a través de los grabados.

\section{Martin Schongauer (1430-1491)}

Schongauer formaba parte de una familia de orfebres y grabadores. El joven recibió su primera educación artística en el taller de su padre en Colmar ${ }^{121}$. También se dedicó a la pintura, aunque la gran mayoría de sus obras pictóricas se han perdido.

Dentro de su colección de estampas, más de un tercio son de tema religioso. Es obvio que no conoció el arte italiano y por ello sus grabados se inspiraron más en temas cotidianos que en la mitología clásica. Sus figuras son en muchas ocasiones deformes, de formas angulosas y desproporcionadas ${ }^{122}$. Mostró interés en el uso de la luz para otorgar mayor profundidad a las escenas y utilizó las medias tintas para crear un contraste entre luces y sombras y cierta sensación de volumen ${ }^{123}$. Se le han atribuido unos ciento quince grabados de los que veintinueve son escenas profanas basadas en la vida aldeana y mercantil. Schongauer logró innovar en la técnica de la estampa en cobre sacándola del nivel artesanal en el que se hallaba sumida y elevó el manejo del buril a la categoría de arte.

Las estampas del grabador alemán se utilizaron principalmente a finales del siglo XV y principios del XVI, siendo las primeras en llegar a la Península Ibérica. Uno de los primeros lugares en recibir su influencia fue la zona de Aragón donde había talleres de grabados de origen alemán como el de Pablo Hurus, que favorecía la difusión de estos modelos ${ }^{124}$. Este uso de las estampas de Schongauer influirá en el desarrollo del estilo del Gótico tardío en algunas zonas, y se extendió incluso hasta el Barroco.

Las más frecuentes por su uso en España fueron sus series dedicadas a episodios del Nuevo Testamento (Anunciación, Natividad, Epifanía, Prendimiento de Cristo, Lamentación ante el cuerpo de Cristo). Son especialmente importantes en la zona Este

${ }^{121}$ VV. AA., The Illustrated Bartsch. 8, formerly volume 6 (part 1), Early german artists, Nueva York, Abaris Books, 1978, pp. 1-8.

122 GONZÁleZ DE ZÁrATE, J. M., Artistas grabadores..., p. 67.

${ }^{123}$ GRIFFITHS, A., El grabado. Historia de un arte, Barcelona, Carroggio, 1981, p. 139; BARTSCH, A., op. cit., vol. 6, p. 111.

${ }^{124}$ LACARRA DUCAY, M. C., "Huella de Martin Schongauer en los primitivos aragoneses", Archivo Español de Arte, tomo 52, no 207, 1979, pp. 345-350; "Influencia de Martin Schongauer en los primitivos aragoneses", Boletín del Museo e Instituto Camón Aznar, no 17, 1984, pp. 15-40. Más recientemente, de la misma autora, "Influencia de Schongauer en la pintura gótica aragonesa, nuevas reflexiones", Artigrama, $\mathrm{n}^{\mathrm{o}}$ 32, 2017, pp. 4170. 
de Soria, fundamentalmente en Ágreda, donde se aprecia su huella en las obras de las iglesias de Nuestra Señora de la Peña (predela con escenas de la Vida de la Virgen) y de la Virgen de los Milagros (Retablo de San Lorenzo)

\section{Israel Van Meckenem (1440/1450-1503)}

Probablemente nació en torno a 1440-1450 en Meckenheim. Adquirió el título de maestro en el año 1480. El joven Israel se formó primero con su padre y después en un taller donde supervisó algunos de los grabados de Master E. S. En su obra se aprecian dos etapas: la primera de ellas hasta 1475, año del matrimonio con su esposa Ida, y que destaca por la escasa calidad de sus producciones. En esta época trabajó como orfebre y grabador en Bocholt. La segunda etapa comprendería desde 1475 hasta la fecha de su muerte. Es en esta época cuando sus obras son más originales: temas ornamentales, escenas religiosas, interiores...etc. Los temas religiosos supusieron una importante fuente de ingresos para el grabador, debido a que se vendían con las Indulgencias.

Muchas de sus estampas suponen copias de otros como Durero, Master E. S, Holbein el Viejo o Schongauer. Su obra se caracteriza por el fuerte carácter ornamental de sus composiciones, derivado de su oficio de orfebre y el influjo de Durero sobre su obra $^{125}$. Entre las obras utilizadas de Meckenem en la provincia de Soria encontramos la Lamentación ante el cuerpo de Cristo empleada para el Retablo de San Lorenzo (Ágreda) o la Huida de Egipto del Retablo de Nuestra Señora del Rosario en Montenegro de Cameros.

\section{Alberto Durero (1471-1528)}

Los grabados de Durero formaron parte no sólo de los repertorios artísticos de muchos de los artistas del siglo XVI, sino de algunos muy posteriores del siglo XVII ${ }^{126}$. Trabajó el cobre mediante el buril, la punta seca y el aguafuerte, mientras que sus xilografías destacaron por un dibujo vigoroso y preciso ${ }^{127}$, probablemente herencia de

\footnotetext{
${ }^{125}$ BARTSCH, A., op. cit., vol. 6, pp. 184-203. GONZÁLEZ DE ZÁRATE, J. M., Artistas grabadores..., pp. 39-40.

${ }^{126}$ LE BLANC, C., Manuel de l'amateur d'estampes 1550-1820, París, 1854, p. 160; DUPLESSIS, G., op. cit., p. 221; MEDER, J., Dürer Katalog, Viena, 1932; SÁNCHEZ CANTÓN, F. J., Durero en España, Diputación Provincial de Pontevedra, 1972, p. 28; GONZÁLEZ DE ZÁRATE, J. M., Artistas grabadores...., 1999, p. 69.

127 STRAUSS, W. L., The Illustrated Bartsch. 10. (Commentary), Sixteenth Century German Artists, Albrecht Dürer, Nueva York, Abaris Books, 1978, p. 5; PAYO HERNANZ, R., y ALONSO ABAD, Mª P., "Notas sobre la influencia de Durero en la plástica burgalesa: Francisco Carrillo y el Antiguo Retablo
} 
su educación en el taller del pintor y grabador Michael Wohlgemut desde los quince años ${ }^{128}$. En este campo tampoco tuvo precursores.

Otorgó a sus composiciones cohesión lógica y visual creando la perspectiva a través de transiciones lumínicas que crearon la ilusión de armonía y profundidad ${ }^{129}$. Las figuras del fondo fueron elaboradas a través de medias tintas delimitadas a través de líneas horizontales.

Respecto al grabado xilográfico, se considera que Durero se limitaba a realizar los dibujos o a diseñar las composiciones, que luego pasaban al grabado diversos artesanos, por tratarse de un trabajo lento y laborioso.

Entre sus obras más influyentes dentro del arte español están tres series de entalladuras publicadas en 1511: La Gran Pasión, La Pequeña Pasión y La Vida de María. El nombre proviene del formato de las estampas. Fueron realizadas probablemente a partir de 1509. En estas composiciones predomina la búsqueda de la nobleza y la dignidad por encima de los aspectos domésticos y burgueses. La grandiosidad de los ropajes, los gestos y los escenarios no limitan el sentimiento de ternura y gracia que transmiten muchas de sus figuras.

El tema de la Pasión, por otro lado, fue objeto de su interés tanto en xilografías como en grabado realizado con planchas de cobre. Sus dieciséis pequeñas láminas fueron fechadas en 1512, aunque probablemente habían sido comenzadas en 1507. Entre ellas estarían: La Pasión Albertina, La Gran Pasión (doce grabados), la Pequeña Pasión (treinta y seis estampas), la Pasión Verde y la Oblonga.

Respecto a la talla dulce, ésta alcanzó con Durero un alto grado de perfección técnica, además de una extraordinaria precisión en el dibujo. Fue la técnica preferida por Durero y la que le permitió plasmar con gran delicadeza los claroscuros, los fondos y los objetos ${ }^{130}$. Durero consiguió a través de esta técnica crear un equilibrio entre las partes sombreadas y las partes luminosas, lo que se traduce en una ilusión de relieve. Otros logros destacables de sus estampas son la atmósfera, la perspectiva y la proporcionalidad. Introdujo además temas muy variados, entre ellos los mitológicos, aunque sin renunciar a la tradición nórdica.

Mayor de Villazopeque (Burgos) y Cristóbal Ferrado y las pinturas de la iglesia de la Cartuja de Miraflores”, Boletín de la Institución Fernán González, no 242, 2011, pp. 8-9.

${ }^{128}$ BARTSCH, A., op. cit., vol. 7, p. 6; HUIDOBRO, C., Durero grabador, Madrid, Electa, 1999, p. 7.

${ }^{129}$ GRIFFITHS, A., op. cit., 1981, p. 142.

${ }^{130}$ GONZÁLEZ DE ZÁRATE, J. M., Artistas grabadores..., p. 78. 
Por último, destacan sus grabados en aguafuerte, que tuvo una gran difusión desde la segunda mitad del siglo XV en toda Europa. En esta técnica Durero fue también pionero. Utilizaba planchas de hierro en vez de las usuales de cobre, ya que resultan mucho más cómodas a la hora de utilizar el ácido. El uso del hierro imposibilitaba que se realizaran correcciones posteriores con el buril, por lo que su técnica no resulta tan vivaz y diversa ${ }^{131}$.

Los grabados de Alberto Durero fueron muy utilizados durante todo el Renacimiento. Se trata de uno de los grabadores más difundidos a través de toda la Península Ibérica. En la provincia de Soria parece que se usaron especialmente en las zonas oriental (Ágreda, Noviercas) y septentrional (Yanguas, Valdeavellano de Tera). Sus estampas de tema religioso sirvieron para copiar, bien algunas composiciones, o bien detalles específicos, como las arquitecturas del fondo, los ropajes de las figuras e incluso algunos objetos (véase el retablo de la iglesia de San Miguel en Ágreda, p. 137). Entre las más usadas encontramos la de San Francisco recibiendo los estigmas, en la cual San Francisco aparece arrodillado mostrando las palmas de las manos. Ha sido utilizada muchas veces, especialmente en retablos como el de San Esteban de Gormaz (véase escena del mismo título, p. 157), que se basa parcialmente en esta estampa para componer la escena del mismo tema, o en el de Caltojar, que copia la escena de manera literal. También las escenas del Camino del Calvario de Cristo, la Flagelación o la Anunciación, en la cual la Virgen aparece en la parte derecha del grabado inclinada frente a un atril y en posición orante, han sido muy utilizadas.

\section{Albrecht Altdorfer (1480-1538)}

Grabador de origen suizo procedente de una familia de artistas y pintores, también trabajó como arquitecto y pintor. La mayoría de sus grabados fueron realizados con las técnicas de la xilografía y el aguafuerte ${ }^{132}$. Fue uno de los más relevantes discípulos de Durero. No le interesaba la perspectiva, sino plasmar un mundo poético y fantástico $^{133}$. Su obra se caracterizó por la preocupación por los problemas lumínicos vinculados al paisaje a través del influjo del pintor y grabador Lucas Cranach (14721553).

\footnotetext{
${ }^{131}$ Id., p. 86.

${ }^{132}$ LE BLANC, C., op. cit., p. 30; DODGSON, C., Catalogue of early German and Flemish woodcuts: preserved in the Department of Prints and Drawings in the British Museum, vol. II, London, British Museum Trustees, 1903, p. 221; KOCH, R., The Illustrated Bartsch. 14, Early German masters: Albrecht Altdorfer, monogrammists, Nueva York, Abaris Books, 1978, pp. 9-173.

${ }^{133}$ VV. AA., Real Colección de Estampas..., t. I, p. 41.
} 
Se conoce a Altdorfer como uno de los "pequeños maestros" $" 134$, debido a las reducidas dimensiones de muchas de las planchas que utilizaba para crear sus grabados. Este grupo de grabadores se formó en Italia y difundieron esos ideales de gracia y belleza en los países nórdicos. Altdorfer creó composiciones muy elaboradas en superficies de reducido tamaño.

Las técnicas utilizadas para sus estampas fueron en primer lugar la xilografía y el grabado en cobre (1506-1511). Más tarde, en 1519, comenzó con el aguafuerte, convirtiéndose en uno de los pioneros de esta técnica.

Los temas de sus grabados son fundamentalmente bíblicos, mitológicos, históricos o paisajísticos ${ }^{135}$. Salvo algunas composiciones en las que copia obras de grabadores italianos como Raimondi, el resto de su producción es totalmente original.

En Soria encontramos uno de sus grabados utilizado como modelo para el retablo de San Medel y San Celedonio de la iglesia de San Miguel de Ágreda. Se trata del grabado San Jorge y el dragón, famosa composición que deriva de otras muchas anteriores, como la de Alberto Durero. La estética del caballero representado luciendo una aparatosa armadura con yelmo decorado con plumas sienta un precedente en la representación del personaje.

\section{Hans Schaufelein (1480/1485-1538/1540)}

Pintor y grabador que fue también discípulo de Durero, al igual que Baldung Grien. Nació en Nuremberg y en el año 1503-1504 entró a trabajar al taller de Durero. Tres años después se trasladó a Augsburgo para trabajar al servicio de Hans Holbein el Viejo. Entre 1508-1510 trabajó durante un tiempo en Austria. Poco después volvió a Augsburgo donde trabajó como ilustrador de libros y diseñador de vidrieras. En 1515 se trasladó a Nordlingen donde fue nombrado pintor Su obra grabada inicial se caracteriza por el fuerte influjo de Durero en los temas religiosos ${ }^{136}$. Este hecho se constata en grabados como Cristo cargando con la Cruz o La Santa Verónica que parecen haber influido en el Retablo de la Flagelación de Yanguas.

\footnotetext{
${ }^{134}$ BARTSCH, A., op. cit., vol. 8, p. 42.

135 GONZÁlEZ DE ZÁRATE, J. M., Artistas grabadores..., p. 89.

${ }^{136}$ BARTSCH, A., op. cit., vol. VII, pp. 244-245. DODGSON, Catalogue of early German..., vol. II, pp. 3-5.
} 


\section{Hans Baldung Grien (1484-1545)}

Fue discípulo de Durero en su juventud por lo que en su obra se ve claramente el influjo del maestro alemán. En su obra destacaron los temas alegóricos, religiosos y fantásticos ${ }^{137}$. En la provincia de Soria observamos el uso fundamentalmente de sus grabados sobre santos como San Jerónimo (Catedral de Burgo de Osma) o San Cristóbal (Iglesia de San Ginés, Ambrona). También su Descendimiento de la Cruz es posible que haya inspirado algunas composiciones del Retablo de San Francisco (San Esteban de Gormaz) o del Retablo de Santa Ana (Ágreda).

\section{Hans Sebald Beham (1500-1550)}

Fue un grabador, dibujante y miniaturista nacido en Nuremberg. Se inspiró en las formas clásicas de ciertas estampas italianas como las de Marcantonio Raimondi. Aunque fue acusado de herejía, motivo por el cual fue desterrado a la ciudad de Frankfurt, muchos de sus grabados tienen una potente carga cristiana. Su obra se ubica dentro del grupo de los llamados pequeños maestros, muy influenciados por el arte de Durero. En su labor grabadora destacó principalmente en el cobre, el aguafuerte y la madera.

Se vio influenciado tanto por Durero como por otros grabadores alemanes como el Maestro del Calvario, Altdorfer, Holbein e incluso su propio hermano Barthel, también grabador. Por otro lado, en su obra se hace patente también el influjo italiano de la obra de Raimondi ${ }^{138}$.

\subsubsection{Grabadores flamencos}

\section{Primera mitad del siglo XVI}

\section{Lucas de Leyden (1494-1533)}

Nació y murió en Leyden (actual Leiden, Holanda) ${ }^{139}$. Hijo de un pintor de vidrieras, del cual recibió su primera educación artística. Lucas se formó en su ciudad natal, que por aquel entonces tenía una gran importancia económica y comercial. Aunque se dedicó también a la pintura, destacó principalmente en el grabado actividad

\footnotetext{
${ }^{137}$ BARTSCH, A., op. cit., vol. VII. GONZÁLEZ DE ZÁRATE, J. M., Artistas grabadores..., p. 64.

138 ROSENBERG, A., Sebald and Barthel Beham, zwei Maler der deutscher Renaissance, Leipzig, Verlag Von E. A. Seemann, 1875, p. 27; GONZÁLEZ DE ZÁRATE, J. M., Artistas grabadores..., pp. 92-95.

${ }^{139}$ LE BLANC, C., op. cit., p. 84; HUIDOBRO, C. y TOMÉ VIRSEDA, C., Grabados flamencos y holandeses del siglo XVI; Madrid, Biblioteca Nacional, 2004, p. 18.
} 
en la que llegó a erigirse como fundador de la Escuela holandesa. Características de su obra son la introducción de la perspectiva aérea en la estampa y la expresividad, lo que podría proceder de algunos grabadores anteriores como Martin Schongauer, o de los gestos y actitudes de Leonardo Da Vinci ${ }^{140}$. Para lograr la impresión de lejanía utilizó recursos como la luz o el uso de líneas más vigorosas para los primeros planos y más suaves para los segundos.

En su obra fueron frecuentes tanto los temas sacros como los profanos, e incluso algunos de carácter ornamental. Destaca para el propósito de esta tesis su Adoración de los Magos, que fue muy utilizada, en especial para las figuras de los tres Reyes Magos de elegantes poses y gestos y ricas vestimentas o la Coronación de la Virgen, uno de los antecedentes para la representación de este tema dentro de la Península Ibérica.

\section{Segunda mitad del siglo XVI}

\section{Cornelis Cort (ca. 1533-1578)}

Además de grabador, trabajó también como orfebre y medallista. Nació en la ciudad de Hoorn, al norte de Holanda. Tuvo una estrecha relación con Italia, donde vivió hasta su muerte, en concreto en las ciudades de Venecia y Roma. Estuvo vinculado a artistas como Tiziano o los Zuccaro ${ }^{141}$.

Cort se distinguió fundamentalmente como grabador de reproducción. Fueron pocas sus obras originales. En ellas predominó el uso de la talla dulce, tan sólo con algunos ejemplos de aguafuertes al comienzo de su carrera ${ }^{142}$.

Durante sus primeros años, en 1567, trabajó al servicio de Hyeronimous Cock en Amberes. En su obra, como en la de muchos otros grabadores flamencos, tuvo gran relevancia el paisaje y en ella se revela una fuerte influencia de maestros italianos como Rafael, Miguel Ángel, Veronés (1528-1588) o Correggio (1489-1534). Es destacable su relación con Tiziano, para quien reprodujo muchas de sus obras.

Sus grabados fueron empleados en España a partir de la segunda mitad del siglo XVI, pero fueron igualmente muy difundidos. Especialmente importante es la Anunciación con la Virgen situada a la derecha junto a un atril con un libro cerrado, con

\footnotetext{
${ }^{140}$ GONZÁLEZ DE ZÁRATE, J. M., Artistas grabadores..., p. 104.

${ }^{141}$ BIERENS DE HAAN, J. C. J., L'oeuvre gravé de Cornelis Cort, graveur hollandais 1553-1578, La Haya, 1948; HOLLSTEIN, F. W. H., The New Hollstein: Dutch and Flemish Etchings, engravings and woodcuts 1450-1700, Cornelis Cort, part I, Sound \& Vision Publisher, Amsterdam, 2014; HUIDOBRO, C. y TOMÉ VIRSEDA, C., Grabados flamencos y holandeses del siglo XVI; Madrid, Biblioteca Nacional, 2004, p. 72, 192; NAVARRETE PRIETO, B., op. cit., p. 111.

${ }^{142}$ GONZÁLEZ DE ZÁRATE, J. M., Artistas grabadores..., p. 273.
} 
una mano extendida hacia delante y otra doblada hacia atrás, mientras que el ángel avanza con el brazo derecho alzado bendiciendo y la vara de lirio en el otro brazo.

También los escenarios de sus estampas han sido con frecuencia imitados por muchos artistas. Cort colocó habitualmente al fondo de sus composiciones arquitecturas clásicas, con frecuencia ruinas que asoman entre el paisaje, herencia de sus contactos con los artistas italianos.

\subsubsection{Grabadores italianos}

\section{Siglo XV}

En la primera etapa destacan los maestros grabadores de finales del siglo XV que, aunque no fueran tan empleados, sí tuvieron una gran importancia para el origen de la estampa en Italia. Es el caso de Francesco Rosselli (1447-1513), grabador de origen florentino que contribuyó a difundir el estilo del Quattrocento italiano, así como Andrea Mantegna (1431-1506), pintor y grabador muy interesado en los temas del volumen y la perspectiva.

\section{Francesco Rosselli (1447-ca. 1513)}

Además de grabador, también desempeñó el oficio de miniaturista y cartógrafo. $\mathrm{Su}$ forma de representar las figuras, a través de líneas en zig-zag, lo acerca a otros grabadores de la época como Mantegna o Pollaiuolo (ca. 1432-1498). Con mucha frecuencia tomó como modelos para sus estampas obras de artistas de su época, el Quattrocento italiano, como Botticelli (1445-1510) o Filippo Lippi (1406-1469) ${ }^{143}$. Muchos de sus grabados sirvieron de modelo por su decoración típica del arte italiano, en este sentido destaca la Virgen con el Niño en un trono entre Santa Helena y San Miguel, de los años 1480 al 1490. En su Asunción de la Virgen o Santo Tomás recibiendo el cíngulo de la Virgen tomó un tema típico de la religiosidad florentina que se difundió hasta llegar a lugares tan lejanos como Soria.

\section{Andrea Mantegna (ca. 1431-1506)}

Mantegna grabó pocas estampas, tan sólo veinte, pero con un estilo propio y original. Su labor se basó también en proporcionar sus modelos y diseños a grabadores de reproducción para que los transformaran en grabados. Entre estos grabadores

\footnotetext{
${ }^{143} I d .$, p. 35.
} 
destacaron Giulio Campagnola (ca. 1482-1514), Nicoletto da Modena (ca. 1490-1569) o Giovanni Antonio da Brescia (ca. 1461-1531) ${ }^{144}$.

Vasari, en sus Vite, atribuyó a Mantegna ser el primer grabador en talla dulce. El artista comenzó a demostrar su interés por el grabado 1459, lo que en un principio podría responder a una necesidad de difundir su obra pictórica más allá de sus fronteras.

Los contornos de sus composiciones aparecen muy marcados, lo que otorga a sus figuras un aspecto escultórico. Con frecuencia usó líneas oblicuas rígidas y paralelas $^{145}$. De Donatello asumió cierto sentido dramático de las figuras. Otras de sus características fueron el uso de una distribución muy particular de luces y sombras y la diversidad de actitudes de sus figuras. Mantegna mostró un gran interés por los temas de la Antigüedad. Dedicó gran parte de su tiempo a estudiar ruinas antiguas, y a contactar con los círculos humanistas de la época.

De las veintitrés estampas que se le atribuyen, se considera que siete salieron realmente de su mano, mientras que el resto son modelos suyos pero realizados por grabadores anónimos. Entre las composiciones originales está el famoso Descendimiento de Cristo, que ha influido enormemente en el arte español y también en el de la provincia de Soria, proporcionando un nuevo modelo sobre cómo representar el tema. Algunos ejemplos son el retablo dedicado a San Francisco en la iglesia de su advocación en San Esteban de Gormaz, o el bancal del retablo de los Santos Celedonio y Medel en la iglesia de San Miguel de Ágreda.

\section{Giovanni Antonio da Brescia (1461-1531)}

En realidad su nombre era Zuane da Asola. Se trata de uno de los grabadores más relevantes en talla dulce. De su obra se conservan tan sólo algunos nielos. Fue uno de los discípulos de Mantegna, en cuya obra se inspira para construir sus formas. De Mantegna tomó el uso de líneas muy delicadas y largas, y la tendencia a crear formas geométricas. Otro de sus modelos a la hora de realizar estampas sería Durero, del cual copiaría algunos modelos durante su estancia en Venecia ${ }^{146}$.

\footnotetext{
${ }^{144}$ BARTSCH, A., op. cit., vol. 13, p. 222; LE BLANC, C., op. cit., p. 596; HIND, A., Andrea Mantegna and the Italian Pre-Raphaelite Engravers, Londres, New York, 1911, pp. 6-15; GONZÁLEZ DE ZÁRATE, J. M., Artistas grabadores..., p. 47.

${ }^{145}$ GONZÁLEZ DE ZÁRATE, J. M., Artistas grabadores..., p. 48.

146 BARTSCH, A., op. cit., vol. 13, p. 315; DUPLESSIS, G., op. cit., pp. 52-53; HIND, A. M., Marcantonio and Italian engravers and etchers of the sixteenth century, New York, Fredk A. Stokes Company, 1912, pp. 5-7; GONZÁLEZ DE ZÁRATE, J. M., Artistas grabadores..., p. 55.
} 
En 1509 se trasladó a Roma, donde recibió influencia de artistas tanto florentinos como romanos. Por último, tomó como modelo para sus composiciones a Marcantonio Raimondi, perteneciente a la escuela romana del grabado, y a Baltassare Peruzzi (1481-1536) o Amico Aspertini (ca. 1474-1552), ambos pertenecientes a la escuela rafaelesca de dibujo.

Al final de su vida mostró gran interés en los temas mitológicos, como demuestra la realización de una serie de grabados basados en los trabajos de Hércules. Entre otras de sus obras basadas en la Antigüedad destaca una versión del Laocoonte, datada entre 1506 y 1520, actualmente en el British Museum, que sirvió de inspiración a muchos artistas como es el caso de Diego de Urbina en la pintura el Bautismo de Cristo o Diego de Madrid en algunas escenas del retablo mayor de la parroquia de Caltojar.

\section{Siglo XVI}

\section{Marcantonio Raimondi (ca. 1470-ca. 1534)}

Además de grabador, trabajó también como orfebre y pintor. Nació probablemente entre 1470 y 1480 .

Las técnicas más utilizadas por Raimondi en sus grabados fueron la talla dulce y el aguafuerte. En sus inicios tomó como modelo a Francesco Raibolini (ca. 1450-1517), con quien realizó algunos nielos y del cual pasó algunos dibujos a estampas. En general, Raimondi grabó siguiendo sus propias composiciones.

Entre 1507 y 1510 aparece documentado en el Norte de Italia, en concreto en Venecia, donde copió diversos temas tanto de Lucas de Leyden (1494-1533) como de Durero. Estas copias en cobre fueron tomadas en principio por auténticas del maestro alemán, lo que causó la denuncia del maestro italiano ante los tribunales, y le obligó a disponer de un monograma y marca propios. Otros artistas que influyeron en Raimondi durante esta etapa veneciana fueron Mantegna o Giorgione (ca. 1477-1510).

Una de sus características fueron las representaciones de los desnudos siguiendo los cánones clásicos, en particular los de Vitrubio, que caracterizaron al primer Renacimiento. En muchas ocasiones tomó los fondos de otros artistas para sus composiciones. Con el fin de difundir el arte de Rafael por toda Europa se creó un taller formado por alumnos seguidores de la estética de Raimondi. 
El mayor mérito de sus estampas es probablemente el haber captado hábilmente la estética del maestro de Urbino, así como difundir el canon clásico ${ }^{147}$. La labor de Raimondi como proveedor de un repertorio de formas a los artistas del Renacimiento y siglos venideros es innegable. En sus dibujos, Rafael siempre tenía en cuenta al grabador que debía pasarlos a estampa. Generalmente dichos dibujos estaban realizados a pluma y tinta en vez de usar el tradicional lápiz de hematites, con el objetivo de plasmar mejor los volúmenes ${ }^{148}$.

Los grabados de Raimondi fueron muy manejados durante todo el siglo XVI. Hay incluso obras, como es el caso del retablo de San Miguel en Ágreda, en las que se utilizaron varios grabados de Raimondi. Entre las obras más utilizadas dentro de las artes plásticas sorianas están el Pasmo de Sicilia, basado en la composición del mismo nombre de Rafael. Suele ser motivo de inspiración sobre todo para la figura de Cristo cargando con la cruz, o bien para uno de los soldados que con una cuerda va arrastrando a Jesús. Esta figura, de espaldas en un complicado escorzo, ha sido muy utilizada en la pintura, quizás por lo inusual de la postura. Otras obras de Raimondi que sirvieron como punto de partida fueron sobre todo sus diferentes modelos de la Virgen con el Niño. Es interesante el uso de la estampa de La Expulsión del Paraíso en la cual aparecen las figuras de Adán y Eva huyendo del Jardín del Edén, y cuyas poses fueron empleadas para la pintura del retablo de San Miguel de Ágreda.

\section{Agostino Veneziano (Musi) (ca. 1490-ca. 1540)}

Oriundo de Venecia, formaba parte de la familia Musi. Su estancia en Venecia sólo se prolongó hasta los años 1514 y 1515, poco después se trasladó a Florencia y por último a Roma, donde trabajó en el taller de Marcantonio Raimondi ${ }^{149}$. Desde los años 1527 hasta 1540, fecha de su muerte, permaneció en Roma ${ }^{150}$.

El estilo de Musi es deudor del clasicismo de Raimondi ${ }^{151}$, aunque también se inspiró en otros maestros del grabado como Giulio Campagnola, Alberto Durero o Jacopo Barbari (ca. 1460/70-ca. 1516). Como es lógico, Musi siguió los modelos que su maestro veneraba, como Rafael, Giulio Romano (ca. 1499-1546) o Miguel Ángel. A

\footnotetext{
${ }^{147}$ BARTSH, A., op. cit., vol. XV, p. 5; DUPLESSIS, G., op. cit., pp. 99-103; DELABORDE, H. Marc Antoine Raimondi: Etude Historique et Critique suivie d'un catalogue raisonné des ouvres du maitre, París, Librairie de l'art, 1888, p. 10; GONZÁLEZ DE ZÁRATE, J. M., Artistas grabadores..., p. 122.

${ }^{148}$ GRIFFITHS, A., op. cit., p. 144.

${ }^{149}$ DUPLESSIS, G., op. cit., pp. 104.

${ }^{150}$ BARTSCH, A., op. cit., vol. 14, p. 13.

${ }^{151}$ Ibídem.
} 
partir de 1520 se asoció al grabador Marco Dente (ca. 1490-1527). Musi abandonó Roma en 1527 debido al Saco de Roma, residiendo a partir de entonces en Florencia o Bolonia, hasta 1531, año en el cual volvió a Roma.

A pesar de que se le considera un grabador poco original, que se inspiró demasiado en el estilo de Raimondi, fue uno de los primeros introductores de la técnica del claroscuro, así como del tema de las academias a través de sus estampas, como la Academia de Baccio Bandinelli, del año 1531. En ella Musi parece manifestar cierta originalidad e innovación respecto al estilo de Raimondi.

En Soria destaca el uso de la estampa de La Virgen con el Niño y San Juanito, de 1516. Artistas como Juan Soreda se inspiraron en las figuras de los dos ángeles y de San Juanito. También su San Miguel (1518-1527), basado en un diseño de Rafael, ha influido en algunos escultores, como el del retablo mayor de la parroquia de Caltojar.

\section{Maestro del Dado (ca. 1512-1570)}

También fue conocido como Bernardo Daddi o Beatricius "El Viejo". Posiblemente nació en Padua o Verona y murió en la ciudad de Roma.

A pesar de las complicaciones de su identificación, el Maestro del Dado se presenta ante todo como un grabador fundamentalmente de reproducción. Sus modelos creativos fueron sobre todo Rafael y Giulio Romano. Su obra se caracterizó por cierta tendencia a errores anatómicos, como extremidades o cabezas demasiado grandes o musculosas $^{152}$

Una de las obras principales dentro de su producción son las Bodas de Psique, compuesta por treinta y dos láminas. La mayoría de sus composiciones son de carácter mitológico o profano, así como algunas de tema esotérico. Sus composiciones han servido de inspiración a muchos artistas, especialmente por su uso de elementos propios de la decoración clásica, como putti, guirnaldas o sarcófagos.

\section{Marco Dente (ca. 1490-1527)}

Originario de Rávena, en muchas ocasiones aparece nombrado como Marco de Rávena $^{153}$. Fue famoso fundamentalmente por sus grabados en talla dulce. Se le suele vincular artísticamente en muchas ocasiones con Agostino Veneziano. Merecen

\footnotetext{
${ }^{152}$ BARTSCH, A., op. cit., vol. 15, p. 181; GONZÁLEZ DE ZÁRATE, J. M., Artistas grabadores...,, pp. 131-132.

${ }^{153}$ DUPLESSIS, G., op. cit., pp. 104-105.
} 
destacarse su calidad y exactitud a la hora de copiar composiciones de otros, especialmente de Raimondi. Sin embargo, sus líneas tienen menos delicadeza y son más gruesas que las de Raimondi. Sus modelos artísticos fueron por una parte Rafael y los del círculo de Raimondi y por otra las esculturas de la Antigüedad Clásica ${ }^{154}$

En ocasiones se hace difícil distinguir la obra de Dente de la del propio Raimondi. Entre sus estampas más célebres encontramos el Laocoonte, El Juicio de Paris o la Anunciación, en la cual se inspiran artistas como Juan Soreda o Pedro del Cerro, tanto para la figura del ángel como para la de la Virgen.

\section{Giorgio Ghisi (1520-1582)}

Dibujante y grabador, fue originario de Parma, aunque su familia llevaba afincada en Mantua desde el siglo XIV ${ }^{155}$. Su padre era Giovanni Battista Ghisi (15031575), más conocido con el nombre de Scultori. Su familia formaba parte de una gran estirpe de grabadores, entre los que destacan los hermanos: Theodoro (1536-1601), Adamo (1530-1585) y Diana (1547-1612). Los tres fueron educados en el taller de su padre y recibieron el influjo de artistas como Rafael o Giulio Romano. Su obra se inspiró en Giulio Romano y Raimondi. En su técnica destaca que sus líneas son suaves y redondeadas ${ }^{156}$.

Su obra comenzó en 1540 en Roma, en colaboración con el editor Antonio Lafreri $^{157}$. En esta época se inspiró en las composiciones de los artistas italianos más célebres, como Miguel Ángel y Rafael. Ghisi visitó Flandes en 1551, en concreto estuvo en Amberes colaborando con Hieronymus Cock en su taller Aux Quattre Vents ${ }^{158}$. Ghisi trabajó a las órdenes de Tiziano y fue maestro de otros muchos grabadores importantes, como Agostino Carracci o Cornelis Cort. Una de sus obras más difundidas fue la Escuela de Atenas, basada en la pintura de Rafael de las Estancias Vaticanas.

\section{Adamo Scultori (ca. 1530-1585)}

Fue otro de los hijos de Giovanni Battista Scultori y hermano menor de Giorgio Ghisi. Nació en Mantua en torno a 1530. Recibió su primera educación artística en el

${ }^{154}$ BARTSCH, A., op. cit., vol. 14, p. 16; GONZÁLEZ DE ZÁRATE, J. M., Artistas grabadores...,, pp. 135-136.

${ }^{155}$ BOORSCH, S., y SPIKE, J., The Illustrated Bartsch. 31, Italian artists of the sixteenth century, Nueva York, Abaris Books, 1978, pp. 28-153; DUPLESSIS, G., op. cit., pp. 113-114.

${ }^{156}$ GONZÁLEZ DE ZÁRATE, J. M., Artistas grabadores..., p. 140.

${ }^{157}$ LEWIS, M. \& R. E., The Engravings of Giorgio Ghisi, New York, Metropolitan Museum, 1985, p. 16.

${ }^{158}$ BARTSCH, A., op. cit., vol. 15, p. 374; GONZÁLEZ DE ZÁRATE, J. M., Artistas grabadores..., p. 141. 
taller de Mantua. Su obra está muy influenciada por la obra de Giorgio Ghisi, aunque algunos autores consideran que su dibujo no posee la fuerza del de su hermano ${ }^{159}$. Sus composiciones son mucho más parecidas a las de su hermana Diana. Entre sus obras más relevantes encontramos sus setenta y tres estampas inspiradas en los modelos de la Capilla Sixtina de Miguel Ángel, que han servido de modelo a artistas como Diego de Urbina. También su Flagelación (1547-1587), basada en la pintura de Sebastiano del Piombo de la iglesia de San Pietro in Montorio, ha sentado un precedente compositivo, especialmente para las figuras de los dos sayones (véase el Velo de Pasión de la Catedral de El Burgo de Osma, catálogo de obras, p. 203) ${ }^{160}$.

\section{Parmigianino (ca. 1503-1540)}

$\mathrm{Su}$ nombre auténtico era Francesco Mazzuola. Fue pintor, dibujante de entalladuras y grabador en aguafuerte. Nació en Parma. Se le consideró un pionero del aguafuerte $^{161}$, aunque también realizó obras en claroscuro. Cuando utilizó esta técnica combinó dos modos de hacer: las planchas de madera y la impresión al aguafuerte ${ }^{162}$.

Uno de sus maestros más importantes fue Correggio. Su estilo se caracterizó por la elegancia, la delicadeza, la luminosidad, las figuras de canon alargado (estrecho y de cabeza pequeña) propias del Manierismo, pero con un toque particular que se conoce como parmigianismo. En su obra la mancha se impone a la línea, y crea contornos de trazos ininterrumpidos ${ }^{163}$.

Grabó pocas estampas, pero su estilo se extendió rápidamente hasta Francia, donde su estética impregnará el modo de hacer de la Escuela de Fontainebleau. Su tendencia a los temas mitológicos y profanos favoreció esa fascinación. Además, asentó una nueva escuela de grabado al aguafuerte, cuyo representante más importante fue Andrea Meldolla (Schiavone).

Uno de sus grabados más difundidos dentro de la provincia soriana es la Virgen con el Niño, San Sebastián y un obispo en la cual se toma la alargada figura del santo mártir como modelo para muchas composiciones. También el Entierro de Cristo o la Resurrección sirven como inspiración por sus estilizadas formas y complicadas poses,

\footnotetext{
159 BARTSCH, A., op. cit., vol. 15, p. 375; DUPLESSIS, G., op. cit., pp. 111-112; GONZÁLEZ DE ZÁRATE, J. M., Artistas grabadores..., p. 142.

${ }^{160}$ COLLAR DE CÁCERES, F., “Diego de Urbina... ”, pp. 113-115.

${ }^{161}$ BARTSCH, A., op. cit., vol. 16, p. 4.

${ }^{162}$ DUPLESSIS, G., op. cit., pp. 86-89; ZERNER, H., The Illustrated Bartsch. 32, Italian artists of the sixteenth century: school of Fontainebleau, New York, Abaris Books, 1978, pp. 9-22.

${ }^{163}$ GONZÁLEZ DE ZÁRATE, J. M., Artistas grabadores..., p. 162.
} 
sin olvidar el elemento paisajístico en obras como el Velo de Pasión de la Catedral de El Burgo de Osma.

\section{Andrea Meldolla (Schiavone) (ca. 1520-ca. 1583)}

Pintor y grabador nacido en Zara (Dalmacia), no se conocen las fechas exactas de su nacimiento y muerte. Su personalidad resulta enigmática, de modo que no se sabe con certeza si Andrea Meldolla y Schiavone fueron la misma persona ${ }^{164}$. Los grabados en talla dulce aparecen firmados con el nombre de Meldolla, mientras que en los realizados en aguafuerte aparece el de Schiavone ${ }^{165}$.

Meldolla fue asociado desde el principio con artistas de origen veneciano como Giorgione o Tiziano. Más tarde su maestro fundamental pasó a ser Parmigianino. En su obra predominaron los temas religiosos sobre los profanos.

Su estilo se caracterizó por la elegancia, recurso que tomó de las estampas de su Parmigianino. Meldolla utilizó una técnica del aguafuerte distinta de la de su maestro. Se basaba en el retoque de las planchas usando el buril, a través de la punta seca, dándole un estilo más innovador a sus composiciones. Muchas veces pasaba a estampa composiciones de Parmigianino, por lo que es difícil diferenciar la obra del alumno de la de su maestro.

\section{Cherubino Alberti (ca. 1553-1615)}

Pintor y grabador en cobre; los temas de sus composiciones fueron fundamentalmente religiosos, históricos o retratos. En sus estampas se observó la influencia de otros maestros italianos, como Agostino Carracci (1557-1602) ${ }^{166}$ o flamencos, como Cornelis Cort, al que muchas veces se considera su verdadero maestro. Su obra se caracterizó por la búsqueda de la plasticidad y de los matices cromáticos a través del modelado. Sin embargo, las figuras muestran unos pliegues duros, y sus composiciones revelan su dificultad para trabajar con el claroscuro.

Cherubino trabajó fundamentalmente siguiendo la técnica de la talla dulce. Generalmente copió las composiciones de otros grandes maestros, como Rafael o Miguel Ángel. Una de sus composiciones más utilizadas es el grabado que reproduce la pintura de la Flagelación de Cristo, obra de Sebastiano del Piombo (1485-1547) que se

\footnotetext{
${ }^{164}$ BARTSCH, A., op. cit., vol. 16, p. 31; DUPLESSIS, G., op. cit., p. 87.

165 ZERNER, H., op. cit., t. 32, pp. 37-112.

${ }^{166}$ BARTSCH, A., op. cit., vol. 16, p. 45.
} 
encuentra en San Pietro in Montorio, en la que se inspiraron varios pintores, sobre todo en la figura de Cristo atado a la columna y en los dos sayones situados a los lados. Existen muchas versiones de esta escena, entre las cuales destaca la de Adamo Scultori realizada en torno a 1547-1587, en la versión del British Museum, o la otra, anónima, fechada entre 1530 y 1587, en la versión de la Biblioteca Nacional (Madrid).

\section{Giulio Bonasone (ca. 1498-1580?)}

Se trata de uno de los discípulos de Raimondi. Le interesó más la difusión de temas muy diversos y la figura humana, que los elementos secundarios como el paisaje o la atmósfera ${ }^{167}$. Se formó con Raimondi con Bolonia. Se caracterizó por la destreza del dibujo, pero sin aportar ninguna innovación. Utilizó en un principio la técnica del grabado en cobre, tomando como modelo al propio Raimondi y a Caraglio. Más adelante se dedicó al aguafuerte, en el que siguió el modelo de Gian Battista Franco, de quien tomó además su interés en los temas mitológicos de la Antigüedad Clásica.

Otros de sus maestros en cuanto a la técnica fueron Giovanni Battista Scultori y Parmigianino. Durante sus últimos años volvió a utilizar la técnica del buril imitando a otros grabadores como Cornelis Cort y Agostino Carracci ${ }^{168}$.

Normalmente sus grabados imitaron modelos de sus propios dibujos ${ }^{169}$. En cuanto a la temática son muy variados: religiosos, profanos, retratos, arquitecturas o ilustraciones de libros. Muchos de sus modelos proceden de obras de Miguel Ángel, Rafael, Tiziano, Giulio Romano o Pontormo. Bonasone fue fundamentalmente un grabador de reproducción. Muchas de sus estampas fueron difundidas gracias al editor Lafreri.

Entre sus obras de mayor recepción destacan especialmente los grabados que reproducen escenas y personajes del Juicio Final de Miguel Ángel (1546-1550), muy utilizadas por artistas seguidores del arte italiano como Diego de Urbina.

Por último, otros grabadores menos utilizados pero sin duda muy relevantes serían el flamenco Lambert Suavius (1515-1568), famoso por sus retratos de personajes históricos; el flamenco Monogramista FVB (doc. 1480-1500), discípulo de Van Meckenem, y uno de los primeros en introducir la perspectiva en los grabados; el francés Nicolás Beatrizet (1507-1570), que trabajó fundamentalmente en Roma; y el

\footnotetext{
${ }^{167}$ Ibídem.

${ }^{168}$ VV. AA., Real Colección de Estampas..., t. I, p. 195.

${ }^{169}$ BARTSCH, A., op. cit., vol. 15, p. 106; DUPLESSIS, G., op. cit., pp. 106-107.
} 
italiano Jacopo Caraglio (1500-1565) de técnica muy próxima a la de Marcantonio Raimondi.

\section{5. ACCESO DE LOS ARTISTAS A LOS GRABADOS.}

¿Cómo llegaban estas obras a España? Ciertos artistas viajaban a Italia para completar sus estudios y allí adquirían estampas. Pero esto no era lo más frecuente. Lo habitual era que los artistas se abastecieran a través del comercio de grabados, sobre todo a través de los puertos marítimos o fluviales de ciudades como Barcelona o Sevilla, famosas por el comercio de grabados. Muchas veces las estampas pasaban de mano en mano en los talleres de los propios artistas. En el mercado español se intercambiaban los productos españoles por obras de arte, entre ellos grabados; incluso se llegaban a solicitar estampas de artistas específicos En el caso de los grabados nórdicos, flamencos y alemanes, éstos llegaban a los artistas españoles debido a las estrechas relaciones de Flandes y Alemania con Castilla durante los siglos XV y XVI ${ }^{170}$.

Se producían copias de composiciones en casas de imprentas y países diferentes. Esta circunstancia se daba especialmente en España, donde existía una concepción gremial y artesanal del artista que explica su carácter receptor de estampas, más que creador. El papel de la estampa fue fundamental en los procesos creativos de muchos artistas españoles de la época.

Dado que Soria se encontraba en un punto de tránsito entre Castilla y Aragón, recibió influencias muy diversas de ambas regiones. Por ejemplo, es conocido el hecho de que en Zaragoza existieron talleres de grabados de origen alemán como los de los hermanos Hurus, que facilitaron la difusión de los modelos nórdicos a través de la estampa por toda la zona, aunque los modelos italianos fueron igualmente muy frecuentes, llegados seguramente a través del Mediterráneo, quizás a través de Barcelona o Valencia. Así mismo, Valladolid, centro político de la Península, ejerció como imán de influencias artísticas sobre todo del norte de Europa, dadas las estrechas relaciones entre la Corona, Flandes y Alemania, que favorecían la llegada de estampas y dibujos procedentes de estas zonas. Por otro lado, es importante destacar el papel que jugaron los mercaderes italianos ${ }^{171}$ en la zona soriana desde el siglo XIII hasta el XVII.

\footnotetext{
${ }^{170}$ MATEO GÓMEZ, I., op. cit., t. I, p. 17.

${ }^{171}$ Ejemplo de la actividad de estos mercaderes italianos en zonas del Norte de España como Navarra es el artículo: TARIFA CASTILLA, M. J., "El comercio de estampas entre Roma y España a finales del siglo XVI: el caso del mercader italiano Antonio Pisano", Archivo Español de Arte, 357, Enero-Marzo 2017, pp. 49-66.
} 
Soria fue una de las comarcas que más contribuyó a las exportaciones laneras de la Corona de Castilla ${ }^{172}$. A pesar de ello, la intensidad de la presencia italiana fue mucho menor en el entorno del Alto Duero. Ningún mercader de origen italiano llegó a fijar su residencia en la provincia de Soria ${ }^{173}$.

La difusión de estampas se llevaba a cabo a través de tres grupos de profesionales: los grabadores, los impresores y los libreros. Las primeras referencias a la autoría de los grabados en España las encontramos en portadas de libros, en las cuales aparecen las identidades de los impresores y editores, pero no de los ilustradores. Era diferente el artista que proporcionaba el dibujo del que grababa las láminas o tacos. En este segundo caso se trataba de profesionales o plateros que llevaban a cabo una traducción o interpretación de las composiciones originales de otros, fueran éstas dibujos, pinturas o grabados españoles o extranjeros.

Este comercio de estampas permitió que se conociera a los pintores más célebres fuera de sus fronteras, lo que favoreció un cierto monopolio del lenguaje, ya que se impusieron muchos modelos artísticos. Por otro lado, la obra se deformó al pasar por tantas manos. La elección de los temas que se debían pasar a grabado también fue decisiva, pues se prefirieron los dibujos o pequeñas pinturas a los frescos o retablos. La transmisión de la obra de un artista respondía más a la elección realizada por el editor que a su propia realidad ${ }^{174}$.

Otro fenómeno a destacar fue el uso de grabados de procedencia extranjera en impresiones españolas ${ }^{175}$. Los grabadores alemanes y flamencos fueron los primeros en establecerse en España, pero sobre todo pertenecía a este ámbito figurativo la mayoría de las estampas que circularon, lo que explicaría el carácter nórdico de muchas de las ilustraciones, y la vigencia del estilo flamenco en la pintura y la miniatura durante la segunda mitad del siglo XVI.

En España había poco interés en la imprenta. Las primeras ilustraciones que se produjeron datan del siglo XV, y tuvieron un carácter medieval. Más adelante, ya en el siglo XVI, llegaron unas ediciones de mayor calidad marcadas por el ambiente del Humanismo y la Contrarreforma.

\footnotetext{
${ }^{172}$ DIAGO HERNANDO, M., "Mercaderes italianos en Soria durante el siglo XVI", Celtiberia, ${ }^{\circ}{ }^{107}$, 2013, p. 199.

173 Id., p. 241.

174 MELOT, M., op. cit., p. 56.

175 AINAUD, J., Grabado $y \ldots$, p. 245
} 
Las estampas podían también transmitirse a través de los propios artistas, quienes a menudo las dejaban en herencia a sus descendientes. Es el caso de Gabriel de Pinedo quien en su testamento legó a su hijo grabados ${ }^{176}$ y otros utensilios del oficio de escultor, o el de Juan Soreda, que transmitió a su amigo, el pintor Luis del Castillo, algunas estampas en sus últimas voluntades ${ }^{177}$. También era frecuente que los artistas compraran directamente a libreros o algún estampero en la calle como ya señalara Navarrete Prieto ${ }^{178}$.

Otras veces la necesidad podía obligar a los artistas a vender sus estampas, en almoneda pública. Por ejemplo, Bartolomé de Ávila ${ }^{179}$ (doc. 1595-1616) vendió algunas de sus grabados a un tal Esteban Salazar, según consta en un documento de $1608^{180}$. En ocasiones los artistas, sobre todo los de menor calidad, se veían obligados a vender sus utensilios y estampas en tiendas al aire libre o en los propios obradores ${ }^{181}$.

En España no todos los artistas poseían una cultura humanística ni tenían acceso a fondos bibliográficos que les permitieran enriquecer sus obras. Era fundamental que el artista poseyera conocimientos sobre Historia, Doctrina de la Iglesia o Mitología clásica. Al parecer otra de las fuentes fundamentales para estos artistas eran los sermones, en particular después de los decretos postconciliares ${ }^{182}$.

Entre las bibliotecas y fondos de libros impresos del Renacimiento, destacó la Biblioteca del monasterio de El Escorial, fundada por Felipe II. Acogía las producciones más importantes en España desde la segunda mitad del siglo XVI, y en su mayor parte se trataba de donaciones de procedencia regia. Para el estudio que nos ocupa son especialmente significativas las colecciones de estampas flamencas, alemanas e italianas. El monarca vinculó su coleccionismo de modelos a su política religiosa. Su principal proveedor de estampas fue Amberes, ciudad flamenca en la cual se ubicaba la

\footnotetext{
${ }^{176}$ MANRIQUE MAYOR, M., op. cit., t. IV, 1987, pp. 398-407; A.H.P.S, prot.506, fol. 404 Francisco Ruiz del Campo, Testamento de Gabriel Pinedo, escultor, vecino de Soria, 30 de Agosto, 1624.

${ }^{177}$ NAVARRO TALEGÓN, J., op. cit., p. 15.

178 NAVARRETE PRIETO, B., op. cit., p. 82.

${ }^{179}$ LASSO DE LA VEGA Y LÓPEZ DE TEJADA, M., op. cit.; ARRANZ ARRANZ, J., "Renacimiento y Barroco", en PÉREZ RIOJA, J. A. (Dir.,), Historia del Soria, Almazán (Soria), Ingrabel, 1985; ID, La escultura...; MANRIQUE MAYOR, M. A., op. cit.; VV. AA., Inventario artístico de Soria y su provincia. Tomo II. Arciprestazgos de San Pedro Manrique y Soria, Madrid, Ministerio de Cultura, 1989; PÉREZ DE GRACIA RODRÍGUEZ, M. V., "Noticias sobre los pintores Bartolomé de Ávila y Francisco Leonardo de Chavaçier”, De Arte, nº 17, 2018, pp. 43-58.

${ }^{180}$ Documento recogido sin transcripción por M. A. MANRIQUE MAYOR, op. cit., t. III, p. 278; AHPS, Protocolos Notariales, Martín de Esparza, Signatura 338, vol.635, fol. 94r.-v; PÉREZ DE GRACIA RODRÍGUEZ, M. V., op. cit., p. 51.

${ }^{181}$ NAVARRETE PRIETO, op. cit., p. 80.

182 Ídem, p. 64. DÁVILA FERNÁNDEZ, M. P., Los sermones y el arte, Valladolid, Universidad de Valladolid, 1980.
} 
firma Plantin-Moretus. Ésta fue considerada la imprenta más importante del mundo durante la segunda mitad del siglo XVI. Ambos lograron el permiso de España para vender sus libros litúrgicos. Junto con estos libros se importaban también los grabados que los ilustraban. El objetivo de dicha acumulación de estampas no era otro que servir de disfrute al propio monarca ${ }^{183}$.

Felipe II ya había mostrado su gusto artístico a través de los viajes que realizó tanto a Italia como a los Países Bajos. Ambos países eran importantes productores de estampas. Después de Felipe II, los monarcas españoles no compartieron su interés, ni contribuyeron a aumentar ni clasificar dichos grabados. Felipe II mantuvo estrechas relaciones con algunos grabadores de renombre, como el ya citado Plantino o Philippe Galle, quienes le enviaban estampas regularmente, muchas de las cuales hoy forman la colección de El Escorial.

Otra de las figuras fundamentales por su vinculación a Felipe II fue Benito Arias Montano, el bibliotecario del Monasterio del Escorial, que se ocupó de organizar todo el material que albergaba siguiendo las instrucciones del monarca. Fue un personaje muy interesado en los temas artísticos, y conoció a diversos grabadores y artistas ${ }^{184}$. Realizó, además, diversos viajes a Flandes e Italia, en los cuales adquirió libros y se relacionó con personajes vinculados a las imprentas europeas.

Durante cuarenta años el Rey logró crear una colección de unas siete mil estampas, entre las cuales se incluyen las de algunos de los artistas más importantes de la época ${ }^{185}$. González de Zárate advirtió que gran parte de las piezas fueron grabados anónimos, probablemente obra de artistas que aún no habían ingresado en el gremio y que carecían del derecho a firmar con su propio nombre. El hecho de que en la Colección aparezcan grandes artistas junto a otros muchos anónimos, parece justificar la idea de que su interés era fundamentalmente iconográfico y no cualitativo. La colección se formó en el siglo XVI, momento en el cual la estampa se incluyó dentro de una importante industria de editores, intelectuales y artistas ${ }^{186}$.

La mayoría de las estampas que componen la colección corresponden a cuatro orígenes: Flandes, Italia, Alemania y Francia. La causa de la escasa repercusión que ha obtenido esta colección de grabados quizás se deba a que toda la fama se la han llevado

\footnotetext{
${ }^{183}$ VV. AA., Real Colección de Estampas..., t. 1, 1992-1996, pp. 5-7.

${ }^{184}$ LÓPEZ GUILLAMÓN, I., "Benito Arias Montano y la Biblioteca Escurialense", Revista de Estudios Extremeños, vol. 52, n 3, 1996, p. 980.

${ }^{185}$ VV. AA., Real Colección de Estampas..., t. 1, p. 7.

${ }^{186}$ Ídem, p. 17.
} 
el resto de obras artísticas del monasterio escurialense, como son las pinturas, las esculturas o la arquitectura. Sin embargo, no se puede negar que existe un fuerte nexo entre dichas pinturas y esculturas y las estampas que alberga la colección.

La función principal de la formación de esta colección fue la creación de una base iconográfica que nutriera el programa artístico del Monasterio y también el ideario artístico del propio Rey ${ }^{187}$. La mayoría de los grabados corresponden a tres grandes bloques iconográficos: mitología, religión y simbólico. Otros temas que están presentes en menor medida son la arquitectura, los paisajes, las vistas y monumentos o los usos y costumbres. Muchas de las estampas representan edificios o vistas arquitectónicas de la Antigüedad clásica, lo que suponía una importante fuente de inspiración para muchos artistas que construían los fondos de sus pinturas a través de estas arquitecturas ${ }^{188}$.

Aparte de esta gran biblioteca escurialense, fue frecuente que otros bibliófilos (nobles o eclesiásticos) poseyeran fondos librarios importantes que los artistas podían utilizar $^{189}$. Es el caso de Pedro de Aponte, que tuvo que conocer la estampa de La expulsión del Paraíso de Raimondi, seguramente siguiendo las instrucciones del doctor Carrascón ${ }^{190}$. La nobleza también reunió importantes fondos de estampas y libros en sus bibliotecas, bien con un sentido devocional, si se trataba de grabados religiosos, o bien históricos, como retratos de emperadores o vistas de ciudades (aunque a veces se usaran como repertorio decorativo) ${ }^{191}$. Muchas de estas estampas se guardaban en los oratorios o en los escritorios del dueño de la vivienda. Los libros de grabados eran muy valorados y muchas veces se tasaron con el precio más alto ${ }^{192}$.

Otro elemento digno de mención fueron los obradores o talleres de los artistas, en los cuales normalmente se encontraban libros, grabados y modelos necesarios para

\footnotetext{
${ }^{187}$ Ídem, p. 16.

188 Al principio se trata simplemente de ubicar las escenas en un espacio real, posteriormente la arquitectura adquiere una mayor autonomía convirtiéndose en un objeto estético independiente. RODRÍGUEZ G. DE CEBALLOS, A., "Los fondos arquitectónicos de la pintura del Siglo de Oro", en VV. AA., El Siglo de Oro de la pintura española, Madrid, Mondadori, 1991, p. 223.

${ }^{189}$ NAVARRETE PRIETO, B., op. cit., p. 64.

${ }^{190}$ VV. AA., El retablo de San Miguel de Ágreda (Soria)..., p. 65.

${ }^{191}$ GONZÁLEZ GARCÍA, J. L., "La colección, librería y relicario de D. Francisco Hurtado de Mendoza, Primer Marqués de Almazán (1532-1591)”, Celtiberia, no 92, 1998, p. 204.

${ }^{192}$ Hernando de Ávila (ca.1538-1595), pintor renacentista que trabajó en la zona de la cuenca del Duero, poseía algunos libros de estampas, sin que sepamos si se trataba de libros impresos o de un álbum en el que se recopilaban diversas estampas sueltas encuadernadas. Entre ellas destacaban un libro de estampas de Durero, posiblemente el de la Gran Pasión, uno de cosas de Rafael (quizás estampas de Raimondi) y un repertorio de estampas del maestro Luca (Lucas van Leyden). También destacaría la colección de estampas del Sumario de Juan de Herrera (1530-1598). ATERIDO FERNÁNDEZ, A. y ZOLLE BETEGÓN, L., "Pintura y Letras: Hernando de Ávila, su biblioteca y su herencia", Anuario del Departamento de Historia y Teoría del Arte, no 11, 1999, p. 148.
} 
aprender el arte de la pintura o de la escultura ${ }^{193}$. Dentro de la provincia soriana destacó el taller de Herreros. Aunque no existen pruebas fehacientes, es muy probable que su existencia se remonte a finales del siglo XVI; desgraciadamente sólo se conservan los fondos a partir del siglo XVIII, momento en que se comienzan a valorar las estampas en España $^{194}$.

Hay que considerar que en aquella época la mayoría de la población era analfabeta; si sabían leer, los artistas poseían un número discreto de libros, pero no grandes bibliotecas. Del resto de la población, por otro lado, sólo los caballeros de las ciudades, el alto clero, los intelectuales o los mercaderes tenían un nivel adquisitivo suficiente como para poder permitirse comprar libros de estampas ${ }^{195}$. Entre los más frecuentes estaban los de Durero seguidos por los de Marcantonio Raimondi, Lucas de Leyden o Schongauer ${ }^{196}$.

Tanto los libros como los grabados proporcionan información de carácter artístico (la composición o modelos clásicos), histórico o mitológico. En las bibliotecas de los artistas predominan los libros de carácter religioso. En muchos casos se trataba de biblias ilustradas, vidas de Santos, el Flos Sanctorum o manuales de ascética o moral ${ }^{197}$.

Las bibliotecas facilitaban a los artistas gran número de imágenes, composiciones y obras fundamentales que les guiaban para crear sus composiciones ${ }^{198}$. La repercusión que tuvo la obra del Escorial entre los artistas tanto del siglo XVI como del XVII se testimonia porque frecuentemente contaban en sus bibliotecas con algún ejemplar de "Las Estampas del Escorial" realizadas por el grabador flamenco Pierre Perret (h. 1555-1625), entre los libros de su biblioteca; esto, manifiesta el interés de muchos artistas por las nuevas ideas ${ }^{199}$. En los inventarios de artistas destacan también las estampas de episodios bíblicos. Las más frecuentes eran las de Durero, así como libros que ilustraban sus teorías a través de grabados como Simetría y Geometría ${ }^{200}$. A muchos artistas, como es el caso de Soreda, se les atribuye un supuesto viaje a Italia,

\footnotetext{
193 NAVARRETE PRIETO, B., op. cit., p. 64.

${ }^{194}$ SAINZ MAGAÑA, E., El taller de Herreros, Trazas y estampas rescatadas del olvido, Caja Duero, Soria, 2009, p. 105.

195 GARCÍA VEGA, B., op. cit., t. I, pp. 15-16.

${ }^{196}$ MARTÍN GONZÁLEZ, J. J., "Las bibliotecas de artistas: una aplicación de la estadística”, Boletín de la Real Academia de Bellas Artes de San Fernando, nº 61, 1985, p. 139.

${ }^{197}$ NAVARRETE PRIETO, B., op. cit., p. 66.

198 Ídem, p. 111.

${ }^{199}$ MARTÍN GONZÁLEZ, J. J., "Las bibliotecas de artistas...”, p. 126.

200 Además también destaca la presencia de libros sobre anatomía, arquitectura clásica y medallística. SOLER I FABREGAT, R., "Libros de arte en bibliotecas de artistas españoles (siglos XVI al XVIII): aproximación y bibliografía”, LOCUS AMOENUS 1, 1995, pp. 154-158.
} 
aunque podrían haber accedido al arte italiano a través de otras muchas fuentes, como estampas, libros o pinturas. En muchos inventarios de artistas aparecen citados los grabados que poseían y en algunos casos especificando el nombre de los mismos. A veces no se diferenciaba entre dibujo y estampa, aplicándose los nombres de papeles de dibujo o envoltorio de muchos papeles ${ }^{201}$.

Otra de las colecciones más importantes de España es la que actualmente se conserva en la Biblioteca Nacional. La colección abarca estampas desde el siglo XV hasta la actualidad. Dentro de la época renacentista, que es la que nos interesa, son especialmente destacables las colecciones de grabadores como Alberto Durero o Lucas Cranach $^{202}$.

\section{6. PRINCIPALES ARTISTAS ACTIVOS EN TIERRAS SORIANAS QUE UTILIZARON GRABADOS}

Entre los bienes que poseyeron los artistas más importantes que estuvieron activos en Soria durante el siglo XVI se encontraban las estampas, a las que recurrieron como un medio para configurar su obra de acuerdo con las nuevas formas y composiciones de los artistas extranjeros y como ayuda para desarrollar a su vez un estilo propio. Cuando esto ocurría, el artista era capaz de transformar la composición en algo personal y original, inspirándose en la estampa de manera casi desapercibida ${ }^{203}$. Los grabados también tuvieron una aportación importante entre los artistas menores, que copiaban literalmente las figuras y las composiciones de las estampas que llegaban a sus manos.

\section{Miguel Ximénez $(f l$. 1462-1505)}

Pintor oriundo de Pareja (Guadalajara), está documentado en Zaragoza desde 1462 hasta 1505. Su personalidad aparece con frecuencia ligada a otros dos pintores famosos de la misma época: Martín Bernat (fl. 1450-1505) y Bartolomé Bermejo (1440h. 1500). También conocía, como se deduce de algunos documentos, al impresor Pablo

\footnotetext{
${ }^{201}$ SOLER I FABREGAT, R., op. cit., pp. 150; MORTE GARCÍA, C., "La colección de pinturas, tapices, dibujos...", p. 137.

${ }^{202}$ Biblioteca Nacional de España, "Colecciones de grabados", Web de la Biblioteca Nacional de España. URL: http://www.bne.es/es/Colecciones/Grabados/

${ }^{203}$ MORTE GARCíA, C., Aportaciones al estudio de la pintura ..., pp. 378-379; ÁVILA PADRON, A., "Influencia de Rafael...", p. 62.
} 
Hurus $^{204}$. Su estilo pertenece al Gótico tardío ${ }^{205}$, muy influenciado por los grabados de Schongauer ${ }^{206}$ y otros maestros nórdicos. En él abundan algunos elementos propios del Gótico, como el uso del dorado para el fondo de las composiciones (lo que les confiere cierto carácter inmaterial) así como para los ropajes y los nimbos de los personajes ${ }^{207}$. Su obra evoluciona desde un estilo más puramente gótico hasta otro más naturalista, suelto y que anuncia un incipiente Renacimiento ${ }^{208}$. Otra de sus características es la búsqueda de expresión psicológica y de fuerza dramática, ambas con influencia de la pintura nórdica, en especial de las estampas de Schongauer. Ximénez creaba una impresión de volumen a través de los paisajes continuos ${ }^{209}$. Al parecer, este pintor fue el primero en España que se sirvió de grabados para enriquecer sus escenas ${ }^{210}$. Destacó por haber sido nombrado pintor del monarca Fernando el Católico el 2 de mayo de $1484^{211}$. Dentro de la provincia soriana es destacable la predela del retablo mayor de la iglesia de Nuestra Señora de la Peña de Ágreda, con escenas de la Vida de la Virgen ${ }^{212}$. En ella utilizó varias estampas de Schongauer para desarrollar las escenas plasmadas sobre fondos dorados.

\section{Maestro de Osma}

Fue un pintor de transición entre la época del Gótico y la del Renacimiento. Se le puede identificar con el llamado Maestro de Sinobas. Su obra se caracterizó por los elementos nórdicos e italianos, pero con una técnica bastante elemental, sin ningún alarde de tipo expresionista ni de belleza. Otra de sus características es el misticismo y el candor que desprenden sus figuras. Ligado a esto, su obra mantuvo ciertos elementos medievales como las vestimentas (muchas veces adornadas con brocados de oro) o los planos colocados de manera escalonada. Entre sus obras fundamentales destacaron las pinturas del retablo de San Ildefonso, actualmente en el Museo Diocesano del Burgo de

\footnotetext{
${ }^{204}$ SERRANO Y SANZ, M., op. cit., pp. 446-448.

${ }^{205}$ MORTE GARCÍA, C., La pintura aragonesa del Renacimiento ..., p. 281.

${ }^{206}$ LACARRA DUCAY, C., "Influencia de Martin Schongauer...”, pp. 20-22; MORTE GARCÍA, C., Aragón y la pintura del Renacimiento..., p. 38-39.

${ }^{207}$ ID, "Tendencia europea en la pintura altoaragonesa...", p. 75.

${ }^{208}$ GUDIOL RICART, J., La pintura medieval...., p. 64.

${ }^{209}$ Ibídem.

${ }^{210}$ VELASCO GONZÁLEZ, A., op. cit., p. 193.

211 YARZA LUACES, J., op. cit., p. 115; ORTIZ VALERO, N., op. cit., p. 272.

${ }^{212}$ POST, Ch. R., op. cit., t. XIII, p. 375.
} 
Osma, y el retablo de la Colegiata de Berlanga de Duero (1516), situado en la capilla de los Coria $^{213}$.

\section{Alonso Sedano (doc. 1486-antes de 1533)}

En su obra fue evidente la utilización de grabados nórdicos como los de Schongauer $^{214}$. También hay presencia de lo italiano, especialmente en cuanto a los fondos arquitectónicos de sus composiciones. Sedano debió de formarse primero en un ambiente flamenco, para más adelante conocer la obra de los italianos del primer Renacimiento. Sus primeras fuentes serán los cuadros de Memling, Diego de la Cruz o el "Maestro de Salomón de Frómista". Parece ser que se formó fuera de Castilla, probablemente en Palma de Mallorca. Se le atribuye una estancia en Italia, en concreto en Nápoles ${ }^{215}$. Su obra abarcó lugares tan distanciados unos de otros como Palma de Mallorca, Burgos, Soria (Retablo de Nuestra Señora de la Asunción en la parroquia de Montenegro de Cameros) ${ }^{216}$. Se caracterizó por la riqueza de los colores con abundancia de tonos rojizos, verdes y amarillos. Mostró poco interés por la belleza, simplificando volúmenes y con un particular estilo para configurar la composición ${ }^{217}$. Cada una de sus figuras presenta un gesto muy preciso con el fin de lograr fines expresivos. Otra de sus cualidades es que sus composiciones no provocan sensación de ahogo, siendo bastante hábil en el tratamiento del espacio, en comparación con otros maestros de la época. A pesar de algunos residuos góticos que se mantienen en su obra, no abusa de los dorados, utilizando este detalle sólo como un elemento accesorio. La riqueza se transmite en la obra de Sedano a través de elementos arquitectónicos o de las vestimentas de las figuras $^{218}$.

\section{Juan Soreda $(f l .1506-1537)$}

Las obras de este pintor de origen incierto se ubican en la zona oriental de Castilla: Soria, la zona septentrional de Guadalajara (Atienza y Sigüenza) y el Este de

\footnotetext{
213 CAMÓN AZNAR, J., La pintura española..., pp. 227-229; AZCÁRATE, J. M., Arte gótico..., pp. 388-389; ARA GIL, C. J., op. cit., p. 144; PARRADO DEL OLMO, J. M., "Cantoral música gregoriana”, pp. 102-103; YARZA LUACES, J., op. cit., p. 166; PARRADO DEL OLMO, J. M., "Cantoral de música gregoriana", p. 304; MUNTADA TORRELLAS, A., Cantorales del Monasterio de San Jerónimo de Espeja..., p. 87.

${ }^{214}$ SILVA MAROTO, P., Pintura hispanoflamenca castellana ..., t. III, pp. 738-739.

${ }^{215}$ GUDIOL RICART, J., Pintura gótica..., pp. 370-371.

${ }^{216}$ CAMÓN AZNAR, J., Pintura medieval..., p. 604.

217 SILVA MAROTO, P., "Retablo de la Virgen", en Paisaje interior: Las Edades del Hombre, Fundación Las Edades del Hombre, 2009, nº 70, pp. 360-361.

${ }^{218}$ ID., Pintura hispanoflamenca..., t. III, pp. 738-739.
} 
Valladolid (Olivares de Duero). Por su apellido se le ha adjudicado un origen catalán, en concreto de la zona de Mallorca ${ }^{219}$, aunque también podría ser de origen aragonés o valenciano $^{220}$. Autores como Mayer ${ }^{221}$ o Camón Aznar ${ }^{222}$ le atribuyen un origen aragonés. Post lo vinculó a la escuela Aragonesa, si bien lo calificó como "castellano", teniendo en cuenta que la mayoría de sus obras se ubican en la zona este de Castilla, aunque muy cerca ya de Aragón ${ }^{223}$. Otros le otorgan un origen portugués, debido a su vinculación con el obispo Fadrique de Portugal ${ }^{224}$. También se barajó la posibilidad de que procediera de la zona de Toledo, relacionándolo con el foco toledano de Juan de Borgoña, opinión defendida por autores como Fernando Marías ${ }^{225}$. Fuera cual fuese su origen, desde luego no desarrolló su actividad artística en ninguna de estas zonas. Soreda debió de sentirse atraído por la riqueza artística de la diócesis de Osma, tal y como sucede con otros artistas del siglo XVI, como Diego de Urbina. También se le atribuiría un origen soriano, debido a que muchas de sus obras se ubican en Soria ${ }^{226}$.

De cualquier modo, el pintor aparece ya como una figura de gran prestigio dentro de la diócesis de Sigüenza en $1506^{227}$. Su actividad en esta zona se hace constante hasta 1512 y entre 1521 y 1528 . Tenía ya su propio taller y en él trabajaba el oficial Pedro de la Puente desde 1512. Al final de su vida vivió en el Burgo de Osma, y seguramente trabajó al servicio de algunos de los obispos de Osma, como Alonso Enríquez (1506-1523), García de Loaysa (1525-1532) y Pedro González Manso (15321539).

Durante su actividad como pintor, Soreda se vio muy influenciado por diversos artistas, tanto españoles (Juan de Borgoña, Yáñez de la Almedina) como italianos (Miguel Ángel, Rafael, Leonardo) $^{228}$.

Esta influencia italiana le llegó probablemente a través de un viaje a Italia que realizaría en sus primeros años de actividad, o bien a través de estampas o de contactos con otros artistas que las poseían. Uno de estos artistas podría haber sido Alonso Berruguete (ca. 1490-1561), como ya señaló Ana Ávila, con el que compartió actividad

\footnotetext{
${ }^{219}$ RAMOS GÓMEZ, F. J., Juan Soreda, p. 97.

${ }^{220}$ ÁVILA PADRÓN, A., "Juan Soreda y no Juan Pereda..., p. 413.

${ }^{221}$ MAYER, A., op. cit., pp. 63-64. Le llama Juan Pereda o Perea.

${ }^{222}$ CAMÓN AZNAR, J., La pintura española del siglo XVI..., p. 237.

${ }^{223}$ POST, R. C., op. cit., t. XIII, p. 227.

${ }^{224} I d .$, , t. IX, parte 2, p. 701.

${ }^{225}$ MARÍAS FRANCO, F., El largo siglo XVI...”, p. 313.

${ }^{226}$ ÁVILA PADRÓN, A., "Juan Soreda...,", p. 413

${ }^{227}$ RAMOS GÓMEZ, F. J., Juan Soreda...., pp. 96-97.

${ }^{228}$ ÁVILA PADRÓN, A., "El pintor Juan Soreda...", pp. 136-145.
} 
artística en Valladolid (Olivares de Duero) ${ }^{229}$, aunque estilísticamente no tuvieran nada en común.

Hay constancia de que Soreda poseyó estampas porque dejó en testamento algunas al pintor Luis del Castillo $^{230}$. Utilizó sobre todo estampas italianas (Marcantonio Raimondi, Agostino Veneziano, Marco Dente, Francesco Rosselli) pero también acudió a algunas de origen nórdico, como hizo en las pinturas del Monasterio de Santa María de Huerta (principalmente de grabadores como Durero o Lucas de leyden). Con frecuencia copió sólo determinadas figuras, rara vez la composición entera.

Aunque existe la teoría de que podría haber adquirido muchas de estas estampas en un viaje a Italia, realizado en sus primeros años, también sería factible que las hubiera adquirido en el comercio español. Dicho viaje a Italia podría haberse realizado durante el pontificado de León X (1513-1521) y hasta el año 1519, formando parte del cortejo de Fadrique de Portugal o de Bernardino de Carvajal $^{231}$. La documentación disponible parece vincular a Soreda más con Fadrique de Portugal que con Bernardino de Carvajal, aunque el pintor trabajó con ambos, y desarrolló su obra también al servicio de algunos de los obispos de Osma. En caso de que el presunto viaje italiano hubiera llegado a realizarse se barajan distintas fechas, dependiendo del obispo con el que viajara. En opinión de Ramos Gómez, si el viaje tuvo lugar entre 1512 y 1515, es más probable que lo hiciera con Bernardino de Carvajal, mientras que si se trasladó a Italia entre los años 1515 y 1520, debió de formar parte del séquito de acompañó a Fadrique de Portugal $^{232}$.

A pesar de ello, no hay certeza de que dicho viaje a Italia se hubiera realizado. Por su parte, otros autores como Fernando Marías defienden que, dada la superficialidad con la que adopta algunos rasgos de la pintura italiana, es más probable que tuviera en su poder estampas o dibujos que la posibilidad de que hiciera algún viaje a Italia ${ }^{233}$. Lo cierto es que en muchas ocasiones utilizó modelos italianos de manera bastante literal y sin ningún interés en el disimulo, como por ejemplo en la Virgen de la Silla o en la Anunciación, ambas en la Concatedral de San Pedro. Sin embargo, en otras obras, como las pinturas de Santa María de Huerta, presenta un influjo de la pintura de Leonardo en

\footnotetext{
${ }^{229}$ ÁVILA PADRÓN, A., “Juan Soreda...,", p. 137;

${ }^{230}$ NAVARRO TALEGÓN, J., op. cit., p. 15.

${ }^{231}$ RAMOS GÓMEZ, F. J., Juan Soreda ..., p. 100.

232 Íd., pp. 100-101.

${ }^{233}$ MARÍAS FRANCO, F., El largo siglo XVI..., p. 313.
} 
los rostros y la captación de la atmósfera, que es difícil que hubiera podido aprender tan sólo a través de estampas.

Algunos estudiosos, como Fernando Marías, consideran su estilo poco original y excesivamente dependiente de dichos modelos italianos. Se critica también su precario uso de la perspectiva en muchas composiciones, lo que para algunos denotaría que realmente no estuvo en Italia ${ }^{234}$. Murió en 1537 en El Burgo de Osma, donde trabajó durante sus últimos años.

\section{Pedro de Aponte (? -1530)}

De origen aragonés, vivió en el primer tercio del siglo XVI y fue uno de los pintores aragoneses más activos durante el primer tercio del siglo $\mathrm{XVI}^{235}$. Su producción abarcó los años que median entre 1507 y 1529, y se repartió a lo largo de un amplio espacio geográfico. Durante su primera etapa se centró en la zona de Aragón, principalmente en Zaragoza y Huesca; en la segunda, se ubicó más en Castilla y Navarra y en la zona Oeste de Aragón que lindaba con ambas regiones y se relacionó con otros artistas que se habían formado en ambientes italianos ${ }^{236}$. Aunque en principio su obra estuvo muy inspirada por los modelos de la tradición hispano-flamenca, con el tiempo fue incorporando imágenes de origen centro-europeo o italiano, a las que accedía a través del grabado. Estas estampas las adquiriría en la propia Zaragoza, que contaba con una importante imprenta regentada por maestros alemanes. En su obra, Aponte muestra más interés por la expresividad y el sentido dramático de las escenas que por la belleza formal ${ }^{237}$, hecho corroborado por su uso de estampas de origen nórdico, como las de Durero. Carmen Morte considera que el pintor no se limita a copiar las composiciones del maestro alemán, sino que las convierte en creaciones personales $^{238}$. Fernando Marías le adjudica a su obra un cierto carácter arcaico en ese

\footnotetext{
${ }^{234}$ Ídem, pp. 313-314.

${ }^{235}$ Durante esta época se señala especialmente la influencia de grabadores nórdicos como Durero, Martin Schongauer, Israel van Meckenem o Lucas Cranach el Viejo, o italianos como Mantegna o Pollaiuolo. MORTE GARCÍA, C., "Los artistas de Aragón y sus patronos en el Renacimiento...”, p. 56.

${ }^{236}$ ANGULO IÑÍGUEZ, D., op. cit., pp. 73-75; POST, Ch. R., op. cit., t. XIII, 1966, p. 79; MORTE GARCÍA, C Aportaciones al estudio de la pintura de Aragón..., 1981, pp. 730-732; La pintura aragonesa del Renacimiento..., vol. 2, 1985, p. 285; "La obra del pintor Pedro de Aponte o del Ponte en Navarra...", 1986, p. 565; Aragón y la pintura del Renacimiento, 1990, pp. 66-78; "Las artes figurativas del Renacimiento aragonés...", 1996-1999, pp. 33-72; “Los artistas de Aragón y sus patronos en el Renacimiento: los proyectos figurativos...”, 2009, pp. 54-79; GAETA, L., op. cit., 2012, p. 81; NAVAL MAS, A., op. cit., 2016, p. 106. URL: http://www.antonionavalmas.net/spip.php?article88.

${ }^{237}$ MORTE GARCÍA, C., "La personalidad artística de Pedro de Aponte...", p.221.

${ }^{238}$ ID., "La obra del pintor Pedro de Aponte...", p. 567.
} 
expresionismo extremo que denotan algunas de sus pinturas, así como en la ausencia de un uso correcto de la perspectiva monofocal ${ }^{239}$.

Las estampas más utilizadas en concreto en la provincia soriana, son las de Marcantonio Raimondi y las de Durero. Es posible que su uso de grabados y su inspiración en modelos figurativos nórdicos procedieran de sus contactos con el escultor valenciano Damián Forment (ca. 1480-1540), el cual también usó estampas de Durero en su obra ${ }^{240}$. Forment conocía al impresor alemán Jorge Coci. En la obra del escultor es también destacable la influencia de otros grabadores como Lucas Cranach, Hans Schaufelein, Marcantonio Raimondi, Marco Dente, Nicoletto Rosex da Modena o Jacopo Caraglio (1500-1565) ${ }^{241}$.

Aponte comenzó utilizando los grabados de los maestros del siglo XV como Martin Schongauer, y más tarde las de sus coetáneos, Alberto Durero, Lucas Cranach y Marcantonio Raimondi. Por ejemplo, en las imágenes del retablo de Ágreda, acudió a modelos italianos del siglo XVI que estaban de moda en aquella época, como son las estampas de Marcantonio Raimondi, probablemente proporcionados por el comitente. Entre ellos la escena de la Expulsión del Paraíso, basada en la escena de la Sixtina, o la de la Natividad, en la cual utilizó las figuras de los pastores para la escena de Gargano y la flecha envenenada ${ }^{242}$.

Esta influencia de los grabados foráneos podemos observarla también en otros detalles. Por ejemplo, sus ángeles se inspiraban en modelos italianos con rostros dulces y de cabellos ensortijados, ropajes amplios y vaporosos. Estos ángeles se basan en los modelos de Francesco Rosselli o en las esculturas del escultor Forment, de carácter italianizante. Este carácter dulce de los ángeles de Aponte contrasta fuertemente con el de otras de las figuras del retablo, mucho más serias y realistas, basadas en algunas de las imágenes grotescas de las estampas de Durero $^{243}$.

\section{Juan de Juni (1506-1577)}

Probablemente nació en Joigny, un pueblo de Borgoña ${ }^{244}$. En el inventario de los bienes del pintor, realizado por el escribano tras su muerte, consta que poseía varias

\footnotetext{
${ }^{239}$ MARÍAS FRANCO, F., El largo siglo XVI..., pp. 207-209.

${ }^{240}$ VV. AA., El retablo de San Miguel de Ágreda..., p. 48.

${ }^{241}$ MORTE GARCÍA, C., Damián Forment, escultor..., pp. 47-50.

242 Ídem, p. 71.

243 Ídem, p. 72.

${ }^{244}$ MARTÍN GONZÁLEZ, J. J., Juan de Juni. Jean natif de Joigny, H. Cohen, 1983; ID., “Con Juan de Juni en Joigny", Academia, n 59, 1984, pp. 247-259.
} 
estampas flamencas ${ }^{245}$. La influencia del arte extranjero se observa tanto en algunas figuras contraídas y atormentadas que podrían ser herencia de las del Laoconte ${ }^{246}$, tan difundidas en el Renacimiento, como en el clasicismo e idealización de otras como el San Sebastián de Medina de Rioseco que podría depender de modelos italianos como Giovanni Francesco Rustici (1474-1554) ${ }^{247}$.

Su uso de grabados italianos aparece ya manifestado desde el comienzo de su actividad artística en lugares como la sillería de coro del convento de San Marcos (León). En especial utiliza grabados italianos como los de Baccio Bandinelli ${ }^{248}$. Es posible que Juni adquiriera muchas de estas estampas a través de su estancia en Italia, en concreto en ciudades como Bolonia o Florencia, que contaban con un importante mercado de grabados. Por otro lado, también es posible que Juni las adquiriera en Valladolid, hecho corroborado por la presencia en su testamento de vínculos con el

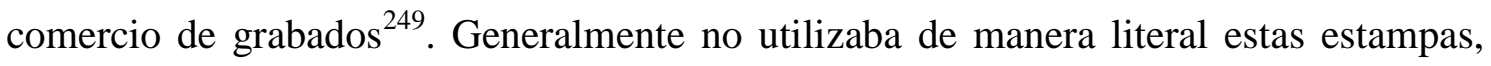
sino que los adaptaba, tomando como referencia las posturas y la sensación de movimiento de algunas obras italianas (como podemos ver en el Cristo Resucitado en la Catedral del Burgo de Osma); además, el traspaso de una imagen grabada a una escultórica se hace muchas veces más difícil que en el caso de la pintura: hay que tener en cuenta aspectos como el volumen y su supeditación a un espacio arquitectónico, que no se dan en la pintura. En su obra predominó la influencia de los grabados italianos de Marco Dente, Marcantonio Raimondi o Mario Cartaro.

\section{Diego de Urbina (1516-1595)}

Este artista de origen madrileño fue de gran importancia para el arte de la provincia de Soria. No se puede descartar que realizara un viaje a Italia con el objetivo de completar su formación cuando estaba en la veintena. Sus conocimientos sobre pintura italiana parecen ir más allá del arte toledano que pudiera haber contemplado

\footnotetext{
${ }^{245}$ MARTÍ Y MONSÓ, J., Estudios histórico-artísticos relativos principalmente a Valladolid, basados en la investigación en diversos archivos, Valladolid, Ámbito, 1992, p. 483.

${ }^{246}$ MARTÍN GONZÁLEZ, J. J., "El Laocoonte y la escultura española”, BSAA, t. 56, 1990, pp. 463-464.

${ }^{247}$ GARCÍA CHICO, E., Juan de Juni..., pp. 16-17.

${ }^{248}$ ORICHETA GARCÍA, A., op. cit., 1996, nº 83, pp. 316-358. ARIAS MARTÍNEZ, M., op. cit., 2013, pp. 27-34. Del mismo autor, "Revisando a Juan de Juni en San Marcos de León...”, 2008, pp. 9-34.

${ }^{249}$ Se hace referencia a estampas y "rollos de dibujo" presentes en su inventario, pero también se destaca su uso de grabados tanto nórdicos como italianos que se puede constatar a través de un estudio iconográfico. MARTÍ Y MONSÓ, J., op. cit., p. 483; FERNÁNDEZ DEL HOYO, M. A., Juan de Juni..., 2012, p. 84.
} 
desde Madrid $^{250}$. En su obra existe una fuerte influencia del arte italiano, especialmente del florentino. En particular destaca el influjo de la obra de Miguel Ángel, que podría basarse en la visión directa de sus obras o en el estudio de dibujos y estampas. Otros artistas italianos que influyeron en su obra fueron Rafael o Andrea del Sarto (1486$1531)^{251}$. Esta presencia de lo italiano en su obra podría deberse también a su estrecha relación con el pintor Gaspar Becerra (1520-1568) durante los años 60, así como a los círculos pictóricos toledanos.

Urbina realizó importantes encargos para obispos de la época, como por ejemplo el obispo de Osma, Pedro Álvarez de Acosta, quien le encomendó realizar algunas obras importantes en Aranda de Duero como un Martirio de Santa Catalina y una Sagrada Familia con San Joaquín y Santa Ana (Iglesia de la Vera Cruz), en la década de los sesenta $^{252}$.

Dentro de la propia catedral oxomense son destacables pinturas suyas como el Salvador, situado dentro de la capilla del Prior Sarmiento en 1569. Su vinculación con la diócesis de Osma puede que se debiera a los contactos de su hermano Cristóbal de Urbina, que era criado del obispo de Osma en 1548. Otras obras atribuidas a él dentro de la catedral son una pintura del Bautismo de Cristo y el magnífico Velo de Pasión.

Respecto al uso de las estampas en su obra, fue importante su relación con el círculo de Felipe II. Es bien conocido el interés del monarca por el arte en general, y en particular por los grabados, como atestigua la colección del Monasterio de San Lorenzo del Escorial. Puede que Urbina viera muchos de los grabados que utiliza a través de esta vía o en sus contactos con otros artistas que trabajaban en El Escorial. Entre las obras influenciadas por estampas es importante destacar el Velo de Pasión de la Catedral del Burgo de Osma, realizado en tres piezas, como un retablo de dos piezas, dos calles, y tres entrecalles ${ }^{253}$. En él hizo un importante uso de los modelos italianos, en particular de Marcantonio Raimondi, Schiavone, Parmigianino, Adamo Ghisi, etc. En total utilizó estampas para cuatro escenas: la Resurrección, el Entierro de Cristo, la Flagelación y la Subida al Calvario. La fuerte influencia que tuvieron en su obra las pinturas de Miguel

250 ANTONIO-SAENZ, T. de, Pintura española del último tercio del siglo XVI en Madrid. Juan Fernández de Navarrete, Luis de Carvajal y Diego de Urbina, Tesis Doctoral, Madrid, Universidad Complutense de Madrid, 1987, pp. 588-589.

${ }^{251}$ ID., "Diego de Urbina, pintor de Felipe II”, Anales de Historia del Arte, no 1, 1989, pp. 141-151.

${ }^{252}$ Procedentes del convento de Sancti Spiritus. MARTÍN ORTEGA, A., "Testamentos de pintores", BSAA, no 32, 1966, p. 433; ANTONIO-SAENZ, T., op. cit., p. 733, y doc. 102, p. 1301; COLLAR DE CÁCERES, F., "Diego de Urbina..., p. 117.

${ }^{253}$ Id., pp. 103-136. 
Ángel se manifiesta en su concepción de figuras con cuerpos poderosos y posturas complicadas.

Esto se evidencia también en otras obras como en la pintura El martirio de San Esteban, de la iglesia de San Juan de Rabanera en Soria, para la cual empleó varios modelos italianos, entre ellos alguna reproducción del Juicio Final de Miguel Ángel (en el cual se basan varias figuras de la composición) y de figuras clásicas de grabados de Marcantonio Raimondi.

\section{Juan de Carranza I el Viejo (ca. 1520-1575)}

Fue un imaginero del periodo anterior al Romanismo. Desgraciadamente se conocen pocas obras realizadas por él ${ }^{254}$. Entre ellas destacan los retablos de las iglesias de Santa María la Mayor en Treviana (Burgos) y Santa María la Mayor (Soria). Su estilo escultórico es deudor del de Bigarny y Siloé. Se le adjudican orígenes vizcaínos, y durante los años centrales de su vida parece que vivió en Burgos. Su fama fue tal que llegó a ser conocida fuera de los círculos burgaleses, por algunos escultores vallisoletanos $^{255}$. Formó en su oficio a su hijo, Juan de Carranza "el mozo", como aprendiz en su taller. Aunque usó estampas para el retablo de Santa María la Mayor de Soria, no hay constancia documental de que las poseyera. Sin embargo, dejó a su hijo en herencia algunos dibujos ${ }^{256}$.

\section{Diego de Madrid (doc. 1532-1574)}

Pintor formado en Sigüenza que trabajó durante sus primeros años en la zona de Madrid. Estuvo al servicio del Marqués de Moya en Segovia y colaboró en las obras de Santo Domingo el Real $^{257}$. Como ya se ha señalado, recibió su primera formación artística en Sigüenza, saliendo poco después de esta ciudad y realizando numerosas obras en la provincia de Guadalajara. Entre sus obras más importantes encontramos los retablos de Auñón y Fuentelaencina. Dentro del estudio planteado en esta tesis destacan

\footnotetext{
${ }^{254}$ ECHEVERRÍA GOÑI, P. L., "Los Ocio y su patronazgo artístico...", p. 82.

${ }^{255}$ PAYO HERNANZ, R., "Bernal Sánchez y la escultura burgalesa...", pp. 624-632.

${ }^{256}$ PAYO HERNANZ, R. y ECHEVERRÍA GOÑI, P. L., op. cit., pp. 80-82.

${ }^{257}$ MUÑOZ JIMÉNEZ, J. M., Arquitectura del Manierismo en Guadalajara, Guadalajara, Institución Provincial de Cultura "Marqués de Santillana", 1987; CORTÉS, S., Y ESTELLA, M., "Los retablos documentados de Fuenlaencina y Auñón, y noticias sobre los de Pozuelo del Rey y Renera", Archivo Español de Arte, n 246, 1989, p. 140; COZAR DEL AMO, J. M., y GARCÍA LÓPEZ, A., "El pintor seguntino Diego de Madrid: Noticias sobre su obra artística en la segunda mitad del siglo XVI", Anales Seguntinos, no 9, 1993, p. 102; RAMOS GÓMEZ, F. J., Juan Soreda y la pintura del Renacimiento..., p. 214; "Documentos sobre pintores seguntinos (II). 1535-1575. Pedro de Villanueva, Francisco de Pelegrina, Diego de Madrid, Pedro de Andrade y Juan de Illana", Wad Al-Hayara, 2005, n 31-32, p. 219240.
} 
las pinturas realizadas para el retablo mayor de Caltojar, donde se muestra el uso de estampas tanto italianas como nórdicas.

\section{Martín de Vandoma (doc. 1540-1577)}

Fue un arquitecto y escultor posiblemente de origen nórdico. Se formó y desarrolló su actividad principalmente en la ciudad de Sigüenza ${ }^{258}$. Entre sus principales obras destacan el coro y los púlpitos de la Colegiata de Berlanga de Duero, el púlpito del Evangelio de la Catedral de Sigüenza o el retablo de la iglesia de San Miguel de Caltojar, ejecutado con la colaboración pictórica de Diego de Madrid.

\section{Pedro del Cerro (doc. 1586- 1597)}

Es un escultor y entallador oriundo de Soria. Desarrolla gran parte de su producción en la zona del Burgo de Osma por lo que se le considera perteneciente al taller del Burgo de Osma ${ }^{259}$. Su estilo se caracteriza por un Romanismo seco basado en figuras grandiosas y expresivas. Suelen destacar por cabezas de gran tamaño de forma ovalada sobre gruesos cuellos, ojos almendrados y bocas pequeñas ${ }^{260}$. Este escultor adolece de un manejo un tanto torpe en cuanto a las composiciones. En sus obras podemos deducir la posible utilización de grabados fundamentalmente de maestros italianos como Marcantonio Raimondi o Giulio Bonasone. Entre sus obras fundamentales aparecen los retablos de las parroquias de Ólvega y Pozalmuro.

\section{Gabriel de Pinedo (1560-1625)}

Se trata de un escultor y tracista activo en Soria entre finales del siglo XVI y principios del siglo $\mathrm{XVII}^{261}$. Su actividad artística se extendió a otras zonas como Santander, La Rioja o Aranda de Duero ${ }^{262}$. Están documentadas sus estrechas relaciones con los canteros montañeses que tenían gran protagonismo en las obras sorianas de la época $^{263}$. Es un representante del estilo romanista en la provincia de Soria.

\footnotetext{
258 PÉREZ VILLAMIL, J., La catedral de Sigüenza..., pp. 161-164; “El Renacimiento español...”, pp. 193-216; AZCÁRATE, J. M., Escultura del siglo XVI..., p. 240; MUÑOZ JIMÉNEZ, op. cit., pp. 136140; MARTÍNEZ FRÍAS, J. M., "Resurrección”, pp. 395-397.

${ }^{259}$ LASSO DE LA VEGA Y LÓPEZ DE TEJADA (MARQUÉS DEL SALTILLO), M., op. cit., pp. 115117; ARRANZ ARRANZ, J. La escultura ...., p. 87.

${ }^{260}$ PÉREZ DE CASTRO, R., "Coronación de la Virgen”, p. 520.

${ }^{261}$ CAMÓN AZNAR, La escultura y rejería españolas ..., p. 360; BARRIO LOZA, J. A., op. cit., p. 276278.

${ }^{262}$ MARTÍNEZ FRÍAS, J. M., “Gabriel de Pinedo...”, p. 332.

${ }^{263}$ LASSO DE LA VEGA Y LÓPEZ DE TEJADA, M., op. cit., p. 313.
} 
Este escultor poseía estampas, ya que en el testamento las lega a su hijo junto a otros utensilios de su oficio. "Mando a mi hijo Graviel de Pinedo todas las herramientas, modelos, estampas y trazas y libros tocantes al arte de escultor y ensamblador que tengo "264. Entre sus obras más importantes se encuentran el retablo mayor de la iglesia de San Nicolás (1597) en Soria, actualmente en la iglesia de San Francisco o el retablo mayor de Nuestra Señora de la Muela, en Monteagudo de las Vicarías.

\section{Bartolomé de Ávila (doc. 1595-1616)}

El pintor trabajó en la provincia de Soria entre finales del siglo XVI y principios del siglo XVII. Se conocen muy pocos datos sobre su vida. La fecha de su muerte fue el 20 de febrero de 1616, pero se desconoce la de su nacimiento, así como su lugar de origen. Se sabe que trabajó en la provincia de Soria, en la de Navarra, y probablemente también en la de Burgos, ya que poseía unas viviendas en Aranda de Duero ${ }^{265}$.

Poseía estampas, ya que las vendió en la almoneda probablemente para pagar algunas de las deudas que tenía antes de morir. "Rematose en Esteban de Salazar vecino de esta ciudad 21 estampas chicas y grandes con los marcos dorados en 70 reales y se obligó a pagarlos el día de Carnestolendas de 1608 y lo firmó siendo testigos Sebastián de Carrasquedo y Melchor de Esparza estantes en Soria. Ante mí Melchor de Esparza. Firma Esteban de Salazar "266.

\section{Juan Sanz (?-1609)}

Fue un arquitecto, ensamblador y escultor que estuvo activo en la diócesis de Sigüenza a finales del siglo XVI. Realizó junto con Juan de Orihuela el retablo mayor de la iglesia de Santa María de Calatañazor en Almazán. Juan de Orihuela era un ensamblador de origen seguntino que trabaja también en la diócesis desde finales del siglo XVI. Colaboró en la realización del retablo de la catedral de Sigüenza ${ }^{267}$.

Aparte de la obra de la iglesia de Almazán participó en numerosos encargos escultóricos, como los retablos de las iglesias de Mezquetillas (Soria), Yelo (Soria),

\footnotetext{
${ }^{264}$ MANRIQUE MAYOR, M. A., op. cit., t. IV, p. 398-407.

${ }^{265}$ MANRIQUE MAYOR, M. A., op. cit., t. III, pp. 258-263 y 309-315; PÉREZ DE GRACIA RODRÍGUEZ, M. V., op. cit., p. 44.

${ }^{266}$ Documento publicado sin transcripción en MANRIQUE MAYOR, M. A., op. cit., t. III, 1987, p. 287; Archivo Histórico Provincial de Soria (en adelante AHPS), Martín de Esparza, signatura 338, fol. 94r. $94 \mathrm{v}$.

${ }^{267}$ MARCO MARTíNEZ, J. A., El retablo barroco en el Antiguo Obispado de Sigüenza, Diputación Provincial de Guadalajara, Gráficas Dehon, 1997, p. 65.
} 
Cortes (Navarra) o Solanillos (Guadalajara). También llevó a cabo numerosos relicarios como los de la iglesia de San Bartolomé en Atienza, en Galbe (Guadalajara), en la Miñosa (Soria) o Coscurita (Soria) ${ }^{268}$.

En el inventario de bienes de Juan Sanz del 4 noviembre de 1609 consta que poseía grabados, en concreto un libro de estampas de 14 hojas de cantería, así como una estampa del Escorial y otras doce imágenes de sepulcros y otras cosas y una de San Pedro (Vaticano) ${ }^{269}$. Aparte de estos valiosos bienes, parece que poseía un libro de arquitectura de Vignola.

${ }^{268}$ Ídem., op. cit., p. 70-71.

${ }^{269}$ Ídem, p. 69. 


\section{RELACIÓN DE OBRAS DE PRODUCCIÓN LOCAL O NACIONAL}

En las páginas que siguen se recogen obras pictóricas y escultóricas procedentes de parroquias de la actual provincia soriana, junto a los grabados que se ha estimado que influyeron en su creación. En algunos casos la influencia es más directa y literal, mientras que en otras se trata de iconografías tan comunes y difundidas que es difícil saber si realmente son resultado del influjo de estampas. Han sido ordenadas cronológicamente, aunque en algún caso la datación puede ser discutible.

\section{Maestro de Osma \\ Coronación de la Virgen \\ Cantoral 12 (E), fol. 20v \\ Principios del Siglo XVI \\ Monasterio de La Espeja (Soria)}

La miniatura (figs. 3 y 4$)^{270}$ sigue la iconografía de la Virgen coronada por la Trinidad. El tipo iconográfico aparece en España desde principios del siglo XV.

A los personajes principales se unen otros secundarios, entre los que destacan santos, ángeles, serafines, querubines y otros muchos miembros de la corte celestial. Los comitentes están situados en la parte inferior, según un rígido orden jerárquico tomado de la estampa (fig. 5) del mismo tema de Pablo Hurus (doc. 1477-1499) ${ }^{271}$. El grabado pertenece al Breviarium Romanum, publicado en Zaragoza en 1499 y aparece de nuevo en Breviarium Secundum ritum celsoni. Pablo Hurus fue editor y librero de los primeros tiempos de la prensa incunable. Sus trabajos tienen una cuidada estética. Combina tipos y tintas diversas, y muchas de sus estampas fueron luego usadas en otras ediciones o por otros impresores. Pablo Hurus editó varias obras de San Jerónimo. En 1498 contrató con sus tres socios (Leonardo Hutz, Lope Appentegger y Jorge Coci) el Breviarium Hieronymitanum ${ }^{272}$.

\footnotetext{
${ }^{270}$ PARRADO DEL OLMO, J. M., "Cantoral música gregoriana”, en La música en la iglesia de Castilla y León, Fundación Las Edades del Hombre, 1991, nº 45, pp. 102-103.; YARZA LUACES, J., op. cit., p. 166; ID., "Cantoral de música gregoriana", p. 304; ID, "Cantoral música gregoriana", en Time to hope. Tiempo de la esperanza, Fundación Las Edades del Hombre, 2002, pp. 334-335; MUNTADA TORRELlAS, A., Cantorales del Monasterio de San Jerónimo de Espeja: Catedral del Burgo de Osma, Catedral del Burgo de Osma, s. 1., 2003 p. 87. BENÍTEZ MORIANA, S., "Historia de la imprenta en Aragón", 2014. Disponible en http://digital.csic.es/bitstream/10261/107569/1/Benitez_Historia\%20de\%20la\%20imprenta\%20en\%20Ar ag\%C3\%B3n.pdf (consultado en 6/12/19)

${ }^{271}$ MUNTADA TORRELLAS, A., op. cit., p. 87. Imagen tomada de Ibídem.

${ }^{272}$ GARCÍA VEGA, B., op. cit., t. I., p. 80; JANKE, R. S., op. cit., p. 335; PEDRAZA GRACIA, M. J, op. cit., p. 132.
} 
La composición es piramidal. En el vértice se encuentra la Trinidad, representada por tres personas diferenciadas: Dios Padre luce la corona cerrada de los emperadores; Dios Hijo es el Cristo encarnado, que se muestra con el torso desnudo, el nimbo crucífero, las señales de las llagas y el manto púrpura de la resurrección; sobre ellos, la paloma que representa al Espíritu Santo. Dios Padre y Dios Hijo sostienen el globo terráqueo ${ }^{273}$.

La Santísima Trinidad corona a María, que se sitúa justo en el centro de la composición, por encima de los santos y por debajo de los ángeles y de la Trinidad, a la que sirve. María tiene un papel de mediadora. Más abajo aparece el colegio apostólico, que incluye entre sus miembros a San Pedro con la llave del Reino de los Cielos, Felipe con su espada, Santiago con su cayado y sombrero de peregrino, etc... Un peldaño más abajo van los demás santos, mártires y vírgenes.

La acción aparece cumplida: la Virgen está ya coronada y sentada en un trono. El rígido esquema compositivo se relaja un poco en la miniatura, que hace uso de algunas tradiciones propias de la pintura gótica, como el chi o el uso evocador del dorado. El chi representa la gloria celestial mediante una cinta ondulada que pasa gradualmente del azul intenso al azul celeste del fondo. María se encuentra en el centro geométrico y conceptual de ese espacio. El color oro representa, con un poder evocador, la luz inmaterial. El trono, las nubes que envuelven a los ángeles, los escalones, la franja que corre junto a la inicial y los nimbos de los santos son todos dorados.

La pintura comparte con el grabado la organización jerárquica y estamentaria, y la cinta propia del chi gótico que rodea la escena. A pesar de la multiplicidad de figuras, no se deja de identificar a los personajes. Algunos se repiten: el Papa con el libro (San Gregorio), Santa Catalina con su manto de armiño y su espada, o la doncella sentada a su izquierda, que luce cota de malla, camisa y tocado.

Otros santos cambian su actitud o desaparecen: un cardenal (San Jerónimo) medita sobre un libro abierto, mientras que en la miniatura lo sujeta con su brazo derecho; San Esteban ha desaparecido; los Padres de la Iglesia, ausentes en la estampa, aparecen en la miniatura (excepto San Ambrosio), posiblemente como símbolo de la devoción a la Virgen, así como por ser una obra destinada al uso eclesiástico y por ser San Jerónimo el fundador de la orden a la que pertenecía el monasterio. También se puede reconocer a San Francisco con los estigmas, Santo Domingo y San Luis.

${ }^{273}$ MUNTADA Y TORRELLAS. A., op. cit., pp. 83-88. 


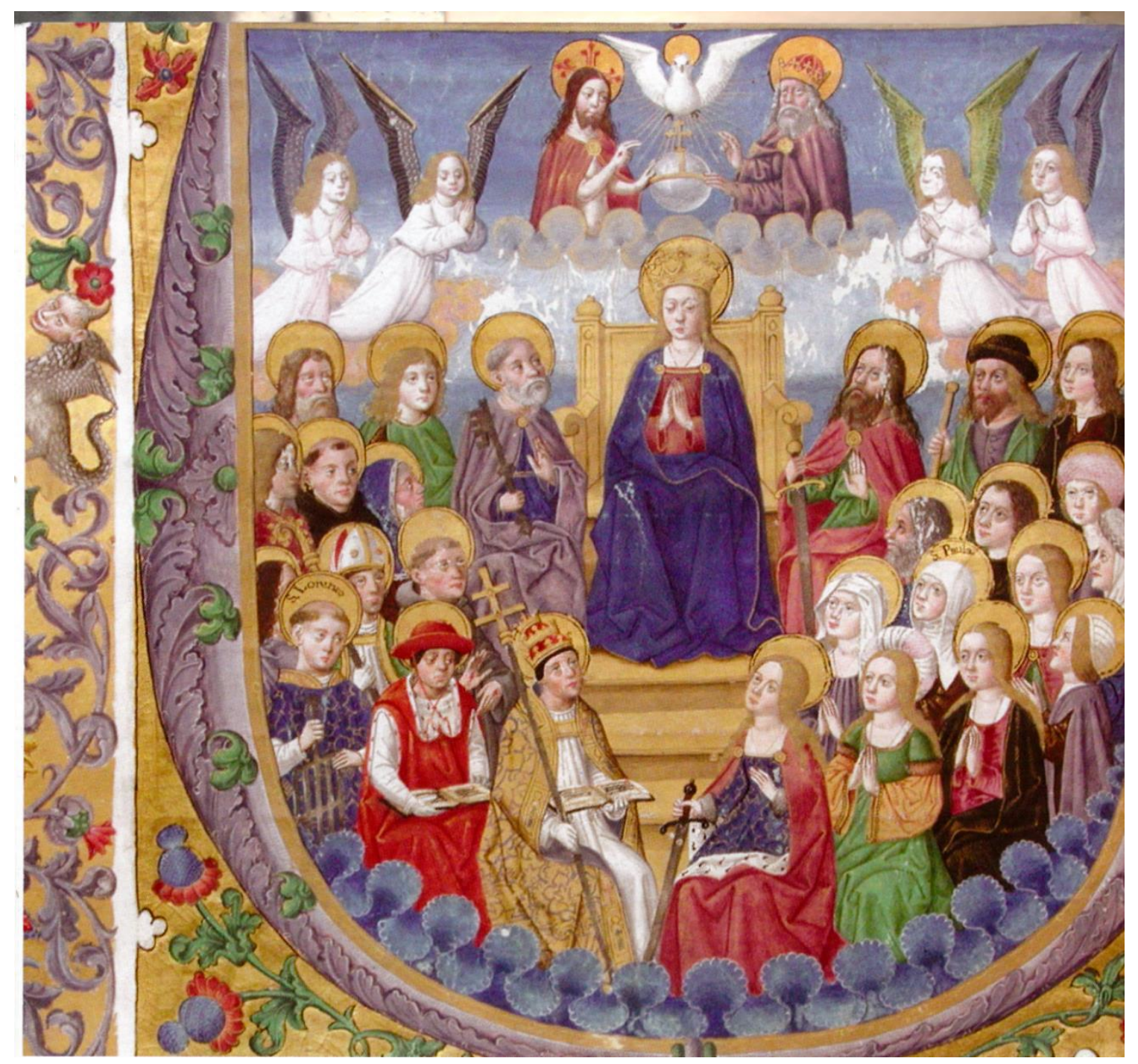

3. Maestro de Osma. Coronación de la Virgen. Cantoral 12 (E) fol. 20. Principios del siglo XVI. Procedencia: Monasterio de la Espeja. Actualmente: Museo Diocesano. Burgo de Osma (Soria).

Los ángeles aparecen mostrando idénticas poses, si bien en el modelo las dos figuras infantiles de los extremos carecen de alas y no se muestran de cuerpo entero. El espacio parece más desahogado y ordenado en la miniatura; en la estampa prima un horror vacui en que las figuras se entremezclan, casi sin espacio entre ellas.

El maestro de Osma suavizó en su pintura el arcaísmo de las formas del grabado. Los colores de tonalidades intensas (rojos, azules y verdes) dotan a la pintura de mayor vitalidad. Por otra parte, la estampa es más gestual, mientras que en la miniatura la expresividad es mucho más recogida: sus protagonistas se encuentran, en su mayoría, en poses de oración. Incluso la Virgen abandona el cetro que sujeta en el grabado, y aparece en posición de plegaria. 


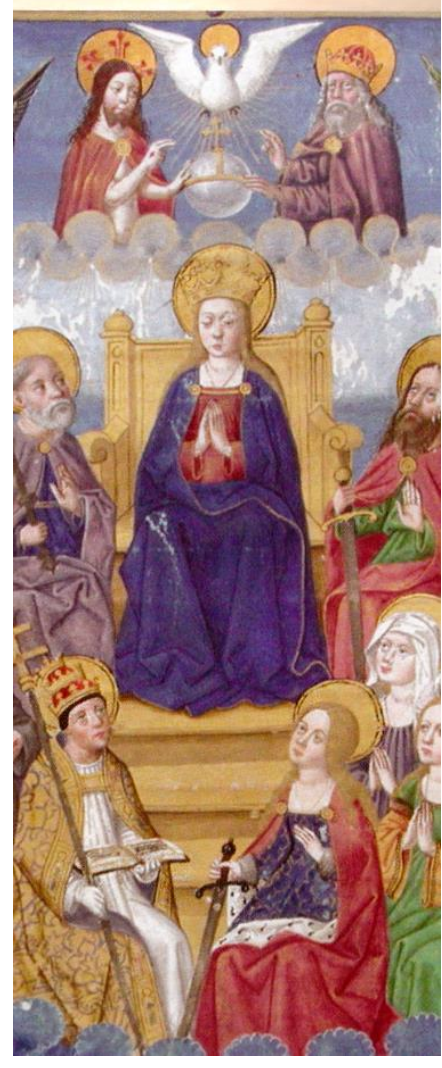

4. Detalle de fig. 3.

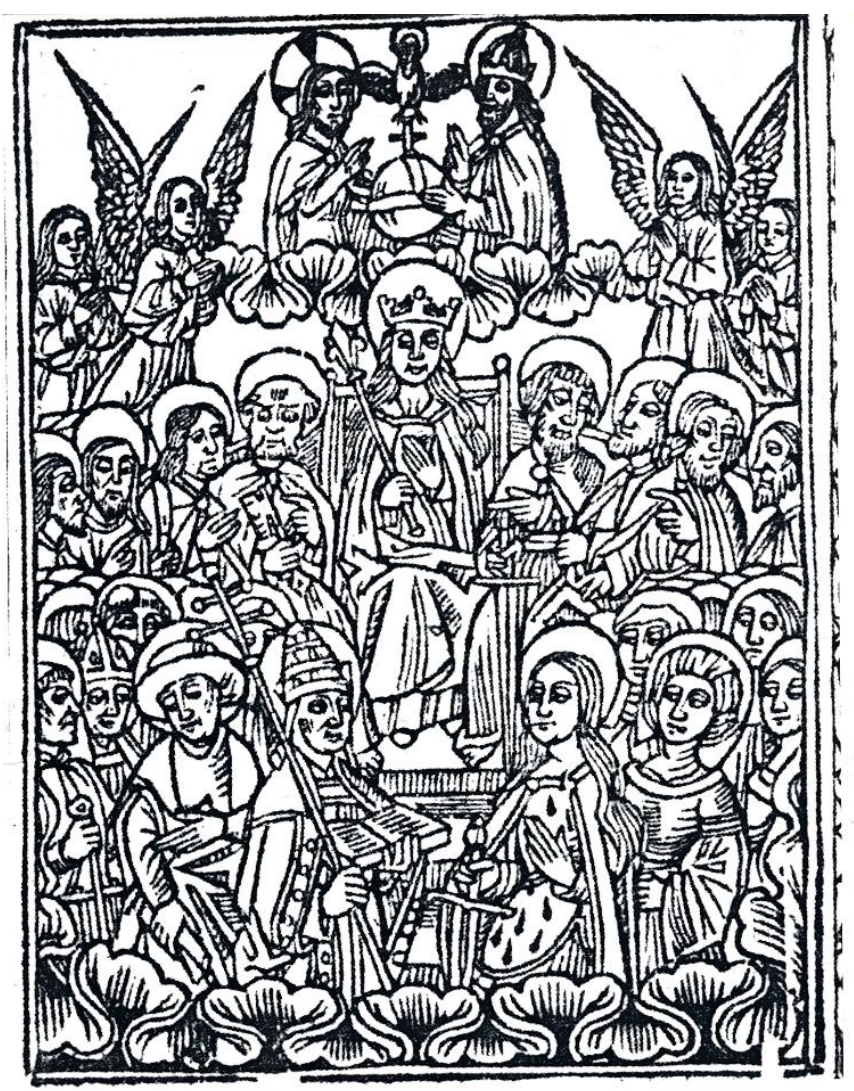

5. Pablo Hurus. Coronación de la Virgen. 1499. En Breviarium Romanum.

\section{Miguel Jiménez \\ Anunciación, Natividad y Adoración de los Magos \\ 1490-1505 \\ Predela de un retablo con escenas de la Vida de la Virgen \\ Iglesia de Nuestra Señora de la Peña \\ Âgreda (Soria)}

La iglesia de Nuestra Señora de la Peña de Ágreda acoge las seis tablas que conforman lo que debió ser un retablo dedicado a la Vida de la Virgen. Es muy posible que fueran reutilizadas como predela del retablo de Santa María del Popolo, en la capilla mayor de la nave central de la iglesia ${ }^{274}$. La obra ha sido atribuida a Miguel Jiménez por autores como Gudiol ${ }^{275}$, Camón Aznar ${ }^{276}$ o Lacarra Ducay ${ }^{277}$.

\footnotetext{
${ }^{274}$ ALCOLEA BLANCH, S., Soria y su provincia, Barcelona, Aries, 1964, p. 87; TARACENA Y AGUIRRE, B. y TUDELA DE LA ORDEN, J., op. cit., pp. 252-253; PEÑA GARCÍA, M., Ágreda: Santa María de los Milagros: libro del peregrino: oracional, arte, historia, Soria: Unión Gráfica, 1979, p. 41; ORTEGO FRÍAS, T., Ágreda: bastión de Castilla hacia Aragón, Soria: Publicaciones de la Caja de Ahorros y Préstamos de la provincia, 1980, p. 89; CARDONA JIMÉNEZ, V., La pintura gótica..., p. 122.

275 GUDIOL RICART, J., Pintura gótica....., p. 309.
} 
Característico del estilo de Jiménez es el carácter monumental de las figuras, que suelen aparecen sobre un fondo dorado sin desarrollo arquitectónico ni paisajístico. Lucen túnicas y mantos pesados de pliegues acartonados. Sus tipos humanos son de complexión fuerte, pero sin dejar de lado la delicadeza, sobre todo en los personajes femeninos. Algunas de las escenas de la predela parecen inspirarse en los grabados de Martín Schongauer. Es probable que las estampas le fueran facilitadas por el pintor aragonés Martín Bernat, que tenía una estrecha relación con los grabadores alemanes Pablo y Juan Hurus, asentados en Zaragoza. La obra ha sido datada en la última década del siglo XV o principios del siglo XVI, por lo cual pertenecería a la etapa final de la producción del pintor.

\section{Anunciación}

Representa la escena de acuerdo a la tradición iconográfica anterior al Concilio de Trento (fig. 6). Se consideraba que la Concepción del Niño se había producido mientras el Arcángel San Gabriel susurraba el mensaje divino a través del oído de María. La imagen sigue un esquema compositivo piramidal que culmina con la cabeza de Dios Padre y se desarrolla en un interior doméstico decorado con baldosas. La Virgen aparece arrodillada frente al atril; con la mano derecha sostiene el libro, y la izquierda dobla su manto con un gesto peculiar. Vuelve el rostro hacia la paloma y hacia el ángel. Este le da el mensaje divino, bendiciendo con una mano mientras con la otra sujeta la filacteria. En la esquina inferior izquierda podemos ver el jarrón de lirios que representan la pureza de la Virgen.

Es una obra de carácter aún muy gótico, inspirada en la estampa homónima de Schongauer (fig. 7) ${ }^{278}$, perteneciente a la etapa de transición del grabador alemán, entre $1480-1485^{279}$. En esta época incorpora un sentido más espiritual y una mayor sobriedad a los hallazgos técnicos que habían caracterizado su primera etapa. Jiménez copió las

${ }^{276}$ CAMÓN AZNAR, J., La pintura medieval ..., p. 543.

${ }^{277}$ LACARRA DUCAY, M. C., "Influencia de Martin Schongauer...”, p. 22; LACARRA DUCAY, M. C., “Anunciación, Visitación...”, pp. 186-188.

${ }^{278}$ LACARRA DUCAY, M. C., “Anunciación, Visitación...”, p. 186.

CARDONA JIMÉNEZ, V., La pintura gótica ..., p. 129.

${ }^{279}$ Estampa disponible en:

http://www.britishmuseum.org/research/collection_online/collection_object_details.aspx?objectId=1551 093\&partId=1\&searchText=annunciation\&images $=$ true \&people $=108158 \&$ page $=$

HOLLSTEIN, F. W. H., German engravings, etchings and woodcuts, c. 1400-1700, Amsterdam, Menno Hertzberger, 1954, vol. XLIX, $\mathrm{n}^{\circ}$ 1, p. 14; LEHRS, M., Geschichte und kristicge Katalog des deutschen, niederländischen und französischen Kupferstichs im XV Jaharhundert, Vienna, 1908, vol. 5, nº 1, p. 39.; BARTSCH, A., op. cit., vol. VI, p. 120. 
figuras literalmente, aunque en sentido invertido. Sin embargo, prescindió del complicado juego de pliegues de las vestimentas de la Virgen de la estampa alemana. El artista también ha suprimido algunos de los objetos que aparecen en el grabado, como la cama con dosel a la derecha del modelo, el pequeño taburete, el jarrón y la arrugada alfombra sobre la que se apoyan la Virgen y el ángel. Tampoco aparece el muro que se ve en la estampa al fondo de la composición.

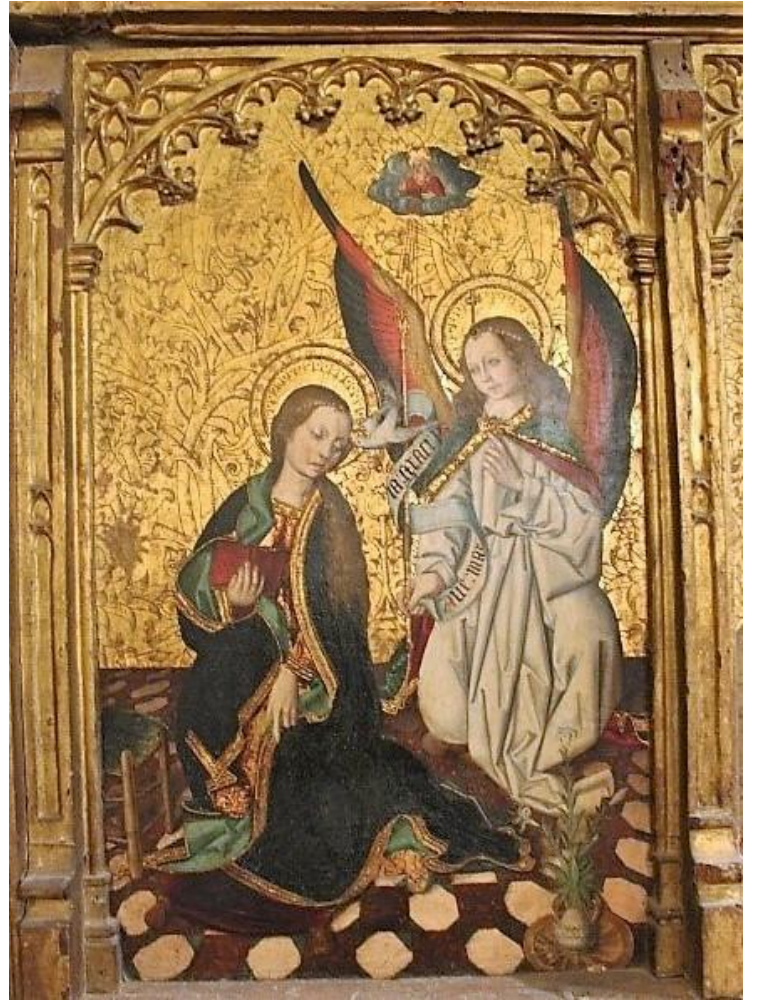

6. Miguel Jiménez. Anunciación. 1490-1505. Iglesia de Nuestra Señora de la Peña Ágreda (Soria).

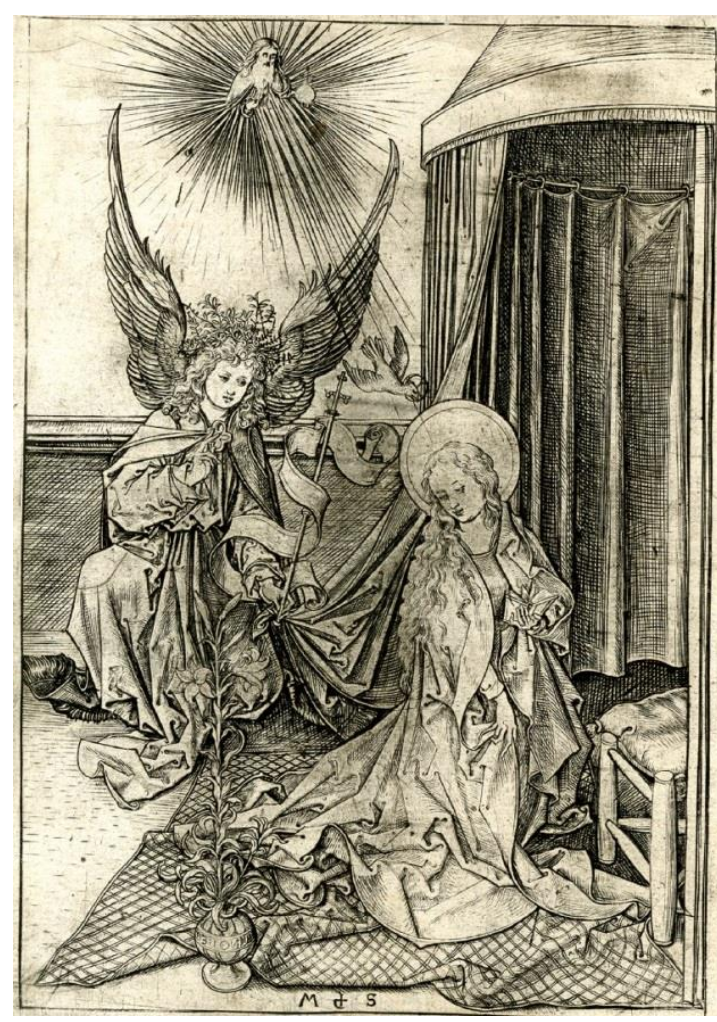

7. Martin Schongauer. Anunciación. 1475-1482. British Museum. Londres (Reino Unido).

\section{Natividad}

En esta pintura la representación de la Virgen se ajusta a la iconografía que la muestra adorando al Niño sin ningún signo de dolor posterior al parto (fig. 8). Por ello, no parece ni pálida ni fatigada, sino solemne. Con ropajes de reina, se arrodilla ante su hijo. Tiene las manos unidas en gesto de adoración y mira al Niño, desnudo sobre un pliegue de su manto. La figura de San José es secundaria, un poco apartada de las otras dos. Portador a veces de un candil con el que ilumina la escena, en la obra de Jiménez lo ha perdido, aunque sí lo encontramos en el grabado en el que se inspira. 


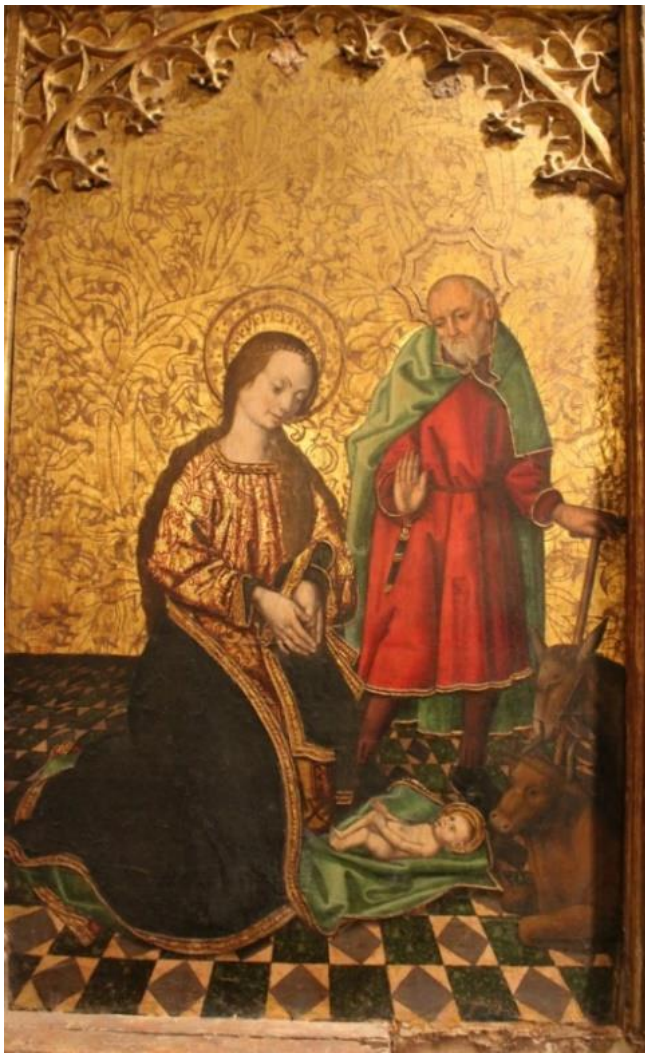

8. Miguel Jiménez. Natividad. 1490-1505. Iglesia de la Virgen de la Peña. Ágreda (Soria).

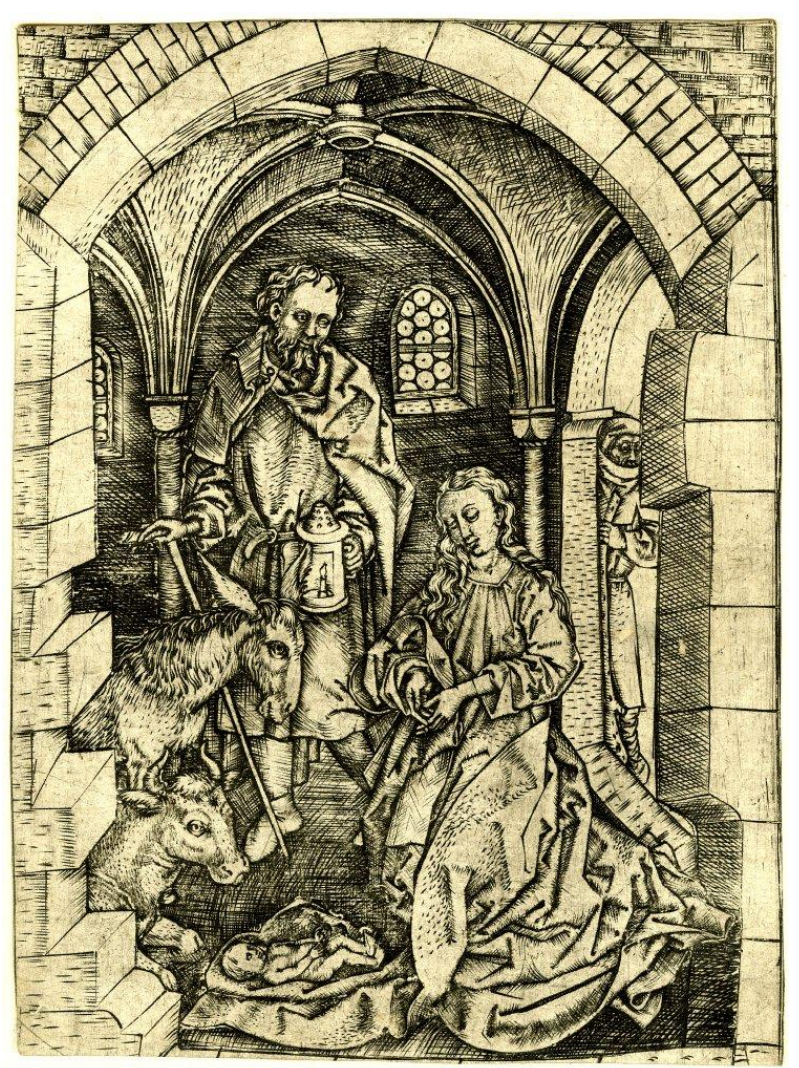

9. Martin Schongauer. Natividad. 1475-1500. British Museum. Londres (Reino Unido).

También en este caso el pintor utilizó una estampa de Schongauer $^{280}$ (fig. 9) (281 $^{28}$ para crear la composición. Se trata de la estampa de la Natividad, de la que toma la figura de la Virgen María ataviada con el mismo complejo vestido lleno de pliegues, con las manos unidas por las puntas de los dedos y la pose de humildad y la mirada baja contemplando al Niño.

Por otro lado, la figura de San José se inspira parcialmente en la estampa. Lleva la misma capa anudada al cuello, y con la mano derecha sujeta la vara. Pero mientras en la estampa la mano izquierda sujeta un candil o una lámpara, en la pintura se limita a mostrar la palma extendida con un gesto de adoración. Jiménez tomó también las figuras de la mula y el buey del grabado, elementos apócrifos que se citan en el

${ }^{280}$ LACARRA DUCAY, M. C., “Anunciación, Visitación...”, p. 187; CARDONA JIMÉNEZ, V., La pintura gótica..., pp. 132-133.

${ }^{281}$ Estampa disponible en:

http://www.britishmuseum.org/research/collection_online/collection_object_details.aspx?objectId=14464 81\&partId=1\&searchText=nativity\&images $=$ true \&people $=108158 \&$ page $=1$

HOLLSTEIN, F. W. H., German engravings, etchings and woodcuts..., n ${ }^{\circ}$ bb, p. 22-23, vol. XLIX, Amsterdam, 1954; LEHRS, M., op. cit., , n 5.b, p. 53. 
Evangelio del Pseudo Mateo. Para ambientar la escena utiliza el suelo de baldosas de colores típico de la pintura flamenca; el fondo dorado y los brocados de las vestimentas son característicos de la pintura aragonesa de la época. La disposición de la Virgen y del Niño, a su vez, recuerda a algunas pinturas primitivas flamencas, como la Natividad del Tríptico Bladelin (1445-1448) de Roger Van Der Weyden (fig. 10) ${ }^{282}$.

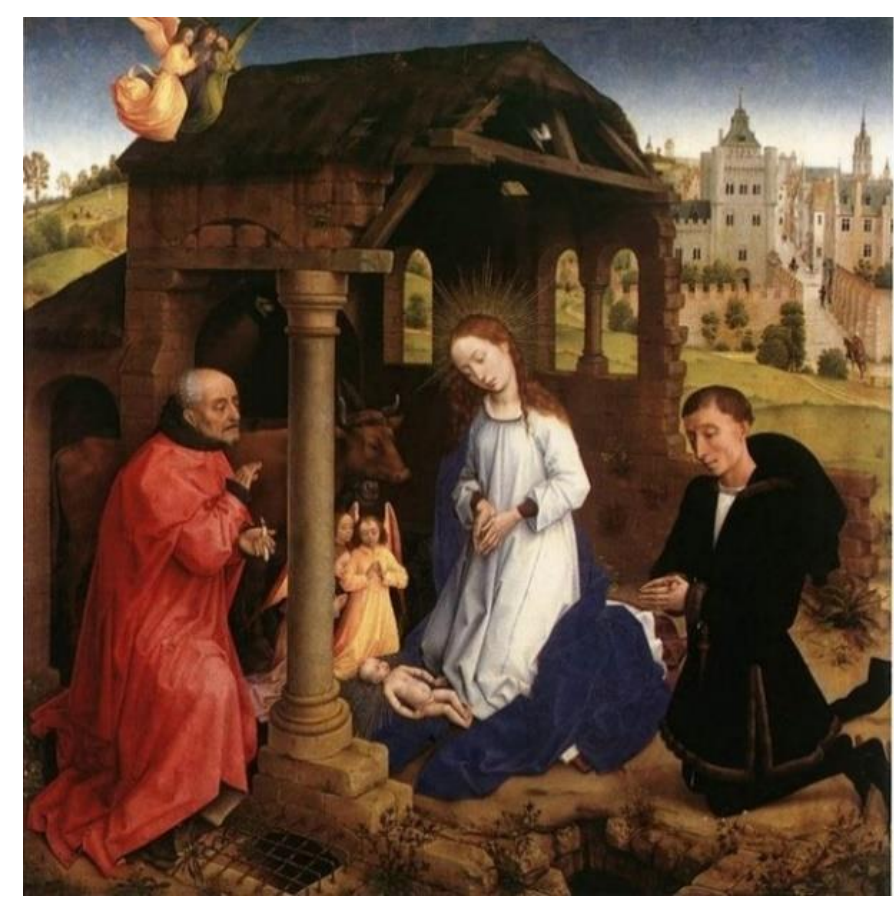

10. Roger Van der Weyden. Natividad. Tríptico Bladelin. 1445-1448. Gëmaldegalerie. Berlín.

\section{Adoración de los Magos}

La escena representa el momento en el cual los Reyes de Oriente llegan hasta Belén para presentar sus presentes al Niño (fig. 11). Miguel Jiménez volvió a utilizar aquí otra estampa de Schongauer ${ }^{283}$ para componer la imagen (fig. 12) ${ }^{284}$. A su vez, la estampa toma como modelo una pintura de Roger van der Weyden del Retablo de los Reyes, actualmente en la Pinacoteca Antigua de Munich (fig. 13) ${ }^{285}$.

\footnotetext{
282 Imagen de dominio público. URL: https://es.wikipedia.org/wiki/Archivo:Rogier_van_der_Weyden_Bladelin Triptych - WGA25617.jpg

${ }^{283}$ LACARRA DUCAY, M. C., “Anunciación, Visitación...”, p. 187; CARDONA JIMÉNEZ, V., La pintura gótica..., pp. 132-133.

${ }^{284}$ Estampa disponible en: VV. AA., The Illustrated Bartsch, Early German Artists, vol. 8, Nueva York, Abaris Books, 1980, p. 219.

BARTSCH, A., op. cit., vol. VI, p. 122; HOLLSTEIN, F. W. H., German engravings, etchings and woodcuts..., n 6, 2, vol. XLIX, p. 26-27; LEHRS, M. op. cit., vol. V, nº 6, p. 56.

${ }^{285}$ Imagen de dominio público.

https://commons.wikimedia.org/wiki/File:Saint_Columba_Altarpiece_(central_panel).jpg
} 


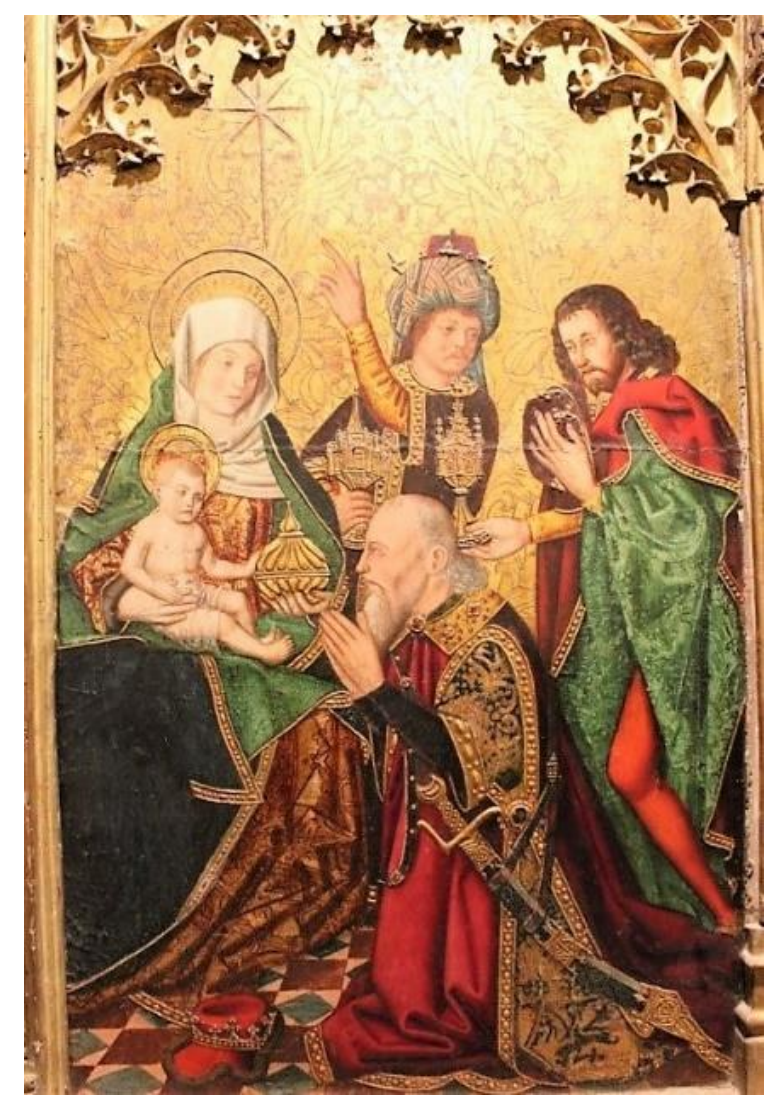

11. Miguel Jiménez. Epifanía.1490-1505. Iglesia de La Virgen de la Peña. Ágreda (Soria).

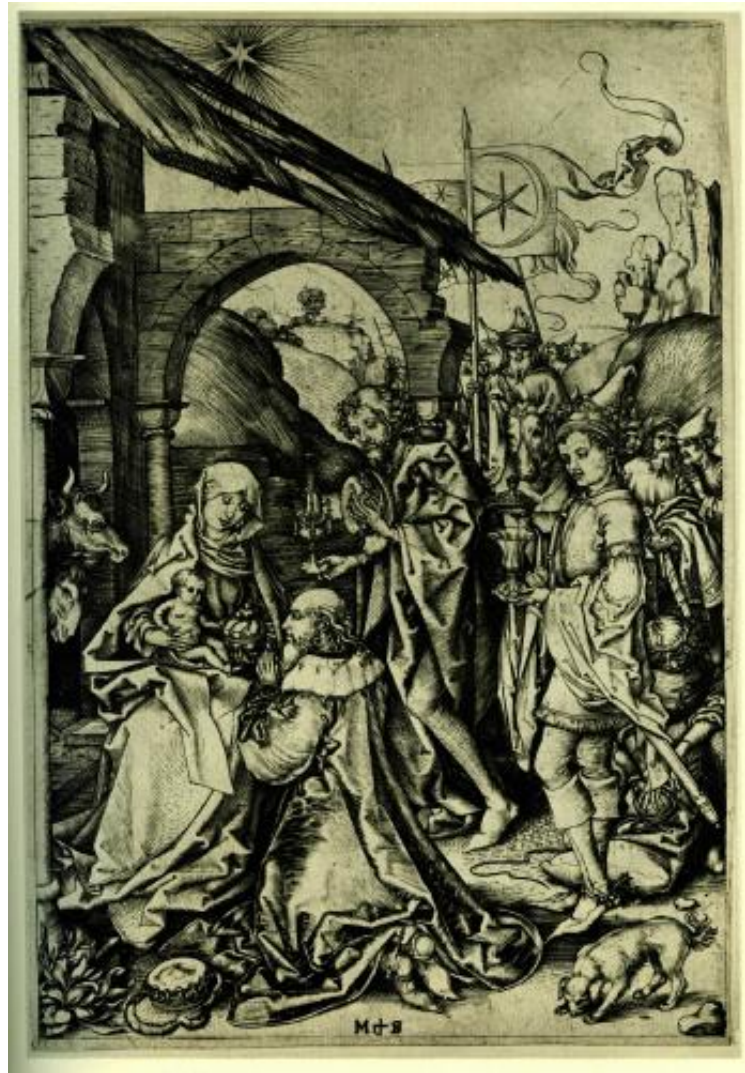

12. Martin Schongauer. Epifanía. 1470-1474. British Museum. Londres

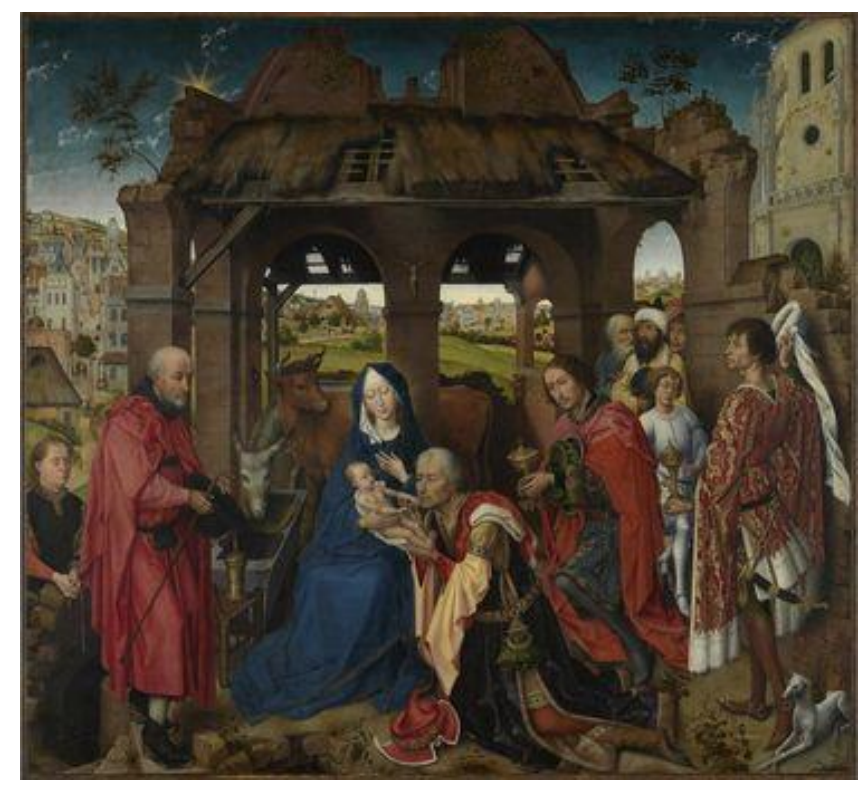

13. Roger van der Weyden. Adoración de los Magos, Tríptico de Santa Columba. Ca. 1455. Alte Pinakothek.Munich (Alemania)

Jiménez se basó en las figuras de la Virgen sentada con el niño en brazos y la del rey Melchor que, arrodillado, ofrece al Niño el presente en un cofre que tiene, como en 
el grabado, forma ovalada. La figura de Gaspar es prácticamente idéntica. Sin embargo, la del rey Baltasar, que señala con la diestra a la estrella, no está tomada de la estampa de Schongauer, sino que podría estar inspirada en la de una estampa flamenca anónima del Monogramista MR de en torno a 1500-1525 (fig. 14) ${ }^{286}$, aunque en este caso las manos se encuentran en posición invertida.

Una vez más, Jiménez prescindió de algunos motivos de la estampa original, como el cortejo que acompaña a los Reyes Magos, la arquitectura en que se enclava la escena, las figuras de la mula y el buey y el perrito que aparece en la esquina inferior derecha de la estampa. Por último, en lugar de un fondo arquitectónico, un suelo ajedrezado de baldosas da algo de profundidad a la composición.

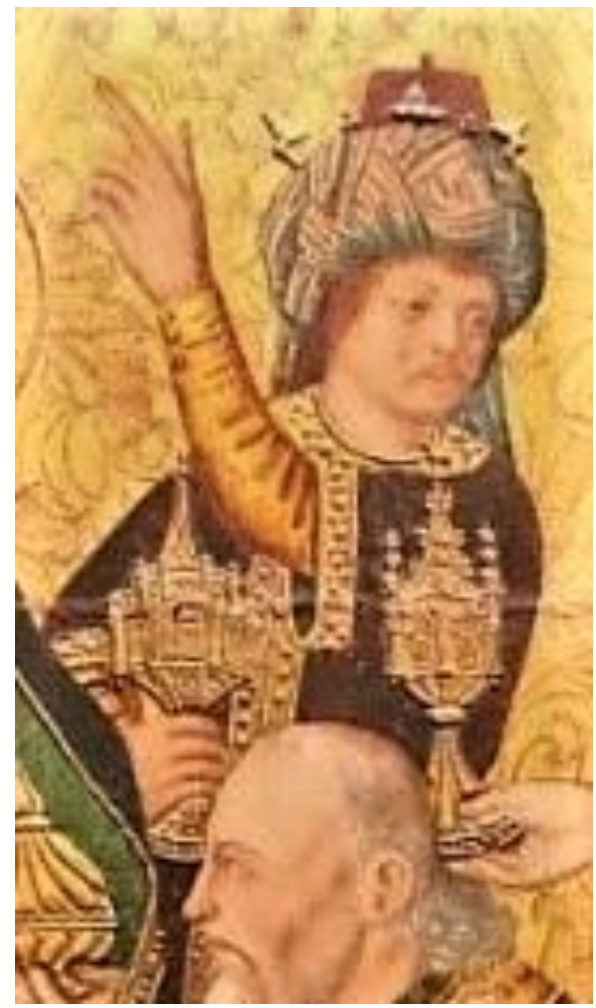

11 bis. Miguel Jiménez. Epifanía.1490-1505. Iglesia de la Virgen de la Peña. Ágreda (Soria)

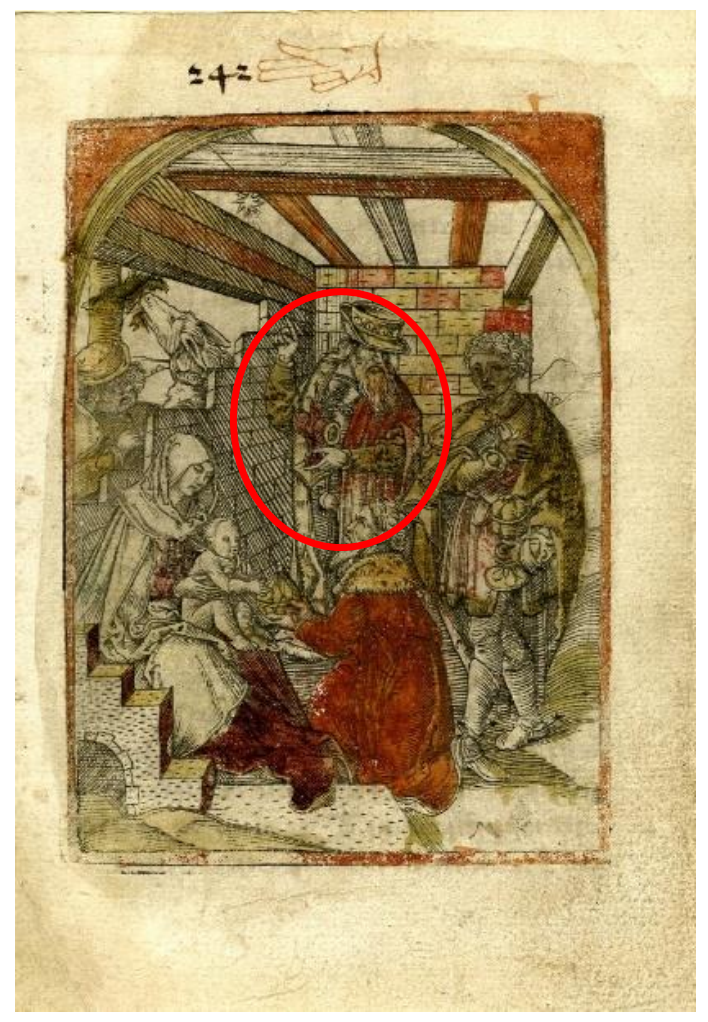

14. Monogramista MR. Epifanía. 1500-1525. British Museum. Londres (Reino Unido).

La preocupación de Jiménez por las calidades se evidencia en el tratamiento de los tejidos y los cabellos, y en su interés por los objetos ornamentales, como los

${ }^{286}$ Estampa disponible en:

http://www.britishmuseum.org/research/collection_online/collection_object details.aspx?objectId=14951 85\&partId=1\&searchText=adoration + of + the + magi\&images $=$ true \&people $=17551 \&$ page $=1$ HOLLSTEIN, F. W. H., Dutch and Flemish etchings, engravings and woodcuts..., vol. XIII, nº 5, p. 97. 
presentes que recibe el Niño. Los colores brillantes y espléndidos de los ropajes de los Magos son típicos de la pintura aragonesa de la segunda mitad del siglo $\mathrm{XV}^{287}$.

\section{Anónimo \\ Retablo de San Lorenzo. \\ Primera década siglo XVI \\ Iglesia de Nuestra Señora de los Milagros \\ Ágreda (Soria)}

Este retablo se sitúa en los pies de la iglesia de Nuestra Señora de los Milagros, en el lado de la epístola, frente al retablo de San Vicente (fig. 15).

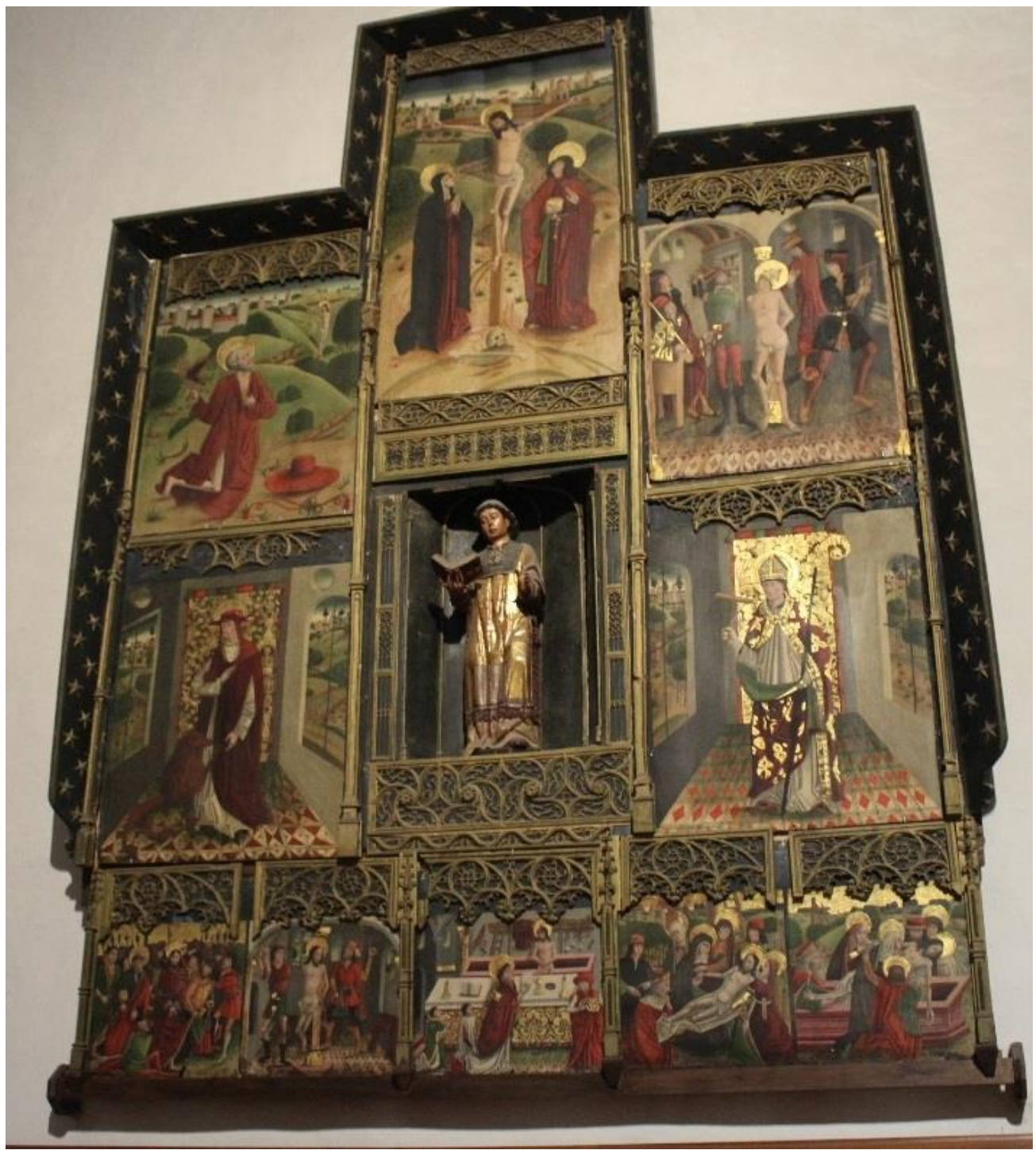

15. Anónimo. Retablo de San Lorenzo. Ca. 1510.

Iglesia de Nuestra Señora de los Milagros Ágreda (Soria)

${ }^{287}$ POST, Ch. R., op. cit., t. XIII, p. 375. 
Respecto al estilo, el retablo es obra de un pintor español que sigue los principios de la pintura hispanoflamenca. Sus modelos de inspiración son fundamentalmente los grabados de la serie de La Pasión de Schongauer, y las pinturas del retablo de San Vicente de la misma iglesia.

Las pinturas son de fuerte carácter flamenquizante: no buscan la belleza ideal, sino que potencian la expresividad, y a veces tienden a la caricaturización de los personajes. Señales de esta preocupación por los valores expresivos son las lágrimas, la sangre, las heridas o los gestos que se introducen en las pinturas y que, sin embargo, están ausentes en los grabados de los que proceden. Por otro lado, el pintor muestra ciertas carencias a la hora de representar las escenas, con torpezas a la hora de plasmar el movimiento, la perspectiva o el volumen. A pesar de ello, sí logra transmitir la sensación de espacio mediante vanos y ventanas, a través de los cuales se muestra un paisaje arbolado que se reduce de tamaño para dar profundidad a la escena. La perspectiva se concibe en altura y no en profundidad, y es probable que se inspirase para ello en las estampas de Israel van Meckenem ${ }^{288}$. El autor no es capaz de representar rostros realistas; los suyos son rostros estandarizados, sólo con las variaciones de los cabellos, la jerarquía y la edad. Las anatomías estilizadas y la falta de expresividad no logran transmitir la fuerza y brutalidad que requerirían algunos de episodios ${ }^{289}$. Las vestimentas de los personajes siguen la moda de finales del siglo XV y principios del siglo XVI, como los jubones y algunos de los sombreros. En cuanto a su autoría se han barajado diversas teorías: Post las atribuye a Fernando Gallego ${ }^{290}$.

\section{Prendimiento}

La escena representa el inicio de la Pasión de Cristo (fig. 16). Es el momento en que Judas traiciona a Cristo, entregándolo a los sacerdotes. Un grupo de soldados, siguiendo las instrucciones de Judas, irrumpe en el Huerto de los Olivos. Según el Evangelio de San Juan, después de reconocer quién era ante los soldados, Cristo se dejó atar las manos sin oponer resistencia. Se presenta el momento en que Pedro, con una cimitarra, corta la oreja a Malco, el ayudante del Sumo Sacerdote que, ayudado por una lámpara, había conducido a los soldados hasta el huerto. El momento escogido es el posterior a que Pedro le haya cortado la oreja. Por los rostros de determinación de

\footnotetext{
${ }^{288}$ MORTE GARCÍA, C., "Retablo de San Lorenzo Mártir", en Las Edades del Hombre. La ciudad de seis pisos, Fundación de Las Edades del Hombre, s. 1., 1997, n 127, p. 231.

${ }_{289}$ CARDONA JIMÉNEZ, V., La pintura gótica..., pp. 166-167.

${ }^{290}$ POST, Ch. R., op. cit., t. IV, parte I, pp. 463-467.
} 
Cristo y de aflicción de Pedro, se deduce que aquél ya ha ordenado a éste que guarde su espada. La pintura se desarrolla sobre un fondo dorado, vestigio de la pintura gótica, en el que aparecen algunos árboles, aunque en general está dominado por una masa de soldados y sus lanzas. En primer plano destacan las figuras de Cristo, San Pedro y Malco. Predominan los tonos verdes y rojos, tal y como ocurre con otras escenas del retablo, y las figuras de Cristo y Pedro lucen enormes aureolas doradas de carácter gótico. Es de destacar la impasibilidad con la que Cristo soporta las torturas de sus raptores, mientras que el rostro de San Pedro se muestra afligido y triste, sentimientos que chocan con la violencia del acto que ha cometido contra Malco, el criado del Sumo Sacerdote, que aparece tirado en el suelo y porta en su mano izquierda el farol que según la tradición le prestó la vieja Hedroit para iluminar el camino hasta Cristo.

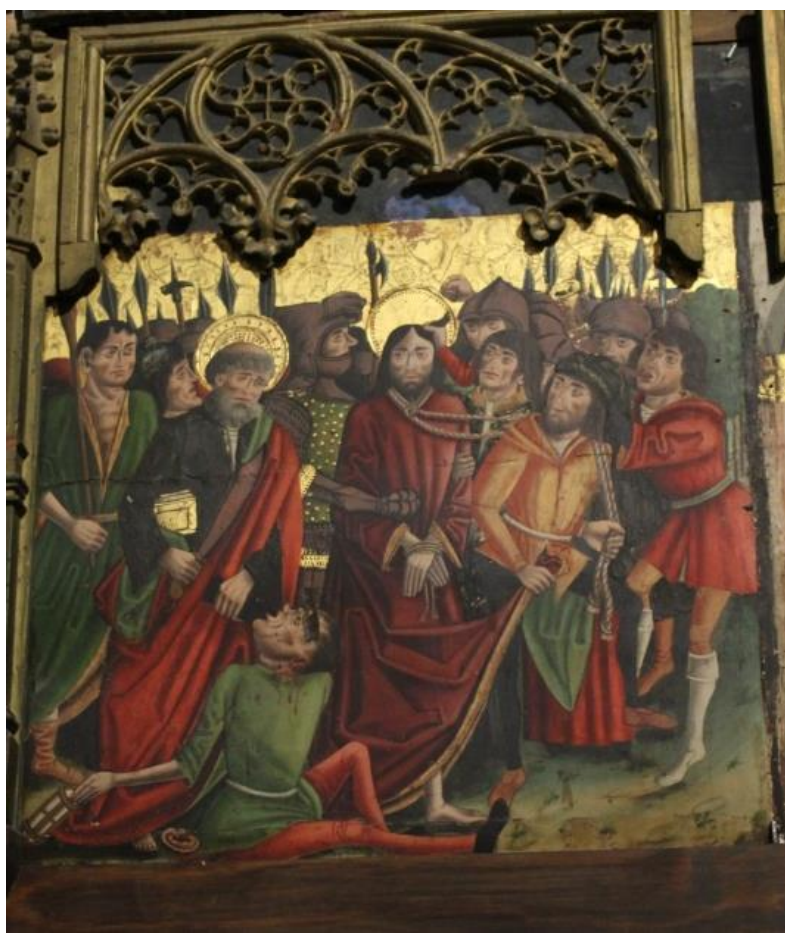

16. Anónimo. Prendimiento. Retablo de San Lorenzo. Ca. 1510. Iglesia de Nuestra Señora de los Milagros. Ágreda (Soria)

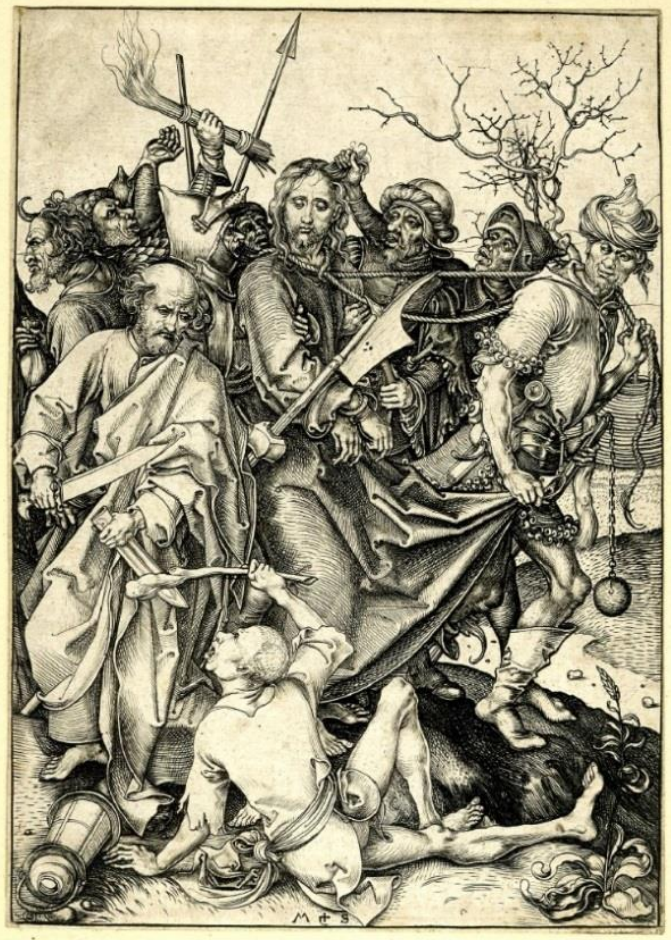

17. Martin Schongauer.

Prendimiento de Cristo. 1470-1482.

British Museum. Londres (Reino Unido).

En esta obra el artista ha copiado, aunque torpemente, las figuras de San Pedro con la espada, a la izquierda de Cristo, y la de Malco, con la oreja cortada, situado en el suelo, de la estampa de Schongauer ${ }^{291}$ (fig. 17) ${ }^{292}$. Ha eliminado el arma de Malco, y ha

\footnotetext{
${ }^{291}$ Estampa disponible en:

http://www.britishmuseum.org/research/collection_online/collection_object_details.aspx?objectId=14003 $\underline{42 \& \text { partId }=1 \& \text { searchText }=\text { arrest }+ \text { of }+ \text { jesus \&images }=\text { true } \& \text { people }=108158 \& \text { from }=\text { ad } \& \text { fromDate }=1450 \& \mathrm{t}}$
} 
reproducido de manera ineficaz el extraño escorzo con que se muestra tendido en el suelo. Se han utilizado también el personaje a la derecha de Cristo, que con una mano sujeta la cuerda y con la otra el manto, y uno de los personajes que aparecen detrás de Cristo y le agarra por los cabellos. La composición piramidal utilizada en la estampa no se sigue en la pintura, como ya señalara Verónica Cardona; ésta es mucho más uniforme: las figuras del fondo aparecen todas a la misma altura, y hay un sentido de homogeneidad ${ }^{293}$ en el que se renuncia a las características expresionistas de muchos de los personajes que aparecían en la estampa.

\section{Lamentación ante el cuerpo de Cristo}

Alrededor de Cristo, cuyo cuerpo ha sido depositado sobre piedra por José de Arimatea y Nicodemo, se colocan las figuras de la Virgen, San Juan y María Magdalena. Se trata de un motivo de origen bizantino que luego se extiende al Trecento italiano y de ahí al resto de Europa. En esta tradición, la Virgen suele situarse junto a la cabeza de Cristo, mientras que la Magdalena aparece junto a sus pies, en relación con la escena de la Unción en casa de Simón; la figura de San Juan media entre las dos. En esta pintura, sin embargo, la figura de la Magdalena aparece junto a la cabeza de Cristo, en el lado opuesto a la Virgen. San Juan consuela a la Virgen, que se apoya sobre su hombro. El resto de las figuras son José de Arimatea, Nicodemo y las santas mujeres. Los rostros, especialmente los de José de Arimatea, la Virgen, la Magdalena y San Juan, muestran gran aflicción.

La escena se ubica en un medio boscoso y montañoso, en el que destacan un pequeño grupo de árboles en el lado izquierdo, y un castillo al fondo arriba (fig. 18). Entre los personajes podemos ver a María, la Magdalena, San Juan Evangelista, Nicodemo y José de Arimatea. En realidad, aparecen los mismos personajes de la estampa de Israel van Meckenem (los propios de la escena de la Lamentación) (fig. $19)^{294}$, aunque no sé sitúan en las mismas posiciones, y no se han utilizado las figuras de una manera literal.

$\mathrm{o}=\mathrm{ad} \&$ toDate=1480\&page $=1$; BARTSCH, A., op. cit., p. 124; LEHRS, M., op. cit., $\mathrm{n}^{\mathrm{o}}$ 20, p. 128; HOLLSTEIN, F. W. H., German engravings, etchings and woodcuts..., vol. XLIX, n 20, p. 59.

${ }^{292}$ CARDONA JIMÉNEZ, V., La pintura gótica...., p. 156.

293 Ídem, pp. 156-157.

294 Estampa disponible en:

http://www.britishmuseum.org/research/collection_online/collection_object_details.aspx?objectId=13559 58\&partId=1\&searchText=lamentation\&images $=$ true $\&$ people $=115186 \&$ from $=$ ad \&fromDate $=1450 \&$ to $=a$ d\&toDate=1480\&page=1; BARTSCH, A., op. cit., vol. VI, p. 212; LEHRS, M., op. cit., vol. IV, p. 228; HOLLSTEIN, F. W. H., op. cit., vol. 24 a, n 638, p. 258. 


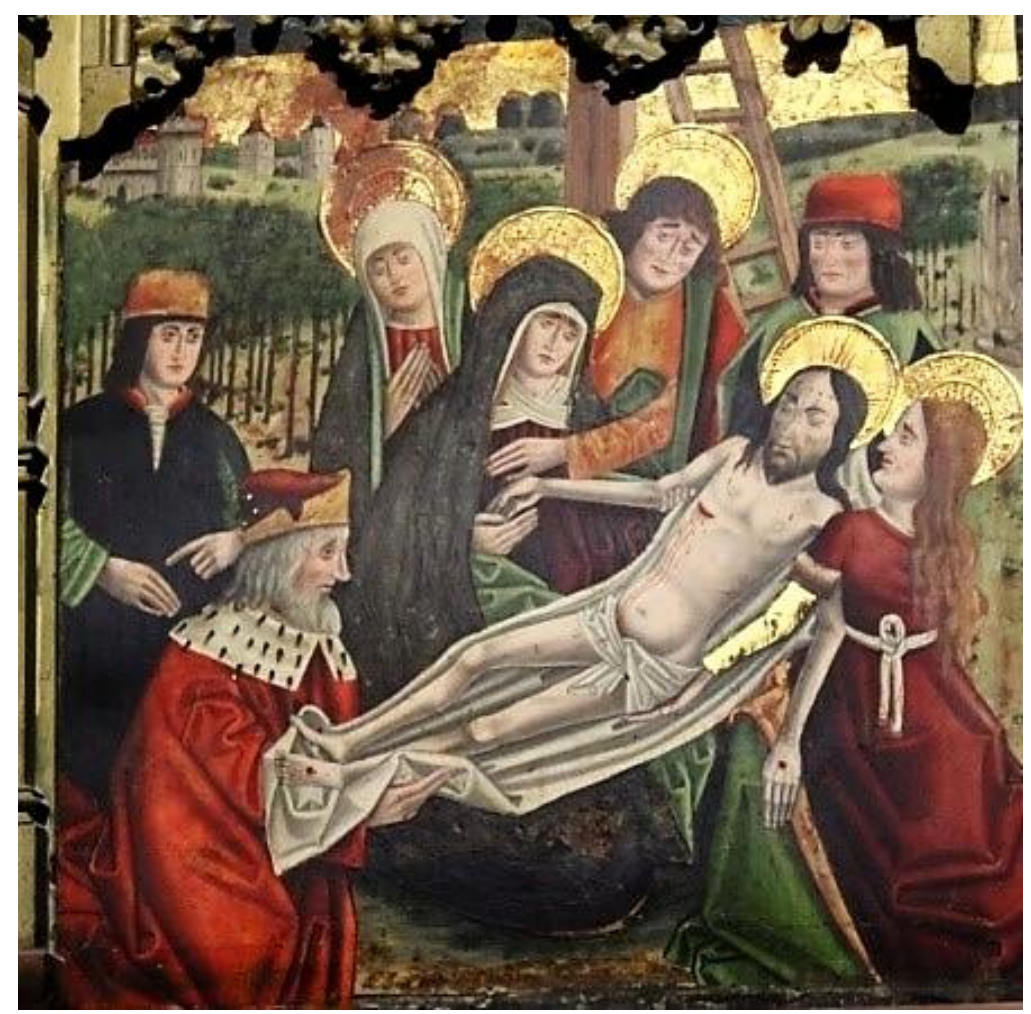

18. Anónimo. Lamentación ante el cuerpo de Cristo. Retablo de San Lorenzo. Ca. 1510. Iglesia de Nuestra Señora de los Milagros Ágreda (Soria)

19. Israel van Meckenem. Lamentación ante el cuerpo de Cristo. 1460. British Museum. Londres (Reino Unido).

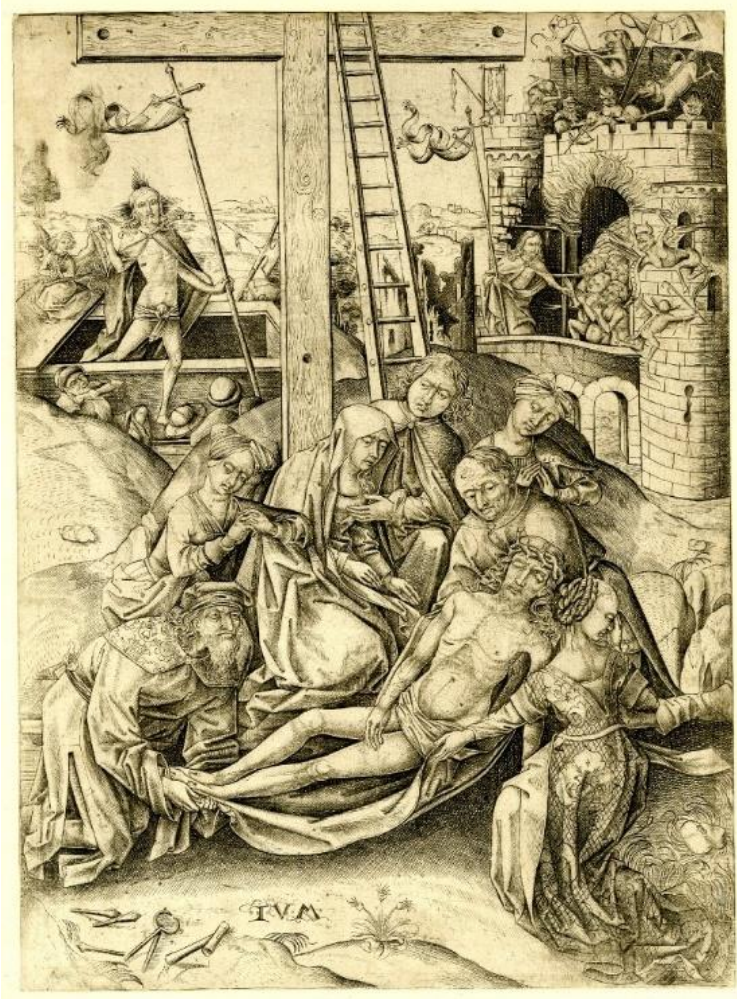

El pintor ha tomado del grabado el cuerpo de Cristo en diagonal, así como la figura de la Virgen a su derecha, si bien en la pintura las manos de la Virgen sujetan las 
de Cristo, detalle ausente de la estampa. Son también análogas las posiciones de San Juan Bautista, detrás de la Virgen, de la Magdalena (la mujer situada junto a Cristo, que coloca un brazo junto a su costado), y de José de Arimatea (el personaje que sujeta las piernas del difunto). Aparece también Nicodemo, que sujeta la cabeza de Cristo, aunque generalmente en la iconografía del tema suele sujetar sus piernas. Antecedentes en la disposición de la Virgen y de Cristo se encuentran en pinturas flamencas como la Lamentación de Dirk Bouts (ca. 1460) (figs. 20a y 20 b). Por otro lado, hay diferencias notables en la ausencia de las escenas de la Resurrección y el Descenso al Limbo del grabado, así como de los Arma Christi del suelo.

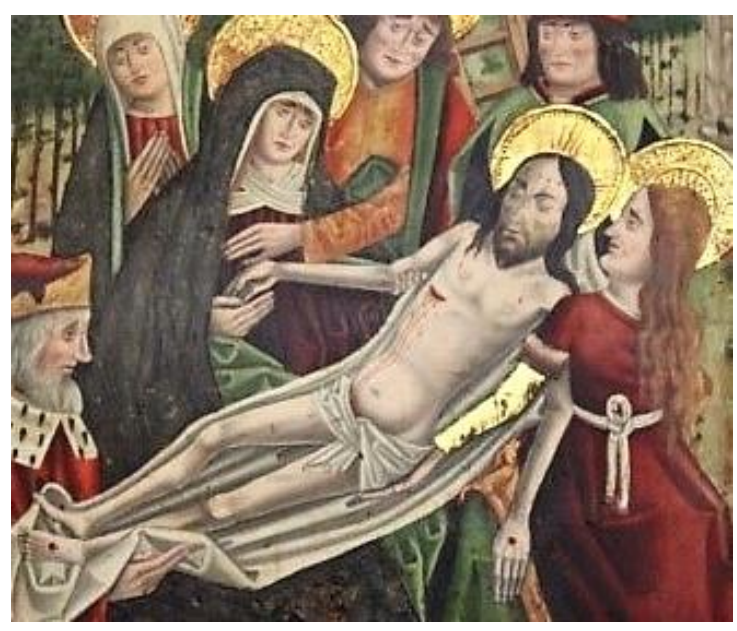

20a. Detalle de fig. 18

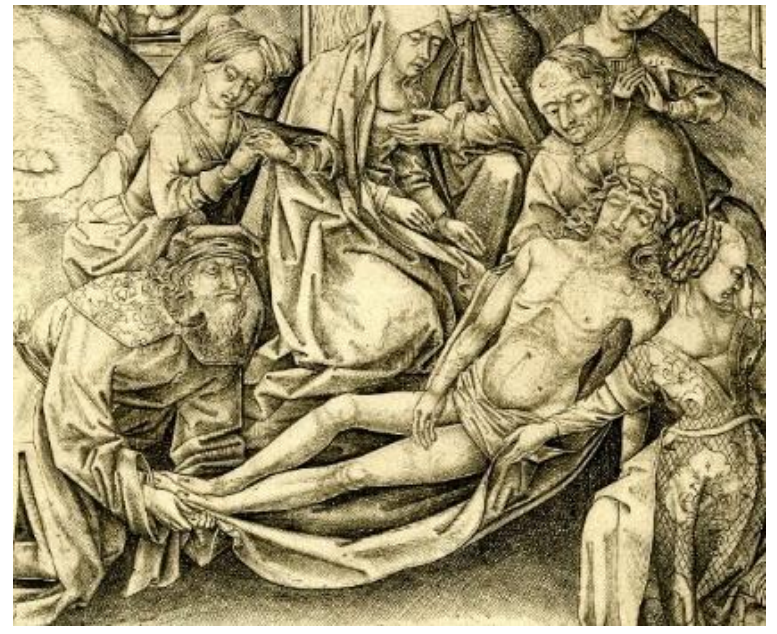

20b. Detalle de fig. 19

\section{Santo Entierro}

La escena se ubica en un paisaje montañoso con pequeños árboles, en el cual, arriba a la izquierda, se vislumbra la figura de la cruz (fig. 21). Los colores son los mismos verdes y rojos vistos en otras escenas. El artista utiliza torpemente la perspectiva, colocando la tumba rectangular en primer lugar, de un tamaño algo desproporcionado. Generalmente la escena está compuesta al menos por seis personajes: Nicodemo, María Magdalena, la Virgen María, San Juan, José de Arimatea y el propio Cristo. En este caso aparecen ocho; se han añadido las figuras de otras dos mujeres a la derecha de Cristo, una con manto blanco y otra con manto negro, de las que sólo vemos las cabezas. 
En esta escena se utilizó también una estampa de $\operatorname{Schongauer}^{295}$ (fig. 22) ${ }^{296}$, en este caso la del Entierro de Cristo, reproduciendo básicamente toda la escena. De ella provienen la figura de Cristo con el brazo izquierdo colgando; la Virgen María, sujetándolo por el torso mientras San Juan apoya un brazo sobre sus hombros; José de Arimatea, a la izquierda, vestido ricamente y con aspecto anciano, que sujeta las piernas de Cristo para introducirlas en la tumba, y toda la serie de personajes de ambos sexos del fondo. Destaca la Magdalena, que sujeta la mano izquierda de Cristo y la apoya contra su rostro con gesto compungido. En general, todas las figuras muestran actitudes pesarosas contemplando la escena. El emplazamiento de Cristo, cuyo cuerpo medio emerge del sepulcro, rodeado por el resto de personajes, procede de algunas pinturas flamencas primitivas como El Santo Entierro de Dirk Bouts, de cerca de 1450 (fig. $23)^{297}$ de los que también pudo tomar una interpretación menos agreste del paisaje.

21. Anónimo. Santo Entierro Retablo de San Lorenzo. Ca. 1510. Iglesia de Nuestra Señora de los Milagros Ágreda (Soria).

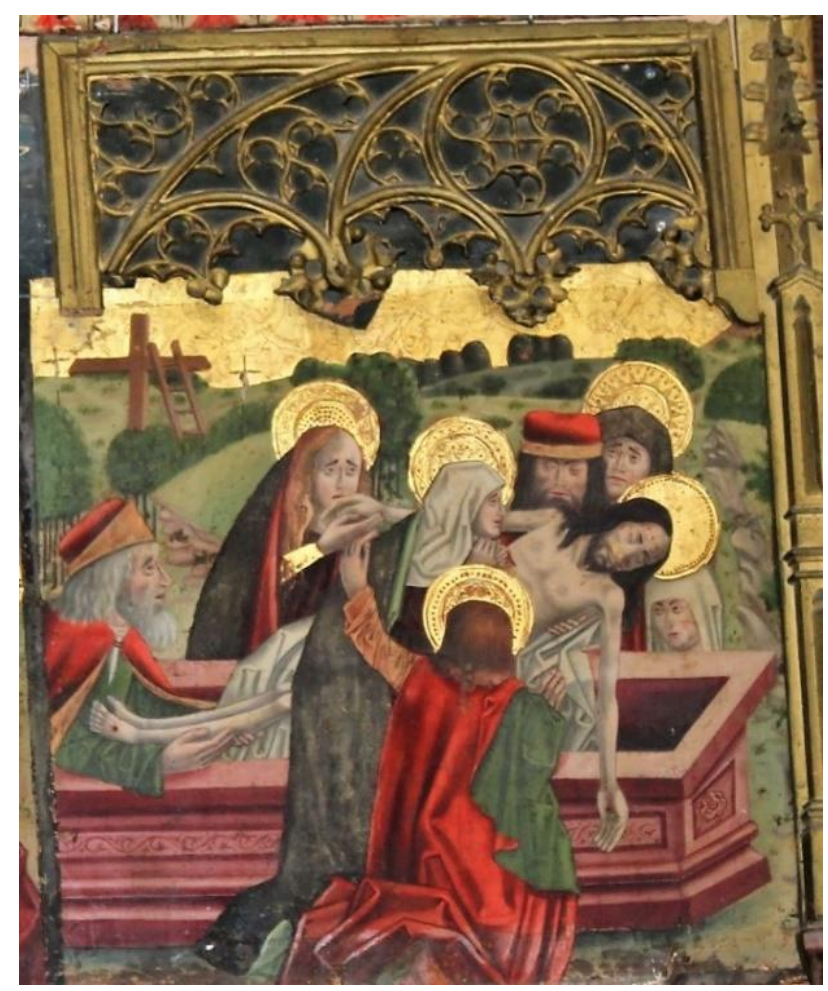

\footnotetext{
${ }^{295}$ Estampa disponible en:

http://www.britishmuseum.org/research/collection_online/collection_object_details.aspx?objectId=14006

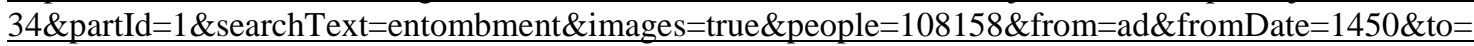
ad\&toDate $=1480 \&$ page $=1$

BARTSCH, A., op. cit., p. 127; LEHRS, M., op. cit., vol. V, no 28, p. 155; HOLLSTEIN, F. W. H., German engravings, etchings and woodcuts..., $\mathrm{n}^{\circ} 28, \mathrm{p} .82$.

${ }^{296}$ CARDONA JIMÉNEZ, V., La pintura gótica ..., p. 160.

${ }^{297}$ Imagen de dominio público:
}

https://commons.wikimedia.org/wiki/Dieric_Bouts\#/media/File:Dieric_Bouts_- The Entombment_-

Artron.jpg 


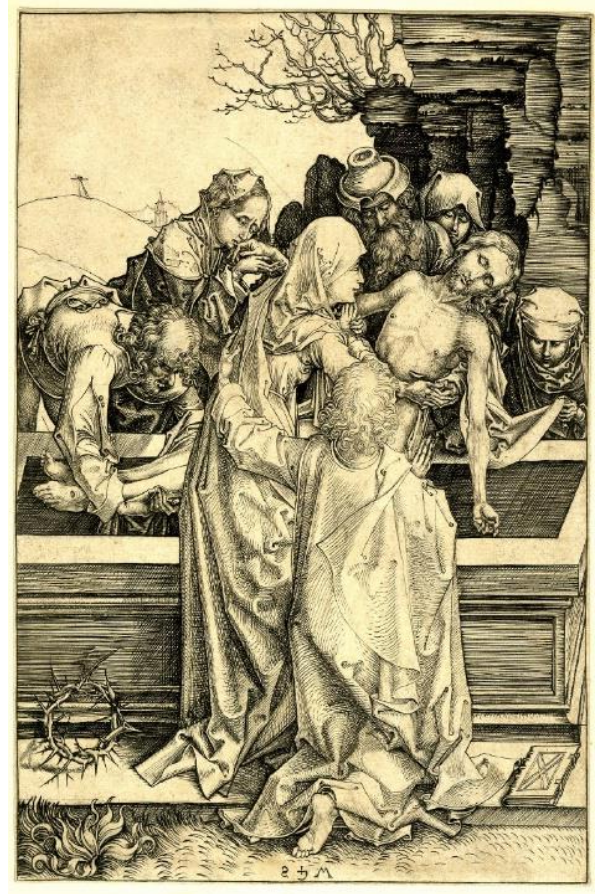

22. Martin Schongauer. Entierro. 1470-1882. British Museum. Londres (Reino Unido).

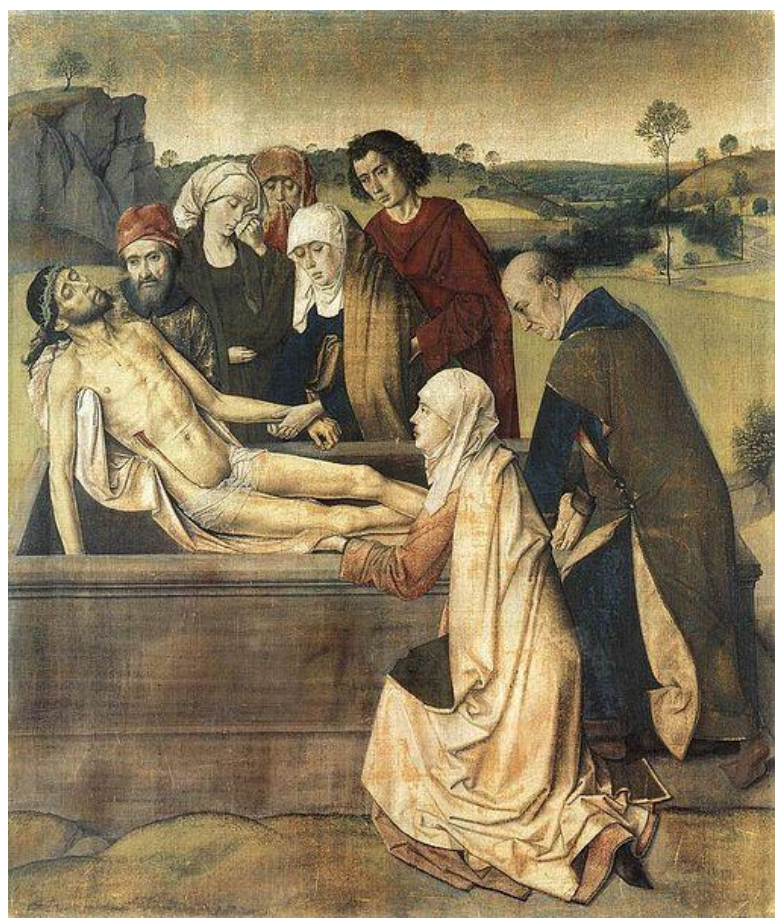

23. Dirk Bouts. Entierro de Cristo. 1450. National Gallery. Londres (Reino Unido).

\section{Alonso de Sedano, Maestro de Osma Retablo de la Virgen del Rosario Ca. 1510 \\ Iglesia de Nuestra Señora de la Asunción Montenegro de Cameros (Soria)}

La localidad de Montenegro de Cameros se encontraba ubicada entre las diócesis de Calahorra, Osma y la Archidiócesis de Burgos, si bien perteneció a ésta última hasta el siglo $\mathrm{XX}^{298}$.

Este retablo se encuentra en el lado izquierdo de la iglesia. Su denominación actual responde a la época barroca, cuando se colocó la actual imagen escultórica, que coincide con el centro del mismo. Diversos autores lo atribuyen bien al maestro de Sedano o bien al de Osma ${ }^{299}$. La riqueza de los colores, las figuras desprovistas de belleza, la simplificación de formas y el modo de resolver las composiciones coincidirían con el estilo del primero ${ }^{300}$.

${ }^{298}$ VICENTE GARCÍA, M., Descripción de la Villa de Montenegro, Madrid, Imprenta de Don Francisco de la Parte, 1818, p. 2.

${ }^{299}$ Gudiol Ricart y Camón Aznar lo atribuyen, respectivamente, al Maestro de Sedano. GUDIOL RICART, Pintura gótica..., p. 370; CAMÓN AZNAR, J., Pintura medieval española..., p. 604; ARRANZ ARRANZ, J., El Renacimiento en la Diócesis..., p. 312.

${ }^{300}$ SILVA MAROTO, P., "Notas para un mejor conocimiento de la pintura burgalesa de fines del siglo XV y el primer tercio del XVI", La ciudad de Burgos, Burgos, 1984, pp. 883-889; "Retablo de la Virgen", pp. 360-361. 
Conserva vestigios de la pintura gótica, que se manifiestan en el uso del dorado para las aureolas y para la decoración de algunas vestimentas. Ciertos detalles, como la indumentaria del rey Baltasar en la escena de La Adoración de los Magos, permiten datar el retablo en torno a $1510^{301}$.

Está conformado por una gran predela y dos cuerpos con cinco calles (fig. 24) ${ }^{302}$. En la predela se ubican las pinturas de varios profetas: Zacarías, Balán, Isaías, Daniel y Jeremías. En el primer cuerpo se encuentran la Adoración de los Magos, Presentación en el templo, Huida a Egipto y Pentecostés. En el segundo aparecen la Anunciación, la Visitación, el Nacimiento y la Circuncisión.

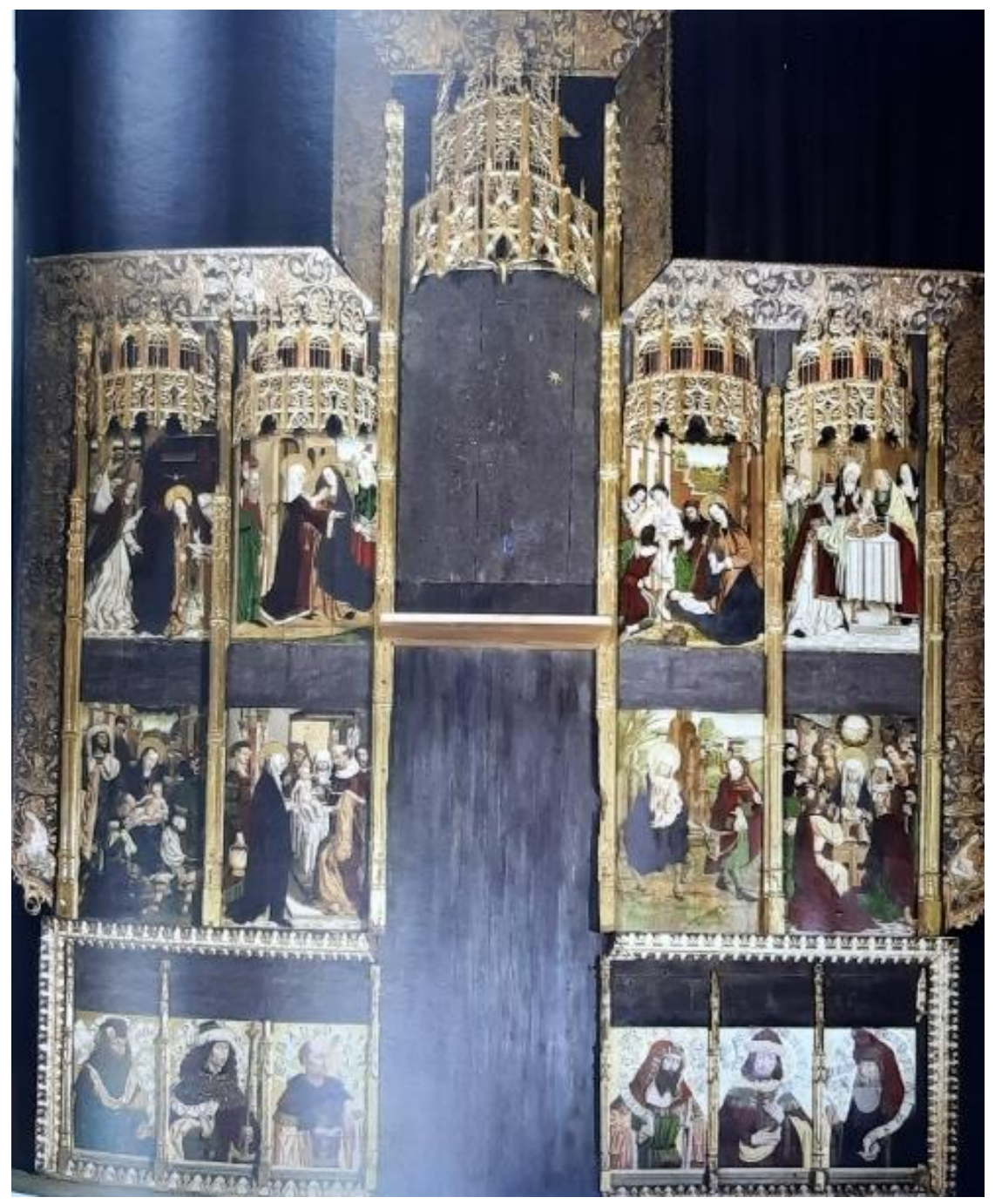

24. Alonso de Sedano. Maestro de Osma. Ca. 1510.

Retablo de la Virgen del Rosario. Iglesia de Nuestra Señora de la Asunción. Montenegro de Cameros (Soria)

\footnotetext{
${ }^{301}$ SILVA MAROTO, P., Pintura hispanoflamenca castellana..., t. III, p. 727.

${ }^{302}$ Imagen procedente de SILVA MAROTO, P., "Retablo de la Virgen”, p. 361
} 


\section{Anunciación}

En esta escena de la Anunciación (fig. 25) Sedano podría haberse inspirado en la estampa del mismo tema de Maestro FVB (fig. 26) ${ }^{303}$. El pintor ha invertido la postura de las manos del ángel, que sujeta con la mano izquierda la vara, mientras hace el gesto de bendición con la derecha, al contrario de lo que sucede en la estampa. Otro aspecto destacable es la vestimenta y el peinado del ángel, muy parecidos. Gabriel lleva el cabello ensortijado, y viste una túnica larga con amplios pliegues y un manto, similares a los de la estampa. La Virgen también es muy semejante en postura y vestimentas. Por último, es reseñable cómo se ha representado el interior burgués en el que se ubica la escena, que proviene de las escenas cotidianas flamencas. Al fondo a la derecha hay una cama alta con amplios doseles; junto a la Virgen, un atril de madera sobre el que reposa un libro.

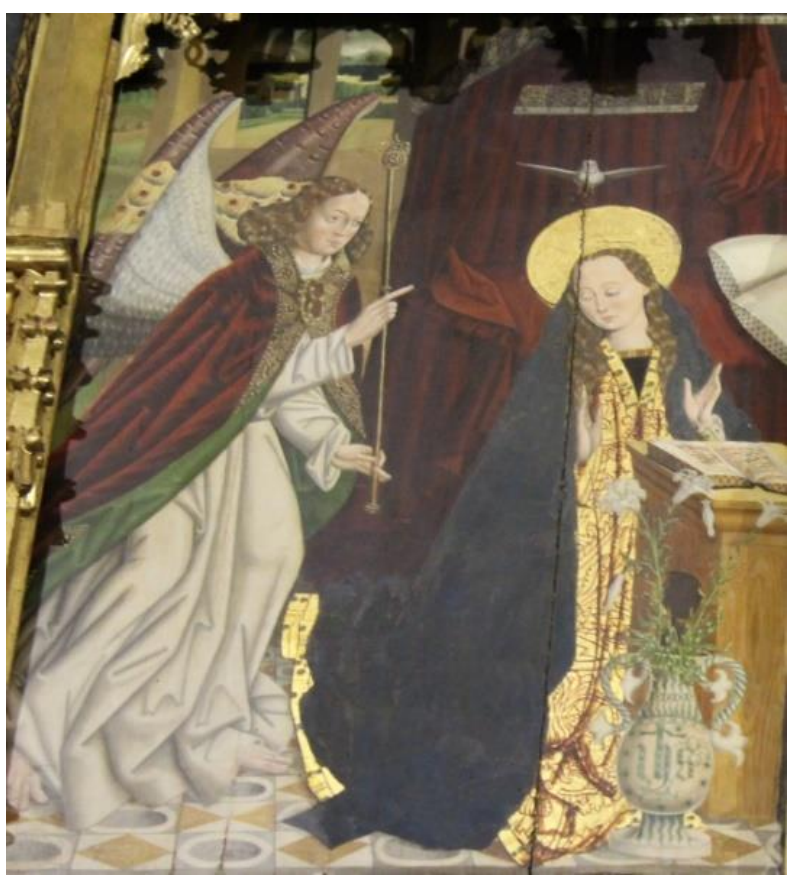

25. Maestro de Sedano. Anunciación. Retablo de la Virgen del Rosario.Ca. 1510. Iglesia de Nuestra Señora de la Asunción. Montenegro de Cameros (Soria).

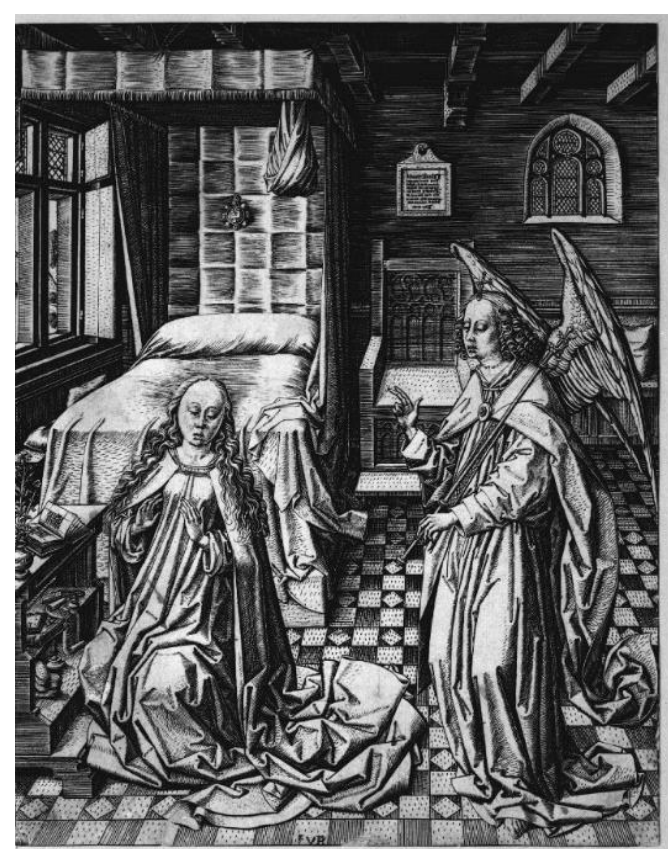

26. Maestro FVB. Anunciación. 1485-1500.

British Museum. Londres

\footnotetext{
${ }^{303}$ Estampa disponible en: http://www.britishmuseum.org/research/collection_online/collection_object_details.aspx?objectId=14036 $17 \&$ partId $=1 \&$ searchText $=$ annunciation\&images $=$ true \&people $=115556 \&$ page $=1$ BARTSCH, A., op. cit., vol. VI, p. 81; LEHRS, M., op. cit., vol. VII, p. 121; HOLLSTEIN, F. W. H., German engravings, etchings and woodcuts..., vol. XII, ${ }^{\circ}$ 4, p. 144.
} 
Otro detalle relevante es el ajedrezado del suelo formado por rombos y círculos, que seguramente el pintor tomó también del mismo grabado o de otros modelos o pinturas flamencos, y que es el elemento más relacionado con la estampa. Estos suelos ya fueron utilizados por Sedano en otras obras como las de la Catedral de Burgos.

Además de todo esto, el pintor ha añadido un vistoso jarrón con lirios que no aparece en la estampa, y al fondo del cuadro observamos una serie de ventanales a través de los cuales vislumbramos un paisaje. Para la figura de la Virgen otra fuente podría ser la estampa del mismo tema de Maestro E. S. (fig. 28) ${ }^{304}$, especialmente para las manos de la misma. El modelo deriva de algunas pinturas de Dirk Bouts, tanto para las figuras del ángel y la Virgen como para el interior flamenco (fig. 29) ${ }^{305}$.

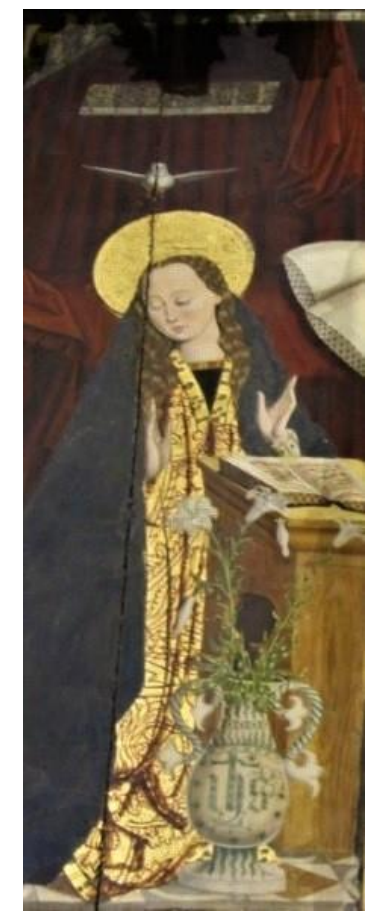

27. Detalle fig. 25 .

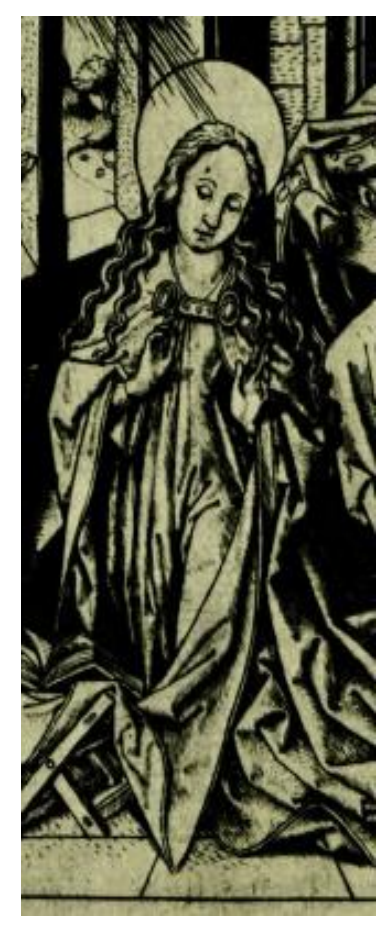

28. Maestro E. S. Anunciación. 1420-1468.

Museo de la Albertina. Viena (Austria).

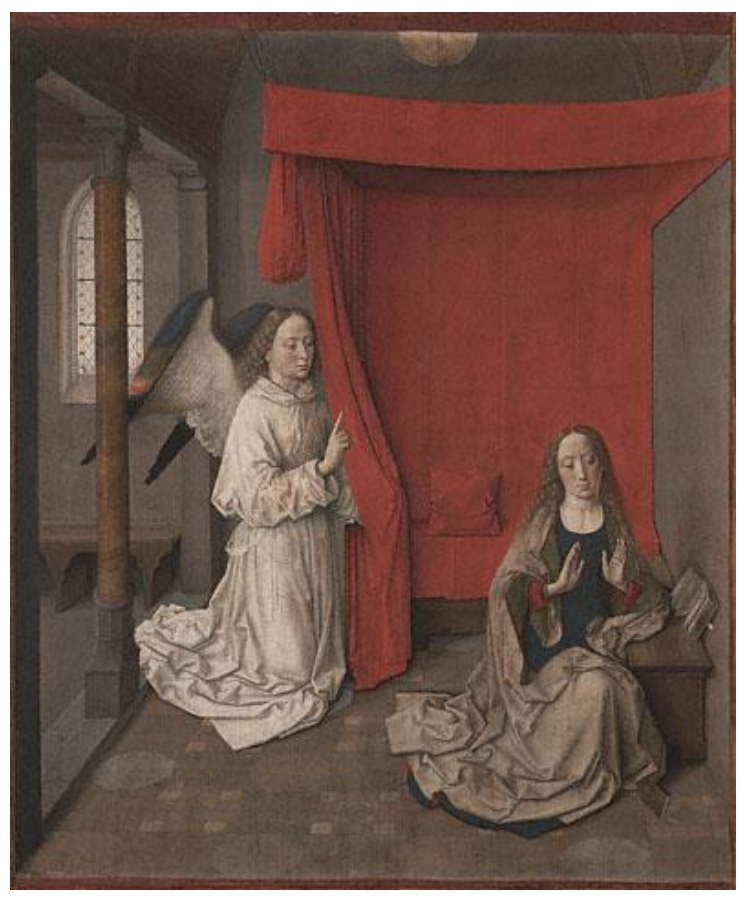

29. Dirk Bouts. Anunciación. 1465-1470. Museo Calouste Gulbekian. Lisboa (Portugal)

\footnotetext{
${ }^{304}$ Imagen procedente de VV. AA.., Illustrated Bartsch, German 15th century: Master E. S., Master FVB, Schongauer, Mair Von Landshut, t. 8, Nueva York, Abaris Books, 1980, p. 17.

305 Imagen procedente de: https://es.wikipedia.org/wiki/Archivo:Bouts, Dieric _ The Annunciation Google_Art_Project.jpg\#/media/Archivo:Dieric_Bouts_The_Annunciation__GCLA_85.PA.24.jpg
} 


\section{Natividad}

El pintor se inspiró aquí (fig. 30) en la estampa de Schongauer de la Natividad (fig. 31) ${ }^{306}$. En concreto, tomó de la estampa las figuras de la Virgen y el Niño. La Virgen aparece a la derecha de la composición, con las manos entrelazadas en posición de oración y la cabeza inclinada en gesto de humildad. Luce el mismo cabello ondulado y con raya al medio. Sobre su amplio manto, que en el cuadro es aún más voluminoso, descansa el niño, aunque con ciertas variaciones respecto a la estampa. En la estampa ambos brazos aparecen hacia delante, reposando sobre su cuerpo, mientras que en el cuadro el Niño se lleva la mano al mentón.

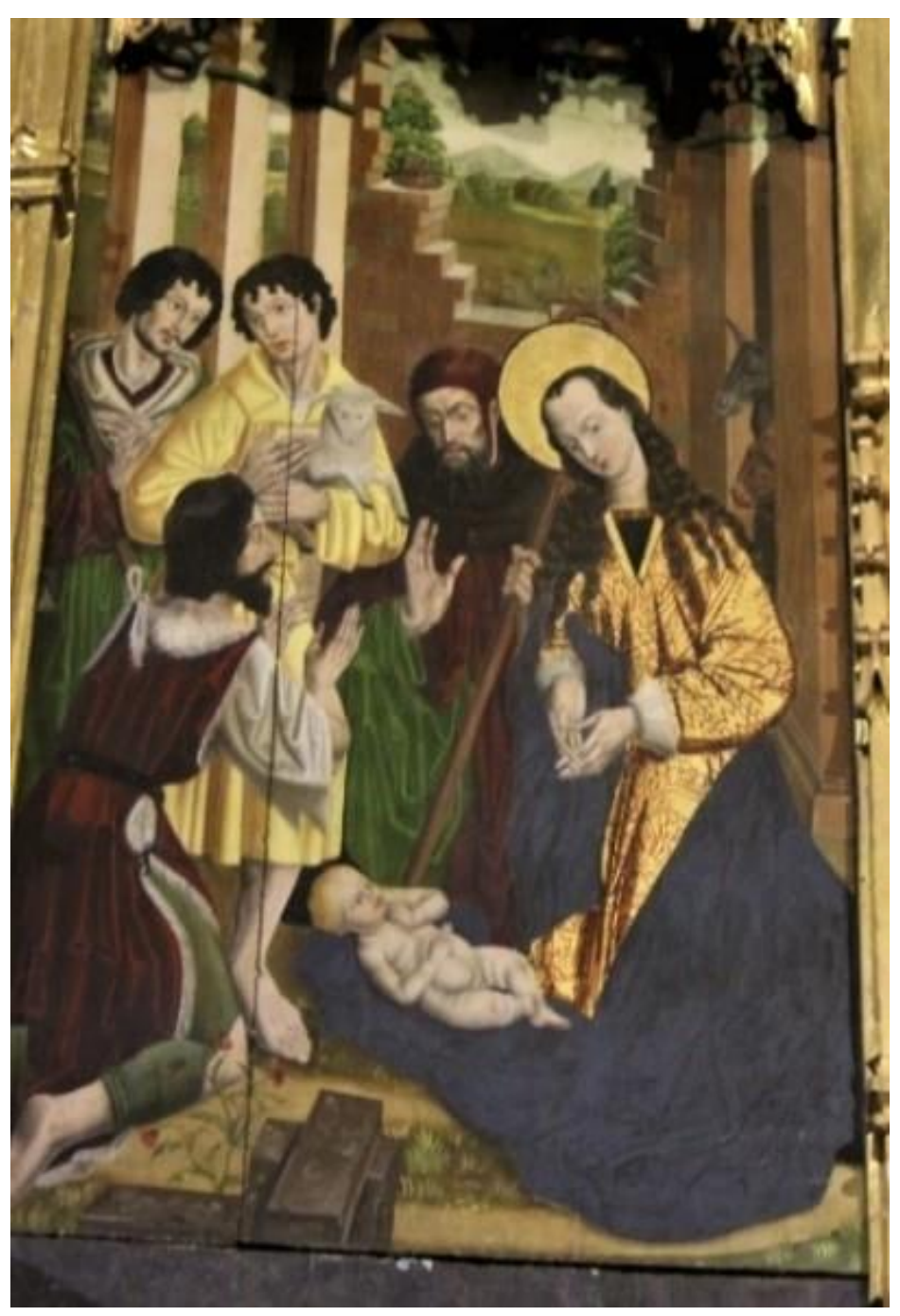

30. Maestro de Sedano.

Natividad.

Retablo de la Virgen del

Rosario.

Ca. 1510.

Iglesia de Nuestra Señora de la Asunción.

Montenegro de Cameros (Soria)

\footnotetext{
${ }^{306}$ Estampa disponible en:

http://www.britishmuseum.org/research/collection_online/collection_object_details.aspx?objectId=14464 81\&partId=1\&searchText=nativity\&images=true\&people=108158\&page=1; BARTSCH, A., op. cit., vol. VI, p. 120; LEHRS, M., op. cit., vol. V, p. 53; HOLLSTEIN, F. W. H., German engravings, etchings and woodcuts..., vol. XLIX, $\mathrm{n}^{\circ} 5 \mathrm{~b}, \mathrm{p} .22-23$.
} 


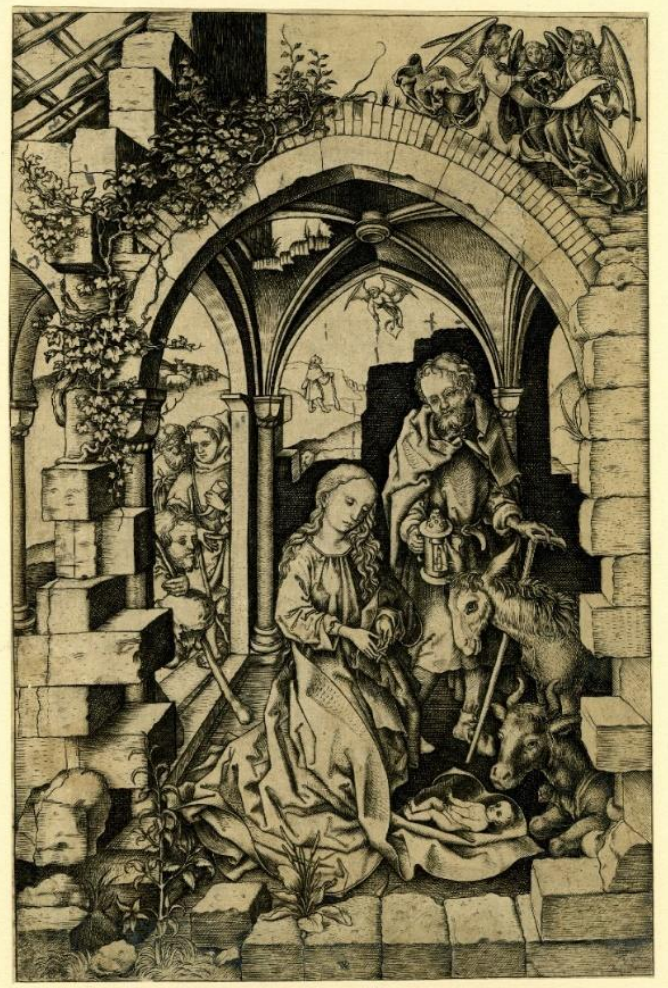

31. Wenzel von Olmütz (a partir de Martin Schongauer). Natividad. 1470-1474. British Museum. Londres (ReinoUnido).

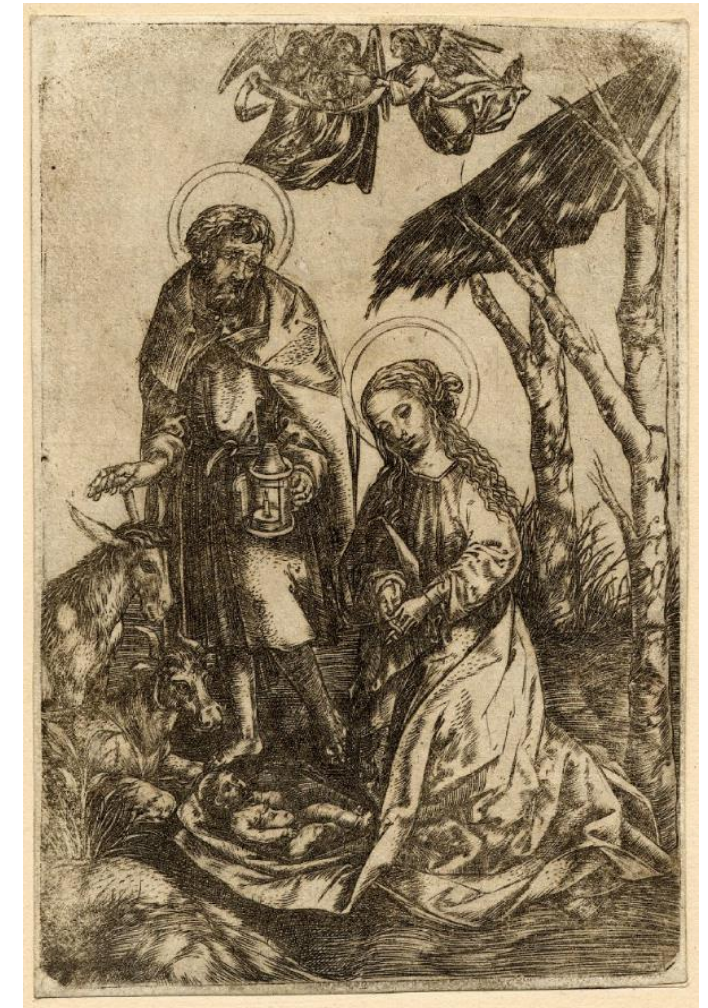

32. Cristofano Robetta (a partir de Schongauer), Natividad. 1495-1500. British Museum. Londres (ReinoUnido).

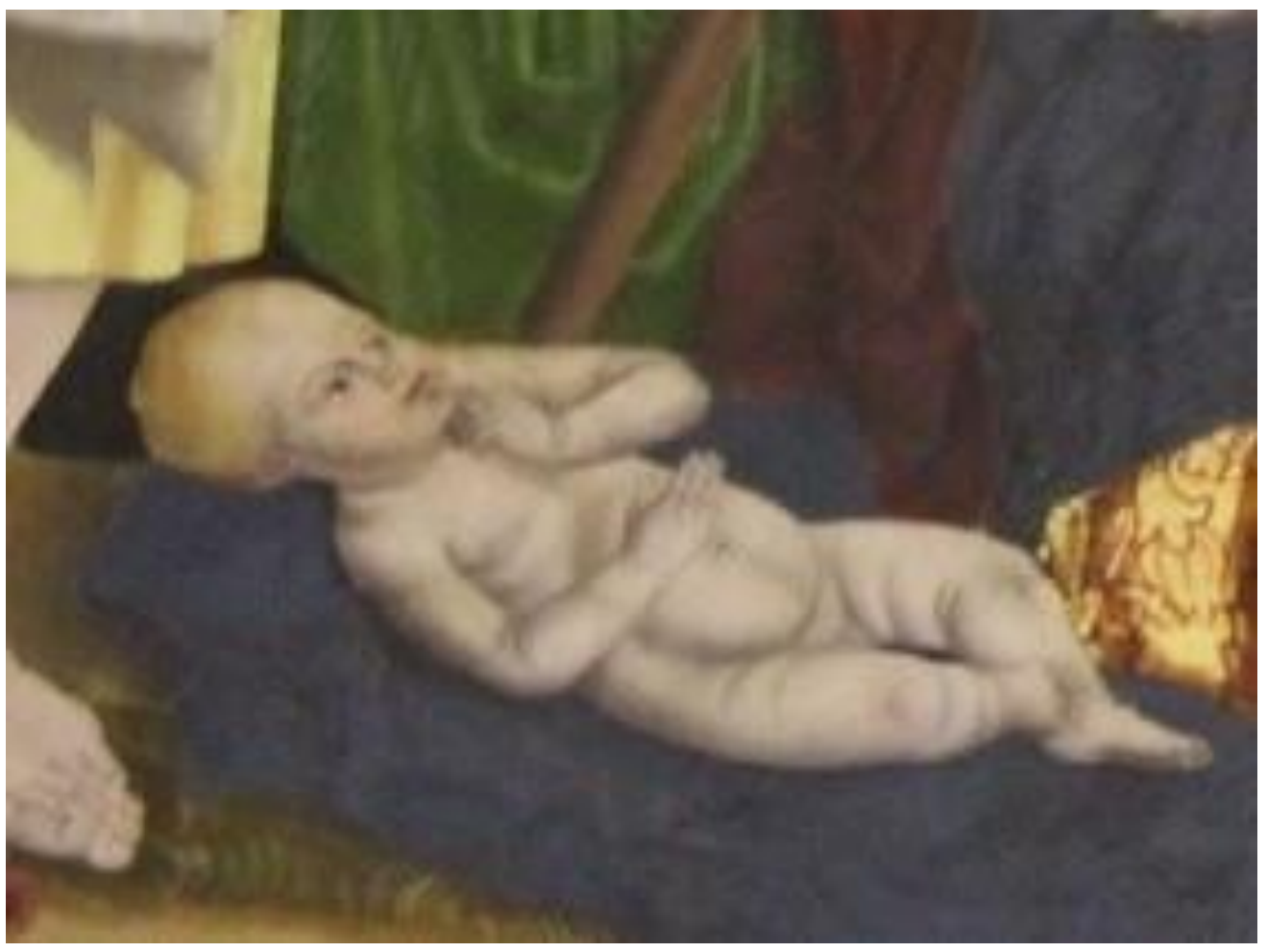

33. Detalle de fig. 30 . 


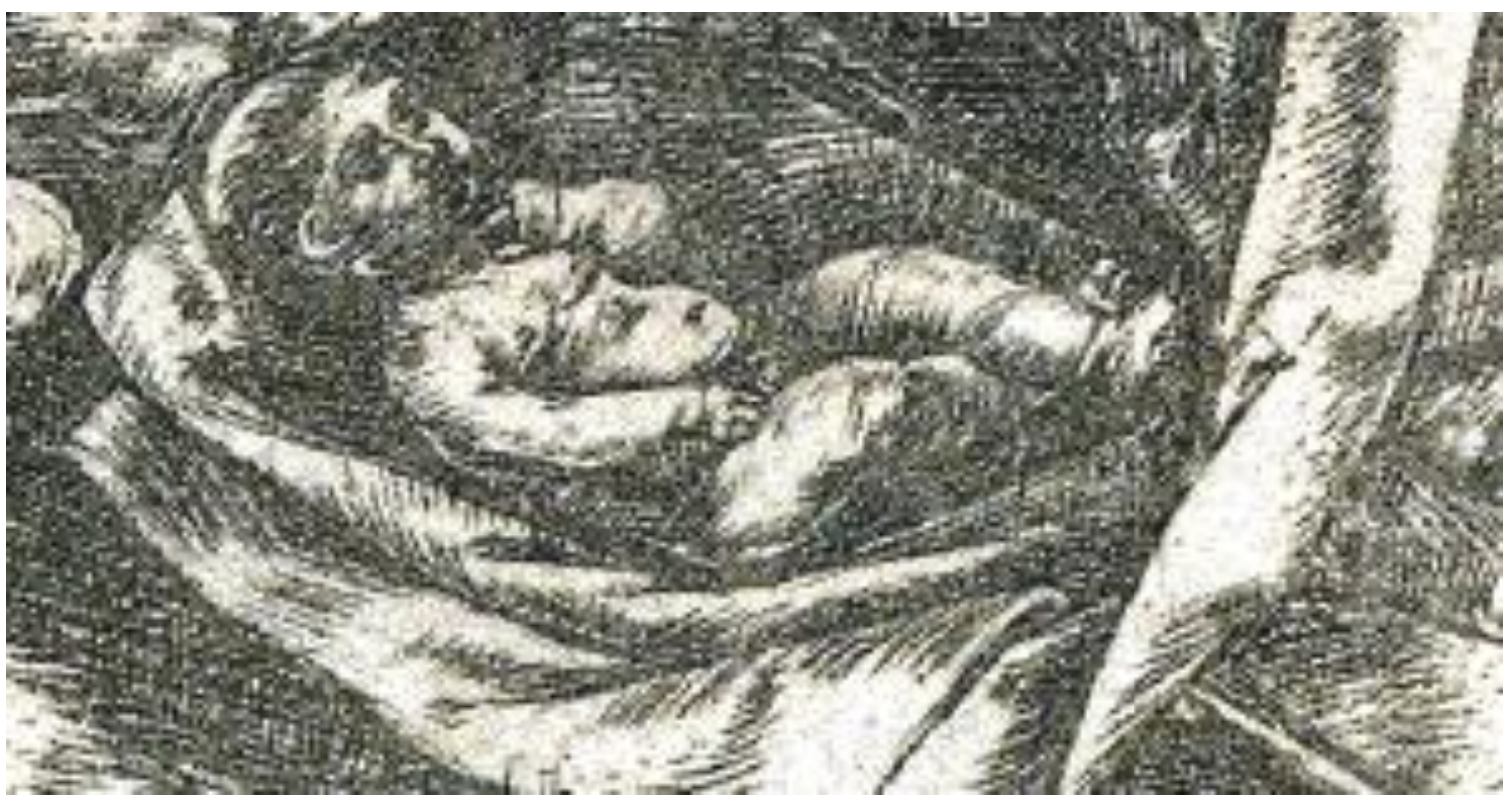

34. Detalle de fig. 32

\section{Visitación}

Para a la escena de la Visitación (fig. 35) el artista tomó como modelo un grabado anónimo (fig. 36) ${ }^{307}$. Existe semejanza entre ambos modelos, si bien no se puede demostrar una relación directa. Este modo de representar el tema fue muy utilizado en la época. La postura de la Virgen e Isabel es muy parecida, así como su caracterización, aunque en este caso la Virgen cubre sus cabellos con el amplio manto que lleva sobre los hombros. El personaje de Zacarías, que surge de una de las puertas situadas a la izquierda de la composición, luce en la pintura una vestimenta similar, aunque levanta su sombrero en señal de saludo. Su gesto podría provenir de alguna otra estampa, ya que lo encontramos en otras pinturas como la del Maestro de Perea (fig. $37)^{308}$. Se ha suprimido aquí el complejo fondo de arquitectura civil formado por una muralla y un arco de medio punto, y en su lugar se ha colocado la figura de la criada de la Virgen, en simetría con Zacarías.

\footnotetext{
307 Imagen procedente de STRAUSS, W. L., y WOLFF, M., Illustrated Bartsch, German and Netherlandish Masters of the Fifteenth and Sixteenth Centuries, t. 23, Nueva York, Abaris Books, 1985, p. 13.

${ }_{308}$ Imagen procedente de : https://www.museodelprado.es/coleccion/obra-de-arte/la-visitacion/03acalf08cf3-4f8e-8df9-f10c9964446a
} 


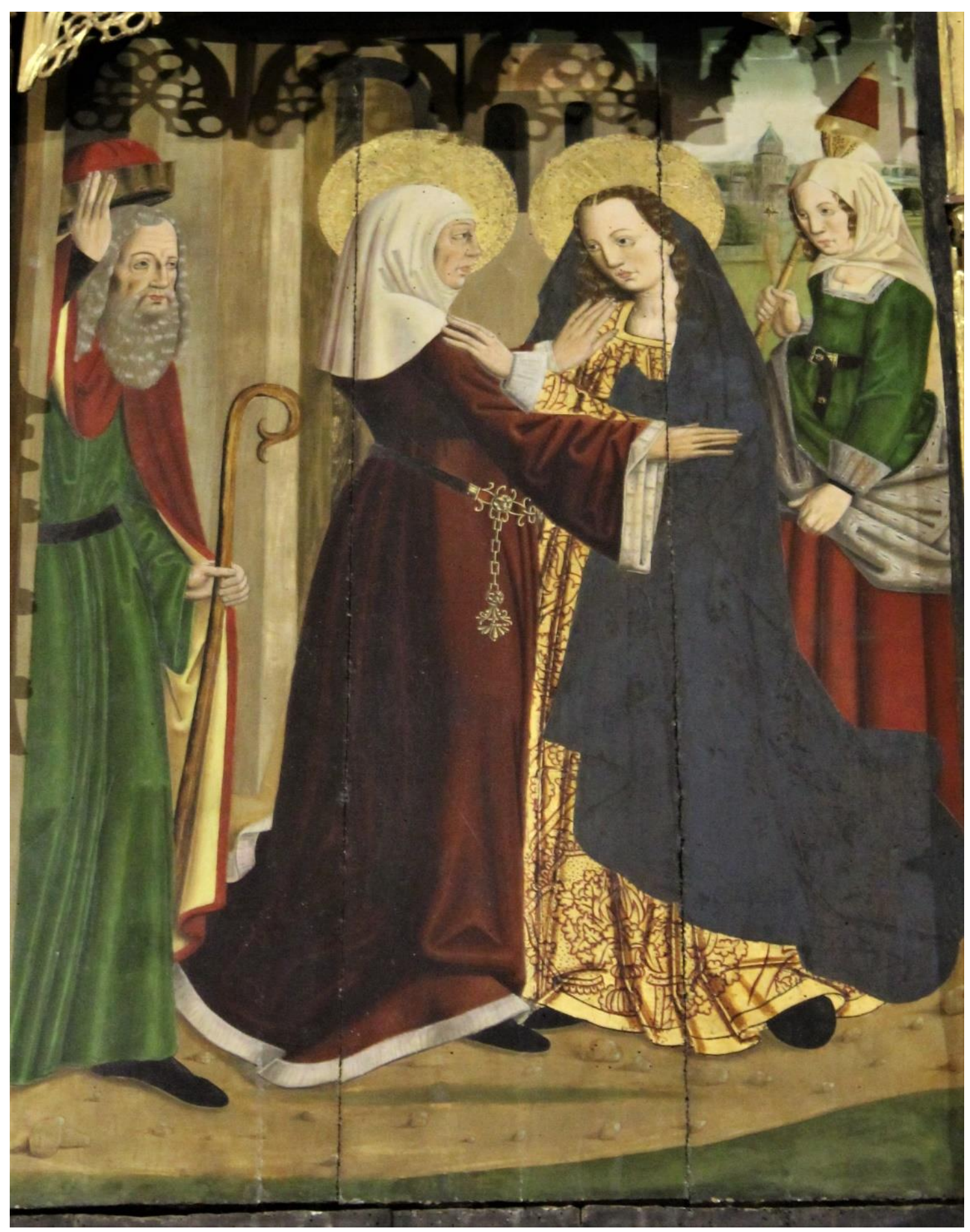

35. Maestro de Sedano. Visitación.

Retablo de la Virgen del Rosario. Ca. 1510.

Iglesia de Nuestra Señora de la Asunción.

Montenegro de Cameros. (Soria) 


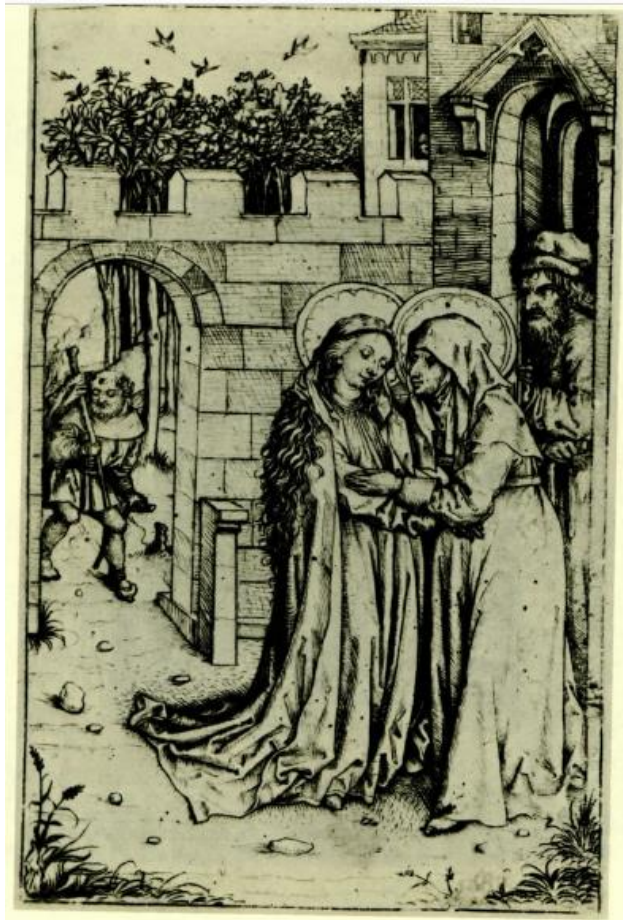

36. Master of the Housebook. Visitación. Rijksmuseum. Amsterdam. (Holanda)

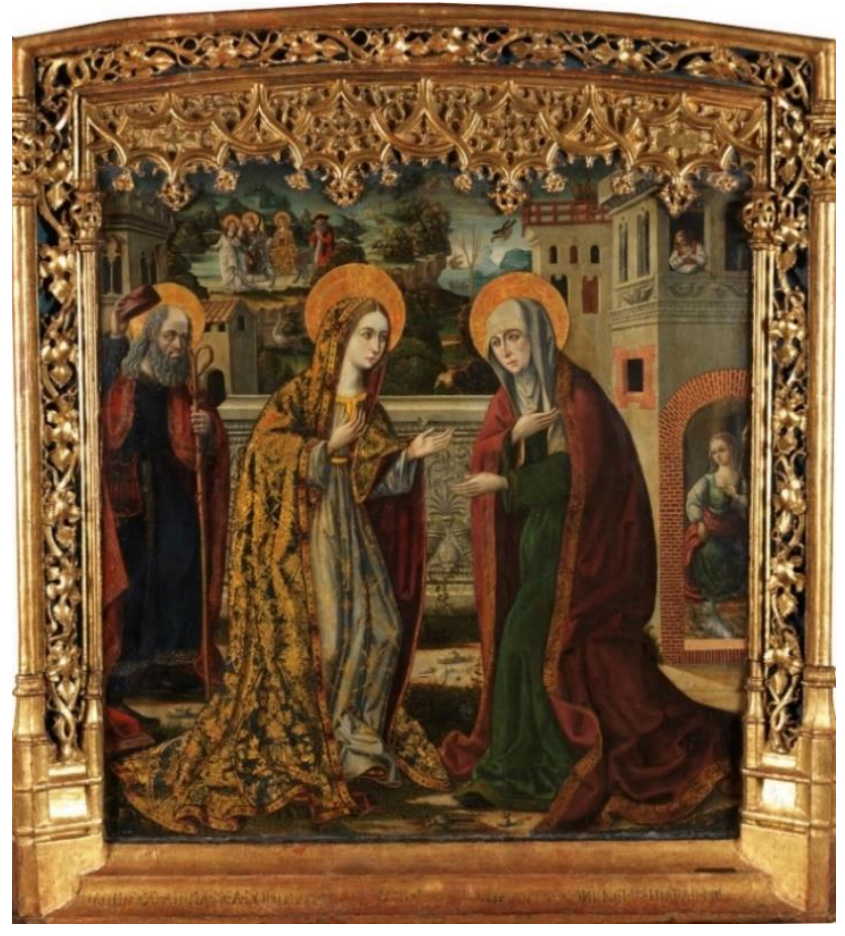

37. Maestro de Perea. Visitación. Ca. 1500. Museo Nacional del Prado. Madrid

\section{Viaje a Egipto}

Para la escena del Viaje a Egipto (fig. 38) es posible que se tomara como modelo la estampa del mismo tema de Maestro del Martirio de los Diez mil, obra en realidad del grabador alemán Israhel van Meckenem (fig. 39) ${ }^{309}$. La estampa está datada del 1460 al 1500. La pintura tiene en común con el grabado las posturas de San José, la Virgen, el Niño y el asno, aunque con algunas diferencias. San José aparece portando sobre el hombro derecho un objeto, que en el cuadro es una vara de la que cuelga un paquete, y en la estampa parece un hacha. Con la mano izquierda sujeta la brida del asno. Lleva la cabeza cubierta, en el cuadro por una capucha y en la estampa por un voluminoso sombrero. Se trata probablemente de una simple coincidencia de composición, una combinación de varios modelos, sin relación directa entre estampa y pintura. De hecho existen muchas composiciones similares en grabados, como es el caso de Monogramista MR (fig. 40) ${ }^{310}$ donde las figuras de la Virgen, el Niño y la mula son también muy parecidas.

\footnotetext{
${ }^{309}$ Estampa disponible en:

http://www.britishmuseum.org/research/collection_online/collection_object_details.aspx?objectId=14016 64\&partId=1\&searchText=the+flight+into+egypt\&images=true\&people=115186\&page $=1$ LEHRS, M., op. cit., vol. IX, p. 87.

${ }^{310}$ Estampa disponible:
} 


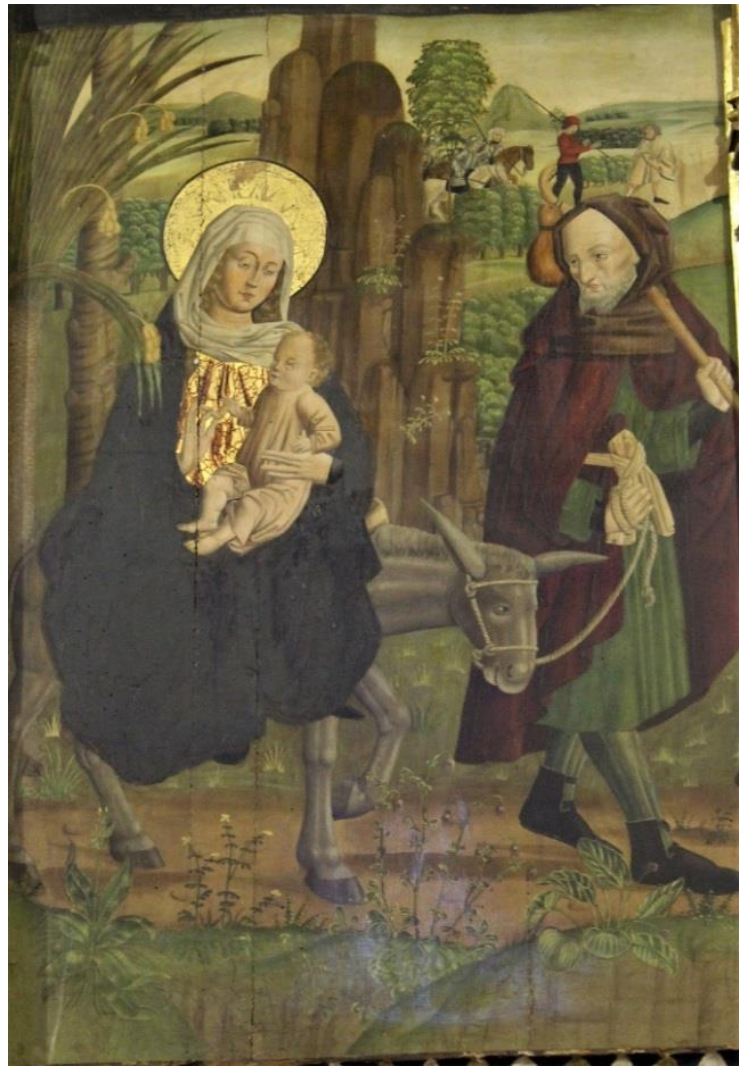

38. Maestro de Sedano. Viaje a Egipto, Retablo de la Virgen del Rosario. Ca. 1510. Iglesia de Nuestra Señora de la Asunción. Montenegro de Cameros (Soria).

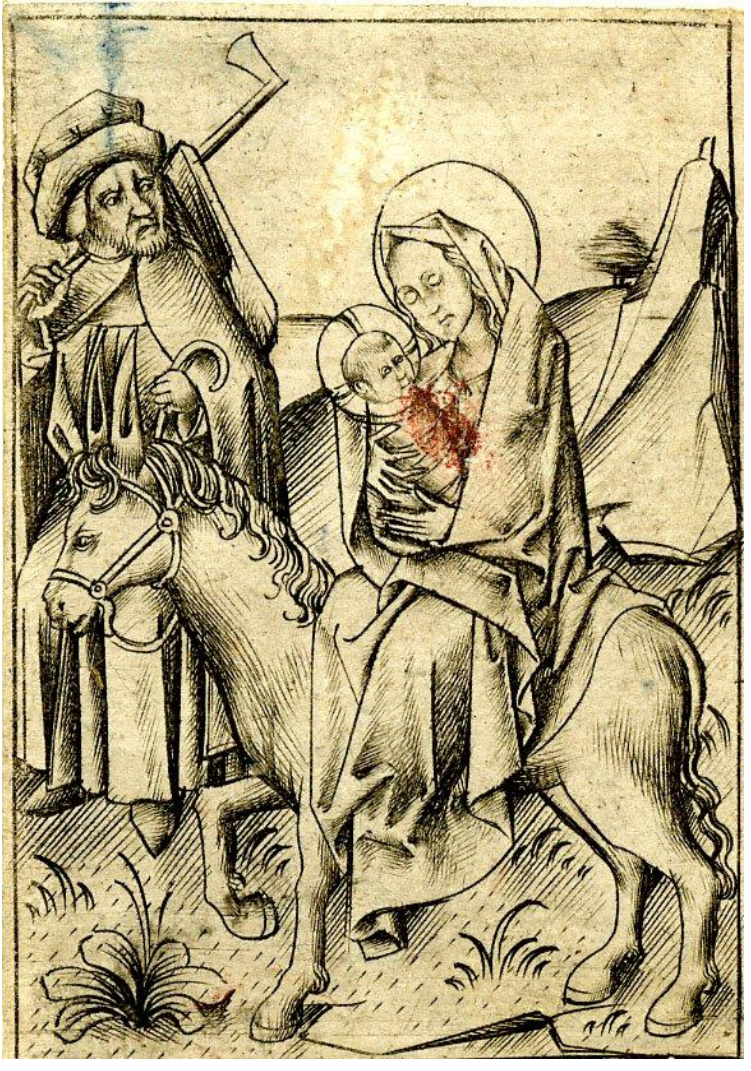

39. Maestro del martirio de los Diez Mil, Israel van Meckenem. Viaje a Egipto. 1460-1500.British Museum. Londres (Reino Unido).

Respecto a la Virgen y el Niño, en ambas composiciones aparecen sentados sobre el asno, y con el Niño mirando a la Virgen. Su cabeza aparece rodeada por una gran aureola y cubierta por un velo que deja ver su pelo ondulado. También viste un grueso manto que le tapa las piernas y cae hasta las extremidades del asno. Respecto a la figura del Niño, en la estampa es más hierática, pues tiene todo el cuerpo cubierto por una tela de la que sólo asoma la cabeza; en cambio, en la pintura aparece más libre, moviendo los brazos en dirección a su madre; de hecho, parece ofrecer a María con su mano izquierda un dátil de la palmera. Este gesto podría haber sido tomado de otra estampa, quizás la del mismo tema de Schongauer (fig. 41) ${ }^{311}$. En este sentido, la escena

https://www.britishmuseum.org/research/collection_online/collection_object_details.aspx?objectId=1495 $143 \&$ partId=1\&searchText=flight+into+egypt\&images=true $\&$ from=ad \& fromDate=1450\&to=ad\&toDate $=1500 \&$ page=1; HOLLSTEIN, Dutch and flemish ..., vol. XIII, p. 95.

${ }^{311}$ Estampa disponible:

https://www.britishmuseum.org/research/collection_online/collection_object_details.aspx?objectId=1363 625\&partId=1\&searchText=flight+into+egypt\&images=true \&from=ad\&fromDate $=1450 \&$ to $=$ ad\&toDate $=1500 \&$ page $=1$; BARTSCH, A., op. cit., vol. VI, p. 123; LEHRS, M., op. cit., vol. V, nº 7, p. 62. 
iría asociada al episodio conocido como el Milagro de la Palmera: la palmera se inclina hacia la Virgen y ella toma uno de sus frutos para ofrecérselo al Niño.

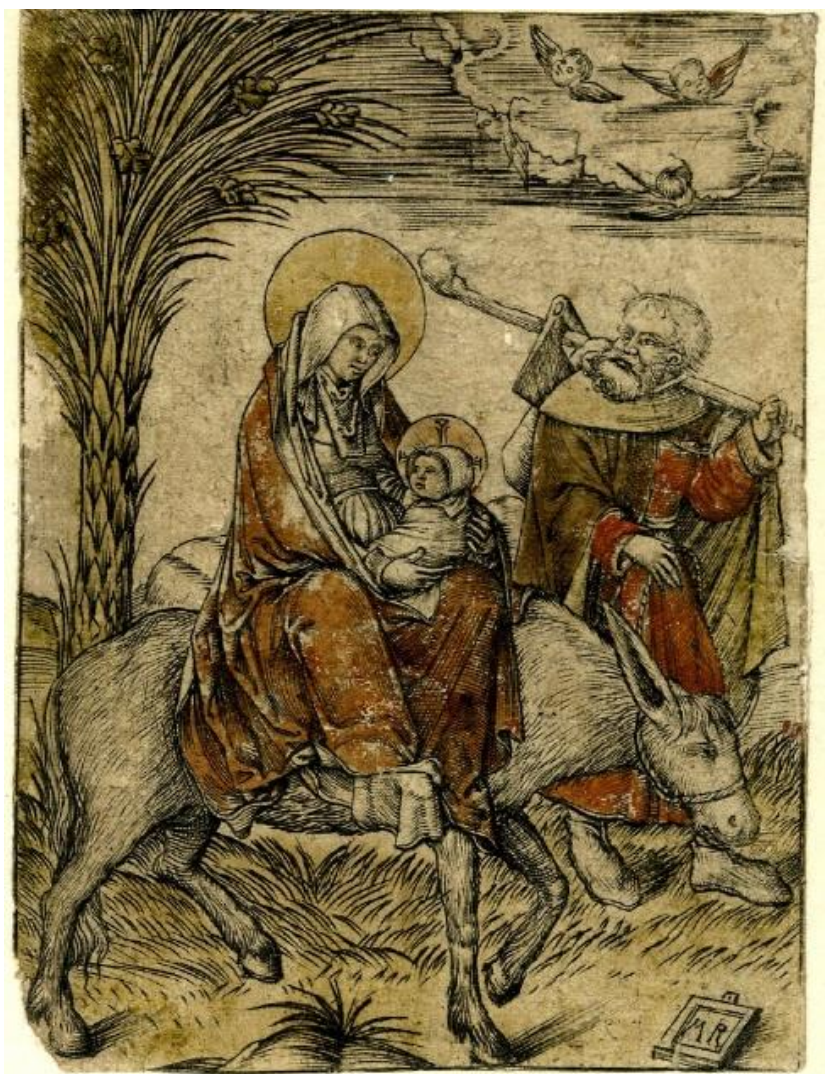

40. Monogramista MR. Viaje a Egipto. 1 500-1525. Museo Británico. Londres (Reino Unido).

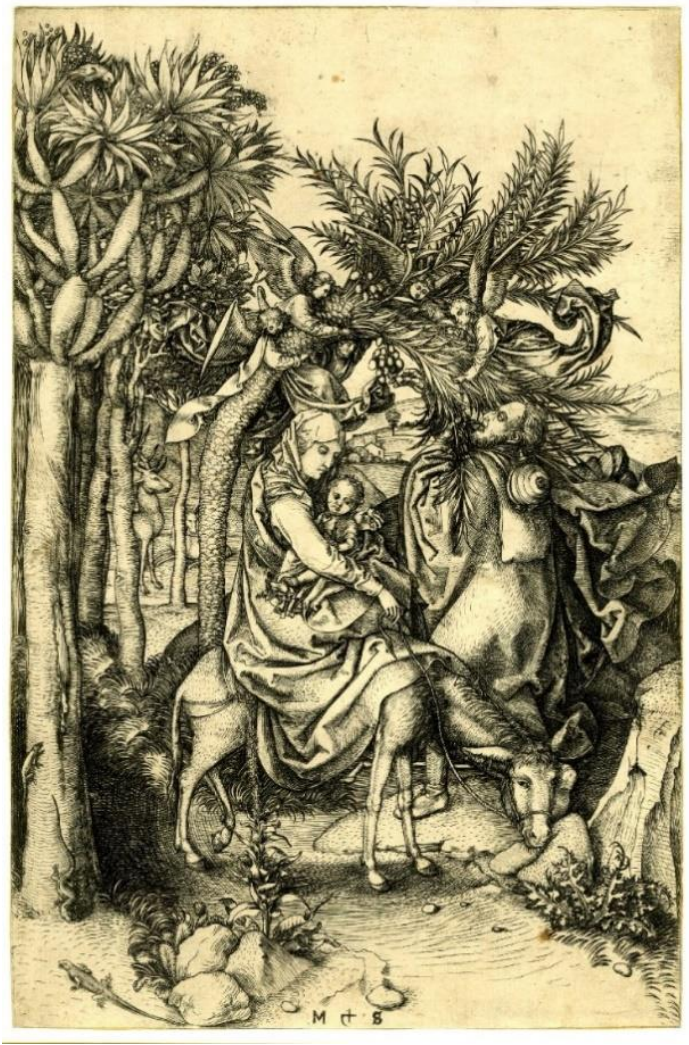

41. Martin Schongauer. Viaje a Egipto. 1470-1474. Museo Británico. Londres (Reino Unido).

Por último, hay que señalar la semejanza de la figura del asno, que muestra una postura semejante a la del grabado, con la pata delantera derecha levantada en señal de movimiento. Podría tratarse una simple coincidencia, sin relación directa con la estampa. El pintor representó al asno con la cabeza más inclinada, quizás denotando fatiga, y obvia casi representar los cuartos traseros, totalmente cubiertos por el manto de la Virgen. Para concluir, es de gran interés el paisaje representado al fondo, en el que destacan unas montañas de aspecto muy volumétrico, características del arte nórdico, así como una escena cotidiana de lo que parece un hombre arando el campo y unos soldados junto a él, quizás asociados a la matanza de los Inocentes, en busca del Niño para matarlo. 


\section{Anónimo \\ Retablo de San Matías y San Francisco \\ Primer tercio del siglo XVI \\ Iglesia de San Juan Bautista \\ Ágreda (Soria)}

Este retablo procedía originalmente de la iglesia de Nuestra Señora de Magaña de la misma población (fig. 42). Se ubicaba en el muro sur, en el arco junto al pórtico sur, antiguo acceso cegado a una capilla derruida por una intervención arquitectónica entre los años 1968 y 1971. Inicialmente se identificó como retablo gótico del siglo $\mathrm{XV}^{312}$.

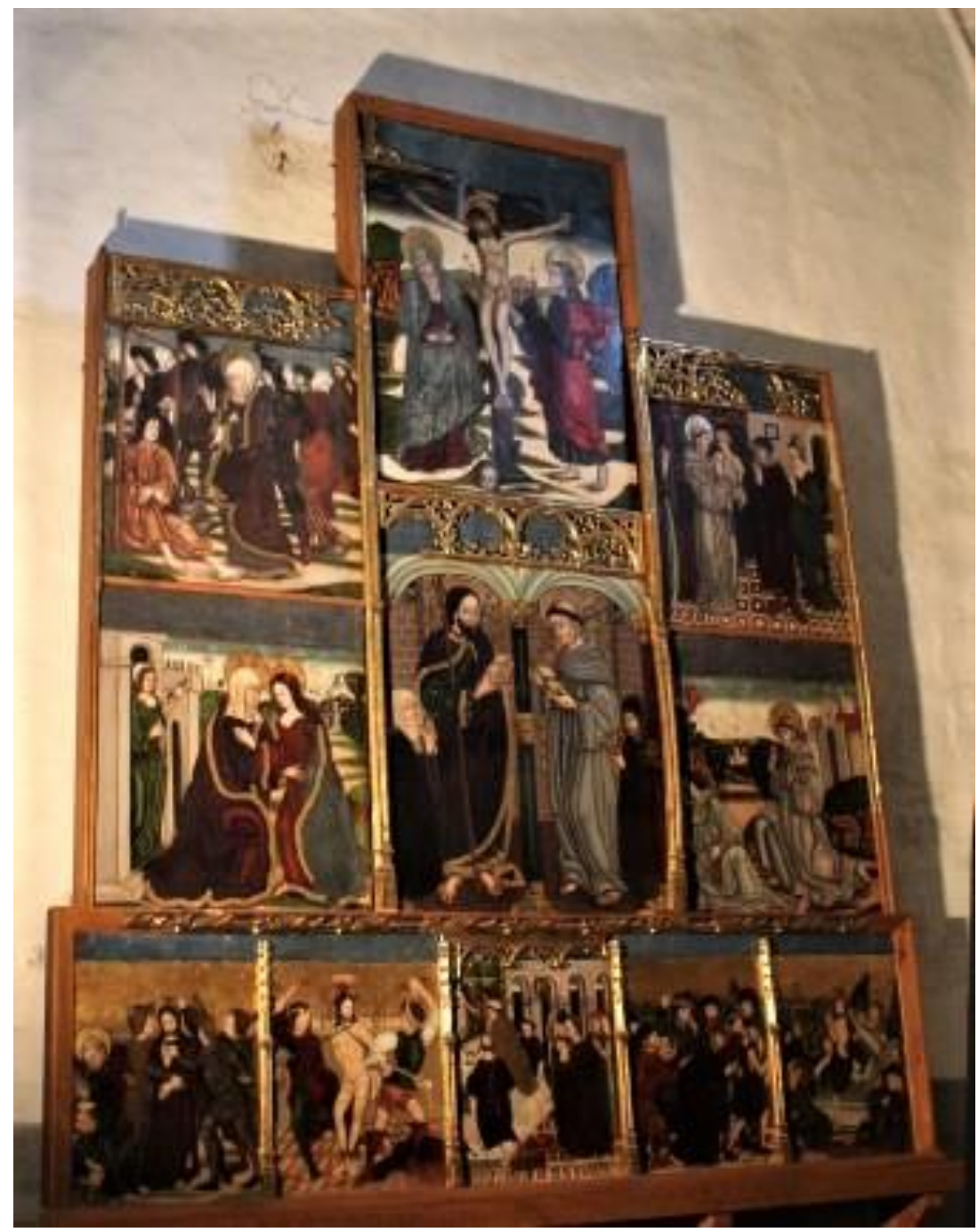

42. Anónimo. Retablo de San Matías y San Francisco. Primer tercio del siglo XVI.

Iglesia de San Juan Bautista. Ágreda (Soria).

\footnotetext{
${ }^{312}$ ALCOLEA BLANCH, S., op. cit., p. 94; ORTEGO FRÍAS, T., op. cit., p. 92.
} 
En 2007 se llevó a cabo un estudio analítico de las muestras proporcionadas por la empresa Albarium. De la arquitectura dorada que conformaba el retablo sólo se conservan actualmente parte de la decoración superior, algunas de las pilastrillas centrales y dos fragmentos de pilastrillas laterales ${ }^{313}$. La polsera o guardapolvo, seguramente realizado en madera policromada, ha desaparecido.

Tras su restauración pasó a colocarse en la segunda capilla de la Epístola de la iglesia de San Juan Bautista de Ágreda. El retablo está dedicado a San Matías y San Francisco $^{314}$. El banco consta de cinco escenas: la Oración en el Huerto, la Flagelación, la Misa de San Gregorio, Jesús con la cruz a cuestas y la Resurrección. Las escenas estaban separadas por una decoración cairelada y flamígera.

En el primer cuerpo están representadas la Visitación, San Matías y San Francisco con los donantes y la Estigmatización de San Francisco. En el segundo cuerpo aparece Santa Isabel liberando a un preso de la horca, el Calvario, San Francisco liberando a Santa Clara de sus parientes.

\section{San Francisco recibiendo los estigmas}

La escena (fig. 43) se inspiró libremente en la estampa de Durero (fig. 44$)^{315}$ del mismo tema, en la cual aparecen San Francisco con las manos levantadas y arrodillado y un fraile dormido junto al santo. El pintor, sin embargo, ha reflejado en su obra el edificio situado a la derecha de la composición, si bien se trata de un edificio muy distinto al del grabado. Tampoco es el mismo paisaje; más montañoso y agreste en el caso de la estampa mientras que en la pintura muestra suaves colinas, con la imagen de una ciudad fortificada al fondo. Los plegados de los dos personajes han sido representados torpemente y el árbol junto al cual aparece la figura de San Francisco tampoco está. Por último, la figura de Cristo no es sostenida por tres céfiros.

\footnotetext{
${ }^{313}$ VV. AA., Memoria Final de Restauración del retablo de San Francisco y San Matías, Iglesia de San Juan Bautista, Ágreda, Soria, Albarium S.L, diciembre de 2007, Junta de Castilla y León, Consejería de Cultura y Turismo, p. 24. URL: https://issuu.com/proyectourdimbre/docs/memoria_final_san_emeterio_i ${ }^{314}$ PEÑA GARCÍA, M., Historia y Arte de Ágreda. Compendio, Burgos, Montecarmelo, 2004, p. 222.

${ }^{315}$ Estampa disponible en: http://www.britishmuseum.org/research/collection_online/collection_object_details.aspx?objectId=13391 46\&partId $=1$ \&searchText $=$ saint + francis\&images $=$ true \&people $=127877$ \&page $=1$

BARTSCH, A., op. cit., VII, p. 138; DODGSON, C., Catalogue of Early German and Flemish Woodcuts..., vol. I, no 33, p. 287; MEDER, J., op. cit., p. 189, no catálogo 224; SCHOCH, R., Albrecht Dürer, das druckgraphische Werk, II Woodcuts, Munich, Prestel, 2001, nº 134, pp. 126-128.
} 


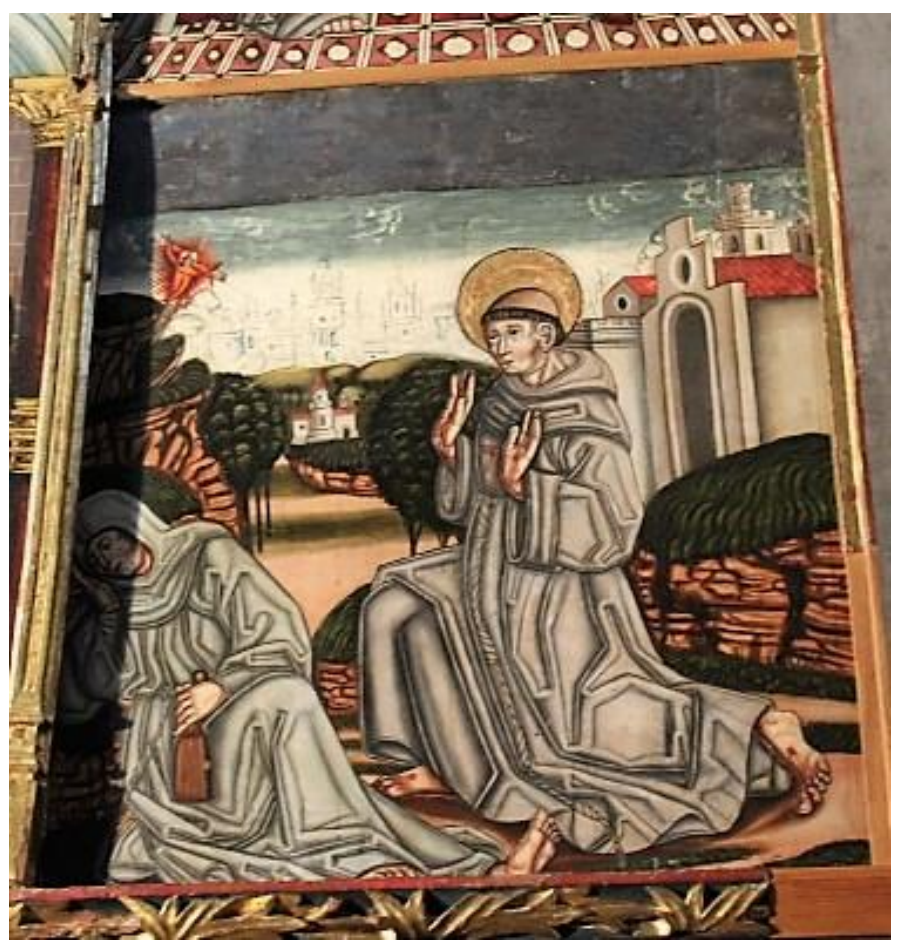

43. Anónimo. San Francisco recibiendo los estigmas. Primer tercio siglo XVI. Retablo de San Matías y San Francisco. Primer tercio del siglo XVI. Iglesia de San Juan Bautista. Ágreda (Soria).

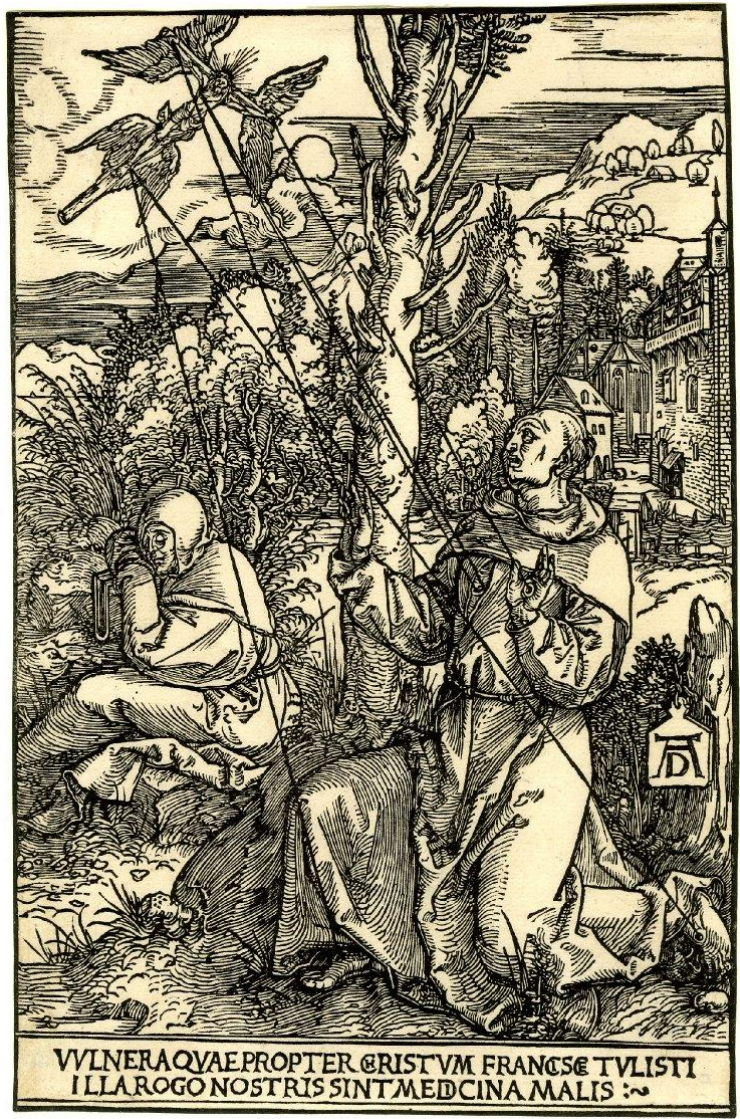

44. Alberto Durero. San Francisco recibiendo los estigmas. 1503-1504. Museo Británico. Londres (Reino Unido). 


\section{Resurrección de Cristo}

El artista ha plasmado la escena sobre un fondo dorado de carácter arcaico (fig. 45). Se inspira en el grabado de Schongauer del mismo tema (fig. 46) ${ }^{316}$. La figura de Cristo saliendo del sepulcro es muy semejante, sobre todo la postura de las manos y de la pierna derecha, que se apoya en el suelo. La cruz que porta es similar, aunque se ha eliminado el estandarte. El sepulcro está invertido respecto a su posición en la estampa; también el ángel, que se apoya en la tapa del sepulcro y de quien sólo vemos el rostro y las alas, es muy parecido.

El fondo en que se desarrolla la escena es montañoso en la pintura, con algunos árboles y un castillo en lontananza; en la estampa no se le otorga demasiada importancia: se coloca tan solo un promontorio rocoso a la derecha de la composición y una valla de madera a la izquierda. Algunos de los soldados situados en torno al sepulcro muestran poses y expresiones similares, en particular el arrodillado a la izquierda que levanta un brazo en gesto de sorpresa. Sin embargo, en la estampa aparecen portando ballestas y en la pintura llevan otro tipo de armas como garrotes y varas. La forma de representar a Cristo saliendo del sepulcro, con un pie dentro del mismo y otro apoyado en el suelo procede de pintores flamencos como Dirk Bouts (1455) (fig. 47) $)^{317}$.

Por otro lado, el pintor ha logrado torpemente representar la ilusión perspectiva que transmite el grabado a través de la línea diagonal del sepulcro y añadiendo además un paisaje al fondo con el fin de lograr una mayor sensación de perspectiva.

\footnotetext{
${ }^{316}$ Estampa disponible en: http://www.britishmuseum.org/research/collection_online/collection_object_details.aspx?objectId=14009 08\&partId=1\&searchText=resurrection\&images $=$ true \&people $=108158 \&$ page $=1$

BARTSCH, A., op. cit., vol. VI, p. 127; LEHRS, M., op. cit., vol. V, p. 162; HOLLSTEIN, F. W. H., German engravings, etchings and woodcuts..., vol. XLIX, $\mathrm{n}^{\circ} 30, \mathrm{p} .84$.

${ }^{317}$ Imagen de dominio público. https://commons.wikimedia.org/wiki/File:Dieric Bouts _-

Resurrection.jpg
} 


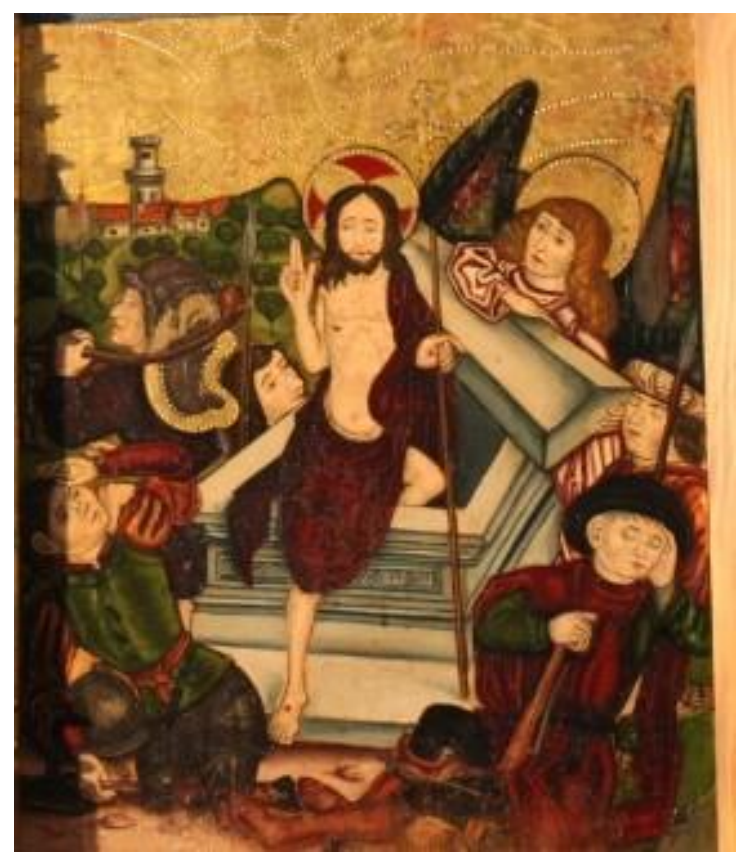

45. Anónimo. Resurrección de Cristo. Retablo de San Matías y San Francisco. Primer tercio del siglo XVI. Iglesia de San Juan Bautista. Ágreda (Soria)).

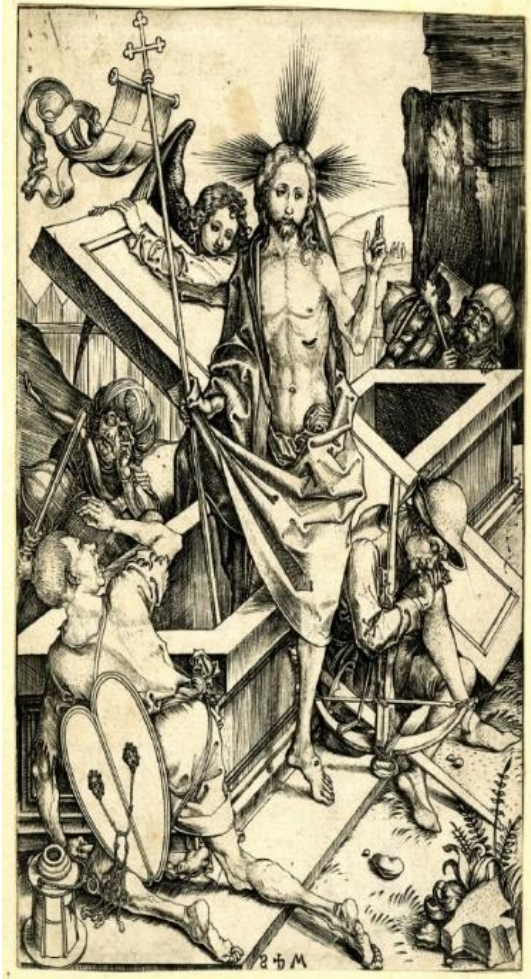

46. Martin Schongauer. Resurrección. 1470-1482. Museo Británico. Londres (Reino Unido).

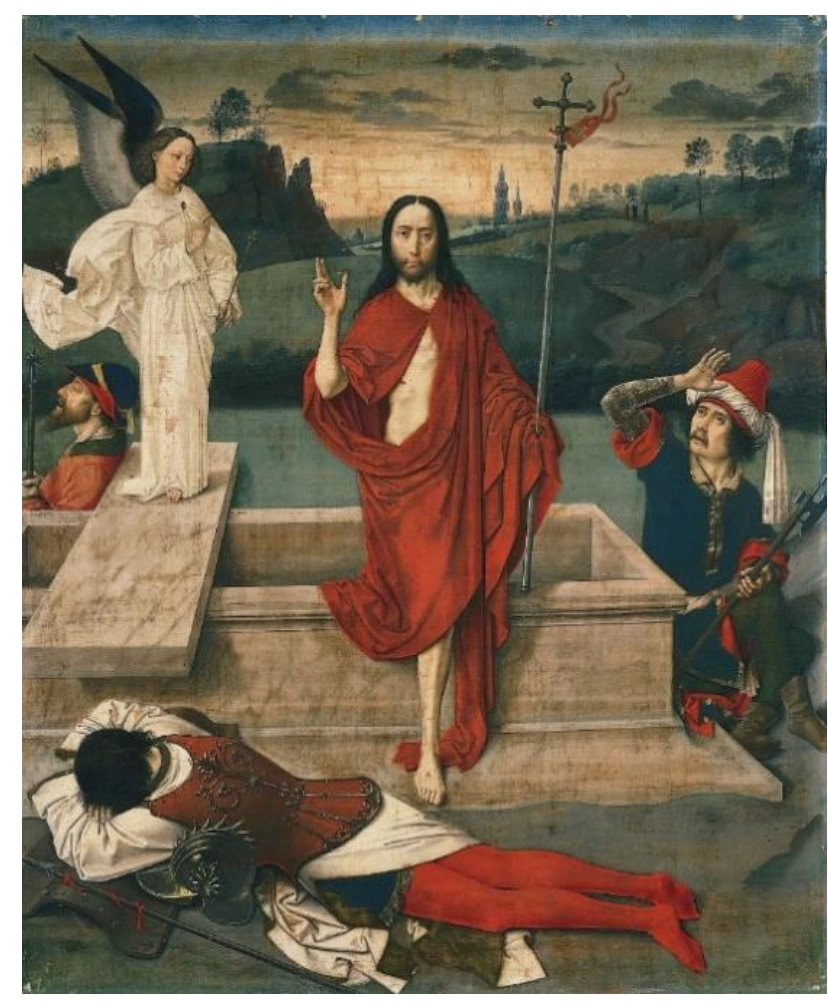

47. Dirk Bouts. Resurrección. 1455.

Norton Simon Museum.

Pasadena (Estados Unidos) 


\section{Camino del Calvario}

Para esta escena (fig. 48) observamos que el pintor ha utilizado algunas de las figuras de un grabado anónimo (fig. 49) ${ }^{318}$. Entre ellas la de Cristo, la de Simón de Cirene, que luce exactamente el mismo atuendo (túnica con capucha, birrete y botas), así como la misma postura, y la del personaje que tira de Cristo con una cuerda. También la figura que aparece tras la cruz y que alza amenazadoramente el puño derecho parece tomada de la estampa, así como otro situado a su lado, del que sólo observamos su rostro de perfil. Sin embargo, el pintor ha simplificado la composición, ya que ha suprimido a la mayor parte de la multitud situada detrás; una serie de personajes que aparecen portando lanzas acompañados por caballos. Uno de ellos, que toca instrumento musical, sí que podría proceder de la estampa. El pintor tampoco ha incluido la escena de la crucifixión que aparece al fondo.

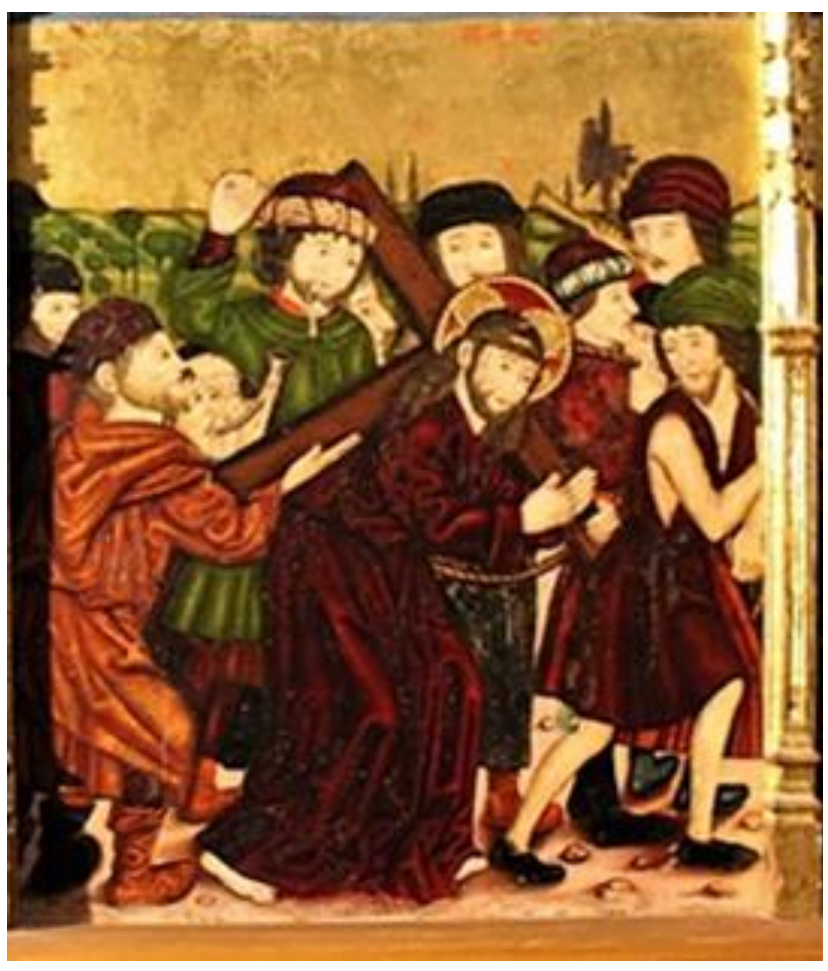

48. Anónimo. Camino del Calvario. Retablo de San Matías y San Francisco. Primer tercio del siglo XVI. Iglesia de San Juan Bautista. Ágreda (Soria)).

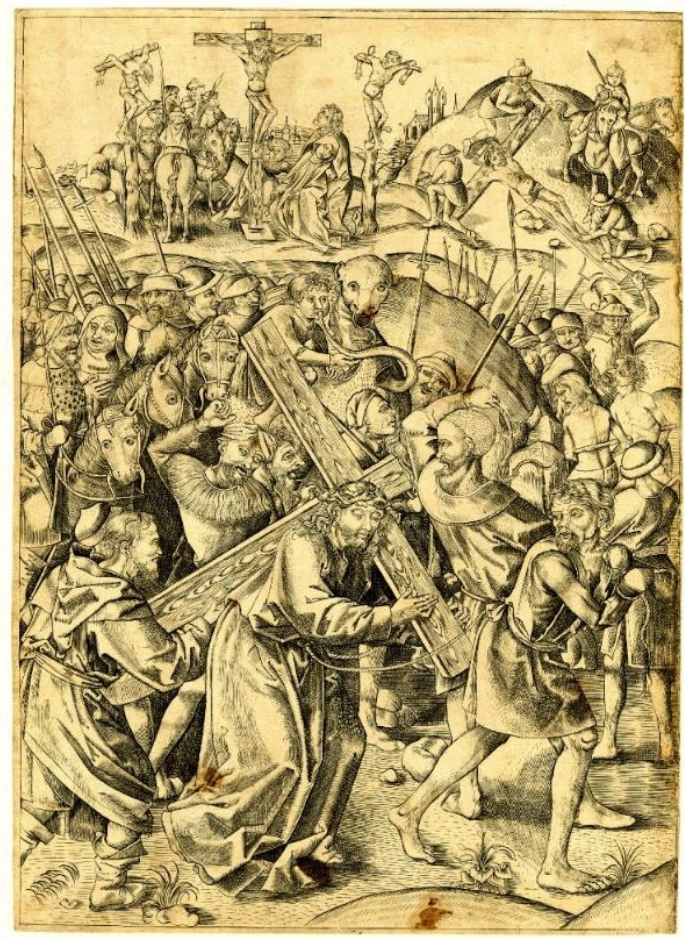

49. Anónimo alemán. Camino del Calvario. 1450-1500. Museo Británico (Londres)

\footnotetext{
${ }^{318}$ Estampa disponible en:

http://www.britishmuseum.org/research/collection_online/collection_object_details.aspx?objectId=13560 $45 \&$ partId $=1 \&$ searchText $=$ calvary \&images $=$ true $\&$ from $=$ ad \&fromDate $=1480 \&$ to $=$ ad \& toDate $=1530 \& p a g$ $\underline{\mathrm{e}=1}$
} 


\section{Anónimo \\ La Oración en el Huerto \\ Ca. 1530 \\ Iglesia de San Juan Bautista \\ Ágreda (Soria)}

Esta pequeña tabla que representa la escena de la Oración en el Huerto ${ }^{319}$ (fig. 50) situada en una de las capillas laterales de la iglesia de San Juan Bautista en Ágreda, parece por su estilo y color inspirada en las pinturas de Pedro de Aponte del Retablo de San Miguel de la iglesia del mismo lugar. A pesar de ello, la escena presenta diferencias con respecto a la del mismo tema representada en éste último retablo. Sólo hay cierto parecido en la figura de Cristo arrodillado.

Los Apóstoles, a diferencia de lo que pasa con el retablo, están tomados de algunas estampas nórdicas. En este caso la figura de San Pedro, que apoya su mano derecha sobre la mejilla y su sujeta con la izquierda la espada de su cinto parece basarse en la estampa del mismo tema de Monogramista AG (fig. 51) ${ }^{320}$. Por otro lado, las otras dos figuras de apóstoles parecen haber tomado como modelo la estampa de Durero (fig. $52)^{321}$ en la cual uno de ellos se sostiene la cabeza entre las dos manos. mientras el otro aparece dormitando sobre un libro que está sobre una roca y apoya la cabeza sobre su brazo derecho.

En cuanto al paisaje y al fondo en general parece haber tomado la imagen del ángel portando la cruz del grabado de Durero, aunque adaptándola y cambiando su postura y disposición en el cuadro. En la escena el ángel guía a su ejército en dirección a Cristo, pero el grupo soldados no proceden de la estampa de Durero, sino de la de Monogramista AG. Si se observa con más detalle se percibe que incluso ha utilizado una arquitectura de madera que aparece al fondo de la composicion. El paisaje, al igual que ocurre en las dos estampas es montañoso, con algunos escasos árboles completando la composición. En el caso de la pintura se ha incluido también la enorme roca junto a la cual se arrodilla Cristo, añadiéndose además un pequeño riachuelo con un puente de piedra que separa a Cristo de sus Apóstoles.

\footnotetext{
${ }^{319}$ PEÑA GARCÍA, M., Historia y arte...., p. 222.

${ }^{320}$ Estampa disponible en:

https://www.britishmuseum.org/research/collection_online/collection_object_details.aspx?objectId=1399 070\&partId=1\&searchText=agony + in + the + garden\&images $=$ true \&from $=$ ad\&fromDate $=1450 \&$ to $=$ ad\&to Date $=1500 \&$ page $=1$ BARTSCH, A., op. cit., vol. VI, p. 345.

${ }^{321}$ Estampa disponible en:

https://www.britishmuseum.org/research/collection_online/collection_object_details.aspx?objectId $=7645$ 49\&partId=1\&searchText=agony+in+the+garden\&images=true\&from=ad\&fromDate=1508\&to=ad\&toD ate $=1510 \&$ page $=1$
} 


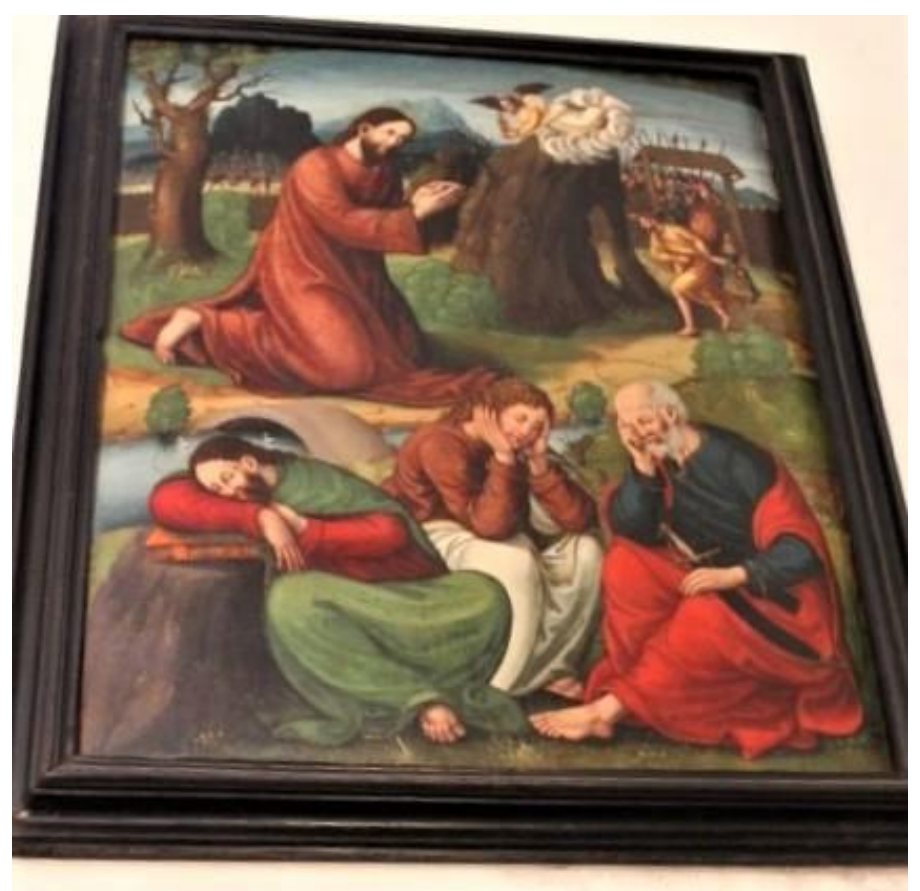

50. Círculo de Pedro de Aponte. Oración en el huerto. Ca. 1530. Iglesia de San Juan Bautista. Ágreda (Soria).

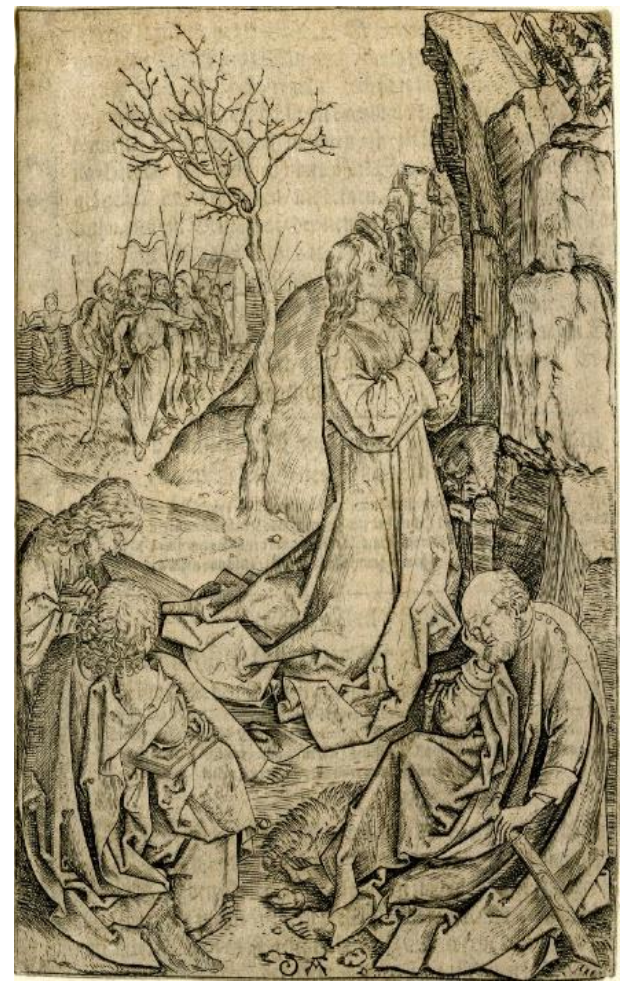

51. Monogramista AG. Oración en el Huerto. 1450-1500. Museo Británico. Londres (Reino Unido).

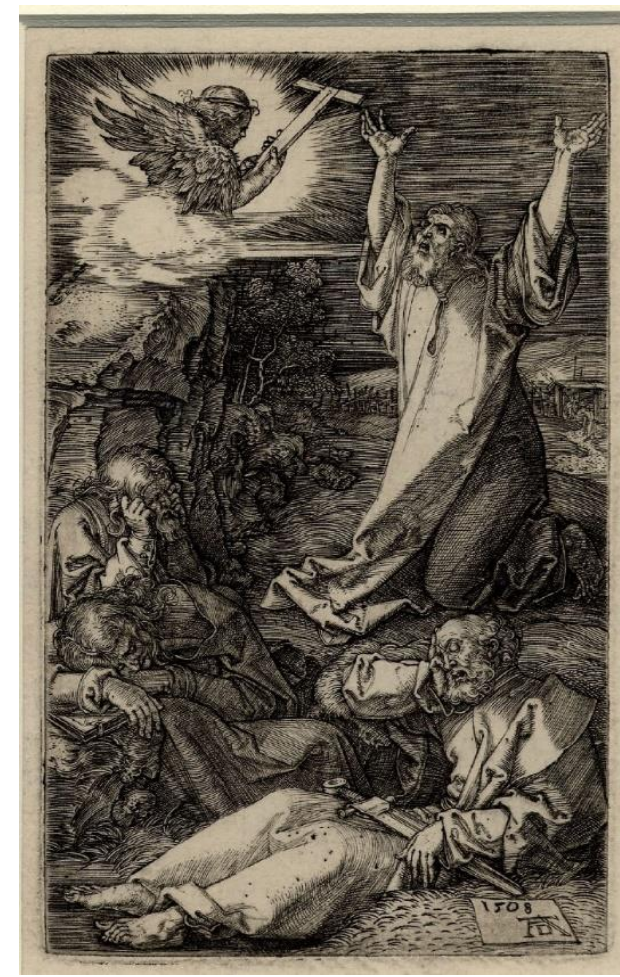

52. Alberto Durero. Oración en el Huerto. 1508. British Museu. Londres (Reino Unido). 
Anónimo

Camino del Calvario

Retablo de Santa Margarita (o Santa Quiteria)

Siglo XVI

Iglesia de San Juan Bautista

Ágreda (Soria)

Se trata de un retablo perteneciente a un Renacimiento temprano (fig. 53). Se sitúa en el muro este de la primera capilla del lado de la Epístola. El retablo reposa sobre un sotabanco con pilares entre cada entrecalle. Los laterales se cierran ligeramente sobre la parte central de manera que dan la impresión de amoldarse a la forma de la cabecera de la capilla. Está formado por tres calles, la central casi el doble de grande que las laterales en la cual se ubica una escena que abarca la altura del cuerpo principal. Está flanqueada por pilastrillas con decoración a candelieri y se cierra mediante un arco carpanel. Las calles laterales están formadas por dos pisos de distinta altura (menor el superior) y se cierran por balaustres.

En el primer cuerpo hay una serie de escenas de la Pasión: la Flagelación, el Calvario, la Oración en el Huerto y el Prendimiento de Cristo, que rodean a la escena central que representa la Lamentación ante el cuerpo de Cristo.

En el segundo cuerpo hallamos cuatro pinturas que representan figuras de santos como Santa María Magdalena, Santa Catalina de Alejandría, San Pedro y San Francisco de Asís. En el centro, la hornacina alberga una escultura de Santa Margarita.

El conjunto remata por un ático avenerado con forma de venera. Respecto al estilo pictórico, Peña García lo pone en relación con el de San Miguel de Ágreda, por su estilo y elegancia ${ }^{322}$.

Algunos de los tipos humanos presentes en muchas de las escenas, en especial las del Calvario y el Prendimiento recuerdan por su realismo descarnado y su aspecto caricaturesco a las de Pedro de Aponte.

Para esta escena anónima del retablo de Santa Margarita (fig. 54) es muy probable que el artista se haya inspirado en la estampa de Durero invertida (fig. 55) ${ }^{323}$ para la figura situada al fondo y que asoma la cabeza entre los peldaños de la escalera portátil. Se trata de una figura escasamente representada en las estampas y cuyo primer

${ }^{322}$ PEÑA GARCÍA, M., Historia y arte...., p. 219. NÚÑEZ MOTILVA, M. M., Proyecto de restaturación del retablo de Santa Margarita (O Santa Quiteria) de la iglesia de San Juan Bautista (Ágreda), ALBARIUM, s. 1., 2008.

${ }^{323}$ Estampa disponible en:

https://research.britishmuseum.org/research/collection_online/collection_object_details.aspx?objectId=14 39782\&partId=1\&searchText=calvary \&from=ad \&fromDate=1510\&to=ad\&toDate=1515\&page $=1$ 
ejemplo encontramos en la de Durero. El pintor también podría haber adoptado otras de las figuras como la de la Verónica, arrodillada en primer plano a la derecha aunque aquí se la representa de frente, o quizás en los extraños tocados de algunas de las figuras del fondo, el patetismo de la postura de Cristo o la agresividad de los personajes armados que le rodean.

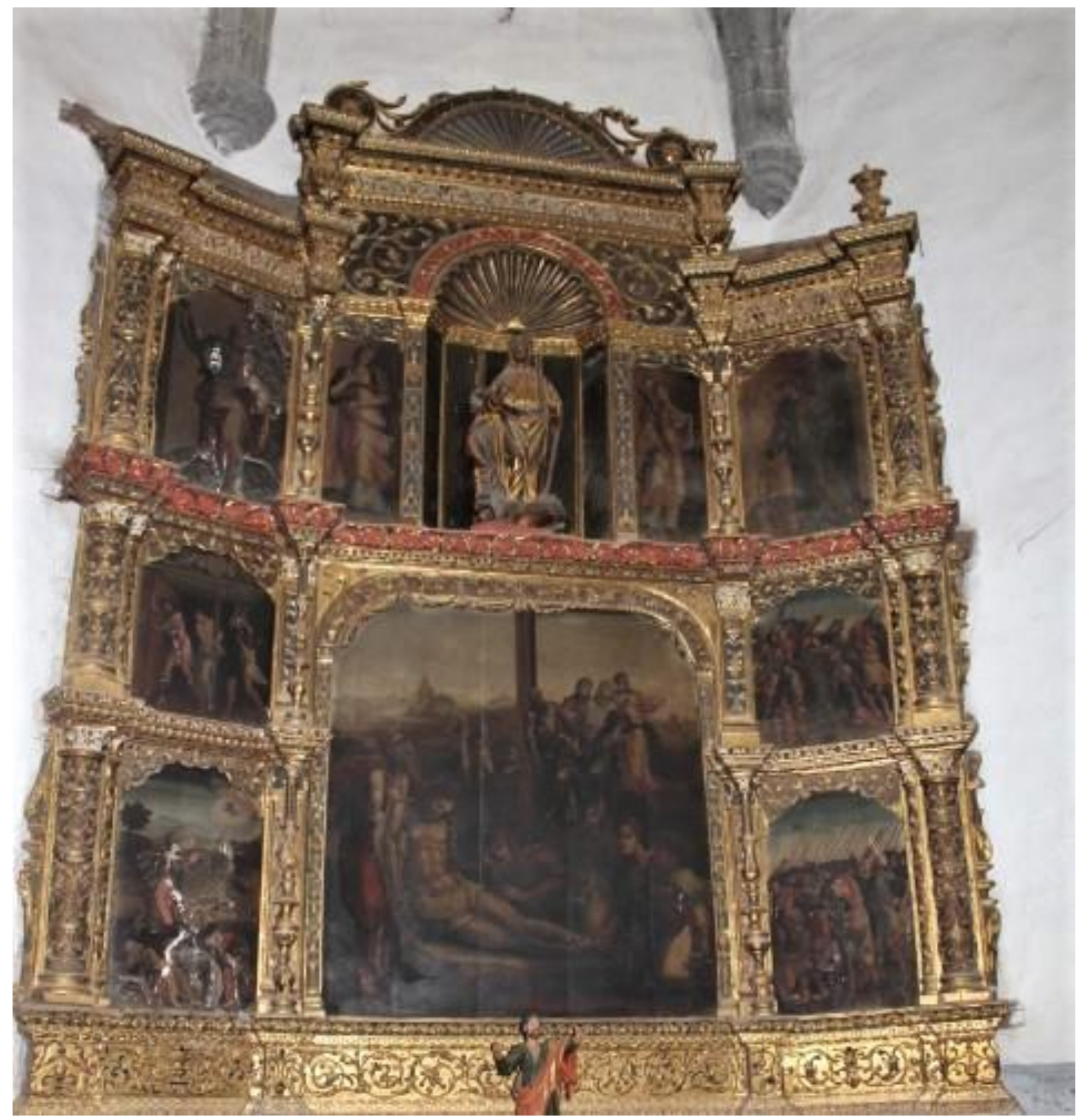

53. Anónimo.

Retablo de Santa Margarita.

Siglo XVI.

Iglesia de San Juan Bautista

Ágreda (Soria). 


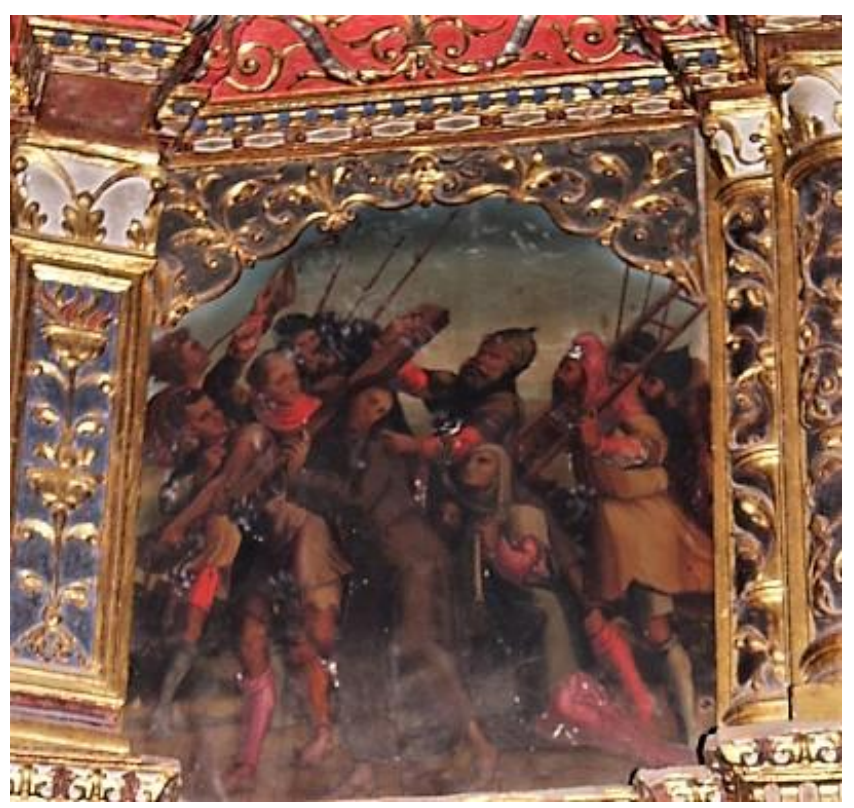

54. Anónimo

Camino del Calvario. Ca.1530.

Retablo de Santa Margarita (o Santa Quiteria). Iglesia de San Juan Bautista. Ágreda (Soria)).

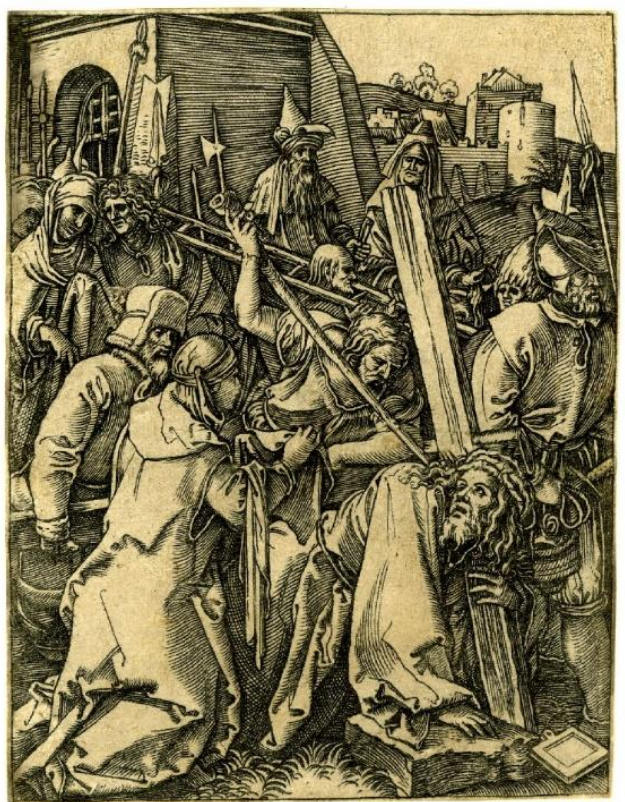

55. Marcantonio Raimodni (a partir de Alberto Durero) Cristo portando la Cruz. 1510-1515. Museo Británico. Londres (Reino Unido).

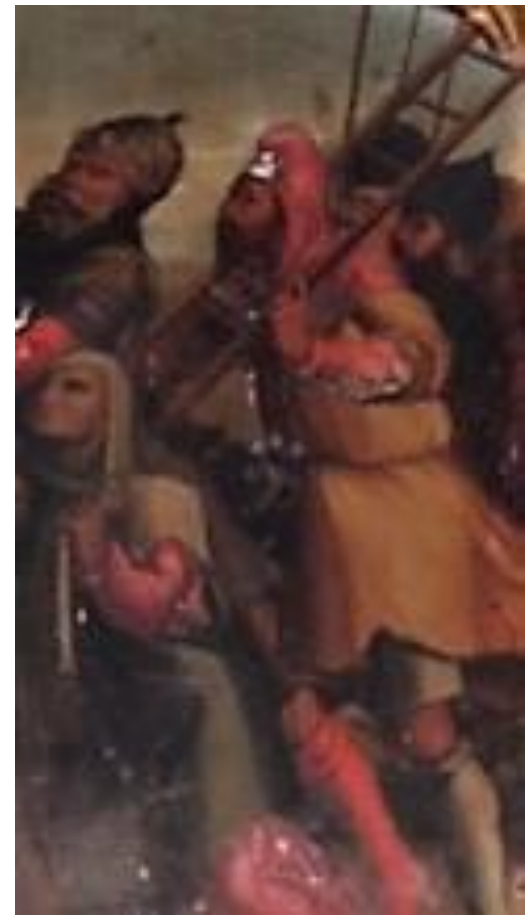

56. Detalle fig. 54.

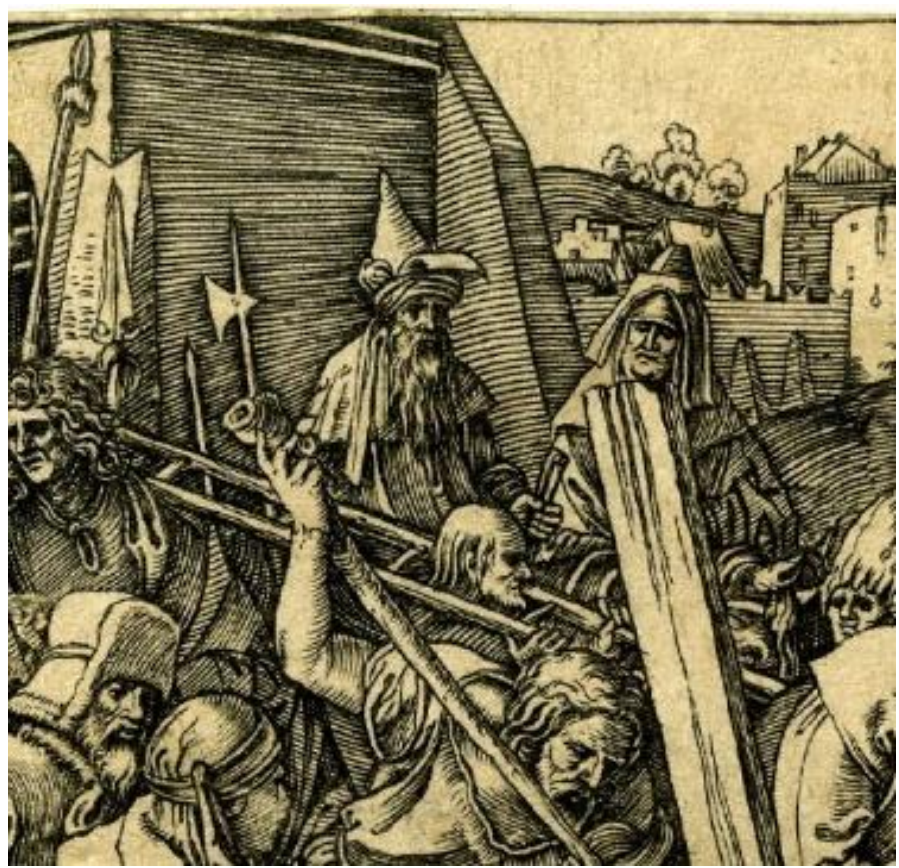

57. Detalle de fig. 55. 


\section{Anónimo \\ Sacristía: Pinturas Última Cena y Flagelación \\ Primer tercio del siglo XVI \\ Iglesia de Nuestra Señora de la Paz \\ Valdeavellano de Tera (Soria)}

Estas dos pinturas, que pudieron haber formado parte de un retablo, se encontraban en el muro derecho de la sacristía ${ }^{324}$. Por su estilo, muy parecido al del retablo mayor, parecen de principios del siglo $\mathrm{XVI}^{325}$.

\section{Última Cena}

El episodio de la última cena de Jesús con sus discípulos ha sido narrado por los cuatro evangelistas con una visión bastante unánime. Aunque se trata de una escena nocturna, en la pintura no aparece antorcha ni lámpara que ilumine la estancia. La cena se sitúa en una estancia estrecha; al fondo, destacan dos vanos alargados y un estandarte de un rojo brillante. El suelo está formado por baldosas de colores decoradas con motivos estrellados, que ayudan a construir la ilusión espacial, sobre el que destaca una jarra de cerámica. Los apóstoles se sitúan en dos grupos de cuatro, de pie a ambos lados de Cristo; de los tres restantes, dos se sitúan delante de la mesa sentados sobre taburetes, y otro, San Juan, se apoya sobre la mesa. Suman once apóstoles, por lo que falta uno, que quizás se perdió al quitar la tabla en uno de los lados (fig. 58) .

Para crear la composición el artista ha utilizado la estampa de Durero ${ }^{326}$ (fig. $59)^{327}$, copiando algunas figuras como la de Judas, a la derecha, sentado en un taburete, agachado, mostrando la mano izquierda mientras que con la derecha esconde la bolsa de dinero tras su espalda. Es la colocación tradicional de este personaje, generalmente situado delante de la mesa, apartado de los demás apóstoles. En este caso Judas no porta ningún distintivo que lo diferencie del resto de los Apóstoles, como suele ser la ausencia de nimbo o la presencia de un nimbo negro que lo denuncia como traidor. También se copian las figuras de los dos apostoles situados en el extremo derecho de la mesa, uno

\footnotetext{
${ }^{324}$ GONZÁLEZ BLASCO, P., Notas sobre Valdeavellano de Tera (Soria), SM, Madrid, 1998, p. 239; FIZ FUERTES, I., "Última cena”, en Kyrios. Las Edades del Hombre, Fundación de Las Edades del Hombre, 2006, $\mathrm{n}^{\circ} 102$, pp. 250-251.

${ }^{325}$ VV. AA., Inventario artístico..., vol. I, pp. 345-347.

${ }^{326}$ FIZ FUERTES, I., "Última cena”, pp. 250-251.

${ }^{327}$ Estampa disponible en:

http://www.britishmuseum.org/research/collection_online/collection_object_details.aspx?objectId=13342 $17 \&$ partId=1\&searchText=last+supper\&images $=$ true\&people $=127877 \&$ page $=1$

BARTSCH, A., op. cit., vol. VII, p. 117; DODGSON, C., Catalogue of Early German and Flemish Woodcuts..., vol. I, n ${ }^{\circ}$ 102, p. 299; SCHOCH, R., op. cit., vol. II, nº 155, pp. 183-185; MEDER, J., op. cit., p. $122, \mathrm{n}^{\circ}$ catálogo 122.
} 
de perfil mirando a Cristo, y el otro con las manos entrelazadas. No se inspira, sin embargo, en la figura de Cristo, que en la pintura tiene un mayor protagonismo, ni en el interior de la estancia que en la estampa se basa en una bóveda de crucería con un óculo al fondo, mientras que en la pintura parece una estancia semicircular con varios vanos y un estandarte rojo en el centro.

En la escena predominan los tonos rojos y verdes intensos que se usan para las vestimentas de los apóstoles, mientras que Cristo luce una túnica parda. El suelo ajedrezado, el estandarte rojo colocado al fondo o la colocación de los personajes eran comunes en la pintura de la época.

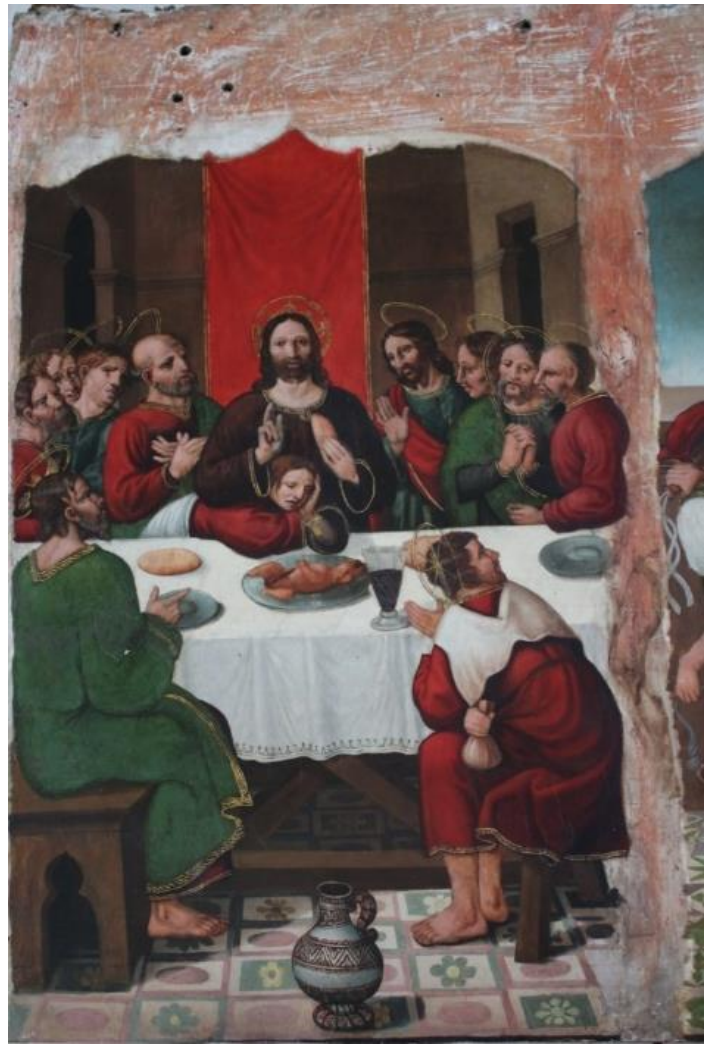

58. Anónimo. Última Cena.

Primer tercio del siglo XVI. Iglesia de Nuestra Señora de la Paz. Valdeavellano de Tera (Soria).

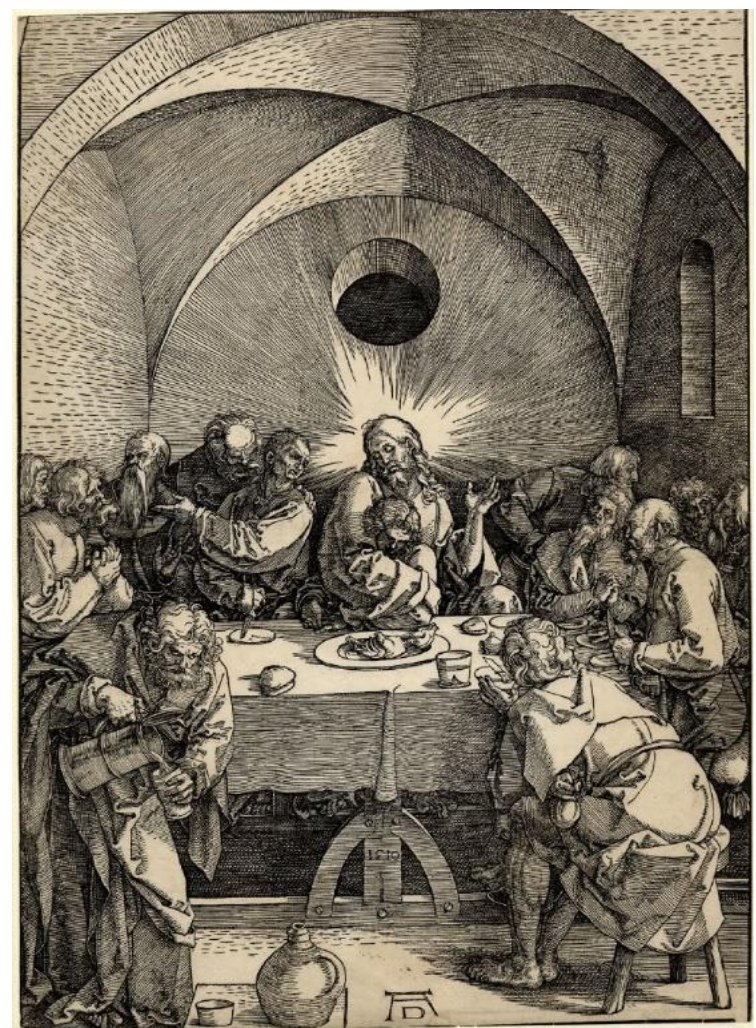

59.Alberto Durero.

Última cena. 1510 .

Museo Británico. Londres (Reino Unido).

\section{Flagelación}

El pintor ha situado la escena en una sala de suelo ajedrezado con estrellas y rombos lo que demuestra el interés del artista por la representación espacial (fig. 60). En el centro destaca la columna toscana, cuyo capitel decora el rostro de un angelote. Al igual que ocurre con la Última Cena, el artista ha utilizado aquí los tonos verdes y rojos 
para las vestimentas de los sayones. Al fondo, un alto muro impide ver con claridad las torres del exterior.

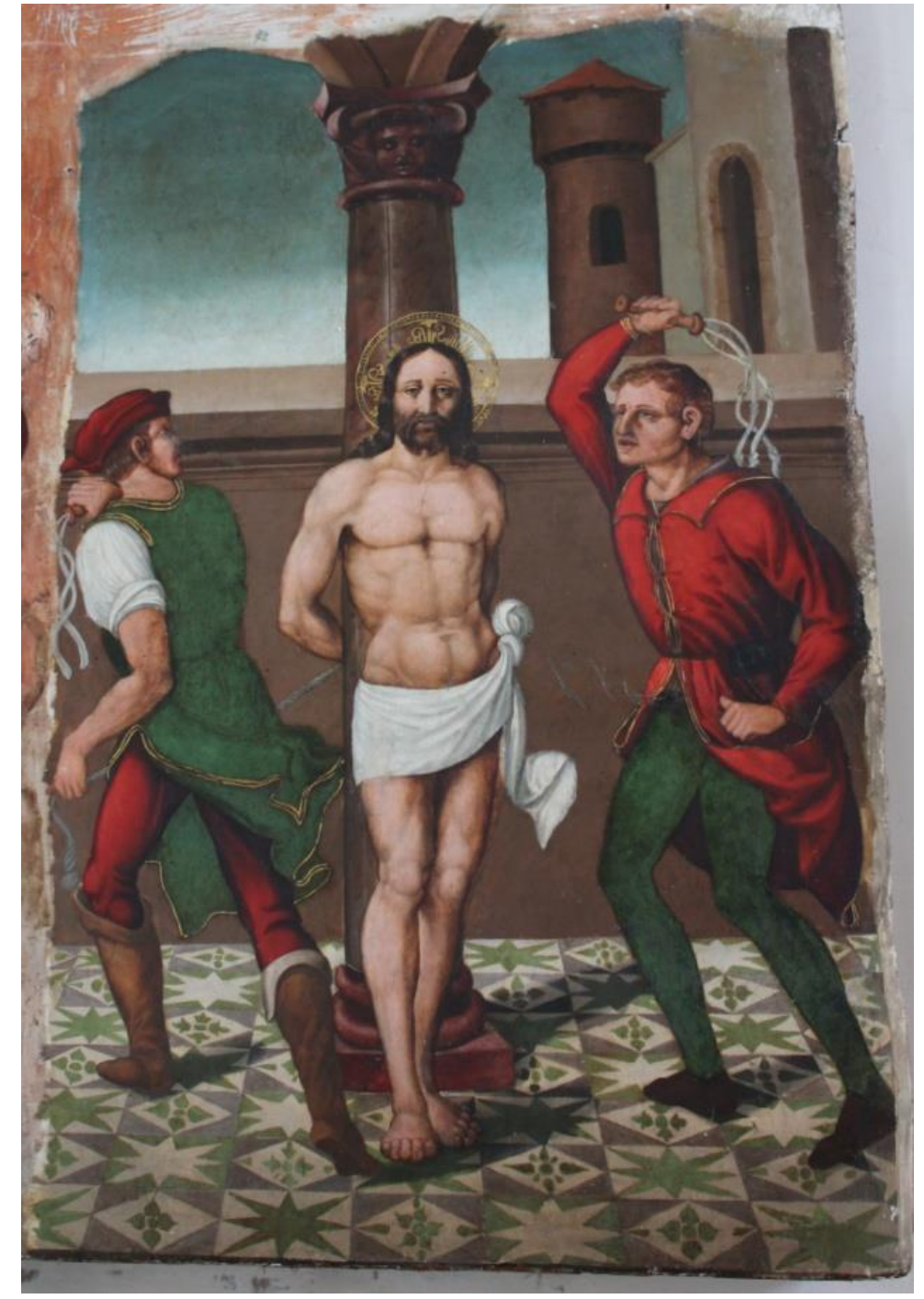

60 Anónimo. Flagelación. Primer tercio del siglo XVI.

Iglesia de Nuestra Señora de la Paz. Valdeavellano de Tera (Soria).

Para esta pintura, situada también en la sacristía de la iglesia, el pintor parece haberse inspirado en dos grabados. De una estampa alemana anónima utiliza la figura del sayón de la derecha (fig. 61) ${ }^{328}$. Dicha figura levanta el brazo derecho con la fusta para golpear a Cristo, y adelanta la pierna derecha en el acto de flagelar. Se basa también en sus vestimentas: la camisa larga de color rojo, las calzas verdes y los zapatos marrones, aunque no se adopta el gorro verde que luce el sayón. El otro sayón adopta las mismas vestimentas, pero su postura corresponde a la del soldado que tira de Cristo

${ }^{328}$ SCHREIBER, W. L., Handbuch der Holz und Metalschnitte des XV Jahrhunderts, Leipzig, Verlag Karl W. Hiersemann, vol. V, $\mathrm{n}^{\mathrm{o}} 2285$, p. 42.Estampa disponible en:

http://www.britishmuseum.org/research/collection_online/collection_object_details.aspx?objectId=13499 54\&partId=1\&searchText=flagellation \&images $=$ true $\&$ from $=$ ad $\&$ fromDate $=1470 \&$ to $=$ ad $\&$ toDate $=1480 \&$ page $=1$ 
en el grabado del Pasmo de Sicilia de Raimondi (fig. 62) ${ }^{329}$. Es una figura colocada de espaldas al espectador, que gira levemente el cuello hacia la derecha, mientras que avanza su pierna izquierda y deja atrás la derecha. El brazo izquierdo aparece doblado como en la estampa, mientras el derecho está oculto tras el cuerpo, y sólo vemos la mano que sujeta la fusta.

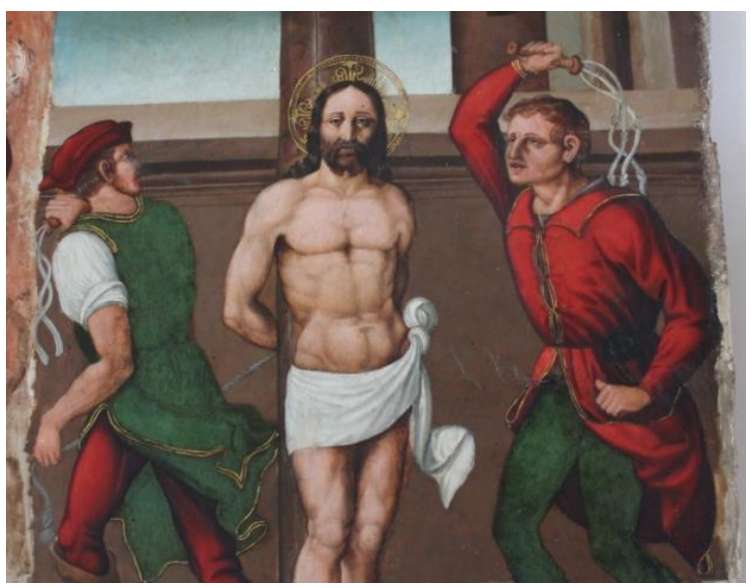

Detalle de fig. 60.

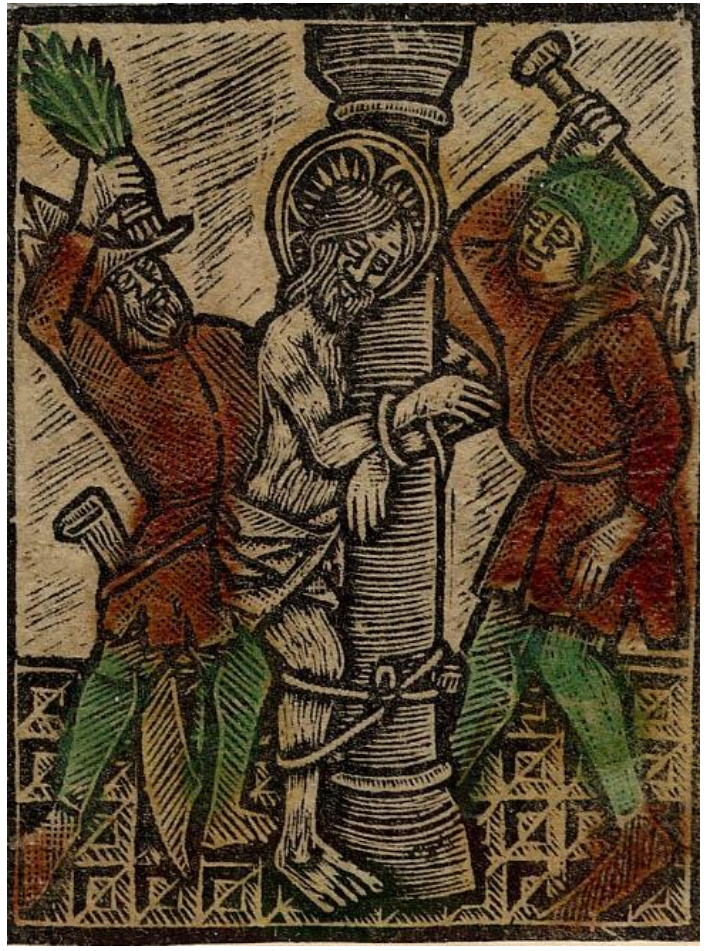

61. Anónimo alemán.

Flagelación. 1470-1480.

Museo Británico. Londres (Reino Unido).

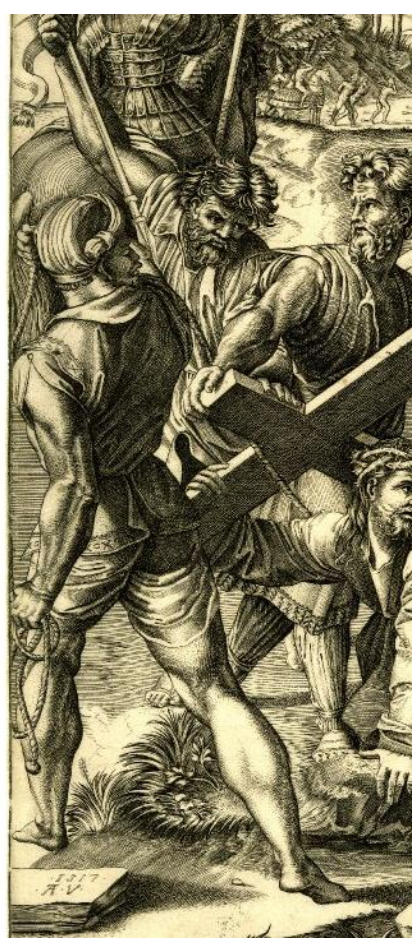

62. Agostino Veneziano. Detalle del Pasmo de Sicilia. 1517. Museo Británico. Londres (Reino Unido).

\footnotetext{
${ }^{329}$ Estampa disponible en:

http://www.britishmuseum.org/research/collection_online/collection_object_details.aspx?objectId=14419 00\&partId $=1$ \&searchText=calvary\&images $=$ true \&people $=134723 \&$ page $=1$ BARTSCH, A., op. cit., vol. XIV, p. 34; PASSAVANT, J. D., op. cit., vol. VI, p. 52.
} 
Anónimo

Retablo mayor

Primer tercio del Siglo XVI

Iglesia de Nuestra Señora de la Paz

Valdeavellano de Tera (Soria)

La iglesia de la localidad de Valdeavellano, que formaba parte de la Diócesis de Osma-Soria, se sustenta sobre unos contrafuertes que soportan la nave central y la cabecera ochavada, que probablemente fueron construidos en el siglo XVI, al igual que el resto de la iglesia. Del retablo original quedan quince tablas (fig. 63): cuatro en el cuerpo bajo, ocho en el cuerpo central (cuatro en cada registro) y otra en el ático. Estas quince tablas representan escenas religiosas y están enmarcadas por estructuras arquitectónicas. Responde a la tipología habitual de los retablos castellanos del Renacimiento.

Desde el punto de vista iconográfico el retablo sigue los patrones tradicionales. Los evangelistas con sus símbolos aparecen en el cuerpo bajo, afrontados dos a dos en composición. Los registros intermedios pueden dividirse en varios grupos iconográficos. Las escenas relacionadas con la infancia de Cristo aparecen distribuidas en torno a la calle central, en sentido cronológico: la Anunciación, el Nacimiento de Jesús, la Presentación en el Templo y la Adoración de los Reyes. En el primer cuerpo se localizan dos parejas de santos: en el lado del Evangelio, San Juan Bautista y Santo Domingo de Guzmán; en el de la Epístola Santa Catalina y San Agustín.

En el segundo cuerpo se componen escenas de las vidas de dos santos, temas muy habituales en este tipo de retablos: el Martirio de San Sebastián y la Misa de San Gregorio. En el cuerpo superior sólo hay dos pinturas el Llanto sobre Cristo muerto y la Asunción de la Virgen. El retablo culmina con un Calvario en el ático, y a ambos lados del mismo dos tallas: Santa Ana y San Bartolomé.

El conjunto plantea ciertas dificultades en cuanto a su datación y autoría. No hay información en los libros parroquiales. Se han relacionado con Pietro Morone y también con el Maestro de Osma. Incluso por las figuras y la influencia de grabados podría ser obra de Soreda. Respecto al estilo se puede decir que aúna elementos tardo-goticos propios de la pintura española de la época con otros más avanzados, característicos del Renacimiento italiano y nórdico. Por sus formas, se podrían datar en torno al primer tercio del siglo XVI.

Los recursos estilísticos renacentistas utilizados son, fundamentalmente, la perspectiva monofocal, que se usa de manera incorrecta en algunas de las pinturas, los 
fondos naturalistas y la proporcionalidad de las figuras. Se mantienen los rasgos más arcaizantes, como la simplicidad de la composición y el dorado como elemento decorativo y de resalte. El uso del dorado y del azul laspislázuli son elementos decorativos propios del arte español del siglo XV. En estas pinturas los nimbos y brocados de las vestimentas están decorados con oro, pero éste ya ha desaparecido de los fondos; por lo que se puede afirmar que las pinturas responden al estilo propio del primer cuarto del siglo $\mathrm{XVI}^{330}$.

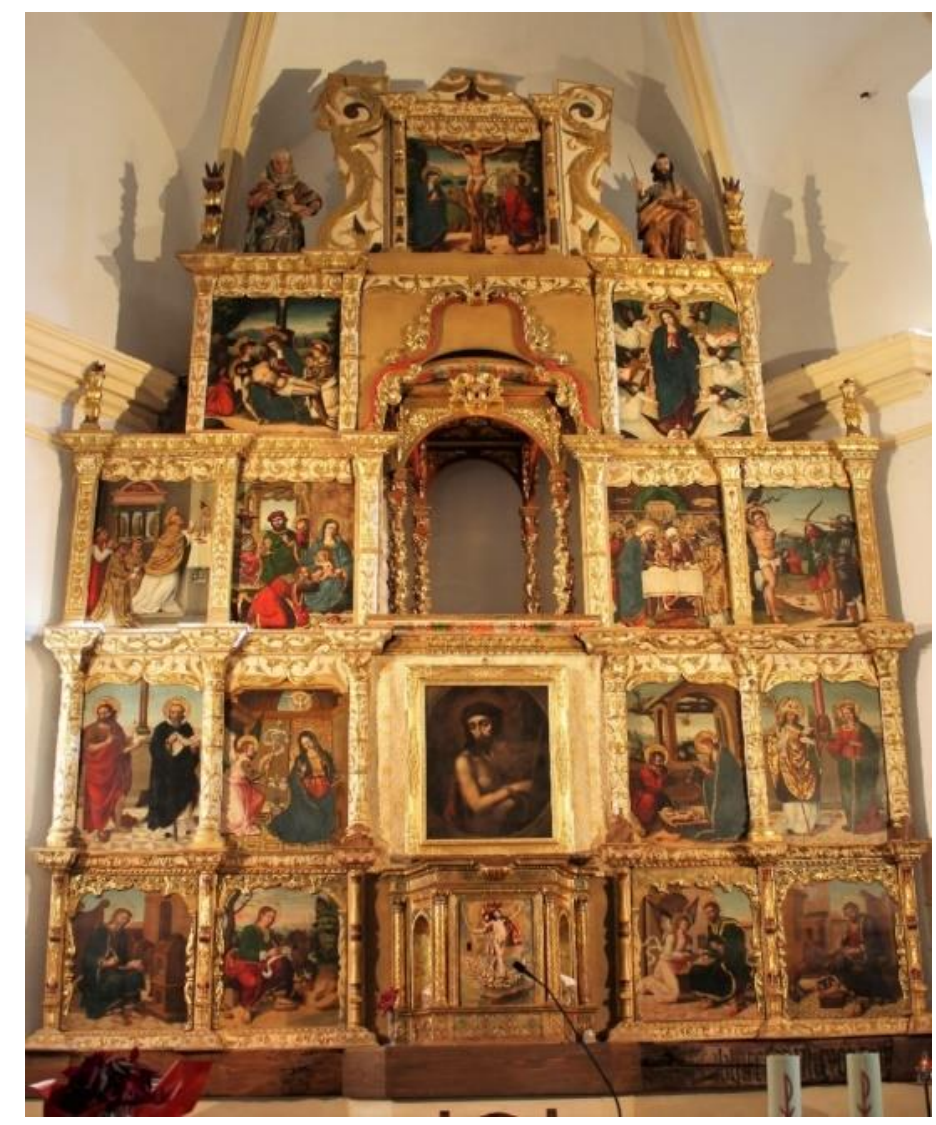

63. Anónimo. Retablo mayor. Primer tercio del siglo XVI. Iglesia de Nuestra Señora de la Paz. Valdeavellano de Tera (Soria).

\section{Anunciación}

La pintura (figs. 64 y 65) probablemente tome como ejemplo la Anunciación de Alberto Durero (fig. 66) ${ }^{331}$. El ángel muestra la misma pose y hace el mismo gesto con

\footnotetext{
${ }^{330}$ GONZÁLEZ BLASCO, P., op. cit., 1998, pp. 233-235.

${ }^{331}$ Estampa disponible en:

http://www.britishmuseum.org/research/collection_online/collection_object_details.aspx?objectId=13399 $07 \&$ partId $=1$ \&searchText $=$ annunciation\&images $=$ true \&people $=127877$ \&page $=1$

BARTSCH, A., op. cit., VII, p. 119; DODGSON, C., Catalogue of Early German and Flemish Woodcuts..., vol. I, no 63, p. 294; SCHOCH, R., op. cit., vol. II, no 189, pp. 291-292; MEDER, J., op. cit., $\mathrm{n}^{\circ}$ catálogo 128, p. 134.
} 
la mano derecha, aunque con la izquierda sujeta la cortina y no la vara con la filacteria como en la pintura. En cuanto a la figura de la Virgen, podría proceder de algún modelo nórdico como por ejemplo las anunciaciones de grabadores como el Maestro E.S. (fig. $67)^{332}$ que muestran una figura femenina muy parecida arrodillada frente a la mesa, con la mirada baja y con gesto humilde y las manos levantadas mostrando las palmas, aunque en este caso la Virgen apoya la mano izquierda sobre la mesa. La postura de la mano derecha es idéntica a la de la estampa, así como el rostro. Ambas escenas se aproximan pero quizás no haya relación directa entre ambas.

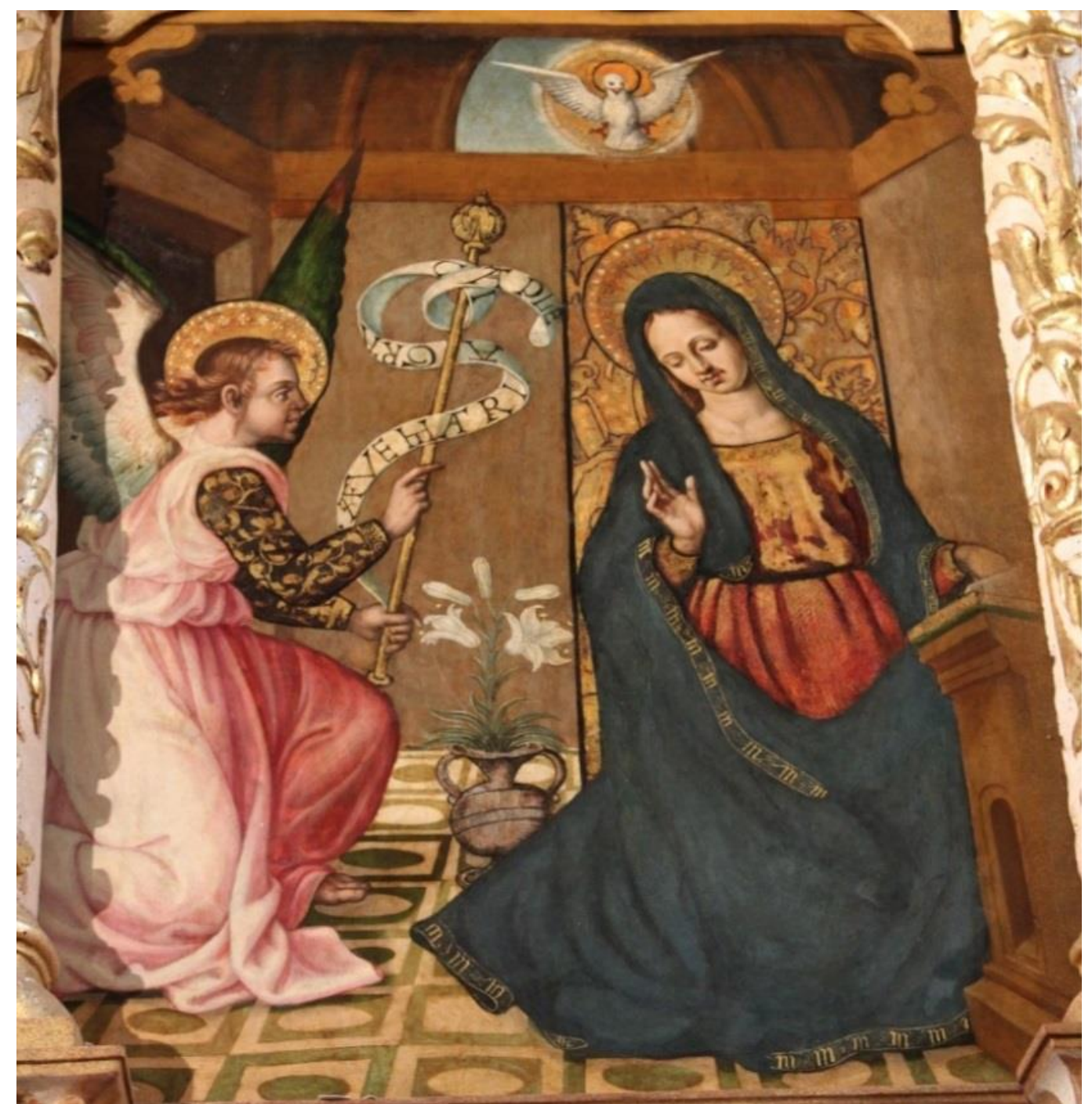

64. Anónimo. Anunciación. Primer tercio del siglo XVI. Retablo mayor. Iglesia de Nuestra Señora de la Paz. Valdeavellano de Tera (Soria).

\footnotetext{
${ }^{332}$ Imagen procedente de VV. AA., Illustrated Bartsch, German 15th Century, Master Es, Master FVB, Schongauer, Mair Von Landshut, p. 17, t. 8, Nueva York, Abaris Books, 1980, p. 192.
} 


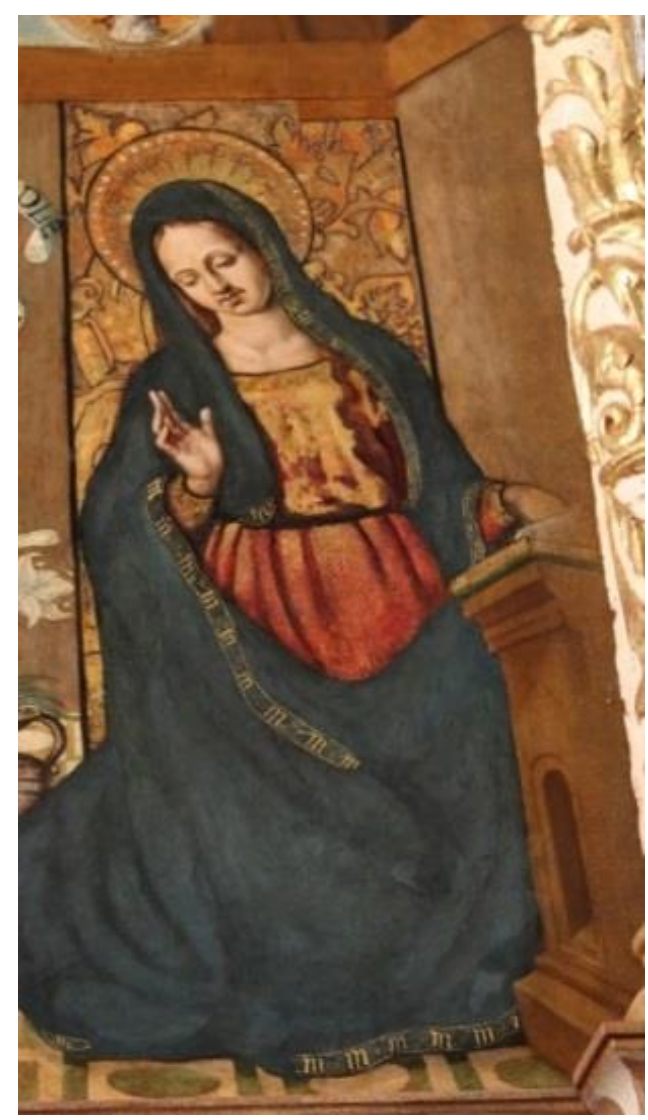

65. Detalle de la fig. 64.

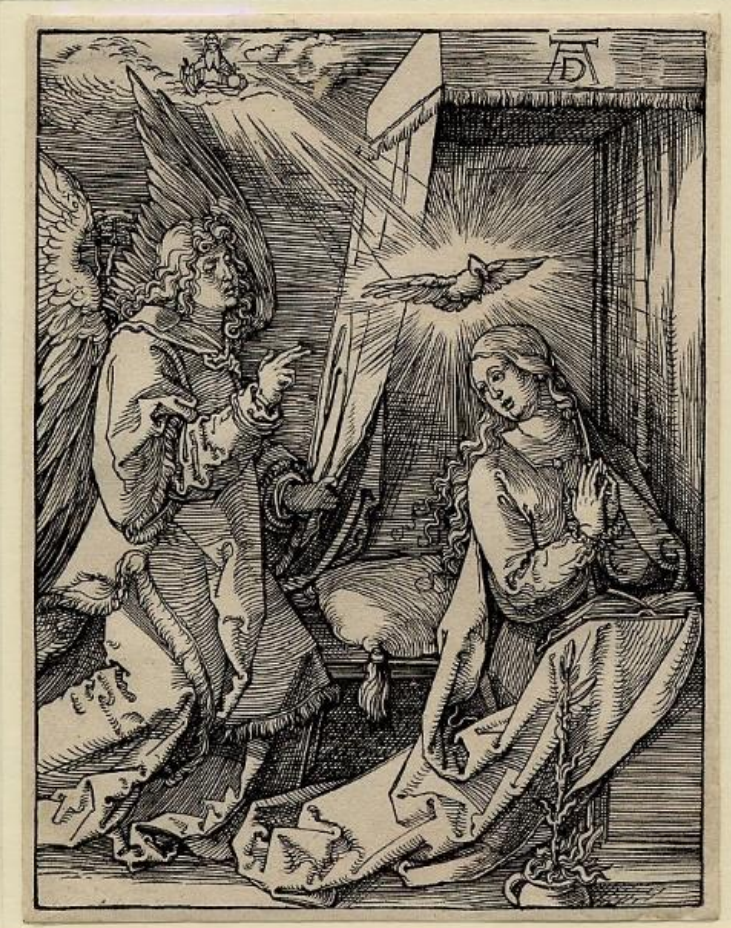

66. Alberto Durero. Anunciación. Pequeña Pasión. 1510 Museo Británico. Londres (Reino Unido)

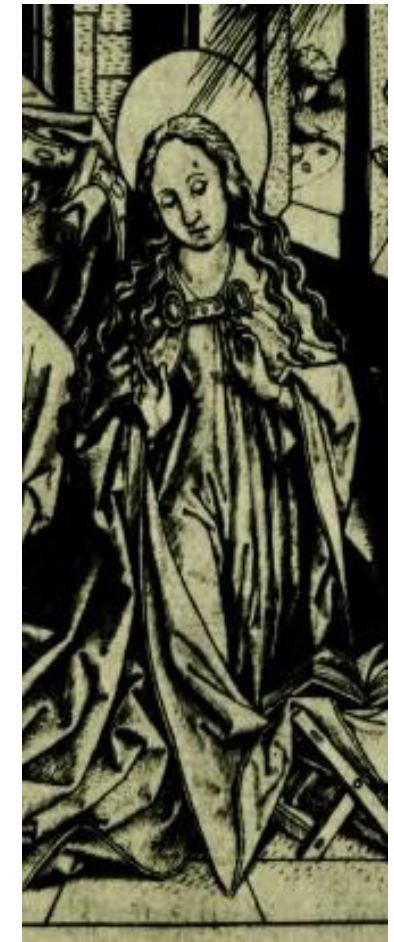

67. Maestro ES. Anunciación. Museo de la Albertina. Viena (Austria). 


\section{Asunción de la Virgen}

La Virgen aparece dentro de la mandorla (fig. 68), con las manos unidas por las puntas de los dedos, orando; a sus pies hay un ángel y a su alrededor vuelan seis más que la rodean de manera simétrica de pies a cabeza y la llevan hacia el cielo. Para esta imagen de la Virgen de la Asunción (fig. 69) ${ }^{333}$ es posible que el pintor que tomara como modelo una xilografía francesa de 1500 del mismo tema, aunque el número de ángeles ha sido reducido de siete a cinco. No hay relación directa entre ambas obras, ya que la pintura recoge composiciones iconográficas habituales. En la pintura se obvian ciertos detalles que suelen aparecer en la iconografía, como la tumba de la que surge la Virgen, las figuras de los apóstoles o la de Dios Padre, arriba entre ángeles.

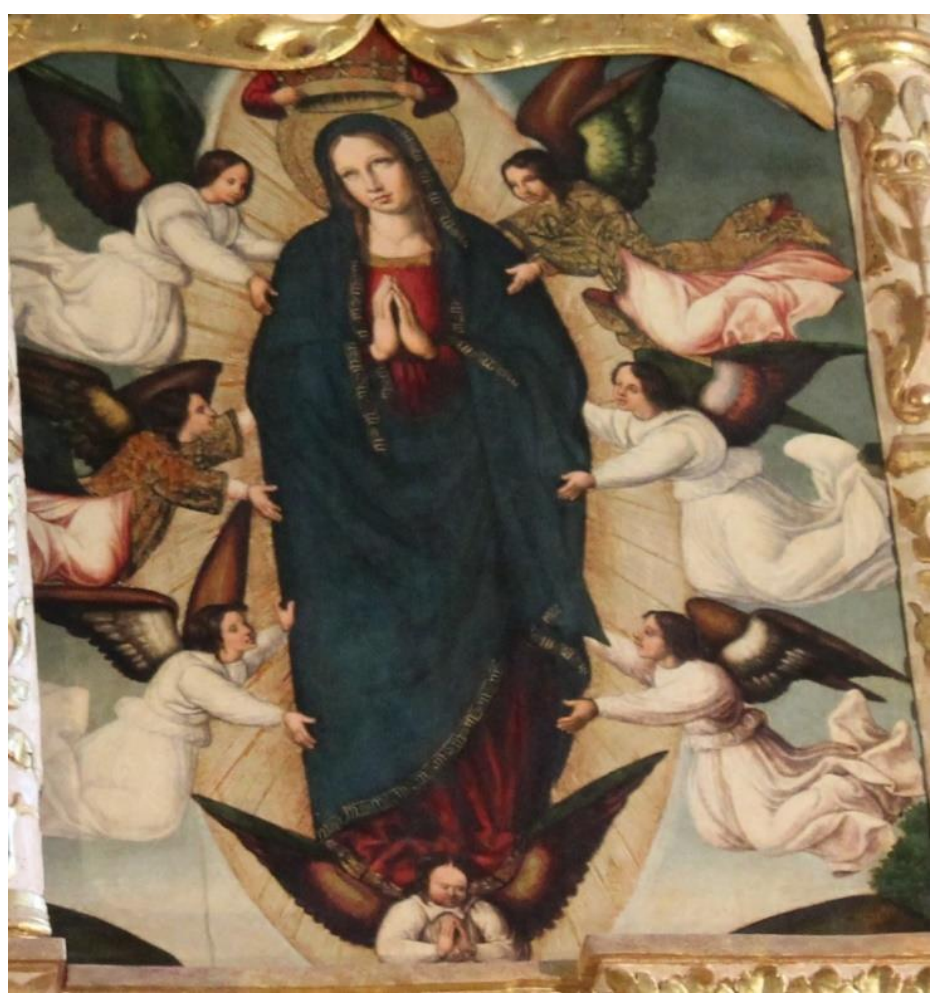

68. Anónimo. Asunción de la Virgen. Primer tercio del siglo XVI. Retablo mayor. Iglesia de Nuestra Señora de la Paz. Valdeavellano de Tera (Soria).

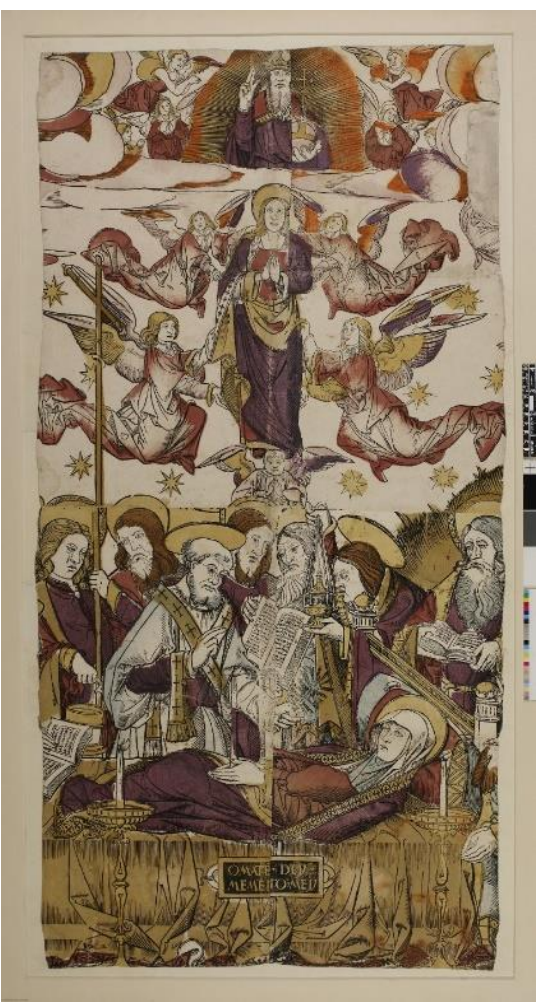

69. Anónimo francés. Asunción de la Virgen. 1500. Museo Británico. Londres (Reino Unido)

\footnotetext{
${ }^{333}$ Estampa disponible en:

http://www.britishmuseum.org/research/collection_online/collection_object_details.aspx?objectId=13522 36\&partId=1\&searchText=assumption\&images=true \& from $=$ ad $\&$ fromDate $=1500 \&$ page $=1$
} 


\section{Llanto sobre Cristo muerto}

Es posible que el pintor utilizara para esta composición (fig. 70) la estampa del mismo tema de Maestro E. S (1450-1465) (fig. 71) ${ }^{334}$, inspirándose en la figura de Cristo, que deja caer su brazo derecho hasta el suelo, así como la pose de la Virgen con las manos entrelazadas. También es similar la figura de San Juan, que ayuda a sostener el cuerpo de Cristo sujetándole por la cabeza, aunque en este caso la postura de las manos varía respecto a la del grabado. El pintor no ha imitado el complicado juego de pliegues propio de la pintura flamenca, que sí vemos en la estampa, en el manto de la Virgen.

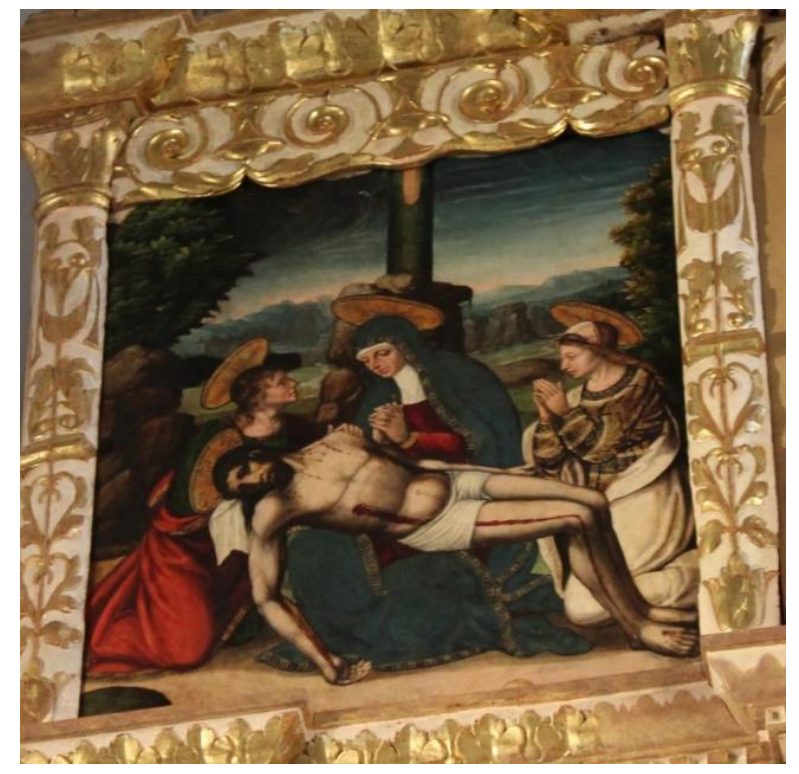

70. Anónimo. Llanto sobre Cristo muerto. Primer tercio del siglo XVI. Retablo mayor. Iglesia de Nuestra Señora de la Paz. Valdeavellano de Tera (Soria).

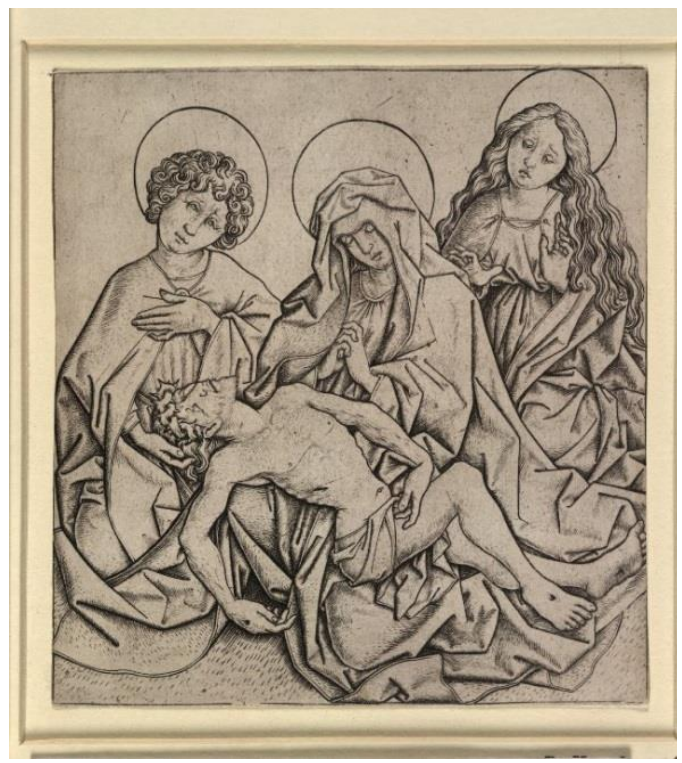

71. Maestro E. S. Llanto sobre Cristo muerto. 1450-1467.

Museo Británico. Londres (Reino Unido).

\section{Adoración de los Magos}

En esta escena de la Adoración de los Magos (fig. 72), los protagonistas se ubican junto a un arco de medio punto que recuerda a muchos grabados alemanes del mismo tema, por ejemplo la estampa de Durero (1505-1515) (fig. 73$)^{335}$. Por otro lado,

\footnotetext{
${ }^{334}$ Estampa disponible en:

http://www.britishmuseum.org/research/collection_online/collection_object_details.aspx?objectId=13659 48\&partId=1\&searchText=MASTER+ES\&images $=$ on\&page $=2$

LEHRS, M., op. cit., vol. II, p. 84.

${ }^{335}$ Estampa disponible en:

http://www.britishmuseum.org/research/collection_online/collection_object_details.aspx?objectId=13395 $10 \&$ partId=1\&searchText=adoration+of +the+magi\&images=true\&people=127877\&page=1
} 
las figuras de los reyes Gaspar y Baltasar (fig. 74) están inspirados parcialmente en el grabado de Hans Guldenmundt (1509-1510) (fig. 75) ${ }^{336}$. Gaspar gira la cabeza mirando a Baltasar, y levanta dos dedos de su mano izquierda (en la estampa es sólo uno), señalando los presentes que llevan al Niño.

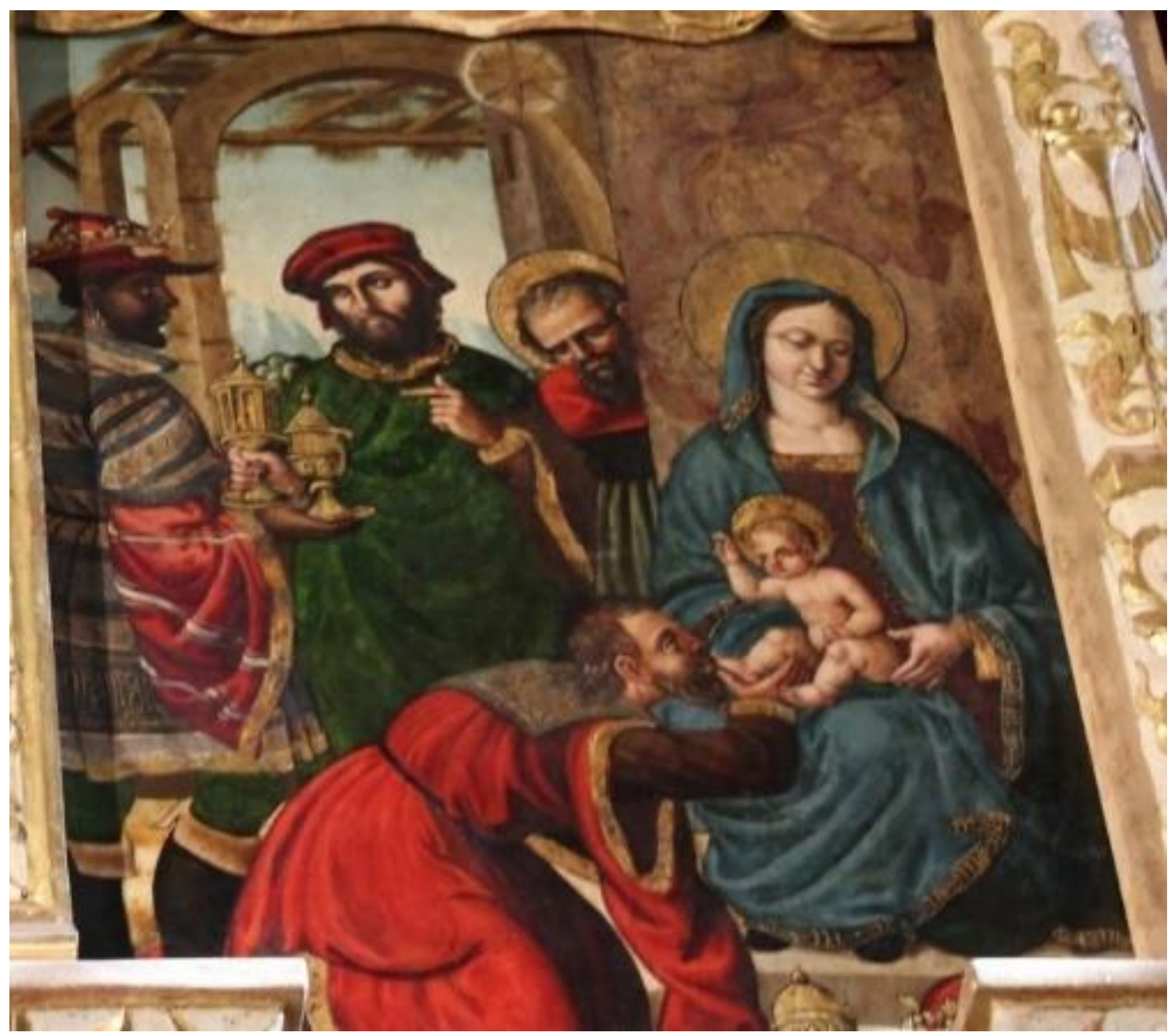

72. Anónimo. Adoración de los Magos.

Retablo mayor. Primer tercio del siglo XVI.

Iglesia de Nuestra Señora de la Paz. Valdeavellano de Tera (Soria).

BARTSCH, A., op. cit., vol. VII, p. 132; DODGSON, C., Catalogue of Early German and Flemish Woodcuts..., vol. I, no 47, p. 289; SCHOCH, R., op. cit., vol. II, n 177, pp. 254-256; MEDER, J., op. cit., $\mathrm{n}^{\circ} 199$, p. 175.

${ }^{336}$ Estampa disponible en:

http://www.britishmuseum.org/research/collection_online/collection_object_details.aspx?objectId=14632 75\&partId=1\&searchText=hans+guldenmundt\&images $=$ on\&page $=1$

BARTSCH, A., op. cit., vol. VII, p. 247; DODGSON, C., Catalogue of Early German and Flemish Woodcuts..., vol. II, $\mathrm{n}^{\mathrm{o}} 39^{\mathrm{a}}$, p. 67; HOLLSTEIN, F. W. H., German engravings, etchings and woodcuts, p. 284. 


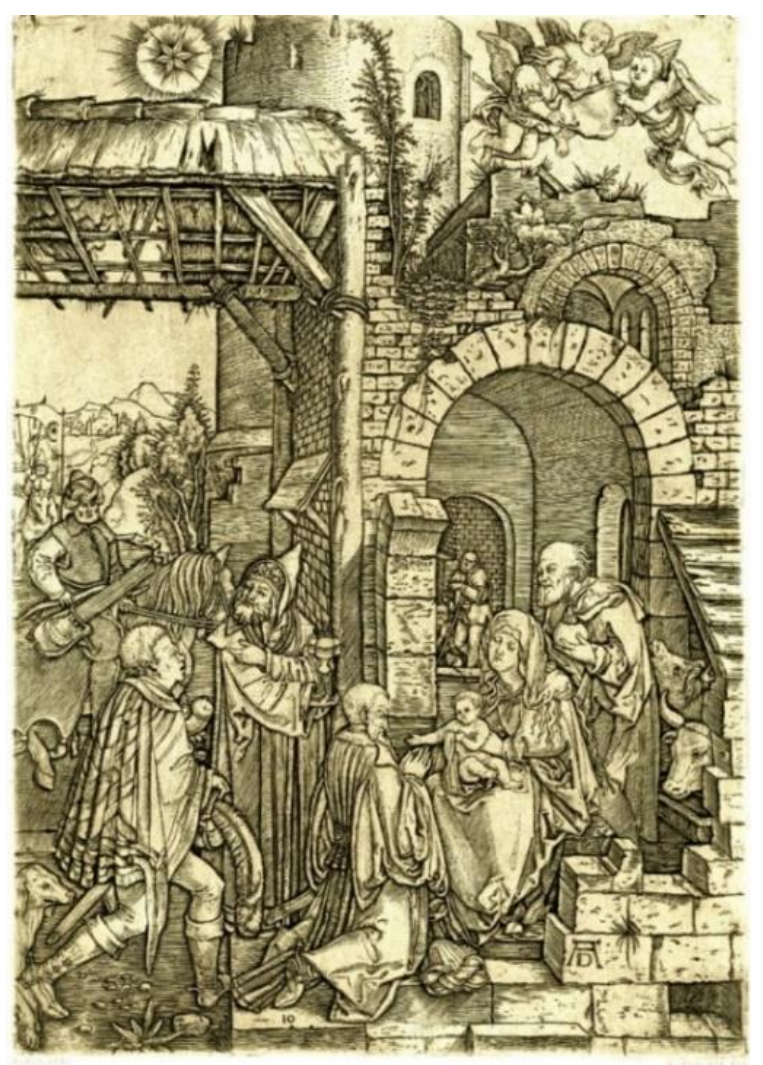

73. Alberto Durero. Adoración de los Magos.

1503. Vida de la Virgen. Museo Británico. Londres (Reino Unido).

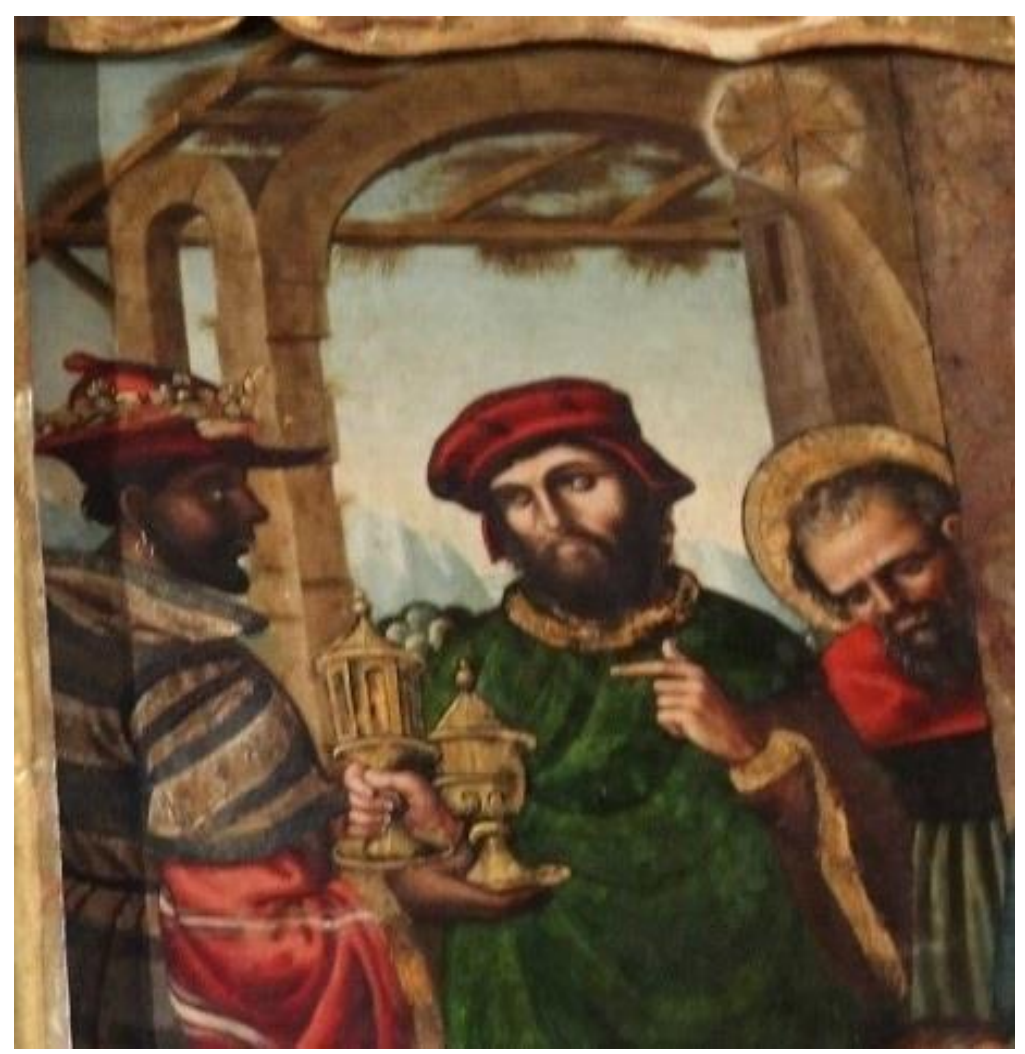

74. Detalle de fig. 72. 


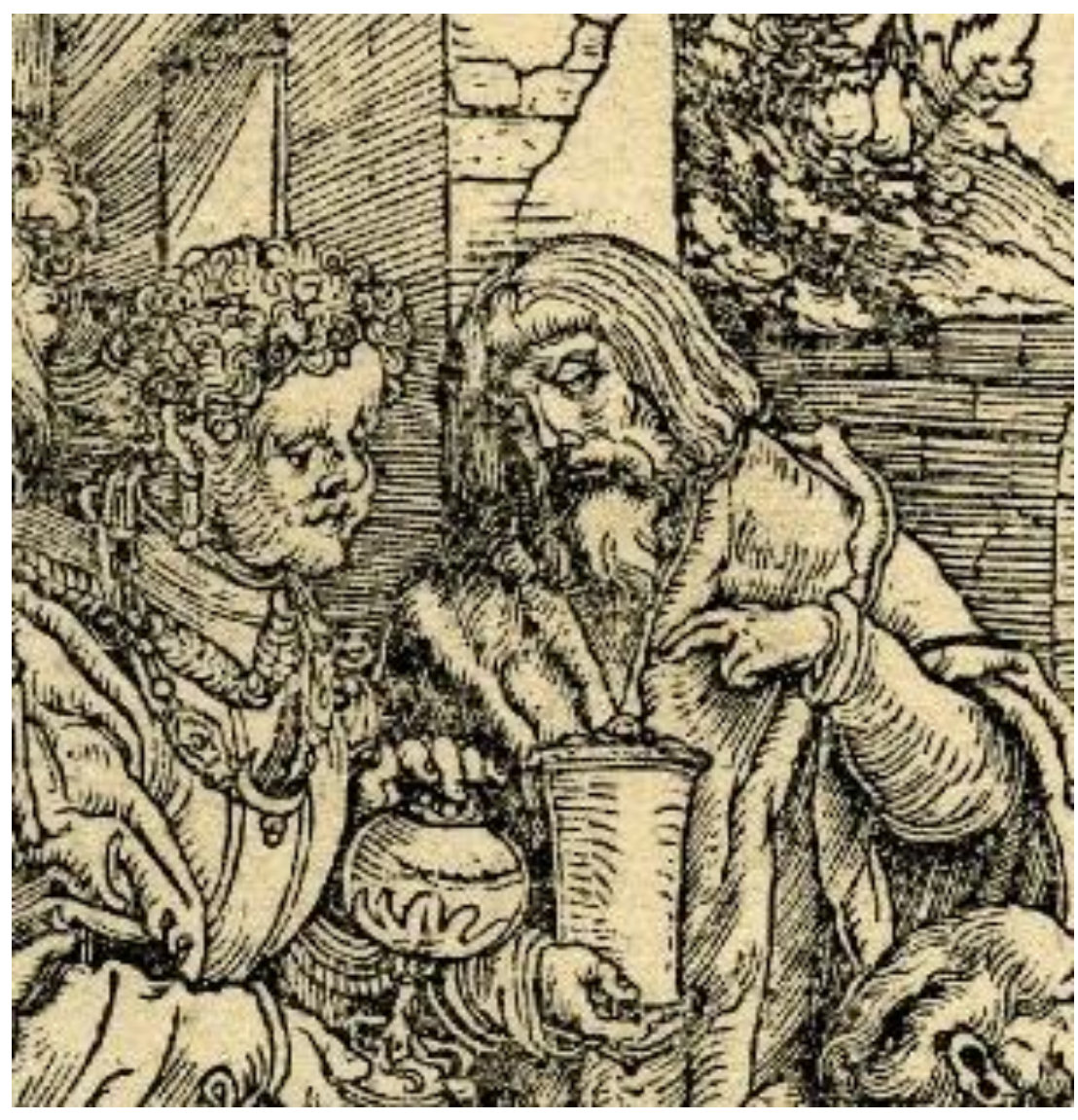

75. Hans Guldenmundt. Adoración de los Magos. 1509-1510. Museo Británico. Londres (Reino Unido).

\section{Juan Soreda \\ Virgen de la Silla y Anunciación \\ Ca. 1524-1532 \\ Concatedral de San Pedro \\ Soria}

Se conservan tres tablas que seguramente formaban parte de un antiguo retablo. Es probable que se las separara por alguna cuestión estética o de reformas posteriores ${ }^{337}$.

\section{Virgen de la Silla}

Una de las tablas es la pintura de La Virgen de la Silla (fig. 76). En ella aparece la Virgen con el Niño, sentada en un trono de jaspe decorado con frutas, rodeada por dos pequeños ángeles en la parte superior y con las figuras de dos ángeles de mayor

\footnotetext{
${ }^{337}$ ÁVILA PADRÓN, A., “Influencia de la estampa...”, p. 83; MARTÍNEZ FRÍAS, J. M., Concatedral de Soria, León, Edilesa, 1992; ALONSO ROMERO, J., La concatedral de Soria: al rumor del Duero, Trobajo del Camino, Edilesa, 2003, p. 85; RUIZ MALDONADO, M., "Virgen de la Silla", en Paisaje interior: Las Edades del Hombre, Fundación Las Edades del Hombre, 2009, n 73 , pp. 365-366.
} 
tamaño y un niño en la inferior, todo en un ambiente de decoración inspirado en la Antigüedad clásica. La tabla ha sido datada entre 1524 y 1532 por Ramos Gómez, coincidiendo con la etapa de madurez de la obra de Soreda, en el mismo período en el que realiza el Retablo de Santa Librada de la Catedral de Sigüenza ${ }^{338}$. Otros autores como Post ${ }^{339}$ han datado la pintura en fechas más tempranas, entre 1515 y 1520. Por las fechas establecidas para las estampas en las que se basa, es más probable que se realizara entre mediados de los años veinte y principios de los treinta.

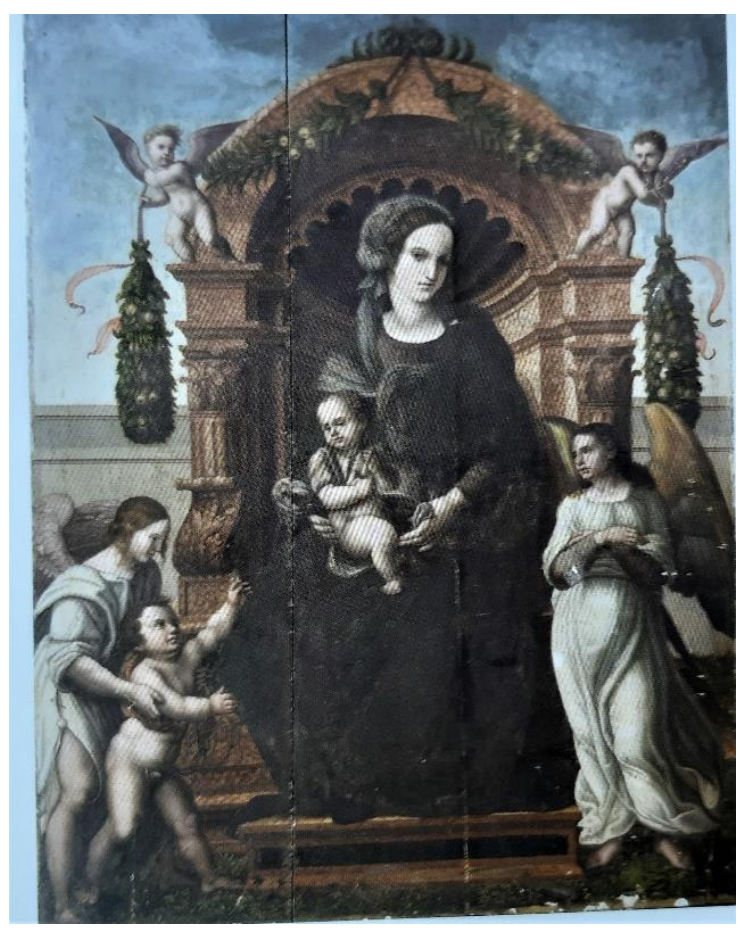

76. Juan Soreda. Virgen de la Silla. 1524-1532. Concatedral de San Pedro. Soria.

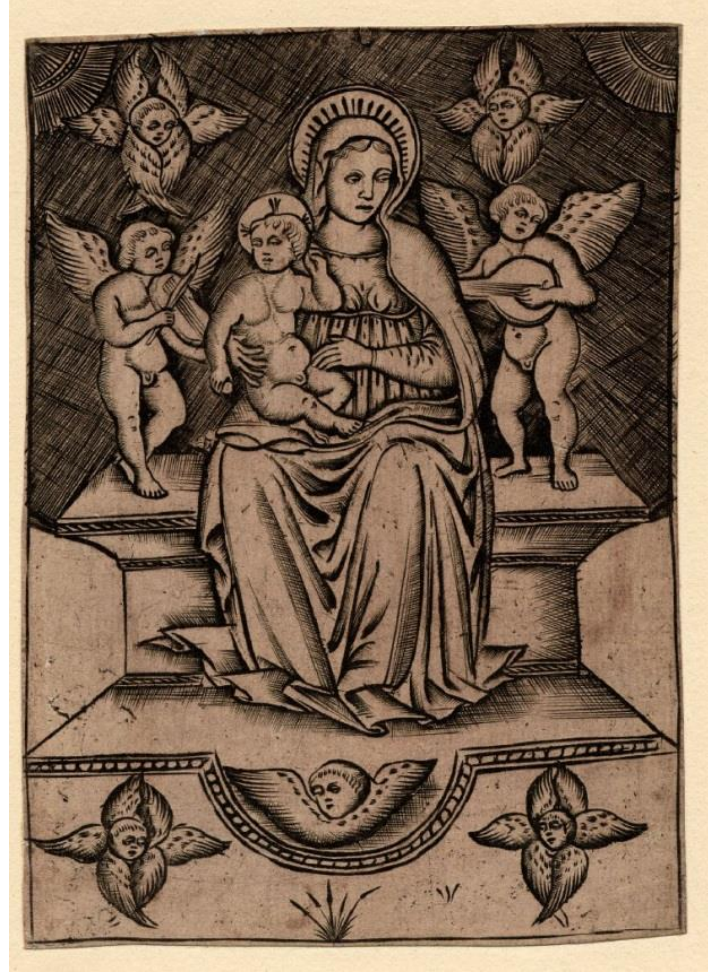

77. Marcantonio Raimondi.

Virgen con el Niño. 1490-1500. Museo Británico. Londres (Reino Unido).

Es evidente que Soreda se basó para crear esta pintura en la Virgen sentada en un trono a partir de una estampa anónima italiana, datada en torno a 1490-1500 (fig. $77)^{340}$. El rostro es muy parecido al de la estampa. Ambas tienen la misma nariz un poco aguileña, la boca pequeña y los cabellos algo ondulados y medio cubiertos con un

${ }^{338}$ RAMOS GÓMEZ, F. J., Juan Soreda y la pintura ..., p. 275

${ }^{339}$ POST, R. C., op. cit., t. IX, parte 2, pp. 703-705.

${ }^{340}$ Estampa disponible en:

http://www.britishmuseum.org/research/collection_online/collection_object_details.aspx?objectId=13392 44\&partId=1\&searchText=virgin + with+child\&images $=$ true $\&$ from $=$ ad $\&$ fromDate $=1490 \&$ to $=$ ad \& toDate $=$ $1500 \&$ page $=1$

BARTSCH, A., op. cit., vol. XIII, p. 84; HIND, A. M., Early Italian engraving a critical catalogue, Londres, Klaus Reprint, vol. I, E III, 1970, nº 82, p. 275. 
pañuelo. La postura también es muy similar, aunque en la estampa el Niño está situado más arriba y además levanta su mano izquierda. También la colocación del trono y el fondo con un muro situado a media altura de la composición son muy semejantes. El rafaelismo de la composición queda plasmado en su clasicismo y en la forma en que los pliegues de las vestimentas se adhieren al cuerpo ${ }^{341}$. Por otro lado, en el grabado de Francesco Rosselli (fig. 78) ${ }^{342}$ vemos también a la Virgen con el Niño en brazos sentada sobre un trono con forma de venera, como en la pintura. El trono y su decoración a base de guirnaldas y figuras aladas tuvo su origen en obras italianas de la época, como la Madonna col Bambino e Santi de Bartolommeo Vivarini, en el Museo Nazionale di Capodimonte en Nápoles (ca. 1465) (fig. 79) ${ }^{343}$.

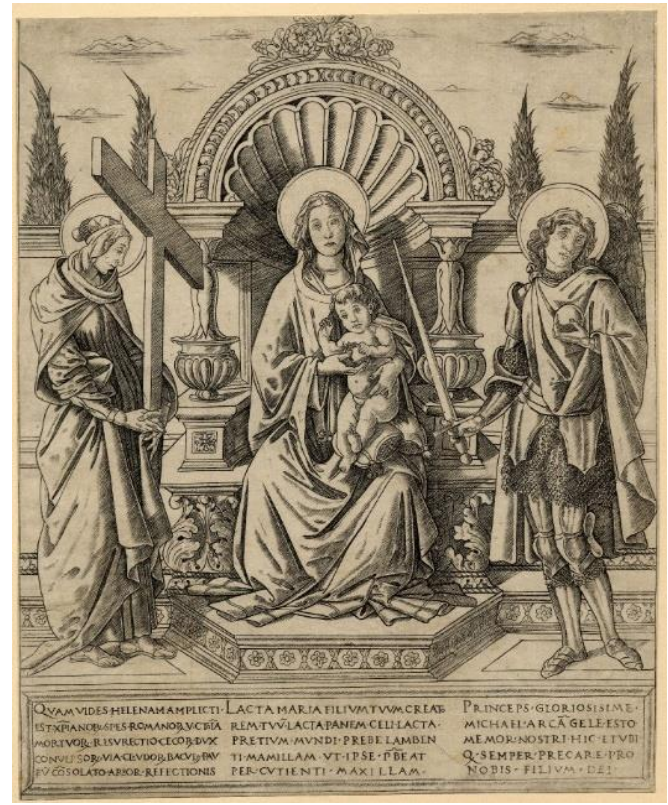

78. Francesco Rosselli.

Virgen con el Niño en un trono entre Santa Helena y San Miguel. 1480-1490. Museo Británico.

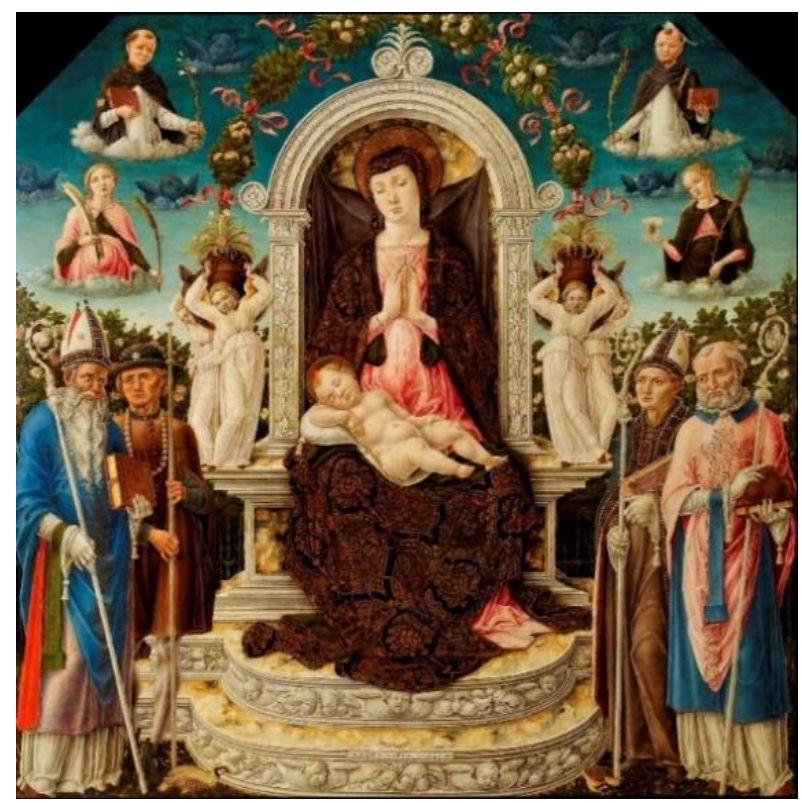

79. Bartolommeo Vivarini. Madonna col Bambino e Santi. Ca. 1465. Museo Nazionale di Capodimonte. Nápoles (Italia).

Londres (Reino Unido).

Los amorcillos o putti que aparecen a ambos lados del trono, son un recurso decorativo propio del Quattrocento, aunque con algunos ejemplos dentro de la Península Ibérica. El motivo de los putti sujetando guirnaldas, como en este caso,

\footnotetext{
${ }^{341}$ RAMOS GÓMEZ, F. J., Juan Soreda y la pintura...., p. 275

${ }^{342}$ Estampa disponible en:

http://www.britishmuseum.org/research/collection_online/collection_object_details.aspx?objectId=76139 $\underline{8 \& \text { partId}=1 \& \text { images }=\text { true \&people }=29519 \& \text { page }=1}$ HIND, A. M., Early Italian engraving...., vol. III, b. III, vol. I, nº 9, pp. 140-141.

${ }^{343}$ Imagen procedente de: https://www.pinterest.ca/pin/547961479644749867/
} 
procede en concreto de los sarcófagos de la Antigua Roma, donde se esculpían figuras muy parecidas. Durante el Renacimiento los putti adquieren un significado simbólico asociado al amor, la abundancia, la música o la inocencia. Estos putti o amorcillos concretos (fig. 80) podrían derivar de composiciones de estampas del Maestro del Dado $^{344}$, como Amorini in Lotta (fig. 81) ${ }^{345}$, en la cual vemos unas guirnaldas muy parecidas.

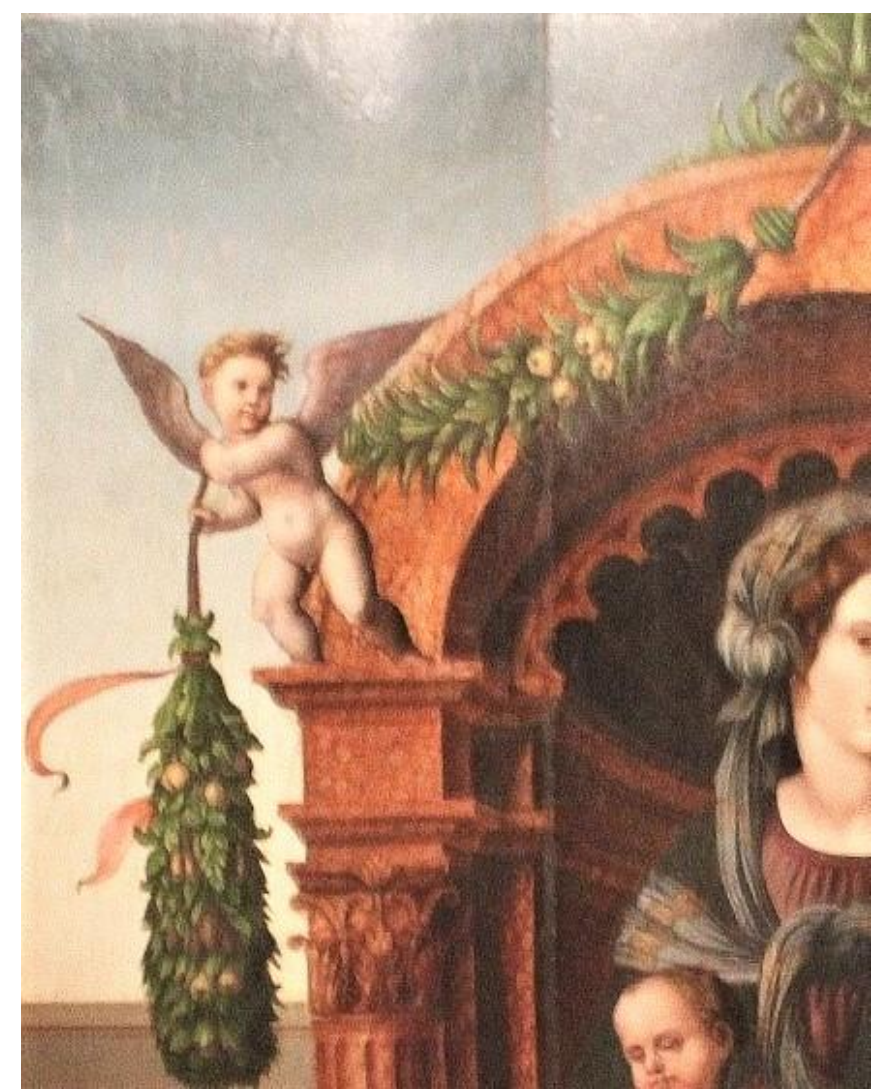

80. Detalle de la fig. 76 .

Para las figuras de la zona inferior Soreda utilizó una estampa de Agostino Veneziano, Virgen con el Niño y San Juanito (fig. 82), copiando de manera literal gestos y posturas de los dos ángeles y el Niño, como ya señalara Ana Ávila ${ }^{346}$. En cambio, la Virgen no se inspira en absoluto en la estampa de Veneziano ${ }^{347}$, ni por la

\footnotetext{
${ }^{344}$ RAMOS GÓMEZ, F. J., Juan Soreda y la pintura ..., p. 134.

${ }^{345}$ Estampa disponible en:

http://www.britishmuseum.org/research/collection_online/collection_object_details.aspx?objectId=15928 $\underline{80 \& \text { partId=1\&searchText=master+of+the+die\&page }=1}$

BARTSCH, A., op. cit., vol. XV, p. 209.

346 ÁVILA PADRÓN, A., "Influencia de la estampa...", p. 83.

${ }^{347}$ Estampa disponible:

https://research.britishmuseum.org/research/collection_online/collection_object_details.aspx?objectId=14 $\underline{26814 \& \text { partId }=1 \& \text { searchText=agostino+veneziano\&images }=\text { true } \& \text { to }=\text { ad } \& \text { toDate }=1516 \& \text { page }=1}$
} 
inestabilidad de su postura, ni por su manierismo, ni por el Niño Jesús, que en la estampa se escurre entre los brazos de la Virgen hasta casi llegar al suelo, y que en la pintura muestra una posición mucho más estable, sentado sobre las rodillas de la madre. Soreda otorga una mayor sensación de espacio a la composición, creando una mayor distancia entre el ángel y San Juanito a la izquierda y la Virgen, y a su vez entre el ángel de la derecha y la misma.

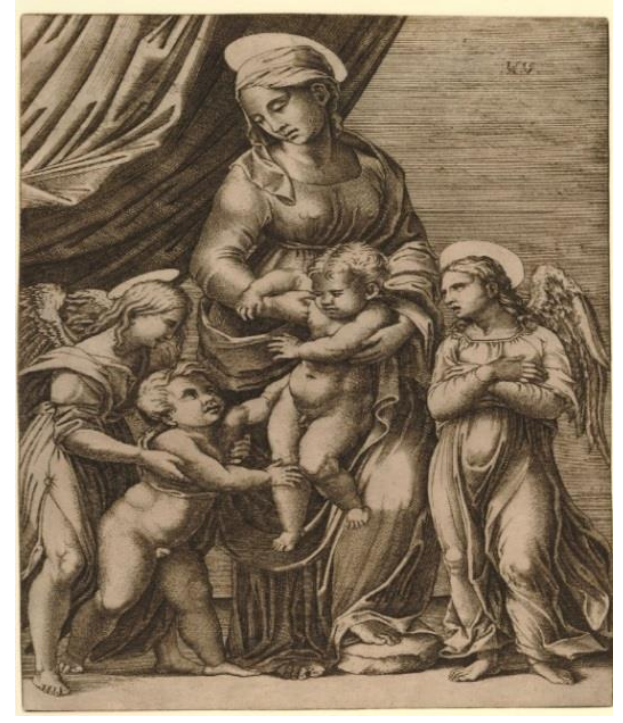

81 Agostino Veneziano. Virgen con el Niño y San Juanito. 1516. Museo Británico. Londres (Reino Unido).

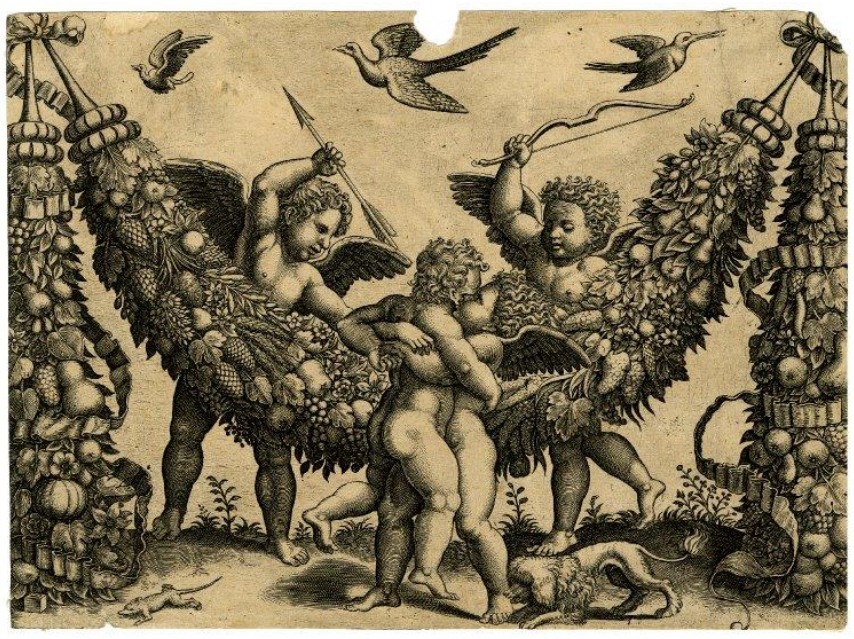

82. Maestro del Dado. Tapices: Amorini in lotta. 1530-1560.

Museo Británico. Londres (Reino Unido).

\section{Anunciación}

En la Anunciación (fig. 83) aparecen la Virgen y el ángel en una estancia con una cama roja con doseles. Es evidente que Soreda se inspiró en la estampa de Marco de Ravena (fig. 84) 348 $^{348}$ crear la figura del ángel, con el que comparte la misma postura, con la mano izquierda sujetando el ramo de lirios y la derecha levantada. Así mismo utiliza el vestido del ángel y sus juegos de pliegues. Por otro lado, el interior acomodado que denotan la cama roja con doseles (fig. 85), el suelo ajedrezado y la ventana situada a la izquierda de la composición derivan de pinturas flamencas e italianas como la de Hans Memling de 1480-1489 (fig. 86) ${ }^{349}$.

\footnotetext{
${ }^{348}$ Estampa disponible en:

http://www.britishmuseum.org/research/collection_online/collection_object_details.aspx?objectId=14389 58\&partId $=1 \&$ searchText=annunciation\&images $=$ true \&people $=115894 \&$ page $=1$ BARTSCH, A., op. cit., vol. VII, p. 16.

${ }^{449}$ Imagen de dominio público. Disponible en:

https://commons.wikimedia.org/wiki/File:Annunciation_Memling.jpg
} 
Soreda muestra cierto interés lumínico aquí con ese rayo de luz divina que entra a través de la ventana izquierda y crea sombras en particular la sombra de la Virgen. Introduce el jarrón con los lirios como elemento situado entre la Virgen y el ángel. Los rostros tanto del ángel como de la Virgen remiten más a modelos flamencos que a la estampa italiana de Ravena.

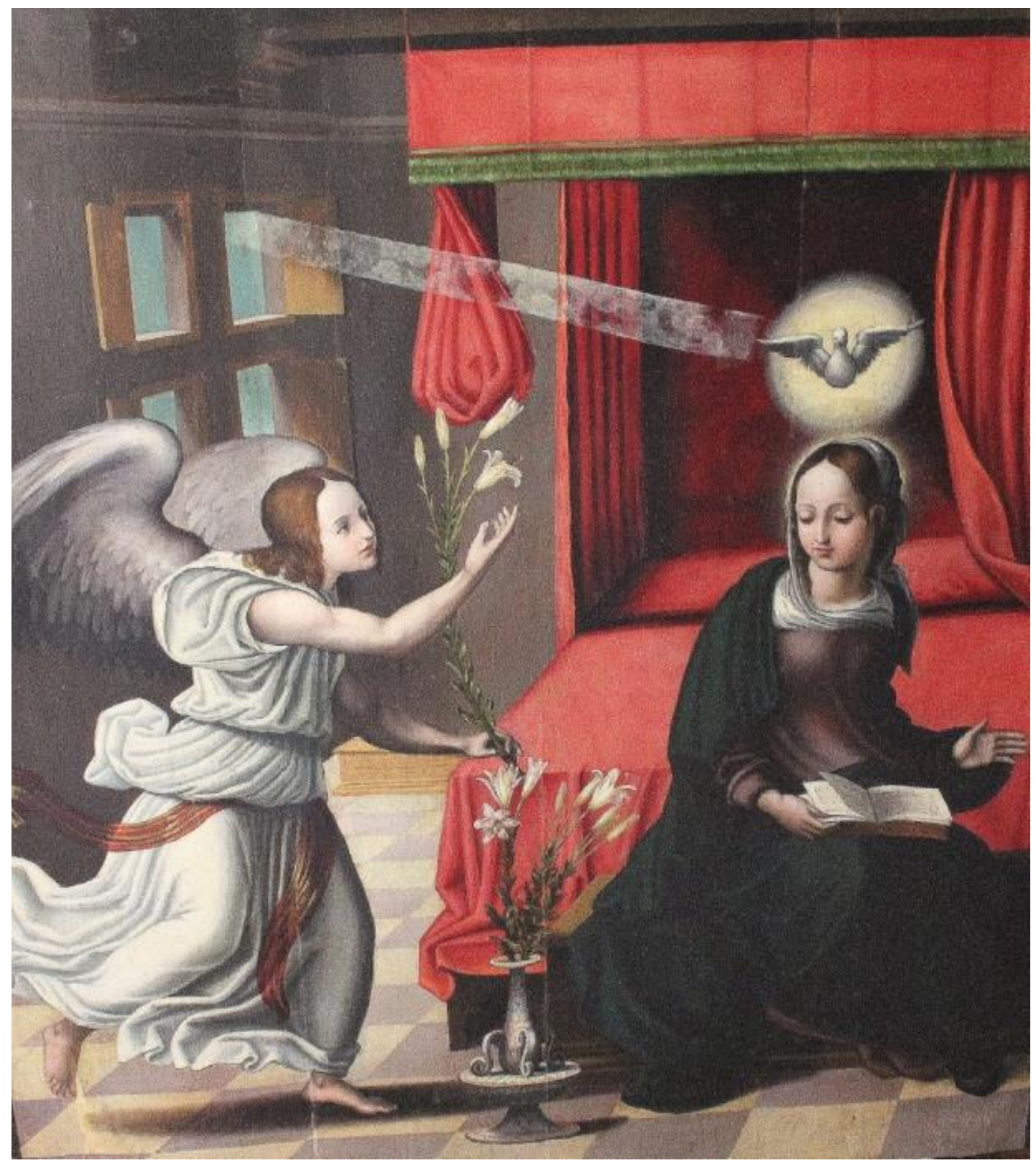

83. Juan Soreda. Anunciación. 1524-1532.

Concatedral de San Pedro. Soria. 
84. Marco de Ravenna. Anunciación.

1519-1527. Museo Británico.

Londres (Reino Unido).
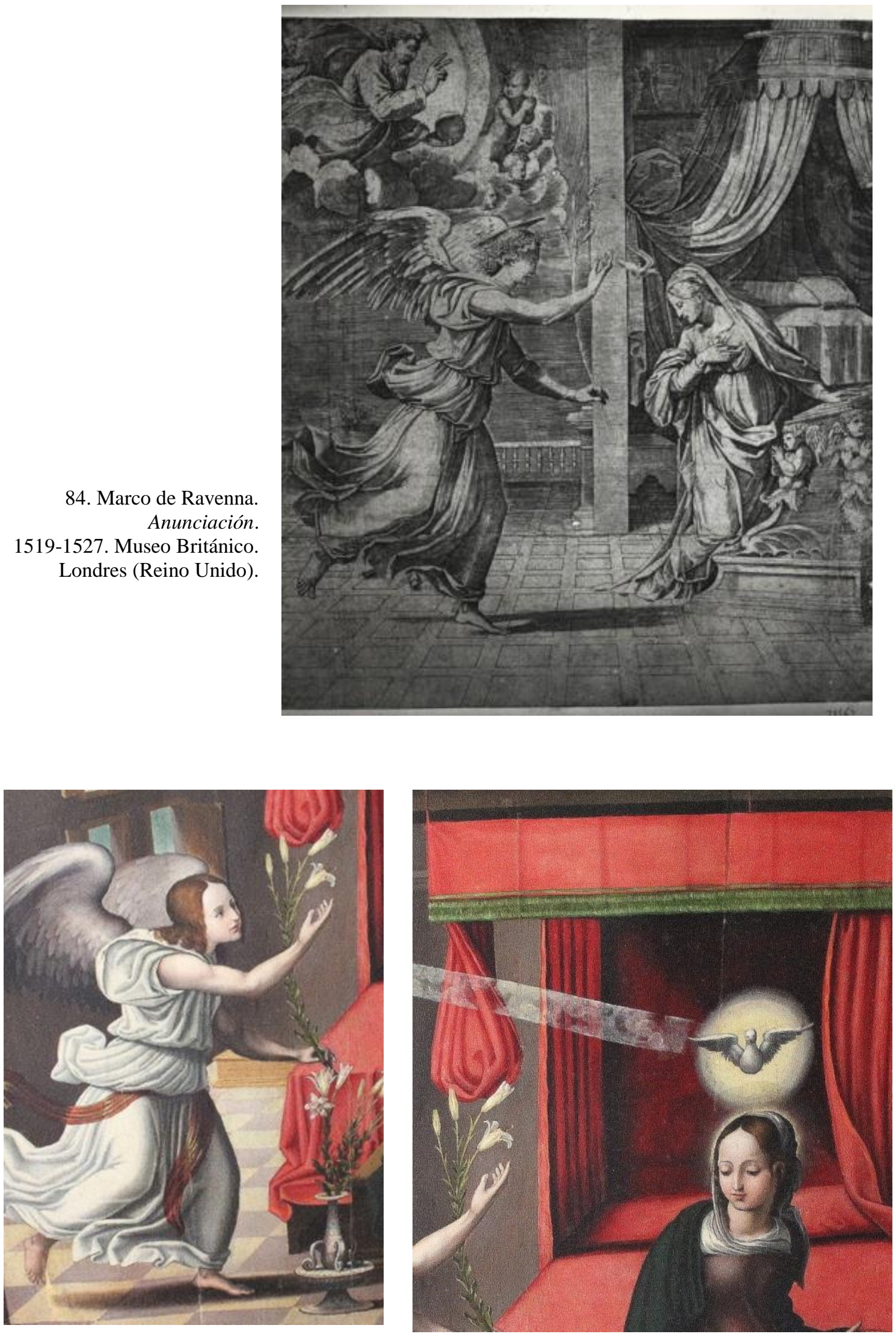

85: Detalles de fig. 83 


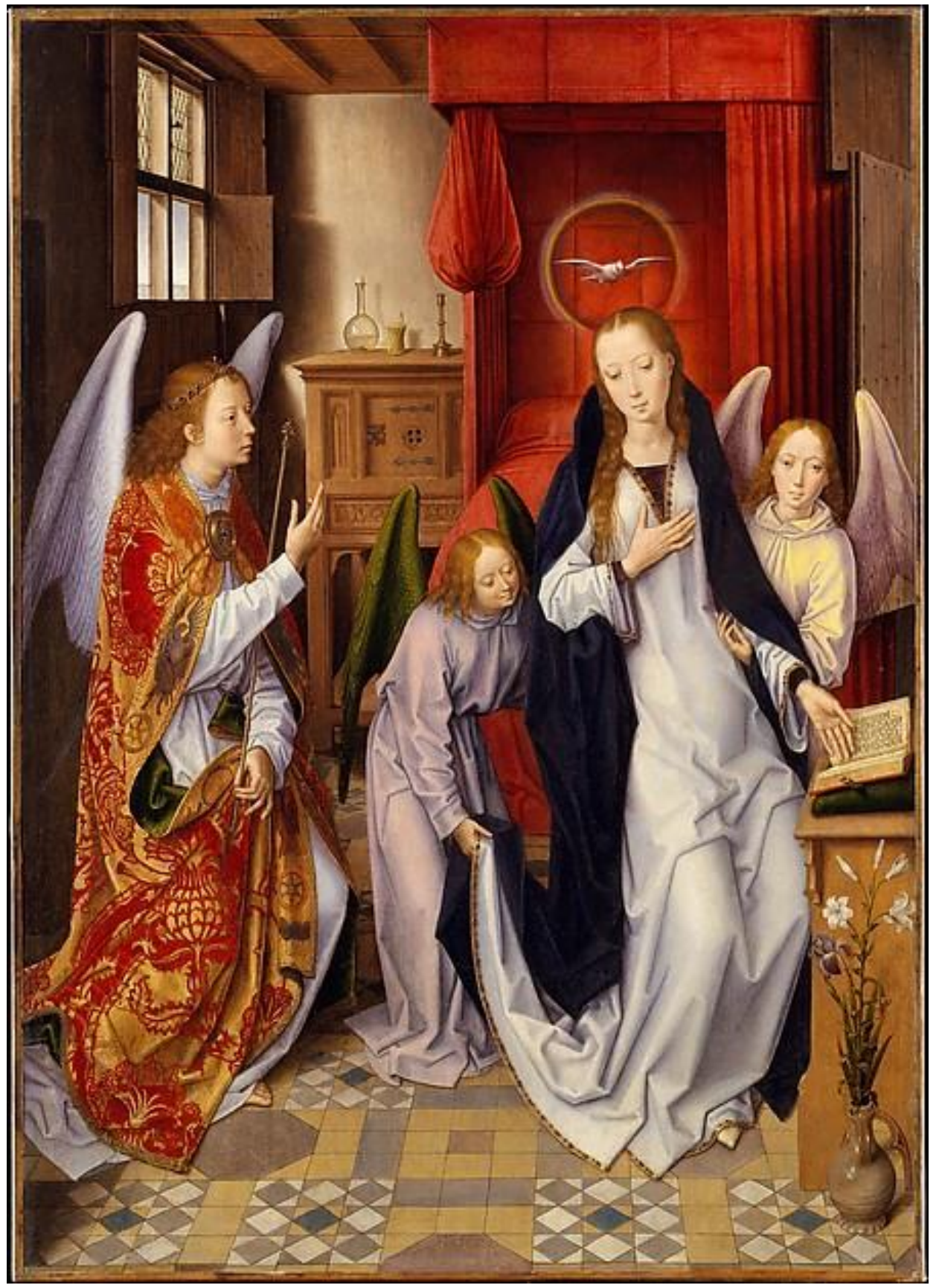

86. Hans Memling. Anunciación. 1480-1489.

Metropolitan Museum. Nueva York (Estados Unidos).

\section{Juan Soreda}

Natividad, la Epifanía y La Virgen ofreciendo el cíngulo a Santo Tomás 1524-1526

\section{Monasterio de Santa María de Huerta (Soria)}

Se conservan tres tablas que representan la. No es extraño que Soreda participase en estas pinturas, pues por aquel entonces Santa María de Huerta formaba parte del 
obispado seguntino $^{350}$. Son tres obras pictóricas vinculadas por su temática a la Vida de la Virgen. Estéticamente podrían considerarse como premanieristas, por las figuras alargadas y los colores brillantes y extraños, aunque con algunos vestigios de las composiciones medievales ${ }^{351}$.

Ramos Gómez las dató en torno a 1524-1526, mientras que Ana Ávila y otros las consideraron anteriores a las de la Concatedral de San Pedro ${ }^{352}$. Fueron atribuidas a Soreda por diversos autores. En primer lugar, Taracena las vinculó con el retablo de Santa Librada ${ }^{353}$; con anterioridad, Post y Diego Angulo, aunque no las atribuyeron a Soreda, sí las relacionaron con la pintura seguntina ${ }^{354}$. Post señaló el carácter leonardesco de algunas figuras, que se repite también en la Presentación en el templo de la Concatedral de Soria. En concreto esta influencia del maestro florentino se observa en las figuras del Niño Jesús, tanto de la Natividad como de la Epifanía, y en uno de los putti situados a la derecha de La Virgen ofreciendo el cíngulo a Santo Tomás.

Las obras se encuentran en un precario estado de conservación, seguramente debido a la humedad y a los cambios de lugar que han sufrido durante años (antes se encontraban en el Instituto Antonio Machado, en Soria). Parte de la capa pictórica se ha desprendido en las tres tablas; en la de la Natividad y la Epifanía la madera se ha combado, haciendo visibles las tablas que constituyen el soporte de las pinturas. $L a$ Virgen ofreciendo el cíngulo a Santo Tomás es un poco más grande que las otras dos tablas.

En todas se hace también uso de los grabados. La Natividad (fig. 87), por ejemplo, se inspira en el fondo de la estampa de Durero, El retorno del Hijo Pródigo ${ }^{355}$ (fig. 88) ${ }^{356}$, copiando literalmente las siluetas de las casas con tejado a dos aguas que se observan al fondo, los montones de heno y la rueda (fig. 89).

\footnotetext{
${ }^{350}$ SEBASTIÁN, S., “Renacimiento...”, p. 240.

351 ÁVILA PADRÓN, A., “Juan Soreda y no Juan Pereda...”, p. 415.

352 Ídem, p. 413.

${ }^{353}$ TARACENA Y AGUIRRE, B. y TUDELA DE LA ORDEN, J., op. cit., p. 100

${ }^{354}$ ANGULO IÑÍGUEZ, D., op. cit., p. 189.

355 ÁVILA PADRÓN, A., “Juan Soreda y no Juan Pereda...”, p. 415.

${ }^{356}$ Estampa disponible en:

http://www.britishmuseum.org/research/collection_online/collection_object_details.aspx?objectId=76467 0 \&partId=1\&images $=$ true \&people $=127877 \&$ from $=$ ad $\&$ fromDate $=1496 \&$ page $=1$

BARTSCH, A., op. cit., vol. VII, p. 49; DODGSON, C., Albrecht Dürer, The Medici Society, 1926, $\mathrm{n}^{\circ}$ 10, p. 13; MEDER, J., op. cit., n 28, p. 80; SCHOCH, R., op. cit., vol. I, no 9, pp. 45-47.
} 


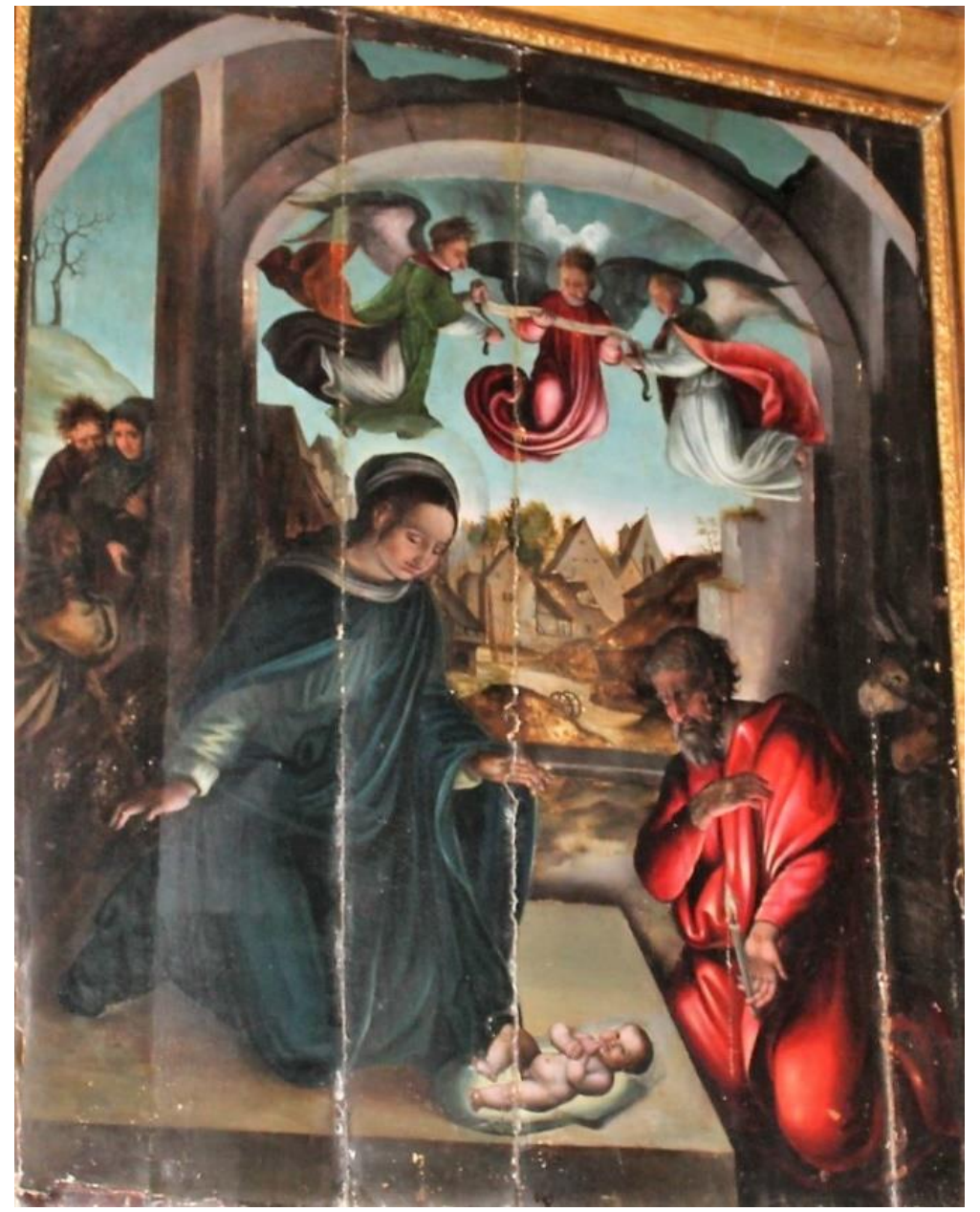

87. Juan Soreda. Natividad. 1524-1526. Monasterio de Santa María de Huerta (Soria).

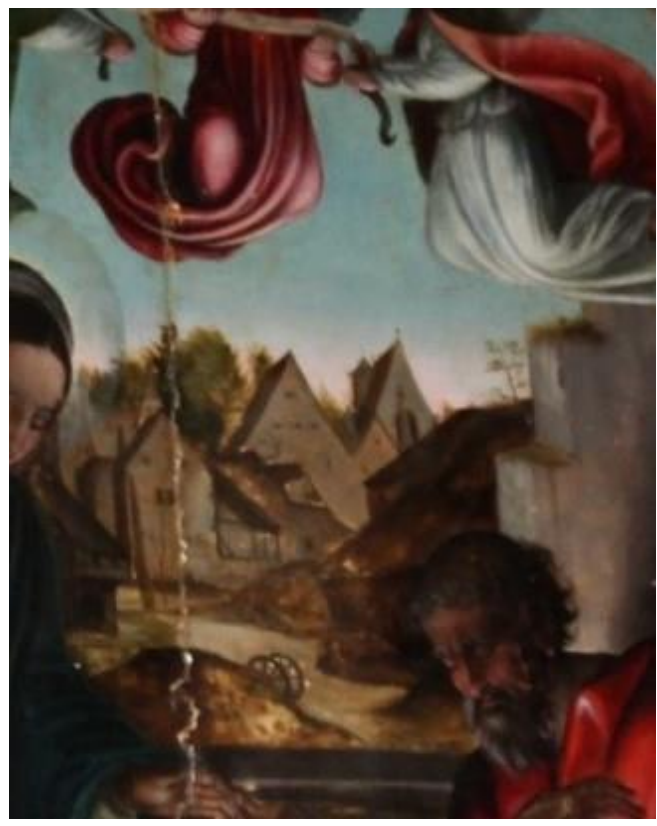

88. Detalle de fig. 88 .

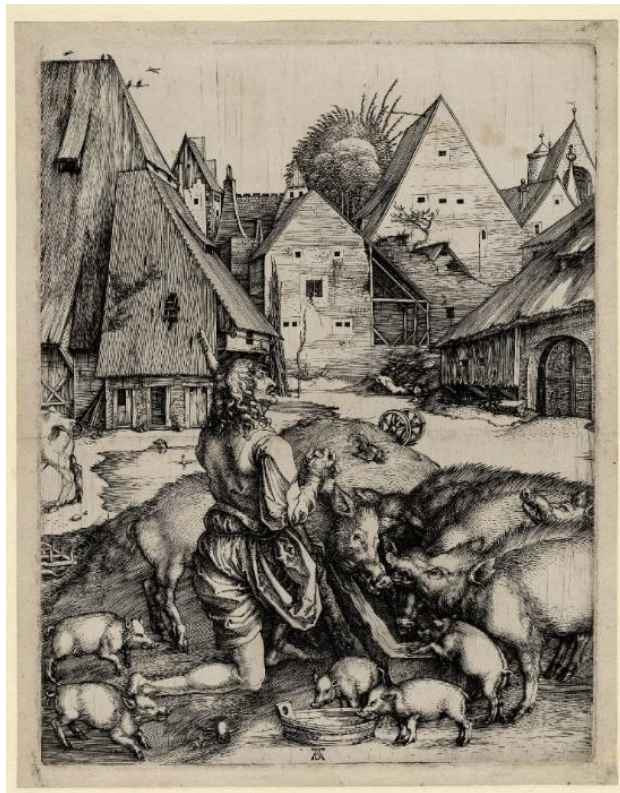

89. Alberto Durero. El retorno del Hijo Pródigo. Ca. 1496. Museo Británico (Reino Unido). 


\section{Adoración de los Magos}

En la Adoración de los Magos (fig. 90), Soreda copió las figuras de la Sagrada Familia, de los reyes Magos y del sirviente situado a la derecha de la composición ${ }^{357}$ de la estampa de Lucas de Leyden (fig. 91) ${ }^{358}$ del mismo tema. Soreda ha simplificado y reducido el canon de las figuras, conservando las posturas y los gestos. La silueta de la Virgen con el Niño que parece querer saltar de sus brazos es similar. Los rostros, tanto de los reyes magos como de la Virgen y el Niño, son distintos a los de la estampa de van Leyden. Hay cierta dureza en las caras el grabado alemán que se ha dulcificado en la pintura. Sin embargo, los ropajes ampulosos y los gestos y actitudes solemnes son bastante parecidos.

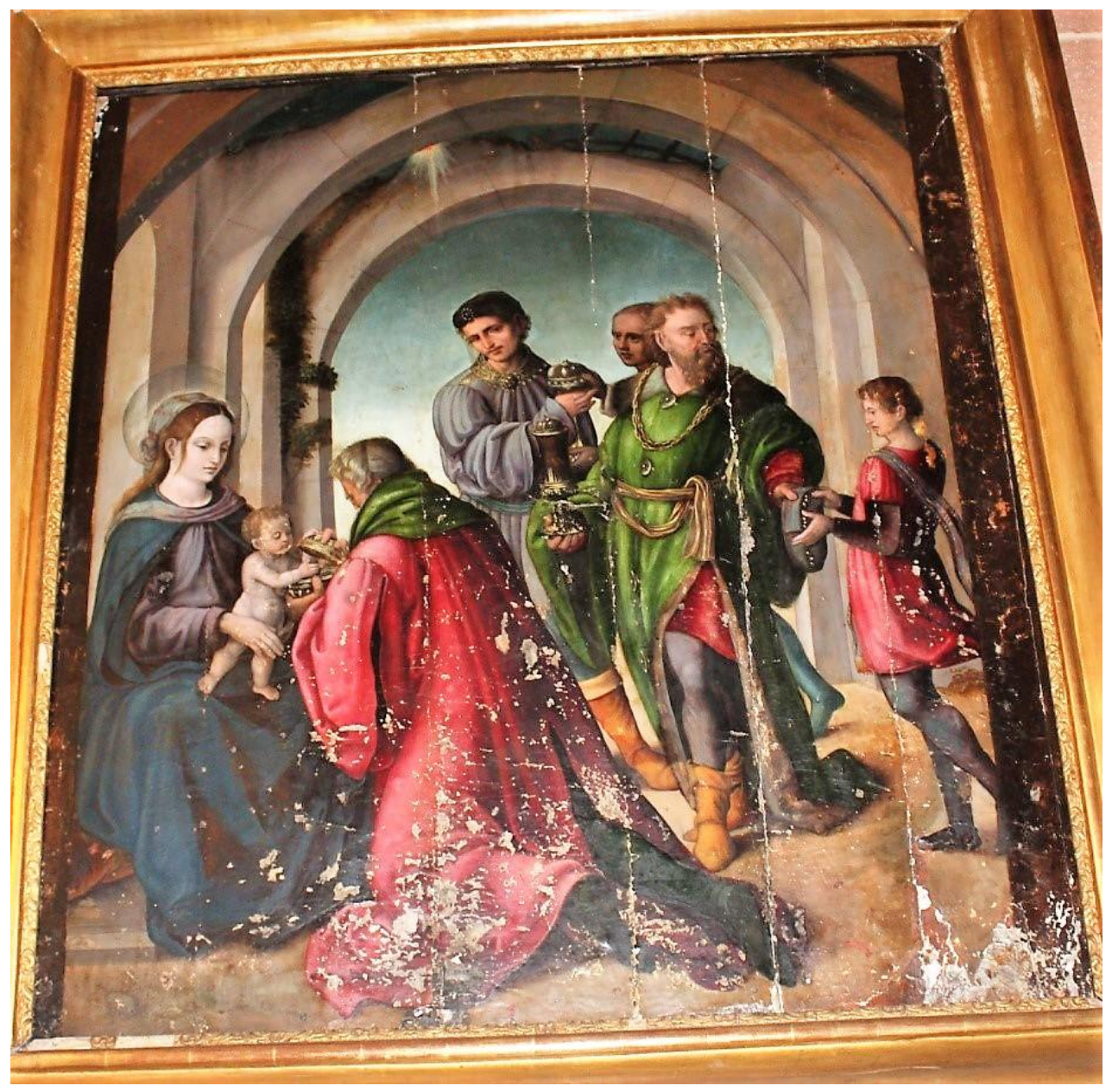

90. Juan Soreda. Adoración de los Magos. 1524-1526.

Monasterio de Santa María de Huerta (Soria).

${ }^{357}$ ÁVILA PADRÓN, A., “Juan Soreda y no Juan Pereda...”, p. 415.

358 Estampa disponible en: VV. AA., The Illustrated Bartsch, vol. 12, Hans Baldung Grien, Hans Springinklee, Lucas Van Leyden, Nueva York, Abaris Books, 1981, p. 169.

BARTSCH, A., op. cit., vol. VII, p. 357; HOLLSTEIN, F. W. H., The New Hollstein..., Lucas van Leyden, no 37 I, pp. 64-65. 


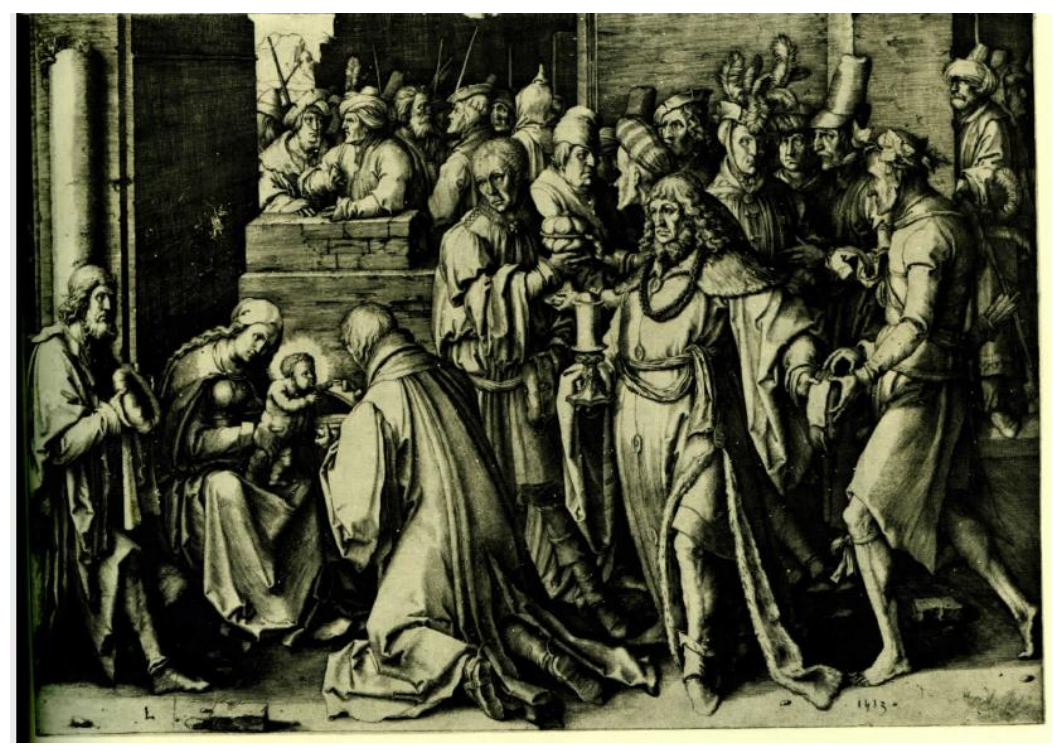

91. Lucas de Leyden. Adoración de los Magos. 1513. Cleveland. Museum of Art.

\section{Santo Tomás recibiendo el cíngulo de la Virgen}

Se trata de un tema muy poco representado dentro de la pintura española (fig. 92). Destaca especialmente el rostro de la Virgen, de una belleza italianizante muy propia de Leonardo, con ese sfumato y una media sonrisa enigmática. Este rostro remite a la Virgen de las Rocas y es extraño que no aparezca en ninguna otra obra de Soreda. En cambio, los rostros más duros de los ángeles evocan los de Pedro de la Fuente ${ }^{359}$.

Es una iconografía de origen italiano, concretamente toscano, para la cual Soreda probablemente se inspiró en el mismo tema del grabador florentino Francesco Rosselli (fig. 93) ${ }^{360}$, sobre todo en cuanto a la figura de la Virgen María, que sujeta el cíngulo con su derecha y se lo tiende a Santo Tomás con la izquierda. En la esquina inferior derecha aparece igualmente la figura de Santo Tomás con las manos alzadas.

El centro devocional de esta iconografía se encontraba en Prato, en la Toscana, y de hecho el tema ha sido tratado básicamente en el ámbito toscano donde se conserva la reliquia y se celebra una gran fiesta el domingo de Resurrección ${ }^{361}$. El cinturón sería un símbolo de la estrecha relación mística entre la Virgen y los Apóstoles. Por otro lado, se

\footnotetext{
359 ÁVILA PADRÓN, A., "Juan Soreda y no Juan Pereda...”, p. 415

${ }^{360}$ Estampa disponible en:

http://www.britishmuseum.org/research/collection_online/collection_object_details.aspx?objectId=76012 6\&partId=1\&searchText=francesco+rosselli\&images $=$ on\&page $=1$

BARTSCH, A., op. cit., vol. XIII, p. 262; STRAUSS, W., op. cit., vol. 24, p. 2404; HIND, A. M., Early Italian engraving..., vol. I., bI, $\mathrm{n}^{\mathrm{o}} 14, \mathrm{p} .126$.

${ }^{361}$ REAU, L., op. cit., pp. 640-641.
} 
ideó con el fin de que formara pareja con el tema de la Aparición de Cristo resucitado a Santo Tomás. En este caso, la Virgen, aparte de aparecer rodeada por los seis ángeles de aspecto muy rafaelesco, con rostros de carrillos hinchados, está acompañada por otros tres pequeños ángeles de color rojo, tres serafines.

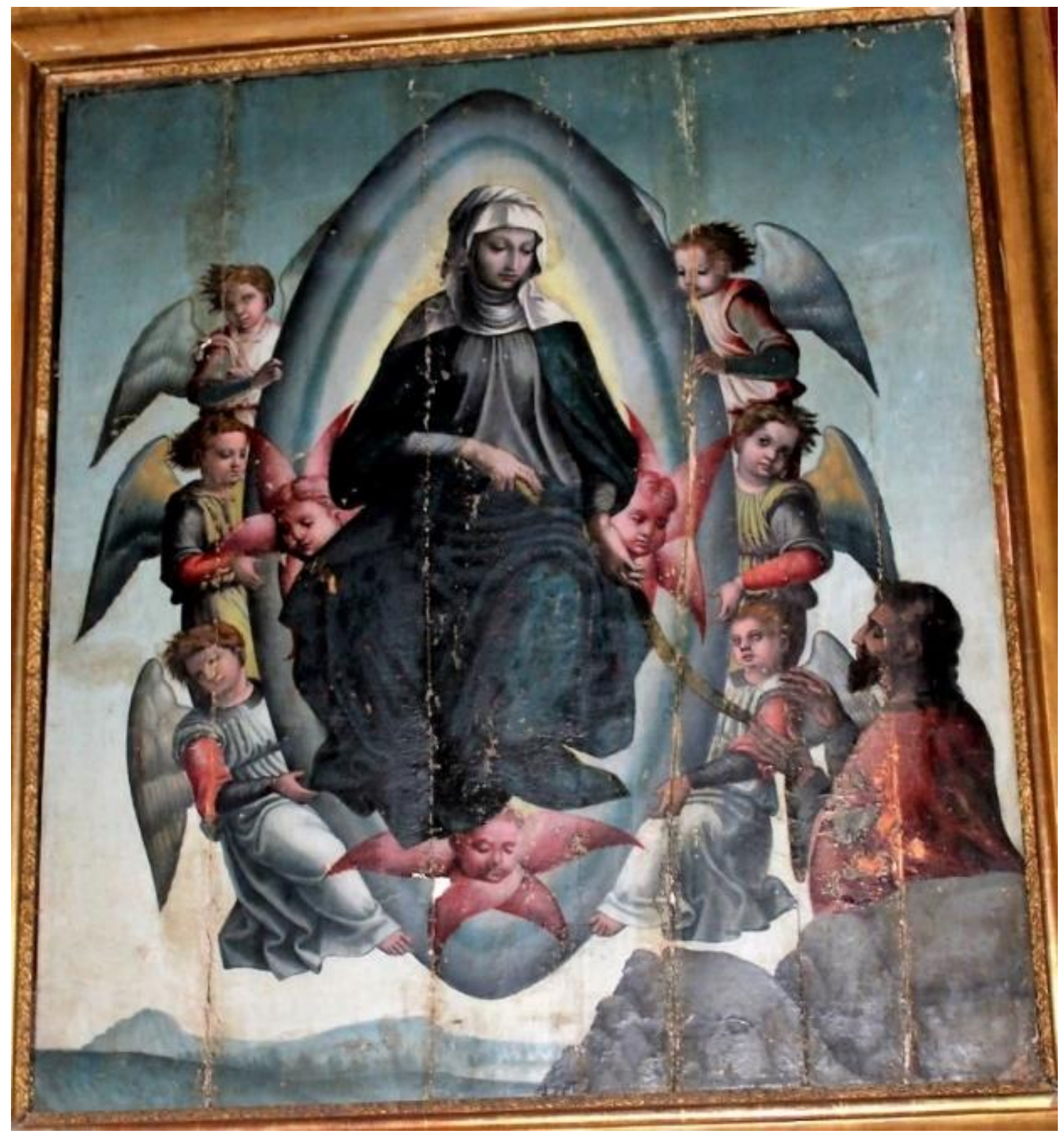

92. Juan Soreda. Santo Tomás recibiendo el cíngulo de la Virgen. 1524-1526. Monasterio de Santa María de Huerta (Soria). 


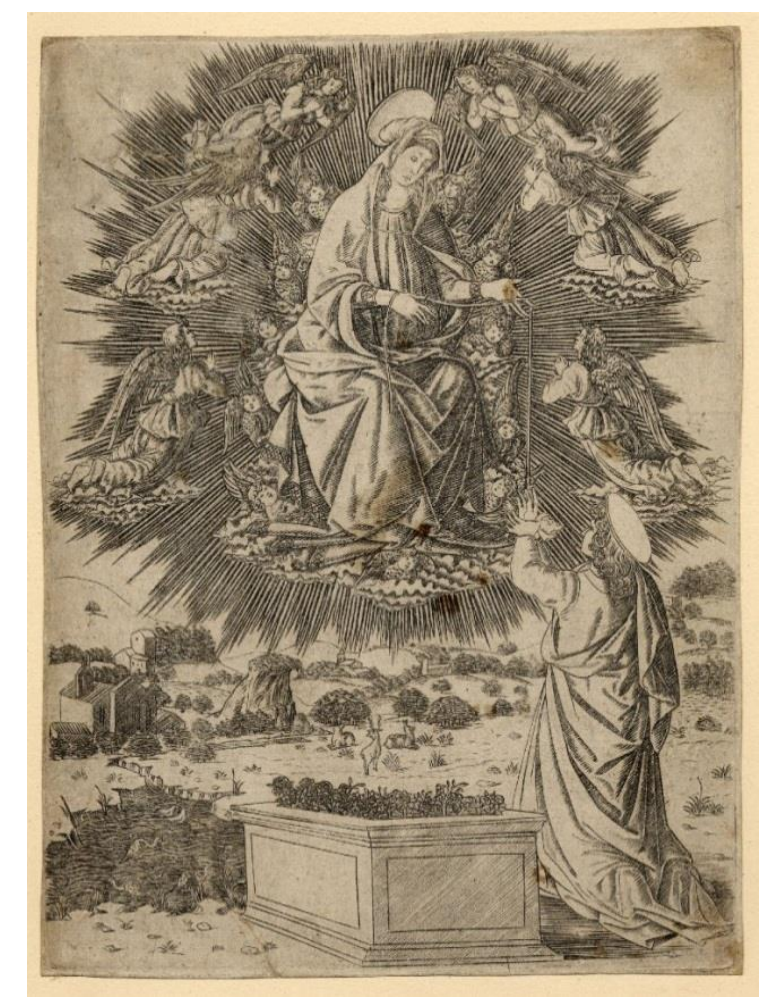

93. Francesco Rosselli. Asunción de la Virgen. 1495-1500. Museo Británico. Londres (Reino Unido).

\section{Pedro de Aponte \\ Retablo mayor \\ 1523 \\ Iglesia de San Miguel Ágreda (Soria)}

El 5 de junio de 1523, en Tarazona, Pedro de Aponte contrató la pintura y estofado de esta obra que se conserva en la capilla mayor de la iglesia de San Miguel de Ágreda $^{362}$. El retablo está formado por trece pinturas al óleo sobre tabla (fig. 94), que representan tanto escenas de la Pasión de Cristo (Oración en el Huerto, Camino del Calvario, Crucifixión) como vinculadas a la vida de San Miguel. La escultura de San Miguel, al que se le dedica el retablo, ocupa el hueco central del segundo cuerpo. La parte superior, de derecha a izquierda, comienza por escenas de la vida de San Miguel:

362 ANGULO IÑíGUEZ, D., op. cit., pp. 73-75; TARACENA Y AGUIRRE, B. y TUDELA DE LA ORDEN, J., op. cit., pp. 255-256; ALCOLEA BLANCH, S., op. cit., p. 90; POST, Ch. R., op. cit., t. XIII, p. 79; PEÑA GARCÍA, M., Historia y arte...., p. 42; MORTE GARCÍA, C., "La personalidad artística..." p. 219; "Huella de Durero...", pp. 55-63; Aportaciones al estudio de la pintura de Aragón..., p. 241, 729-730; La pintura aragonesa del Renacimiento..., p. 285; "La obra del pintor Pedro de Aponte...", p. 565. Aragón y la pintura del Renacimiento..., pp. 66-78. "Las artes figurativas del Renacimiento aragonés...", pp. 33-72; "Pedro de Aponte en Bolea y una noticia de la Calahorra (Granada)", pp. 95-122, "Los artistas de Aragón y sus proyectos en el Renacimiento...”, pp. 54-79; ORTEGO FRÍAS, T., op. cit., pp. 105-107; GAETA, L., Juan de Borgoña e gli altri: relazioni.., p. 81. 
Batalla de los Ángeles, San Miguel presentando a los salvados al Todopoderoso, Expulsión del Paraíso, San Miguel y la mujer de Tombelaine, El Arcángel defendiendo el cuerpo de Moisés, Gargano herido por la flecha envenenada, Procesión al Monte Gargano, y Aparición de San Miguel sobre el castillo de Roma. En el cuerpo inferior aparecen las escenas de la Pasión de Cristo: la Oración del Huerto, la Flagelación, el Camino del Calvario y la Piedad.

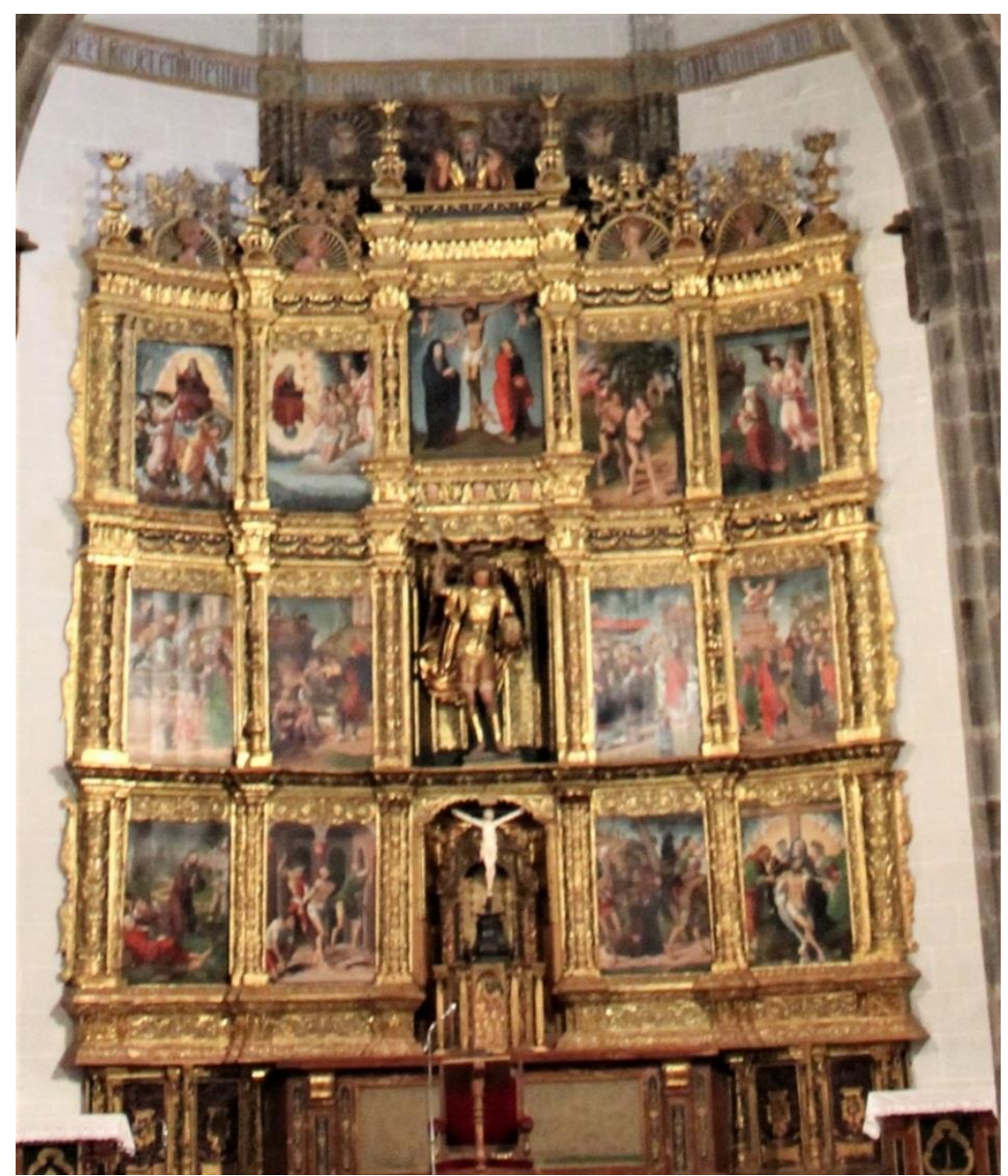

93. Pedro de Aponte. Ca. 1523. Retablo mayor de la iglesia de San Miguel. Ágreda.(Soria)

Sabemos con certeza que Pedro de Aponte utilizó algunas estampas para las composiciones porque Carmen Morte lo confirma en muchos de sus textos. Entre ellas una que representaba la Expulsión del Paraíso de Adán y Eva de Marcantonio Raimondi $^{363}$, que se inspira en el mismo tema pintado por Miguel Ángel en la capilla Sixtina (fig. 95).

\footnotetext{
${ }^{363}$ Estampa disponible en:

http://www.britishmuseum.org/research/collection_online/collection_object_details.aspx?objectId=14175 $\underline{23 \& \text { partId=1\&searchText=adam+eve \&images }=\text { true \&people=115934\&page }=1}$
} 
Esta misma estampa la utilizó De Aponte para crear una de las escenas del retablo (fig. 94) ${ }^{364}$, copiando las posturas y gestos de Adán y Eva de manera literal, aunque cubriendo sus vergüenzas con una hojas de parra, y cambiando un poco sus peinados y la forma de sus cuerpos, que no son tan musculosos como los pintados por Miguel Ángel.

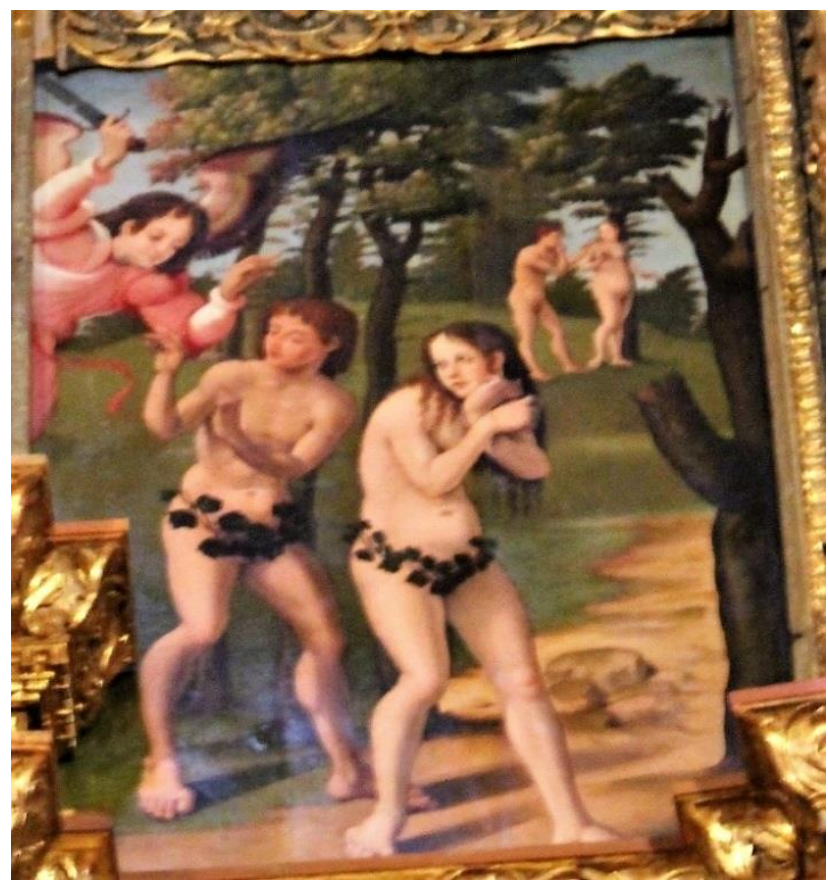

94. Pedro de Aponte. Expulsión del Paraíso. Ca. 1523. Retablo mayor de la iglesia de San Miguel. Ágreda (Soria).

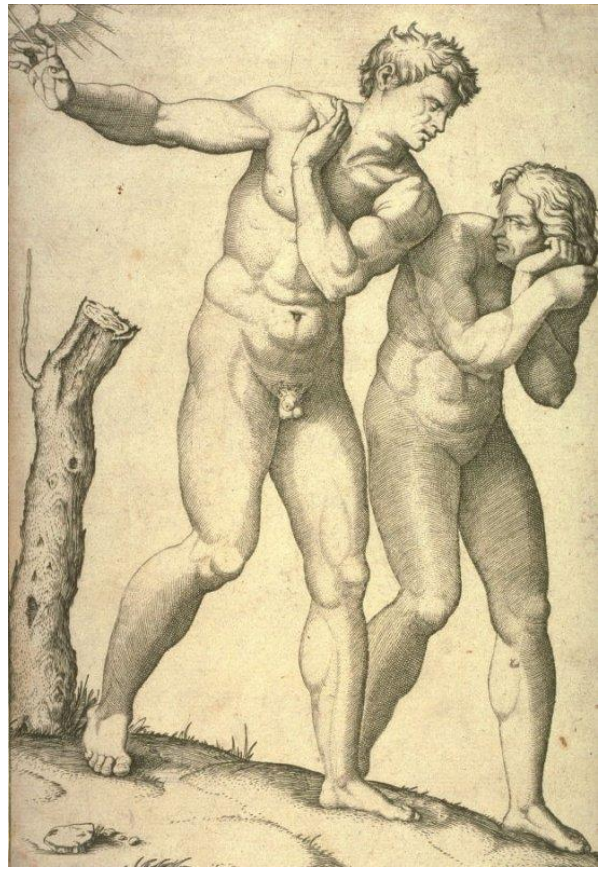

95. Marcantonio Raimondi, a partir de Miguel Ángel.

Expulsión del Paraíso. 1510-1527.

Museo Británico. Londres (Reino Unido)

En esta escena plasmó en primer plano el tema de la Expulsión, mientras que en el fondo observamos el momento previo, el del Pecado Original o La tentación de Eva que se ve al fondo, entre una masa arbolada, con las figuras desnudas de los padres de la Humanidad, en el momento justo en que el Diablo disfrazado de serpiente tienta a Eva a través de la manzana. En la escena principal Adán y Eva huyen del ángel, que sigue el mismo modelo del resto de ángeles retratados por Aponte: cabellos rizados, túnica rosada y carácter italianizante. Es interesante destacar el uso del desnudo, poco utilizado en la pintura española de la época, que demuestra la influencia italiana en todo el conjunto. También son importantes la monumentalidad de las figuras y el interés por el estudio anatómico, características procedentes de la pintura del Renacimiento italiano.

BARTSCH, A., op. cit., vol. XIV, p. 4; DELABORDE, H., op. cit., nº 2, p. 88.

${ }^{364}$ VV.AA., El retablo de San Miguel (Ágreda)..., p. 100. 


\section{Crucifixión}

Para la pintura de la Crucifixión (fig. 96) representada en el mismo retablo es muy probable que De Aponte utilizara la estampa del mismo tema de Alberto Durero (fig. 97 $)^{365}$. Las figuras de la Virgen y San Juan son idénticas, aunque en éste último Aponte ha invertido la postura de los brazos, colocados hacia la derecha en vez de hacia la izquierda. Además ha añadido las figuras de cuatro serafines de alas rosadas, que con pequeñas copas recogen la sangre de las heridas de Cristo y que dotan al conjunto de cierta ternura; sin embargo, no incluye la calavera de Adán, que simbolizaría el Pecado Original, ni las figuras de soldados romanos que se observan al fondo de la estampa. Aponte ha simplificado, dulcificado las figuras.

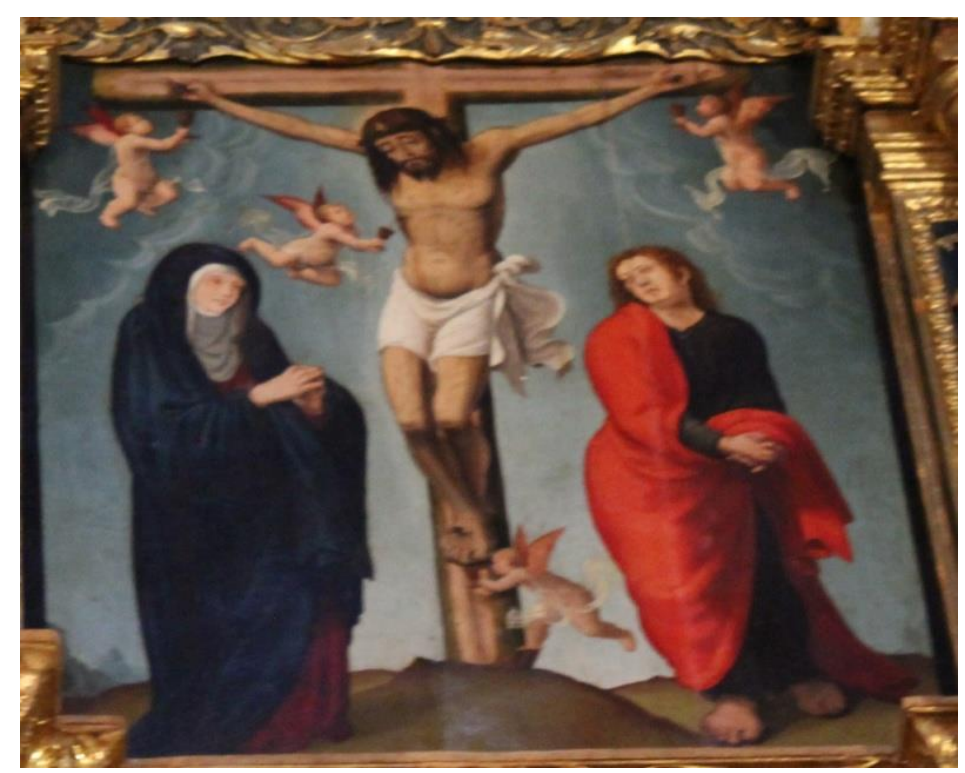

96. Pedro de Aponte. Crucifixión. Ca. 1523. Retablo de San Miguel. Ágreda (Soria).

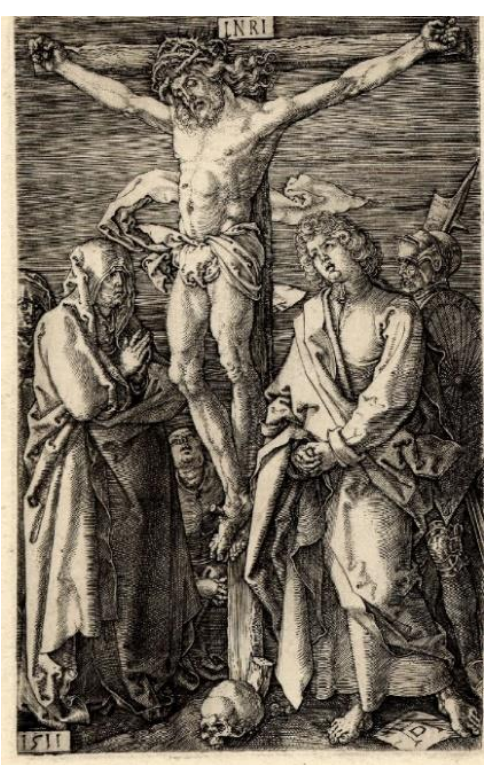

97. Alberto Durero, Crucifixión. 1511. Museo Británico. Londres (Reino Unido)

San Miguel expulsando a los demonios del paraíso

En la escena de San Miguel expulsando a los demonios del Paraíso (fig. 98) el pintor usó la estampa de Durero del mismo tema (fig. 99) ${ }^{366}$ para la figura de uno de los

\footnotetext{
${ }^{365}$ Estampa disponible en:

http://www.britishmuseum.org/research/collection_online/collection_object_details.aspx?objectId=13508 80\&partId=1\&searchText $=$ crucifixion\&images $=$ true \&people $=127877 \&$ page $=1$

BARTSCH, A., op. cit., vol. VII, p. 37; DODGSON, C., Albrecht Dürer..., nº 53, p. 71; MEDER, J., op. cit., n' 13, p. 73; SCHOCH, R., op. cit., vol. I, n 55, pp. 143-144.

${ }^{366}$ Estampa disponible en:

https://www.metmuseum.org/art/collection/search/368340 HOLLSTEIN, F. W. H., German engravings, etchings and woodcuts..., Albrecht and Hans Durer, vol. VII, $\mathrm{n}^{\mathrm{o}}$ 174; SCHOCH, R., op. cit., vol. II, p. $141, \mathrm{n}^{\circ} 122$, pp. 94-96.
} 
ángeles ${ }^{367}$; en concreto, el vestido con una túnica rosada que blande una lanza con las dos manos en actitud de ataque. También el ángel situado a la derecha, que porta un escudo y una espada parece inspirado en la estampa.

Aponte repitió aquí la italianización de modelos nórdicos que caracteriza a muchas otras figuras angélicas del retablo. Este es un recurso ya utilizado por el escultor Damián Forment ${ }^{368}$. En cuanto a la gama cromática, destacan los tonos intensos de la túnica roja de Dios Padre, así como la vestimenta rosa pálido y amarillo intenso de los ángeles.

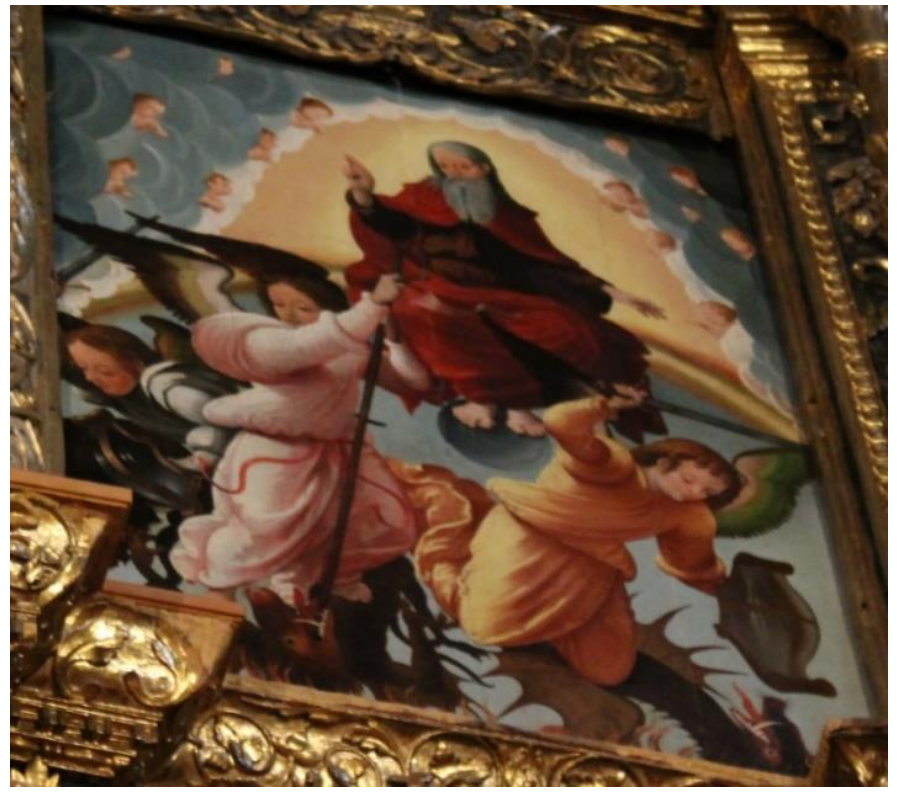

98. Pedro de Aponte. Expulsión de los demonios. Ca. 1523. Retablo de San Miguel. Ágreda (Soria).

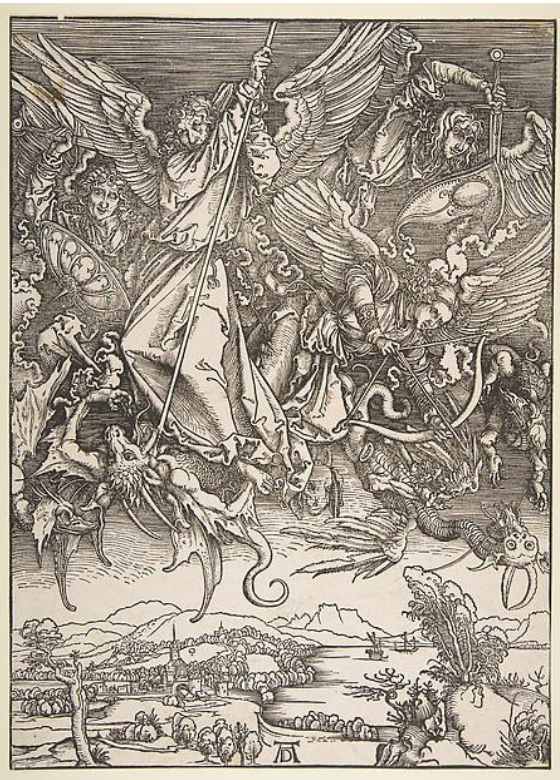

99. Alberto Durero.

San Miguel luchando con el dragón. 1511. Metropolitan Museum. Nueva York (Estados Unidos).

\section{La aparición sobre el Monte Gargano}

La escena narra un episodio de la vida de Gargano que es poco habitual en las representaciones pictóricas (fig. 100). Este era un propietario de ganado que vivía en la ciudad italiana de Siponto. Un día, uno de sus toros se descarrió del grupo, y acabó llegando a la entrada de una cueva. Gargano hizo que un arquero disparara una flecha en dirección al toro pero, ante su sorpresa, la flecha cambió de dirección y acabó clavándose en el arquero. Esto, según la tradición, fue voluntad del arcángel San Miguel, por lo que allí se construyó un templo dedicado al Arcángel. Es un tema de representación muy habitual durante la Edad Media.

\footnotetext{
${ }^{367}$ VV. AA., El retablo de San Miguel (Ágreda)..., pp. 96-97.

${ }^{368}$ Ibídem. MORTE GARCÍA, C., Damián Forment, escultor..., pp. 47-50.
} 
Aponte adaptó la escena a la época del Renacimiento español, y algunos de sus personajes, como el arquero, muestran la vestimenta típica de ese periodo. Consiste en el sayo de color rojo fuerte y sin mangas, el jubón acuchillado, el capuz doblado, la gorra roja y los zapatos picados ${ }^{369}$.

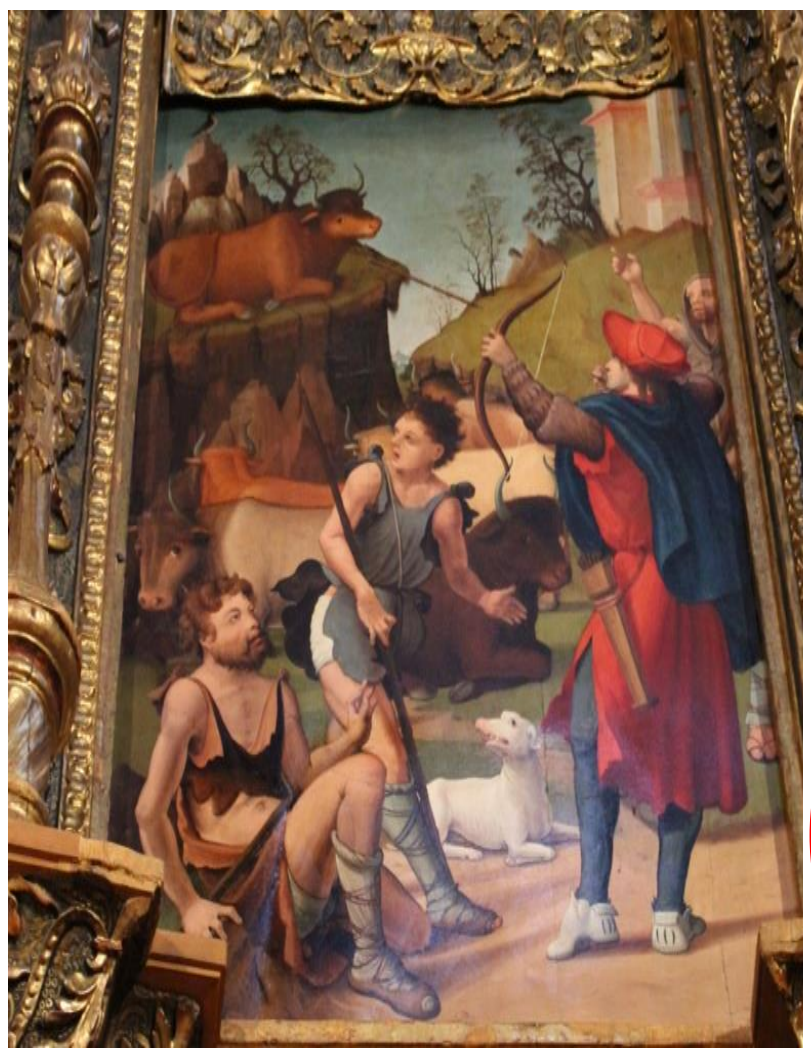

100. Pedro de Aponte. Milagro del Monte Gargano. Ca. 1523. Retablo de la iglesia de San Miguel. Ágreda (Soria9)

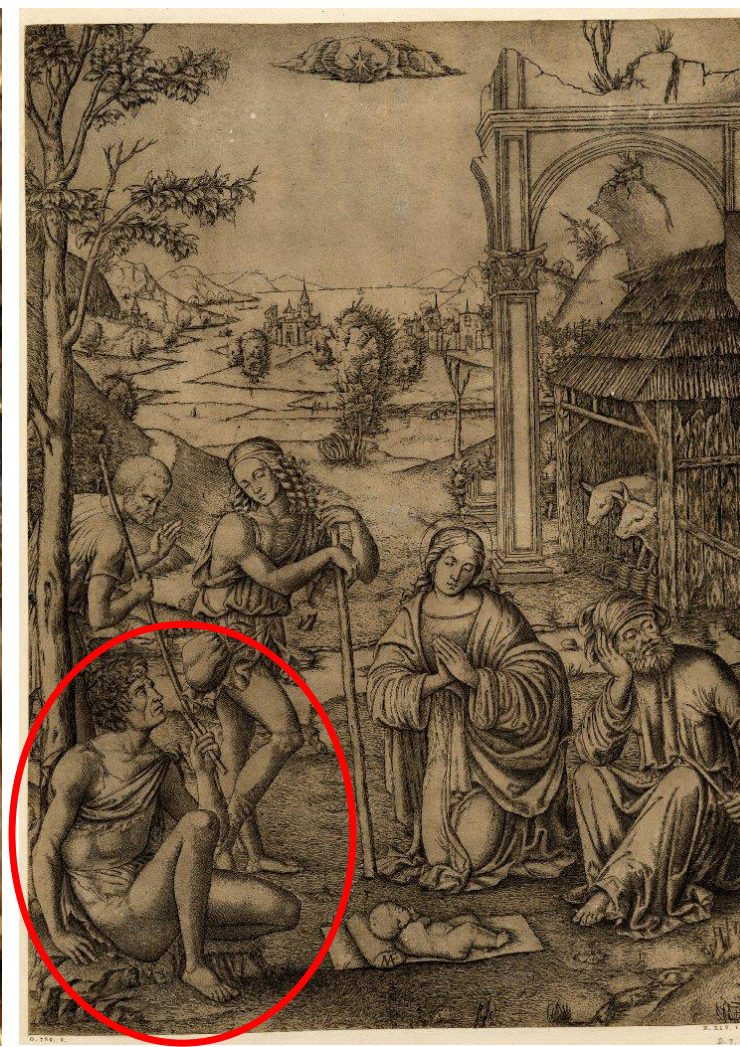

101. Marcantonio Raimondi. Adoración de los pastores. 1502-1506. Museo Británico. Londres

Para la escena de La Aparición sobre el Monte Gargano y el milagro del toro, Aponte se basó en una de las figuras laterales de la estampa de Raimondi ${ }^{370}$ de $L a$ Adoración de los pastores (fig. 101) ${ }^{371}$. Se trata de un pastor sentado en el suelo a la izquierda de la composición, del que Aponte copió la silueta, la vestimenta, el brazo derecho y la pierna derecha. El cabello, con pequeños rizos, es también similar. Sin embargo la mano y el brazo izquierdo son diversos; en la estampa el pastor sujeta una vara, mientras que en la pintura no sujeta nada y hace un gesto de sorpresa.

\footnotetext{
${ }^{369}$ VV. AA., El retablo de San Miguel (Ágreda)..., pp. 96-97.

${ }^{370}$ Estampa disponible en:

http://www.britishmuseum.org/research/collection_online/collection_object_details.aspx?objectId=14176 56\&partId=1\&searchText=adoration+of+the+shepherds\&images=true\&people $=115934 \&$ page $=1$ BARTSCH, A., op. cit., vol. XIV, p. 17; DELABORDE, H., op. cit., nº 7, p. 90.

${ }^{371}$ VV. AA., El retablo de San Miguel (Ágreda)..., pp. 88.
} 


\section{Lamentación ante el cuerpo de Cristo}

De Aponte ha utilizado en esta pintura (fig. 102) la estampa de Durero ${ }^{372}$ de la Trinidad (fig. 103) ${ }^{373}$, copiando la postura de las piernas y los pies de Cristo.

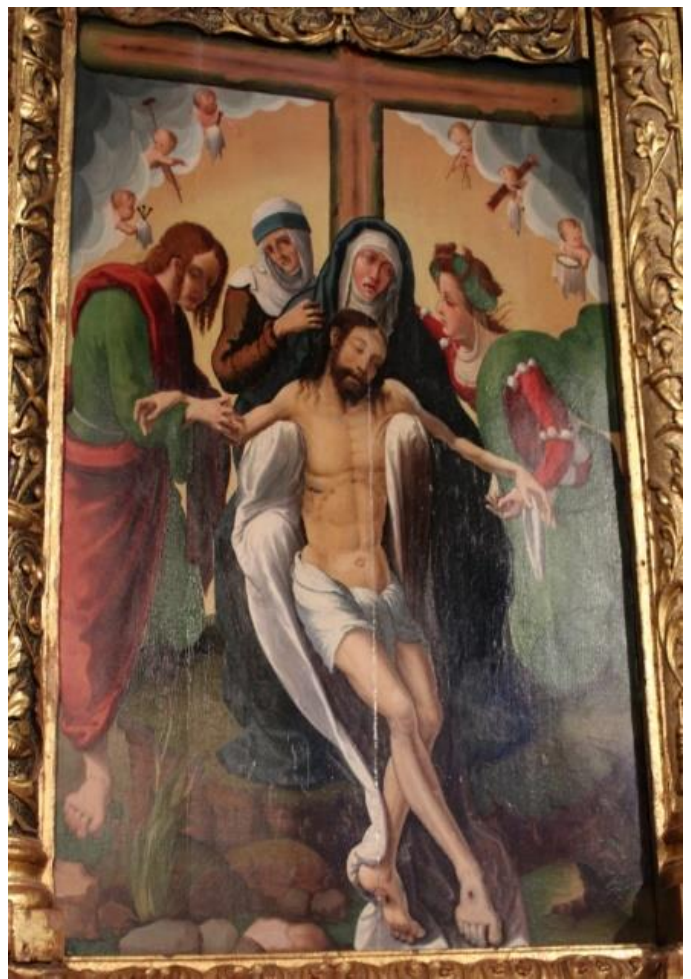

102. Pedro de Aponte. Lamentación ante el cuerpo de Cristo. Ca. 1523, Retablo de San Miguel. Iglesia de San Miguel. Ágreda (Soria).

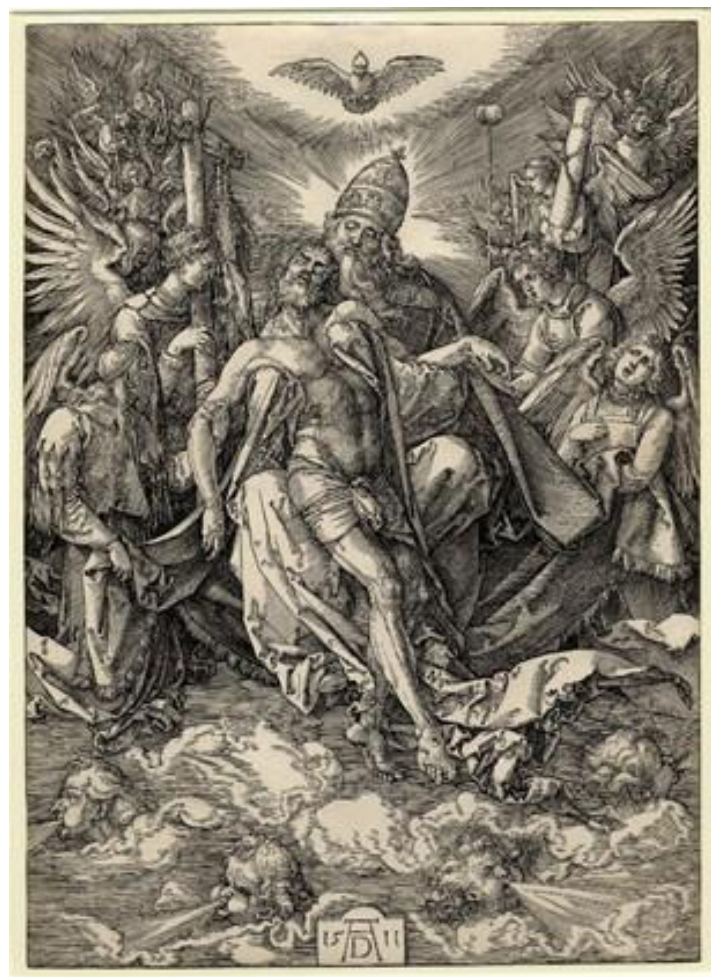

103. Alberto Durero. Trinidad. 1511. Biblioteca Nacional .Madrid.

La disposición del brazo izquierdo es también semejante, pero la del derecho es distinta: en la estampa el brazo y el antebrazo caen, mientras que en la pintura el brazo es sujetado por la joven situada a la derecha de la composición e identificada como María Magdalena. La forma en que el paño ciñe la cintura de Cristo y la caída de la tela sobre la que se coloca su cuerpo también son muy parecidas a la estampa, si bien en el segundo caso no se ha logrado captar en su totalidad la multiplicidad de los pliegues.

En la pintura Cristo aparece rodeado por las figuras de la Virgen, San Juan, María Magdalena y otra mujer situada detrás de la Virgen, mientras que en el grabado lo

\footnotetext{
${ }^{372}$ Estampa disponible en:

http://www.britishmuseum.org/research/collection_online/collection_object_details.aspx?objectId=13372 58\&partId $=1 \&$ searchText=trinity\&images $=$ true \&people $=127877 \&$ page $=1$

BARTSCH, A., op. cit., vol. VII, p. 141; MEDER, J., op. cit., nº 187, p. 165; DODGSON, C., Catalogue of Early German And Flemish ..., no 116, p. 303; SCHOCH, R., op. cit., vol. II, n 231, pp. 366-369.

${ }^{373}$ VV. AA., El retablo de San Miguel (Ágreda)..., p. 82.
} 
rodean ángeles, en un ámbito celestial repleto de nubes. Además, se añade la imagen de la cruz al fondo, tras la cabeza de la Virgen, así como seis pequeños angelitos entre algunas nubes. Tampoco los rostros son iguales, dado que en la estampa el de Cristo parece más inclinado hacia atrás y en la pintura hacia delante.

\section{Flagelación}

En la escena de la Flagelación (fig. 104) copió Aponte las piernas de Adán de la ya mencionada estampa de la Expulsión del Paraíso de Raimondii ${ }^{374}$, para las del sayón situado a la derecha de la composición (fig. 105) ${ }^{375}$. Para ambos sayones utilizó el modelo de la estampa de la Flagelación de Alberto Durero de 1512 (fig. 106) ${ }^{376}$. El sayón derecho levanta su brazo derecho para golpear a Cristo, mientras que el sayón izquierdo hace lo mismo desde el otro lado.

Para el fondo, Aponte creó un espacio arquitectónico estructurado en torno a una columna que actúa como eje simétrico de la composición. La columna separa visualmente las figuras de los dos sayones y los dos vanos del fondo. Dicho espacio está inspirado libremente en la estampa de Durero de la Flagelación ${ }^{377}$ (fig. 107), de la Pasión de la Albertina ${ }^{378}$. Los horribles rostros de los dos sayones, que muestran un interés por el realismo grotesco propio del arte nórdico, están posiblemente basados en tipos humanos de Schongauer ${ }^{379}$. Ambos blanden fustas de cuero, mientras que el personaje aparece agachado en la esquina inferior izquierda prepara un nuevo paquete de varas de sarmiento. Estos tipos humanos son utilizados por Aponte en otras obras, como los retablos navarros de Cintruénigo (fig. 108) ${ }^{380}$ y Olite (fig. 109) ${ }^{381}$.

\footnotetext{
${ }^{374}$ Estampa disponible en:

http://www.britishmuseum.org/research/collection_online/collection_object_details.aspx?objectId=14175 23\&partId=1\&searchText=adam+eve\&images $=$ true \&people $=115934 \&$ page $=1$

BARTSCH, A., op. cit., vol. XIV, p. 4; DELABORDE, H., op. cit., nº 2, p. 88.

${ }^{375}$ VV. AA., El retablo de San Miguel en Ágreda..., p. 78.

${ }^{376}$ Imagen procedente de STRAUSS, W. L., The Illustrated Bartsch, Sixteenth Century German Artists, vol. 10, Opal Publishing Corporation, Nueva York, 1980, p. 32.

BARTSCH, A., op. cit., vol. VII, p. 35; DODGSON, C., Albrecht Dürer, no 57, p. 75; MEDER, J., op. cit., $\mathrm{n}^{\circ} 8$, p. 72; SCHOCH, R., op. cit., vol. I, n ${ }^{\circ}$ 50, pp. 137-138.

${ }^{377}$ Estampa disponible en:

http://sammlungenonline.albertina.at/default.aspx?lng=english2\&query=record/objectpackage=[D\%C3\% BCrer,\%20Michelangelo,\%20Rubens\%20\%20\%20Meisterwerke\%20der\%20Albertina\%20(2014)]\&label $\equiv \% 20$ Objektgruppe\&sortfield=sort WP Meisterwerke\&sortlabel=Spezielle\%20Sortierung\#dc70fc96$8 \mathrm{~b} 92-477 \mathrm{e}-957 \mathrm{~d}-36 \mathrm{cc} 7 \mathrm{e} 670 \mathrm{~b} 49$

${ }^{378}$ MORTE GARCÍA, C., "La obra del pintor Pedro de Aponte...", p. 576.

${ }^{379}$ VV. AA., El retablo de San Miguel en Ágreda ..., p. 78.

${ }^{380}$ Imagen procedente de: NAVAL MAS, A., op. cit., p. 34

381 Ídem, p. 54.
} 


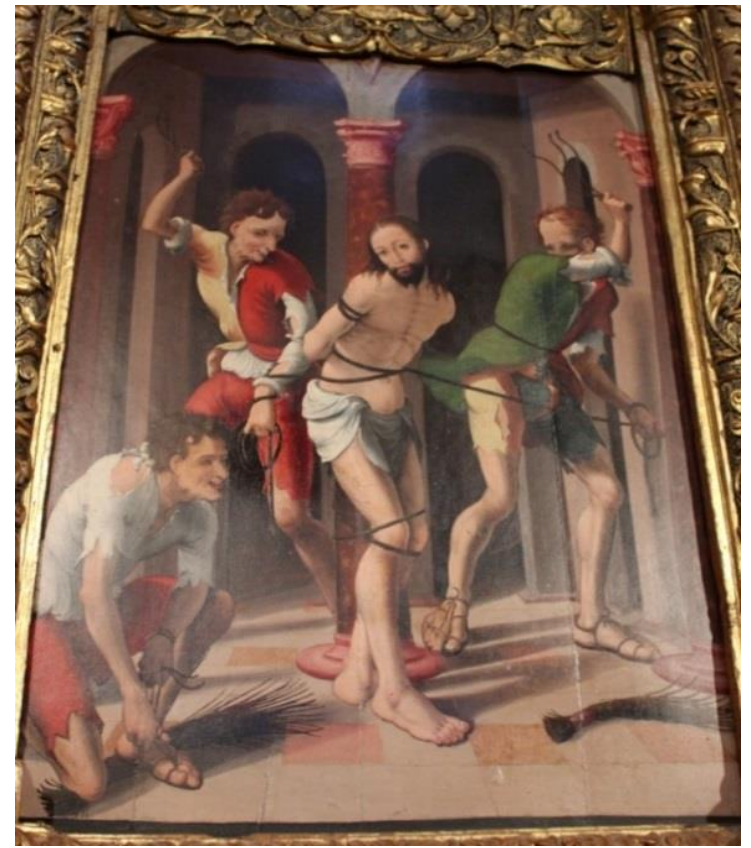

104. Pedro de Aponte. Flagelación. Ca 1523. Retablo de San Miguel. Iglesia de San Miguel. Ágreda (Soria).

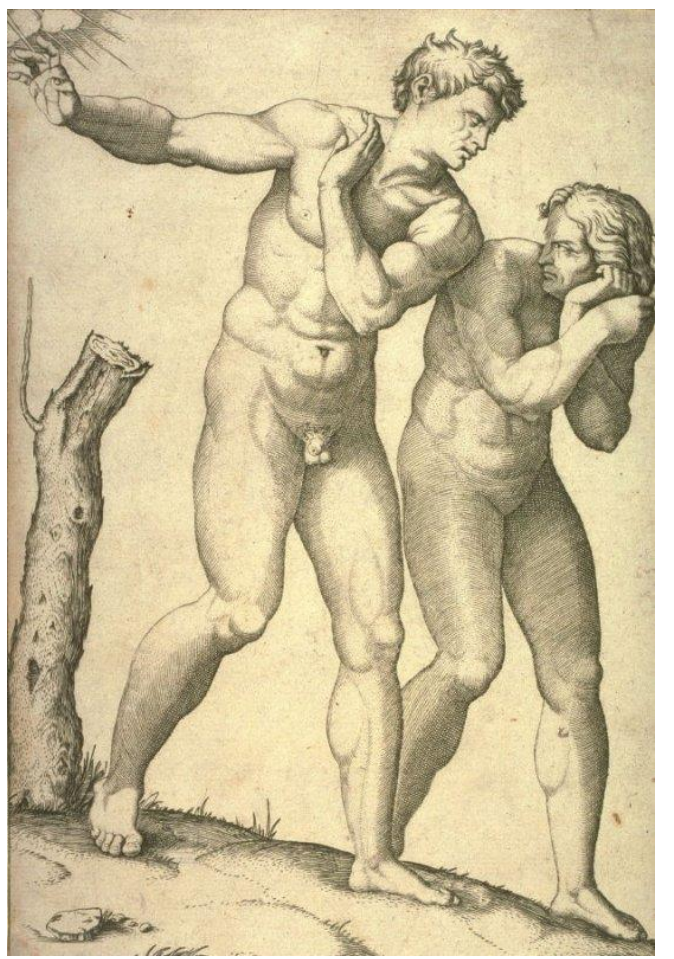

106. Marcantonio Raimondi. Expulsióndel Paraíso. A partir de Miguel Ángel.1510-1527.

Museo Británico. Londres (Reino Unido).

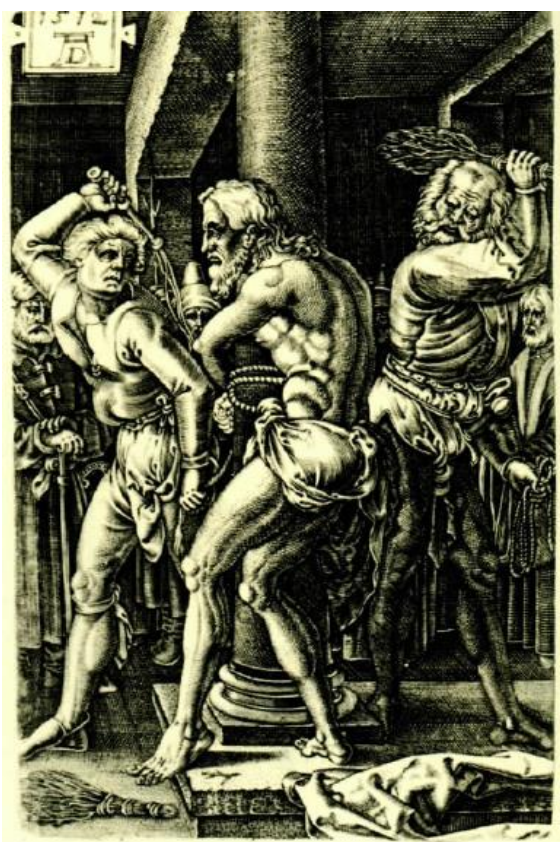

105. Alberto Durero. Flagelación. 1512. Munich (Alemania).

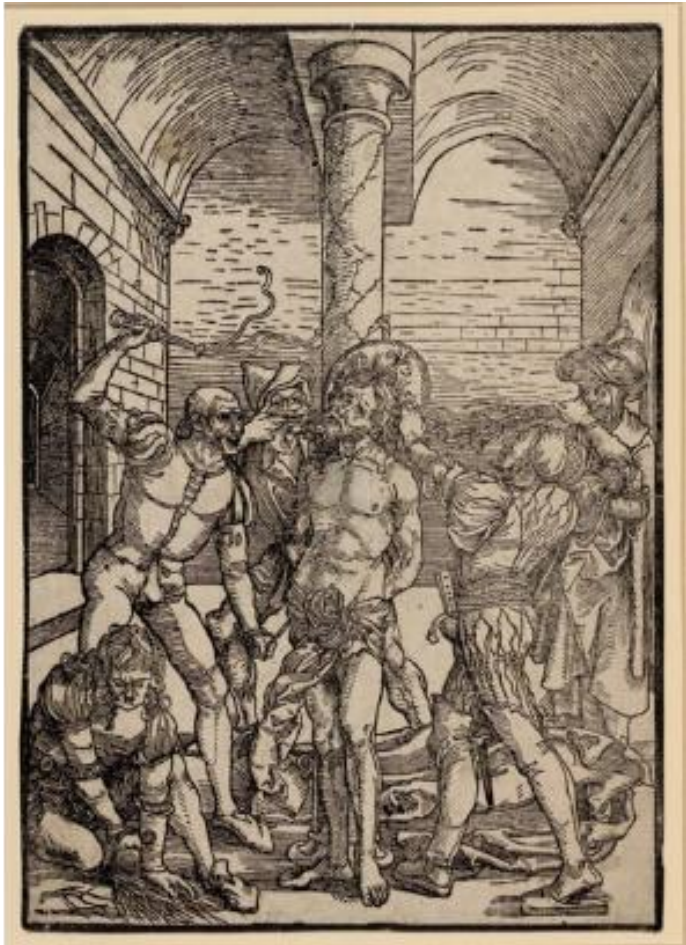

107. Alberto Durero. Flagelación. Pasión de la Albertina. 1500.

Museo Albertina Viena (Austria). 


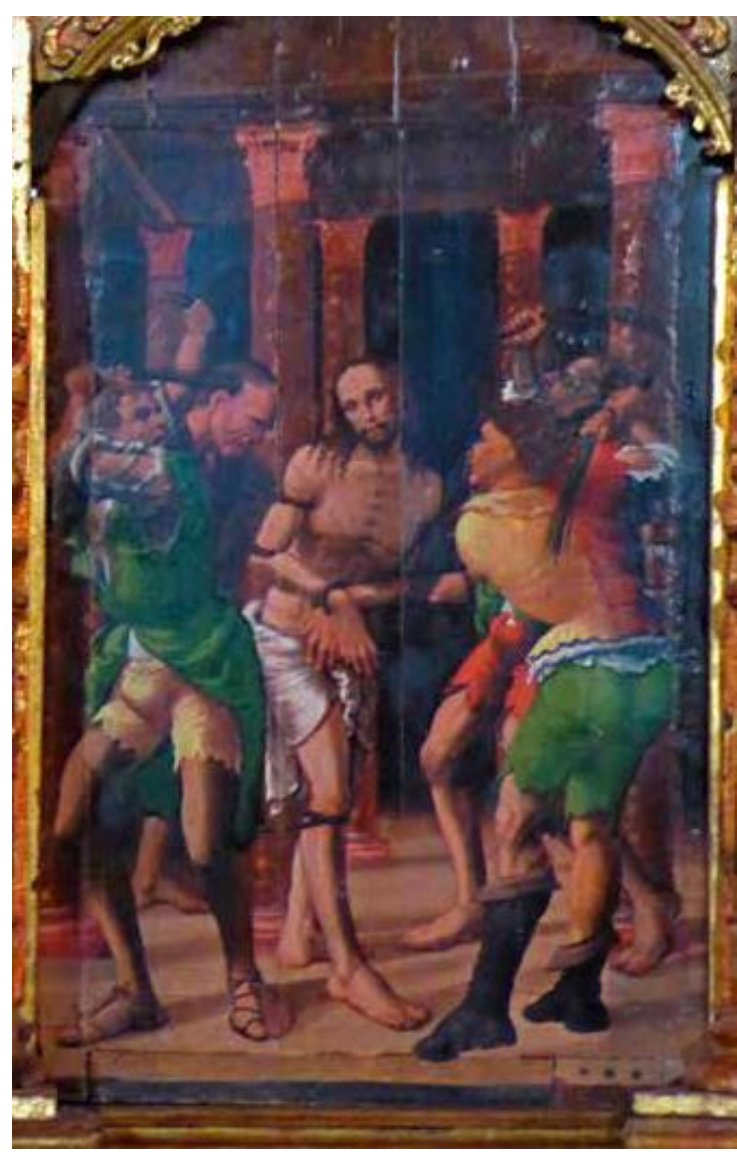

108. Pedro de Aponte. Flagelación. Ca. 1525. Retablo. Iglesia de San Juan Bautista. Cintruénigo (Navarra).

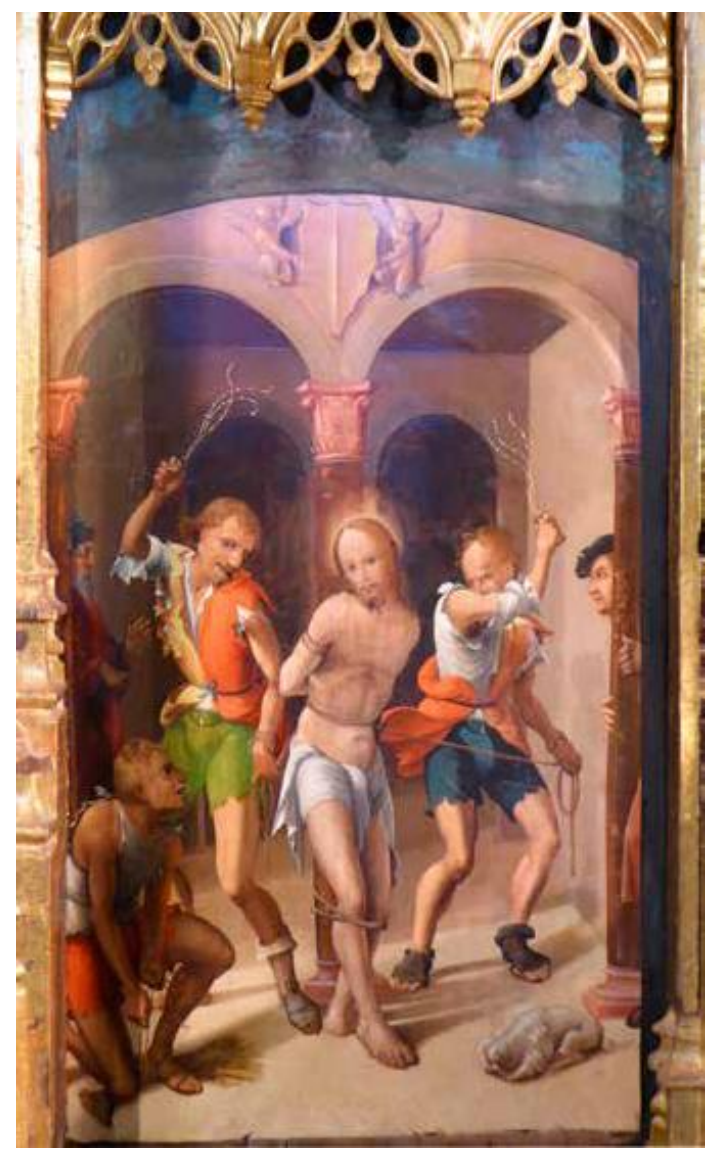

109. Pedro de Aponte. Flagelación. Ca. 1528. Retablo mayor. Iglesia de Santa María la Real. Olite (Navarra).

La escena muestra diferencias con la del retablo de Cintruénigo. En éste las posturas de los sayones son más forzadas y menos naturales que en el de Ágreda. La figura de Cristo es muy parecida, aunque muestra las manos atadas por delante en vez de por detrás. El retablo de Ágreda se parece más al de Olite; de hecho, sólo se diferencia en la gama cromática usada para las vestimentas de los sayones.

\section{Milagro en Mont Sant Michel}

La escena representa otra de las importantes apariciones del arcángel (fig. 110). $\mathrm{Su}$ origen está en la orden que San Miguel dio al obispo de Abranches para que construyera una iglesia en su honor en un lugar llamado Tumba, junto al mar. El día de su festividad ocurrió un milagro: las aguas que normalmente se alejaban de la tierra para permitir el paso de los fieles regresaron de pronto. La mayoría de los fieles pudieron ponerse a salvo, excepto una mujer embarazada, a quien San Miguel protegió, facilitandole que diera a luz bajo el agua. Hasta que las aguas se alejaron permaneció 
amamantando al niño, protegida por San Miguel. Este es el origen del importante culto que San Miguel recibiría en toda Francia, partiendo de Normandía.

En la escena predominan los tonos intensos de las vestimentas de la mujer (el rojo, el verde y un blanco saturados), mientras que el ángel luce una túnica de color rosa pálido. Las figuras se recortan sobre el fondo en el que destacan la imagen del santuario, con altas torres que se elevan sobre un promontorio rocoso con algunos árboles situados a la izquierda, el fondo marino y celeste de tonos azul pastel, en el que se observan algunos barcos y cisnes, se sitúa a la derecha.

Destacan la expresividad y la falta de idealización de la figura femenina, más cercana a los modos expresivos flamencos en cuanto a rostro y vestimenta. Tanto ella como el niño parecen formar parte más de una escena cotidiana de interior que de una escena milagrosa. En cambio el ángel procede de una influencia italiana, a juzgar por su dulce rostro y sus vestimentas vaporosas. Esta misma figura del arcángel la utiliza Aponte para otras composiciones, como la ya citada San Miguel expulsa de la gloria al dragón y los demonios o La expulsión de Adán y Eva del Paraíso.

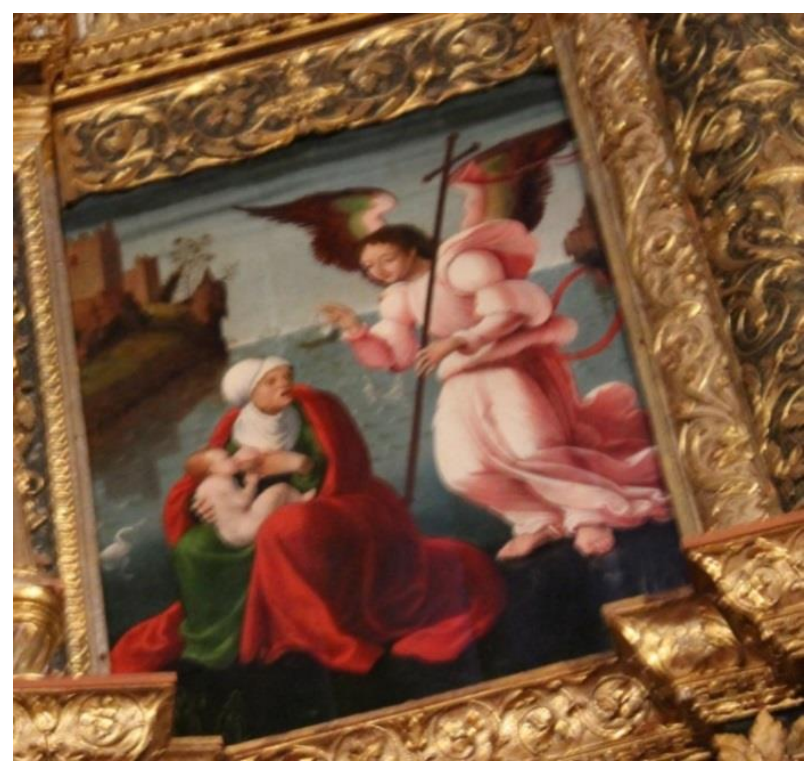

110. Pedro de Aponte. Aparición de San Miguel a una mujer. 1523. Retablo de la iglesia de San Miguel Ágreda (Soria).

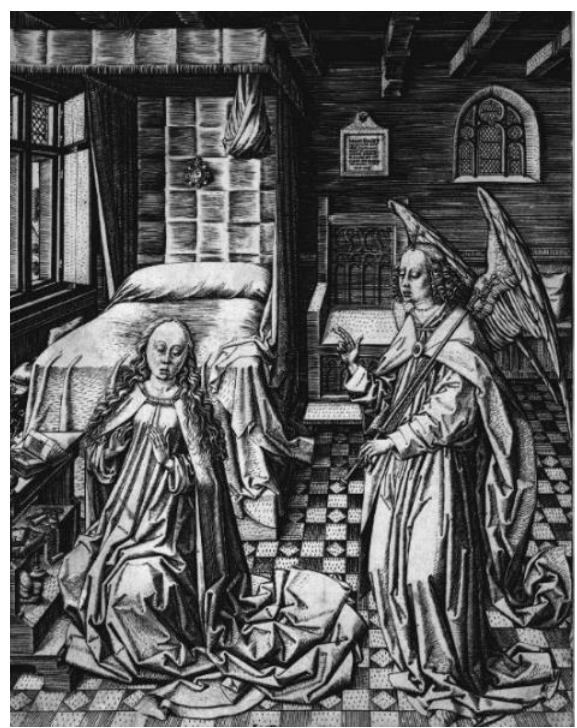

111. Master FVB. Anunciación. 1485-1500. Museo Británico. Londres (Reino Unido)

Para esta escena del ciclo de San Miguel en que el ángel se aparece a una mujer embarazada y la protege de las mareas para que pueda dar a luz, Aponte podría haberse 
basado en el grabado de Dirk Bouts de la Anunciación (fig. 111) ${ }^{382}$, para la figura del ángel, cuya posición de manos es muy semejante a la de la estampa. La derecha bendice, mientras que la izquierda sujeta la cruz. No obstante, las vestimentas no responden al modelo flamenco sino a otro más italiano, con los pliegues en movimiento.

\section{Camino del Calvario}

También en el Camino del Calvario (fig. 112) del Retablo de Ágreda, Aponte ha copiado la postura del brazo de Cristo de la estampa de Durero (fig. 113) ${ }^{383}$, con la mano derecha alzada. No sigue el resto de la figura, pues sitúa la cruz mirando hacia el lado derecho, en vez de hacia el izquierdo. También se inspiró en la estampa de Durero para la figura de la Virgen, situada al fondo a la izquierda (fig. 114).

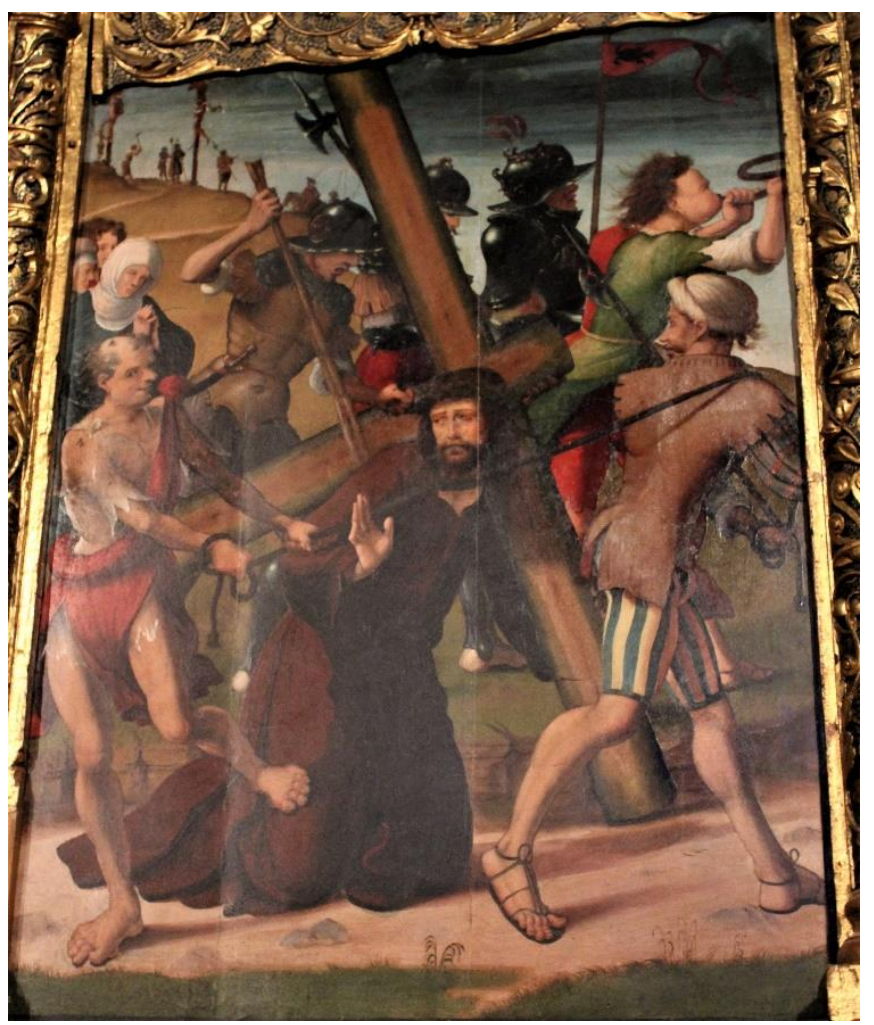

112. Pedro de Aponte. Camino del Calvario. Retablo de San Miguel. Ca. 1523. Iglesia de San Miguel. Ágreda (Soria).

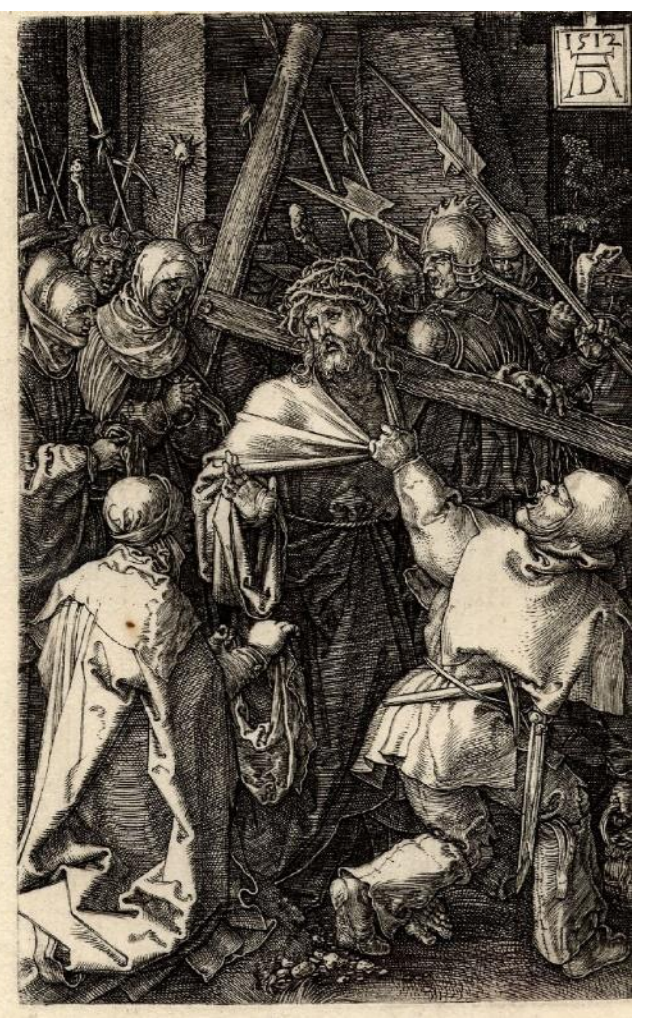

113. Alberto Durero.

Camino del Calvario. Pequeña Pasión. 1515-1550. Museo Británico. Londres

\footnotetext{
${ }^{382}$ Estampa disponible en:

http://www.britishmuseum.org/research/collection_online/collection_object_details.aspx?objectId=14036 $17 \&$ partId $=1$ \&searchText $=$ annunciation\&images $=$ true \&people $=131416 \&$ page $=1$

BARTSCH, A., op. cit., vol. VI, p. 81; LEHRS, M., op. cit., vol. VII, p. 121; HOLLSTEIN, F. W. H., German engravings, etchings and woodcuts..., p. 4.

${ }^{383}$ Estampa disponible en:

http://www.britishmuseum.org/research/collection_online/collection_object_details.aspx?objectId=13399 01\&partId $=1$ \&searchText $=$ calvary\&images $=$ true \&people $=127877 \&$ page $=1$

BARTSCH, A., op. cit., vol. VII, p. 37; DODGSON, C., Albrecht Dürer, nº 61, p. 79; MEDER, J., op. cit., $\mathrm{n}^{\circ}$ 12, p. 73; SCHOCH, R., op. cit., vol. I, n 54, p. 142.
} 


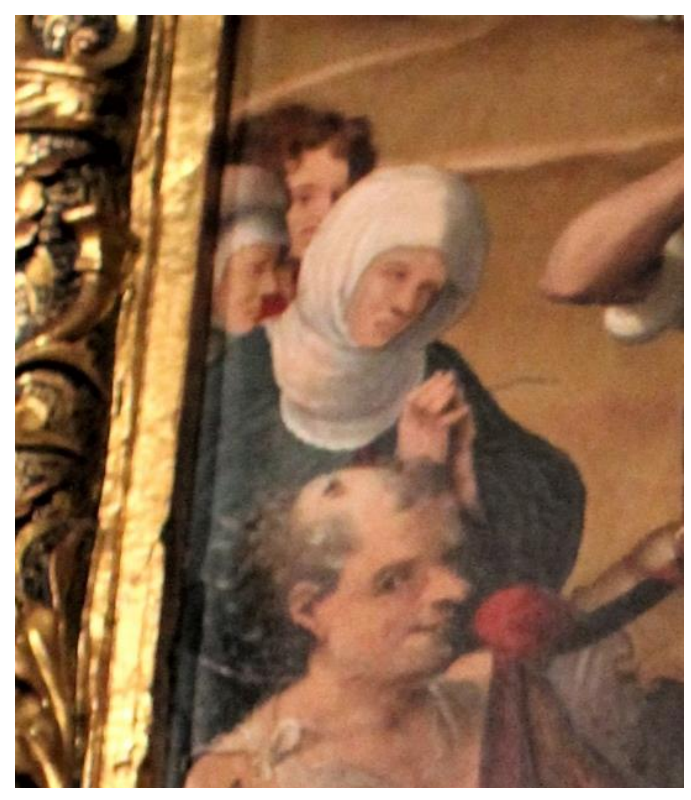

114. Detalle de la fig. 112

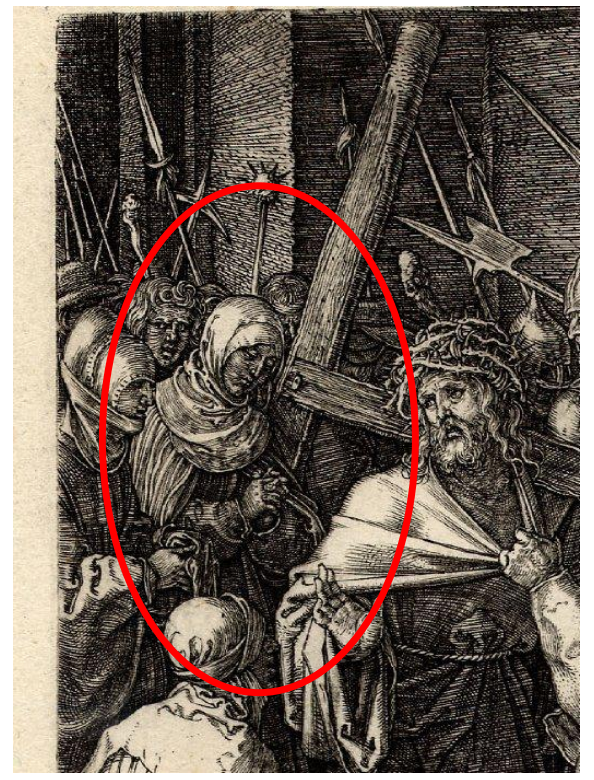

115. Detalle de la fig. 113.

De ella copió el tocado y la posición de rostro y manos. Tomó incluso de la estampa (fig. 115) la otra figura femenina, situada a la derecha de la Virgen, que luce un complicado tocado y muestra la misma posición de manos que ella, así como la figura masculina de abundantes cabellos situada entre ambas mujeres, de la que sólo vemos el rostro. Si lo comparamos con los posteriores retablos de Olite y Cintruénigo (Navarra) las escenas son muy semejantes, si bien en el caso de estos dos últimos se ha producido un descenso cualitativo, debido probablemente a una mayor participación del taller ${ }^{384}$. En el de Ágreda hay algo más de interés por el ideal de belleza, y los gestos son menos crispados que el retablo de Cintruénigo. Las diferencias se extienden al dibujo y la ejecución ${ }^{385}$. El realismo patético que se desprende de toda la escena es de carácter nórdico, y evoca los tipos humanos de Juan de Flandes ${ }^{386}$.

\section{Pedro de Aponte \\ Retablo de Nuestra Señora del Rosario \\ Primer tercio del siglo XVI \\ Iglesia de la Virgen de la Peña \\ Ágreda (Soria)}

En un retablo de estructura barroca del siglo XVIII (fig. 116) ${ }^{387}$, las tablas del banco han sido puestas en relación con la pintura de Pedro de Aponte. Representan la

\footnotetext{
${ }^{384}$ VV. AA., El retablo de San Miguel..., p. 80.

${ }^{385}$ POST, Ch. R., op. cit., t. XII, p. 79.

${ }^{386}$ VV. AA., El retablo de San Miguel..., p. 80.

${ }^{387}$ Imagen procedente de ALCALDE CRESPO, G., op. cit., p. 53; ORTEGO FRÍAS, T., op. cit., p. 89; PEÑA GARCIA, M., Historia y Arte de Ágreda ..., p. 165; ALCALDE CRESPO, G., op. cit., pp. 55-56.
} 
Oración en el Huerto y la Caída de Jesús Camino del Calvario. Respecto a las pinturas de la zona superior, no hay información sobre su autoría, si bien parecen de un pintor distinto y de un estilo más avanzado que las de la zona inferior. Representan la Virgen del Rosario, Santo Domingo de Guzmán y San Juan Evangelista. En la parte superior se encuentra a Dios Padre bendiciendo.

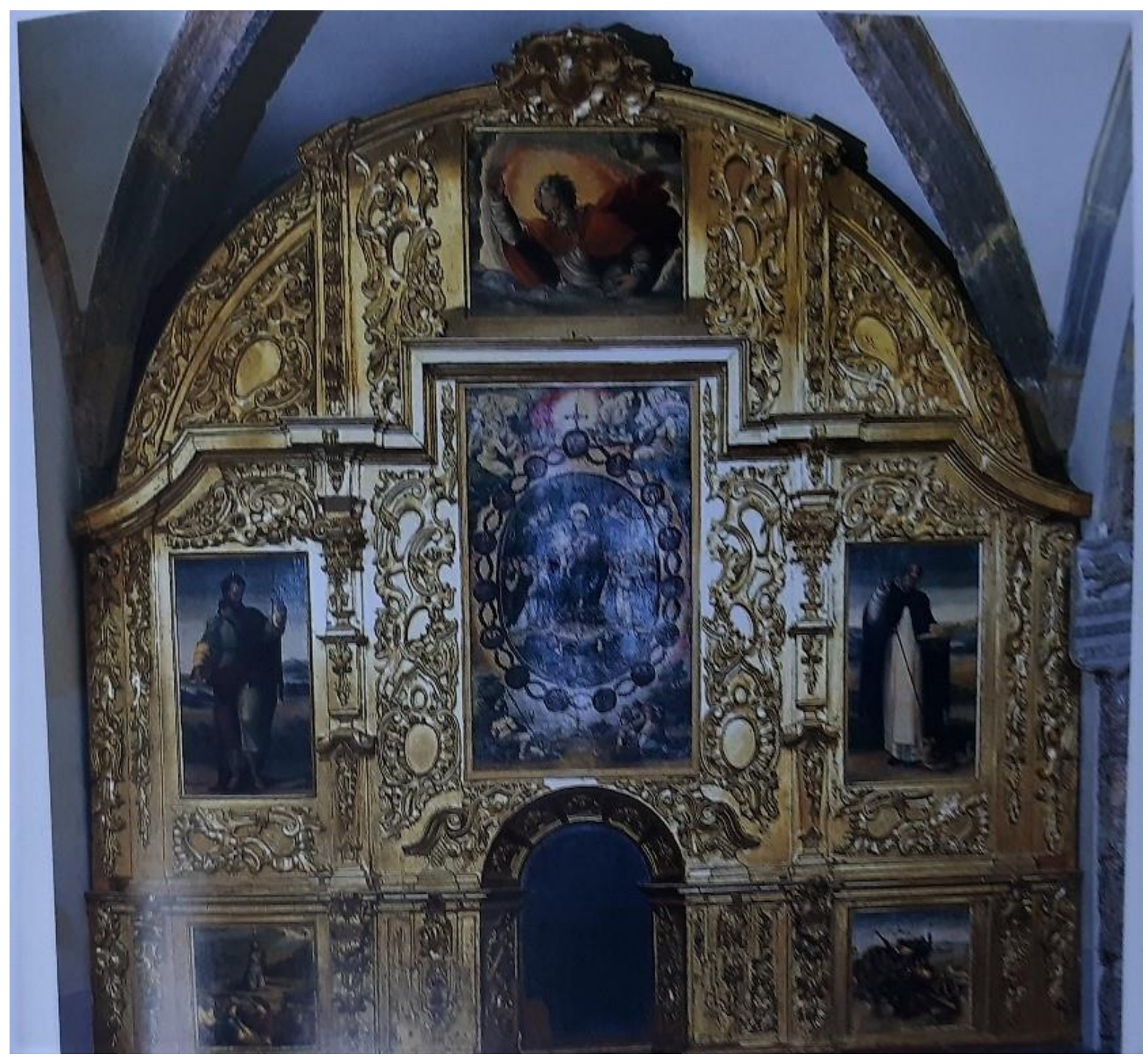

116. Pedro de Aponte y otros. Retablo de Nuestra Señora del Rosario. Primer tercio Siglo XVI. Iglesia de la Virgen de la Peña. Ágreda (Soria). 


\section{Virgen del Rosario}

En esta complicada composición, de autor anónimo (fig. 117), parece que el pintor se inspiró en la estampa homónima de Nicolás Beatrizet (fig. 118) ${ }^{388}$. La disposición de las figuras en el medallón central es idéntica. La Virgen con el Niño de pie sobre sus rodillas, sentada bajo un baldaquino decorado con doseletes que sostienen dos putti. Las figuras, que se arrodillan a ambos lados del trono son muy parecidas. Entre ellas destacan Santa Catalina de Siena (situada a la derecha) y Santo Domingo de Guzmán (a la izquierda). En el suelo, abajo, aparecen así mismo las figuras de dos donantes que en la pintura aparecen más alejadas de la Virgen el Niño, tras un escalón y con un jarrón de lirios entre ellos, mientras que en la estampa aparecen más juntas y sin el jarrón.

En la parte superior, se encuentran una serie de ángeles, entre nubes y alrededor de la cruz que remata el medallón, que también son muy similares. Se trata de seis ángeles de mayor tamaño que tocan instrumentos musicales y que se han representado de manera idéntica a las del grabado de Beatrizet. Debajo de estos ángeles más grandes, se sitúan seis angelitos que aparecen a ambos lados del medallón. Estas figuras aparecen leyendo enormes libros. Alrededor del medallón se situan varias cuentas de rosario en las cuales aparecen escenas de la Pasión de Cristo, correspondientes a los misterios del Rosario. Parece que para estas escenas no se ha seguido la estampa de Beatrizet, al igual que ocurre con las Virtudes de la Fe y la Caridad.

En la parte inferior, sin embargo, observamos las figuras de la Fe (a la izquierda) y de la Caridad (a la derecha). La figura de la Fe (fig. 119) parece inspirada en alguna de las figuras de la Capilla Sixtina de Miguel Ángel, posiblemente en la de Josías (fig. $120)^{389}$. Muestra igualmente una pose de espaldas con la pierna derecha flexionada y la izquierda estirada, aunque Miguel Ángel usó esa postura reclinada de la figura en otras ocasiones. La soriana difiere en en el género, las vestimentas, la cabeza o la mano derecha, que en la pintura sujeta un bastón que culmina en cruz, y en la estampa no aparece.

\footnotetext{
${ }^{388}$ Estampa disponible en: http://www.britishmuseum.org/research/collection_online/collection_object_details.aspx?objectId=14274 24\&partId $=1 \&$ searchText=virgin\&images $=$ true \&people $=132984 \&$ page $=1$ BARTSCH, A., op. cit., vol. XV, p. 253, no 29; ROBERT-DUMESNIL, A. P. F., Le Peintre-Graveur Français, París, G. Warée, 1835-71, vol. IX; p. 147, nº 23.

${ }^{389}$ Estampa disponible en: http://www.britishmuseum.org/research/collection_online/collection_object_details.aspx?objectId=32653 59\&partId=1\&searchText=ancestors\&images=true \&people $=114829 \&$ page $=1$
} 


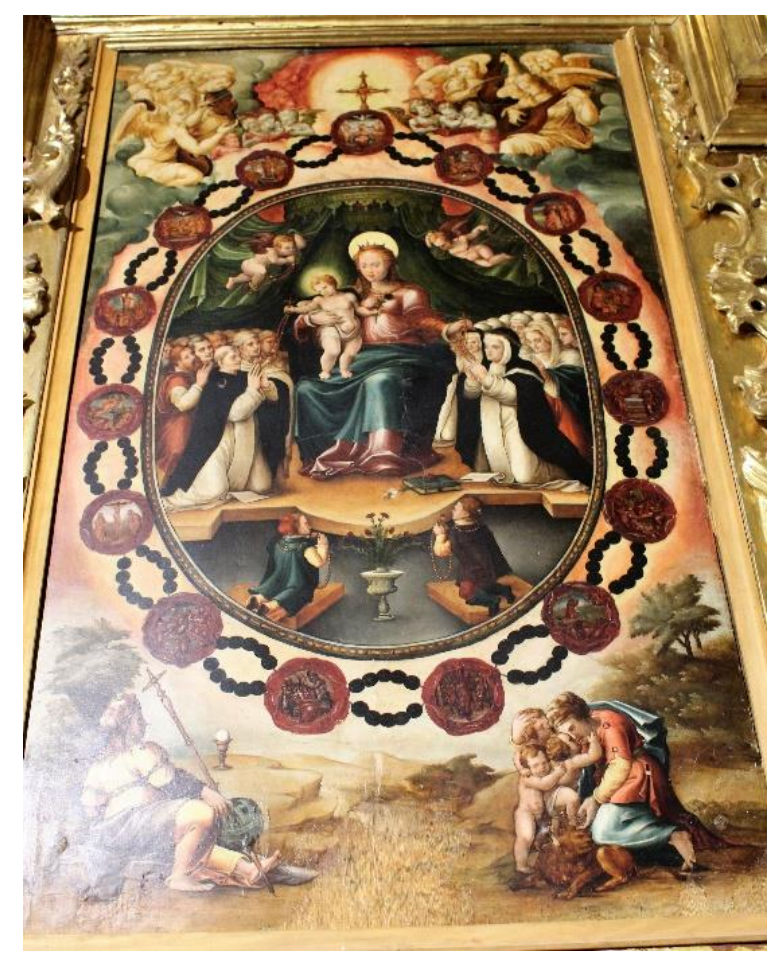

117. Anónimo. Virgen del Rosario. Segunda mitad del siglo XVI. Retablo de Nuestra Señora del Rosario. Iglesia de la Virgen de la Peña. Ágreda (Soria)

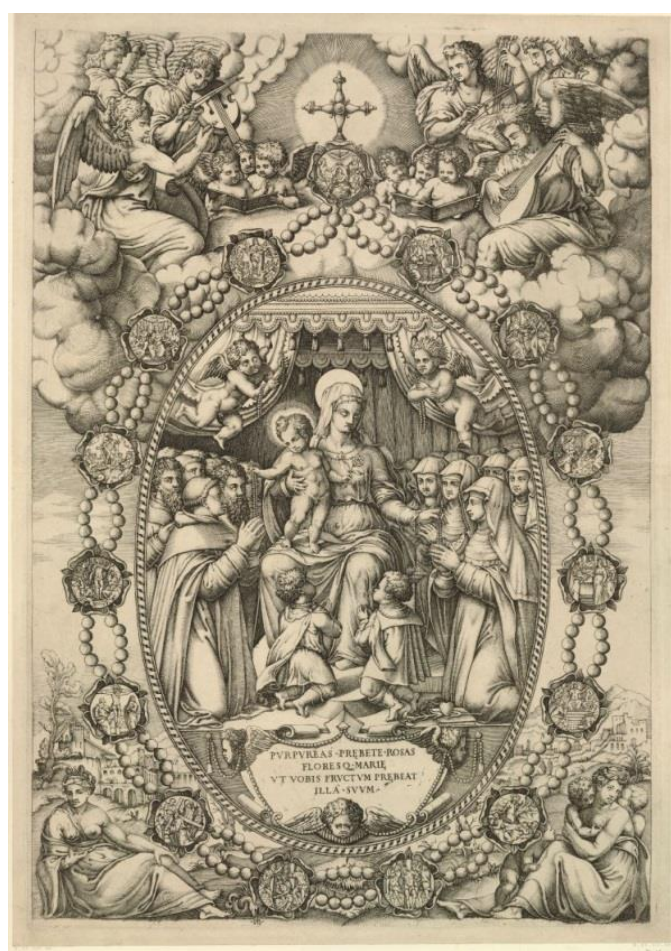

118. Nicolás Beatrizet.

Virgen del Rosario.

1550-1570. Museo Británico.

Londres (Reino Unido)

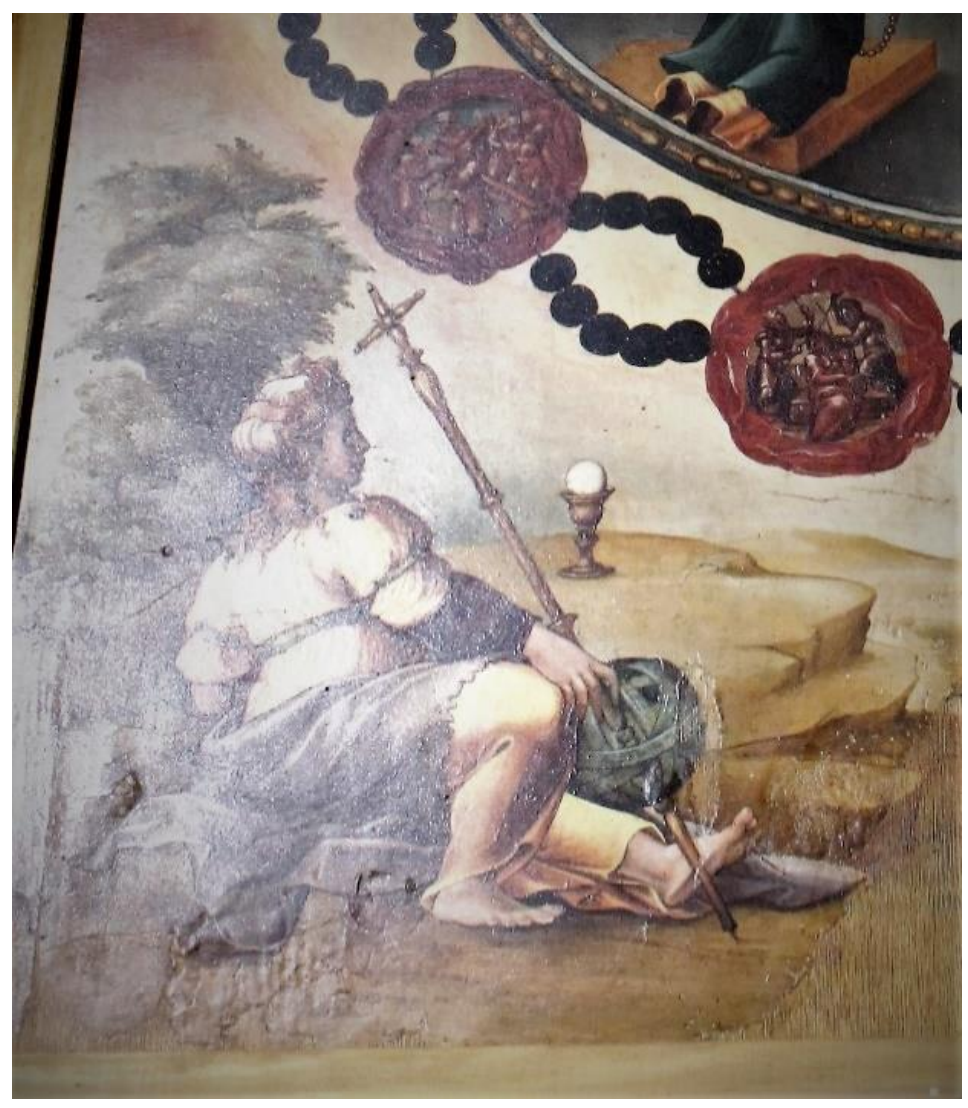

119. Detalle de la fig. 117. 


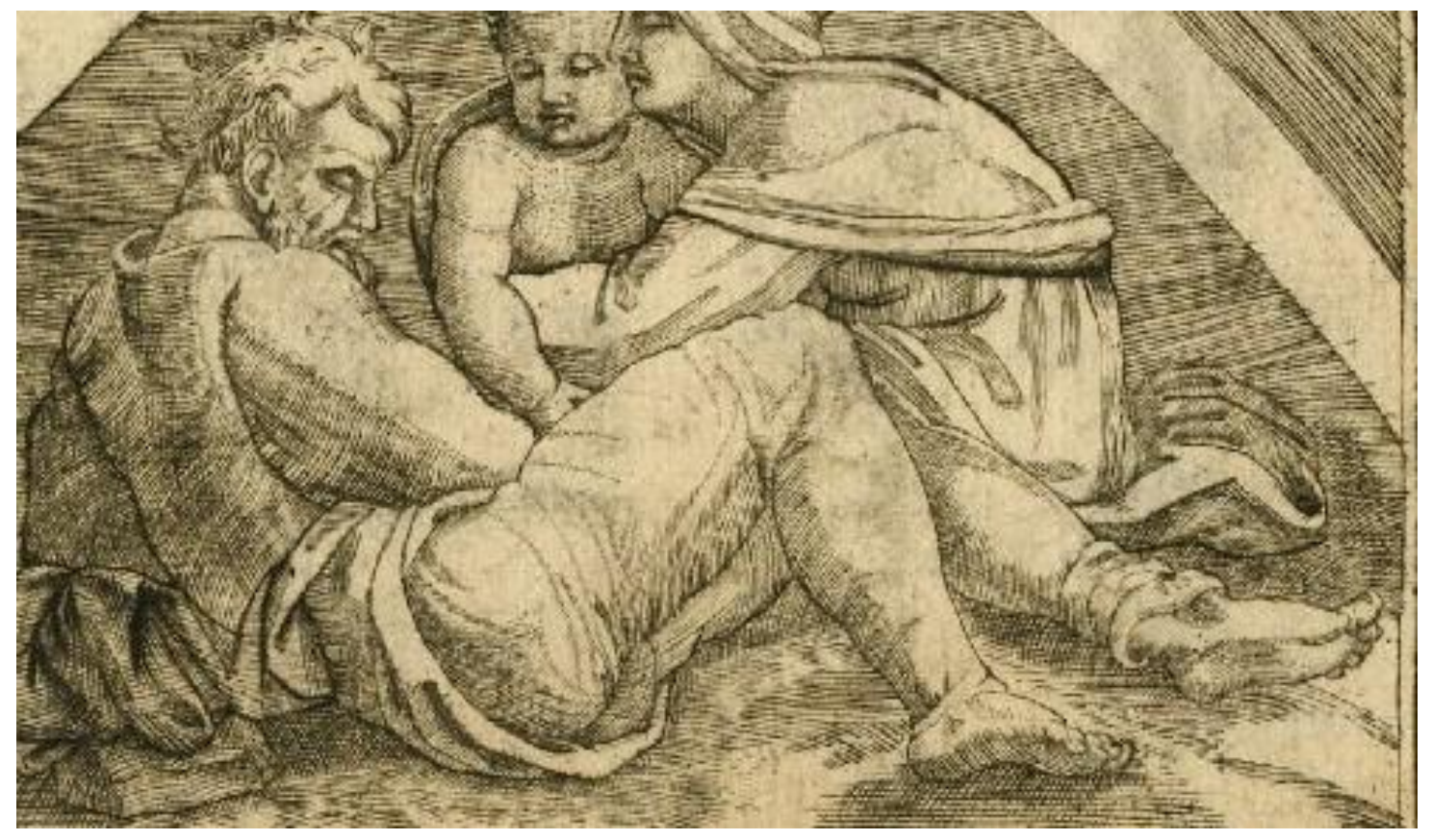

120. Anónimo (a partir de Miguel Ángel). Los ancestros de Cristo (genealogía), Josías, de la segunda pechina de la Capilla Sixtina. 1550-1580. Museo Británico. Londres (Reino Unido).

\section{Cristo camino del Calvario}

Para esta escena del pequeño retablo (fig. 121), en que algunas imágenes se atribuyen al llamado maestro de Ágreda, es decir Pedro de Aponte, el pintor se ha inspirado parcialmente en la estampa de Raimondi del Pasmo de Sicilia (fig. 122) ${ }^{390}$. Se ha utilizado en particular la figura de Cristo, que vuelve su rostro hacia la derecha y apoya su brazo izquierdo sobre una roca. Se basó también en el soldado que tira de Cristo, y aparece de espaldas al espectador, aunque desgraciadamente se ha perdido la parte inferior de su cuerpo. Hay asimismo inspiración parcial en otros personajes, como Simón de Cirene o la Verónica. Al fondo de la composición hay un paisaje brumoso y difuminado en el que se adivinan algunas montañas, árboles y torres; en el caso del grabado el paisaje es más preciso y frondoso. El pintor ha sustituido todo el grupo de soldados a caballo portando estandartes por un grupo más grotesco, probablemente de influencia nórdica, de personajes armados con poses violentas y amenazantes.

\footnotetext{
${ }^{390}$ Estampa disponible en:

http://www.britishmuseum.org/research/collection_online/collection_object_details.aspx?objectId=14419 $00 \&$ partId $=1 \&$ searchText $=$ calvary \&images $=$ true $\&$ people $=134723 \&$ page $=1$ BARTSCH, A., op. cit., vol. XIV, p. 34; PASSAVANT, J. D., op. cit., vol. VI, p. 52.
} 


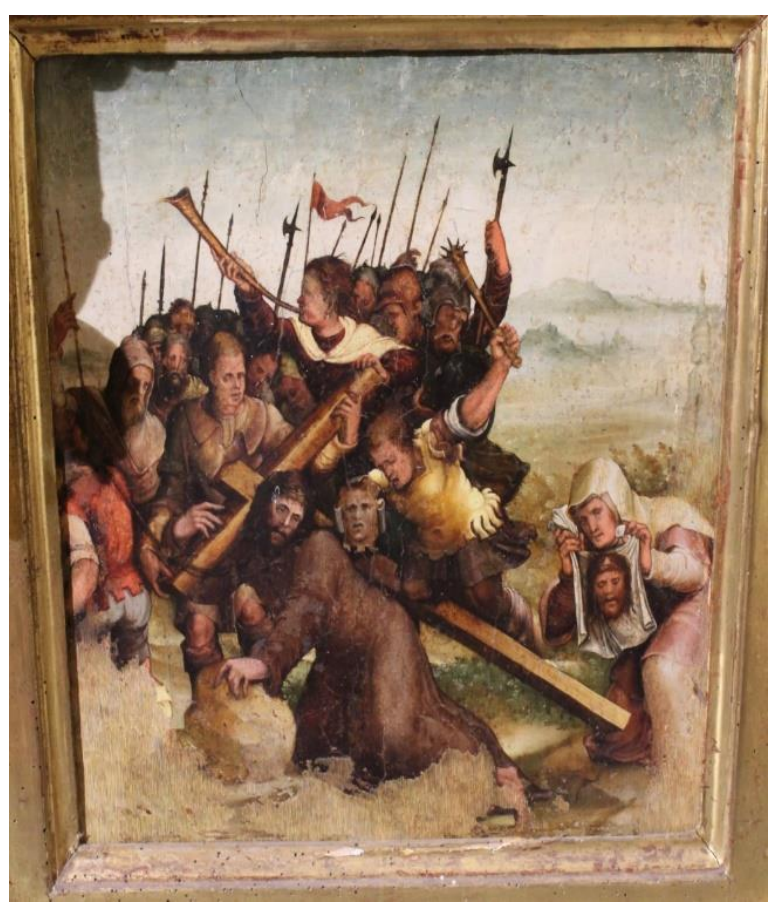

121. Pedro de Aponte. Camino del Calvario.Primer tercio siglo XVI. Retablo de Nuestra Señora del Rosario. Iglesia de la Virgen de la Peña. Ágreda (Soria).

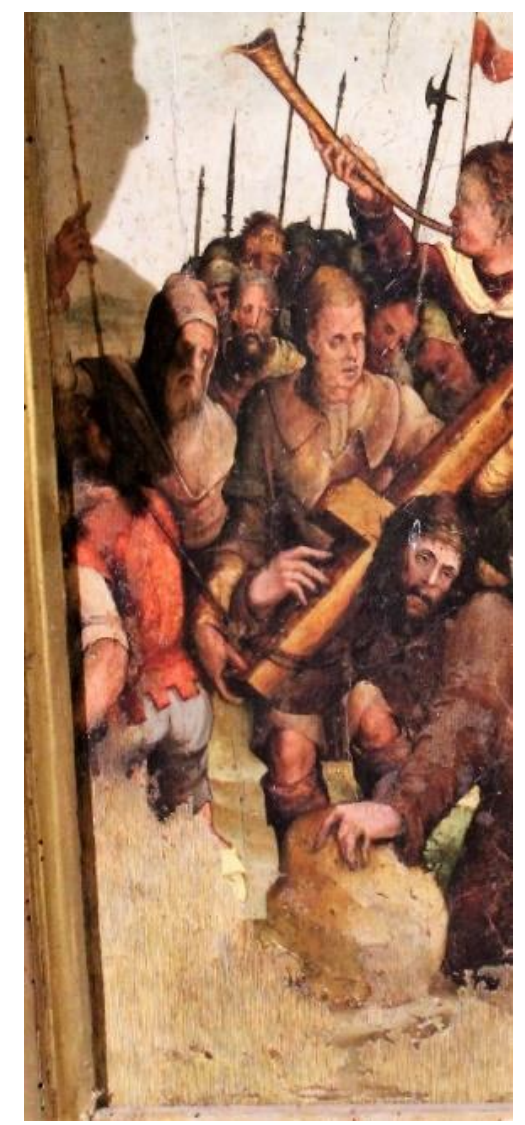

123. Detalle de la fig. 121.

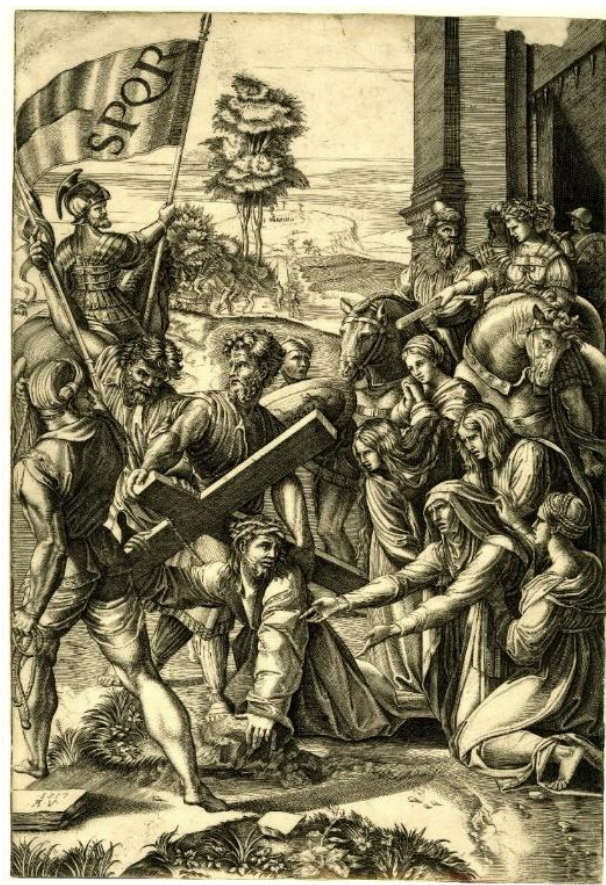

122. Agostino Veneziano.

Pasmo de Sicilia. 1517.

Museo Británico.

Londres (Reino Unido).

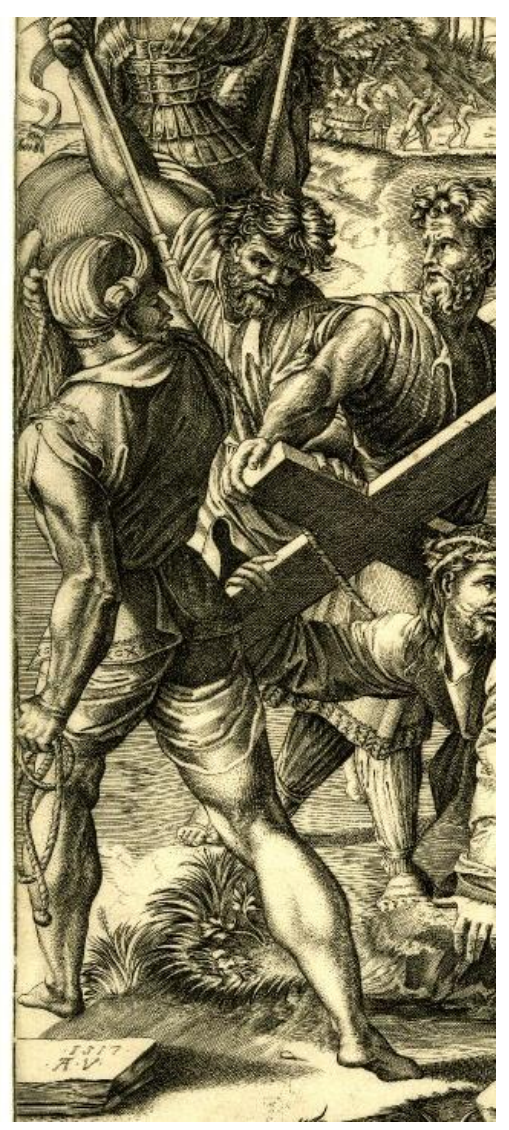

124. Detalle de la fig. 122. 


\section{Círculo de Juan Soreda \\ Retablo mural \\ 1530-1535 \\ Iglesia de San Francisco \\ San Esteban de Gormaz (Soria))}

Estas pinturas fueron descubiertas gracias a una intervención arquitectónica que se iba a realizar en la parroquia entre 1982 y 1985 con objeto de crear un presbiterio más amplio y colocar un pedestal de piedra que elevara el retablo mayor ${ }^{391}$. Las pinturas se encontraban ocultas en el testero de la iglesia tras un retablo del siglo XVII. Se trata pues de un retablo fingido, cosa poco común, y que sólo se realizaba cuando los medios económicos eran escasos (fig. 125).

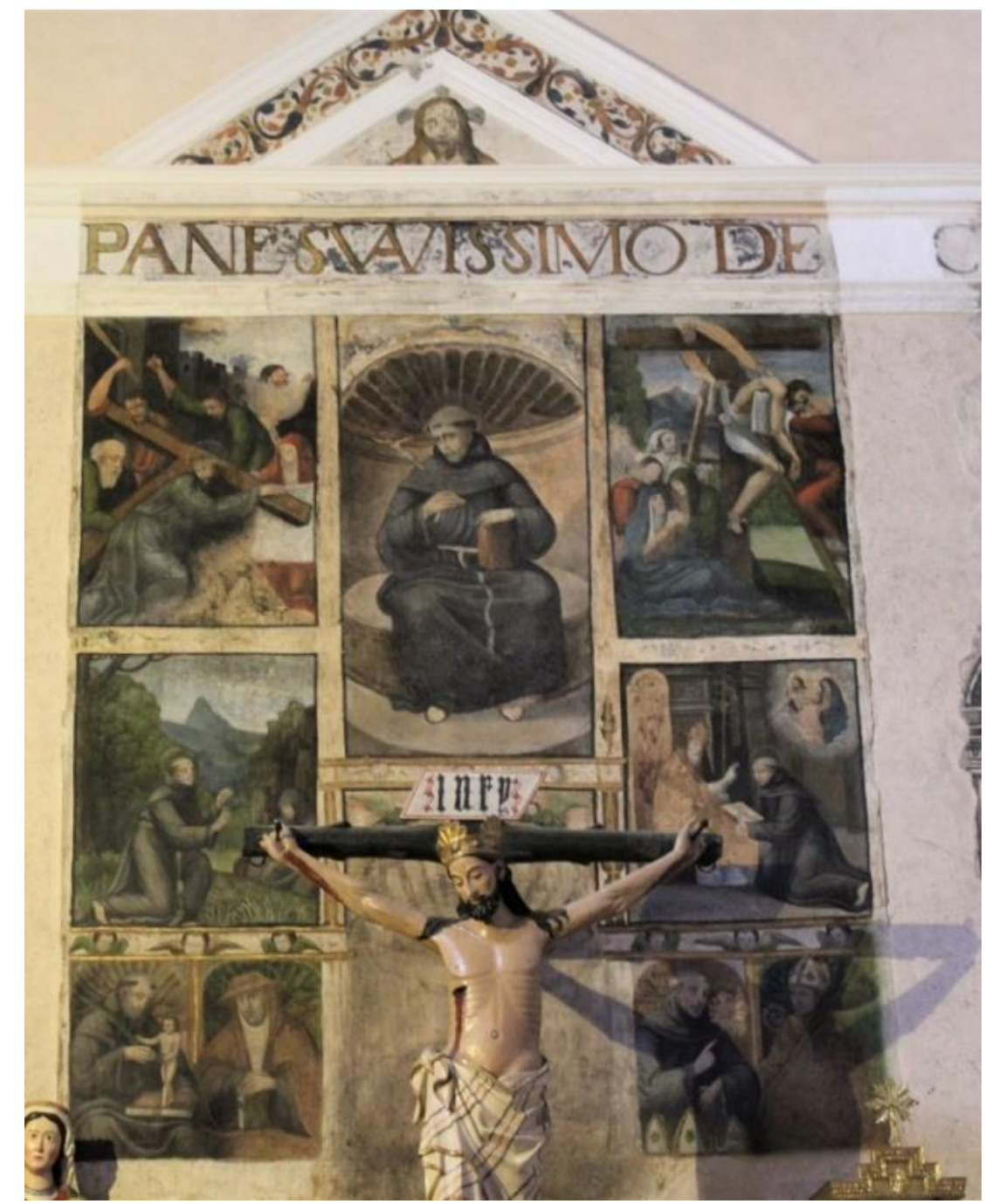

125. Círculo de Juan Soreda. Retablo mural de la iglesia de San Francisco. 1530-1535. San Esteban de Gormaz (Soria)

391 FIZ FUERTES, I., "El retablo mural del antiguo convento de San Francisco en San Esteban de Gormaz (Soria). Análisis iconográfico y filiaciones estilísticas" en Estudios de Historia del Arte: homenaje al profesor de la Plaza Santiago, Universidad de Valladolid, 2009, p. 93. 
Las pinturas son de la misma época en la que se construyó el templo; es decir, de principios del siglo XVI, siguiendo el estilo del Gótico tardío. El retablo adopta la estructura típica de los retablos del siglo XVI. Está formado por un banco, dos cuerpos separados por un ensamblaje y tres calles divididas a través de decoración abalaustrada. La mayoría de las escenas corresponden a episodios de la vida de San Francisco de Asís, aunque dos representan temas de la vida de Cristo. En la calle central, más alta que las laterales, aparece la imagen de San Francisco. Debajo de él, un nicho con forma de venera que divide el banco en dos partes. Este recurso, muy propio del Renacimiento, se usaba sobre todo en los sitios más sagrados.

En el banco se representan cuatro santos franciscanos: San Antonio de Padua, San Buenaventura, San Bernardino de Siena y San Luis. En las calles laterales del primer cuerpo se han figurado escenas relativas a la vida de San Francisco: la Estigmatización a la izquierda, la Aprobación de la regla de la orden franciscana por el Papa Honorio III a la derecha. En el segundo cuerpo podemos observar dos episodios de la Pasión de Cristo: el Descendimiento y el Camino del Calvario.

Fiz Fuertes relaciona esta obra con las pinturas soredianas tardías, realizadas cuando Soreda se encontraba en el Burgo de $\mathrm{Osma}^{392}$. La fidelidad a un estilo renacentista aún puro, sin el influjo de las formas manieristas, y el uso de fondos dorados en la predela datarían la obra en torno a 1530. El uso de motivos típicos de la decoración renacentista como son los putti, los balaustres o las formas aveneradas corroboran esta opinión.

Aun así, ciertas escenas muestran ciertas dificultades en su adaptación al espacio, lo que provoca una acumulación de figuras debido a la falta de holgura. También se muestra cierta torpeza en las poses y la configuración de las figuras. Probablemente se tratase de una obra de taller, lo que explicaría las diferencias de calidad entre las diferentes escenas que forman el retablo. También en este círculo de discípulos de Soreda, se utilizaron las estampas. En algunas de las escenas del retablo los pintores se inspiraron en grabados.

\section{San Francisco recibiendo los estigmas}

El tema de la estigmatización de San Francisco es uno de los principales dentro de la iconografía de la orden, ya que se compara a San Francisco con Cristo. Siempre se

\footnotetext{
${ }^{392} I d$., p. 95.
} 
representa a San Francisco orando, arrodillado y con las manos extendidas. Los estigmas salen de un Cristo-serafín rojo a través de una serie de rayos luminosos. Las llagas constituyen su principal atributo.

Probablemente el artista se inspiró aquí (fig. 126) en la estampa del mismo tema de Durero (fig. 127) ${ }^{393}$ en la manera en la que el santo coloca las piernas -una doblada y la otra estirada hacia atrás, el lugar que ocupa en la composición, así como en el rostro y la postura de la figura del fondo, que se oculta con una capucha.

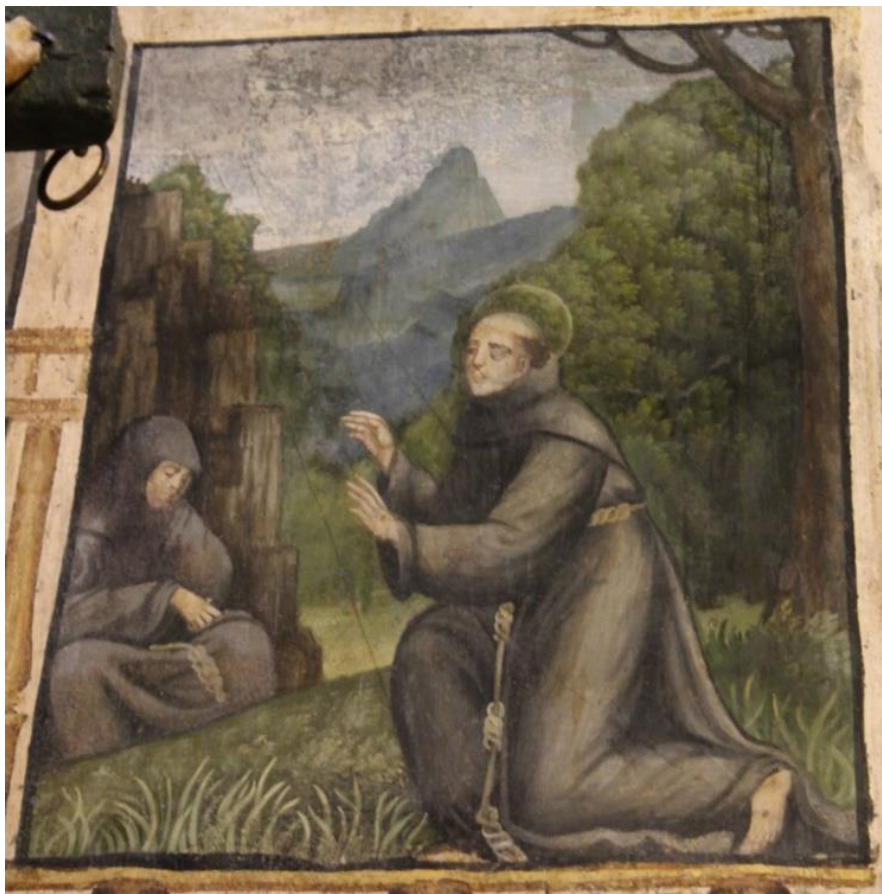

126. Círculo de Juan Soreda. San Francisco recibiendo los estigmas. Ca. 1530. Retablo de San Francisco. San Esteban de Gormaz (Soria).

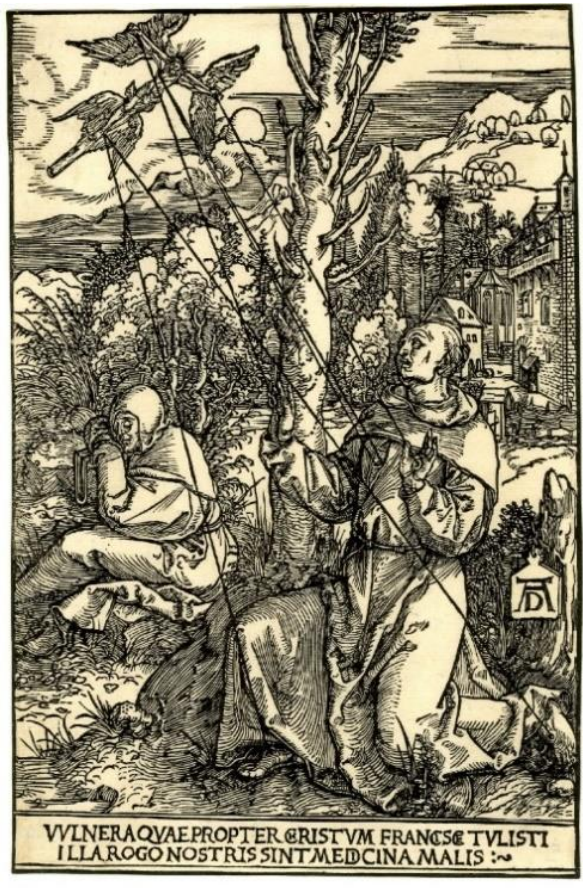

127. Alberto Durero. San Francisco recibiendo los estigmas. 1503-1504. Museo Británico. Londres (Reino Unido).

\section{Descendimiento de Cristo}

El pintor o pintores utilizaron la estampa de Andrea Mantegna (fig. 129) ${ }^{394}$ para configurar la composición de la bajada del cuerpo de Cristo de la cruz (fig. 128),

\footnotetext{
${ }^{393}$ Estampa disponible en:

http://www.britishmuseum.org/research/collection_online/collection_object_details.aspx?objectId=13391 46\&partId $=1 \&$ searchText $=$ saint + francis \&images $=$ true \&people $=127877 \&$ page $=1$

BARTSCH, A., op. cit., vol. VII, p. 138; DODGSON, C., Catalogue of Early German and Flemish Woodcuts...., vol. I, n 33, p. 287; MEDER, J., op. cit., n 224, p. 189; SCHOCH, R., op. cit., vol. II, $\mathrm{n}^{\circ}$ 134, pp. 126-128.

${ }^{394}$ Estampa disponible en:

http://www.britishmuseum.org/research/collection_online/collection_object_details.aspx?objectId=13459 44\&partId=1\&searchText=andrea+mantegna\&images=on\&page $=1$
} 
basándose fundamentalmente en la figura superior, cuyos brazos asoman por arriba y por debajo de la cruz, y que sostiene el cuerpo de Cristo. La posición de la Virgen, rodeada de otras mujeres en el ángulo izquierdo de la composición, es semejante. A diferencia de la estampa de Mantegna, la pintura muestra poco o nulo interés por el paisaje, limitándose a algunos árboles y montañas que se adivinan vagamente al fondo. También es posible que se inspirara en la estampa de Hans Baldung (fig. 130) ${ }^{395}$ del mismo tema, aunque adaptando torpemente la figura de la parte superior. La influencia de la estampa de Mantegna desde el Quattrocento se observa en algunas pinturas italianas, como el Descendimiento de la iglesia de la Annunziatta de Cossignano atribuida a Nicola Filotesio (ca. 1480-ca. 1547) (Cola dell Amatrice) (fig. 131) ${ }^{396}$.

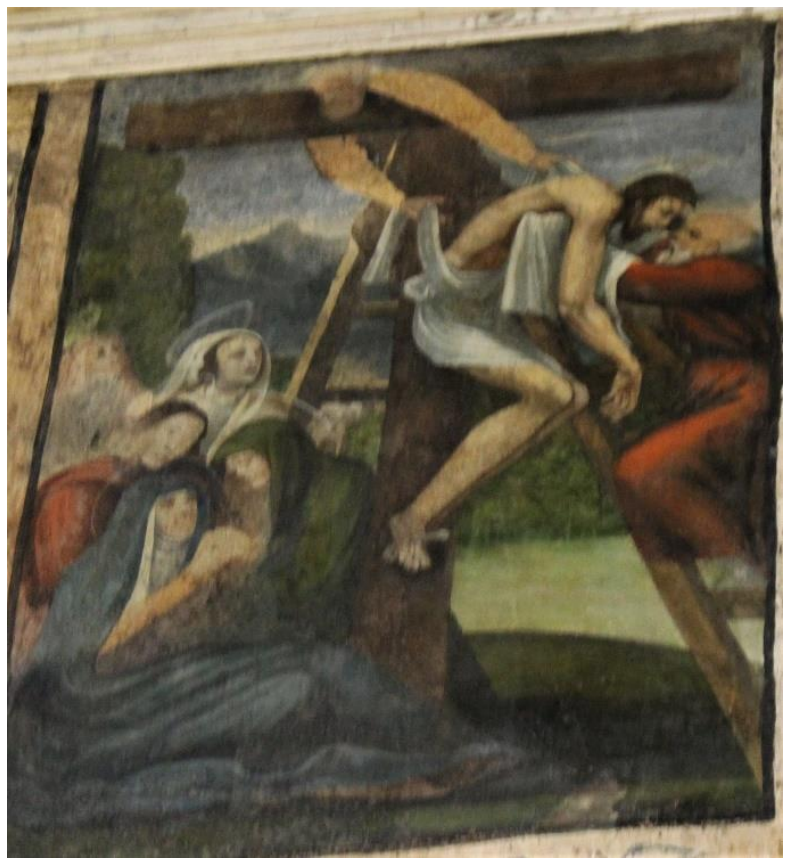

128. Círculo de Juan Soreda. Descendimiento. 1530-1535. Retablo mural.

Iglesia de San Francisco. San Esteban de Gormaz (Soria.).

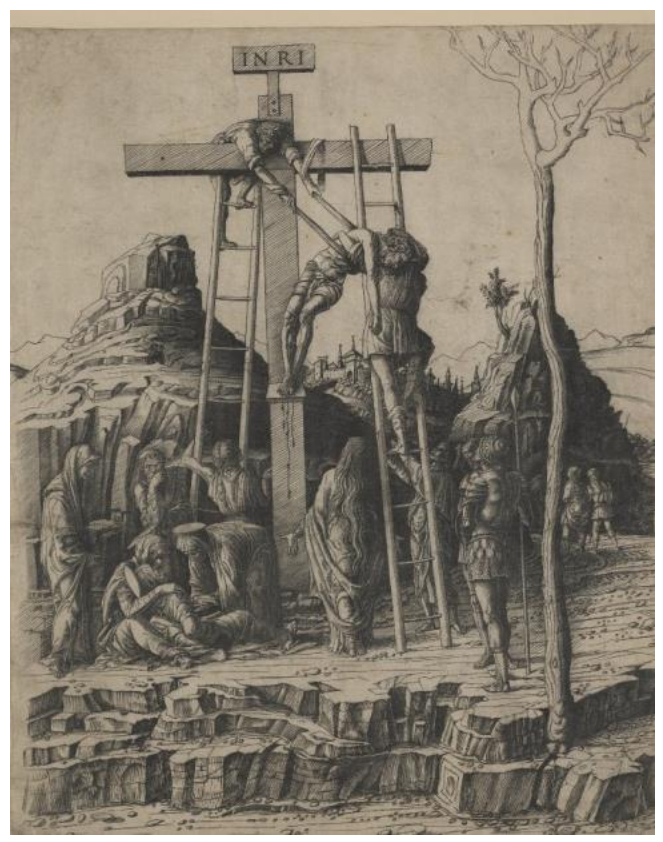

129. Andrea Mantegna.

Descendimiento 1470-1500.

Museo Británico.

Londres (Reino Unido).

BARTSCH, A., op. cit., vol. XIII, p. 230; HIND, A. M., Early Italian engraving..., vol. V, catálogo nº 2, $\mathrm{n}^{\mathrm{o}} 10, \mathrm{p} .19$.

${ }^{395}$ Estampa disponible en:

http://www.britishmuseum.org/research/collection_online/collection_object_details.aspx?objectId=14244 29\&partId=1\&searchText=hans+baldung + grien\&images $=$ on\&page $=1$

HOLLSTEIN, F. W. H., German engravings, etchings and woodcuts..., p. 51.

${ }^{396}$ Imagen procedente de: http://www.italianfoodandflavours.com/category/images/ 


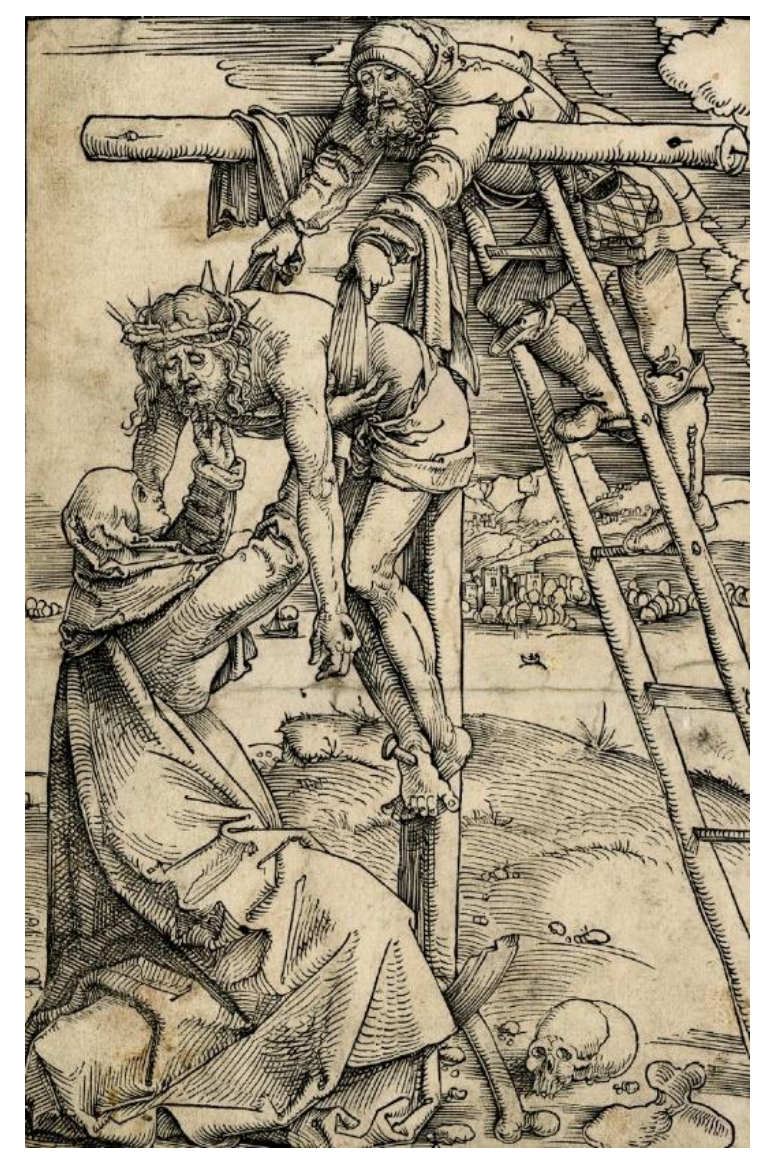

130. Hans Baldung. Descendimiento. 1505-07.

Museo Británico. Londres (Reino Unido).

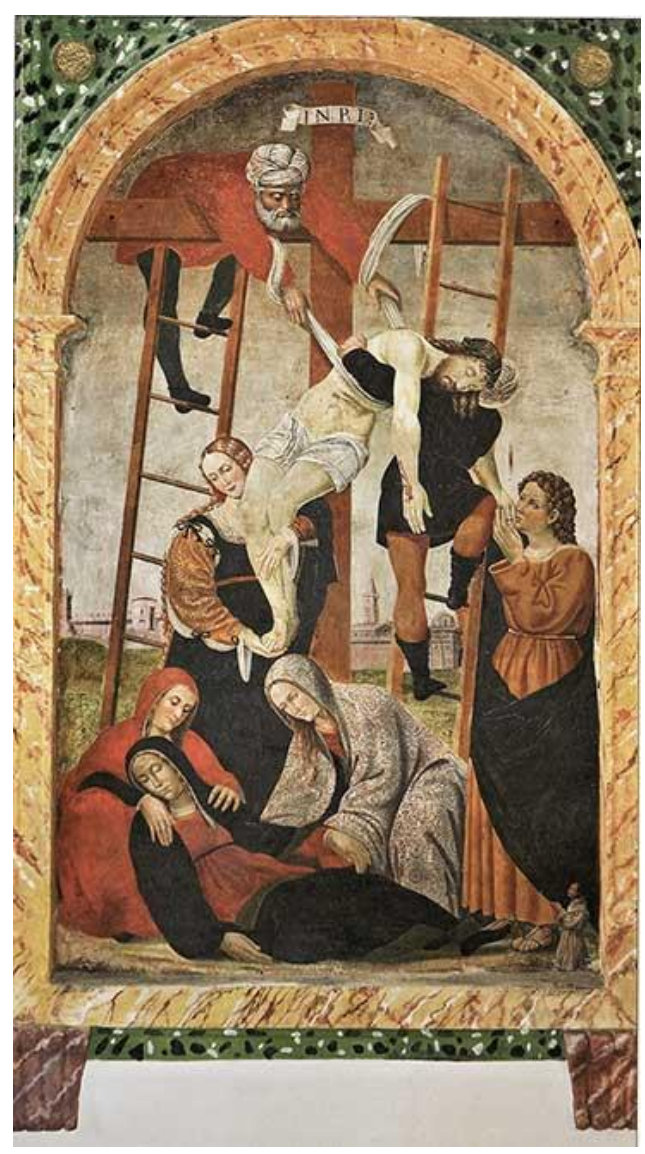

131. Atribuida a Nicola Filotesio (Cola dell' Amatrice). Descendimiento 1500-1530. Iglesia de la Annunziata. Cossignano (Italia)

\section{Anónimo \\ Retablo de Santa Ana \\ Primer cuarto del siglo XVI \\ Iglesia de San Miguel de Ágreda}

Se trata de un retablo renacentista calificado como de Escuela Aragonesa y originalmente ubicado en la capilla de Santa Ana. Actualmente se sitúa en una de las capillas de la Epístola ${ }^{397}$. Se encuentra parcialmente desmantelado.

En el primer cuerpo se encuentran las escenas de El Abrazo ante la Puerta Dorada, y el Nacimiento de la Virgen, situadas a ambos lados de una talla que representa a San Ana Madre. En el segundo cuerpo se ubican las escenas pictóricas de la Crucifixión y San Jerónimo orando en el desierto.

Por último, en la predela se hallan representadas las escenas de El Prendimiento, la Flagelación, la Misa de San Gregorio, del Descendimiento y el Entierro.

\footnotetext{
397 ORTEGO FRÍAS, T., op. cit., p. 100. TARACENA Y AGUIRRE, B. y TUDELA DE LA ORDEN, J., op. cit., pp. 256-157. ALCALDE CRESPO, G., op. cit., p. 79.
} 


\section{Prendimiento de Cristo}

La escena representa el momento en el que Pedro va a cortarle la oreja a Malco (fig. 132), el criado del Sumo Sacerdote hebreo. Cristo aparece en el centro con las manos atadas por cuerdas, sin oponer la menor resistencia. Lo rodea un mar de soldados con sus lanzas.

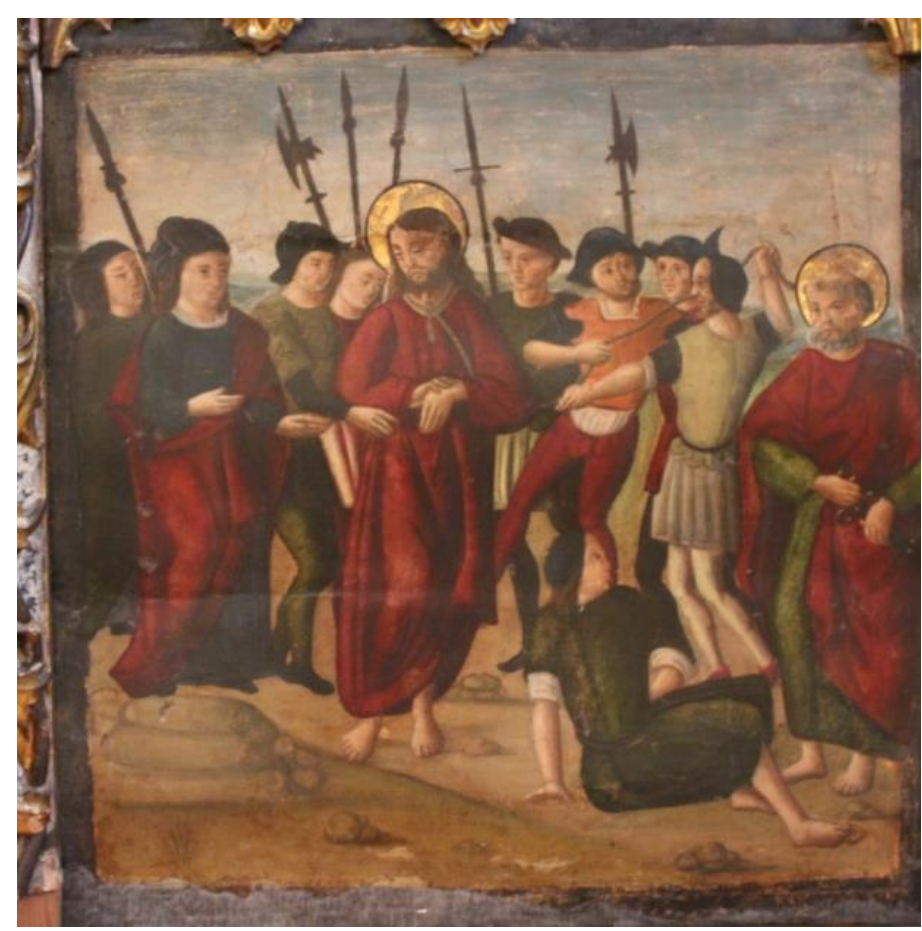

132. Anónimo. Prendimiento de Cristo. 1525-1550. Retablo de Santa Ana. Iglesia de San Miguel Ágreda (Soria).

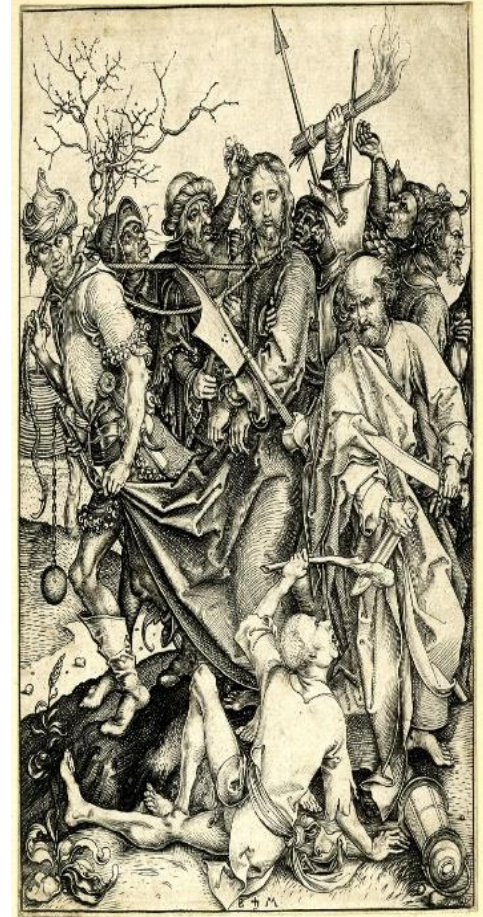

133. Martin Schongauer.

Prendimiento de Cristo. 1470-1482. Museo Británico. Londres (Reino Unido).

Esta pequeña pintura del retablo parece haberse inspirado parcialmente en la estampa del Prendimiento de Cristo de Schongauer (fig. 133), especialmente en las figuras de San Pedro y de Malco en el suelo de espaldas, del cual toma la postura del tronco y de las piernas, pero no la del brazo derecho, que se alza sobre la cabeza. El resto de personajes representados al fondo de la composición no parecen haber tomado como modelo la estampa. El autor se ha basado muy sumariamente en las poses de las siluetas, pero sin adoptar las vestimentas ni los complejos pliegues que lucen las figuras. Tampoco parece haberse inspirado ni en la vegetación ni en los objetos que aparecen tanto en el suelo, en primer plano, como en el fondo. Los personajes no logran transmitir ni la expresividad ni el naturalismo de la escena de Schongauer y sus colocación en la escena resulta poco natural, imitando torpemente las actitudes de las figuras. 


\section{Descendimiento de Cristo}

En esta pequeña escena del banco del retablo (fig. 134) se pueden encontrar referencias a un grabado anónimo florentino del Descendimiento (fig. 135) ${ }^{398}$. En particular en la figura superior que ayuda a bajar a Cristo, así como en la misma figura de Cristo.

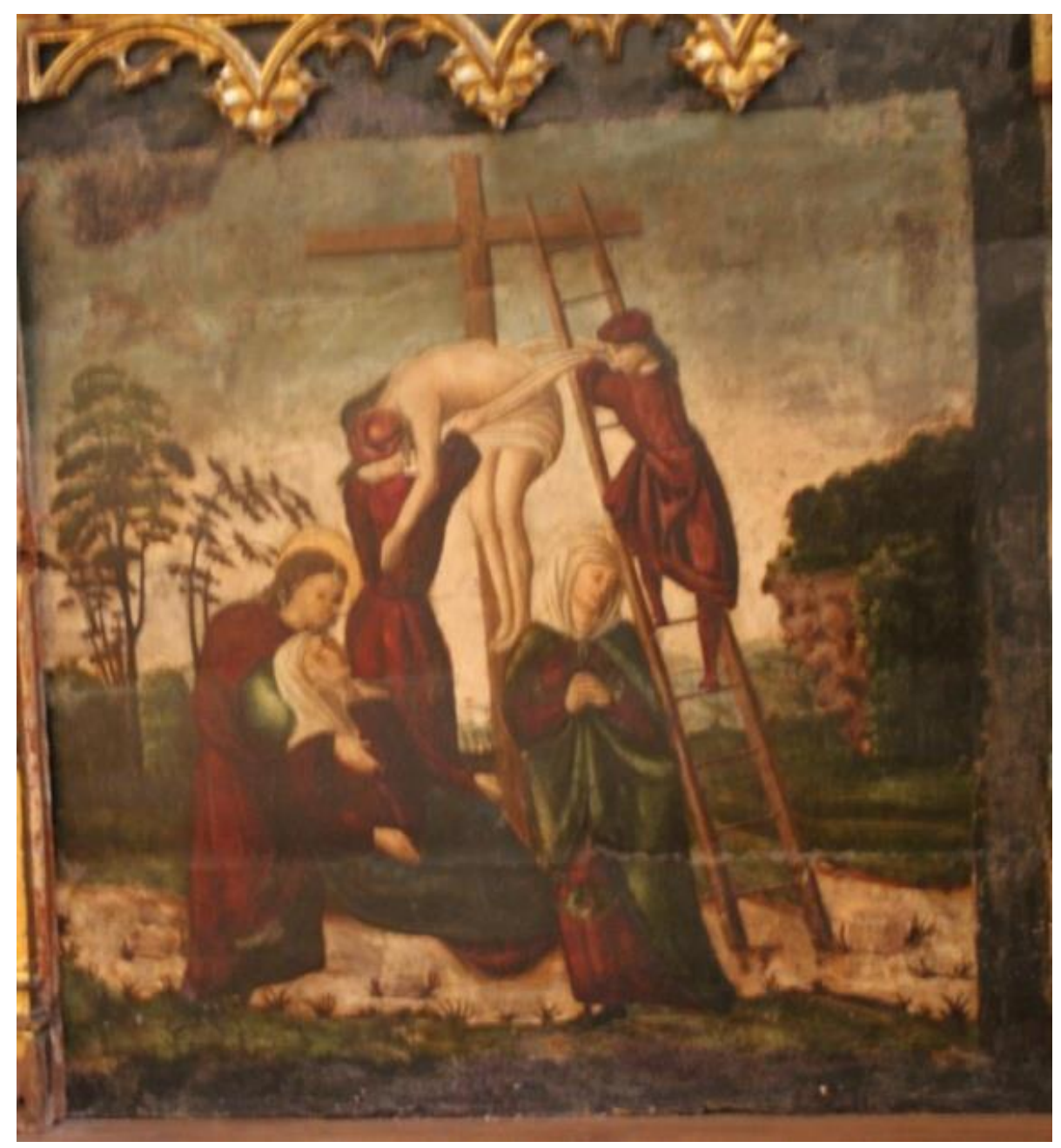

134. Anónimo. Descendimiento de la cruz. 1525-1550. Banco del retablo de Santa Ana. Iglesia de San Miguel. Ágreda (Soria).

También hay referencias del ya citado grabado de Baldung (fig. 136) ${ }^{399}$ del mismo tema, donde la Virgen sujeta a Cristo mientras lo bajan de la cruz, aunque en

\footnotetext{
${ }^{398}$ Estampa disponible en:

http://www.britishmuseum.org/research/collection_online/collection_object_details.aspx?objectId=76146 8\&partId=1\&searchText=descent\&image $=$ true $\&$ from $=$ ad \& fromDate $=1490 \&$ to $=$ ad\&toDate $=1500 \&$ page $=1$; HIND, A. M., Early Italian engraving..., vol. I, catálogo $\mathrm{n}^{\circ}$ 1, $\mathrm{n}^{\circ}$ 16, p. 144; STRAUSS, W., op. cit., vol. 24, p. 2405.

${ }^{399}$ Estampa disponible en:
} 
este caso la Virgen ha sido sustituida por una figura masculina. Las figuras, sin embargo, no poseen la misma armonía y gracia italiana del grabado florentino ni transmiten el mismo patetismo que las de Baldung.

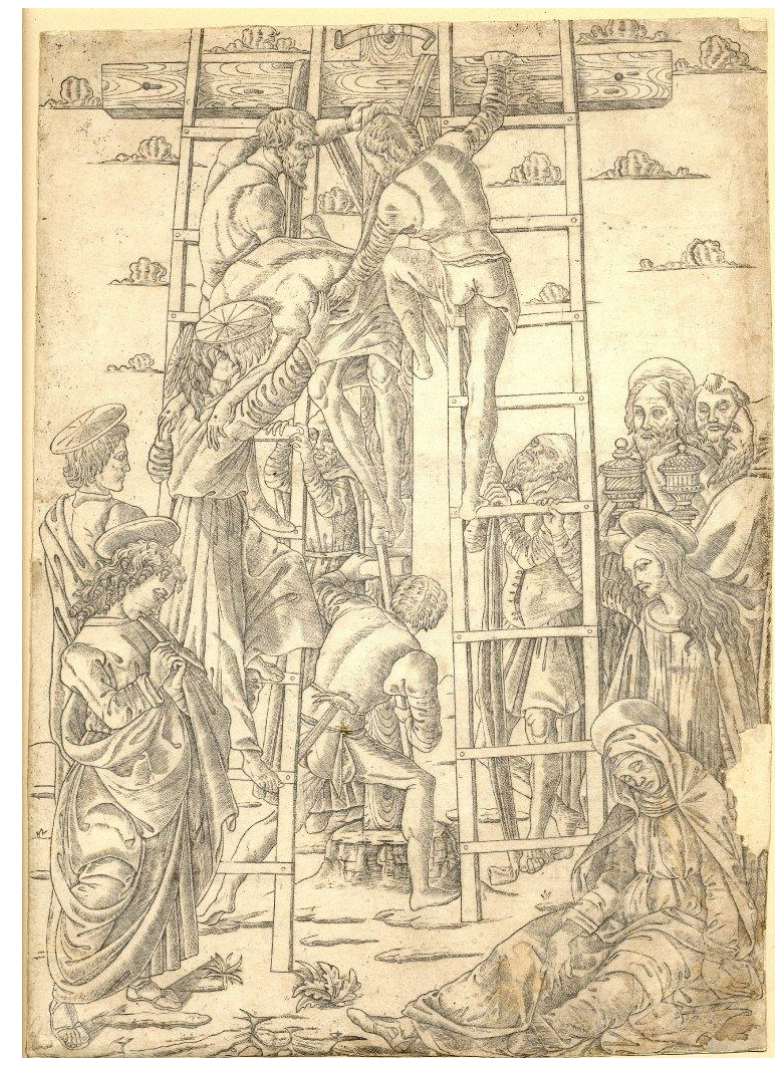

135. Anónimo florentino. Descendimiento. . 1490-1500. Museo Británico. Londres (Reino Unido).

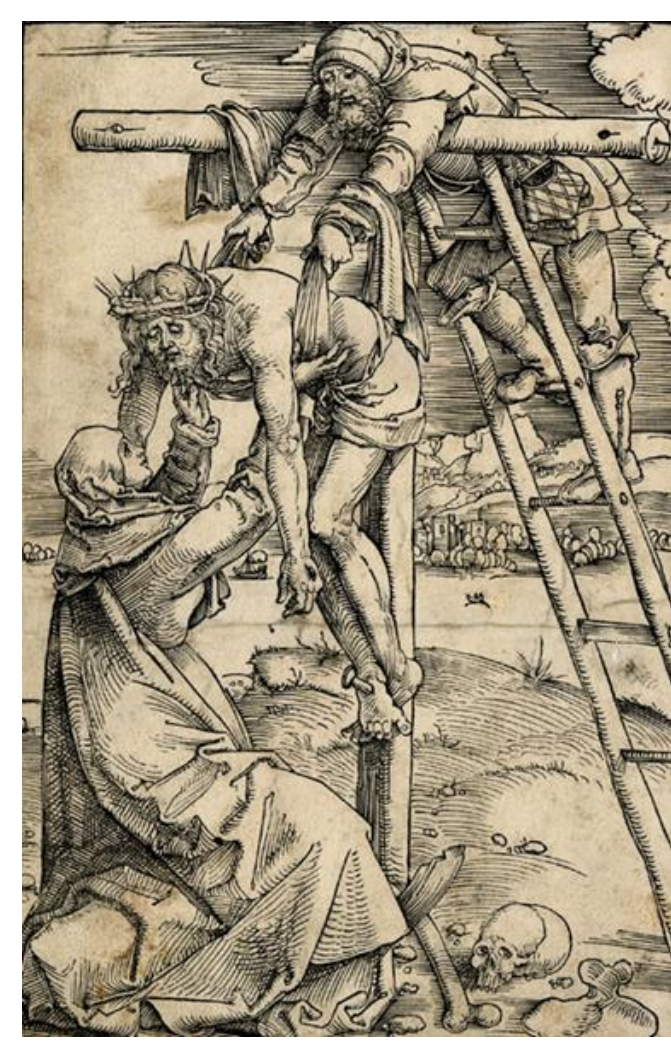

136. Hans Baldung. Descendimiento. 1505-1507. Museo Británico. Londres (Reino Unido).

\section{Anónimo escuela castellana \\ Retablo de San Emeterio y San Celedonio \\ 1525-1540 \\ Iglesia de San Miguel \\ Ágreda (Soria)}

Este retablo se localiza en la capilla del mismo nombre, la primera del lado de la Epístola, dentro de la iglesia de San Miguel. Fue donación de Juan de Soria, fallecido en 1525, y de su esposa, Ana Garcés, fallecida en 1523, respectivamente ${ }^{400}$. Dicho Juan de

http://www.britishmuseum.org/research/collection_online/collection_object_details.aspx?objectId=14244 29\&partId=1\&searchText=hans+baldung+grien\&images=on\&page=1; HOLLSTEIN, F. W. H., German engravings, etchings and woodcuts..., p. 51.

${ }^{400}$ ARRANZ ARRANZ, J., El Renacimiento en la Diócesis..., p. 360. 
Soria fue secretario "del muy esclarecido principe de Castilla, Don Juan, de gloriosa memoria" según recoge la inscripción.

Se trata de un retablo renacentista estructurado en tres calles y tres pisos (fig. 137). Está compuesto por pinturas sobre tabla que representan en la calle central la Visitación de la Virgen, San Emeterio y San Celedonio y también la Presentación de Jesús en el Templo. A la izquierda se encuentran San Jorge, San Cristobal y la Estigmatización de San Francisco. A la derecha, El rico Epulón y el pobre Lázaro, la Comunión de Santa María Egipciaca y Santa Catalina. La arquitectura se decora con motivos platerescos. Es un retablo de medianas dimensiones, que consta de banco, dos cuerpos y tres calles. La central destaca por su altura. Su traza sigue el estilo "romano", y se decora con motivos a candelieri, máscaras y motivos vegetales que cubren las estructuras del mismo. El mueble aparece protegido por una polsera ricamente decorada, que se encaja en el nicho que acoge el retablo. En las esquinas superiores, un cordón anudado enmarca el conjunto. El retablo tiene la misma traza y decoración que el de la capilla mayor. Se trata de una obra del mismo entallador, Antonio de Baños, realizada en la misma época que el Retablo de San Miguel en la segunda década del siglo $\mathrm{XVI}^{401}$.

En cuanto a la pintura, el retablo se compone de nueve tablas pintadas al óleo con toques en temple ${ }^{402}$ en las que se representan escenas de santos que fueron objeto de gran devoción a principios del siglo XVI. En el eje central del retablo se colocan las escenas más importantes, como son la tabla de los santos titulares y dos momentos de la vida de la Virgen: en el centro del banco la Visitación, y en el ático la Purificación. Posiblemente está ubicación de las escenas corresponda al deseo expreso de los comitentes de dedicar el retablo a la alabanza de Dios y la Virgen y también a la invocación a los santos Celedonio y Medel.

La obra manifiesta que, aunque se adoptaran muchas de las nuevas formas procedentes de Italia, sobre todo en la mazonería, las tablas muestran el gran peso que tenía aún la pintura hispanoflamenca, si bien suavizada por las nuevas maneras renacientes. Es evidente la existencia de una nueva sensibilidad, que se muestra a través de las formas elegantes, el equilibrio de los colores y una búsqueda de la belleza ideal.

\footnotetext{
${ }^{401}$ PEÑA GARCÍA, M., Historia y arte..., p. 194.

${ }^{402}$ CARDONA JIMÉNEZ, V., "El retablo de los Santos Emeterio y Celedonio de Ágreda (Soria): estudio iconográfico y estilístico" en Memoria final de la restauración del retablo de San Emeterio y San Celedonio de la Iglesia de San Miguel Arcángel de Ágreda (Soria), Empresa Albarium, s. 1. ABRIL2008, Web de la Junta de Castilla y León, p. 31.

URL: https://issuu.com/proyectourdimbre/docs/memoria_final_san_emeterio_i
} 


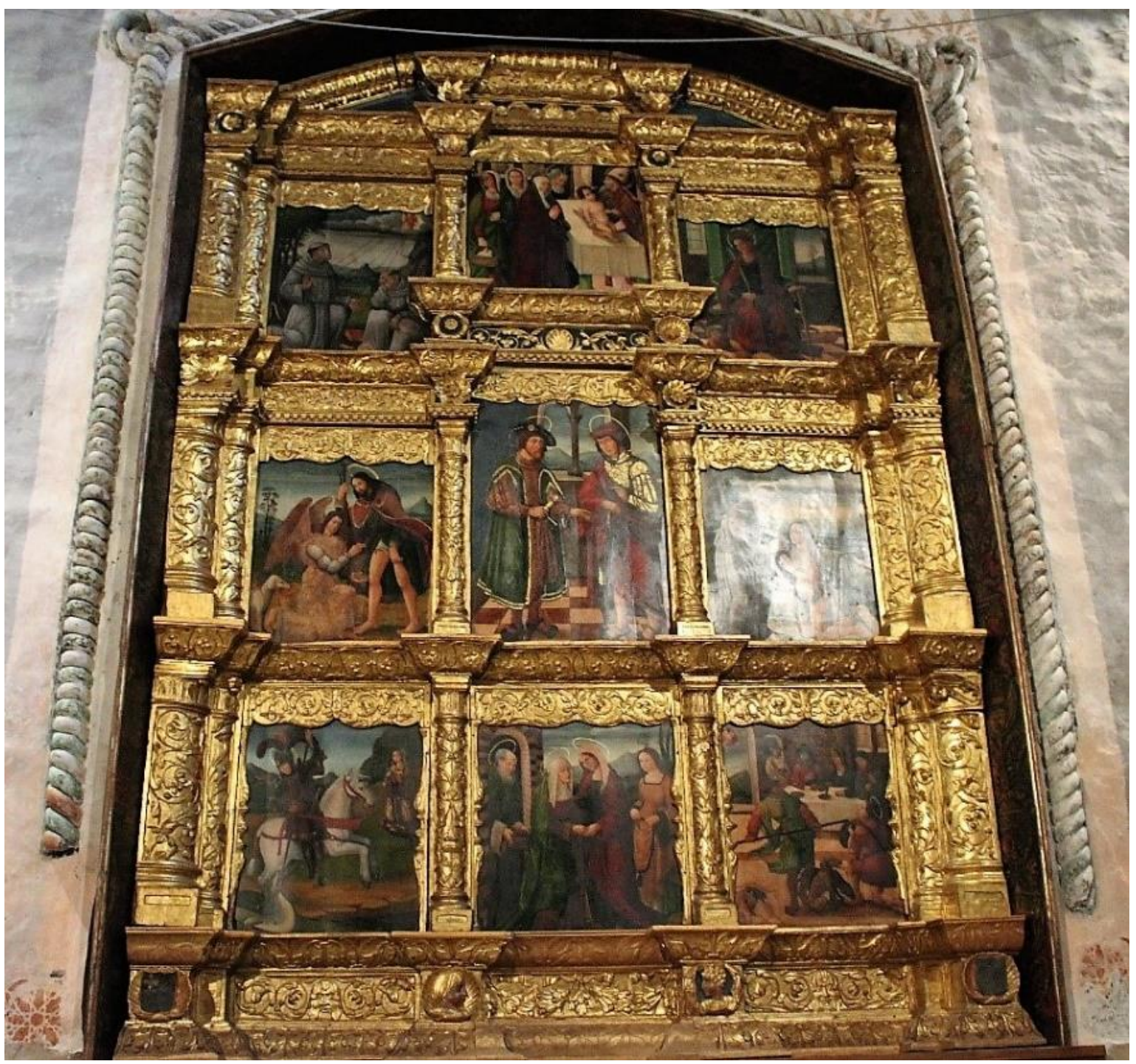

137. Anónimo. Retablo de San Medel y San Celedonio. Segundo cuarto del siglo XVI. Iglesia de San Miguel. Ágreda (Soria).

A pesar de ello el pintor incurrió en algunos errores, por ejemplo a la hora de plasmar los espacios a través de la perspectiva geométrica basada en las teorías de Brunelleschi y Alberti. Un detalle que muestra el arcaismo que aún manifiestan estas pinturas es su forma de articular las composiciones: primero se colocan las figuras en primer plano, y por tanto se da a los fondos poca importancia (al contrario de lo que hacían los pintores italianos, que primero creaban los fondos arquitectonicos o paisajisticos y después las figuras). Se trata de un procedimiento ya usado por Pedro 
Berruguete ( $c a$. 1450-1503) $)^{403}$. No se trata de grandes escenografías. El pintor muestra dificultades a la hora de adaptar las figuras al marco en que se desarrollan las escenas.

Generalmente utilizó como fondos paisajes donde siempre aparecen más nítidas las figuras que están más cerca, y más difuminadas las más lejanas. Aunque podría haberse inspirado en el sfumato de Leonardo, es más probable que conociera ese tipo de recursos a través de estampas. También pudo basarse en grabados a la hora de plasmar la caida de los paños, de forma natural, y en la idealización de algunos de los rostros.

El cromatismo es homogéneo. Predominan los colores intensos, sobre todo rojos y verdes, junto con grises y ocres. El oro se aplica sólo en los nimbos de los santos, en algunos detalles de los ropajes y en algún que otro fondo. Respecto al estilo, es evidente que las diferentes pinturas pertenecen a una misma escuela o taller. Debido a las influencias de algunos importantes pintores de la época como el Maestro de Osma (en los rostros y la ingenuidad de algunas figuras) o Juan Soreda (el uso de los colores y ciertos modelos humanos), se podría datar el retablo en torno al segundo cuarto del siglo $\mathrm{XVI}^{404}$.

\section{San Jorge y el dragón}

Los atributos de San Jorge en esta pintura de Ágreda son la lanza y el dragón o serpiente, que aparece sometido a sus pies (fig. 138). En esta ocasión el santo no blande el estandarte blanco con la cruz roja que es el símbolo de los cruzados (fig. 139). Para configurar esta escena el pintor se sirvió de la estampa del mismo tema de Altdorfer (1511) (fig. 140) $)^{405}$.

\footnotetext{
${ }^{403}$ GARRIGA RIERA, J., "Diestros en el contra açer de la vista...": La perspectiva lineal y los talleres de pintores hispanos en el siglo XVI", en El modelo italiano en las artes plásticas de la Península Ibérica durante el Renacimiento, Universidad de Valladolid, 2004, p. 138 y "Geometría espacial en la pintura de Pedro Berruguete en Castilla", en Pedro Berruguete y su entorno, Diputación de Palencia, 2004, pp. 214215.

${ }^{404}$ CARDONA JIMÉNEZ, V., "El retablo de los santos...", pp. 32-33. En abril de 2008 se llevó a cabo una restauración del retablo por parte de la empresa Albarium S.L. Se limpiaron la mazonería y las tablas de pintura; se desmontó el retablo y se realizó una revisión del estado de conservación de la armadura, construyéndose al final una nueva; se hizo un tratamiento antixilófagos, y se mejoró la estabilidad del conjunto a través de la restauración de la carpintería; por último, se utilizó un tratamiento de conservación de aparejos, policromías y dorados. En la misma obra pp. 83-173.

${ }^{405}$ Estampa disponible en:

http://www.britishmuseum.org/research/collection_online/collection_object details.aspx?objectId=14232 20\&partId=1\&searchText=saint+george\&images $=$ true \&people $=134476 \&$ page $=1$

BARTSCH, A., op. cit., vol. VIII, p. 79; DODGSON, C., Catalogue of Early German and Flemish Woodcuts..., vol. II, $\mathrm{n}^{\circ}$ 56, p. 229; HOLLSTEIN, F. W. H., The New Hollstein: Dutch and Flemish etchings, engravings and woodcuts 1450-1700 (Altdorfer), w. 58 I, Amsterdam, pp. 134-135.
} 
El penacho del yelmo del caballero es idéntico al de la estampa, aunque con plumas menos abundantes. Así mismo, sigue la misma postura, aunque está invertida: en la pintura soriana el caballero ataca el dragón por el lado izquierdo, y en la estampa lo hace al revés. El caballo también está representado de manera muy parecida. El escarpado fondo de la estampa no aparece en el cuadro y la figura de la princesa tampoco se inspira en la misma. La estampa de Durero (1503-04) (fig. 141) (06407 $^{\text {tiene }}$ también semejanzas con el cuadro en cuanto a la estética del caballero.

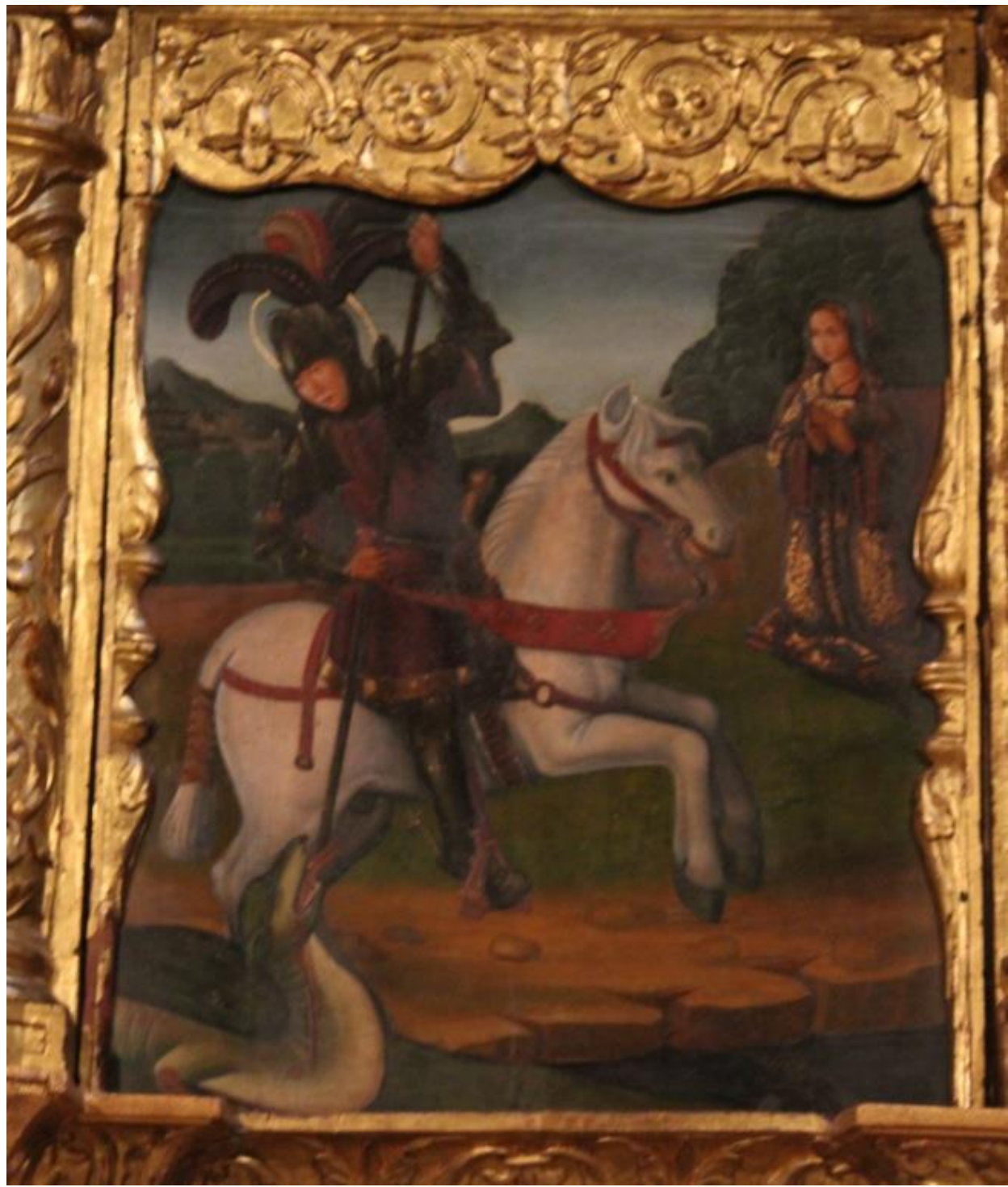

138. Anónimo, San Jorge y el dragón. Ca. 1525-1550. Retablo de San Medel y San Celedonio. Iglesia de San Miguel. Ágreda (Soria)).

${ }^{406}$ CARDONA JIMÉNEZ, V., “El retablo de los santos...”, pp. 18-19.

${ }^{407}$ Estampa disponible en:

http://www.britishmuseum.org/research/collection_online/collection_object_details.aspx?objectId=13556 49\&partId=1\&searchText $=$ saint + george \&images $=$ true \&people $=127877 \&$ page $=1$

BARTSCH, A., op. cit., vol. VII, p. 138; DODGSON, C., Catalogue of Early German and Flemish Woodcuts...., vol. I, $\mathrm{n}^{\mathrm{o}}$ 36, p. 287; MEDER, J., op. cit., $\mathrm{n}^{\mathrm{o}}$ 225, p. 189; SCHOCH, R., op. cit., vol. II, $\mathrm{n}^{\circ}$ 138, pp. 135-137. 


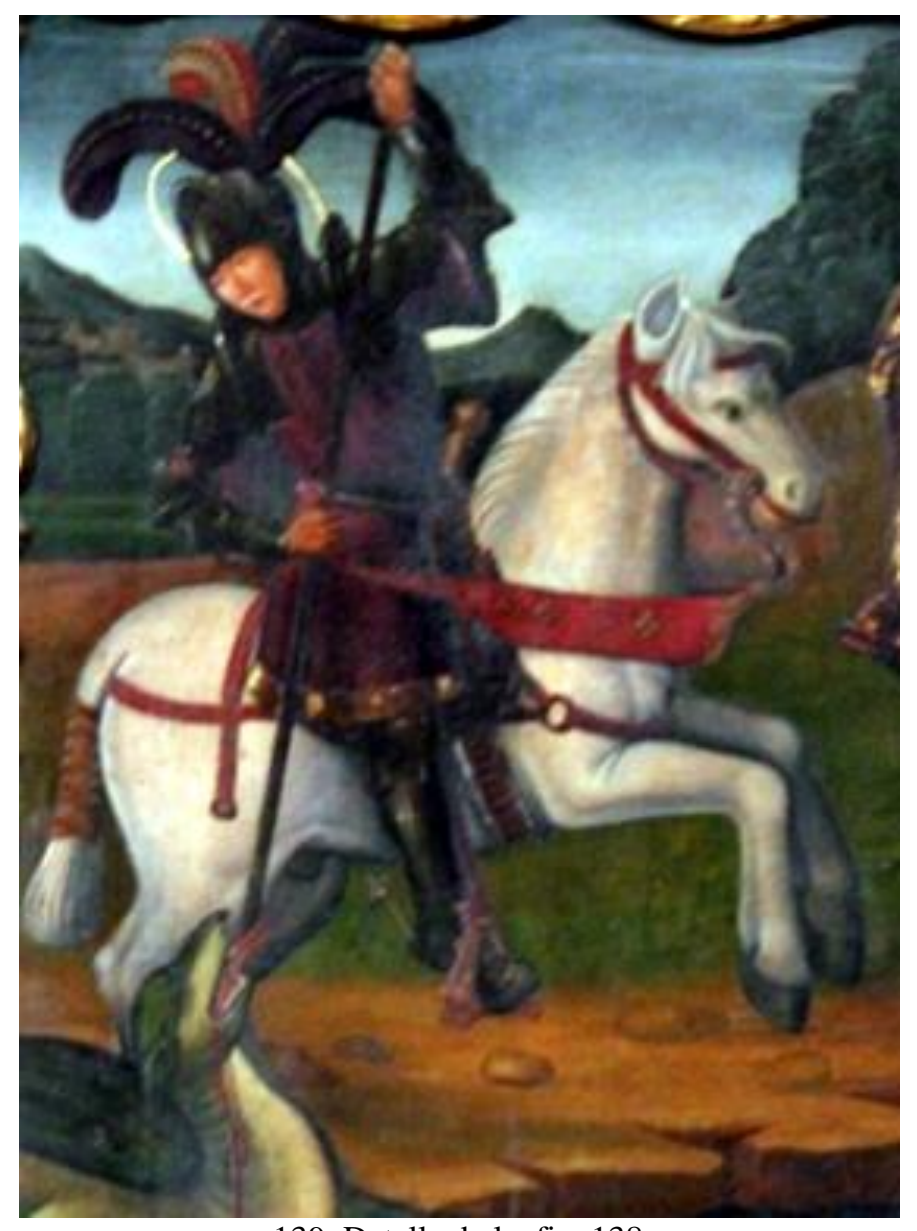

139. Detalle de la fig. 138.

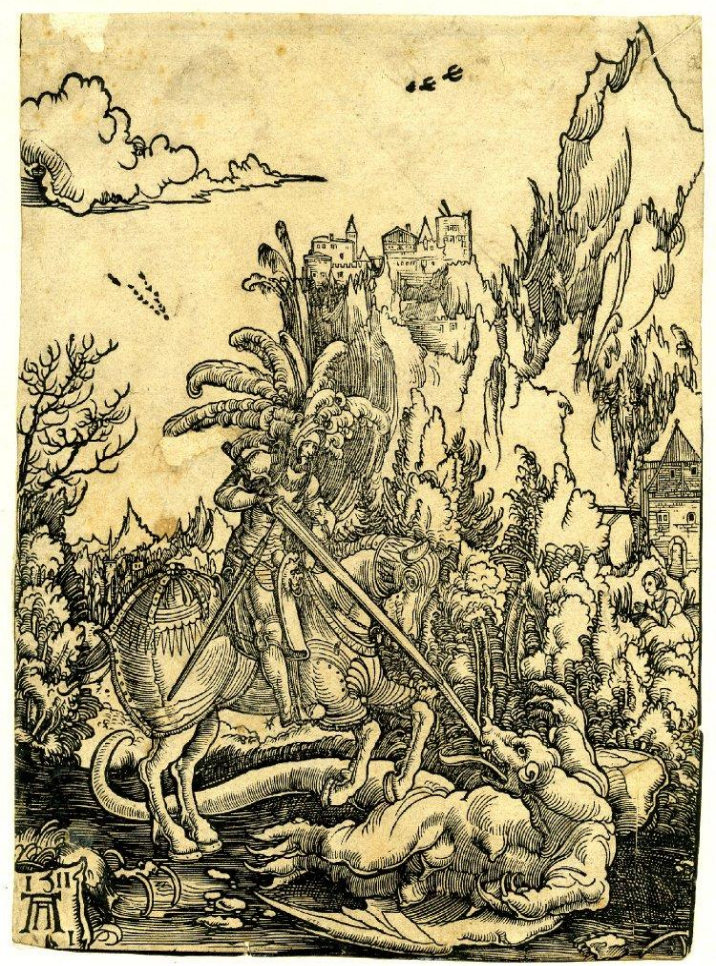

140. Altdorfer. San Jorge y el dragón. 1511. Museo Británico. Londres (ReinoUnido).

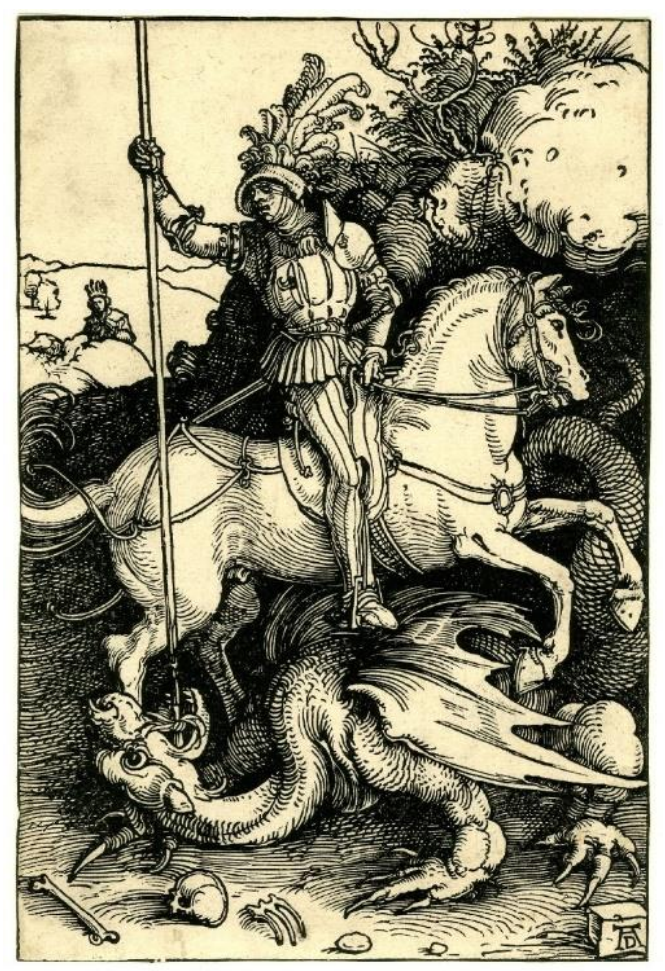

141. Alberto Durero. San Jorge y el dragón. 1504-05. Museo Británico. Londres (ReinoUnido). 


\section{Visitación}

En esta escena (fig. 142) el pintor parece haberse inspirado parcialmente en la estampa del mismo tema de Alberto Durero (fig. 143) ${ }^{408409}$.

La figura de Zacarías saliendo de la puerta con arco de medio punto es muy semejante, así como su emplazamiento al aire libre en un paisaje montañoso, y los árboles situados a la derecha de la composición. No tomó sin embargo ni las figuras de las criadas situadas a la derecha de las escena, ni el perrito situado a los pies de Zacarías. El pintor simplificó las vestimentas y la composición, creando una escena bastante más sencilla que la del grabado.

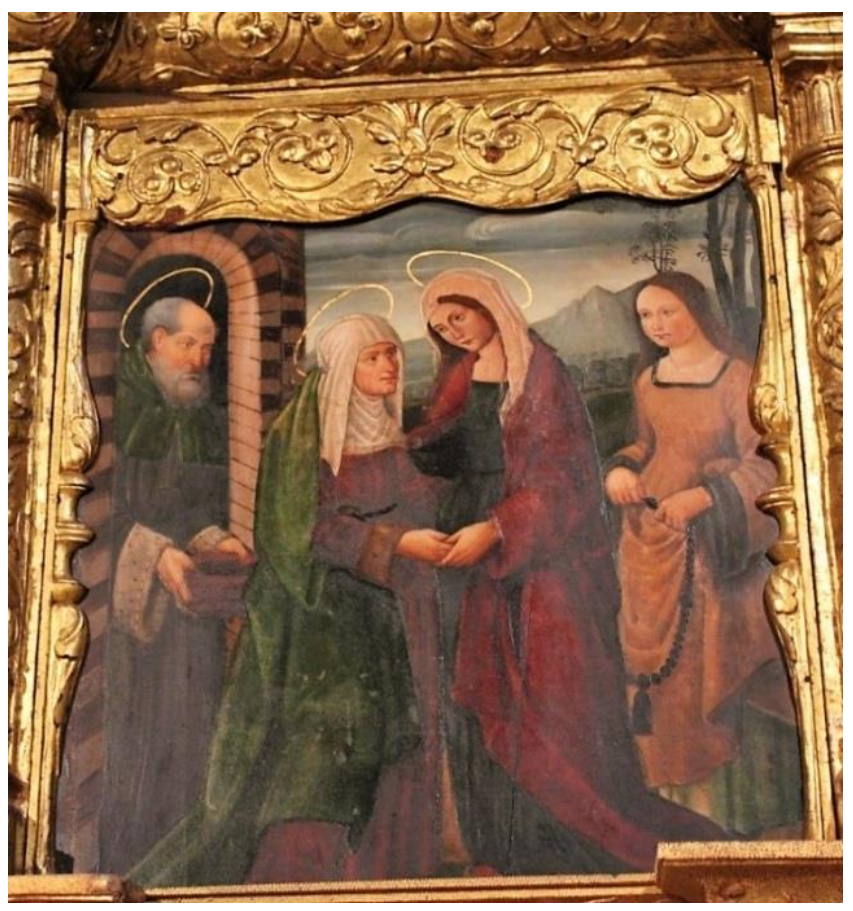

142. Anónimo de escuela castellana. Visitación. Retablo de San Medel y San Celedonio. 1525-1550. Iglesia de San Miguel. Ágreda (Soria).

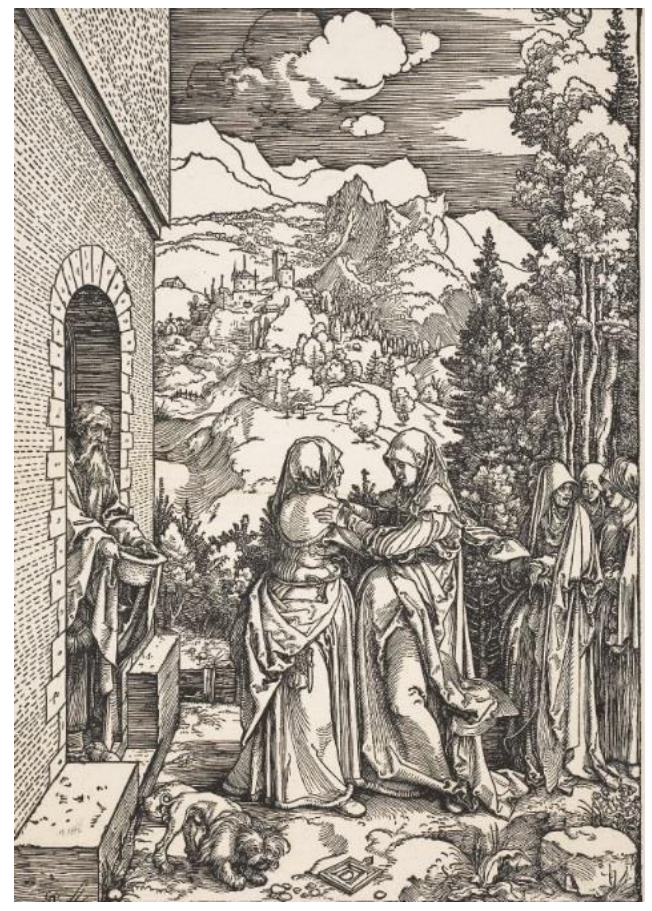

143. Alberto Durero. Visitación. 1503-1504.

Museo Británico. Londres (ReinoUnido.

\section{Anónimo \\ Retablo de Santiago en la iglesia de Nuestra Señora de la Muela Monteagudo de las Vicarías (Soria) \\ Ca. 1524}

Ubicado en una de las capillas laterales situadas al pie de la iglesia, en la inscripción de la predela está escrito que el retablo lo mandó hacer Juan Martínez y sus

\footnotetext{
${ }^{408}$ CARDONA JIMÉNEZ, V., "El retablo de los santos...”, p. 20.

${ }^{409}$ Estampa disponible en:

http://www.britishmuseum.org/research/collection_online/collection_object_details.aspx?objectId=14042 28\&partId=1\&searchText=visitation \&images $=$ true \&people $=127877 \&$ page $=1$

BARTSCH, A., op. cit., vol. VII, p. 132; DODGSON, C., Catalogue of Early German and Flemish Woodcuts..., vol. I, n 44, p. 289; MEDER, J., op. cit., $\mathrm{n}^{\mathrm{o}}$ 196, p. 173; SCHOCH, R., op. cit., vol. II, $\mathrm{n}^{\circ}$ 174 , pp. 246-248.
} 
hijos, así como que fue terminado en el mes de septiembre de $1524^{410}$. Tiene forma de tríptico, con predela y tres calles. Las escenas están separadas por sencillos marcos platerescos (fig. 144) ${ }^{411}$.

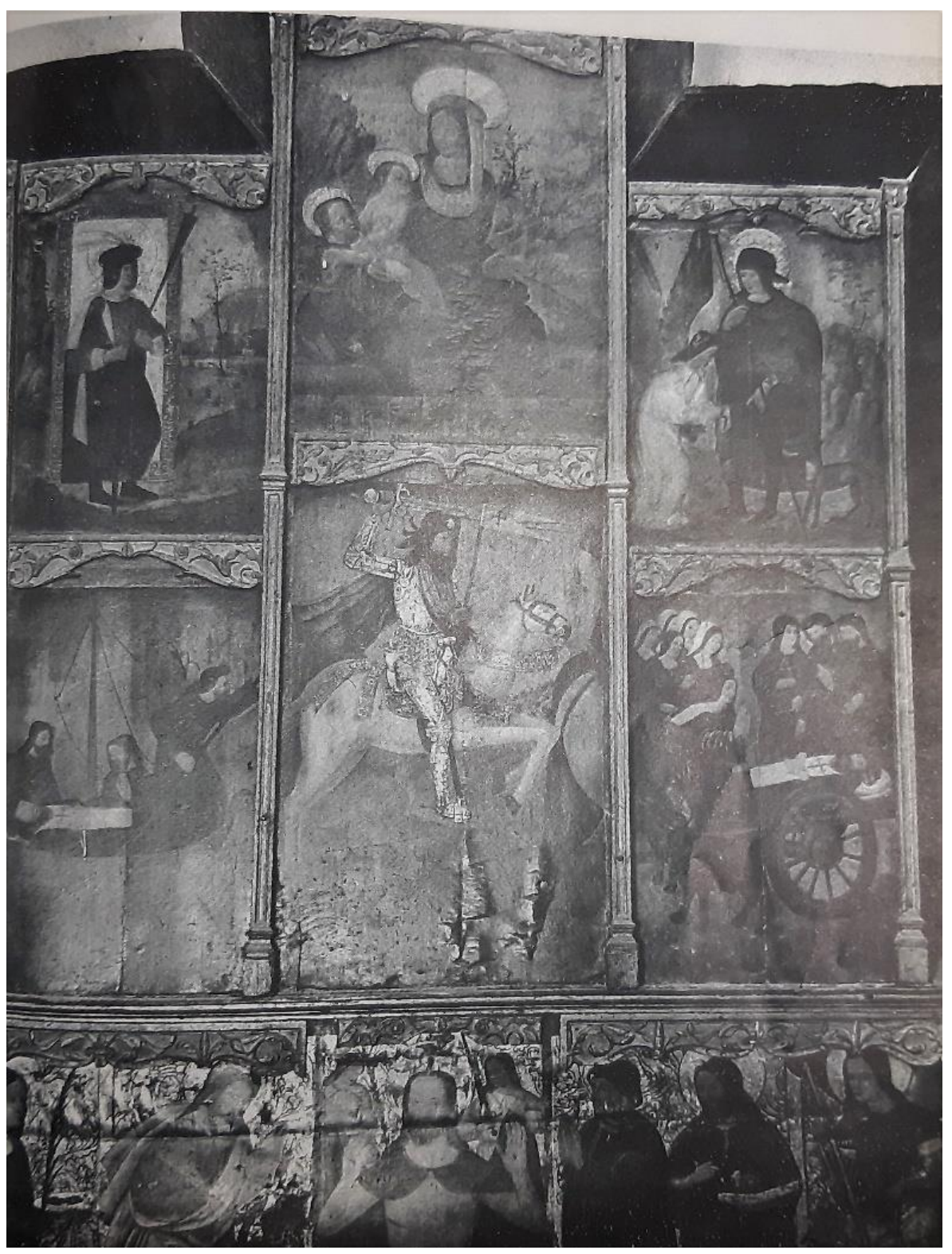

144. Anónimo. Ca. 1524. Retablo de Santiago.

Iglesia de Nuestra Señora de la Muela. Monteagudo de las Vicarías (Soria).

El retablo muestra un estilo que mezcla lo gótico hispanoflamenco y un incipiente lenguaje renacentista. Su estructura sigue siendo gótica, si bien se han añadido algunos detalles platerescos. El banco mantiene el su uso de los fondos dorados, más propio del Gótico; las escenas superiores muestran una mayor influencia

\footnotetext{
${ }^{410}$ ALCOLEA BLANCH, S., op. cit., pp. 116-118; VV. AA., Inventario artístico de Soria ..., vol. I, p. 52.

${ }^{411}$ Imagen procedente de ARRANZ ARRANZ, J., Renacimiento en la Diócesis..., p. 342.
} 
del Renacimiento italiano, si tenemos en cuenta el uso de las estampas. Parece tener influencia de la pintura aragonesa que se realizaba en aquellos momentos, en concreto de Pedro de Aponte ${ }^{412}$.

En la predela se representan los temas de Cristo mostrando las llagas junto a la figura del donante, San Juan Bautista, Santiago, Santa Inés y Santa Bárbara.

En las tablas laterales las escenas figuradas son: el Traslado del cuerpo del apóstol Santiago, en el centro la imagen de Santiago Matamoros, el Milagro de los toros de la reina Lupa, sobre éste la imagen de la Virgen con el Niño y San Juanito, y en los laterales la imagen de San Roque siendo curado por un ángel y la de San Sebastián.

\section{Virgen con el Niño y San Juanito}

La escena de la Virgen con el Niño y San Juanito (fig. 145) situada en la parte superior, se inspira parcialmente en el grabado de Marcantonio Raimondi Virgen con Niño sobre nubes (fig. 147) para el tocado, la forma del rostro, con los ojos que miran hacia el Niño y la aureola de la Virgen (fig. 146) ${ }^{413}$. El artista ha captado perfectamente la dulzura y serenidad que transmite la composición de Raimondi, a pesar de su torpeza a la hora de representar algunas partes anatómicas como las manos. El fondo nebuloso de la estampa ha sido sustituido aquí por un paisaje árido en el cual sólo se vislumbran algunos arbolitos raquíticos y rocas.

Por otro lado, tenemos la figura de San Juanito, situado a la izquierda de la composión, junto al Niño, que le sujeta por los brazos. La postura de San Juanito se ha basado, aunque sea vagamente, en un grabado de Raimondi (fig. 148), la Virgen de la palmera (fig. 149) ${ }^{414}$ del 1520-1530, donde la figura de San Juanito aparece también arrodillada y luciendo una vestimenta muy semejante a la de la estampa.

\footnotetext{
${ }^{412}$ FIZ FUERTES, I., "Retablo de Santiago", en Paisaje interior. Las Edades del Hombre, Fundación Las Edades del Hombre, 2009, nº 88, pp. 389-390.

${ }^{413}$ FIZ FUERTES, I., "Retablo de Santiago", op. cit., pp. 389-390

${ }^{414}$ Estampa disponible en:

http://www.britishmuseum.org/research/collection_online/collection_object_details.aspx?objectId=14328 $19 \&$ partId $=1 \&$ searchText=virgin $+\&$ images $=$ true \&people $=115934 \&$ from $=a d \&$ fromDate $=1520 \&$ to $=a d \& t$ oDate $=1530 \&$ page $=1$

BARTSCH, A., op. cit., vol. XIV, p. 69; PASSAVANT, J. D., op. cit., vol. VI, p. 25; LE BLANC, C., Manuel de l'amateur d'estampes 1550-1820, París, 1854, nº 28, p. 275; DELABORDE, H., op. cit., $\mathrm{n}^{\circ}$ 13, p. 96.
} 
145. Anónimo.

Virgen con el Niño y

San Juanito. Ca. 1524

Retablo de Santiago,

Iglesia de Nuestra

Señora de la Muela.

Monteagudo de las

Vicarías (Soria).

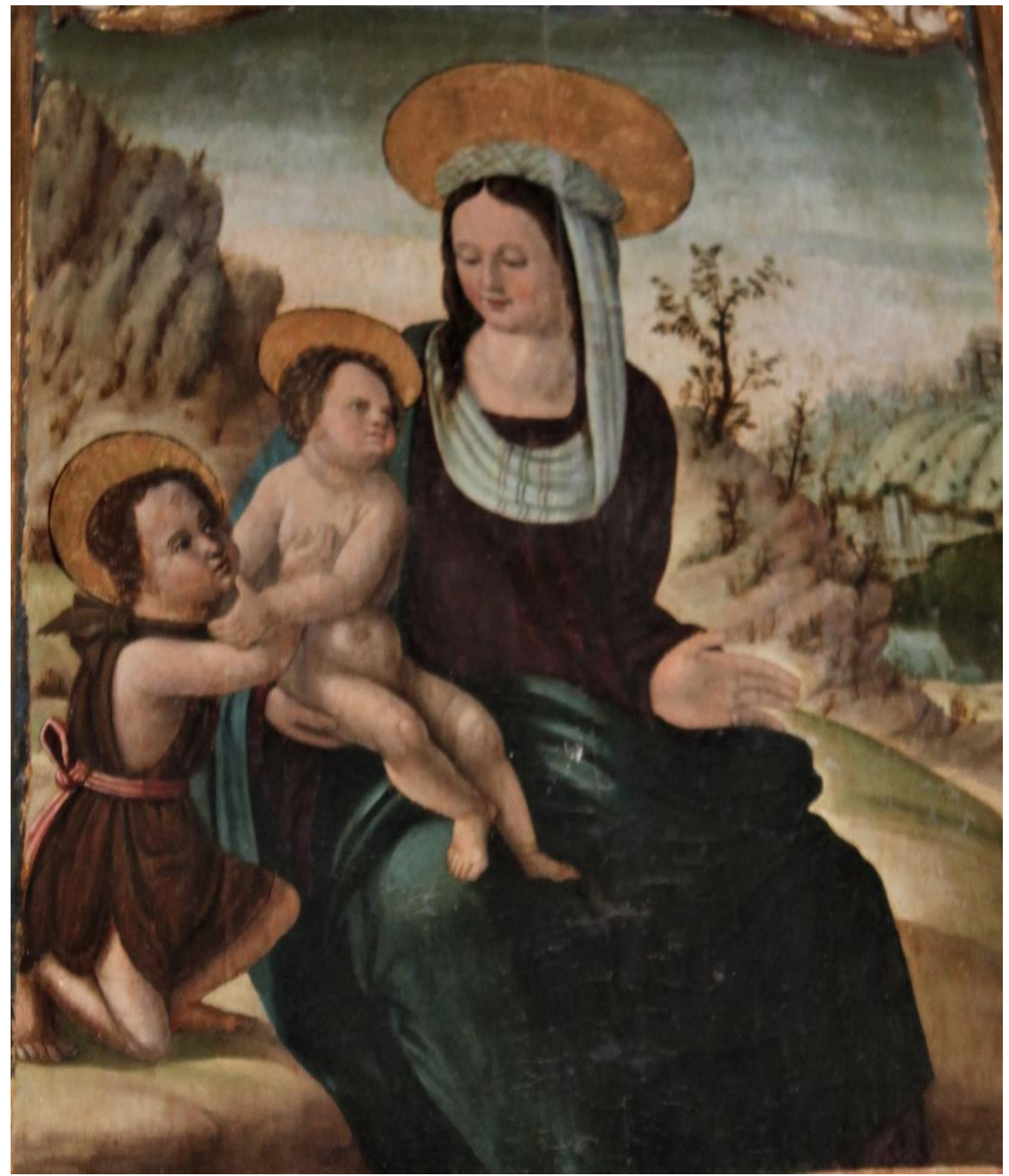

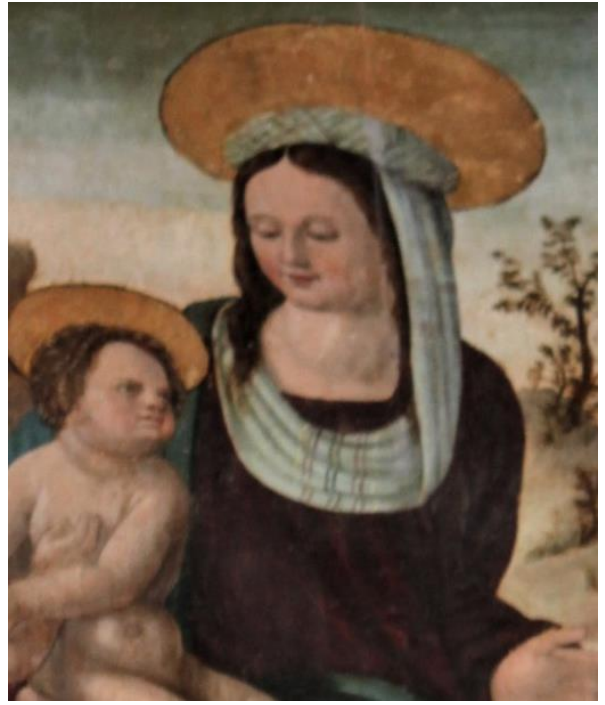

146. Anónimo. Detalle de la fig. 145.

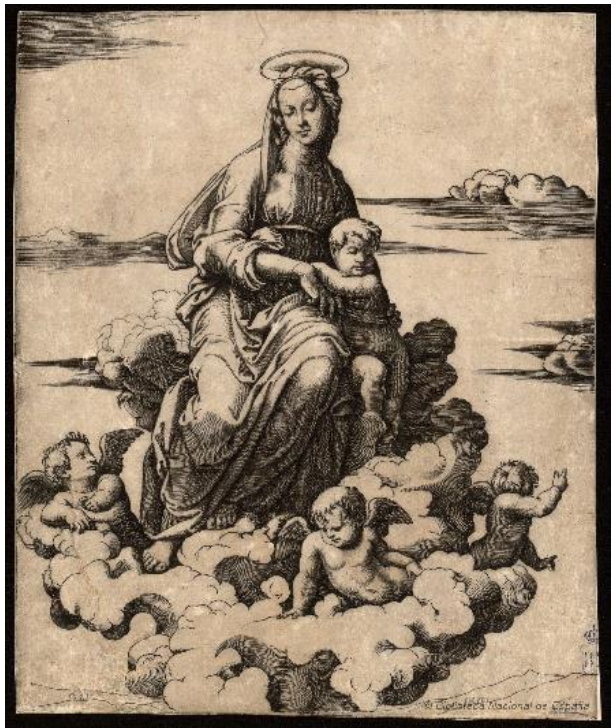

147. Marcantonio Raimondi. Virgen con niño sobre nubes. 1513.

Biblioteca Nacional. Madrid 


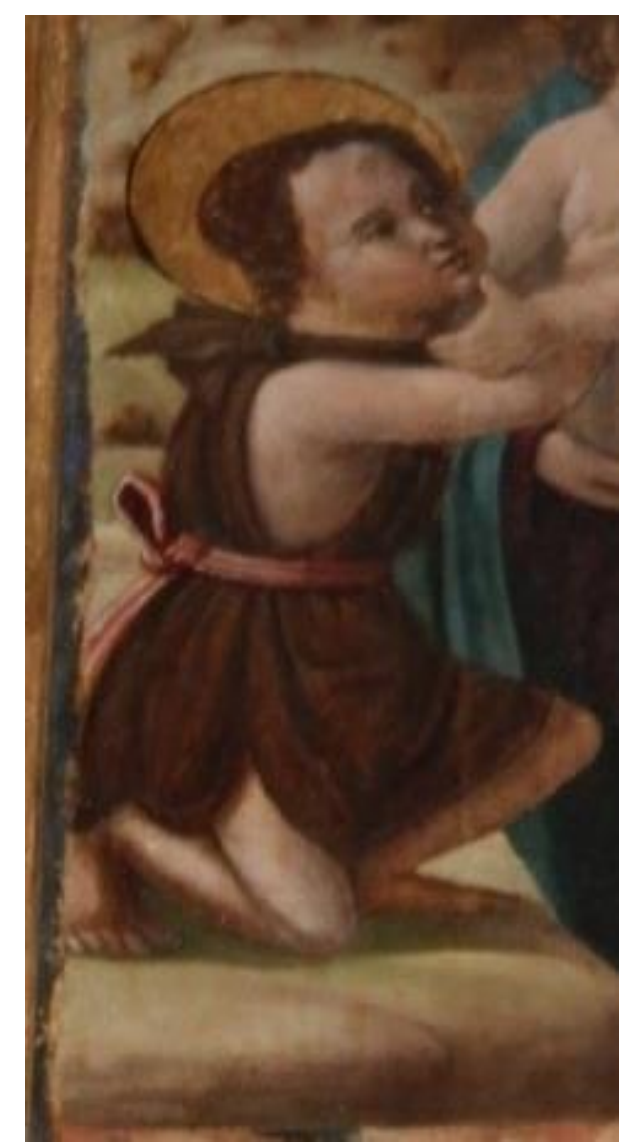

148. Detalle de la fig. 145.

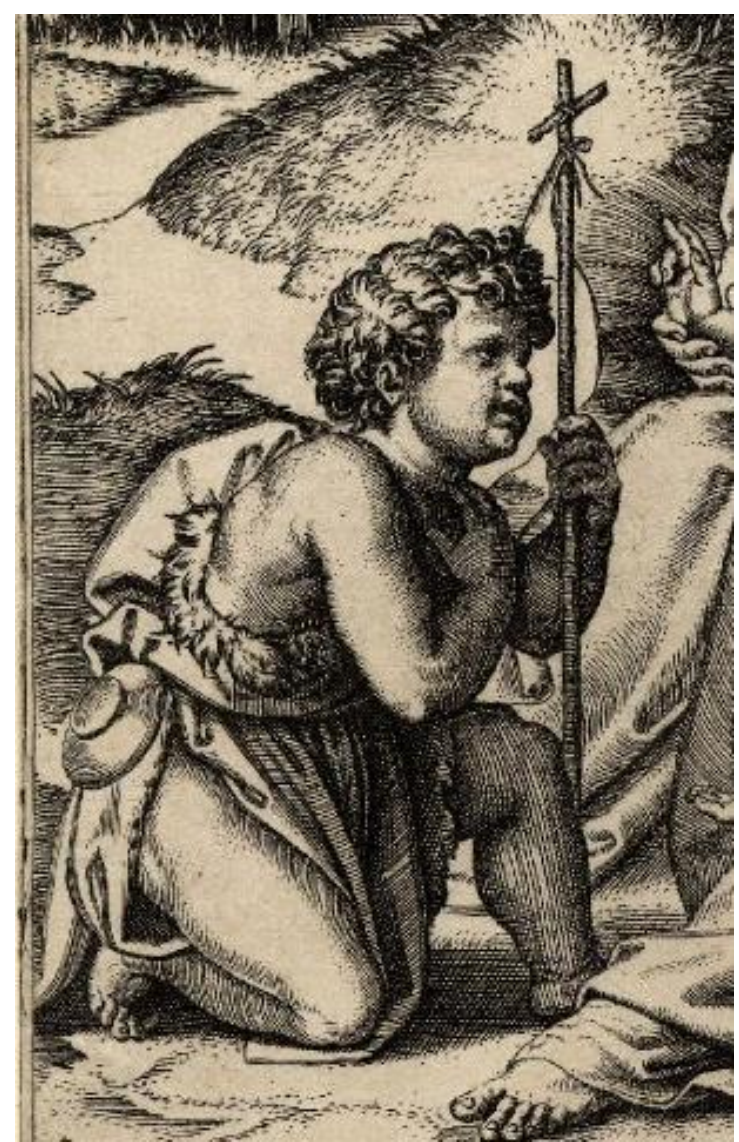

149. Marcantonio Raimondi. Detalle de Virgen de la palmera. $1520-1530$.

Museo Británico. Londres (ReinoUnido).

\section{Anónimo \\ Retablo de la Flagelación \\ 1543 \\ Iglesia de Santa María \\ Yanguas (Soria)}

Es la primera obra escultórica de la zona en inspirarse en grabados. Es un retablo que representa diferentes momentos de la Pasión y Resurrección de Cristo (fig. 150). Se ubica en el lado del Evangelio.

Probablemente procediera de la antigua iglesia de San Miguel de Yanguas, actualmente en ruinas y parece que más tarde estuvo también en la de San Lorenzo ${ }^{415}$. Se engloba dentro del círculo castellano-riojano, ya que ésta iglesia perteneció a la Diócesis de Calahorra $^{416}$. Es característico de esta zona el uso de dorados en los relieves.

\footnotetext{
${ }^{415}$ BONAFÉ VALDUÉRTELES, B., Yanguas, Soria: Guía histórico artística, Grupo CG Inmakor, 2016, p. 90.

${ }^{416}$ ARRANZ ARRANZ, J., El Renacimiento en la Diócesis..., p. 162.
} 


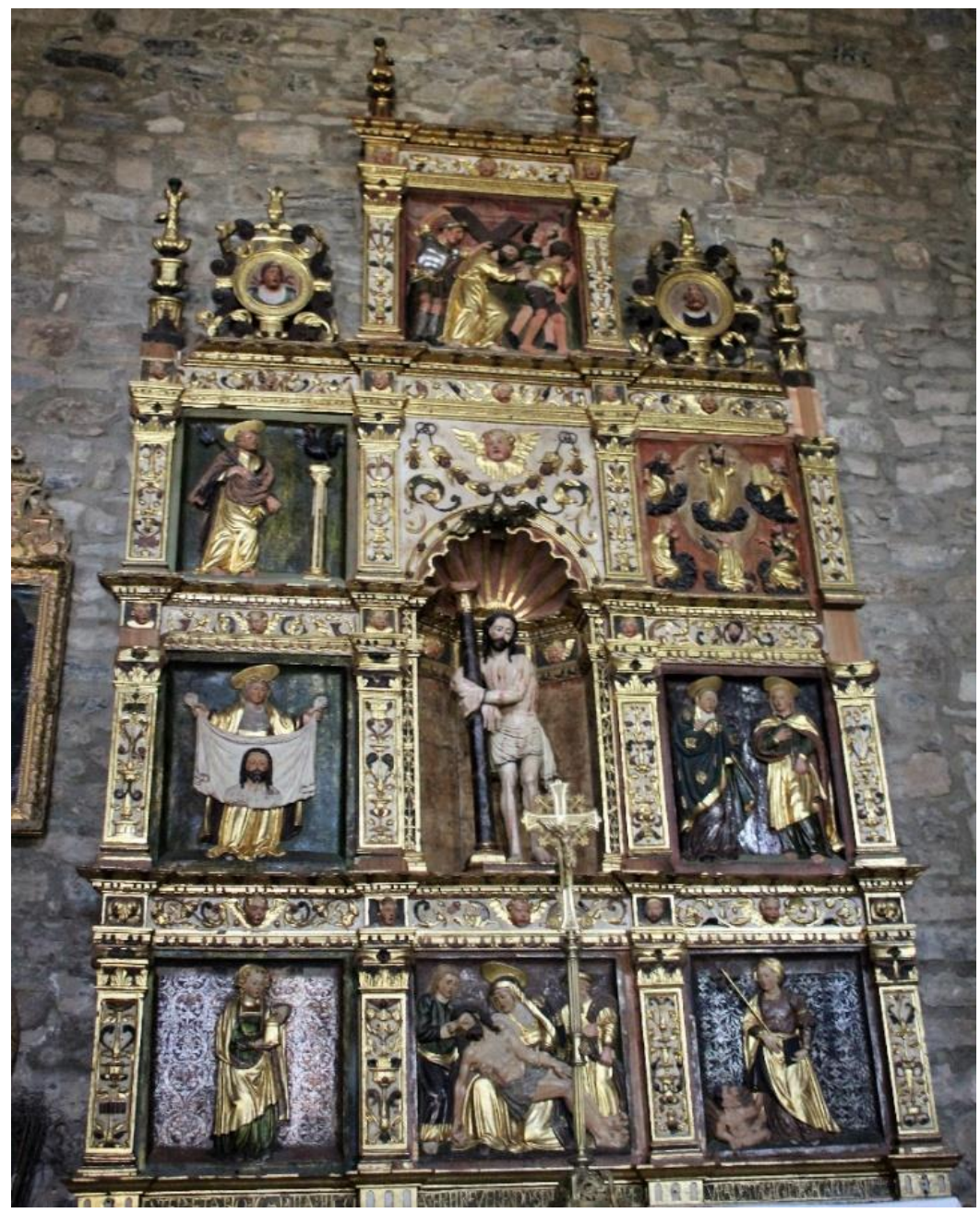

150. Anónimo. Ca. 1543. Iglesia parroquial de Santa María. Yanguas (Soria).

La arquitectura del retablo es de un Renacimiento temprano. Esta formado por un banco, dos cuerpos y el remate, separados mediante frisos con decoración a candelieri y grutescos. Resalta por su magnificencia el cuerpo central, que culmina en una venera decorada con grutescos. Otros motivos decorativos renacentistas son dos tondos con cabezas humanas o los roleos vegetales. Está realizado en madera policromada .

En el transversal inferior del banco aparece la siguiente inscripción: "este retablo y capilla hizo hacer el Reverendo Señor Diego Álvarez, Cura de estas iglesias. Acabose el año de 1514". En realidad actualmente se ha identificado dicha fecha con 1543, debido tanto a la grafía como al estilo ${ }^{417}$. Yanguas alcanzó un importante desarrollo económico a principios del siglo XVI, lo que se plasmó en importantes obras de arte.

\footnotetext{
${ }^{417}$ PAYO HERNANZ, R. J., "Retablo de la Flagelación", en Las Edades del Hombre. Paisaje Interior, Soria: 2009, Fundación Las Edades del Hombre, 2009, n 128, p. 467; VV. AA., Inventario artístico de Soria ..., vol. II, p. 149.
} 


\section{La Verónica}

La figura de la Verónica fue difundida a través de diferentes estampas de origen alemán $^{418}$, comenzando por la de Durero, Santa Verónica entre San Pedro y San Pablo (fig. 152) ${ }^{419}$, perteneciente a la Pequeña Pasión, datada entre 1510-15. Sin embargo, ésta (fig. 151) se encuentra más próxima al grabado del artista alemán Hans Schaufelein entre 1511-1515 (fig. 153) ${ }^{420}$. Ejemplos de ello son la forma del halo sobre la cabeza cubierta por un manto o velo y su posición más frontal que otras obras de la época. Otra semejanza sería la cabeza de Cristo que carece de corona de espinas.

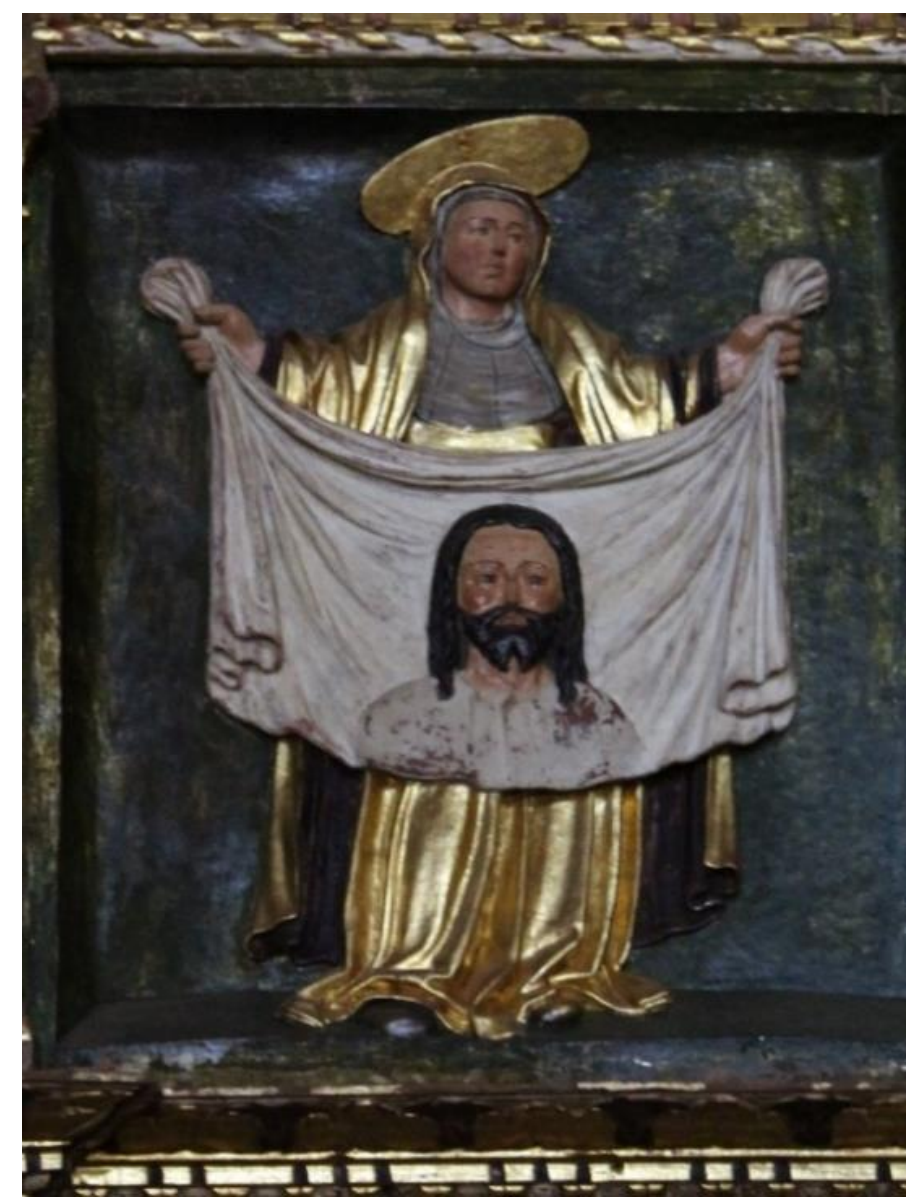

151. Anónimo. La Verónica. Retablo de la Flagelación. Ca. 1543. Iglesia parroquial. Santa María de Yanguas (Soria)

\footnotetext{
${ }^{418}$ PAYO HERNANZ, R. J., "Retablo de la Flagelación”, p. 470.

${ }^{419}$ Estampa disponible en: http://www.britishmuseum.org/research/collection_online/collection_object_details.aspx?objectId=14397 79\&partId $=1 \&$ searchText=saint+veronica\&images $=$ on\&page $=1$ BARTSCH, A., op. cit., vol. XIV, p. 404.

${ }^{420}$ Estampa disponible en: VV. AA., The Illustrated Bartsch, Hans Baldung Grien, Hans Springinklee, Lucas Van Leyden, vol. 12, Nueva York, Abaris Books, 1981, p. 247.

BARTSCH, A., op. cit., vol. VII, p. 257; DODGSON, C., Catalogue of Early German and Flemish Woodcuts..., $\mathrm{n}^{\circ}$ 16, p. 77; HOLLSTEIN, F. W. H., Dutch and Flemish etchings, engravings and woodcuts..., vol. XLII, nº 30, pp. 118.
} 


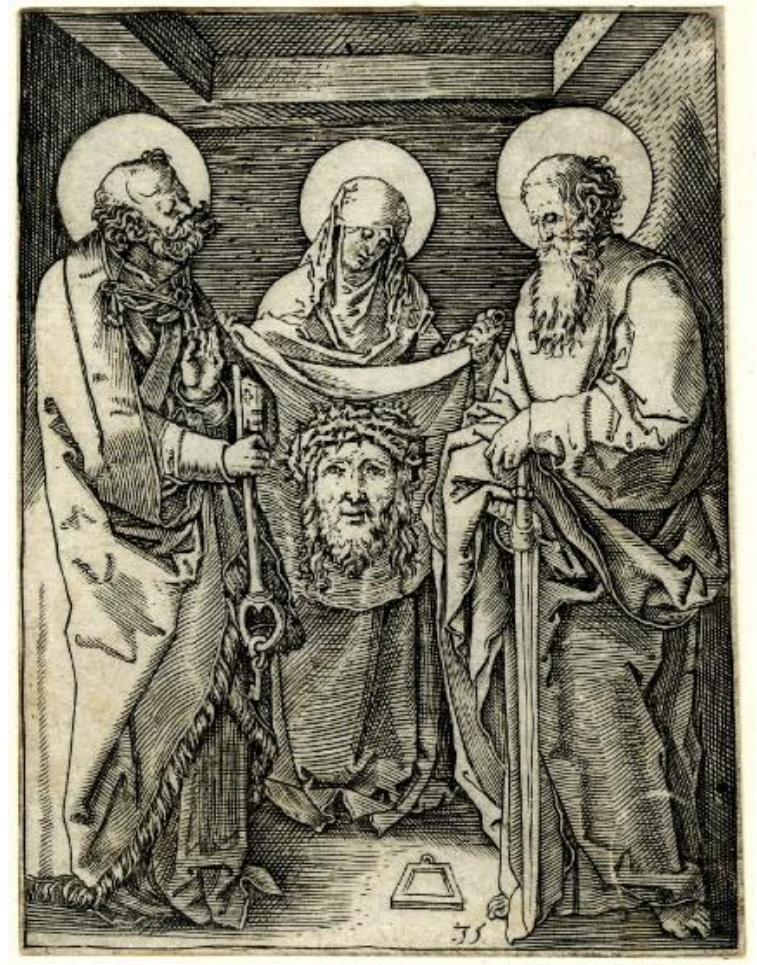

152. Alberto Durero. La Verónica entre San Pedro y San Pablo. Pequeña Pasión. 1510-1515. Museo Británico. Londres (ReinoUnido).

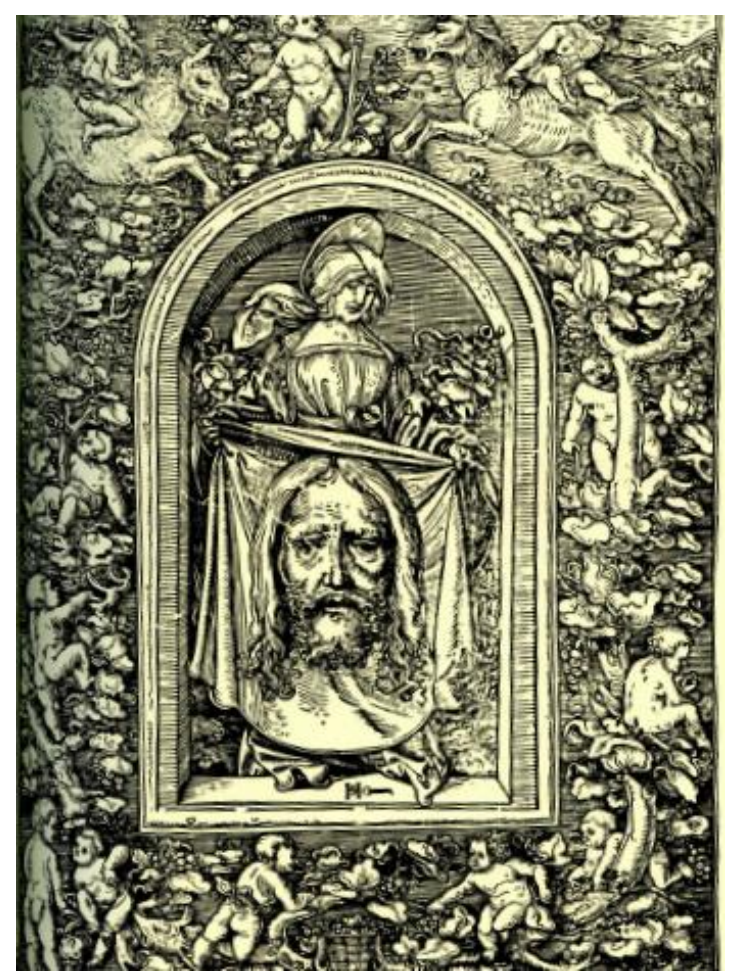

153. Hans Schäufelein. Santa Verónica, 1500-1540. Museo Británico. Londres ((ReinoUnido).

\section{Cristo camino del Calvario}

En el relieve de Cristo camino del Calvario (fig .154), el artista pudo inspirarse en el grabado de Hans Schaufelein (fig. 155) ${ }^{421}$, aunque invertido y con algunas variaciones. En el relieve, Cristo no apoya su brazo derecho en el suelo sino que sujeta con las dos manos un brazo de la cruz. La figura del soldado que arrastra a Cristo es muy parecida. Sus piernas tienen la misma postura y sujeta así mismo la cuerda con su brazo derecho por encima del hombro, mientras que con la izquierda la recoge por debajo. Existen otros grabados donde aparece representada la misma figura como en algunas estampas del mismo tema de Schongauer (fig. 156) ${ }^{422}$. En el relieve se elude representar todo tipo de fondo o espacio arquitectónico, así como el resto de figuras que aparecen en los dos grabados, limitandose a añadir la figura de la derecha que aparece tocando la trompeta.

\footnotetext{
${ }^{421}$ Estampa disponible en: https://research.britishmuseum.org/research/collection_online/collection_object_details.aspx?objectId=14 67050\&partId=1\&searchText=schaufelein $\&$ from=ad \&fromDate=1509\&to=ad\&toDate=1512\&page=1

${ }^{422}$ Estampa disponible en:

https://www.britishmuseum.org/research/collection_online/collection_object details.aspx?objectId=1400 599\&partId=1\&searchText=calvary+schongauer\&images=on\&page $=1$ BARTSCH, A., op. cit., vol. VI, p. 126; LEHRS, M., op. cit., vol. V, p. 147.
} 


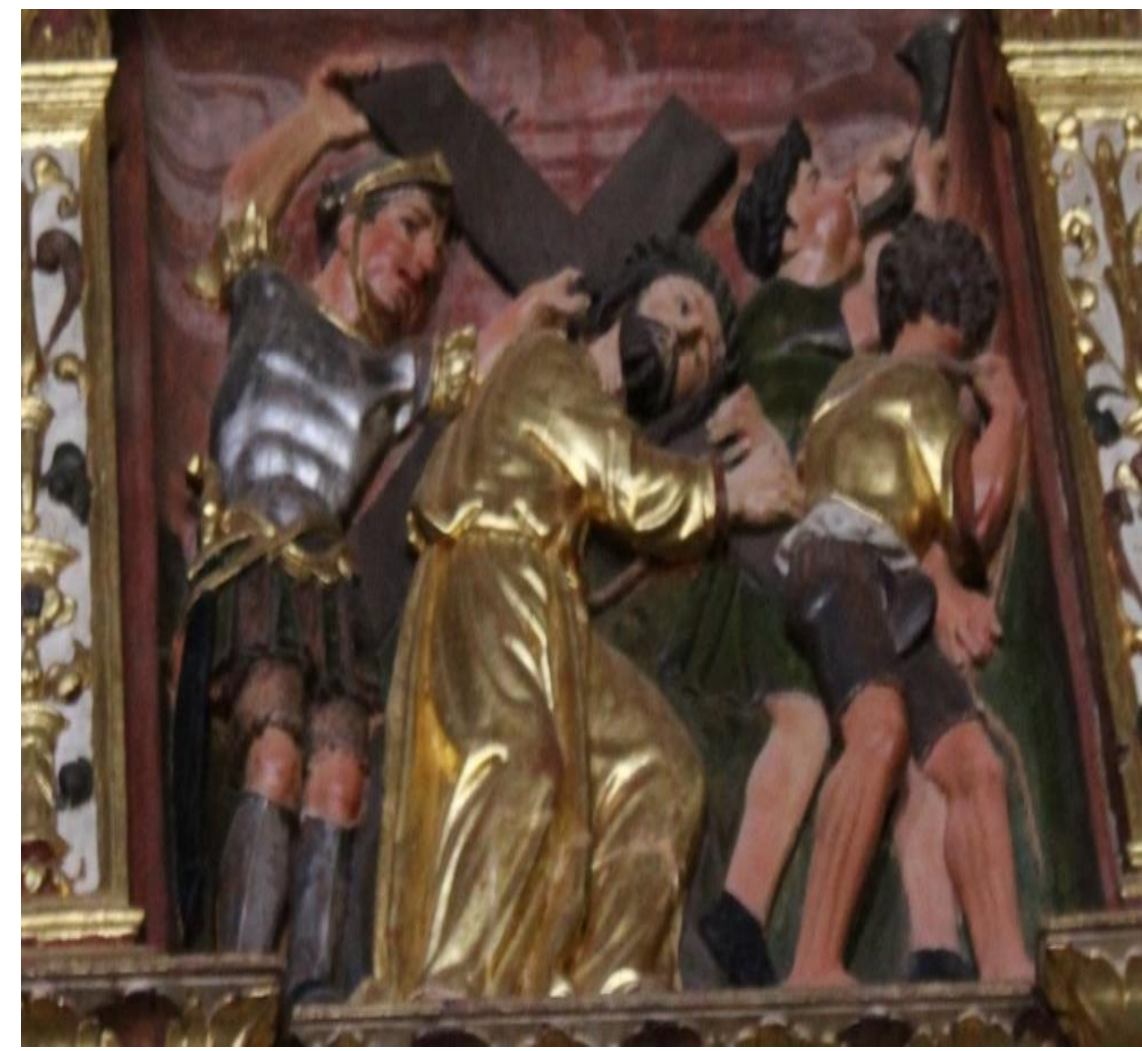

154. Anónimo.

Camino del Calvario.

Ca. 1543.

Retablo de la

Flagelación.

Iglesia parroquial.

Santa María de

Yanguas (Soria)

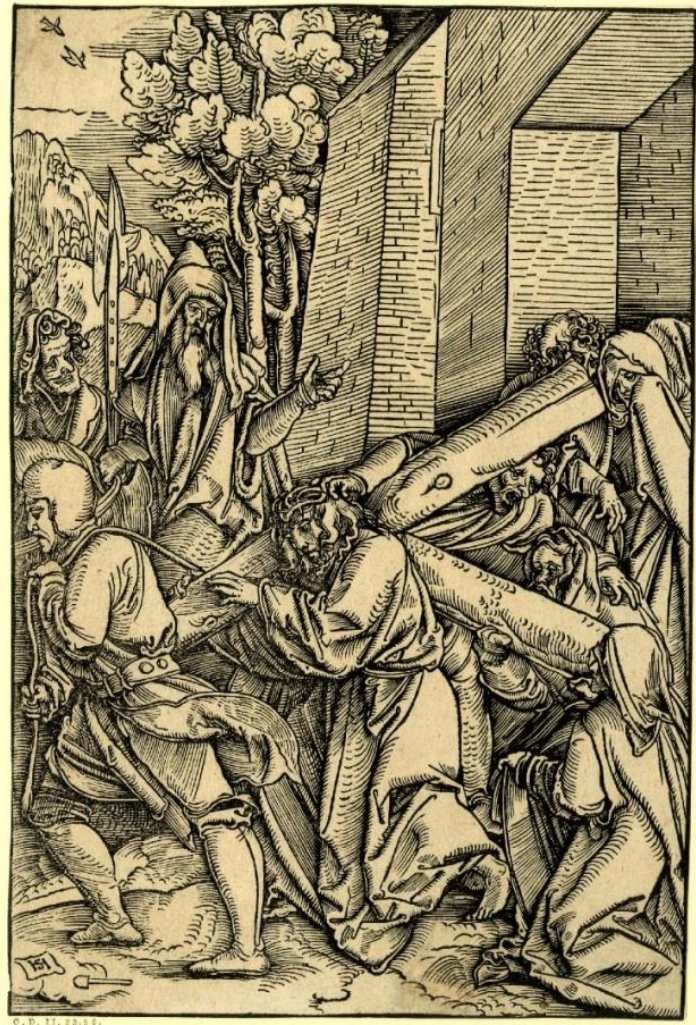

155. Hans Schaufelein.

Cristo cargando con la cruz. 1509-1512.

Museo Británico. Londres (ReinoUnido).

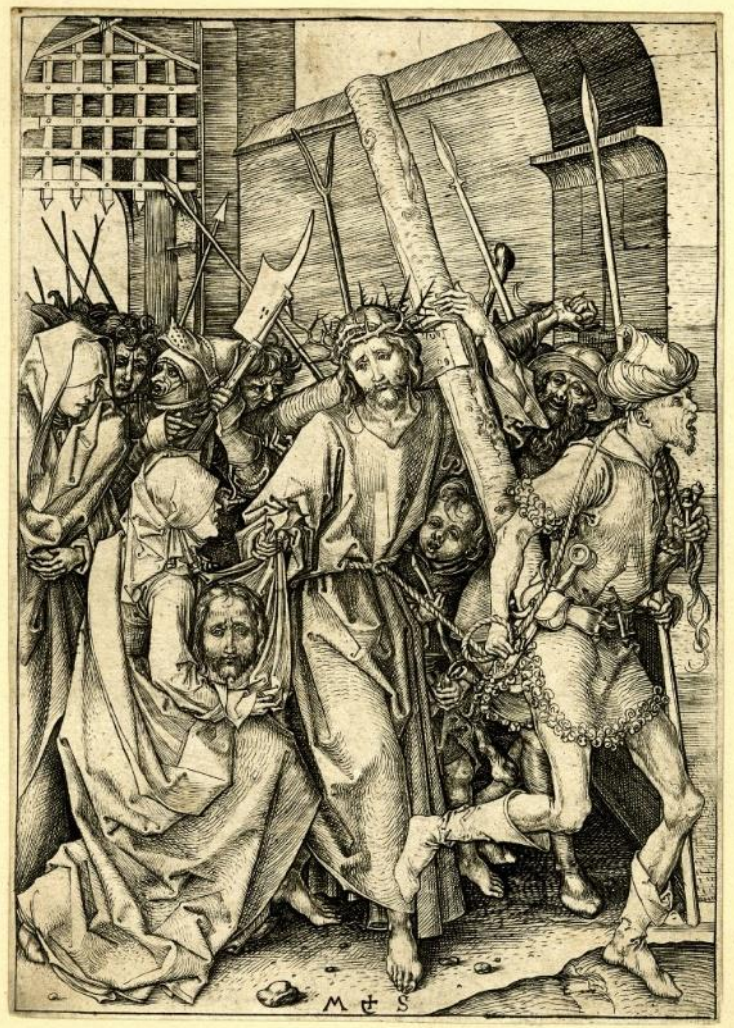

156. Martin Schongauer.

Camino del Calvario. 1470-1482.

Museo Británico. Londres (ReinoUnido). 


\section{Maese Andrés \\ Retablo de la Flagelación \\ Ca. 1550 \\ Sacristía \\ Iglesia parroquial de los Santos Justo y Pastor \\ Noviercas (Soria)}

La pintura formaba parte seguramente de un retablo, en palabras de Arranz Arranz ${ }^{423}$. De Maese Andrés sólo se sabe que trabajaba en Noviercas a mediados del siglo XVI y que había sido también autor del retablo mayor de la parroquia ${ }^{424}$. La escena se ubica en un espacio porticado formado por arcos de medio punto y un suelo de baldosas de ajedrez. Cristo está atado a una columna jónica, y luce una enorme aureola dorada. Su cuerpo se encuentra en una posición muy estática, en paralelo a la columna y con las manos atadas por delante de la misma.

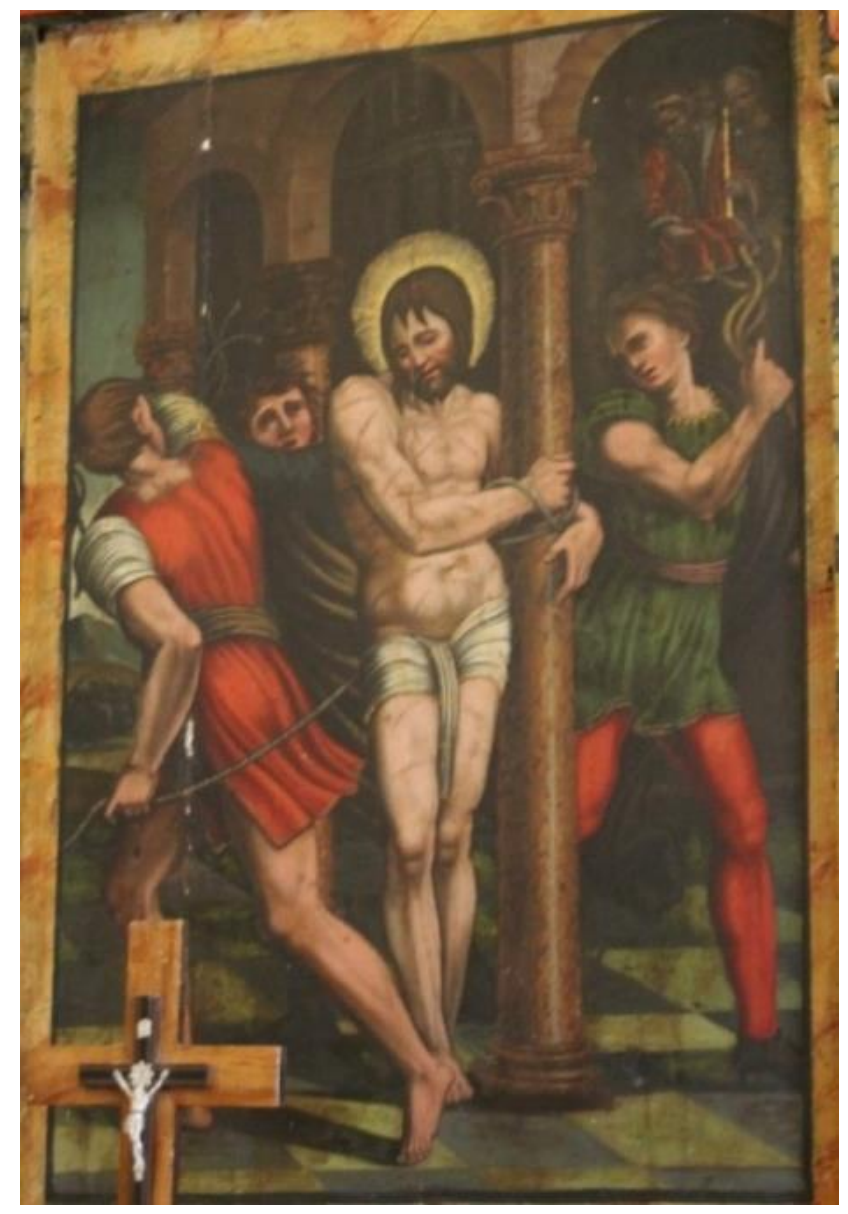

157. Maese Andrés. Flagelación. Mediados del siglo XVI. Iglesia parroquial de los Santos Justo y Pastor. Noviercas (Soria)

\footnotetext{
${ }^{423}$ ARRANZ ARRANZ, J., El Renacimiento en la Diócesis..., pp. 368-369.

424 Ídem, p. 180.
} 
La figura de Cristo, así como las de los dos sayones, muestra un acentuado interés en el estudio anatómico. Predominan los tonos rojos y verdes de las vestimentas de los sayones. Al fondo a la derecha, entre los arcos, se observa a dos personajes que contemplan la escena, probablemente Pilatos y alguno de sus compañeros.

En este caso el pintor ha utilizado la estampa de la Flagelación de Durero ${ }^{425}$ (fig. 157) para crear la figura del sayón situado a la izquierda, que levanta el brazo derecho para golpearle, aunque transformando radicalmente su aspecto, que en el caso de la pintura es más juvenil y musculoso. El otro sayón podría estar tomado de la estampa del Pasmo de Sicilia inspirada en Rafael, y convertida en grabado tanto por Raimondi como por Agostino Veneziano (1517) (fig. 158).

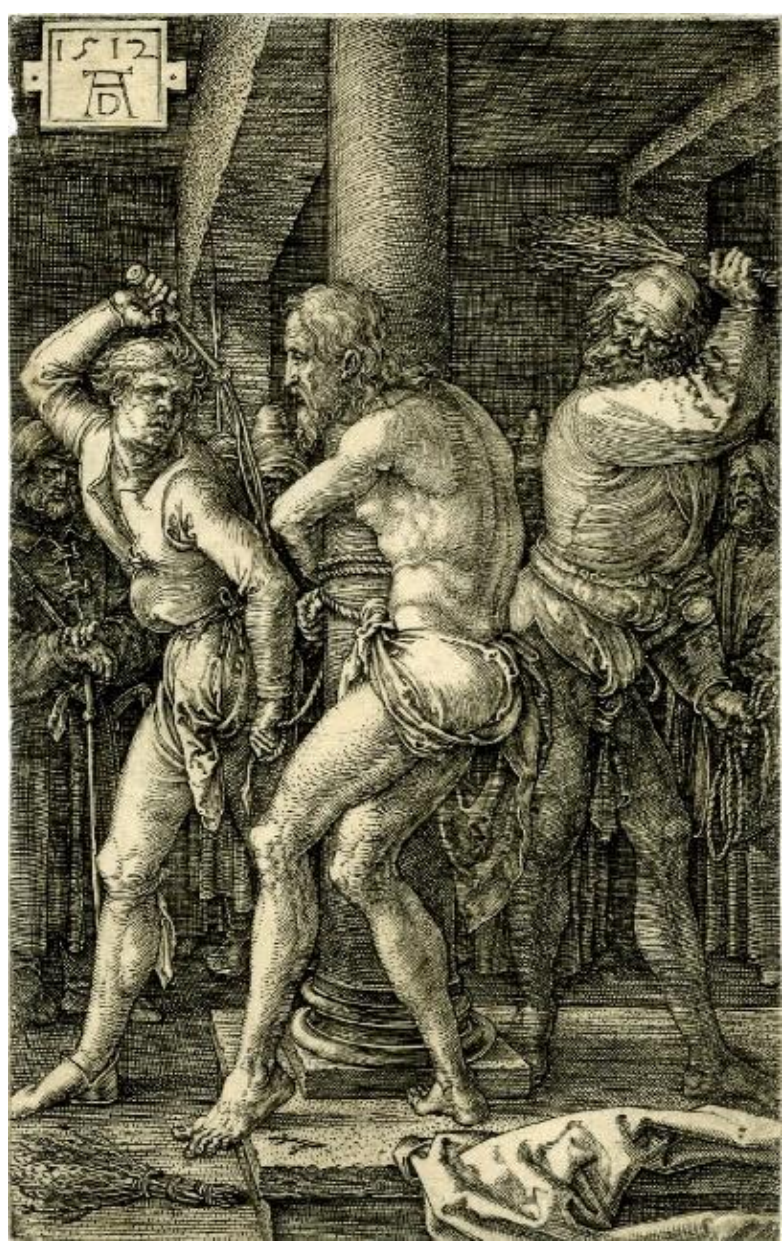

158. Alberto Durero. Flagelación. La Pasión grabada. 1522.

Museo Británico. Londres (ReinoUnido).

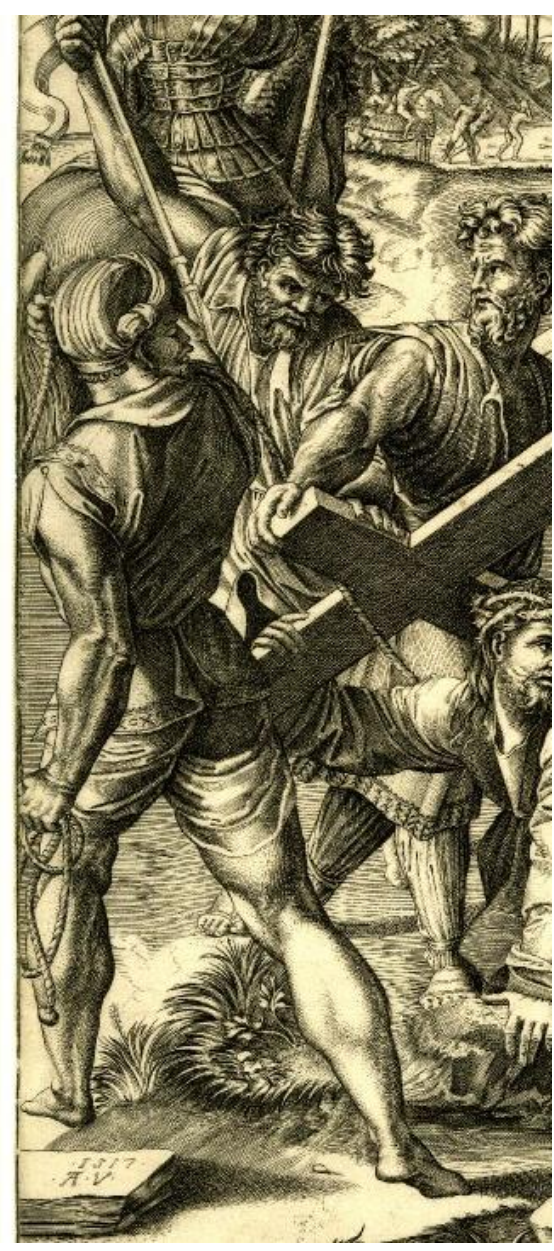

159. Agostino Veneziano.

Detalle del Pasmo de Sicilia, 1517. Museo Británico. Londres (ReinoUnido).

\footnotetext{
${ }^{425}$ Estampa disponible en:

http://www.britishmuseum.org/research/collection_online/collection_object_details.aspx?objectId=13508 85\&partId $=1$ \&searchText=flagellation\&images $=$ on\&page $=1$

BARTSCH, A., op. cit., vol. VII, p. 35; DODGSON, C., Albrecht Dürer, n ${ }^{\circ}$ 57, p. 75; MEDER, J., op. cit., no 8, p. 72; SCHOCH, R., op. cit., vol. I, nº 50, pp. 137-138.
} 


\section{Anónimo \\ Retablo del Calvario \\ Primer tercio del siglo XVI \\ Iglesia parroquial de los Santos Justo y Pastor \\ Noviercas (Soria)}

El retablo, que se encuentra en un deplorable estado de conservación, se compone de dos cuerpos y tres calles (fig. 160). Remata con un frontón semicircular avenerado En el primer cuerpo se ubican pinturas relativas a San Pedro, y San Andrés. En el segundo aparecen las escenas de San Miguel venciendo al demonio, el Calvario de Cristo y San Francisco recibiendo los estigmas.

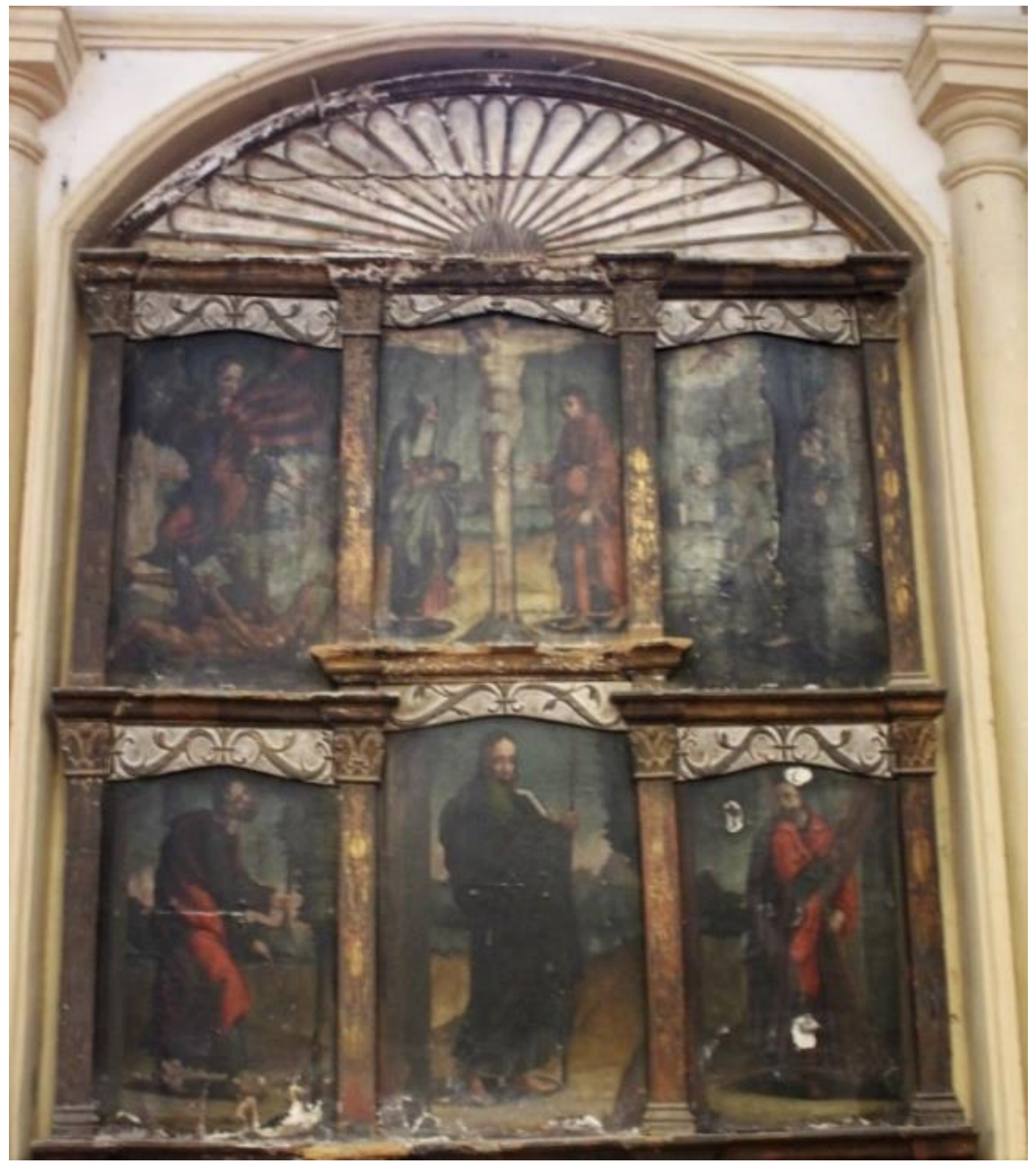

160. Anónimo. Retablo del Calvario.

Primer tercio del siglo XVI. Iglesia de los santos Justo y Pastor.

Noviercas (Soria). 
La escena de la vida de San Francisco (fig. 161) se ubica por lo tanto en el segundo cuerpo. El artista parece haberse inspirado en el grabado homónimo de Alberto Durero (fig. 162) ${ }^{426}$. Las figuras de San Francisco y del fraile adormecido son idénticas. Por otro lado, el pintor ha reducido aquí los tres serafines a uno solo, al igual que ocurría en el retablo de San Matías y San Francisco de Ágreda. Por lo poco que se puede observar del fondo de la composición parece que también se ha reproducido, aunque sea parcialmente, el paisaje arbolado y montañoso del fondo de la estampa.

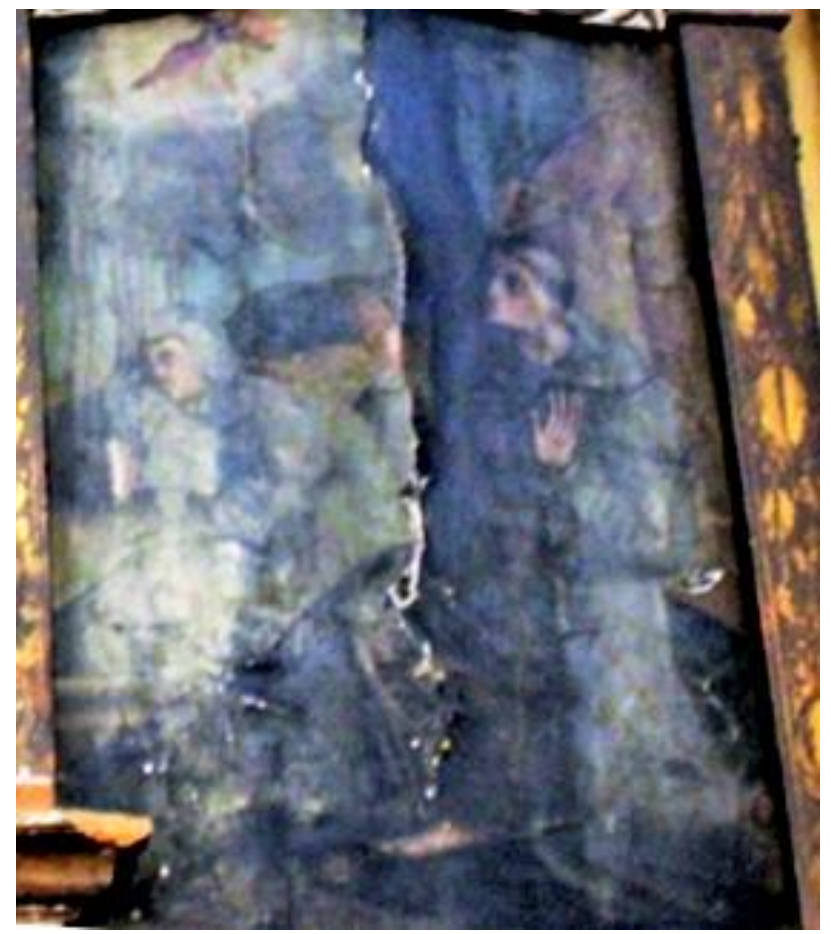

161. Anónimo. San Francisco recibiendo los estigmas. Primer tercio del siglo XVI.

Iglesia parroquial de los Santos Justo y Pastor. Noviercas (Soria)).

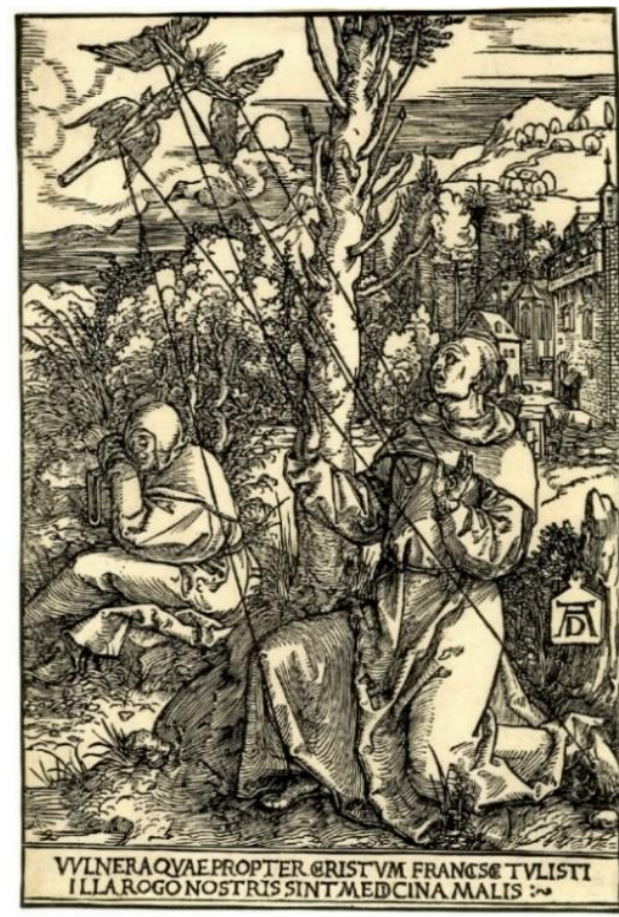

162. Alberto Durero, San Francisco recibiendo los estigmas, 1503-1504, Museo Británico. Londres (ReinoUnido)

\footnotetext{
${ }^{426}$ Estampa disponible en:

http://www.britishmuseum.org/research/collection_online/collection_object_details.aspx?objectId=13391 46\&partId $=1$ \&searchText $=$ saint + francis\&images $=$ true \&people $=127877 \&$ page $=1$

BARTSCH, A., op. cit., VII, p. 138; DODGSON, C., Catalogue of Early German and Flemish Woodcuts..., vol. I, nº 33, p. 287; MEDER, J., Dürer Katalog, nº 224, p. 189; SCHOCH, R., op. cit., II Woodcuts, no 134 , pp. 126-128.
} 


\section{Juan de Carranza I \\ Retablo mayor \\ 1554 \\ Iglesia de Santa María la Mayor \\ Soria}

La construcción de este retablo responde a las intenciones de Constanza Calderón, esposa de Juan de Torres. La dama se hizo con el patronato de la capilla mayor. Los Calderón eran una de las familias más adineradas de la ciudad, gracias especialmente a la ganadería y la agricultura. Tenían la categoría de hidalgos y formaban parte del linaje de San Llorente debido al gran prestigio que alcanzaron a finales del siglo XV y principios del $\mathrm{XVI}^{427}$. Gracias a su protección se llevaron a cabo varias transformaciones del primitivo templo románico, cambiándose su ábside por un presbiterio de estilo tardogótico. Para cubrir dicho espacio se contrataron en 1554 los servicios de un entallador, que realizó el retablo. Éste quedó terminado tres años después, en $1557^{428}$.

El retablo se encargó a Juan de Losada, entallador oriundo de Soria, a finales del siglo XVI. Las esculturas corrieron a cargo, sin embargo, de un burgalés, Juan de Carranza I. Esto es debido seguramente a la escasez de escultores de calidad en Soria a finales del siglo XVI.

Se trata de una obra de traza manierista con columnas de orden colosal en los extremos laterales y otros elementos serlianos (fig. 163). Es un retablo de casillero con entrecalles. Está formado por banco, dos cuerpos y ático de tres calles. En los flancos se ubican dos polseras. Está rematado por un tímpano curvo. Respecto a la arquitectura, predominan las columnas, las pilastras, los entablamentos, los netos, las hornacinas con veneras y las cajas adinteladas. Los elementos decorativos ligados al Manierismo fantástico son fundamentalmente las cartelas correiformes, guirnaldas de frutos, putti, grutescos, dentículos, frutos, cabezas de niños y ángeles, máscaras, hermes, medias figuras y medallones.

Las escenas del retablo corresponden a episodios de la Virgen y de Cristo. La escultura de María con el Niño aparece rodeada por la Anunciación, el Nacimiento, Epifanía y Presentación en el templo.

\footnotetext{
${ }^{427}$ ALCOLEA BLANCH, S., op. cit., p. 48; PAYO HERNANZ, R. y ECHEVERRÍA GOÑI, P. L., op. cit., p. 74.

${ }^{428}$ Documentación publicada en PAYO HERNANZ, R. y ECHEVERRÍA GOÑI, P. L., op. cit., p. 74.
} 


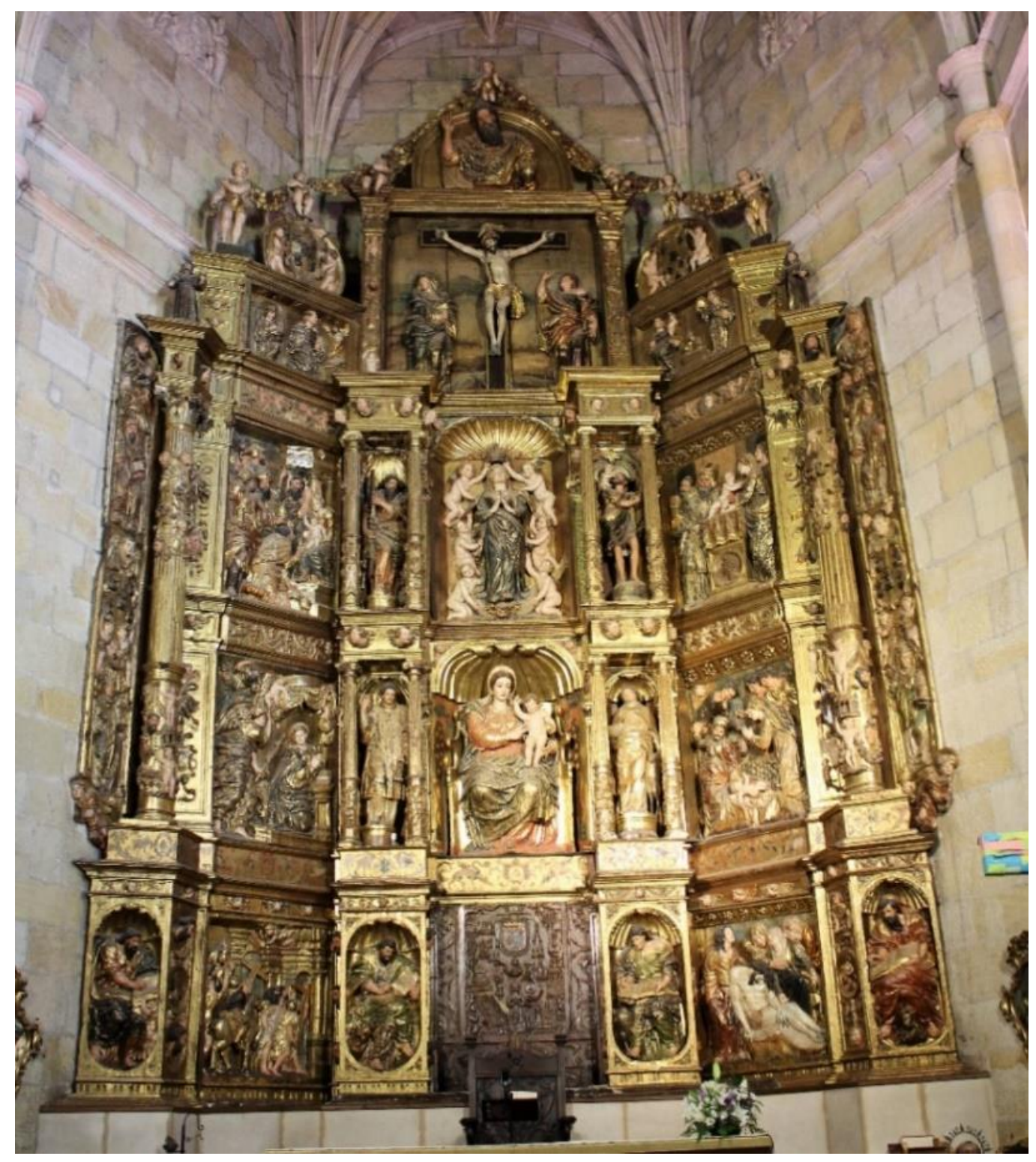

163. Juan de Carranza I. Retablo mayor.

Iglesia de Santa María la Mayor.1554. Soria.

En el segundo cuerpo se ubican las escenas de la Coronación-Asunción de la Virgen, la Epifanía y la Presentación en el templo. En el banco se encuentran las escenas de la Recuperación de la Cruz por Heraclio y la Lamentación ante el cuerpo de Cristo. El ático culmina con una representación del Calvario y entre las escenas principales se hallan las figuras de algunos santos como los cuatro Evangelistas que rodean a la Virgen con el Niño y a la Coronación. El retablo presenta muchas semejanzas con el retablo de la parroquia de Ólvega, tanto en la articulación como en algunos detalles decorativos ${ }^{429}$.

${ }^{429}$ Id., p. 87. 


\section{Santa María la Mayor}

Santa María la Mayor era la patrona de la capilla de patronato de los Calderón, además de dar nombre a la iglesia y al retablo. Vemos a la Virgen sentada en una silla dorada de doble brazal avolutado, decorada con una venera invertida (fig. 164). Sostiene al Niño de pie entre sus manos. Los pies del Niño se apoyan sobre la pierna izquierda de la Virgen. El Niño aparece desnudo y en contraposto. Bendice con su mano derecha, y lleva la bola del mundo en la izquierda. Su iconografía responde a la de Salvador del Mundo.

La escena remite tanto a algunos modelos grabados como a esculturas del foco de Burgos, probablemente de Bigarny. Como fuente grabada se puede señalar una estampa italiana anónima (1490-1500) (fig. 165) ${ }^{430}$, en la cual la Virgen muestra una pose semejante.

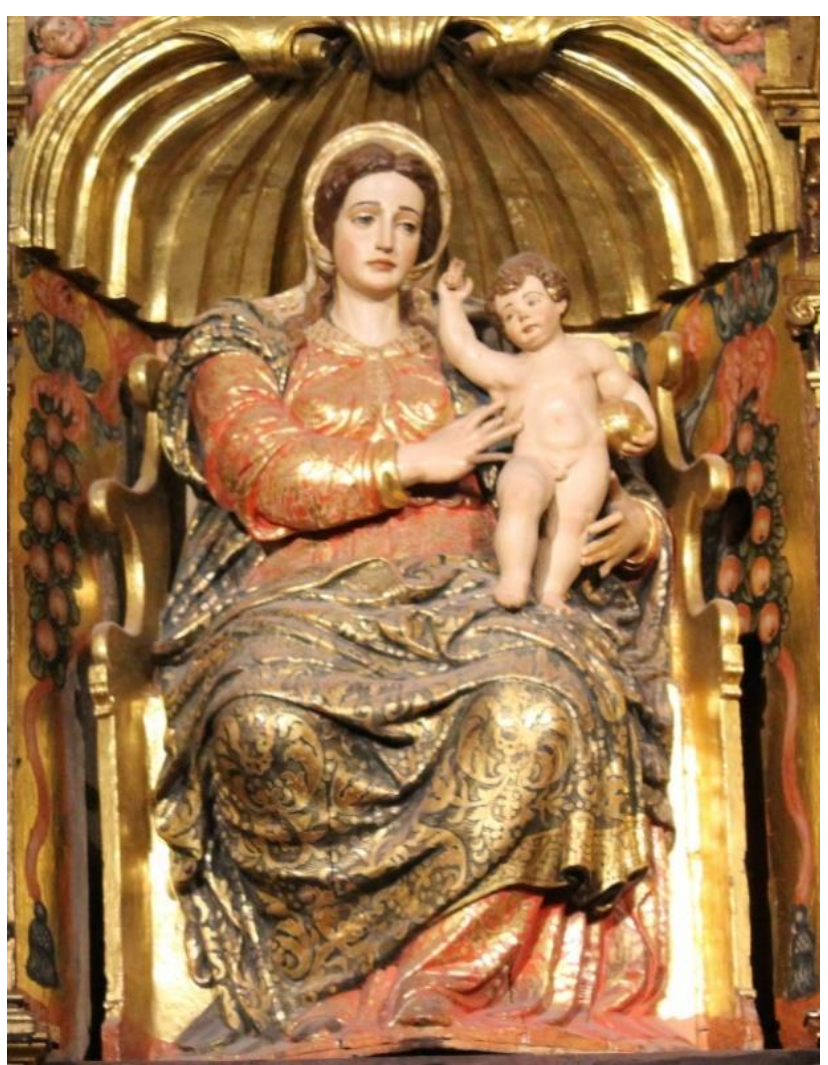

164. Juan de Carranza I.

Virgen con el Niño. 1554.

Iglesia de Santa María la Mayor. Soria.

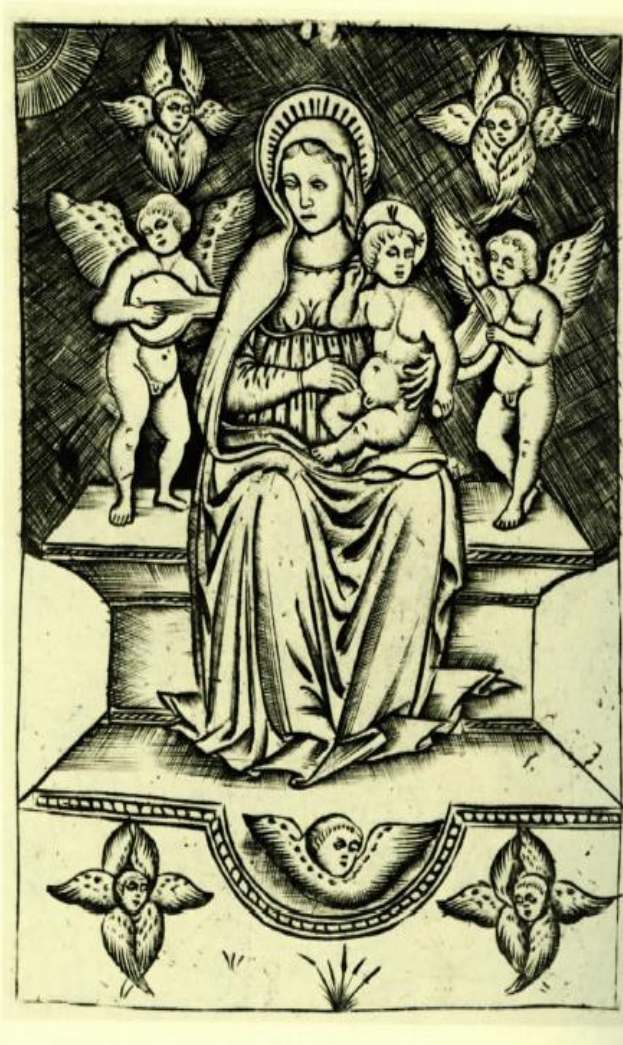

165. Anónimo italiano. Virgen con el Niño. 1490-1500. Museo Británico. Londres (ReinoUnido).

${ }^{430}$ Estampa disponible en:

ZUCKER, M. J., The Illustrated Bartsch, vol. 25, Early italian masters, Nueva York, OPAL Publishing Corporation, 1980, p. 43; BARTSCH, A., op. cit., vol. XIII, p. 84; HIND, A. M., Early Italian engraving...., vol. I, E III, n ${ }^{\circ} 82$, p. 275. 


\section{Presentación en el templo}

En la escena, el sacerdote Simeón coge al Niño Jesús de manos de su madre durante la ceremonia de la Presentación (fig. 166). La escena parece inspirada en el retablo mayor de la Capilla del Condestable, aunque invertida. A ambos lados, en simetría, encontramos a San José y a la profetisa Ana.

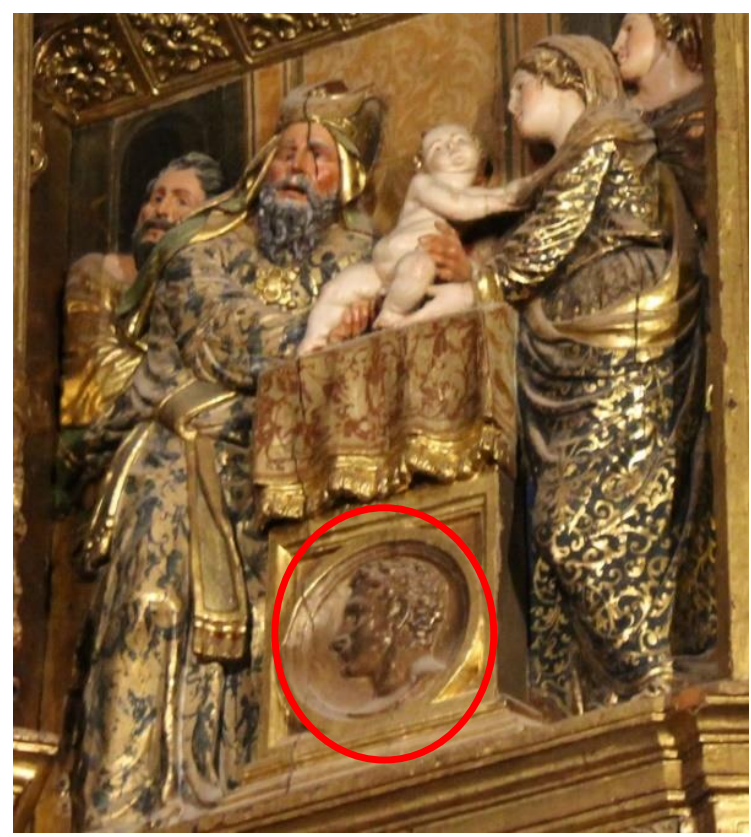

166. Juan de Carranza I. Presentación en el templo. 1554. Iglesia de Santa María la Mayor. Soria.

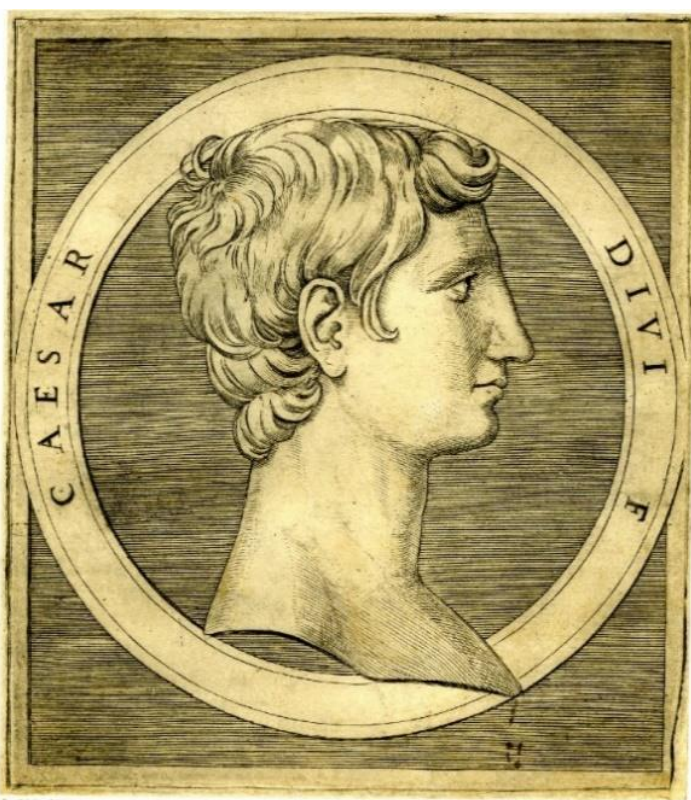

167. Marcantonio Raimondi. Medalla de Octavio Augusto. 1510-1527.

Museo Británico. Londres (ReinoUnido).

En el frontal de la mesa de altar en la cual se lleva a cabo la ceremonia hay un busto de un emperador romano que corresponde al de Octavio Augusto ${ }^{431}$. El busto, de perfil, podría haberse basado en una colección de retratos de emperadores romanos ${ }^{432}$ llevada a cabo por Marcantonio Raimondi ${ }^{433}$, inspirada en monedas y medallones clásicos (fig. 167). Otros grabadores también trataron estos mismos temas, como

\footnotetext{
${ }^{431}$ La vinculación de la representación de bustos de emperadores romanos con la política de Carlos $\mathrm{V}$ ha sido estudiada en textos como el de CASTRO SANTAMARÍA, A., "La imagen de César en los libros de medallas del siglo XVI. A propósito del medallón del claustro", en La impronta humanística (ss. XVXVIII): saberes, visiones e interpretaciones (coordinado por A. Castro Santamaría y J. García Nistal), Palermo, 2013, pp. 393-412. En el mismo volumen también interesa el texto de CAMPOS SÁNCHEZ BORDONA, M. D.," Melior Traiano, Felicitor Augusto, Medallas y medallones al servicio de la propaganda e imagen imperial de Carlos V", pp. 377-392.

${ }^{432}$ PAYO HERNANZ, R. y ECHEVERRÍA GOÑI, P. L., op. cit., p. 92.

${ }^{433}$ Estampa disponible:

http://www.britishmuseum.org/research/collection_online/collection_object_details.aspx?objectId=14404 74\&partId=1\&searchText=augustus\&images $=$ true \&from $=$ ad\& fromDate $=1500 \&$ to $=$ ad\&toDate $=1550 \&$ ob ject=20898\&page=1; BARTSCH, A., op. cit., vol. XIV, p. 373 .
} 
Battista Angolo del Moro (fig. 168) ${ }^{434}$ o Lambert Suavius (fig. 169) ${ }^{435}$. Esta colocación de motivos decorativos de origen pagano, tendría en principio un mero sentido ornamental, sin ninguna significación simbólica, excepto que Cristo nació durante el mandato de este emperador ${ }^{436}$.

Otra interpretación sería su vinculación a la figura del emperador Carlos V. Se relaciona al monarca español con el emperador romano debido a su prudencia, virtud necesaria para cualquier gobernante renacentista, y su gobierno pacífico y provechoso $^{437}$. Durante los últimos años de su mandato, como ocurre en este caso, aparece representado imitando los modelos numismáticos de la Antigüedad Clásica: de perfil $^{438}$.

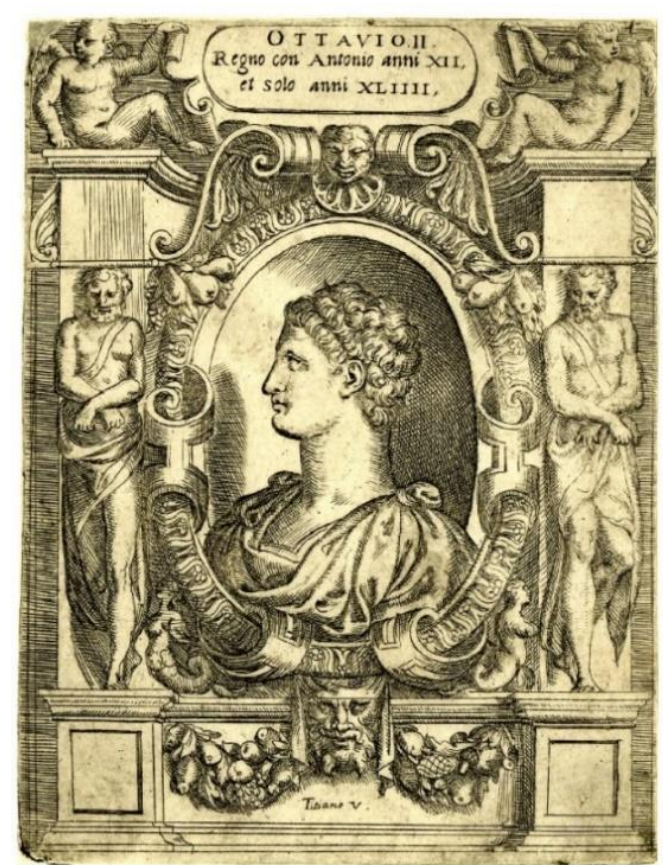

168. Battista Angolo del Moro. Retrato del Busto de Octavio Augusto. 1515-1573. Museo Británico. Londres (ReinoUnido).

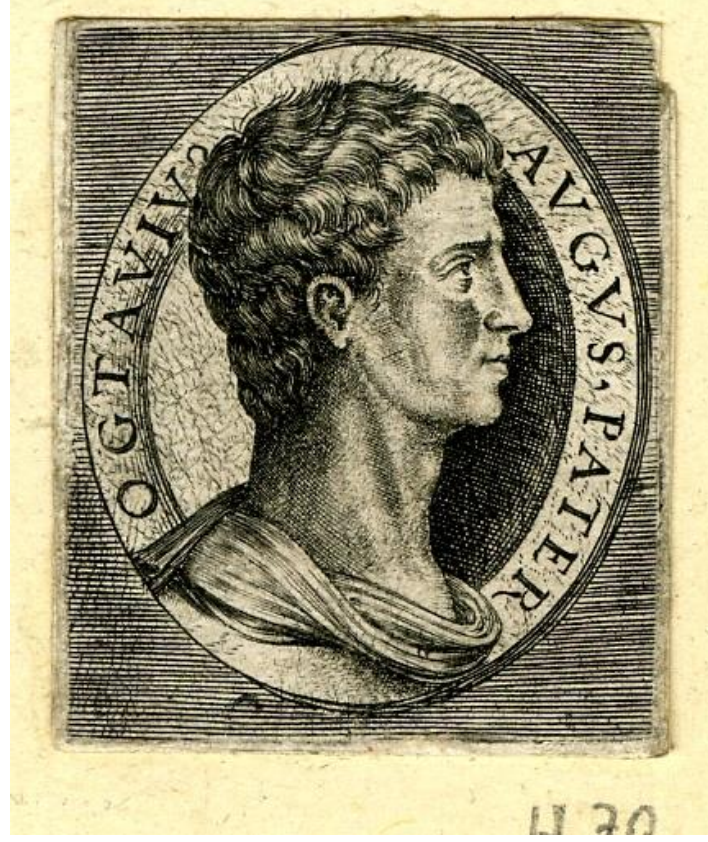

169. Lambert Suavius. Retrato de Octavio Augusto. Ca. 1550. Museo Británico. Londres (ReinoUnido).

Aunque también se podría concebir como el triunfo de Cristo sobre los reyes terrenales de la época y el comienzo de una nueva era, la cristiana. Desde principios del

\footnotetext{
${ }^{434}$ Estampa disponible en:

http://www.britishmuseum.org/research/collection_online/collection_object_details.aspx?objectId=14432 04\&partId=1\&images=true\&people=134320\&page=1; BARTSCH, A., op. cit., vol. XVI, p. 80.

${ }^{435}$ Estampa disponible en:

http://www.britishmuseum.org/research/collection_online/collection_object_details.aspx?objectId=14889 07\&partId=1\&images $=$ true\&people $=106104 \&$ page $=1$; HOLLSTEIN, F. W. H., Dutch and Flemish Etchings, engravings and woodcuts c. 1450-1700, $\mathrm{n}^{\circ} 70$, vol. XXVIII, p. 184.

${ }^{436}$ MARÍAS, F., El largo siglo XVI..., p. 247.

437 CAMPOS SÁNCHEZ BORDONA, M. D., op. cit., pp. 379-380.

438 Ídem, pp. 388.
} 
siglo XVI la emblemática italiana se difundió a través de dibujos y estampas por toda la Península Ibérica. Este influjo se plasmó a través de la decoración de multiples monumentos arquitectónicos. Los ejemplos en la provincia de Soria son escasos, y sólo en algunos retablos encontramos esta ornamentación plateresca. Es una manifestación del gusto por las medallas, que se superponen con frecuencia en los programas decorativos a partir de 1520/30.

\section{Anunciación}

Respecto a esta imagen se pueden proponer varios modelos compositivos (fig. 170). Por un lado, la estampa del mismo tema de Alberto Durero ${ }^{439}$ de 1510 (fig. $172)^{440}$. La Virgen muestra una pose muy similar, con el rostro inclinado hacia la izquierda, mientras su cuerpo y sus manos unidas giran más hacia la derecha. Está arrodillada frente al atril.

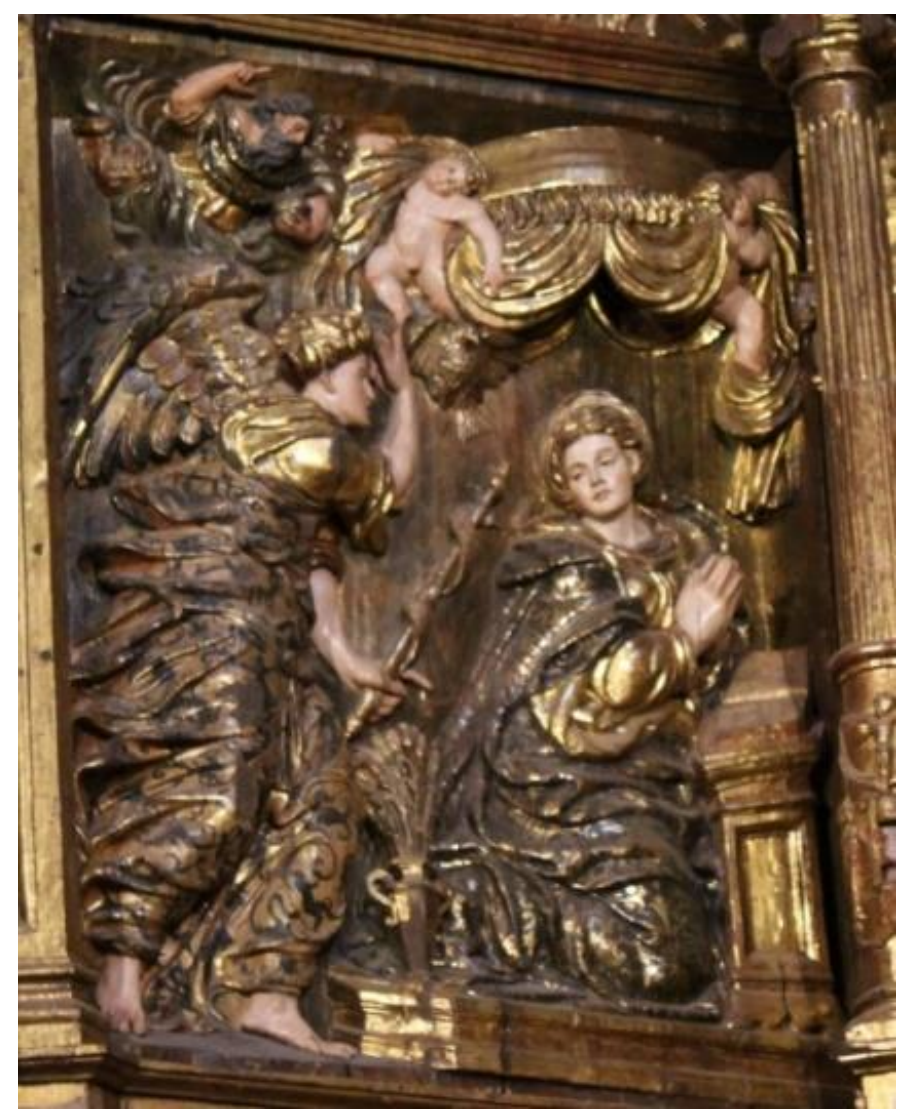

170. Juan de Carranza I. Anunciación. 1554.

Retablo mayor.

Iglesia de Santa María la Mayor.

Soria

${ }^{439}$ PAYO HERNANZ, R. y ECHEVERRÍA GOÑI, P. L., op. cit., p. 90.

${ }^{440}$ Estampa disponible en:

http://www.britishmuseum.org/research/collection_online/collection_object_details.aspx?objectId=13399 $07 \&$ partId $=1 \&$ searchText $=$ annunciation\&images $=$ true \&people $=127877 \&$ page $=1$

BARTSCH, A., op. cit., vol. VII, p. 119; DODGSON, C., Catalogue of Early German and Flemish Woodcuts...., vol. I, $\mathrm{n}^{\circ}$ 63, p. 294; MEDER, J., op. cit., n $\mathrm{n}^{\mathrm{o}}$ 128, p. 134; SCHOCH, R., op. cit., vol. II, $\mathrm{n}^{\circ}$ 189, pp. 291-292. 
Por otro lado, en una estampa de Marco de Ravenna el ángel aparece representado de forma idéntica (fig. 173): la mano derecha señala al cielo, al Padre Eterno, mientras que la izquierda sostiene la vara; además, su pie izquierdo avanza delante del derecho. En sus propios ropajes también se intenta transmitir el dinamismo de su modelo, a través de los pliegues voluminosos de la túnica que ondean hacia la izquierda. Otro elemento destacable sería la figura de Dios Padre que emerge con ímpetu entre las nubes de una manera muy parecida al grabado. En cuanto al mobiliario que observamos en la escena, encontramos una cama con doseles muy parecidos a los de la estampa italiana (fig. 171), si bien Juan de Carranza añadió un jarrón con lirios símbolo de la pureza de María.

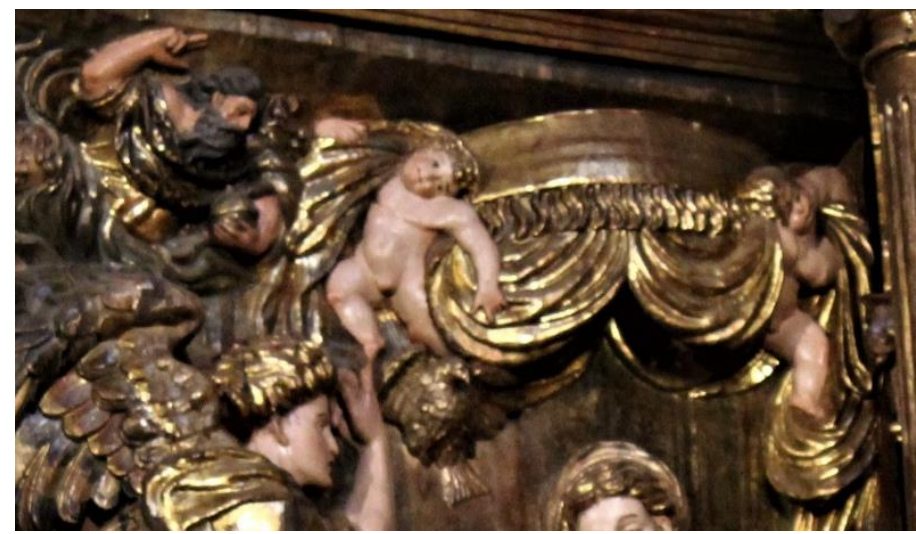

171. Juan de Carranza I. Anunciación. Detalle. 1554. Retablo mayor. Iglesia de Santa María la Mayor. Soria.

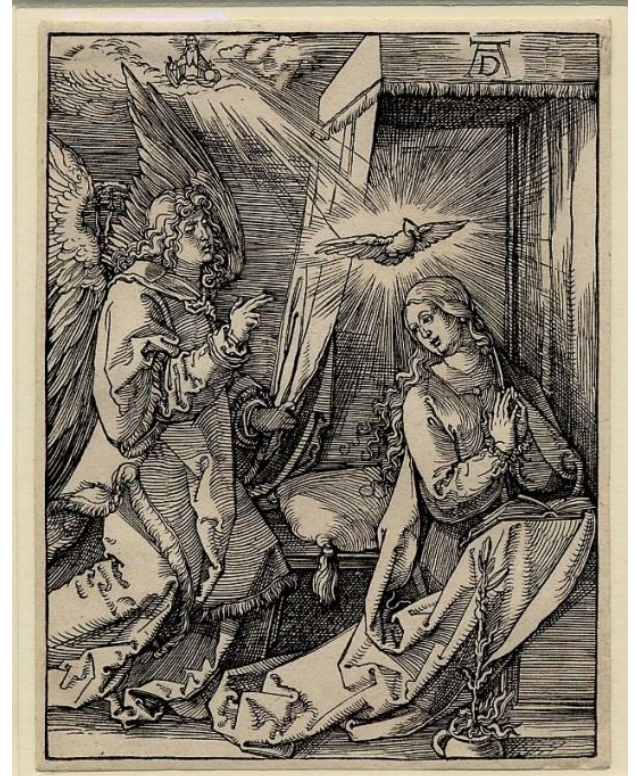

172. Alberto Durero. Anunciación, Pequeña Pasión. 1510. Museo Británico. Londres (Reino Unido).

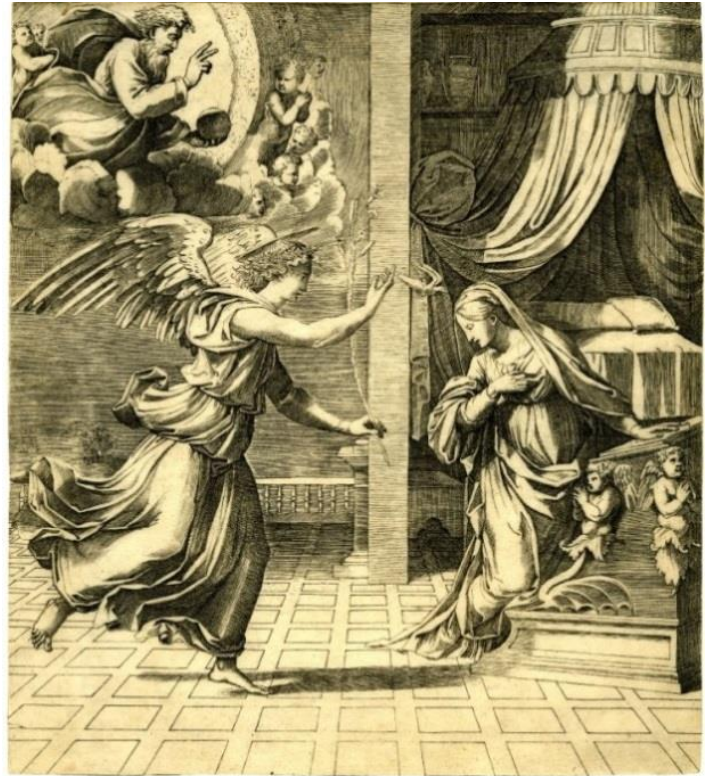

173. Marco de Ravenna. Anunciación. 1519-1527. Museo Británico. Londres (Reino Unido). 


\section{Diego de Madrid \\ Retablo mayor \\ 1553-1574 \\ Iglesia de San Miguel \\ Caltojar (Soria)}

Esta parroquia pertenecía a la diócesis de Sigüenza, dentro del arciprestazgo de Berlanga de Duero ${ }^{441}$. La escultura del retablo es obra del famoso entallador de Sigüenza, Martín de Vandoma (ca. 1540-1578) ${ }^{442}$. La pintura se contrató con Diego de Madrid $^{443}$ aunque después sus descendientes lo culminaron tras su muerte en 1577. Se trata por lo tanto de una obra tardía y que muestra la decadencia del estilo de Diego, que deja el trabajo en manos de sus ayudantes, con un estilo que acaba volviéndose repetitivo. Es de destacar también la mayor presencia en las figuras de los principios contrarreformistas relativos al decoro de los personajes (fig. 174).

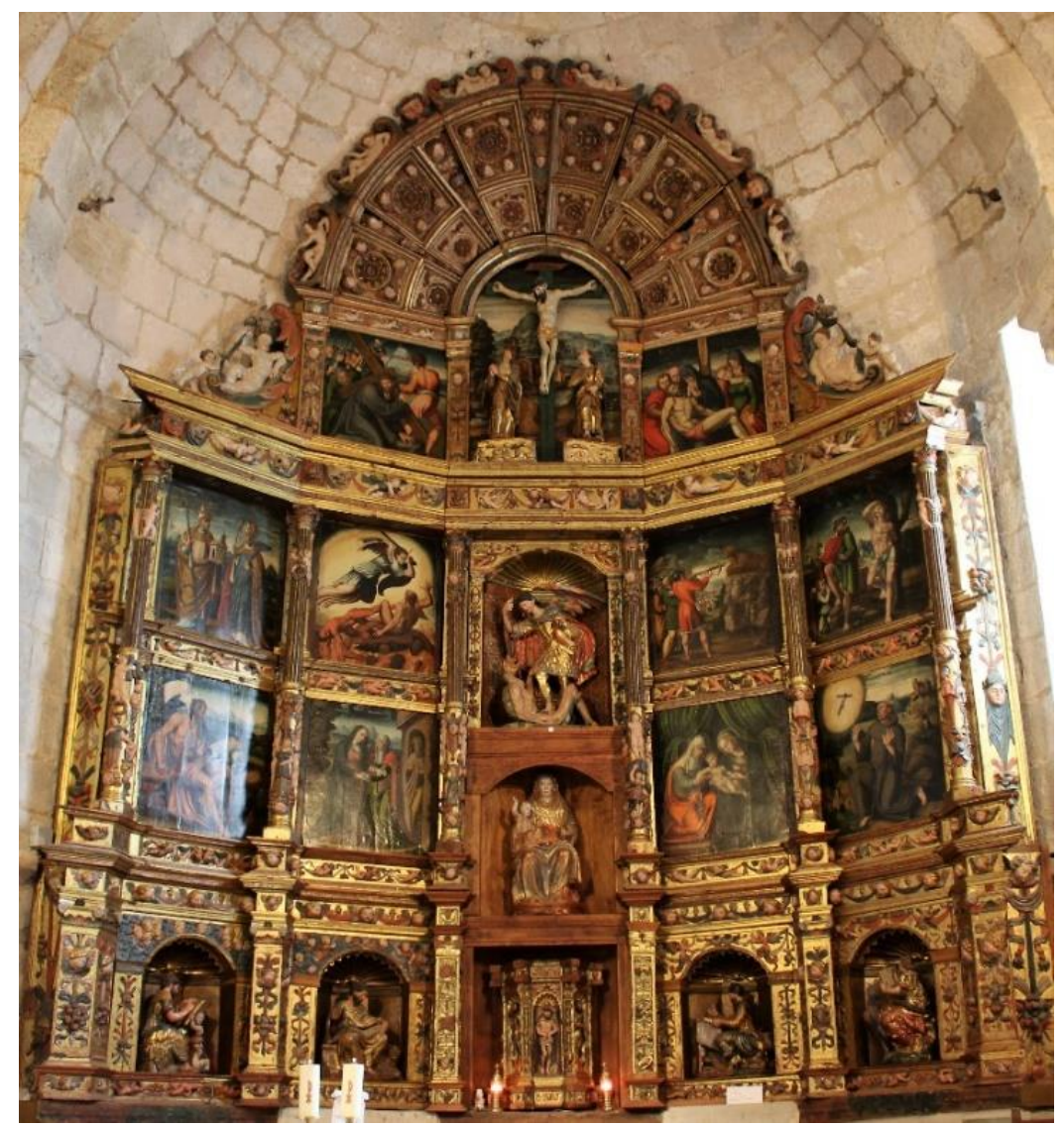

174. Diego de Madrid. Retablo mayor. 1553-1574. Iglesia de San Miguel. Caltojar (Soria).

\footnotetext{
${ }^{441}$ ALCOLEA BLANCH, S., op. cit., p. 197.

${ }^{442}$ PÉREZ VILLAMIL, J., La catedral de Sigüenza..., pp. 161-164; AZCÁRATE, J. M., Escultura del siglo XVI..., p. 240; MARTÍNEZ FRÍAS, J. M., "Resurrección”, pp. 395-397.

${ }^{443}$ MUÑOZ JIMÉNEZ, J. M., op. cit., pp. 136-140; COZAR DEL AMO, J. M., y GARCÍA LÓPEZ, A., op. cit., p. 105; RAMOS GÓMEZ, F. J., "Documentos sobre pintores seguntinos...”, no 31-32, p. 228.
} 
Es un retablo de cinco calles con un banco de esculturas, en el cual aparecen representados los cuatro Evangelistas. En los dos cuerpos y en el ático del retablo hay en total diez tablas que representan a diversas figuras del santoral; en la calle central se ubica la custodia, mientras que en el ático se coloca la figura del santo titular, San Miguel. Las escenas que se representan son: San Juan Bautista, la Visitación, Santa Ana Triple, Estigmatización de San Francisco, San Agustín en compañía de San Blas, San Miguel luchando con los demonios, San Miguel en el Monte Gargano y San Roque con San Sebastián. En opinión de Ramos Gómez las pinturas resultan de una calidad inferior a las de Fuentelencina, probablemente debido a que se trata de una obra de taller. En el contrato no se exigió que fueran enteramente de su mano, como si ocurrió en otras ocasiones ${ }^{444}$. Se evidencia la influencia de la pintura flamenca en cuanto a colores, formas y vestimentas.

\section{San Francisco recibiendo los estigmas}

En esta escena (fig. 175) se compara a la imagen de San Francisco con la de Cristo, ya que según la tradición éste recibió los estigmas que Cristo tras retirarse a rezar al monte Albernia, en 1224. Para crear la pintura el artista se inspiró en la estampa del mismo tema de Durero (fig. 176) ${ }^{445}$; copió de manera íntegra la figura del santo arrodillado, con la pierna derecha adelantada y la izquierda tocando el suelo. La postura de las dos manos alzadas mostrando las palmas también es idéntica. Se basó también en el tocón de un árbol, que Diego de Madrid coloca más lejos, entre el paisaje. El monje que en la estampa aparece orando a la izquierda, se muestra sin embargo en la pintura detrás del santo, a la derecha de la composición. Otros elementos de los que se ha prescindido son el árbol situado junto al santo, los tres serafines que sujetan a Cristo, la frondosa vegetación del fondo y el palacio situado a la derecha. Diego de Madrid colocó, sin embargo, un paisaje montañoso al fondo y unas construcciones amuralladas a la derecha de la composición.

\footnotetext{
${ }^{444}$ RAMOS GÓMEZ, F. J., Juan Soreda y la pintura del Renacimiento ..., p. 214.

${ }^{445}$ Ídem, pp. 214-215.
} 


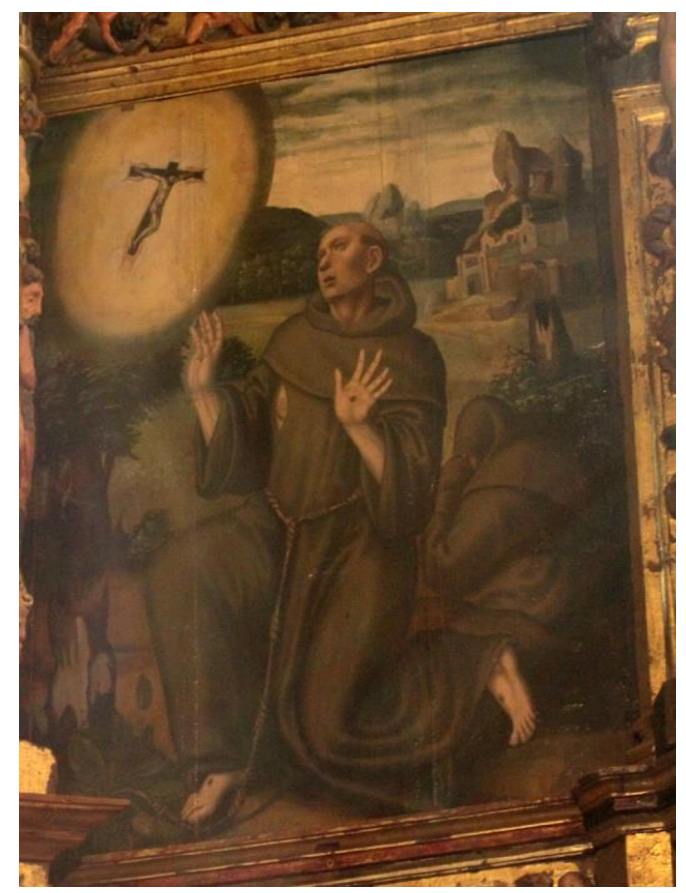

175. Diego de Madrid. San Francisco recibiendo los estigmas. 1553-1574. Iglesia de San Miguel. Caltojar (Soria).

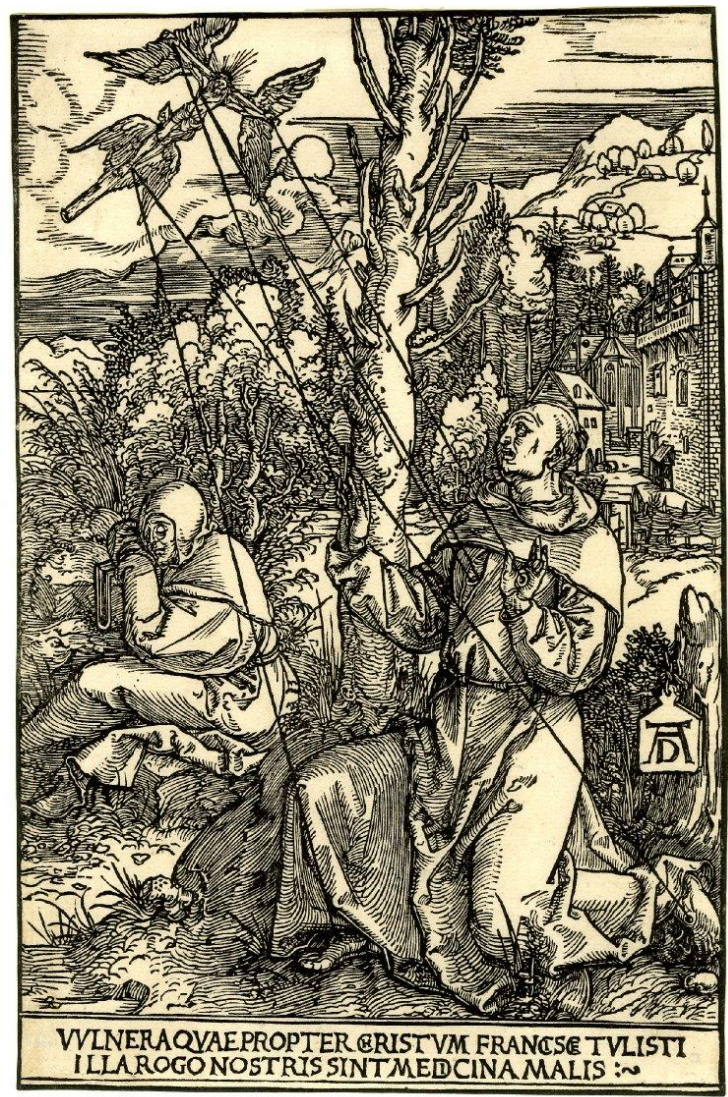

176. Alberto Durero.

San Francisco recibiendo los estigmas.

1503-1504. Museo Británico. Londres (Reino Unido). 


\section{Visitación}

Esta escena partió (fig. 177) de una inversión de la estampa de Durero de 1503 (fig. 178) ${ }^{446}$, de la que toma la figura de San Zacarías saliendo de una puerta con forma de arco de medio punto, así como el paisaje montañoso del fondo, tal y como ocurre en la misma escena del Retablo de San Medel y San Celedonio (Ágreda). El personaje de Zacarías difiere respecto al de la estampa en que no sujeta su sombrero sino que une sus dos manos en señal de oración. Además, en la pintura luce una capucha que cubre su cabeza. Las figuras de la Virgen e Isabel, aunque similares en sus ropajes, difieren en las posturas de sus brazos. En la pintura se cogen de las manos y se muestran más sus rostros de expresión dulce. En cambio en el grabado apenas vemos sus caras y se sujetan más de la zona de los hombros. Además, Diego de Madrid también se ha inspirado en Durero colocando una serie de árboles en el lado opuesto a la puerta, si bien no ha incluido ni el castillo del fondo ni el perrito que aparece en primer plano.

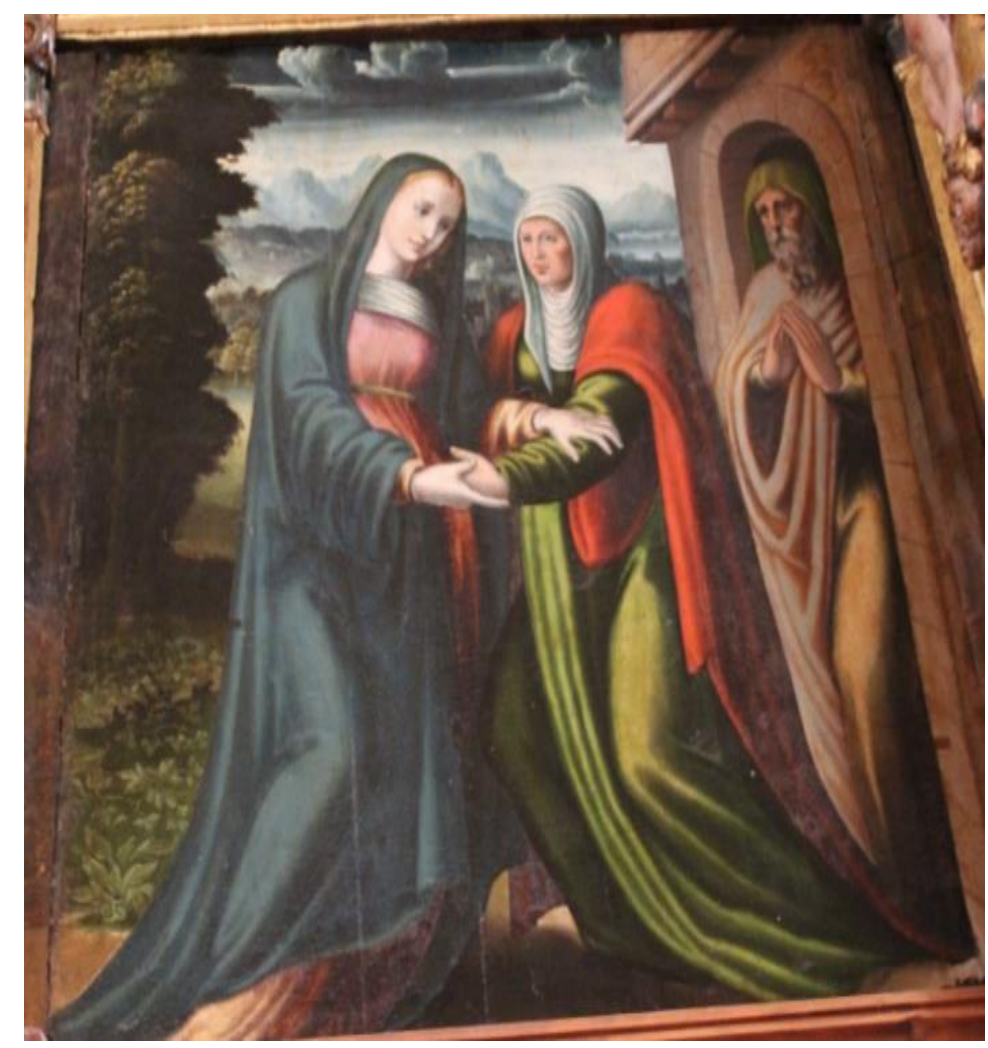

177. Diego de Madrid. Visitación. Retablo mayor. 1553-1574. Iglesia de San Miguel. Caltojar (Soria).

\footnotetext{
${ }^{446}$ Estampa disponible en:

http://www.britishmuseum.org/research/collection_online/collection_object_details.aspx?objectId=14042 28\&partId $=1 \&$ searchText=visitation\&images $=$ true \&people $=127877 \&$ page $=1$

BARTSCH, A., op. cit., vol. VII, p. 132; DODGSON, C., Catalogue of Early German and Flemish Woodcuts...., vol. I, no 44, p. 289; MEDER, J., op. cit., n ${ }^{\circ}$ 196, p. 173; SCHOCH, R., op. cit., vol. II, $\mathrm{n}^{\circ}$ 174, pp. 246-248.
} 


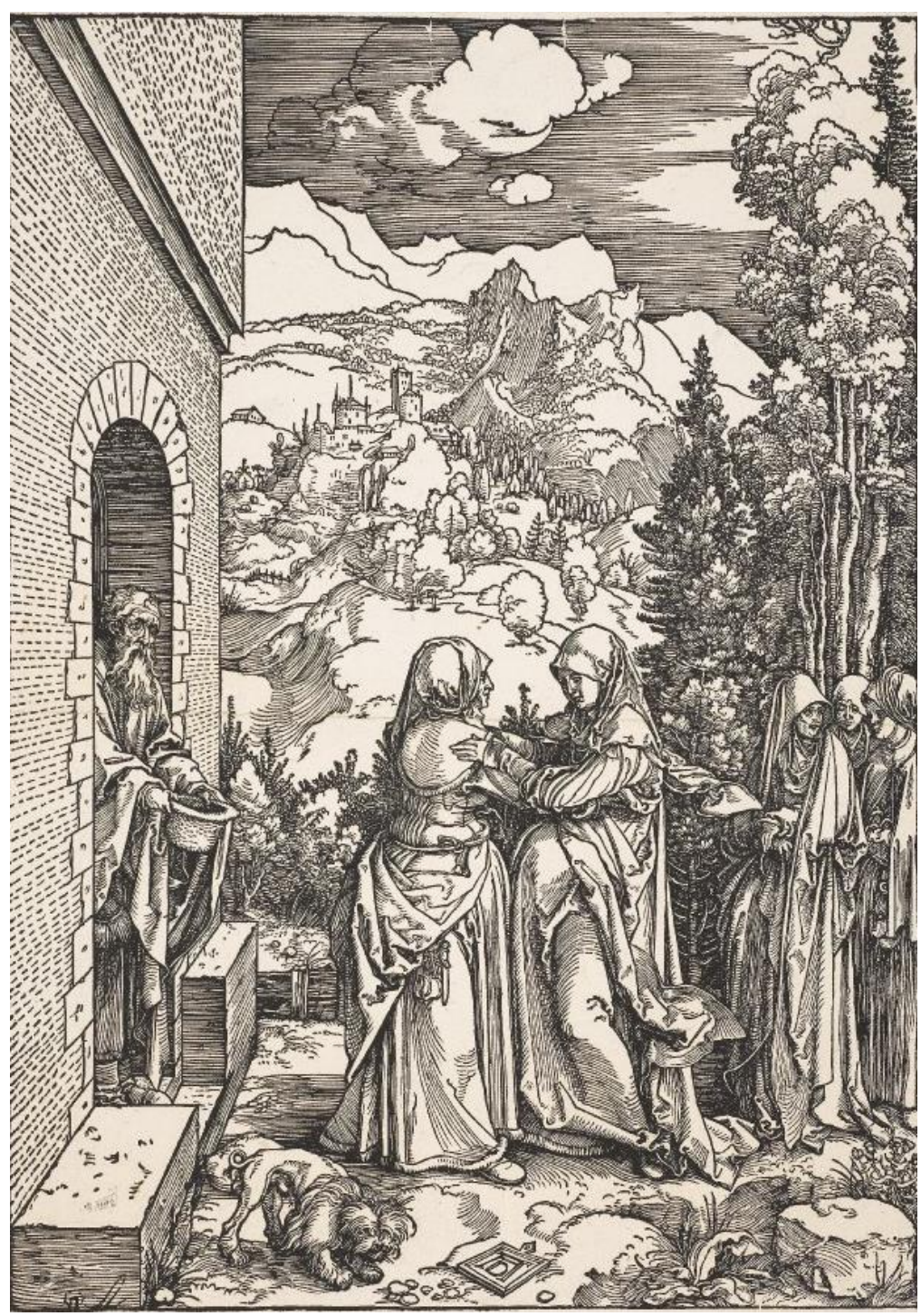

178. Alberto Durero. Visitación. 1503.

Museo Británico. Londres (Reino Unido).

\section{San Sebastián y San Roque}

El personaje de San Roque aparece con sus característicos atributos: el perro y el ángel. En esta pintura del retablo de Caltojar (fig. 179) aparece vestido con su traje de peregrino, con su característico bordón, esclavina (la capa corta que lleva sobre los hombros), y la concha, que en este caso luce sobre el bordón ${ }^{447}$. Con la mano izquierda levanta su túnica para mostrar su pierna infectada. Al tratarse de un santo sanador de enfermedades, y especialmente de la peste, se le relaciona siempre con San Sebastián, con el que comparte el mismo poder milagroso.

La presencia de ambos santos dentro de la pintura de la diócesis seguntina es muy importante, probablemente debido a sus poderes curativos. San Sebastián aparece

${ }^{447}$ CARMONA MUELA, J., op. cit., p. 396-397. 
prácticamente desnudo, con una anatomía muy marcada. La postura de ambos personajes es muy similar, aunque el rostro de San Roque mira hacia el lado contrario. Para la figura de San Sebastián se podría haber basado en la estampa de Parmigianino de Virgen con el Niño, San Sebastián y un obispo probablemente la de Ugo da Carpi en el Museo Británico (fig. 180) ${ }^{448}$, y que representa al santo con la misma posición. La parte superior estaría invertida, pero la inferior habría sido utilizada de manera literal. Ramos Gómez también señaló como posible fuente para San Sebastián alguna estampa del Laocoonte, concretamente la figura de uno de los hijos, tanto para la parte superior como la inferior ${ }^{449}$. Diego de Madrid podría haber tomado aquí como modelo la estampa del Laocoonte de Giovanni Antonio da Brescia datada del 1506-1520 (fig. $181)^{450}$.

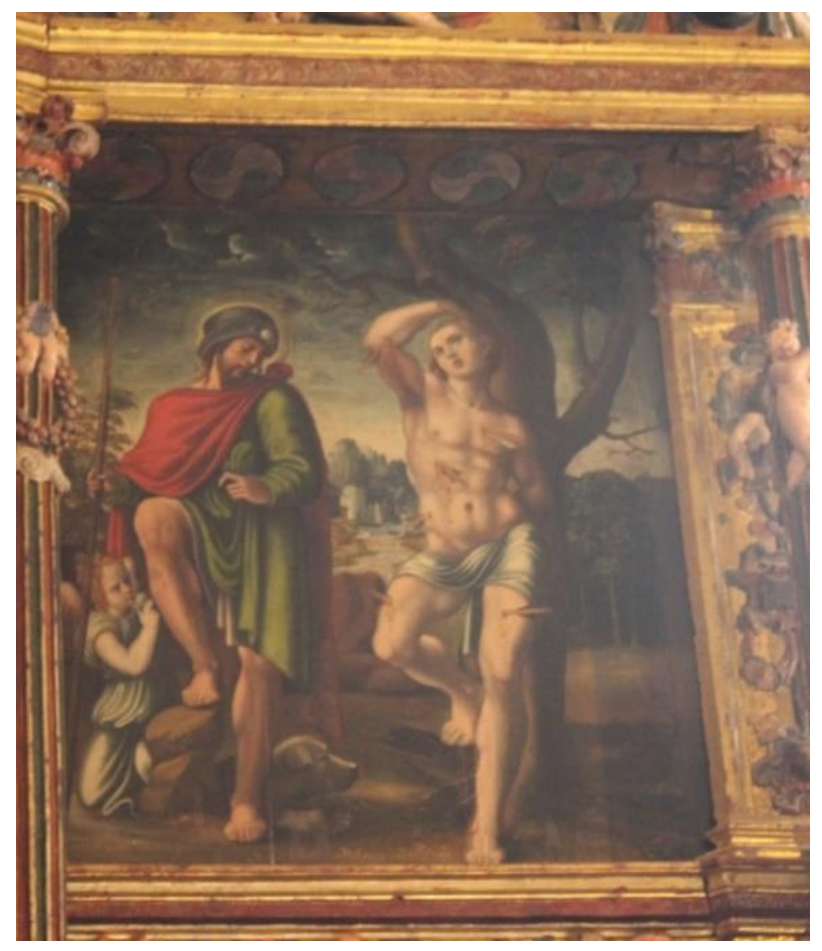

179. Diego de Madrid.

San Roque y San Sebastián.

1553-1574. Retablo mayor. Iglesia de San Miguel. Caltojar (Soria)

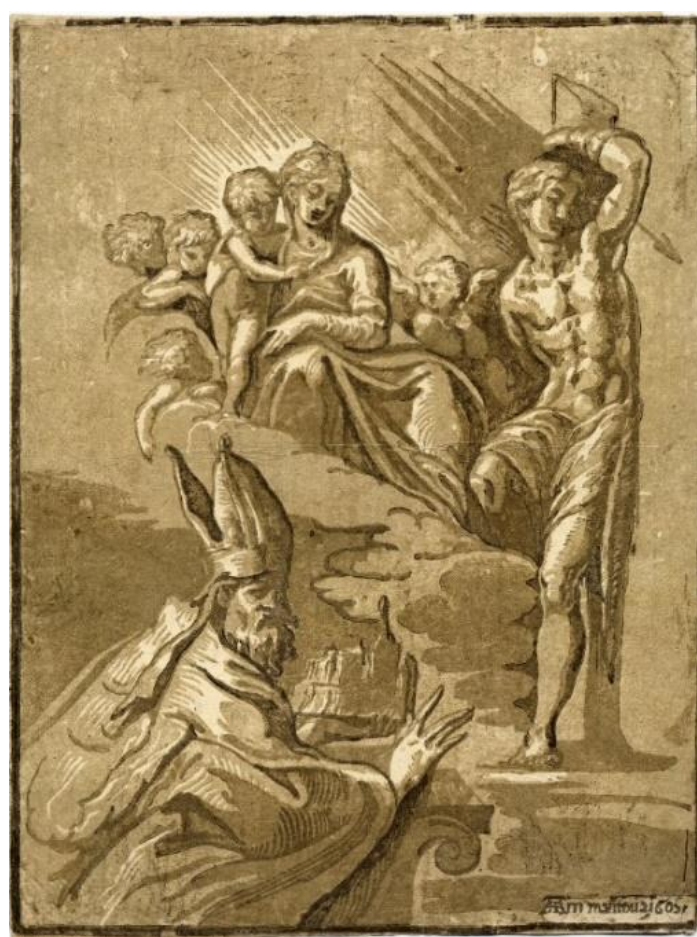

180. Andrea Andreani, A partir de Parmigianino. Virgen con el Niño, San Sebastián y un obispo. 1510-1520.

Museo Británico. Londres

${ }^{448}$ Estampa disponible en:

http://www.britishmuseum.org/research/collection_online/collection_object_details.aspx?objectId=15119 98\&partId=1\&searchText=ugo+da+carpi\&images=on\&page=1; BARTSCH, A., op. cit., vol. XII, p. 66. ${ }^{449}$ RAMOS GÓMEZ, F. J., Juan Soreda y la pintura ..., p. 215.

${ }^{450}$ Estampa disponible en:

http://www.britishmuseum.org/research/collection_online/collection_object_details.aspx?objectId=13467 41\&partId=1\&searchText=laocoon\&images=true\&people=123512\&page=1; BARTSCH, A., op. cit., vol. XIII, p. 326; HIND, A. M., Early Italian engraving..., vol. V (parte 2), n 20, p. 43. 


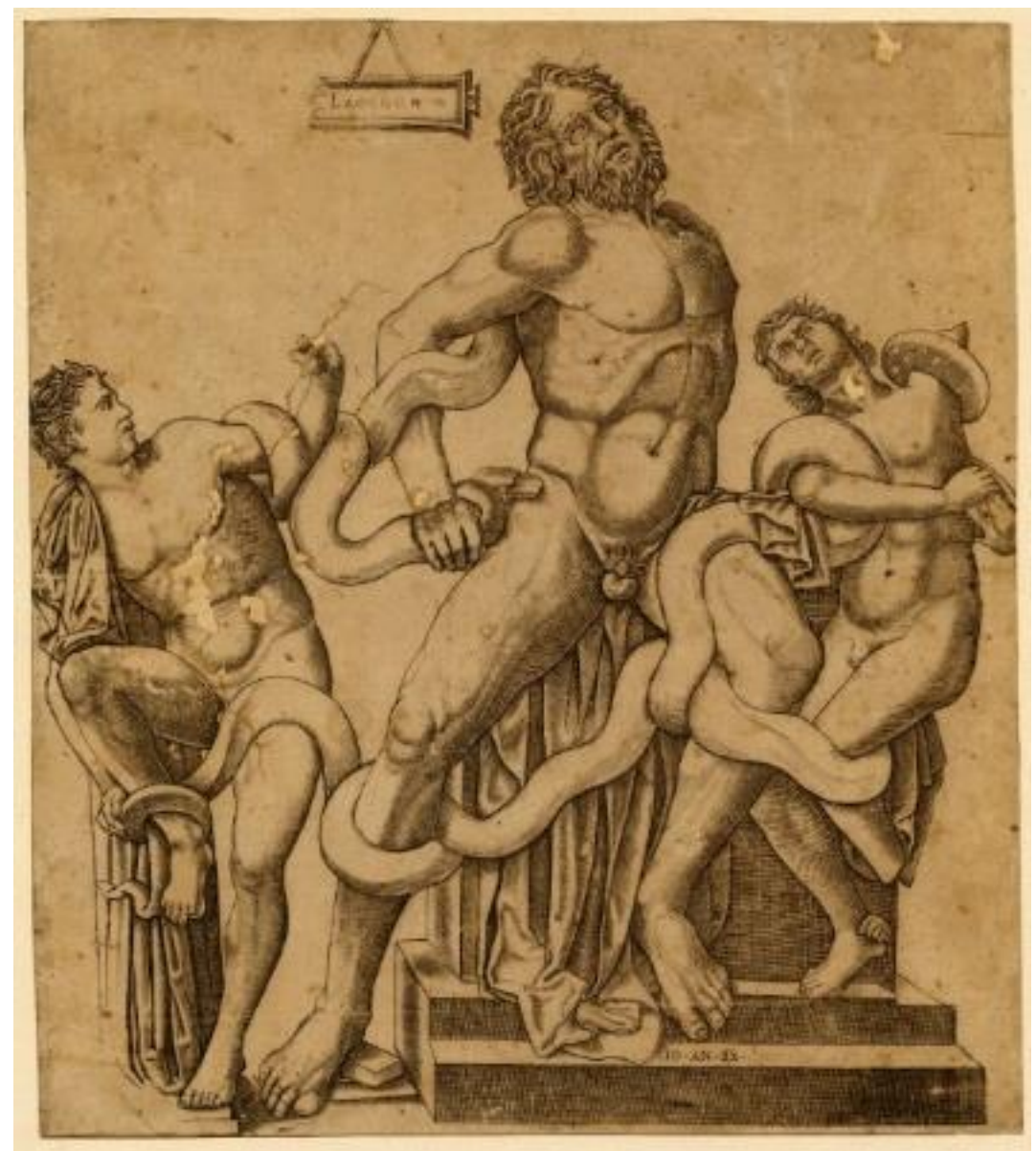

181. Giovanni Antonio da Brescia. Laocoonte y sus hijos. 1506-1520. Museo Británico. Londres (ReinoUnido).

\section{Camino del Calvario}

Se inspiró en la misma composición del retablo de Fuentelencina ${ }^{451}$. En la escena del Camino al Calvario (fig. 182) es probable que se basara en la figura que camina delante de Cristo, de espaldas, del Pasmo de Sicilia de Raimondi (fig. 183), sobre todo en sus piernas aunque invertidas. También la figura de Cristo, que en este caso apoya su mano izquierda sobre una piedra, en vez de la derecha. Otro elemento tomado de la estampa podría ser el soldado que aparece al fondo a la derecha y que porta el estandarte con las iniciales S. P. Q. R.

Diego de Madrid ha reducido el número de figuras que aparecen en la composición, colocando la mayoría a la izquierda, y dejando a la derecha un espacio para la representación de un paisaje montañoso, dando mayor protagonismo a la figura de Cristo y del hombre que tira de él con una cuerda.

${ }^{451}$ RAMOS GÓMEZ, F. J., Juan Soreda y la pintura ..., p. 217. 


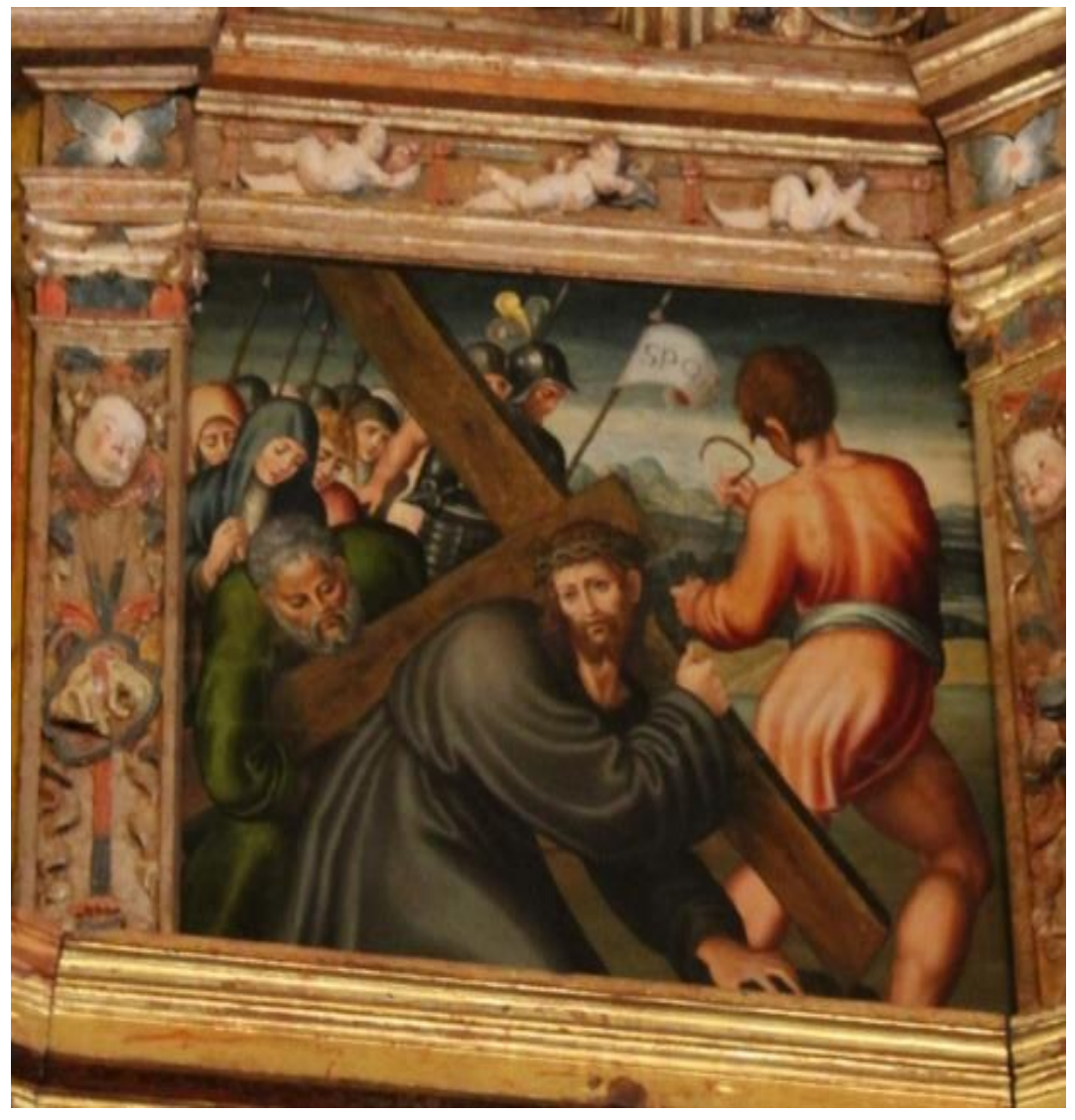

182. Diego de Madrid. Camino del Calvario. 1553-1574. Iglesia de San Miguel. Caltojar (Soria).

183.Agostino Veneziano. Detalle del Pasmo de Sicilia. 1517. Museo Británico. Londres (ReinoUnido)

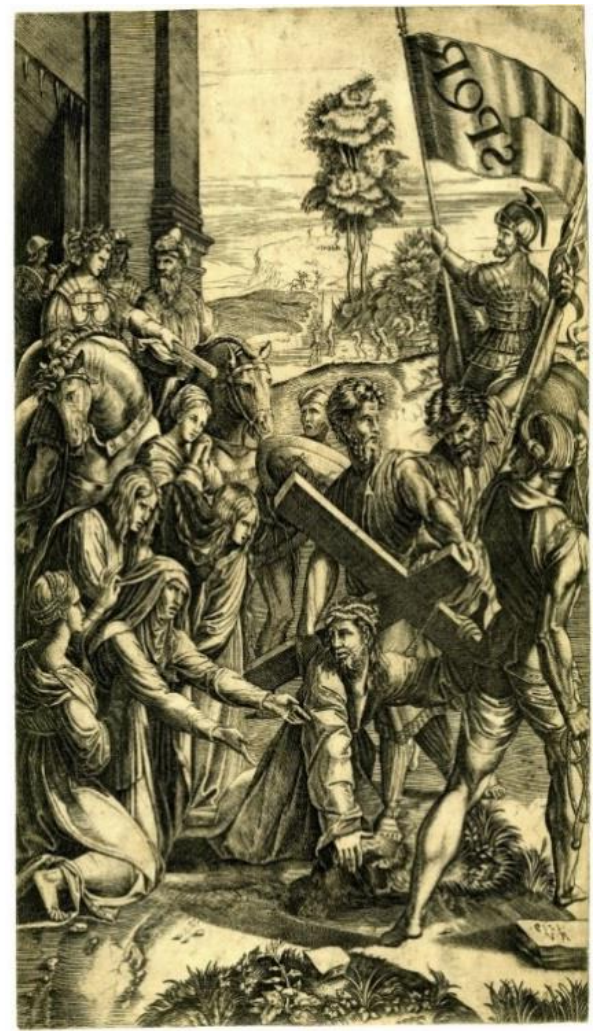




\section{San Juan Bautista}

Es una figura más natural, sin las contorsiones de etapas precedentes, debido probablemente a la influencia de la Contrarreforma ${ }^{452}$. Para la figura del San Juan Bautista (fig. 184) es probable que se inspirase en diferentes estampas que parecen funcionar como academias, como modelos para aprender sobre anatomía.

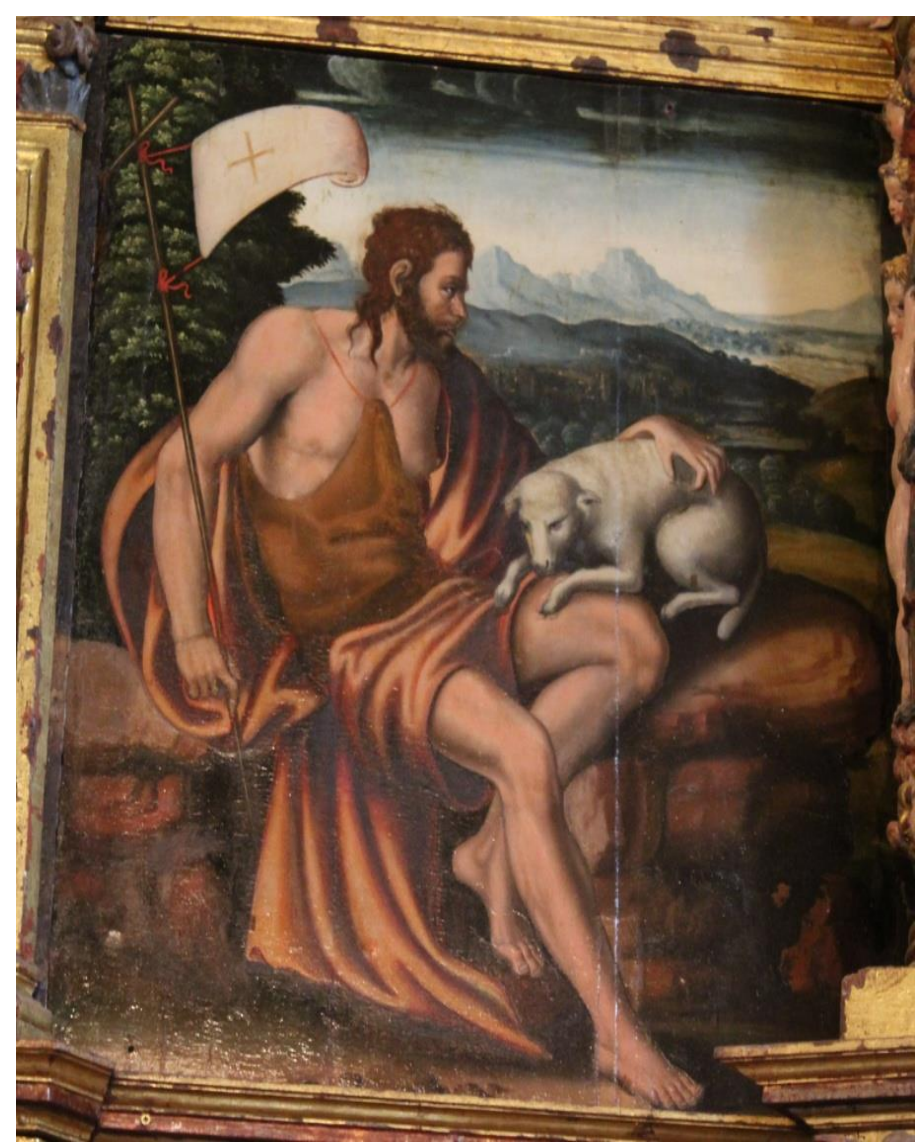

184. Diego de Madrid. San Juan Bautista. 1553-1574. Iglesia de San Miguel. Caltojar (Soria).

Por un lado la postura del santo, con la pierna derecha curvada apoyada sobre una roca y la otra medio extendida, así como el musculoso brazo derecho podrían provenir de la estampa invertida de Raimondi de Galatea escapando de Polifemo (fig. $185)^{453}$, en la cual el cíclope aparece representado de manera muy parecida.

También encontramos otros ejemplos parecidos en la obra de Raimondi (fig. 186), como en Joven olímpico (fig. 187), en el cual las piernas muestran una pose

\footnotetext{
452 Ídem, p. 214.

${ }^{453}$ Estampa disponible en:

http://www.britishmuseum.org/research/collection_online/collection_object_details.aspx?objectId=16188 40\&partId=1\&searchText=marco+da+ravenna\&page=1; BARTSCH, A., op. cit., vol. XIV, p. 182.
} 
similar a la de San Juan Bautista ${ }^{454}$. Por último en la estampa de Raimondi de Hombre desnudo sujetando una flauta (fig. 188) ${ }^{455}$, el personaje muestra unas piernas con una posición semejante, si bien la estampa ha sido invertida en este caso.

La figura del santo, de todas maneras, es de extremidades más alargadas y menos musculosas que las de los grabados de Raimondi. Su pose resulta más afectada y menos natural que las de las estampas italianas en las cuales se basó.

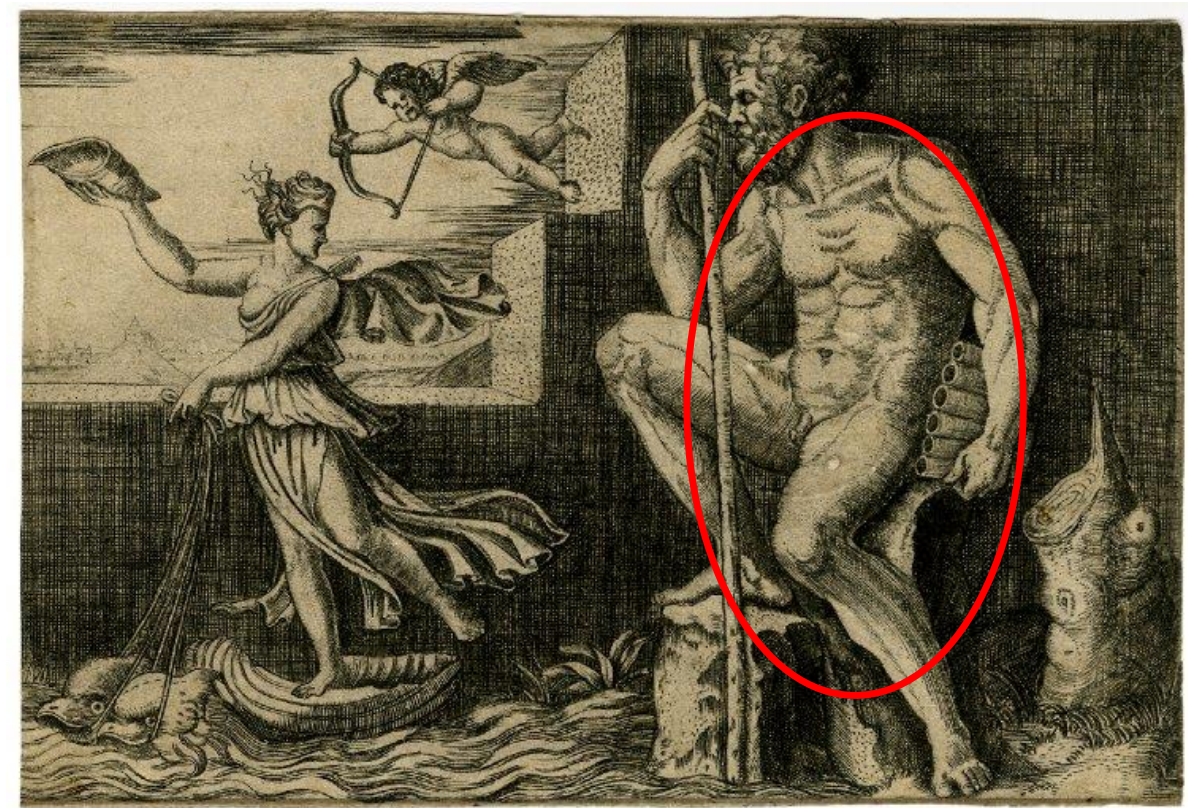

185. Marco da Ravenna. Polifemo persiguiendo a Galatea.

Serie bajorrelieves antiguos. 1510-1527. Museo Británico. Londres (Reino Unido).

186. Detalle de la fig. 184.

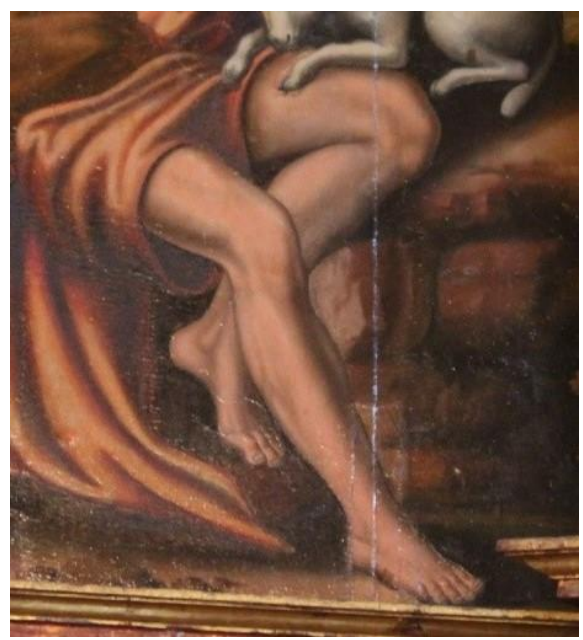

${ }^{454}$ Estampa disponible en:

http://www.britishmuseum.org/research/collection_online/collection_object_details.aspx?objectId=14381 24\&partId=1\&searchText=marco+da+ravenna\&page=1; BARTSCH, A., op. cit., vol. XIV, p. 233; PASSAVANT, J. D., op. cit., vol. VI, p. 83.

${ }^{455}$ Estampa disponible en:

http://www.britishmuseum.org/research/collection_online/collection_object_details.aspx?objectId=14407 15\&partId=1\&searchText=man+with+flute\&images=true\&people=115934\&page=1; BARTSCH, A., op. cit., vol. XIV, p. 348. 


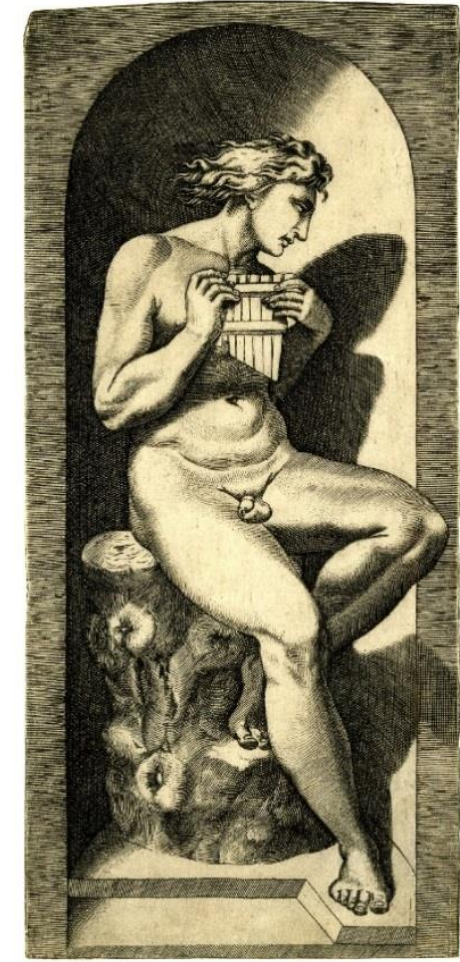

187. Marco da Ravenna. Joven olímpico sentado en el tronco de un árbol tocando la siringa con las dos manos. 1510-1512.

Museo Británico. Londres (ReinoUnido)

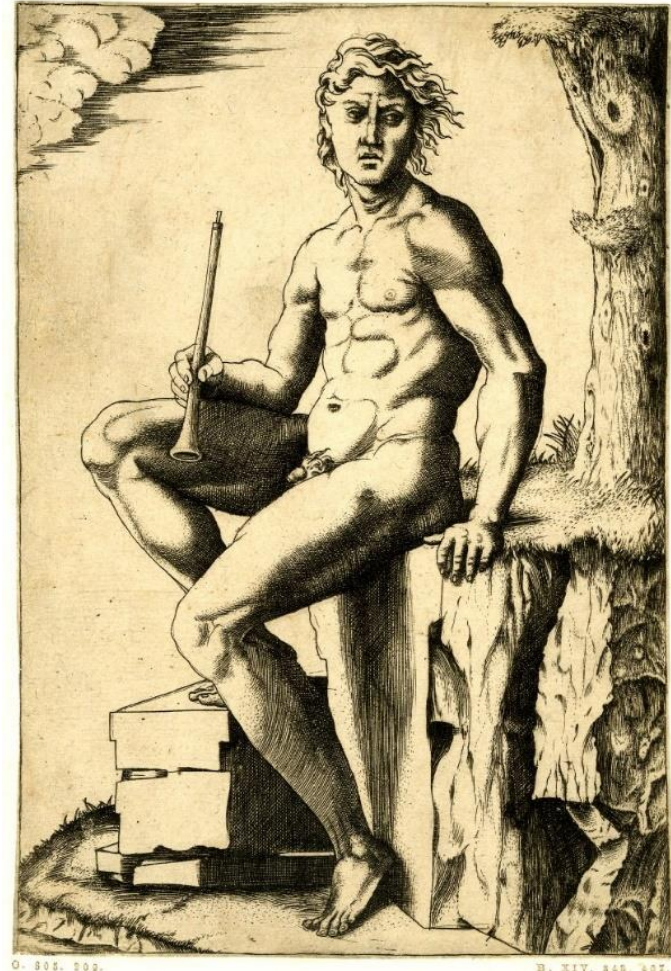

188. Marcantonio Raimondi. Hombre desnudo sujetando una flauta. 1518-1527. Museo Británico. Londres (ReinoUnido)

\section{Martín de Vandoma Escultura de San Miguel 1553-1574 iglesia de San Miguel Caltojar (Soria}

En esta escultura del retablo de Caltojar ${ }^{456}$ San Miguel luce como atributos: el demonio, que aparece sometido bajo sus pies; la vara, con la que ataca al demonio, y que normalmente remata en la forma de una cruz; su armadura y su escudo, con las iniciales QUD (Quis ut Deus) que simboliza el propio nombre del arcángel. A San Miguel siempre se le representa con alas, con aspecto juvenil y sin barba. Sus ropajes responden a sus altos cargos celestiales, así que aparece ataviado como si fuera el capitán de un ejército ${ }^{457}$. En este caso el ángel amenaza al demonio con el palo que porta en la mano derecha, mientras que con la izquierda sujeta su escudo (fig. 189).

456 ANGUlO IÑíGUEZ, A., op. cit., p. 193. AZCÁRATE, J. M., Escultura del siglo..., p. 240. ALCOLEA, S., op. cit., p. 196. COZAR DEL AMO, J. M., y GARCÍA LÓPEZ, A., op. cit., p. 105. RAMOS GÓMEZ, F. J., Juan Soreda..., p. 213.

${ }^{457}$ CARMONA MUELA, J., op. cit., pp. 329-331. 


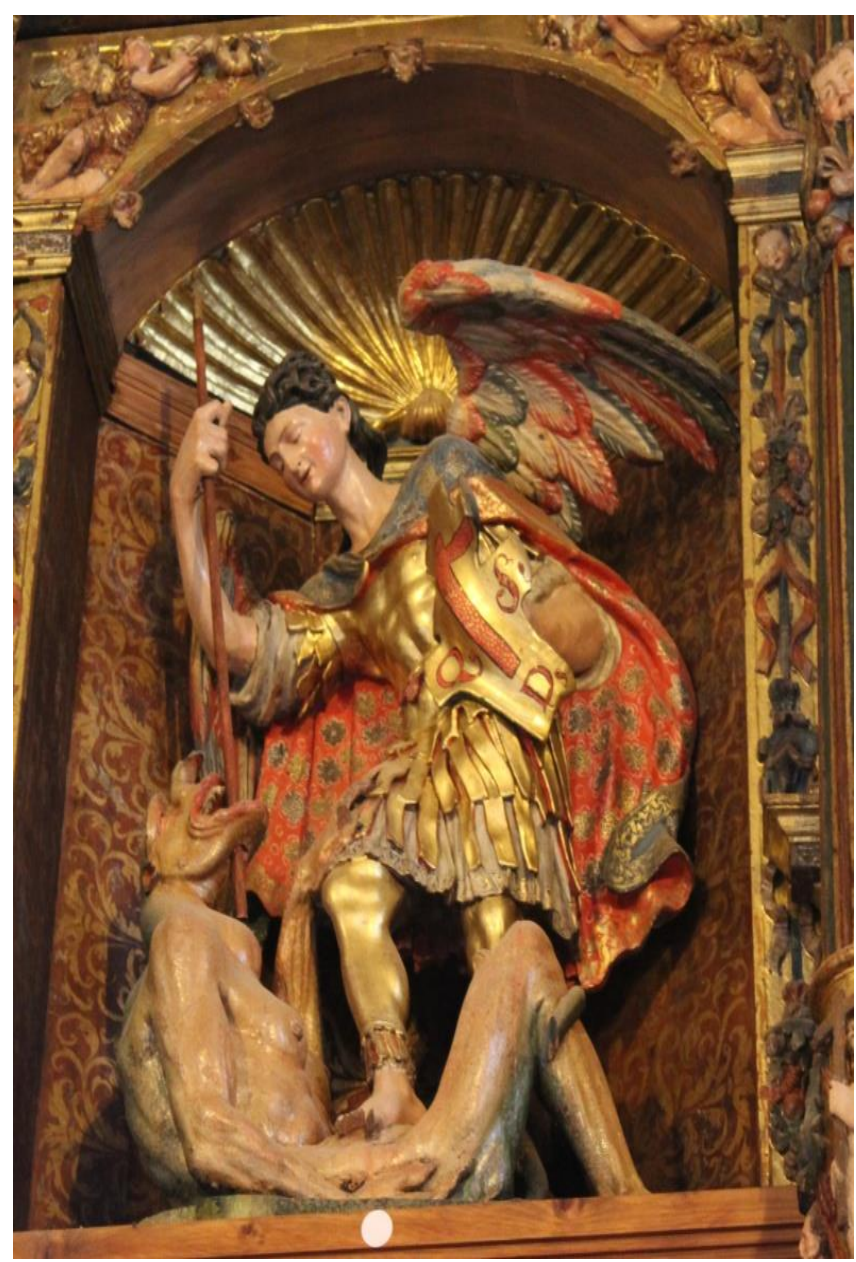

189. Anónimo. San Miguel. 1553-1574.

Iglesia de San Miguel (Caltojar).

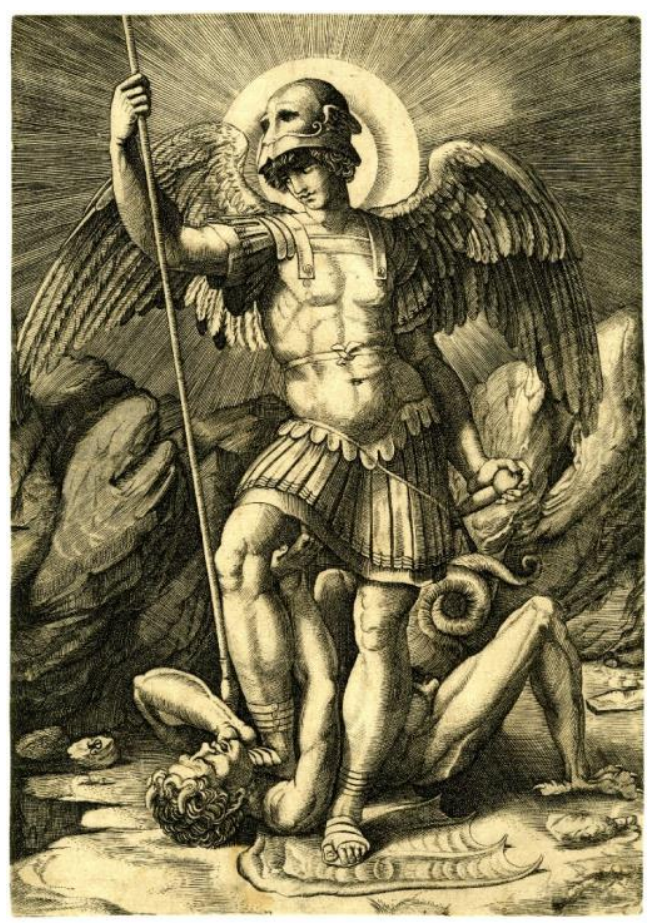

190.Agostino Veneziano. A pàrtir de Rafael. San Miguel. 1518-1527. Museo Británico. Londres 
Para esta escultura es posible que el artista utilizara la estampa del mismo tema de Agostino Veneziano (fig. 190) ${ }^{458}$, inspirada en un diseño de Rafael. También sigue la misma postura con el pie derecho pisando al demonio y el brazo derecho sujetando la vara que se apoya sobre el suelo; sin embargo, en la estampa el ángel sujeta con la mano izquierda el pomo de su espada, mientras que en la escultura sujeta un escudo.

\section{Diego de Urbina \\ Velo de Pasión \\ 1557 \\ Catedral \\ Burgo de Osma (Soria)}

En la sarga que decora el altar de la catedral durante la Semana Santa (Fig. 191 y $192)^{459}$ podemos observar la evidente influencia de carácter italiano de muchas de sus figuras. Esta obra se ha atribuido también a otros artistas, como Alonso Berruguete ${ }^{460}$, Villoldo o Juan Navarrete "el Mudo ${ }^{461 "}$ ya que no existen pruebas de que fuera realizado por Diego de Urbina ${ }^{462}$. Aún así, las semejanzas entre esta sarga y la que se encuentra en el Monasterio del Parral (Segovia) hacen pensar que realmente sí se trata de una obra de Urbina. En la parte superior aparece la figura de Dios Padre, rodeado por los escudos del obispo Acosta, el donante.

Está formada por tres piezas, que fingen a un retablo de dos cuerpos, tres calles, y dos entrecalles, con una estructura basada en columnas jónicas. En la parte alta remata con una decoración de máscaras y tarjas, mientras en la inferior hay figuras de doncellas.

Las figuras son profundamente manieristas, de canon alargado y posturas complejas y afectadas. El estilo y la forma de representar a las figuras corresponden a la etapa intermedia dentro de la producción de Urbina, con cierta influencia de Villoldo y Becerra $^{463}$. Los libros de fábrica de la catedral reflejan que la sarga fue restaurada en

\footnotetext{
${ }^{458}$ Estampa disponible en: http://britishmuseum.org/research/collection_online/collection_object details.aspx?objectId=1441422\&p artId=1\&searchText=saint+michael\&images=true\&people=134723\&page=1; BARTSCH, A., op. cit., vol. XIV, p. 94.

${ }^{459}$ ABAD ZAPATERO, J. G., y ARRANZ ARRANZ, J., La Catedral de Burgo de Osma. Guía Turística, Soria, 1981, p. 64.

${ }^{460}$ ABAD ZAPATERO, J. G., y ARRANZ ARRANZ, J., Las iglesias de Aranda, Burgos, Caja de Ahorros Municipal de Burgos, 1989, p. 104.

${ }^{461}$ CAPILLA DE BLAS, J. M., "Velos de pasión, jirones olvidados", Arévacos, n 29, 2007, pp. 2-6

${ }^{462}$ COLLAR DE CÁCERES, F., "Diego de Urbina...”, p. 113.

${ }^{463}$ Ídem, p. 115.
} 
1576 por Pedro Ruiz de Valpuesta, debido a que estaba rota y quemada. Fue restaurada en 2008-09 por la empresa Fénix Conservación ${ }^{464}$

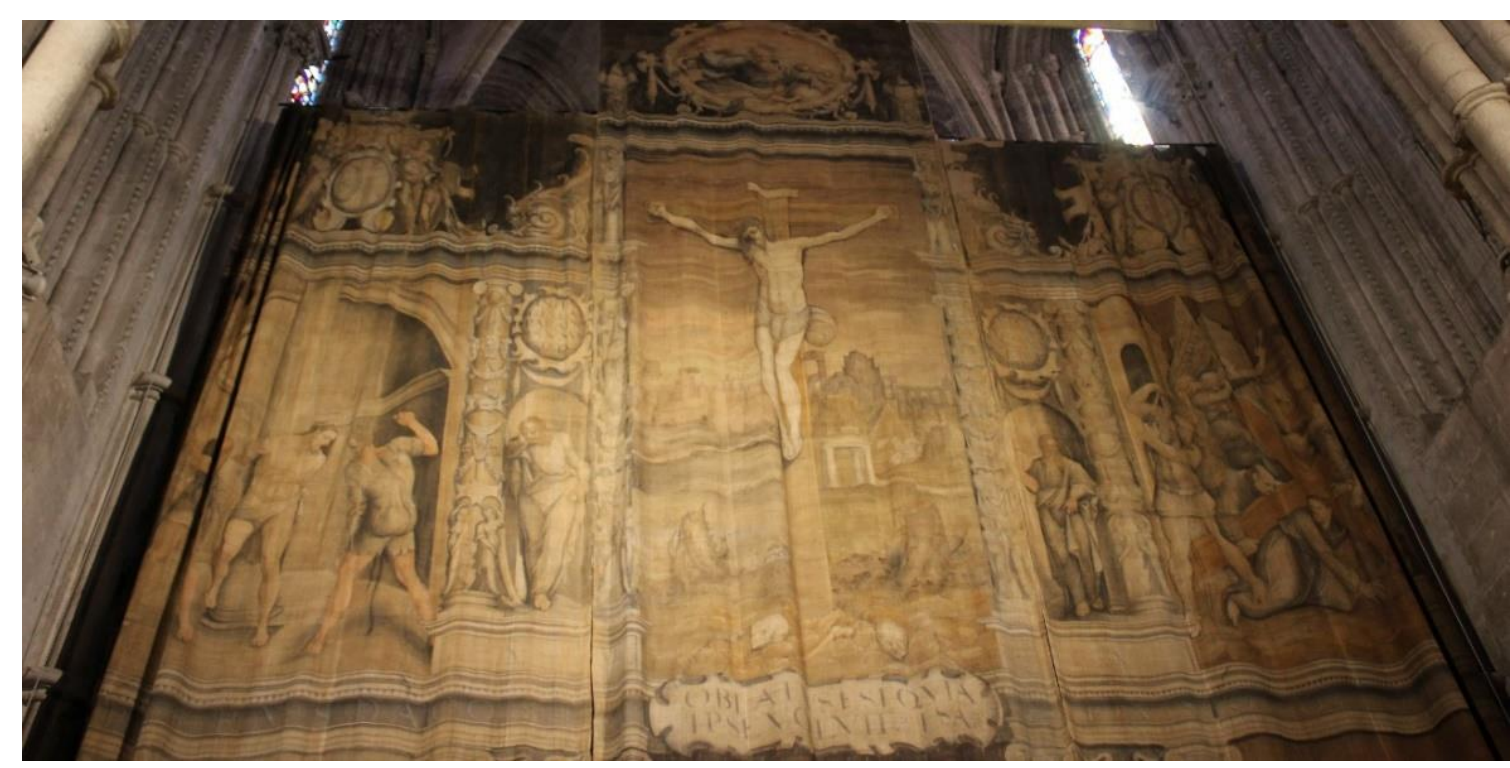

191. Diego de Urbina.

Velo de Pasión. 1557. Catedral del Burgo de Osma (Soria).

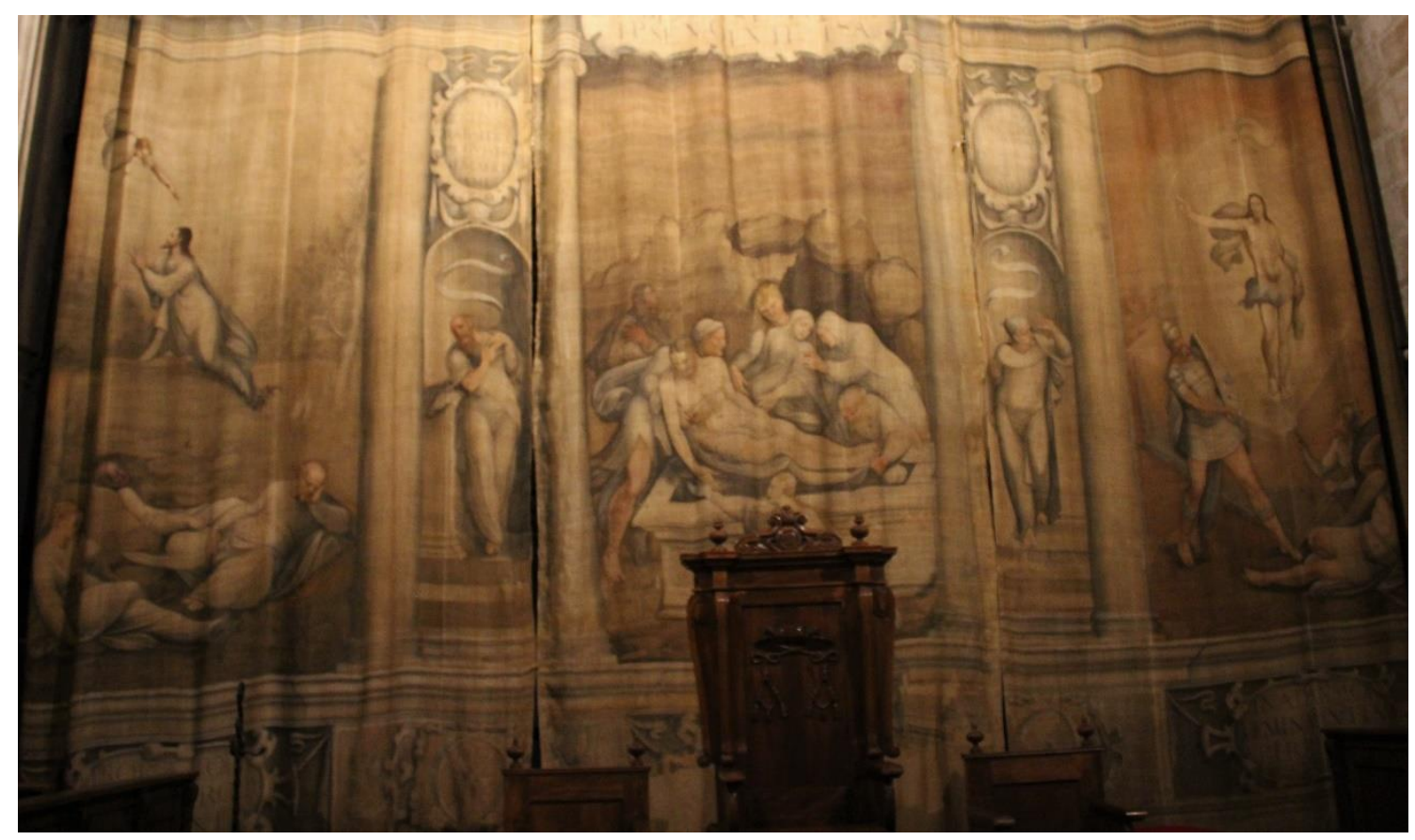

192. Diego de Urbina.

Velo de Pasión. 1557. Catedral del Burgo de Osma (Soria).

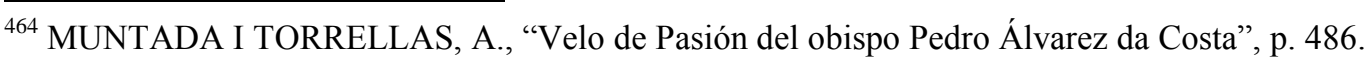




\section{Flagelación}

La escena está situada en la parte superior izquierda de la sarga (fig. 193) ${ }^{465}$. En ella, Urbina ha utilizado la estampa basada en la composición del mismo tema de Sebastiano del Piombo ${ }^{466}$ (fig. 194) ${ }^{467}$, sobre todo en la figura de Cristo, que aparece en el centro atado a la columna, y en la del sayón de la derecha que muestra la misma postura de espaldas y con el brazo derecho alzado para golpear a Cristo. Para el sayón izquierdo, especialmente para las piernas, también tomó como referencia la estampa, aunque coloca los brazos en una pose distinta. En la estampa utiliza el brazo izquierdo para golpear, levantandolo sobre la cabeza, mientras que en la sarga usa el brazo derecho a la altura del pecho. Por otro lado, Urbina eliminó las otras dos figuras que aparecían al fondo participando en la flagelación y dejó el fondo arquitectónico vacío, otorgando una mayor sensación de espacio.

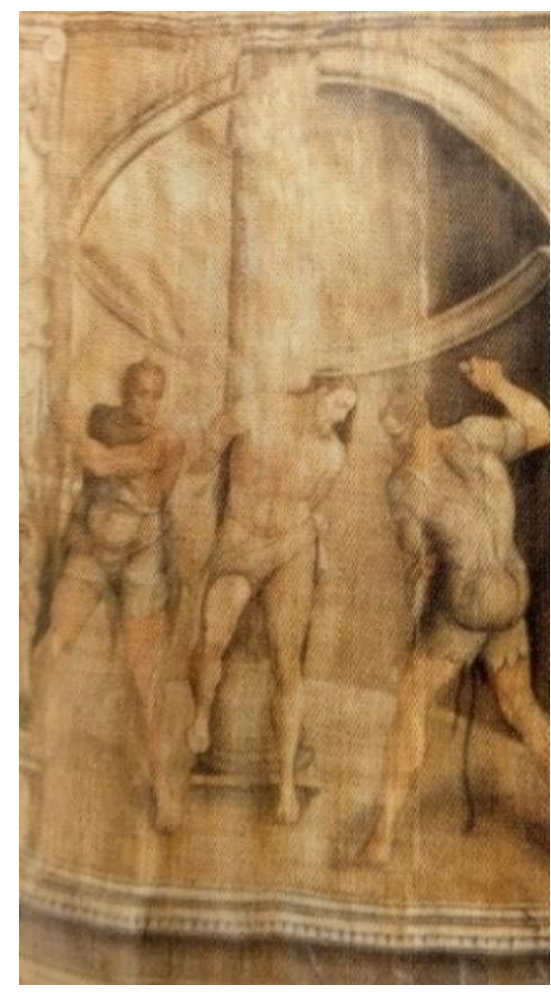

193. Diego de Urbina. Flagelación. Velo de Pasión. 1557. Catedral. Burgo de Osma (Soria).

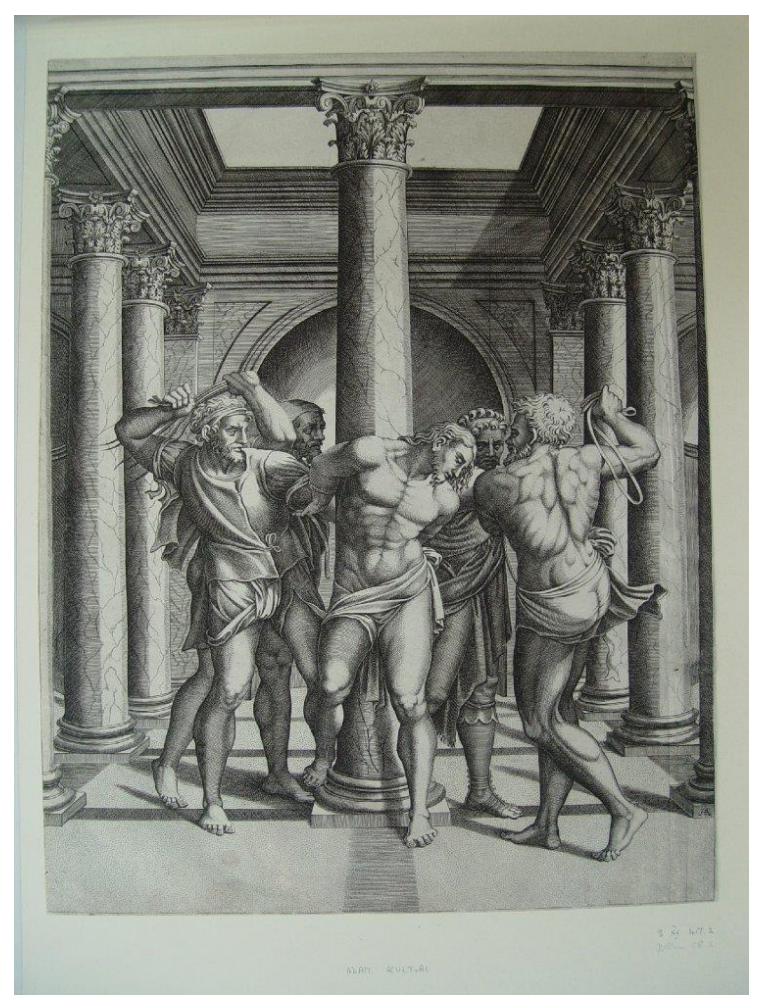

194. Adamo Ghisi. Flagelación. 1547-1587.

Museo Británico. Londres (Reino Unido).

\footnotetext{
${ }^{465}$ Imagen procedente de https://liturgia.mforos.com/1699118/8737959-el-altar/?pag=4.

${ }^{466}$ Estampa disponible en:

http://www.britishmuseum.org/research/collection_online/collection_object_details.aspx?objectId=14941 20\&partId=1\&searchText=flagellation\&images=true\&people=107927\&page=1; BARTSCH, A., op. cit., vol. XV, p. 417; BELLINI, P., L' Opera incisa di Adamo e Diana Scultori, Vicenza, Neri Pozza, 1991, ${ }^{\circ}$ 108, pp 131-134.

${ }^{467}$ COLLAR DE CÁCERES, F., op. cit., p. 114.
} 
La representación es bastante idealizada en comparación con las pinturas alemanas de la época, que inciden más en un realismo caricaturesco. En este caso y siguiendo el estilo del grabado italiano en el que se inspira, se recrea en la belleza de los cuerpos masculinos, tanto en el de Cristo como en el de los dos sayones; aunque en la estampa los verdugos aparecen semidesnudos, para mostrar el estudio anatómico de los cuerpos musculosos, y en la sarga el sayón de la derecha cubre su cuerpo con una camisa que marca su anatomía.

\section{Camino del Calvario}

En concreto en esta escena se representa también El desmayo de la Virgen, en italiano el Spasimo della Vergine (fig. 195) ${ }^{468}$. Es evidente que Urbina utilizó para inspirarse la estampa del Pasmo de Sicilia ${ }^{469}$ basada en la pintura de Rafael (fig. 196) ${ }^{470}$, aunque en este caso se ha invertido la composición.

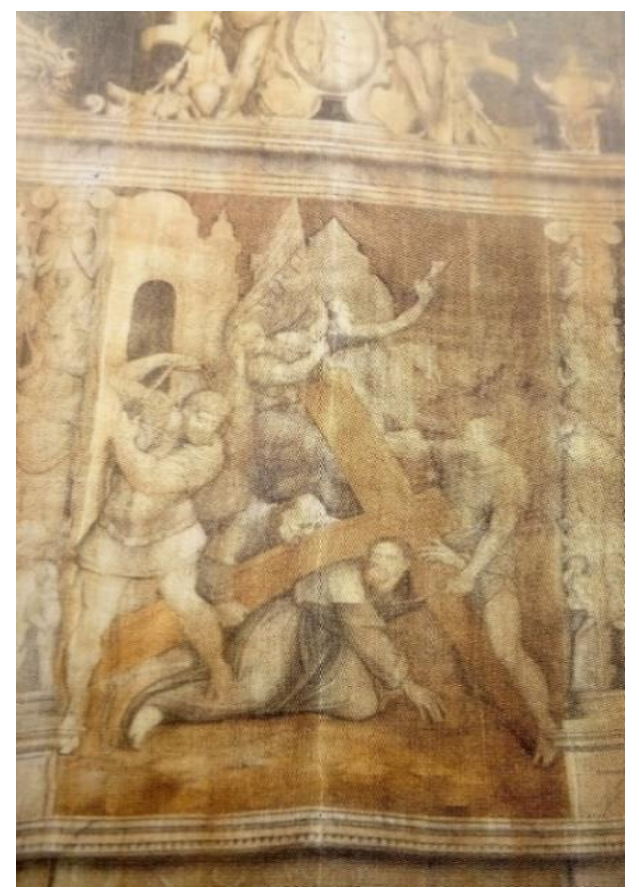

195. Diego de Urbina. Camino del Calvario de Cristo. 1557. Velo de Pasión. Catedral. Burgo de Osma (Soria).

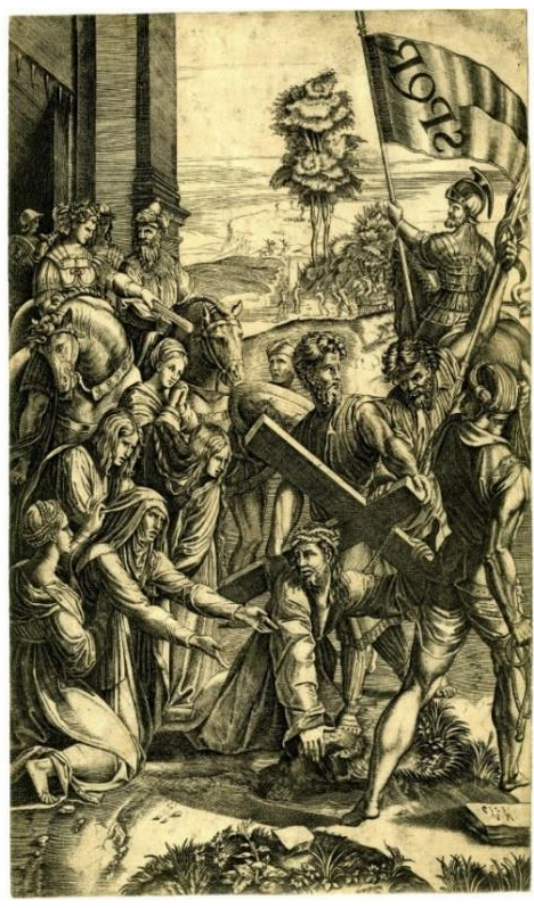

196.Agostino Veneziano.

Pasmo de Sicilia. 1517.

Museo Británico. Londres (Reino Unido).

\footnotetext{
${ }^{468}$ Imagen procedente de MUNTADA I TORRELLAS, A., "Velo de Pasión del obispo Pedro Álvarez da Costa”, p. 483.

${ }^{469}$ Estampa disponible en:

http://britishmuseum.org/research/collection_online/collection_object_details.aspx?objectId=1441900\&p artId $=1 \&$ searchText $=$ calvary \&images $=$ true \&people $=134723 \&$ page $=1$

BARTSCH, A., op. cit., vol. XIV, p. 34. PASSAVANT, J. D., op. cit., vol. VI, p. 52.

${ }^{470}$ COLLAR DE CÁCERES, F., "Diego de Urbina...”, p. 114.
} 
Sobre todo en la figura de Cristo que aparece arrodillado y con el brazo derecho estendido apoyado sobre una roca (fig. 197) ${ }^{471}$. También en el personaje que se situa delante de Cristo y le ayuda a sujetar la cruz con las dos manos vemos la huella del grabado italiano. El fondo, con el soldado que sujeta el estandarte y algunos de los caballos, se basaron igualmente en la estampa.

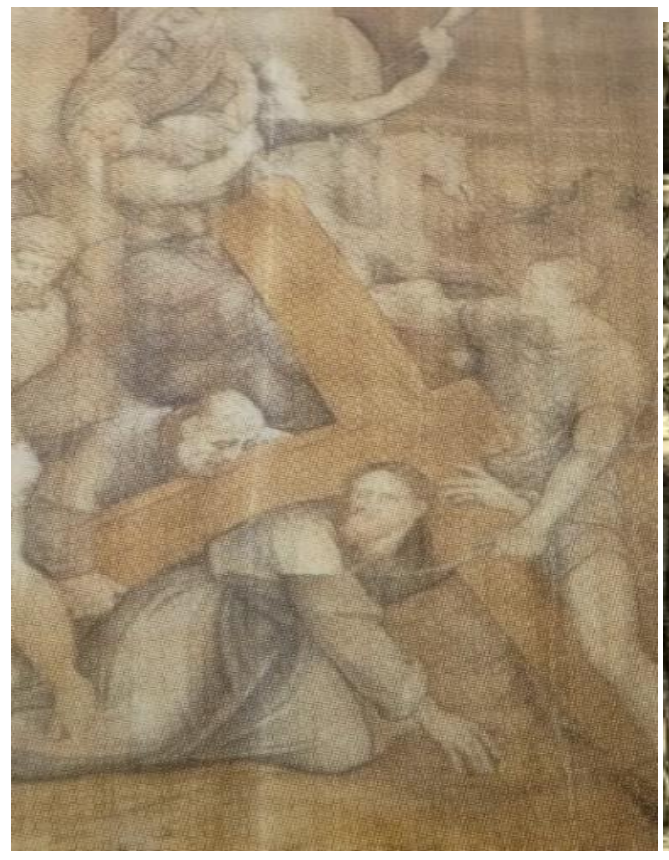

197. Detalle de la fig. 195.

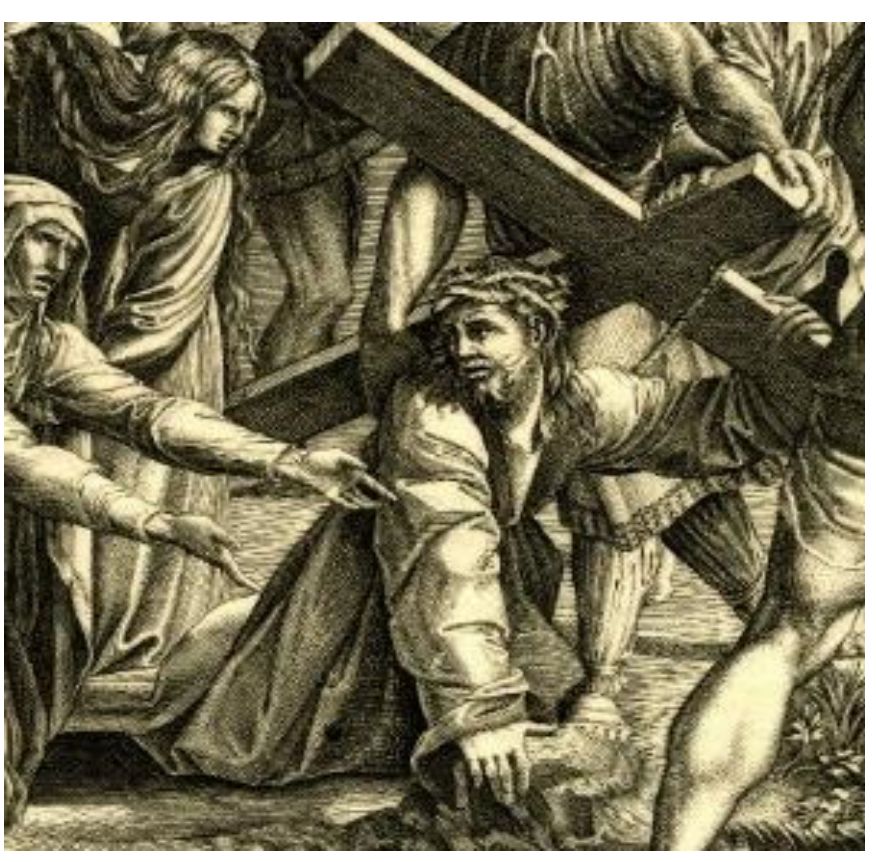

198. Detalle de la fig. 196.

\section{Santo Entierro}

Para esta escena (fig. 199) ${ }^{472}$ Collar de Cáceres señaló que Urbina se había inspirado en dos estampas de Andrea Schiavone con mismo tema, una de ellas basada en el grabado de Parmigianino (fig. 200) ${ }^{473}$. De ésta tomó la figura de Cristo, de pronunciada musculatura, medio sentado sobre el sepulcro semi-abierto con el brazo derecho extendido, y la figura de la Virgen, desmayada en brazos de otro personaje (fig. $201)^{474}$. También la ambientación de la escena con un paisaje rocoso que la rodea, parecen proceder de una de los grabados de Schiavone (fig. 202). Las poses lánguidas y

\footnotetext{
${ }^{472}$ Para el estudio de esta obra véase COLLAR DE CÁCERES, F., "Diego de Urbina...", p. 114.

${ }^{473}$ Estampa disponible en:

http://britishmuseum.org/research/collection_online/collection_object_details.aspx?objectId=1487793\&p artId=1\&searchText=entombment\&images=true \&people=108336\&page $=1$

${ }^{474}$ Estampa disponible en:

http://britishmuseum.org/research/collection_online/collection_object_details.aspx?objectId=1612958\&p artId=1\&searchText=entombment\&images=true \&people=108336\&page=1; BARTSCH, A., op. cit., vol. XIV, p. 49.
} 
las anatomías alargadas denotan que el artista captó supo captar con habilidad las cualidades de las obras de pintores manieristas como Parmigianino.

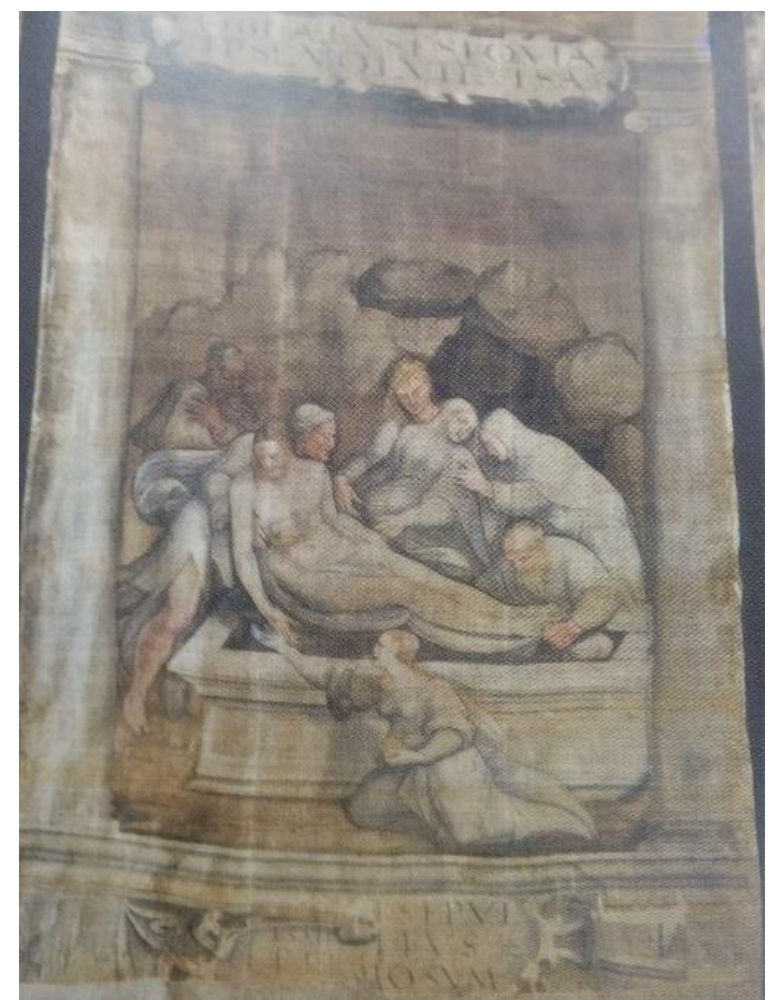

199. Diego de Urbina. Entierro de Cristo. Velo de Pasión. 1557. Catedral. Burgo de Osma (Soria).

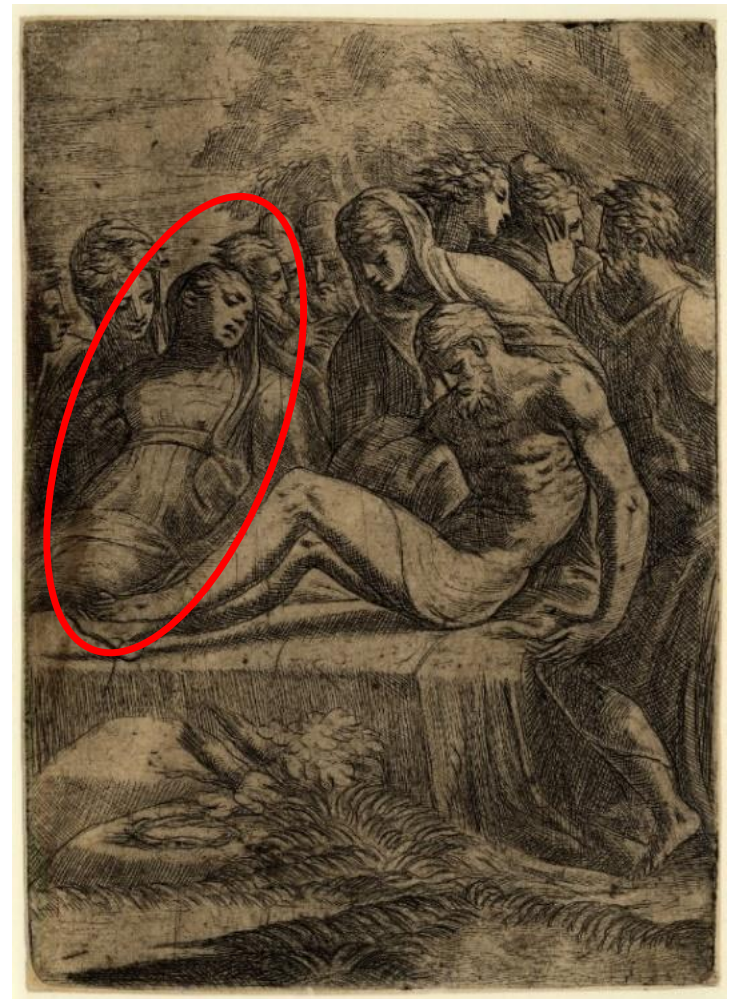

200. Andrea Schiavone. Entierro de Cristo. 1540-1563. Museo Británico. Londres 


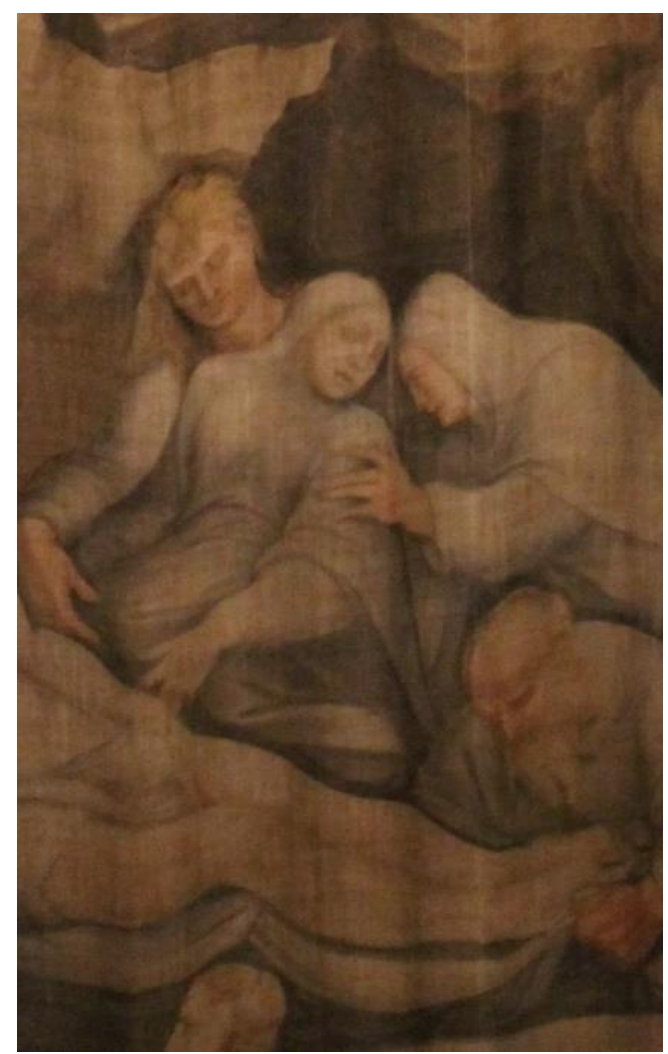

201. Diego de Urbina Detalle de la fig. 199.

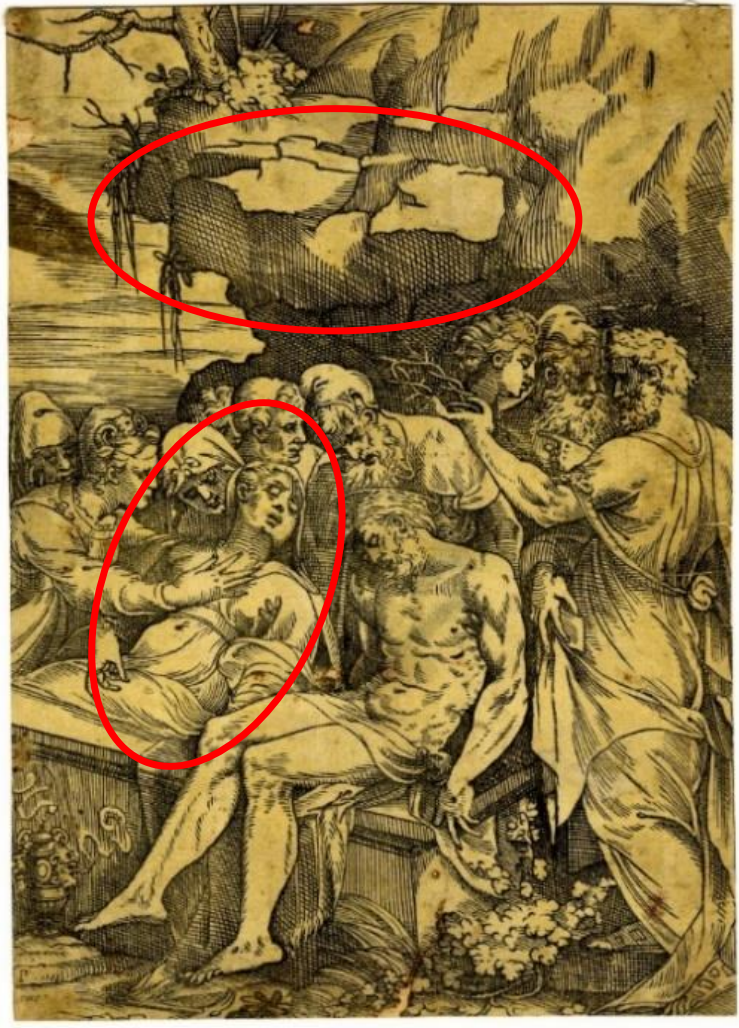

202. Andrea Schiavone. Entierro de Cristo, 1550-1560. Museo Británico. Londres (Reino Unido).

\section{Resurrección}

En la última escena, la de la Resurrección, encontramos también una fuerte influencia de estampas. En la sarga Cristo aparece representado siguiendo la iconografía del Cristo planeando por encima de su tumba, de pie sobre el sarcófago, pero parece como si estuviera levitando dentro de una mandorla.

Los soldados aparecen al pie de la tumba. En este caso son tres, uno de ellos de pie y los otros dos caídos en el suelo a la derecha del sepulcro, como desmayados ante la potencia de la luz divina. Sus reacciones son muy expresivas, casi rozando lo caricaturesco. Su indumentaria y armas se componen de cascos, lanzas y botas, imitando al uniforme de la soldadesca romana. El que se encuentra en la esquina derecha de la escena se cubre los ojos con su escudo para protegerse de la deslumbrante luz.

Para la figura de Cristo (fig. 203) (75 $^{475}$ se inspiró sobre todo en la figura de la estampa de Parmigianino $(1503-1540)^{476}$ (fig. 204) ${ }^{477}$. Tiene la misma pose con el brazo

\footnotetext{
${ }^{475}$ Imagen procedente de MUNTADA I TORRELLAS, A., "Velo de Pasión del obispo Pedro Álvarez da Costa”, p. 483.
} 
derecho alzado portando el estandarte así como el izquierdo pegado al cuerpo sujetandose el manto, también las piernas son muy semejantes, colocando el pie izquierdo un poco por delante del derecho. Incluso el soldado situado en el ángulo inferior derecho (fig. 205), y que se protege con un escudo, parece tomado de la estampa, aunque en este caso se ha invertido la imagen del grabado (fig. 206). A pesar de ello, la escena de Urbina resulta más serena y sosegada que la Parmigianino, debido probablemente a que no introduce ese movimiento de paños que le otorga un mayor dinamismo a las figuras.

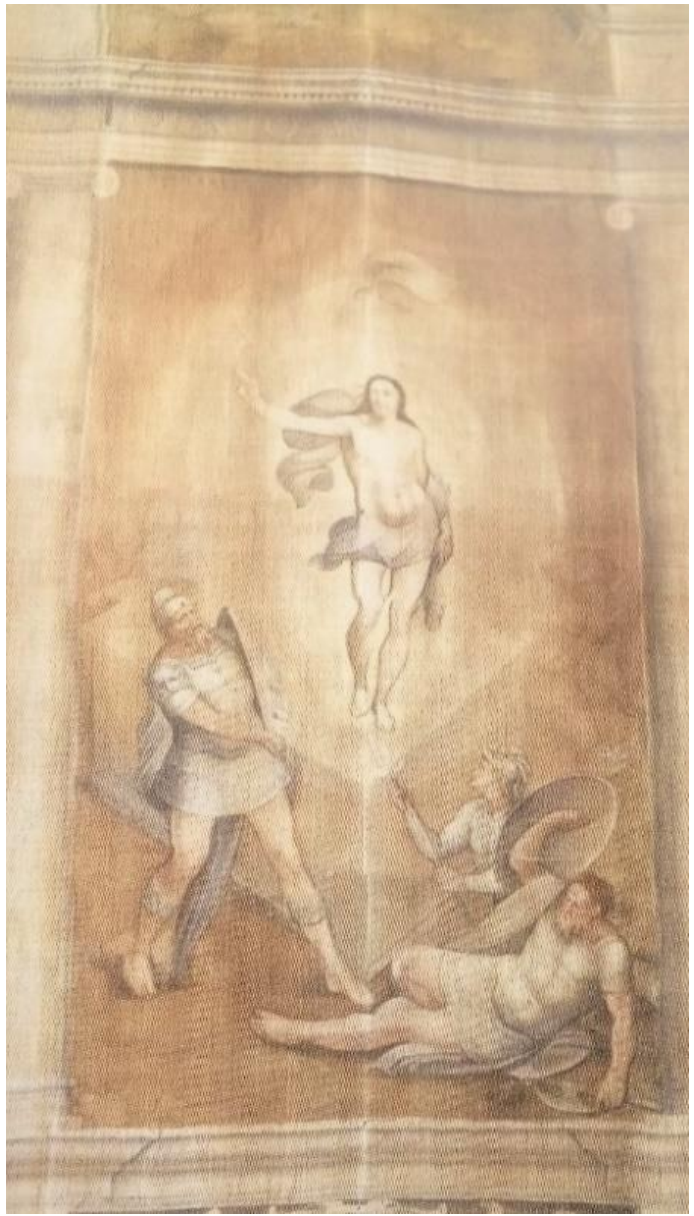

203 . Diego de Urbina. Resurrección. 1557. Velo de Pasión. Catedral. Burgo de Osma (Soria).

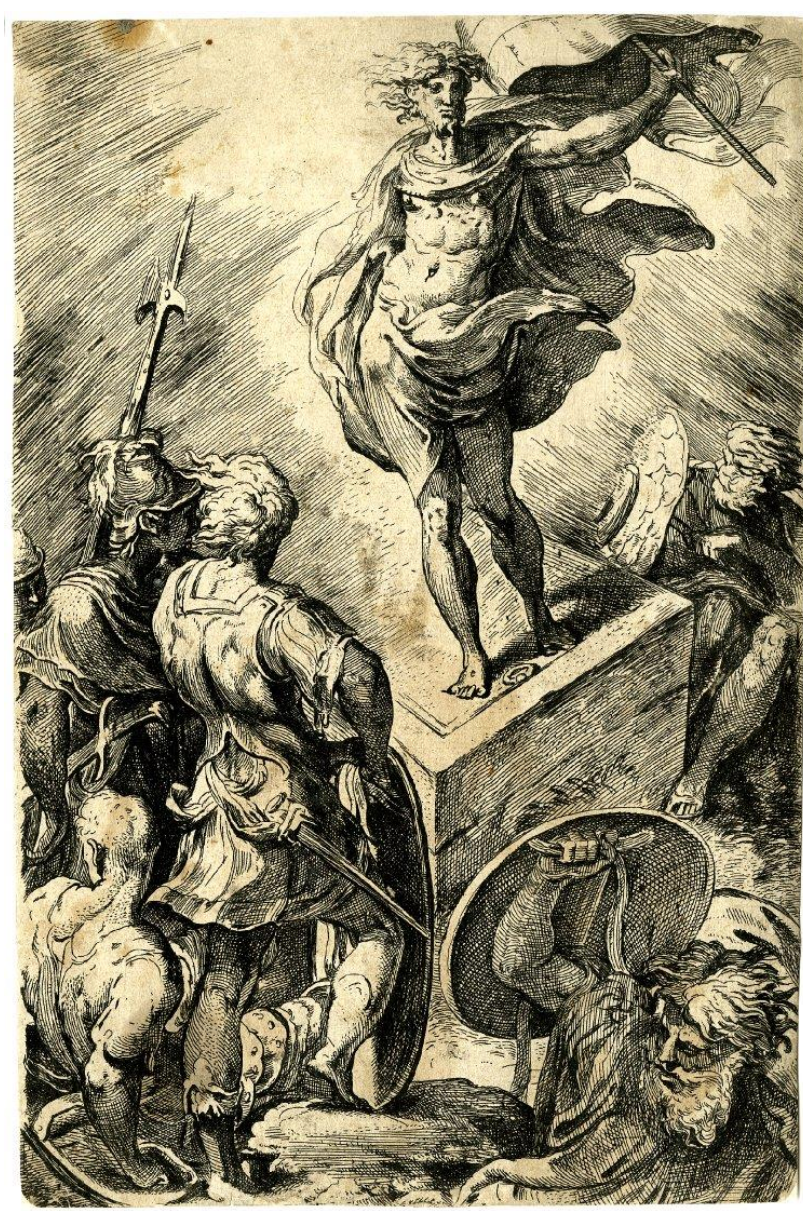

204. Parmigianino.

Resurrección. 1503-1540.

Museo Británico. Londres (ReinoUnido).

\footnotetext{
${ }^{476}$ Estampa disponible en:

http://www.britishmuseum.org/research/collection_online/collection_object_details.aspx?objectId=16034 69\&partId=1\&searchText=resurrection \&images=true \&people $=112268 \&$ page $=1$ BARTSCH, A., op. cit., vol. XVI, p. 9.

${ }^{477}$ COLLAR DE CÁCERES, F., “Diego de Urbina...”, p. 114.
} 


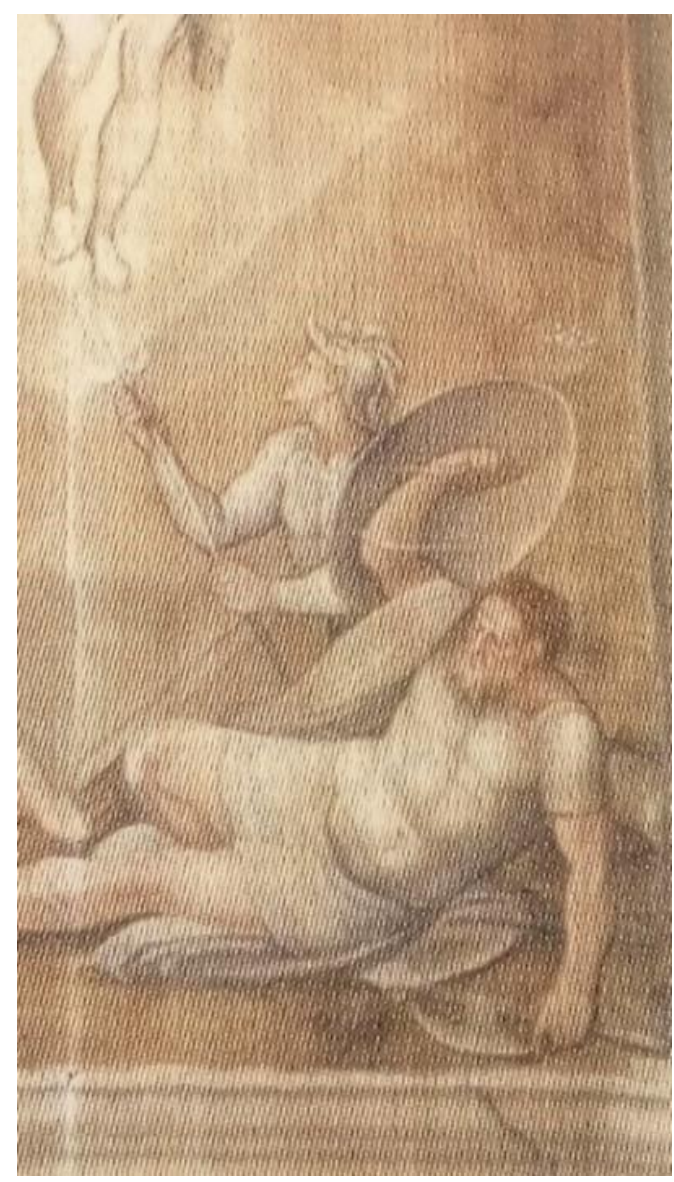

205. Diego de Urbina. Detalle de la fig. 203.

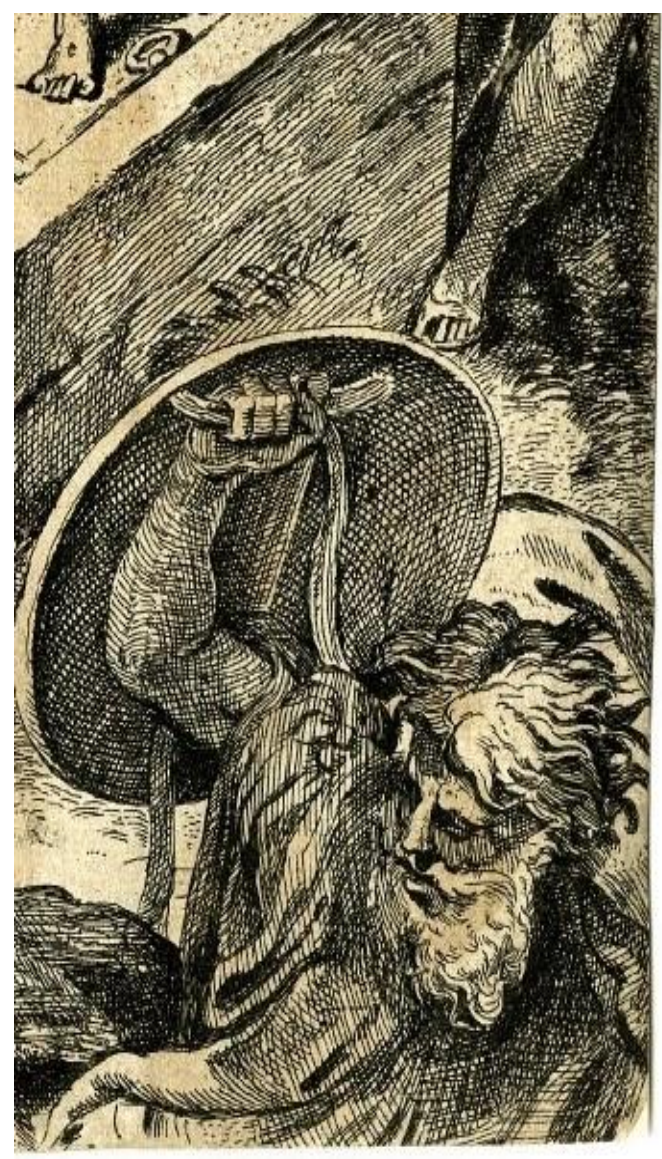

206. Detalle de la fig. 204.

Por último, en algunas de las calles de la sarga colocadas entre las escenas hay varias figuras de profetas que nos remiten también a algunos temas. Como podemos ver en la figura de Jeremías (fig. 207) cuya postura parece tomada de La Escuela de Atenas $^{478}$ de Rafael, del grabado de Giorgio Ghisi de 1550 (fig. 208) ${ }^{479}$, en particular en la figura de Platón, que avanza con el brazo de derecho levantado.

También junto a la escena de la Resurrección encontramos la figura de Sofonías (fig. 209) que según Anna Muntada está inspirada en el rostro del soldado caído de la Batalla de Anghiari (fig. 210 $)^{480}$. Muestra de cualquier modo un rostro muy leonardesco en su expresión sorprendida.

\footnotetext{
${ }^{478}$ Estampa disponible en:

http://www.britishmuseum.org/research/collection_online/collection_object_details.aspx?objectId=13448 47\&partId=1\&searchText=school+of+athens\&images=true \&people=86834\&page $=1$ BARTSCH, A., op. cit., vol. XV, p. 394; LEWIS, M. \& R. E., op. cit., no 11, p. 61-63. ${ }^{479}$ COLLAR DE CÁCERES, F, "Diego de Urbina...", p. 114.

${ }^{480}$ MUNTADA I TORRELLAS, A., "Velo de Pasión del obispo Pedro Álvarez da Costa", pp. 482-86.
} 


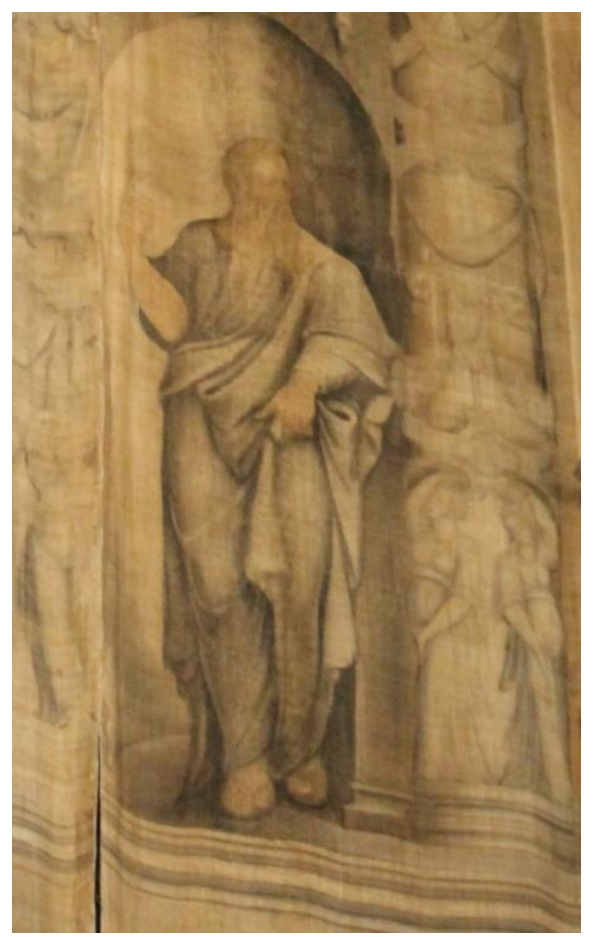

207. Diego de Urbina Detalle Jeremías. 1557. Velo de Pasión, Catedral. Burgo de Osma (Soria).

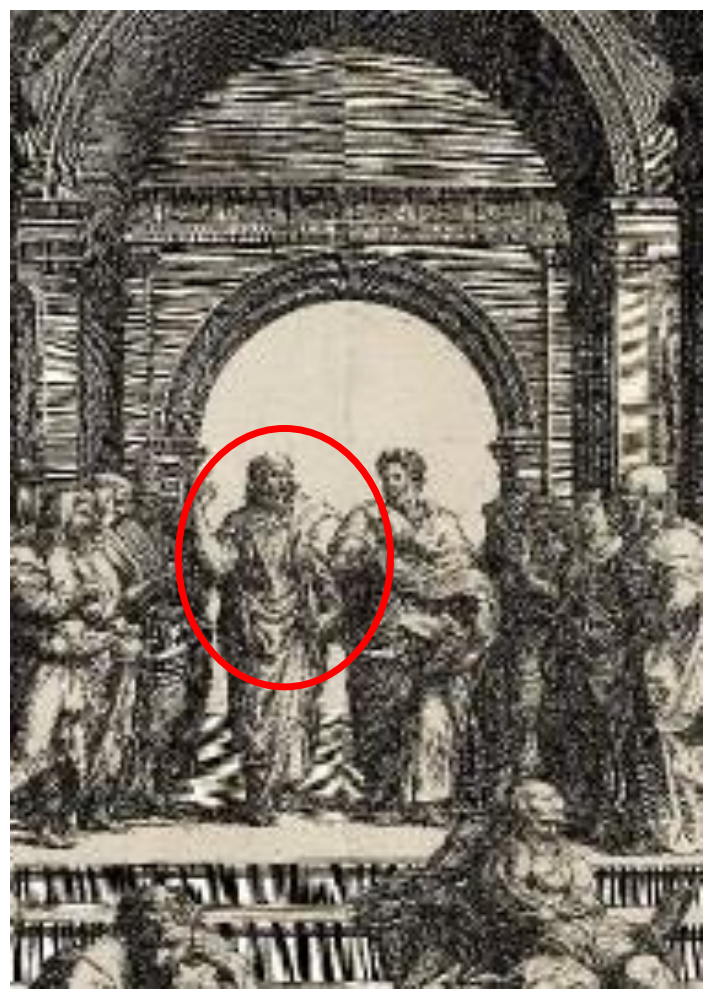

208. Giorgio Ghisi. A partir de Rafael. Escuela de Atenas. 1550.

Museo Británico. Londres (ReinoUnido). 


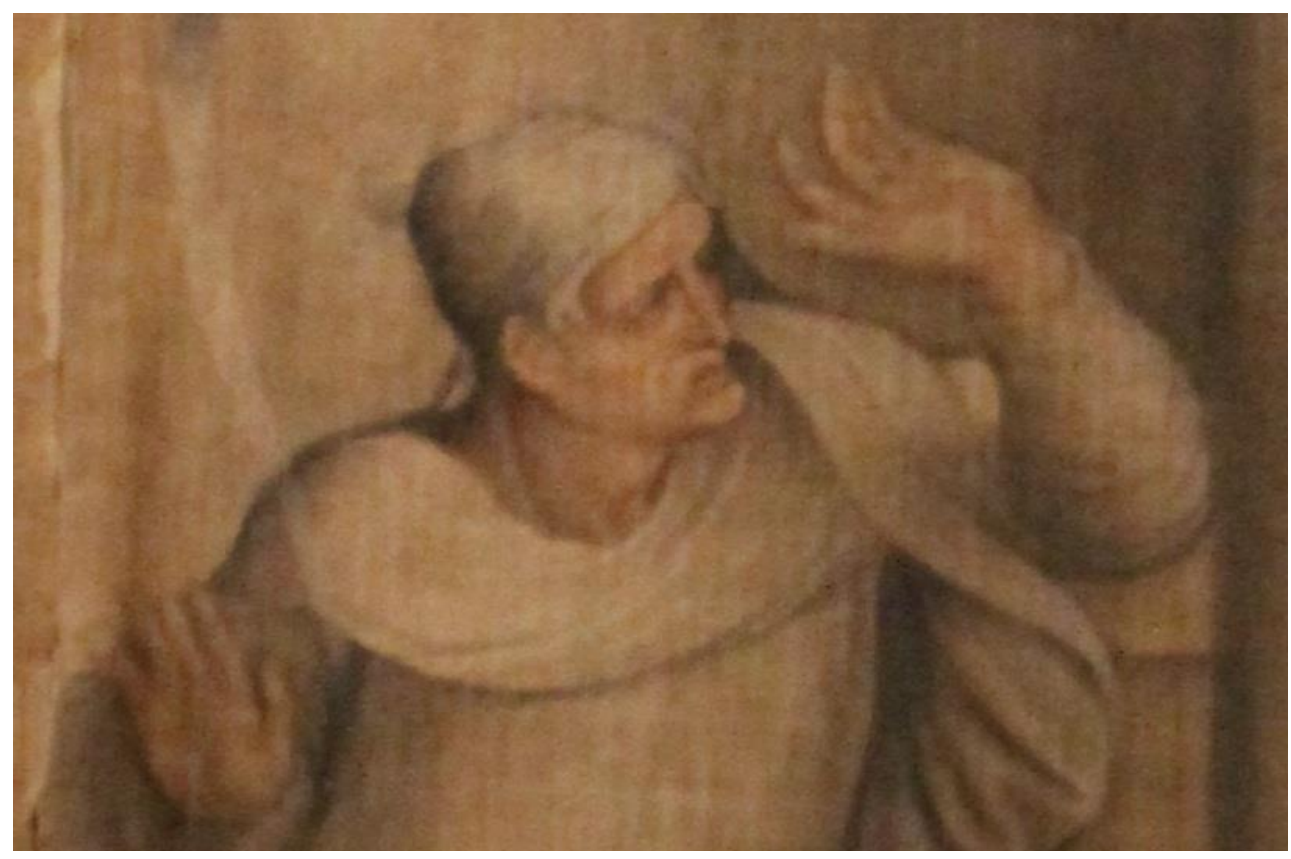

209. Diego de Urbina. Sofonías. Detalle 1557. Velo de Pasión. Catedral. Burgo de Osma (Soria).

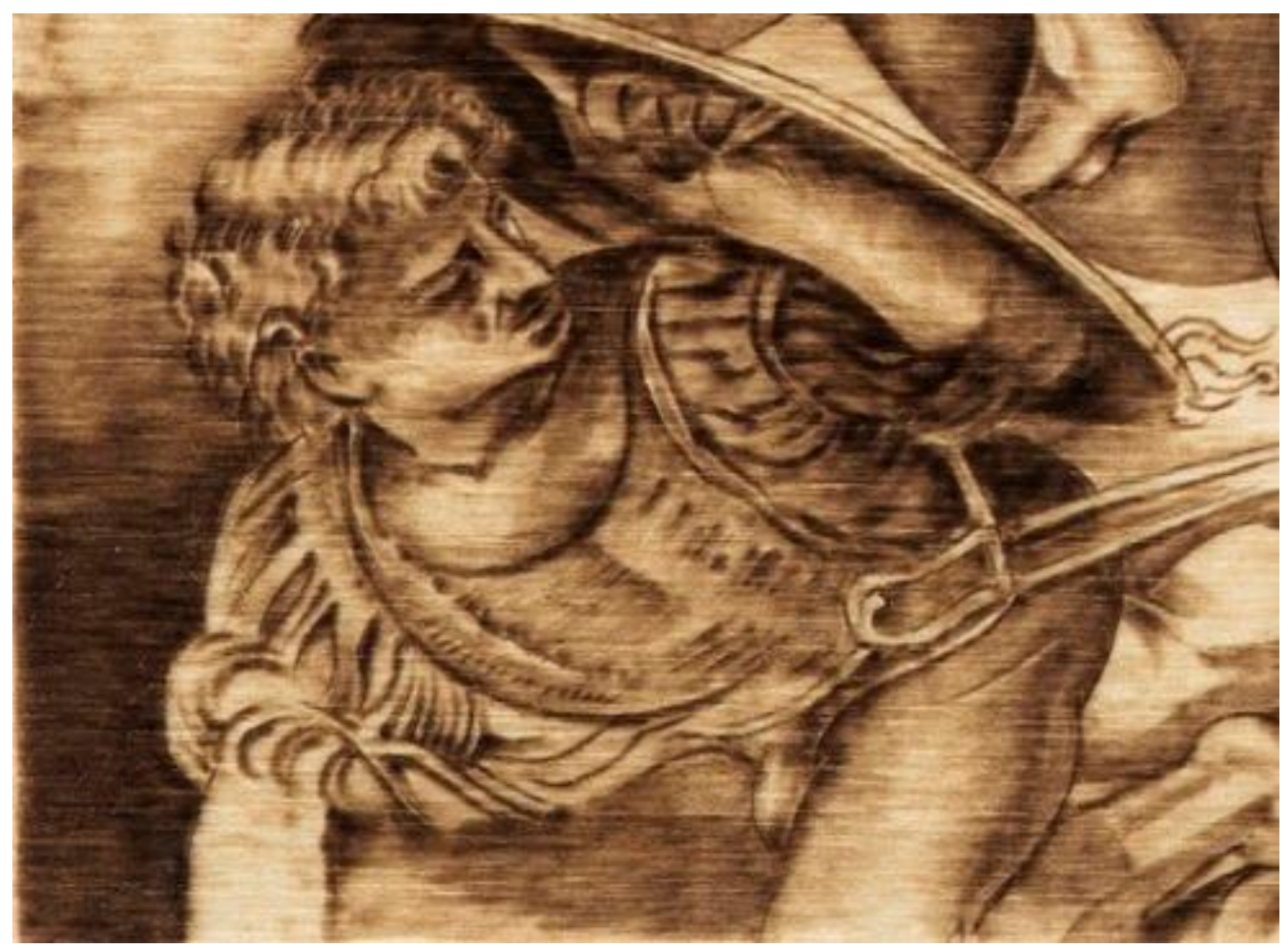

210. Gerard Èdelinck. Batalla de Anghiari. 1657-1666.

A partir de Rubens copiando a Leonardo.

Museo Británico. Londres (Reino Unido). 


\section{Círculo de Pedro de Andrade \\ Retablo lateral \\ 1560 \\ Iglesia de Santa Cruz \\ Liceras (Soria)}

Este retablo está colocado en el muro lateral del Evangelio del presbiterio de la iglesia. Se sitúa sobre el muro, dentro de un arco, de modo que las tablas de los santos aparecen de manera transversal al espectador, en el intradós (fig. 211). Sus figuras son de aspecto dulce, estilizadas y con posturas gesticulantes. Parece mostrar más interés en los fondos que en el resto de la composición. Hay cierta influencia de Alonso Berruguete $^{481}$. Se trata de una obra devocional dedicada a uno de los santos con poderes curativos. La figura de San Sebastián es de las más importantes como santo curador. En torno a él, en los laterales internos del arco, vemos las imágenes de San Roque, San Juan Bautista, San Blas y San Nicolás de Bari. En la parte superior se sitúa el Llanto sobre Cristo muerto.

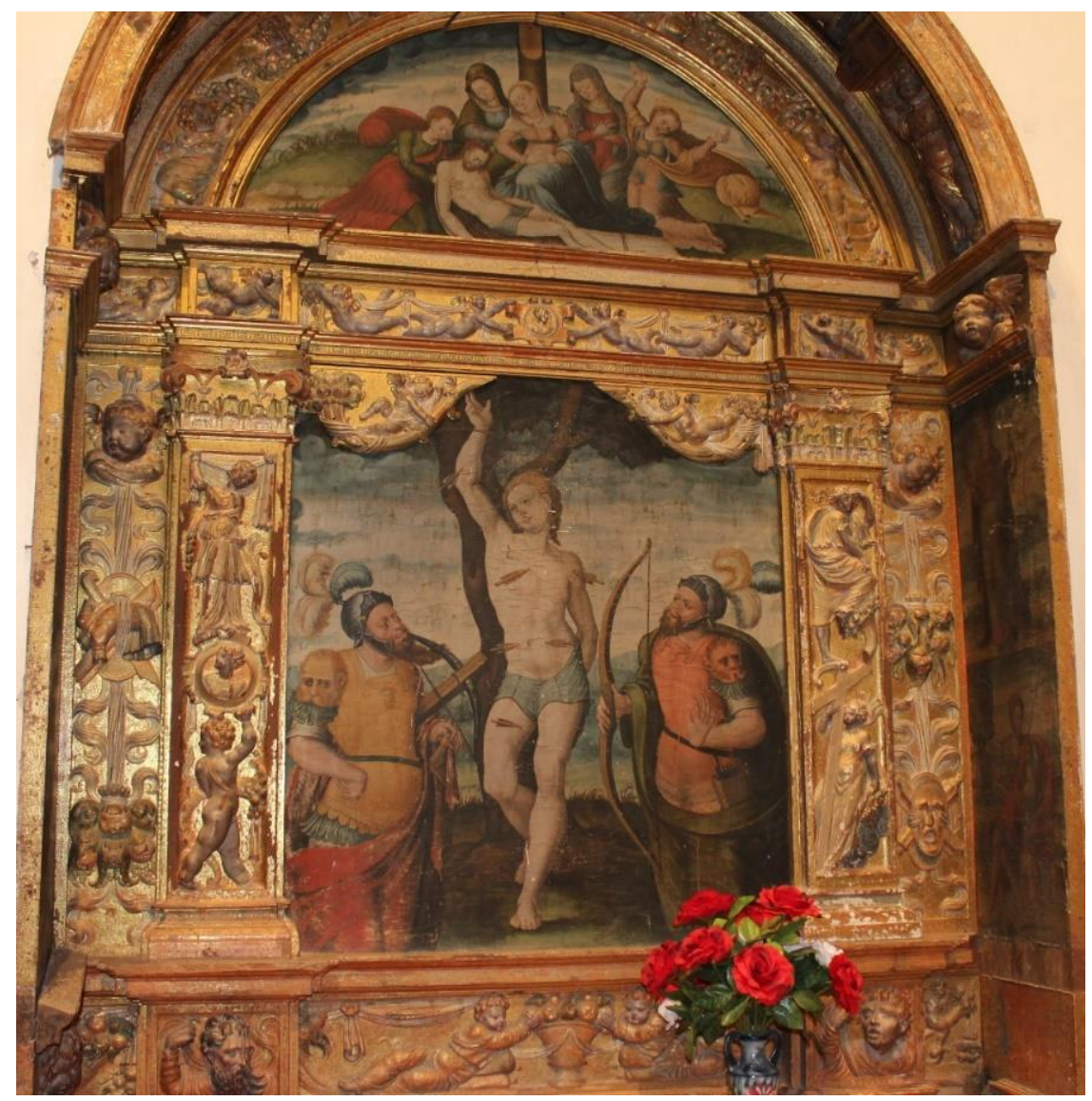

211. Círculo de Pedro de Andrade. Retablo de San Sebastián. 1560. Iglesia de la Invención de la Santa Cruz. Liceras (Soria).

${ }^{481}$ RAMOS GÓMEZ, F. J., Juan Soreda y la pintura ..., p. 266. 


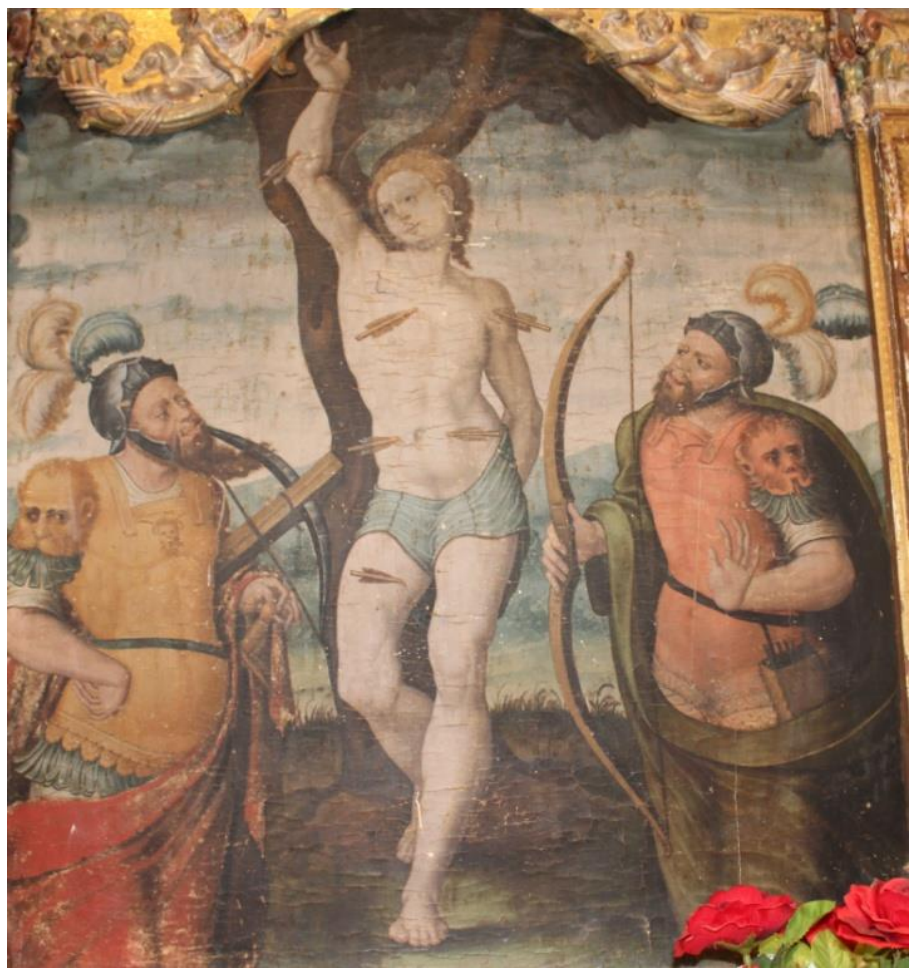

212. Anónimo. Martirio de San Sebastián.

Retablo de San Sebastián. Mediados del siglo XVI. Iglesia de la Invención de la Santa Cruz. Liceras (Soria).

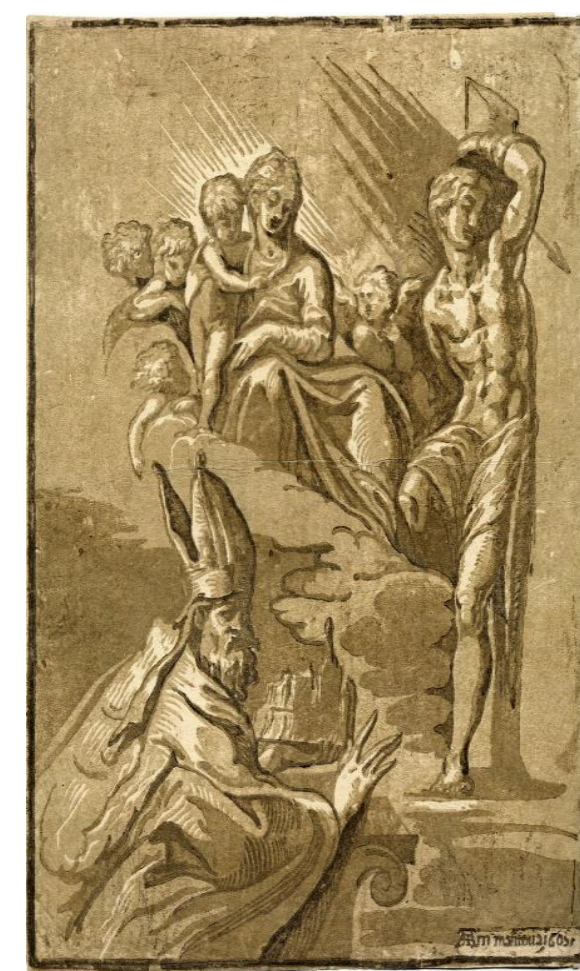

213. Andrea Andreani y Ugo da Carpi, a partir de Parmigianino. Virgen con el Niño, San Sebastián y un obispo. 15101520. Museo Británico.

Londres (Reino Unido).

\section{Martirio de San Sebastián}

Se trata también aquí de una composición piramidal, en cuya cúspide está la figura de San Sebastián (fig. 212). La figura del santo se sitúa en el centro de la composición, atado al árbol y rodeado por dos soldados.

Para esta escena del martirio de San Sebastián parece basarse, al igual que en la escena de Caltojar, en el grabado de Parmigianino Virgen con el Niño, San Sebastián y

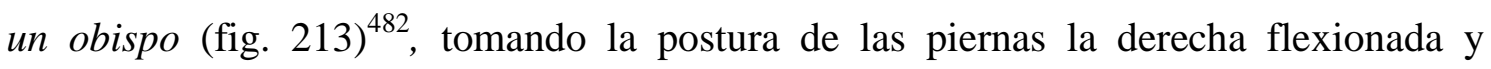
apoyada contra el tronco del árbol y la izquierda estirada.

Sin embargo no ha introducido en la pintura ni la anatomía más marcada del grabado ni el trazo nervioso del mismo. Además, los arqueros siguen modelos monumentales y reposados, ajenos al nerviosismo de la estampa.

El San Sebastián de la pintura posee una mayor corporeidad y equilibrio físico y gestual. Parece más firmemente asentado sobre el suelo que el de el grabado. Así

${ }^{482}$ Estampas disponible en:

http://www.britishmuseum.org/research/collection_online/collection_object_details.aspx?objectId=15120 $19 \&$ partId=1\&searchText=saint+sebastian\&people $=112268 \&$ page $=1$

BARTSCH, A., op. cit., vol. XII, p. 66. 
mismo, se ha prescindido de las figuras de la Virgen con el Niño y el obispo, situando la escena en el habitual escenario de este tipo de representaciones, en mitad del paisaje.

\section{Llanto sobre Cristo muerto}

Esta escena parece inspirada en los tipos humanos propios de Pedro de Andrade (fig. 214), y en su representación de los paños tanto en el caso de los celajes como en el del paño de pureza de Jesús ${ }^{483}$. Los personajes aparecen colocados de manera simétrica, siguiendo una composición piramidal y adaptandose perfectamente al marco semicircular.

En este caso el artista se basó para crear las figuras del Cristo yacente y de San Juan Evangelista, que le sujeta por la espalda, en las mismas figuras dentro de la estampa de Durero $^{484}$ del año 1498-1499 (fig. 215) ( $^{485}$.

Sin embargo, no se dejó influir por el resto de figuras, ya que la Virgen no aparece sujetando las manos de Cristo, ni en el árbol situado en el centro de la composición que en el caso de la pintura se recuce a un simple tronco. Tampoco logra transmitir la expresividad ni el patetismo de la figura de Cristo, mucho más realista en la estampa. Las vestimentas de las figuras muestran unos plieugues mucho más duros y acentuados en la estampa que en la pintura.

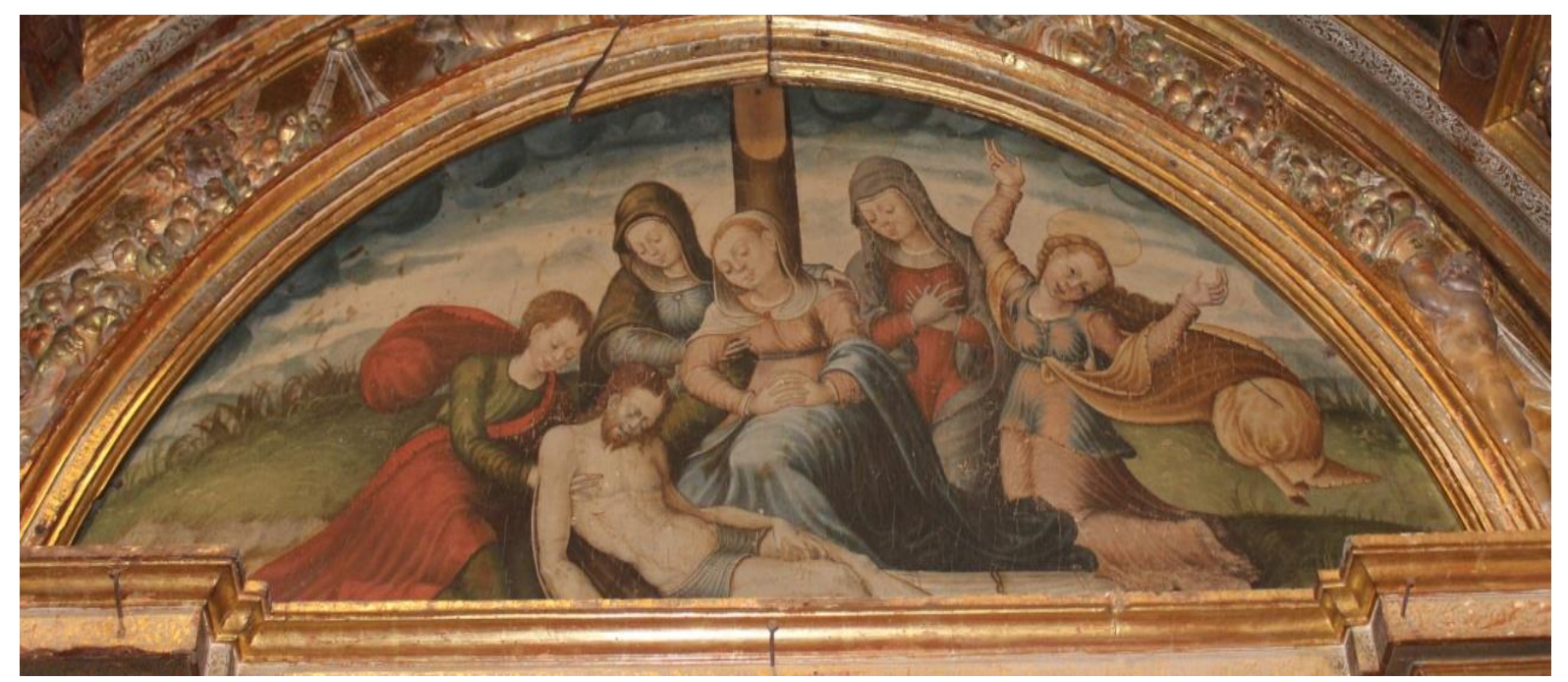

214. Círculo de Pedro de Andrade. Lamentación ante el cuerpo de Cristo. Retablo de San Sebastián. 1560. Iglesia de la Invención de la Santa Cruz. Liceras (Soria).

\footnotetext{
${ }^{483}$ RAMOS GÓMEZ, F. J., Juan Soreda y la pintura ..., p. 266.

${ }^{484}$ Ibídem.

${ }^{485}$ Estampa disponible en:
}

http://www.britishmuseum.org/research/collection_online/collection_object_details.aspx?objectId=14392 91\&partId=1\&searchText=lamentation\&images=true\&people $=127877 \&$ page $=1$ BARTSCH, A., op. cit., vol. XIV, p. 412. 


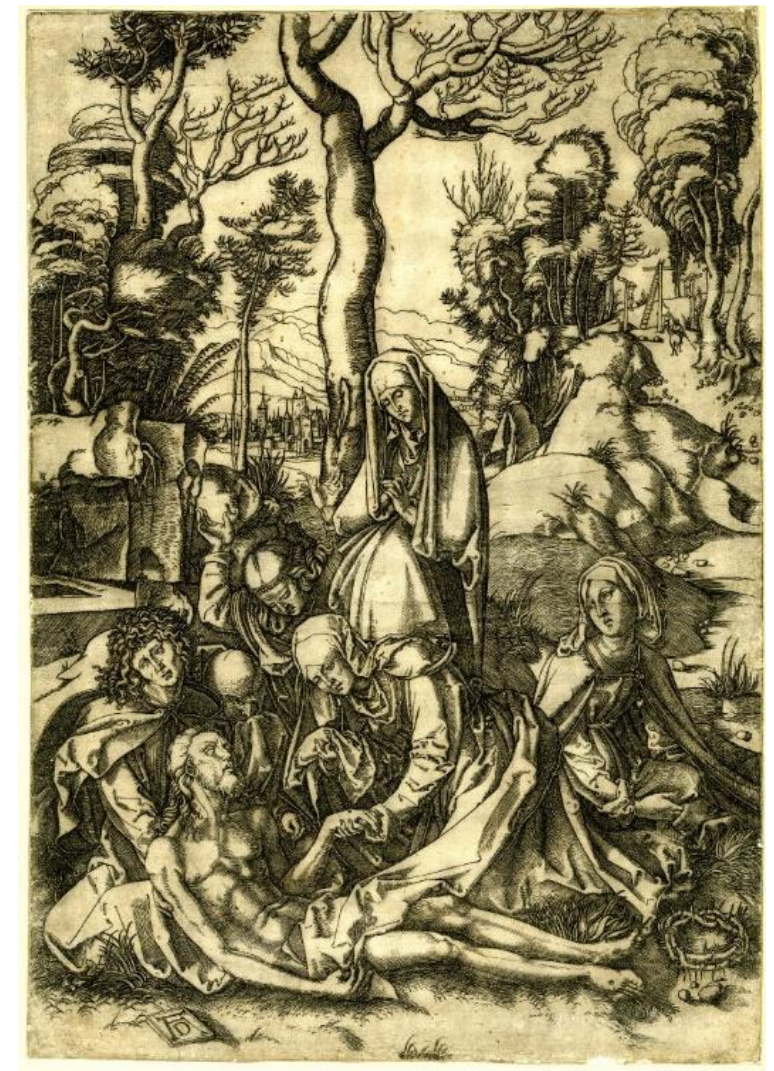

215. Alberto Durero. Lamentación ante el cuerpo de Cristo. 1497-1500. Museo Británico. Londres (ReinoUnido).

\section{Círculo de Martín Vandoma y Vicente Marcos \\ Retablo mayor \\ Ca. 1561 \\ Procedencia: Iglesia parroquial de San Ginés. \\ San Ginés de Ambrona (Soria) \\ Actualmente: Museo Diocesano. \\ Burgo de Osma (Soria)}

En esta zona de Ambrona, perteneciente a la diócesis de Sigüenza, es de gran importancia el influjo de la colegiata de Berlanga. El retablo mayor constaba de dos cuerpos y tres calles, además de la predela y el ático. Durante la década de los 60 del siglo XX se produjo el hundimiento del templo parroquial, provocando la destrucción de la arquitectura del retablo, de la que sólo se salvaron parte del guardapolvo y algún pilarcillo con pináculos. Actualmente las figuras aparecen expuestas en el Museo Diocesano del Burgo de Osma, con una reconstrucción hipotética de cómo debían estar colocadas.

El retablo de la parroquia se puede relacionar con el círculo escultórico de Alentisque, Aguaviva y Caltojar, todos obra del escultor Martín de Vandoma ${ }^{486}$. Carece

${ }^{486}$ MARTÍNEZ FRÍAS, J. M., "Resurrección”, p. 395. 
de ensamblaje, debido al hundimiento que sufrió la iglesia ${ }^{487}$. En sus figuras, hay una posible influencia de la escuela burgalesa de Siloé.

Las escenas principales están dedicadas al tema de la Vida y la Redención de Cristo: la Anunciación, Adoración de los pastores y Epifanía se colocaron en el primer cuerpo; en el segundo los temas representados fueron la Resurrección, Pentecostés y la Ascensión de Cristo. En las entrecalles se colocaron algunas figuras de santos que gozaban de gran devoción en esa época.

\section{Resurrección}

Esta escultura se inspira (fig. 216) ${ }^{488}$ en el grabado del mismo tema de la Gran Pasión de Durero, como el que se encuentra en el Museo Británico (fig. 217) ${ }^{489}$. Hasta el siglo XVI los soldados solían aparecer dormidos, pero después del Concilio de Trento fue más frecuente que aparecieran despiertos, mostrando que son conscientes de la divinidad de Cristo y protegiéndose los ojos de la luz cegadora procedente de la Divinidad. El cuerpo de Cristo es de anatomía esbelta y bien formada, y no muestra las llagas ni las heridas de la Pasión ${ }^{490}$.

La figura de Cristo es casi idéntica: de pie, con un paño que le cae sobre los hombros y el brazo derecho. En la mano izquierda seguramente también enarbolaría el estandarte con la cruz, aunque desgraciadamente en la escultura se ha perdido. El sarcófago aparece de manera horizontal en la escultura, mientras que en la estampa aparece plasmado de manera vertical, ya que intenta plasmar la tercera dimensión.

En cuanto al resto de figuras, el soldado situado a la izquierda de Cristo, que apoya su cabeza sobre el brazo izquierdo, tendido sobre el sarcófago, parece basarse en otro de los grabados de Durero, en este caso el de 1512. Otro de los soldados, el que aparece de espaldas, en primer plano, y que levanta la cabeza, asombrado, hacia Cristo, parece provenir también de la misma fuente.

\footnotetext{
${ }^{487}$ ARRANZ ARRANZ, J. M., El Renacimiento en la Diócesis..., p. 252.

${ }^{488}$ Imagen procedente de CASTRO SANTAMARÍA, A., "Resurrección”, p. 513.

${ }^{489}$ Estampa disponible en: http://britishmuseum.org/research/collection_online/collection_object_details.aspx?objectId=1350875\&p artId=1\&searchText=resurrection\&images $=$ true \&people $=127877 \&$ page $=1$

BARTSCH, A., op. cit., vol. VII, p. 39; DODGSON, C., Albrecht Dürer, no 64, p. 82; MEDER, J., op. cit., $\mathrm{n}^{\circ}$ 17, p. 73; SCHOCH, R., op. cit., vol. I, n 59, pp. 149-150.

${ }^{490}$ CASTRO SANTAMARÍA, A., "Resurrección", pp. 513-514.
} 


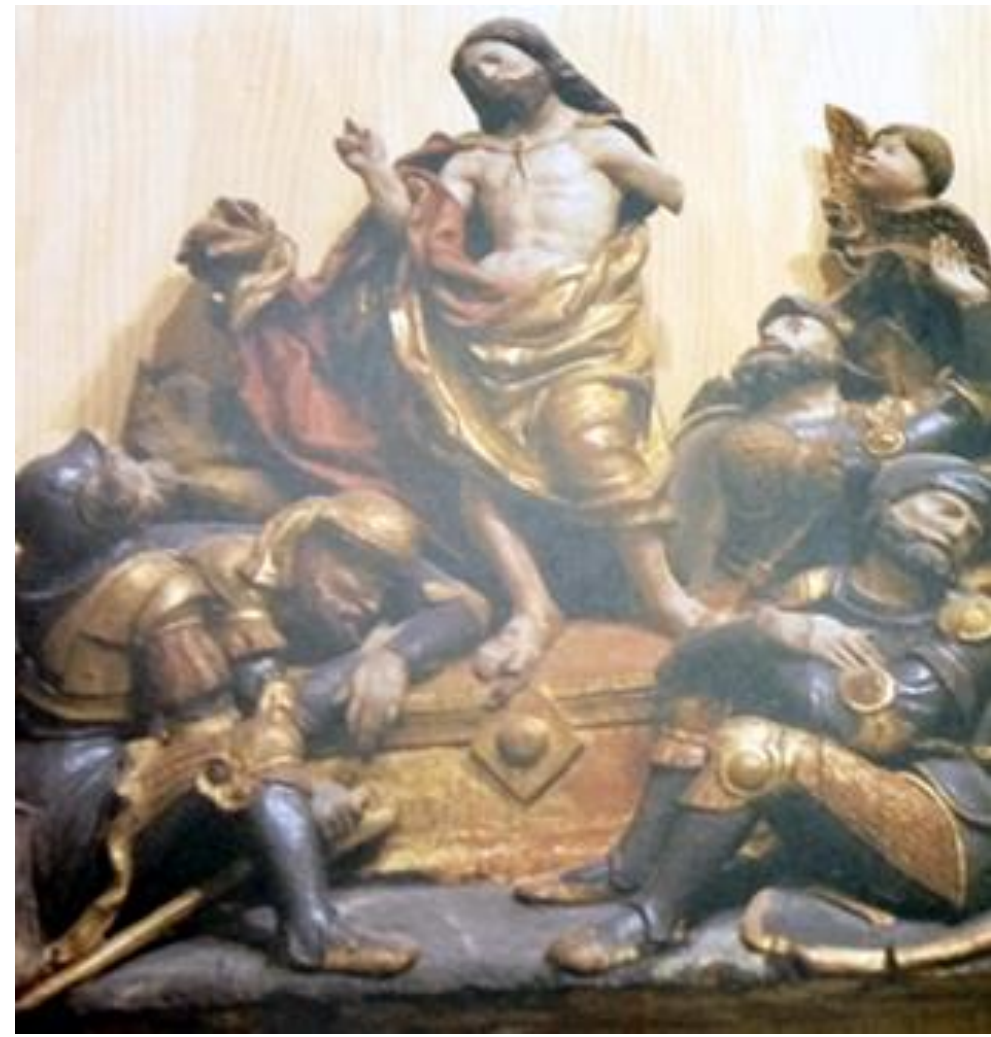

216. Anónimo. Resurrección. 1561. Museo Diocesano. Burgo de Osma (Soria).

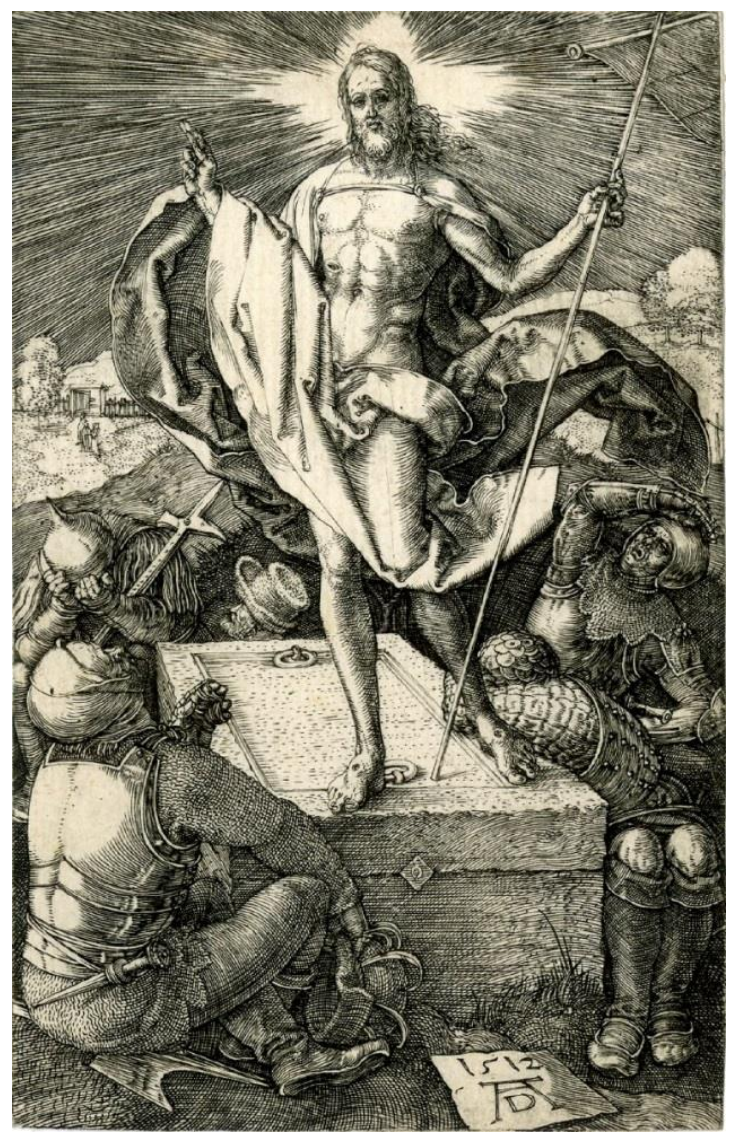

217. Alberto Durero. Resurrección. 1512.

Museo Británico. Londres (ReinoUnido). 


\section{Escultura de San Cristóbal.}

En este caso el artista ha evitado la frontalidad, ya que San Cristóbal aparece caminando y con la cabeza girada hacia la derecha mirando al Niño (fig. 218). El Niño adopta una postura inestable. Hay en la composición un cierto interés por transmitir una mayor humanidad y naturalidad. El santo aparece representado siguiendo la iconografía más frecuente. Es un hombre de mediana edad, con barbas y de complexión fuerte, que lleva sobre el brazo izquierdo al pequeño niño ${ }^{491}$.

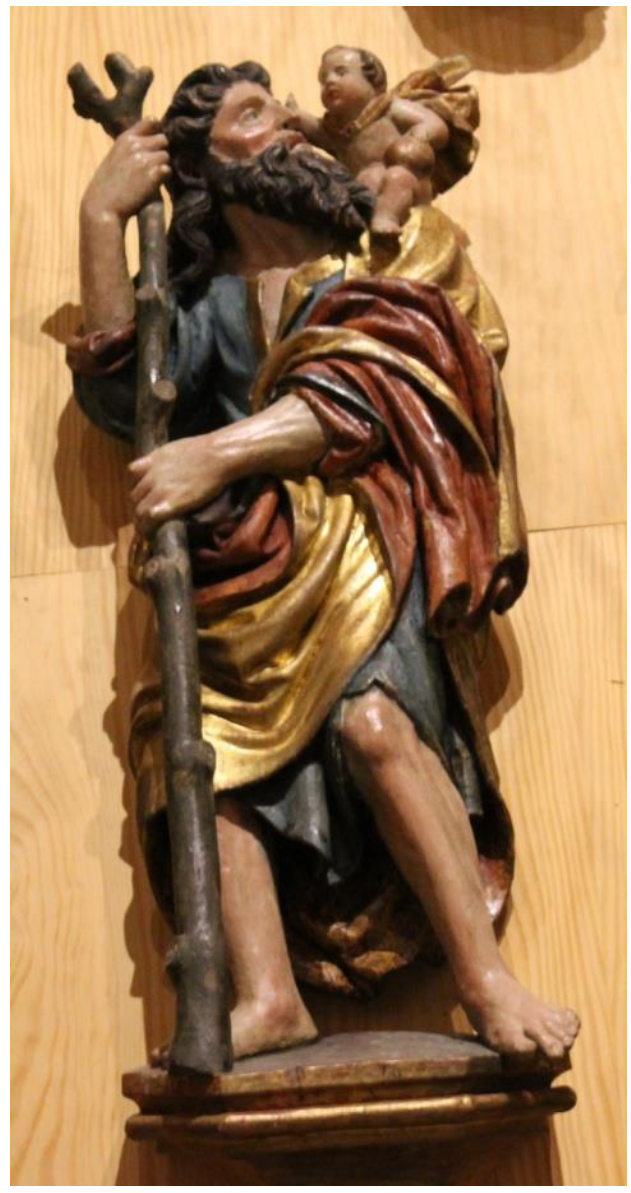

218. Anónimo. San Cristóbal. 1561. Museo Diocesano. Burgo de Osma (Soria).

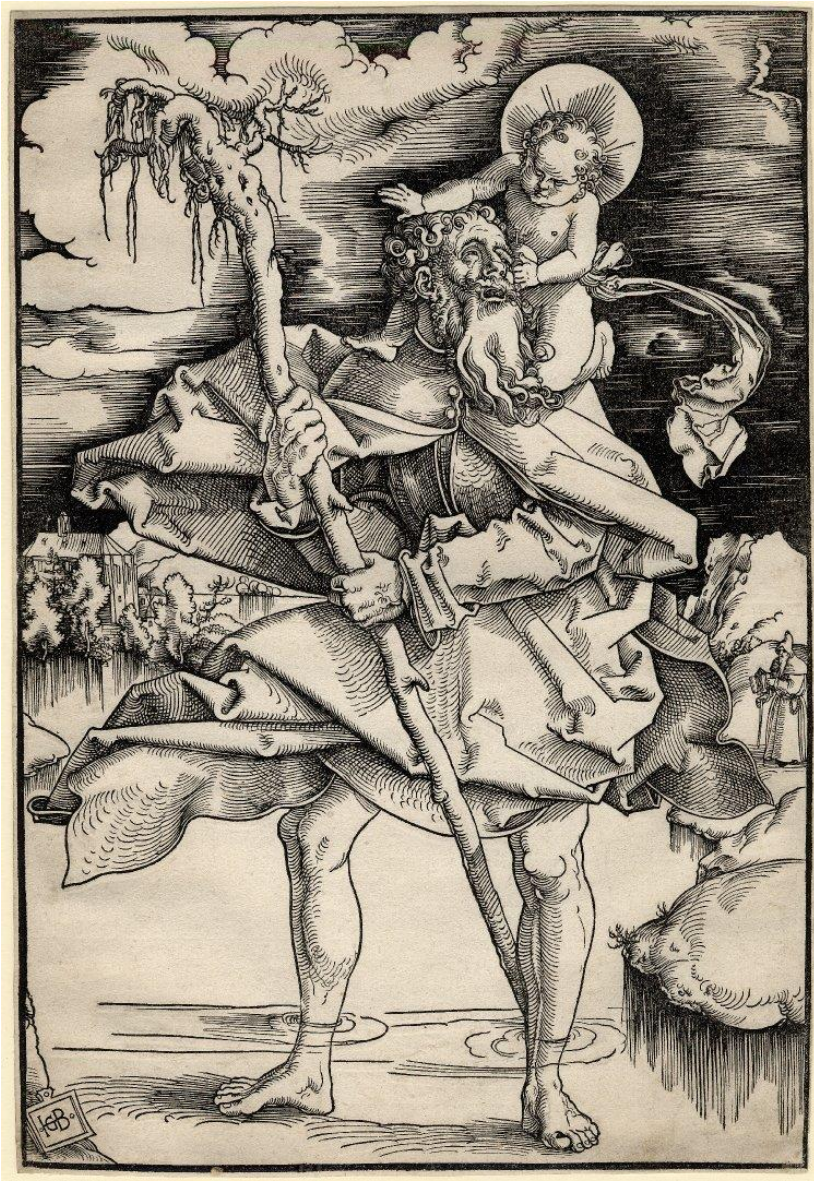

219. Hans Baldung Grien. San Cristóbal. 1510-1511.Museo Británico. Londres (Reino Unido)

Para las figuras el escultor pudo tener en cuenta la estampa de Hans Baldung Grien (fig. 219) ${ }^{492}$, con la que comparte la misma pose con las piernas abiertas y la

\footnotetext{
${ }^{491}$ RUPÉREZ ALMAJANO, M. N., “San Cristóbal”, en Paisaje interior..., nº 112, pp. 429-430.

${ }^{492}$ Estampa disponible en:

http://britishmuseum.org/research/collection_online/collection_object details.aspx?objectId=1424152\&p artId=1\&searchText=saint+christopher\&images=true \&people=133539\&page $=1$

BARTSCH, A., op. cit., vol. VII, p. 313; DODGSON, C., Catalogue of Early German and Flemish Woodcuts...., vol. I, ${ }^{\circ}$ 18, p. 560; HOLLSTEIN, F. W. H., German engravings etchings and woodcuts, $c$.
} 
cabeza mirando hacia su izquierda, y la misma manera de sujetar la vara con las dos manos. No aparece sin embargo, ninguna referencia al paisaje que contribuiría a caracterizar la estampa como una creación germánica. Se trata de un tema muy popular y cuya devoción ha contribuido a la difusión de la iconografía de San Cristóbal, cuya imagen protegía de la muerte súbita a los fieles que tuvieran a la vista su imagen ${ }^{493}$.

\section{Diego de Urbina \\ Martirio de San Esteban \\ 1561-1563 \\ Iglesia de San Juan de Rabanera \\ Soria}

Esta obra (fig. 220) procedía de la parroquia del mismo nombre, hoy desaparecida. Probablemente Urbina la pintó a finales de su estancia en Aranda de Duero en torno a $1561-1563^{494}$. A parte del nombre de Urbina se barajaron otros nombres de pintores que trabajaron en el monasterio de San Lorenzo del Escorial, como por ejemplo Pellegrino Tibaldi, que también utilizaba muchos modelos miguelangelescos. Es una obra profundamente romanista. Es posible que fuera realizada para colocarse sobre el altar mayor de la iglesia, teniendo en cuenta su tamaño y el tema tratado. San Esteban viene considerado como el primer mártir de la cristiandad. Es un joven imberbe y tonsurado. Sus vestimentas son el alba blanca y la túnica dalmática. Se muestra en posición arrodillada y con los brazos abiertos, aceptando con resignación su destino $^{495}$. Desde la esquina superior izquierda desciende un ángel portando la palma símbolo de su martirio.

En esta pintura de Urbina San Esteban es caracterizado con el típico aspecto joven y barbilampiño con el que normalmente se le representa. Lleva el alba blanca, la dalmática, que es de color dorado en vez de rojo, y la estola, también dorada, sobre los hombros.

Para la composición de este pequeño cuadro, actualmente situado en una de las capillas laterales de la iglesia de San Juan ${ }^{496}$, Urbina usó diversos modelos de estampas italianas. Se tiene la impresión de que algunas figuras han sido introducidas en la escena

1400-1700, p. 116; BARTRUM, G., German Renaissance Prints, 1490-1550, Londres, BMP, 1995, $\mathrm{n}^{\circ}$ 62, p. 74.

${ }^{493}$ GARCÍA CUADRADO, M. D., "San Cristóbal: significado iconológico e iconográfico", Antigüedad y cristianismo. Monografías históricas sobre la Antigüedad tardía, $\mathrm{n}^{\circ}$ 17, 2000, p. 352.

${ }^{494}$ COLLAR DE CÁCERES, F., "Diego de Urbina..”, p. 120

495 TARACENA Y AGUIRRE, B. y TUDELA DE LA ORDEN, J., op. cit., p. 100; URREA, J., "La lapidación de San Esteban”, pp. 238-239.

${ }^{496}$ VV. AA., Inventario artístico..., vol. I, p. 305. 
de manera forzada, como el ángel o el joven que se apoya contra el templo. Urbina muestra cierta dificultad a la hora de expresar los sentimientos de sus personajes.

Por otro lado, la plasmación del espacio es ciertamente torpe: hay cierta desproporción entre los personajes situados en primer plano y los colocados en segundo. El uso del color en esta escena es plenamente manierista. Predominan las tonalidades frías que dan sensación de inquietud, y toda la escena aparece rodeada por una luz dorada sobrenatural.

Se ha propuesto que la figura musculosa situada a la derecha de la composición podría estar inspirada, dados sus rasgos, brazos musculosos y figura, en una estampa del Midas del Juicio Universal de Miguel Ángel ${ }^{497}$ (fig. 221) ${ }^{498}$.

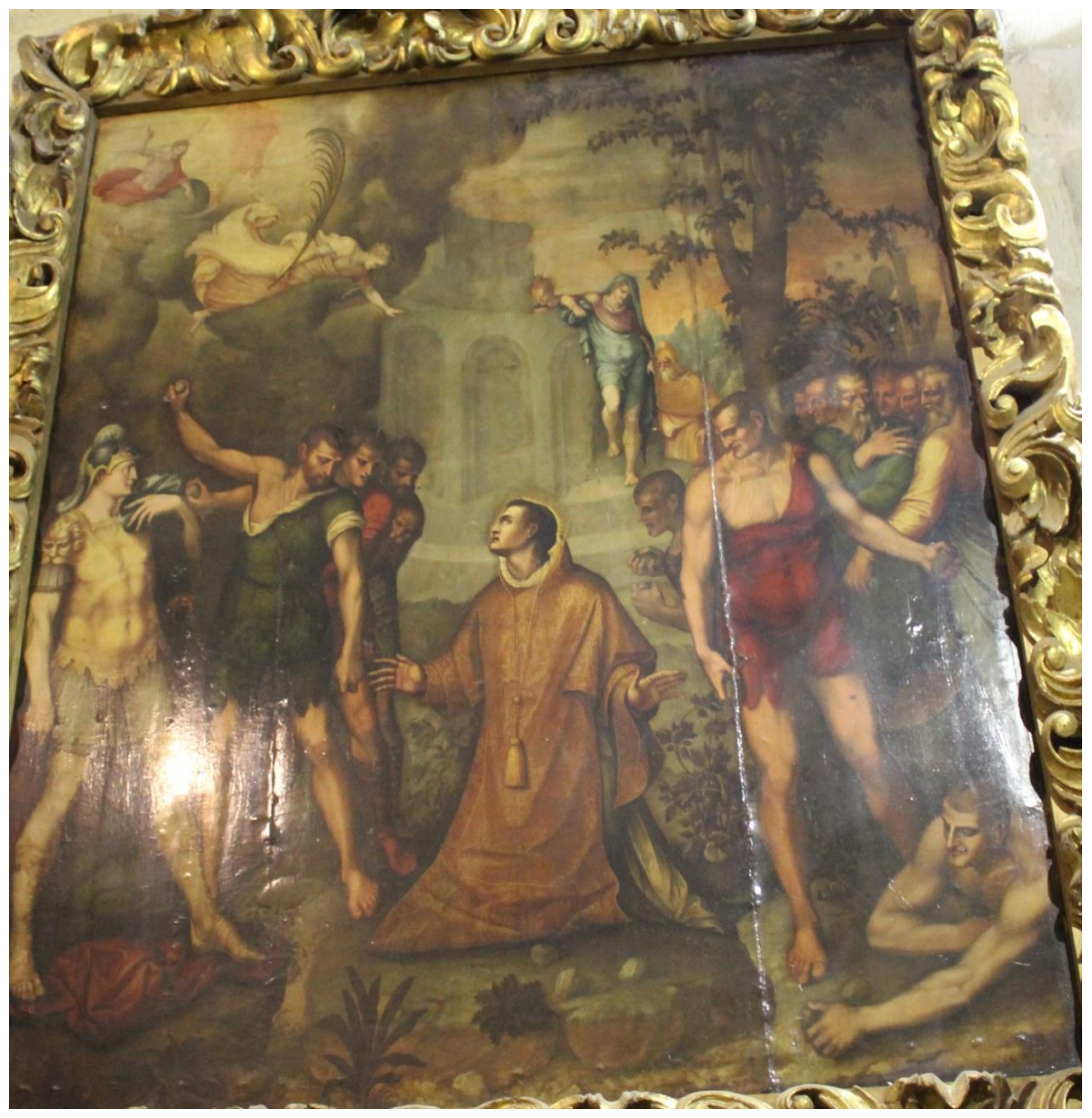

220. Diego de Urbina. Martirio de San Esteban. 1561-1566. Iglesia de San Juan de Rabanera. Soria.

${ }^{497}$ Estampa disponible en:

http://www.britishmuseum.org/research/collection_online/collection_object details.aspx?objectId=14421 25\&partId=1\&searchText=last+judgement\&images $=$ true \&people $=134656 \&$ page $=1$ BARTSCH, A., op. cit., vol. XVII, p. 75.

${ }^{498}$ COLLAR DE CÁCERES, F., “Diego de Urbina...”, p. 120. 


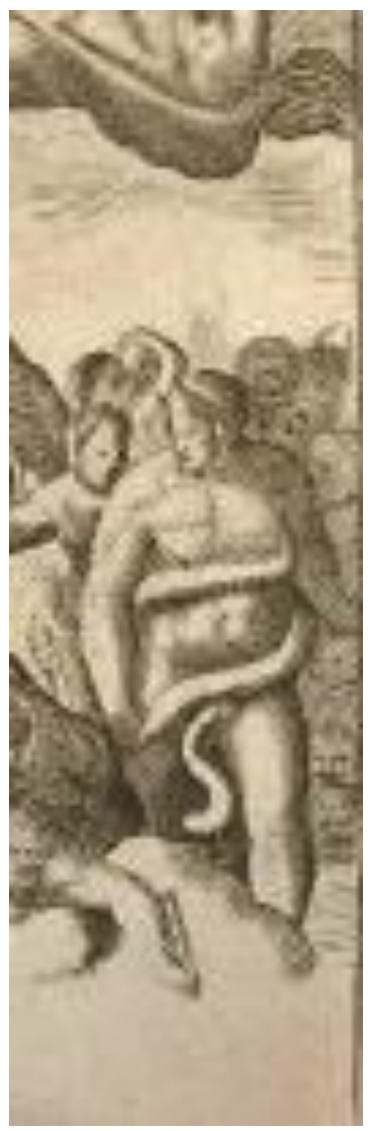

221 .Giulio Bonasone. Detalle de Varios Demonios.

A partir de Miguel Ángel. Museo Británico. Londres (ReinoUnido).

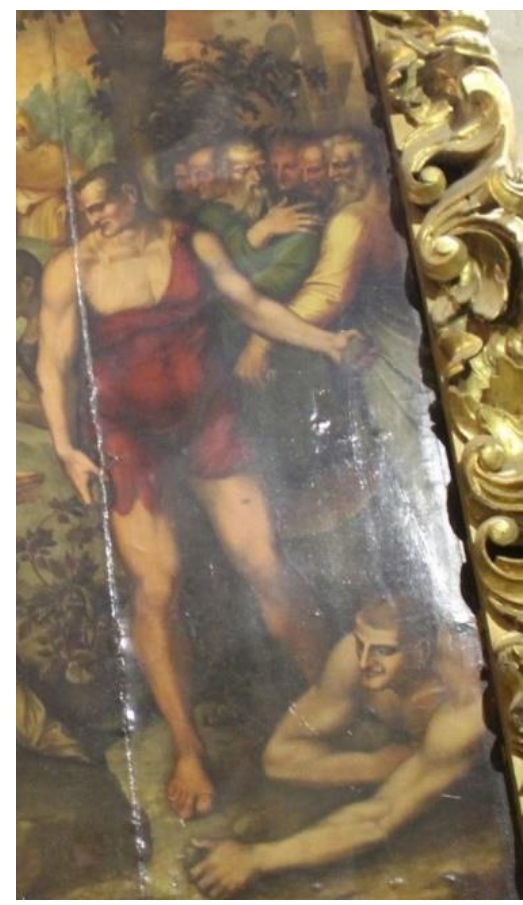

222. . Diego de Urbina Detalle de la fig. 220.

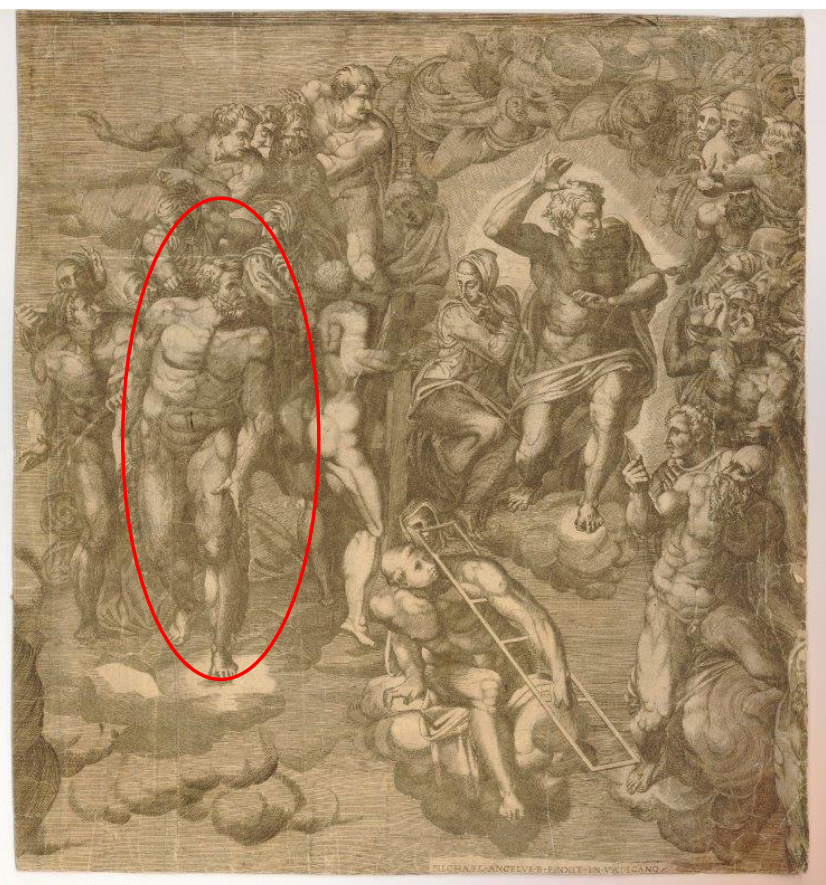

223.Niccolo della Casa. Juicio Final. 1543-1548. Museo Británico. Londres (ReinoUnido). 
También podría haberse basado (fig. 222) en la figura a la izquierda de Cristo de

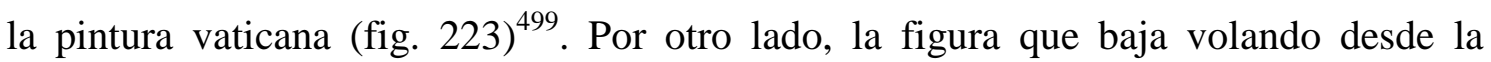
izquierda del cuadro (fig. 224) podría proceder de la figura alada de la Discordia de la estampa del Juicio de Paris de Raimondi (fig. 225) ${ }^{500}$.

Para la figura del fondo, que aparece apoyada en el edificio de aspecto clásico (fig. 226), es muy posible que Urbina siguiera alguna estampa inspirada en la estatuaria clásica, como se deduce del contraposto que muestra la figura. Probablemente se basase en la estampa de Apolo de Raimondi (fig. 227), en la cual el joven representado presenta la misma posición de cintura para abajo ${ }^{501}$.

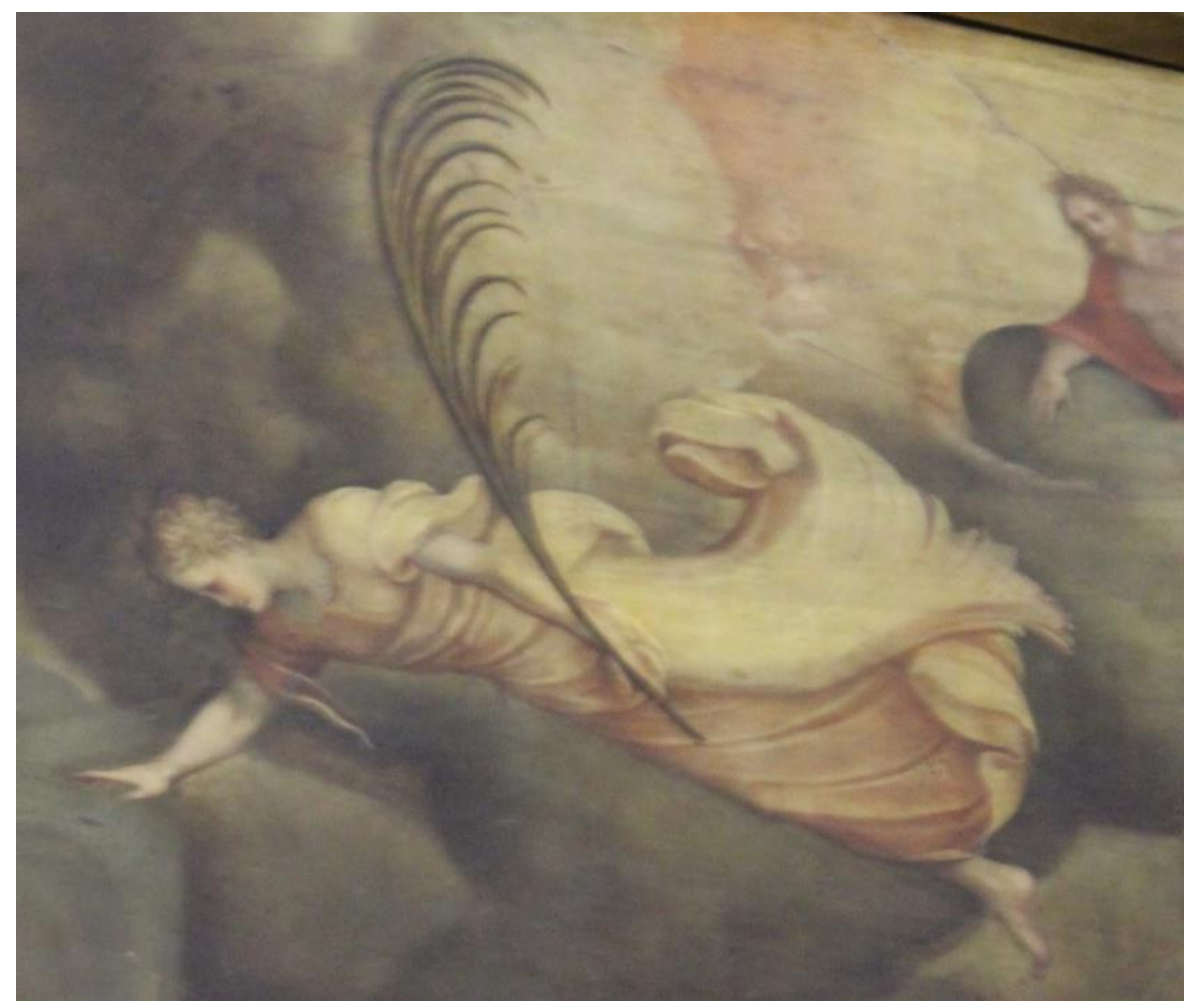

224. Detalle de la fig. 220.

\footnotetext{
${ }^{499}$ Estampa disponible en:

http://britishmuseum.org/research/collection_online/collection_object_details.aspx?objectId=3087622\&p artId=1\&searchText=last+judgement\&images=true \&people $=129891 \&$ page $=1$

BARTSCH, A., op. cit., vol. XIV, p. 197; ROBERT DUMESNIL, A. P. F., Le Peintre-Graveur Français ou Catalogue raisonné des estampes gravées par les peintres et les dessinateurs de l'ecole français, París, G. Wareé, 1844., vol. IX, nº 1, p. 181.

${ }^{500}$ Estampa disponible en:

https://www.britishmuseum.org/research/collection_online/collection_object details.aspx?objectId=1435 334\&partId=1\&searchText=raimondi\&from $=$ ad\&fromDate $=1510 \&$ to $=$ ad \& toDate $=1520 \&$ page $=1$ BARTSCH, A., op. cit., vol. XIV, 197.

${ }^{501}$ Estampa disponible en:

http://britishmuseum.org/research/collection_online/collection_object_details.aspx?objectId=1435850\&p artId=1\&searchText=apollo\&images $=$ true \&people $=115934 \&$ page $=1$ BARTSCH, A., op. cit., vol. XIV, p. 251.
} 


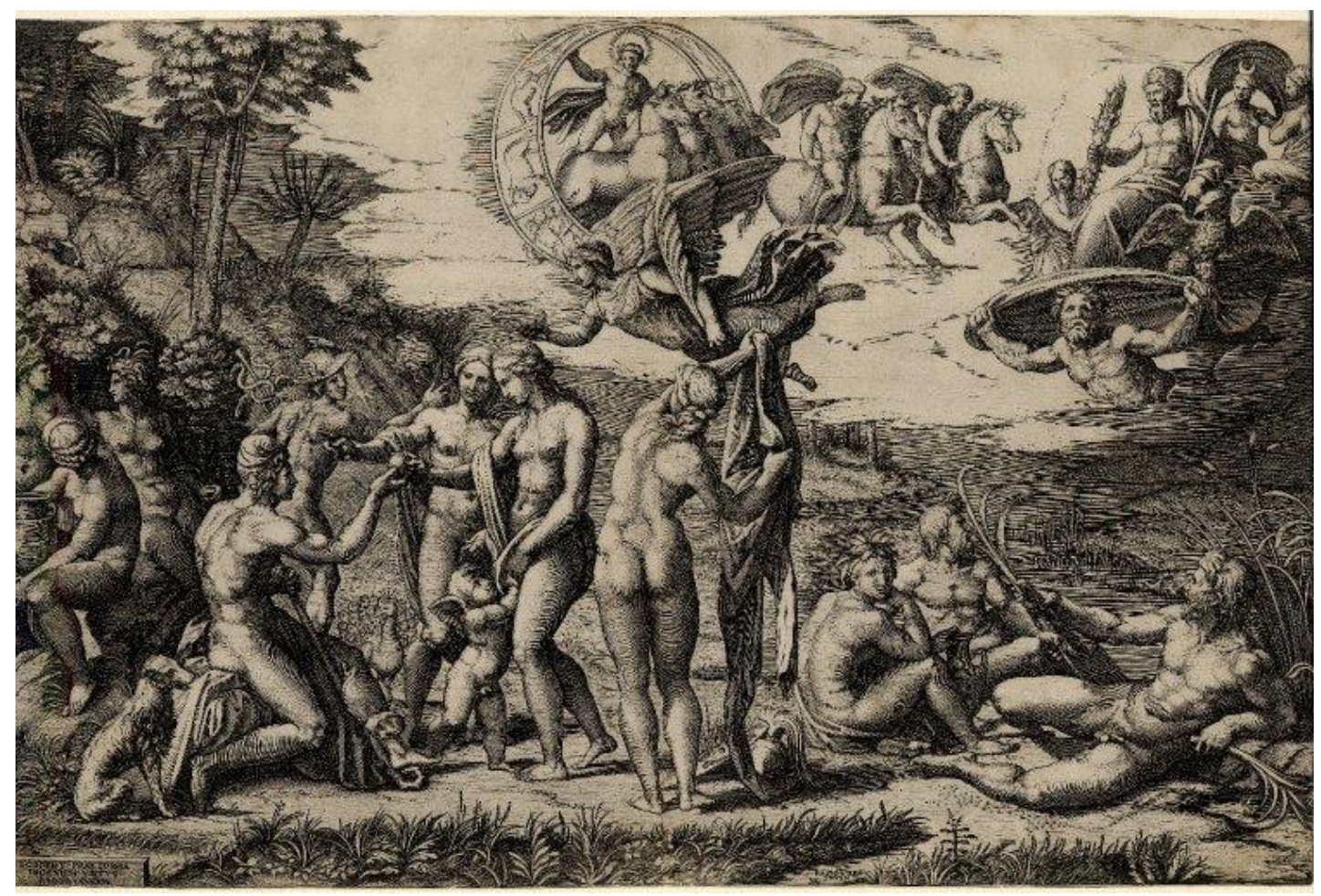

225. Marcantonio Raimondi. Juicio de Paris. 1510-1520.

Museo Británico. Londres (Reino Unido)s.

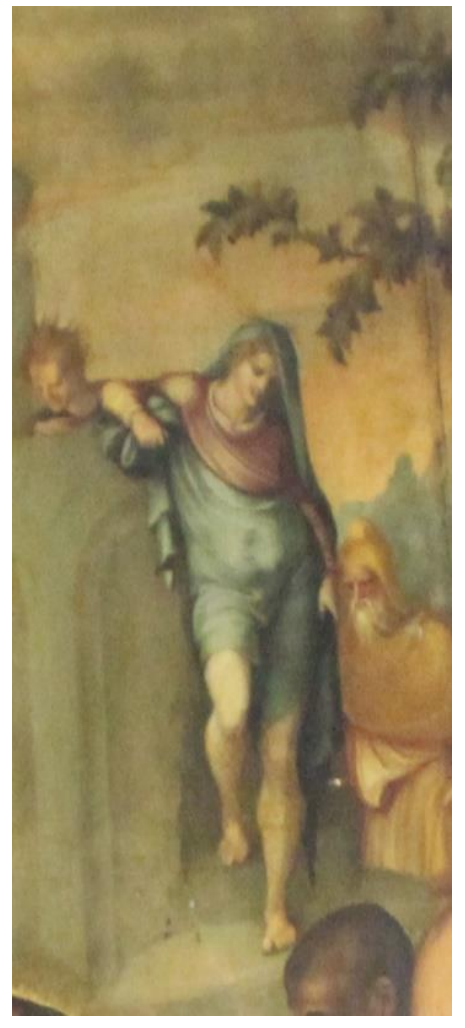

226. Detalle de la fig. 220.

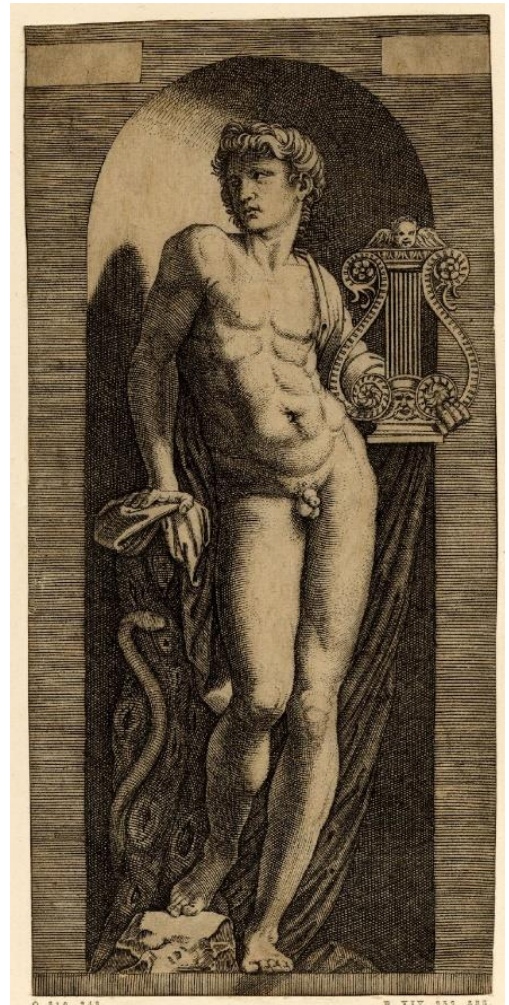

227. Marcantonio Raimondi. Apolo.

A partir de Rafael. 1512-1515.

Museo Británico. Londres (ReinoUnido). 
Así mismo, para el edificio en el cual se apoya, construido a través de enormes arcos de medio punto (fig. 228), es muy probable que su fuente de inspiración sea una estampa de Cherubino Alberti de la Adoración de los Magos (1574) (fig. 229) ${ }^{502}$, aunque la estampa parece ser más tardía y está basada en un dibujo de Rosso Fiorentino que se perdió. También existe otra representación de un edificio semejante en la estampa de San Jorge matando al dragón (1577) (fig. 230) de Cornelis Cort ${ }^{503}$, que sigue un diseño de Giulio Clovio. Además, la forma del edificio, de planta circular y con grandes arquerías nos remite al modelo del Colíseo, muy presente en algunas estampas italianas de la época (fig. 231) ${ }^{504}$.

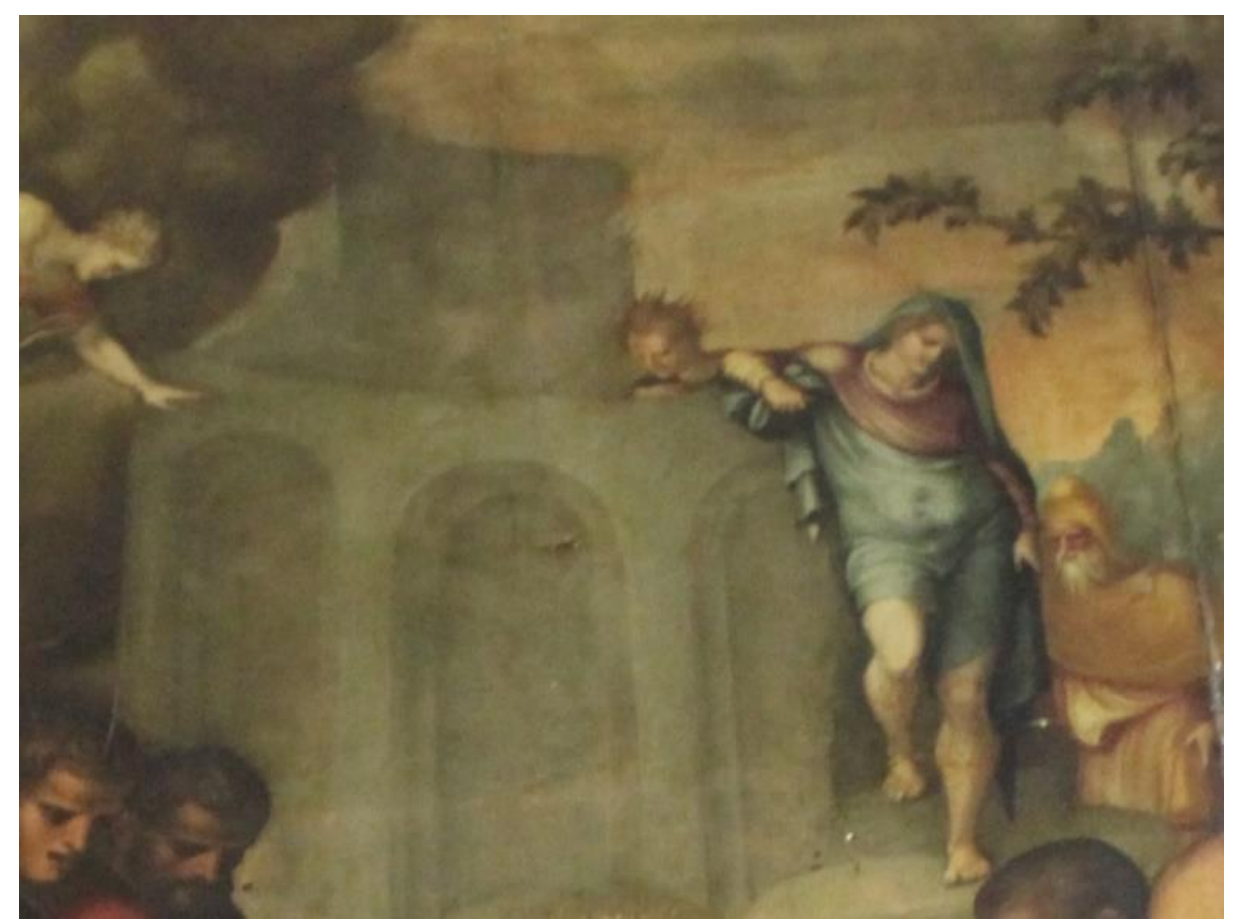

228. Detalle de la fig. 220.

\footnotetext{
${ }^{502}$ Estampa disponible en:

http://britishmuseum.org/research/collection_online/collection_object_details.aspx?objectId=1438405\&p artId=1\&searchText=adoration+of+the+magi\&images $=$ true $\&$ people $=134656 \&$ page $=1$

BARTSCH, A., op. cit., vol. XVII, p. 54.

${ }^{503}$ Estampa disponible en:

http://britishmuseum.org/research/collection_online/collection_object_details.aspx?objectId=3269466\&p artId=1\&searchText=saint+george $+\&$ images $=$ true \&people $=128446 \&$ page $=1$

BIERENS DE HAAN, J. C. J., L'ouvre gravé de Cornelis Cort, graveur hollandais 1553-1578, La Haya, 1948, n 130, p. 138; HOLLSTEIN, F. W. H., The New Hollstein, Cornelis Cort, part II, n 112 1, p. 142143.

${ }^{504}$ Estampa disponible en:

https://www.britishmuseum.org/research/collection_online/collection_object_details.aspx?objectId=3133 430\&partId=1\&searchText=rome\&images $=$ true $\&$ from $=$ ad \&fromDate $=1500 \&$ to $=$ ad \& toDate $=1560 \&$ page $=1$

HUELSEN, C., Das Speculum Romanae Magnificentiae, Monachii, Jacques Rosenthal, 1921, 19a, p. 146.
} 


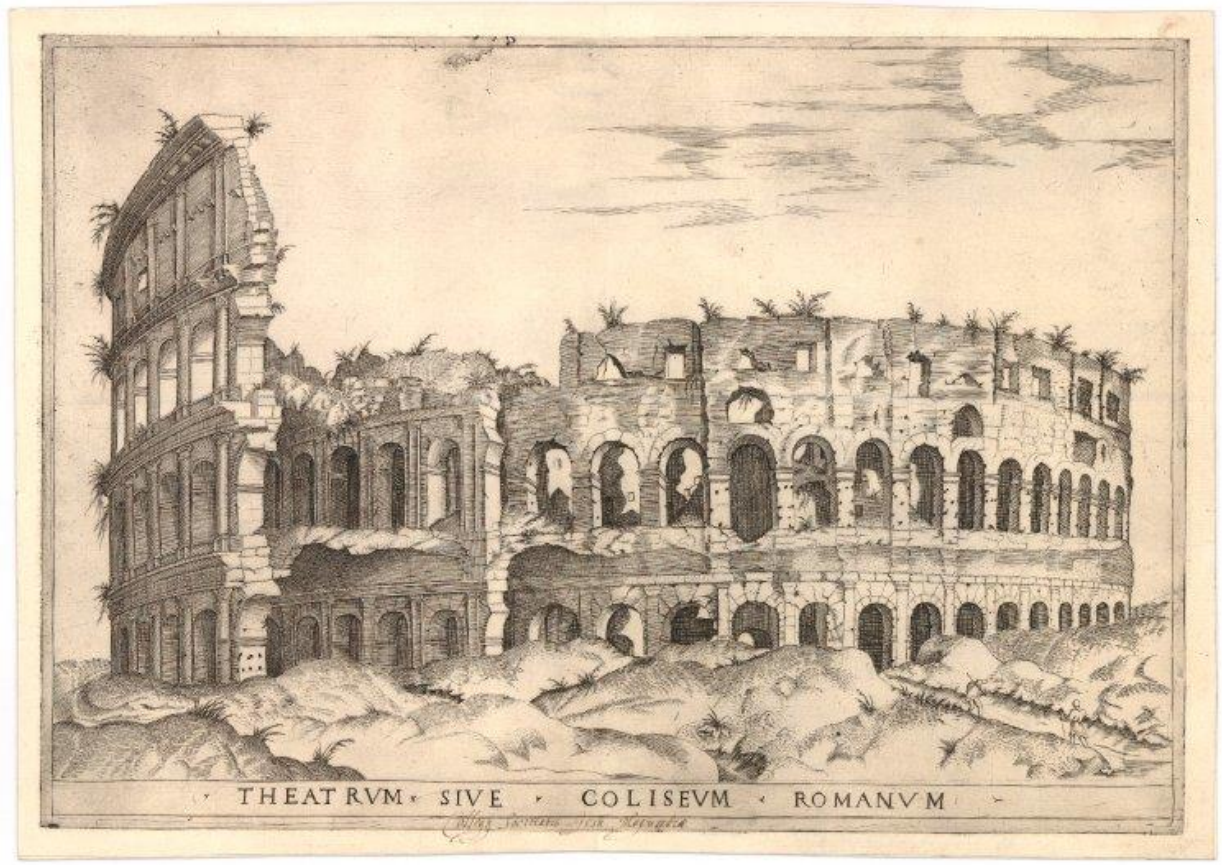

229. Anónimo. Speculum Romanae Romanificientia.

1547-1560. Museo Británico. Londres (ReinoUnido).

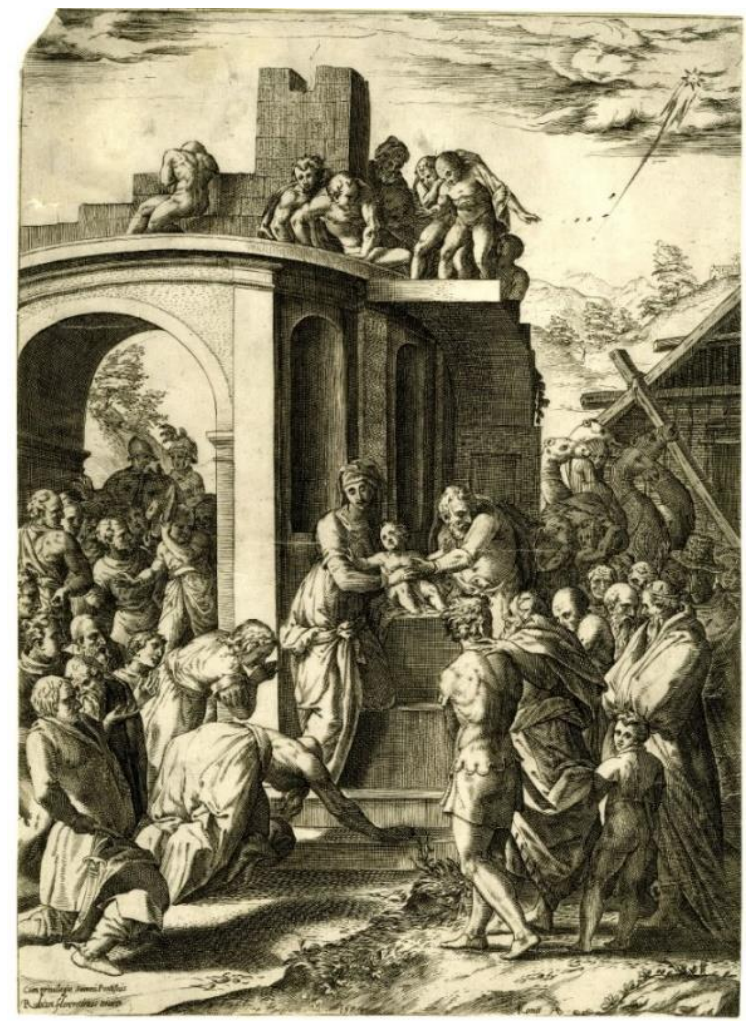

230. Cherubino Alberti.

Adoración de los magos. 1574.

Museo Británico. Londres (ReinoUnido).

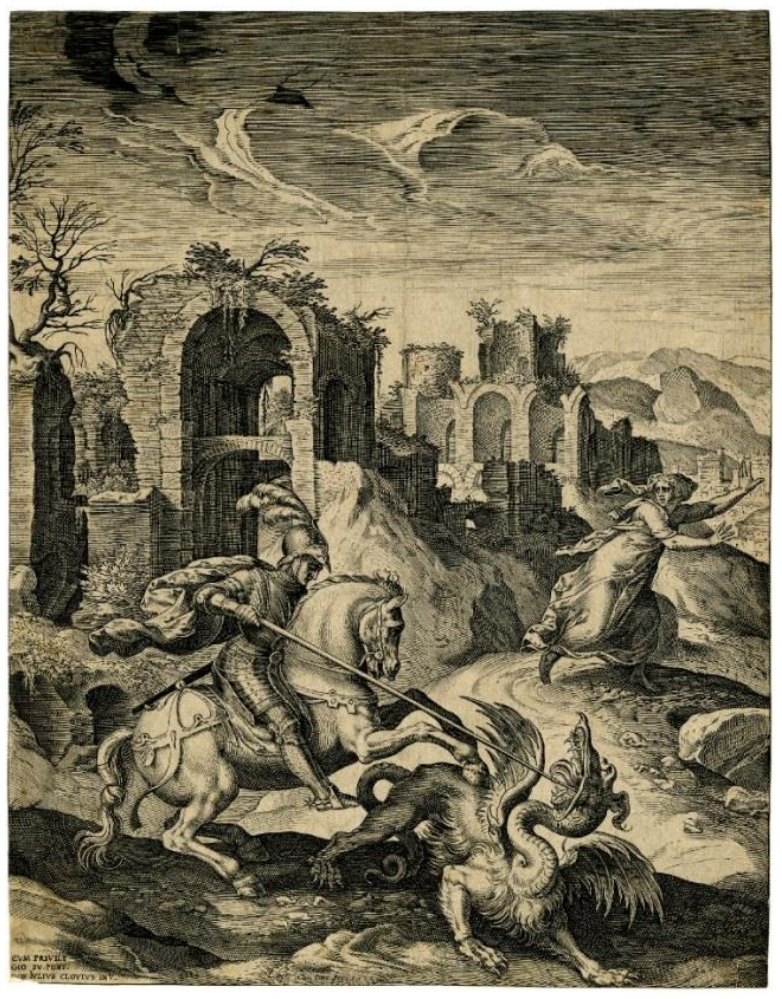

231. Cornelis Cort.

San Jorge matando al dragón. 1577.

Museo Británico. Londres (ReinoUnido). 


\section{Juan de Illana (doc. 1553-1567) \\ Retablo mayor \\ Ca. 1562 \\ Iglesia de Santa Cruz \\ Liceras (Soria))}

Las tablas de este retablo formaban parte del original retablo renacentista del siglo XVI, pero durante el siglo XVIII pasaron a formar parte del retablo churrigueresco del siglo XVIII ${ }^{505}$. Esto era algo muy común durante la época barroca y puede deberse o bien a falta de dinero para realizar unas nuevas pinturas o porque la mazonería se hubiera conservado peor que las pinturas.

Basándonos en los documentos encontrados en los libros de fábrica de la parroquia, el retablo estaría terminado ya en 1562, fecha en la que se data el último pago. El estilo pictórico de Juan de Illana está muy influenciado por los maestros seguntinos del segundo tercio del siglo $\mathrm{XVI}^{506}$. La obra había sido atribuida también a otros pintores como Francisco Pérez del Castillo ${ }^{507}$. Es la única obra conocida de este autor (fig. 232).

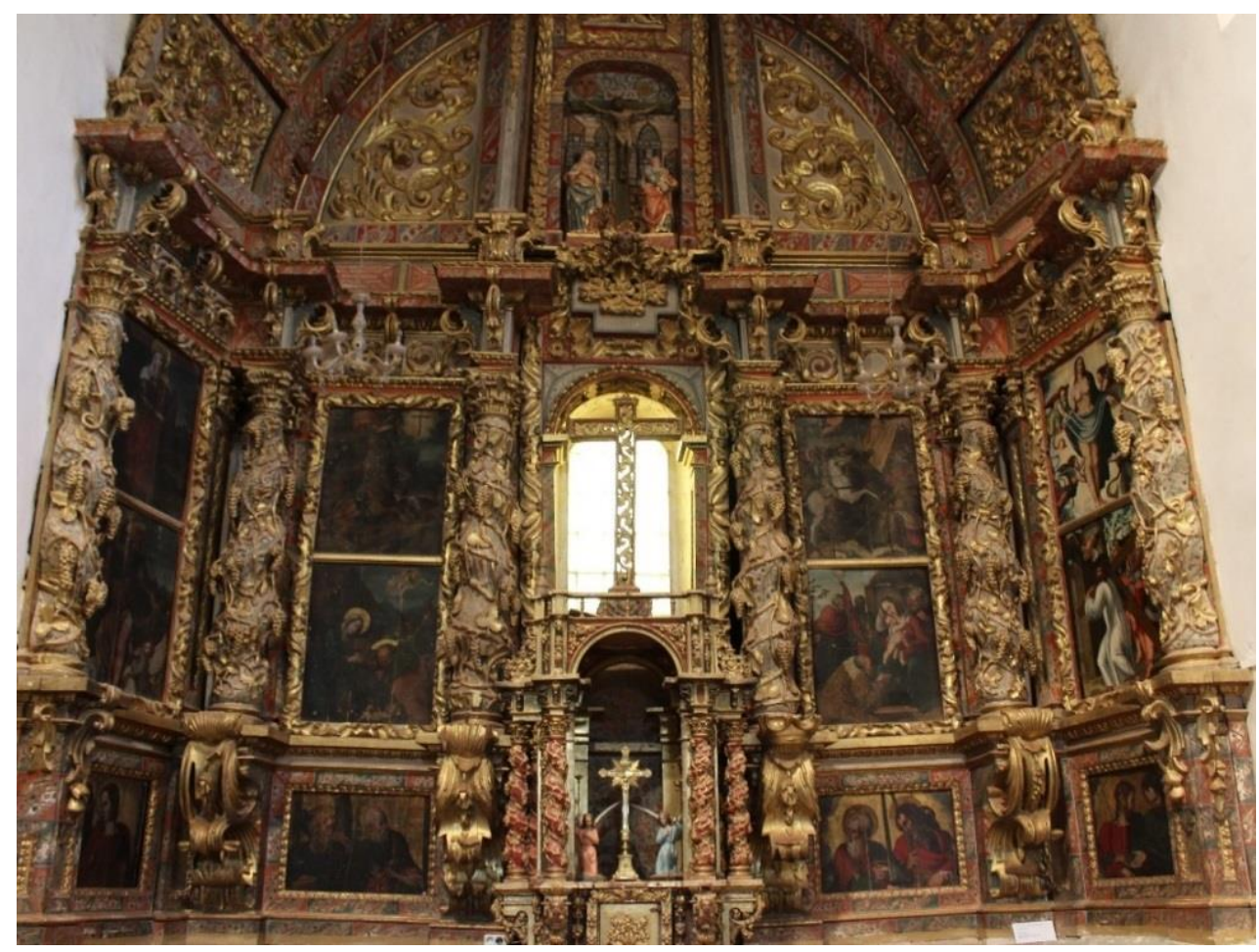

232. Juan de Illana. Retablo mayor. Ca. 1562. Iglesia de Santa Cruz. Liceras (Soria).

\footnotetext{
${ }^{505}$ RAMOS GÓMEZ, F. J., Juan Soreda y la pintura ..., p. 274.

507 ALONSO ROMERO, J. y HERNÁNDEZ DEL VALLE, M. V., “Tránsito de la Magdalena”, en Paisaje interior, Valladolid, Fundación Las Edades del Hombre, 2009, n 148, p. 510; "Heraclio entrando en Jerusalén”, Paisaje interior, Valladolid, Fundación Las Edades del Hombre, 2009, n 123, pp. 458459.
} 
En el banco se encuentran una serie de cuatro escenas con los retratos de medio cuerpo de los Apóstoles. En el primer cuerpo se hallan las escenas de San Roque, la Natividad, la Adoración de los magos y Heraclio entrando con la cruz en Jerusalén; en el segundo Santa Elena, El sueño de Constantino, La batalla de Puente Milvio y el Tránsito de la Magdalena. En la calle central se ubica un tabernáculo que contiene la Santa Cruz con un transparente y el conjunto se remata con el grupo escultórico del Calvario en el ático.

\section{Natividad}

La escena se ambienta a cielo descubierto. La Virgen aparece a la izquierda y San José a la derecha, ambos en posición orante y con nimbos dorados sobre las cabezas, mientras el Niño Jesús, desnudo, se ubica entre ambos. Al fondo observamos una estructura de madera que representaría el pesebre, y más allá, en la esquina superior derecha, la Adoración de los pastores, con la figura del ángel portando la filacteria que se recorta contra el cielo y los dos pastores (fig. 233).

En cuanto al cromatismo, predominan los tonos azules del manto de la Virgen, del paisaje montañoso del fondo y del cielo, mientras que un rojo intenso es utilizado para la capa de San José y las vestimentas de los pastores. Desgraciadamente la escena se encuentra en muy mal estado, la madera se ha cuarteado dejando ver las separaciones de las tablas que la conforman. Por otro lado, los colores se encuentran deslucidos y oscurecidos, y se ha perdido parte de la capa pictórica en la parte inferior probablemente debido a la humedad.

Para esta escena de la Natividad, Ramos Gómez apuntó que el artista podría haberse inspirado en la arquitectura lignaria de la estampa del mismo tema de Alberto Durero $^{508}$ (fig. 235) ${ }^{509}$, aunque también podría haberse basado en otras estampas de grabadores alemanes, como es el caso de Maestro E. S. (fig. 236) ${ }^{510}$, el cual también utilizaba ese mismo tipo de arquitectura, de madera, con techumbre a dos aguas y sostenida por columnas.

\footnotetext{
${ }^{508}$ Estampa disponible en: http://britishmuseum.org/research/collection_online/collection_object_details.aspx?objectId=1339564\&p artId=1\&searchText=NATIVITY\&images $=$ true\&people $=127877 \&$ page $=1$

BARTSCH, A., op. cit., vol. 132, p. 85; DODGSON, C., Catalogue of Early German and Flemish Woodcuts, vol. I, no 45, p. 289; MEDER, J., op. cit., nº 197, p. 173; SCHOCH, R., op. cit., vol. II, n 175, pp. 248-250.

${ }^{509}$ RAMOS GÓMEZ, F. J., Juan Soreda y la pintura..., p. 275

${ }^{510}$ Estampa disponible en VV. AA., Illustrated Bartsch, German 15th century: Master E. S., Master FVB, Schongauer, Mair Von Landshut, t. 8, Nueva York, Abaris Books, 1980, p. 21.

LEHRS, M., op. cit., vol. II, n 23 , p. 70.
} 


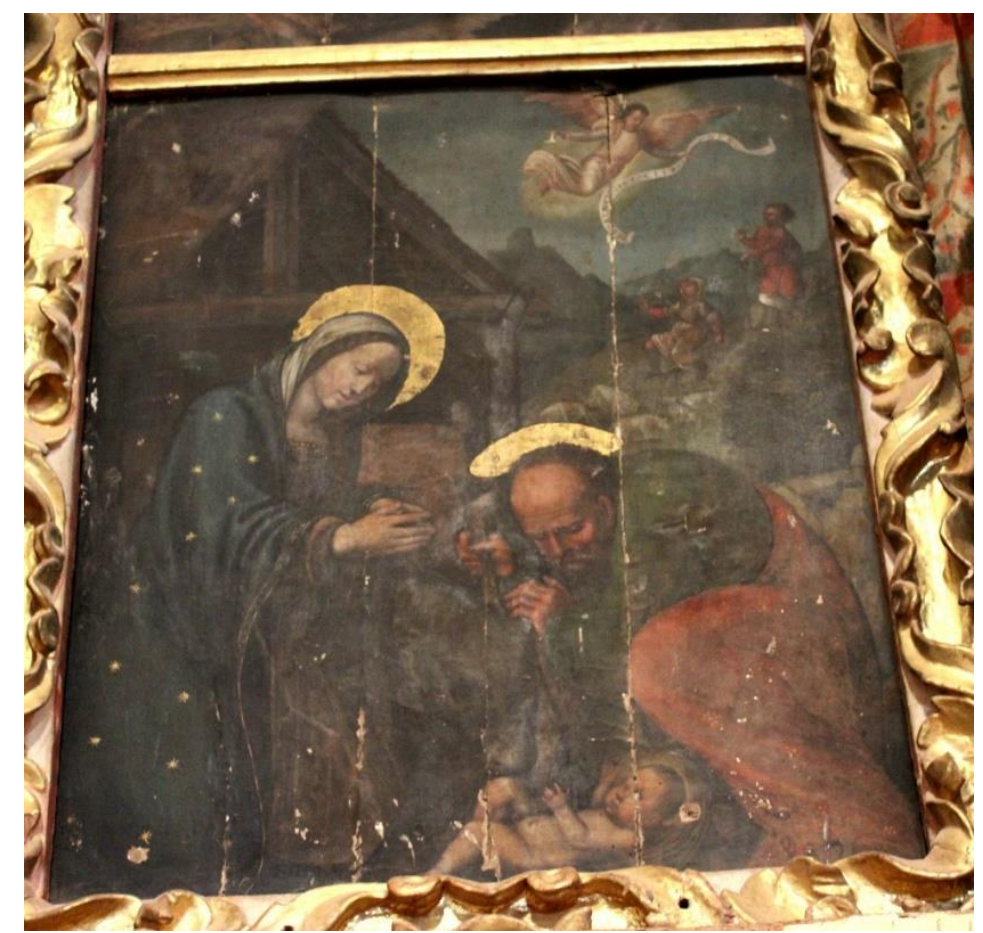

233. Juan de Illana. Natividad. 1500-1530. Retablo mayor. Iglesia de Santa Cruz. Liceras (Soria).

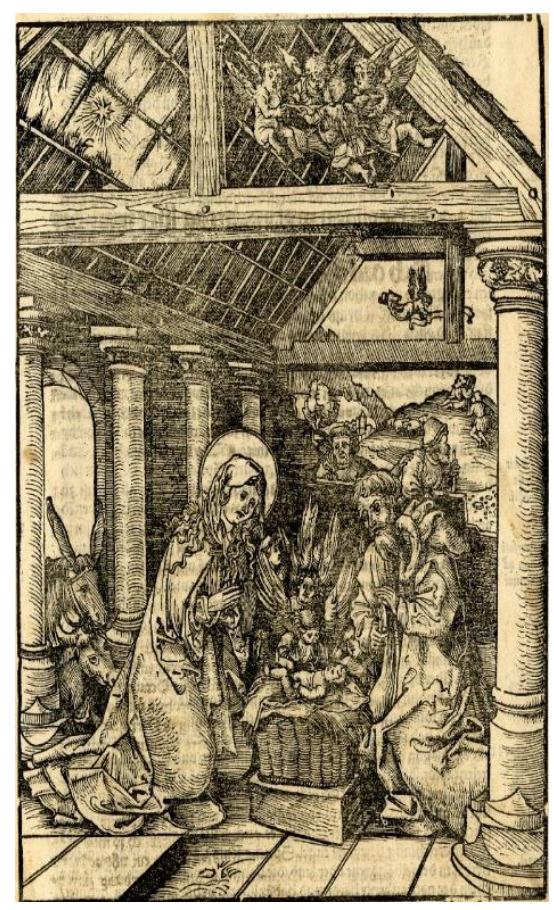

234. Hans Wechtlin. Natividad. 1508. Museo Británico. Londres (Reino Unido).

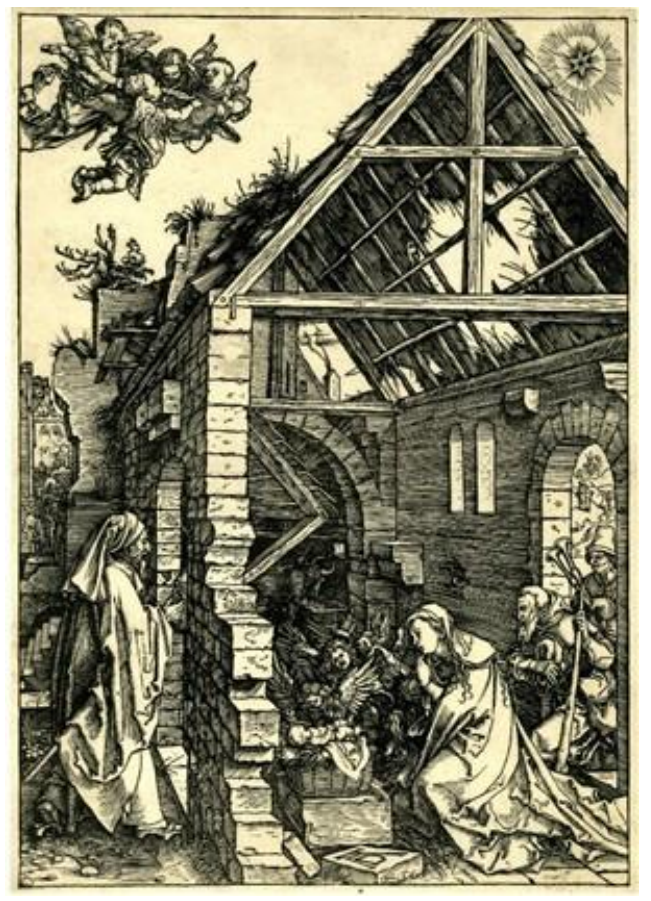

235. Alberto Durero. Natividad. 1502-1503. Museo Británico, Londres (Reino Unido).

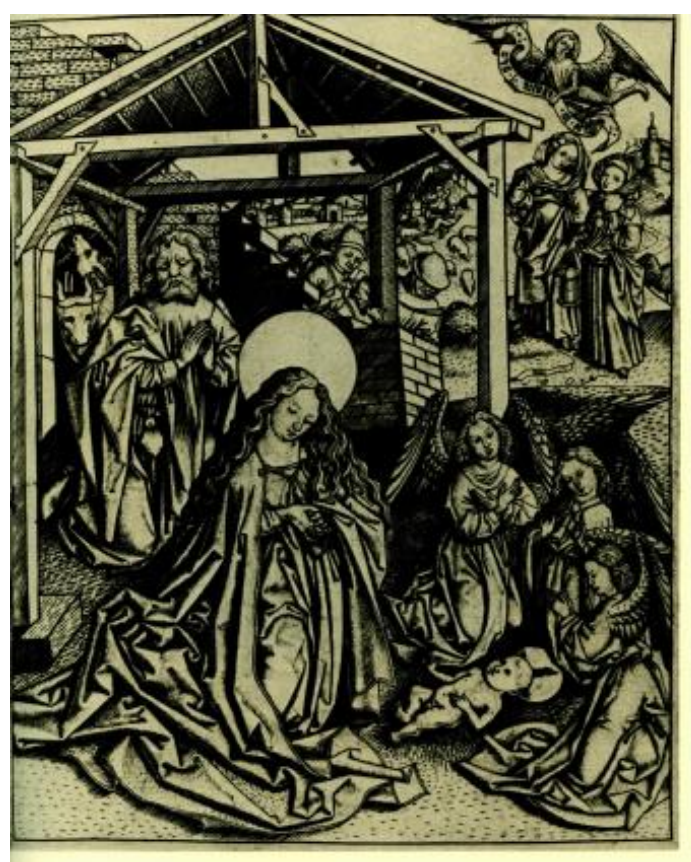

236. Maestro ES. Natividad. 1450-1467. Cincinatti (Herbert Greer French bequest. Ex coll. Yorck von Waterburg). (Estados Unidos) 
Otro elemento que procede de la estampa del Maestro E. S. parece ser la figura del Niño, la cual aparece con la misma pose con los brazos levantados y la rodilla derecha flexionada.

Por último, un último modelo sería el grabado de Hans Wetchlin (fig. 236) ${ }^{511}$ en el cual Illana pudo inspirarse, además de para la arquitectura, para las figuras de la Virgen y San José, que muestran posturas muy semejantes a la de la estampa: la Virgen agachada con las manos unidas y la mirada baja, y San José también arrodillado, con una vela en la mano derecha mientras con la izquierda la protege. Al fondo se puede ver la escena de la Anunciación a los Pastores, también representada al fondo en las estampas que he citado, y que es típica de la pintura andaluza y castellana ya desde finales de la Edad Media ${ }^{512}$.

\section{Tránsito de María Magdalena}

En esta escena María Magdalena asciende al cielo entre cuatro ángeles. Se representaría el momento en el cual los ángeles la trasladaban al cielo desde su retiro en el desierto para que asistiese a los oficios divinos ${ }^{513}$. Está prácticamente desnuda y es uno de los pocos desnudos femeninos que se representan en la pintura religiosa española. (fig. 237). Cubre su desnudez con una larga tela azul, que se desliza entre sus manos y cae también sobre su hombro izquierdo. Largos cabellos dorados caen sobre hombros y espalda, y en su mano derecha porta el tarro de perfumes atributo de la santa. De hecho, el cuadro fue repintado posteriormente, cubriéndose su cuerpo con los cabellos, ya que probablemente se consideraba ofensivo representar un desnudo.

Es muy posible que Juan de Illana se basase aquí en algún grabado mitológico, puesto que se trataba de un tema poco frecuente en el arte religioso. En concreto podría haberse inspirado en la estampa de Sebald Beham del Museo Británico con el título de Venus (fig. 238) ${ }^{514}$. En él la diosa aparece desnuda, pero cubriéndose el sexo con una tela, eso sí, más pequeña y delgada que la de la pintura.

\footnotetext{
${ }^{511}$ Estampa disponible en:

http://britishmuseum.org/research/collection_online/collection_object_details.aspx?objectId=1540926\&p artId=1\&searchText=NATIVITY\&images=true\&people=103414\&page $=1$

PASSAVANT, J. D., op. cit., vol. III, p. 331.

${ }_{512}$ RAMOS GÓMEZ, F. J., Juan Soreda y la pintura..., p. 275

${ }^{513} \mathrm{Su}$ aspecto original se desveló tras la restauración realizada en 2009 con ocasión de las Edades del Hombre. ALONSO ROMERO, J. y HERNÁNDEZ DEL VALLE, M. V., "Tránsito de la Magdalena", pp. 510-511.

${ }^{514}$ Estampa disponible en:

http://britishmuseum.org/research/collection_online/collection_object_details.aspx?objectId=1516102\&p

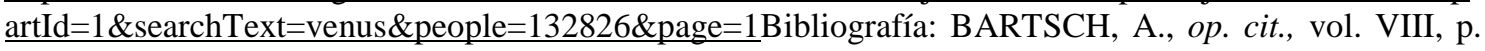




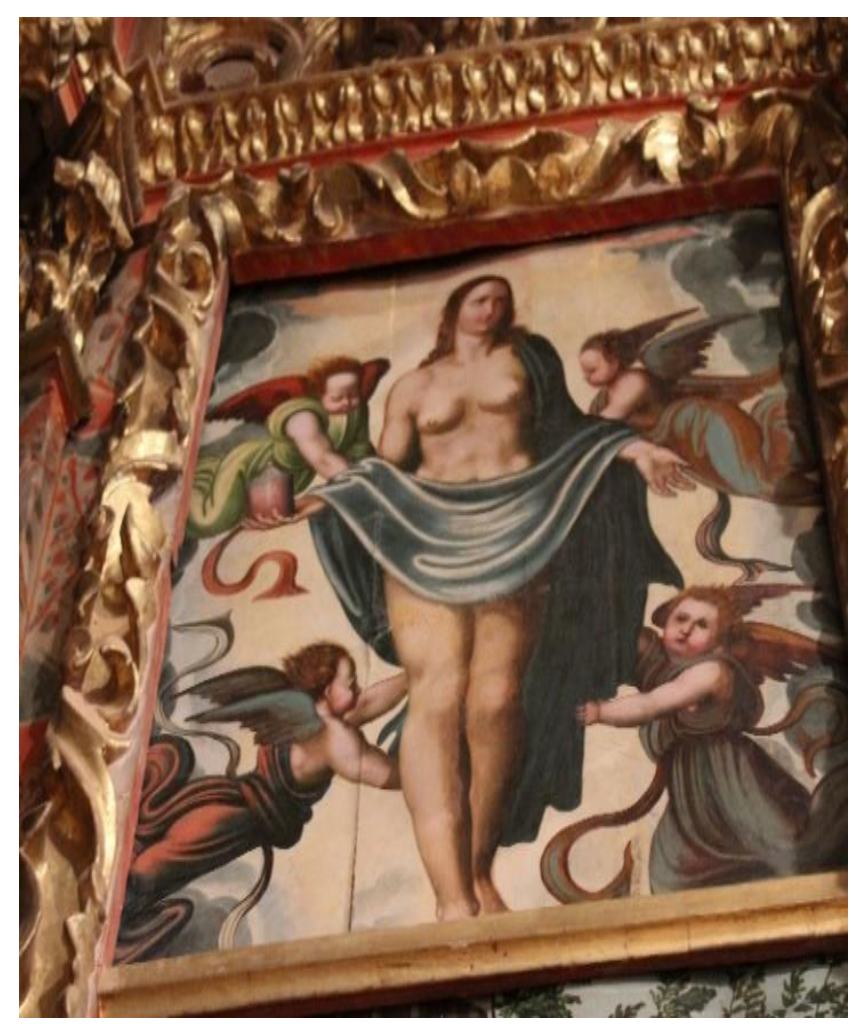

237. Juan de Illana. Tránsito de la Magdalena. 1500-1530. Retablo mayor. Iglesia de Santa Cruz. Liceras (Soria).

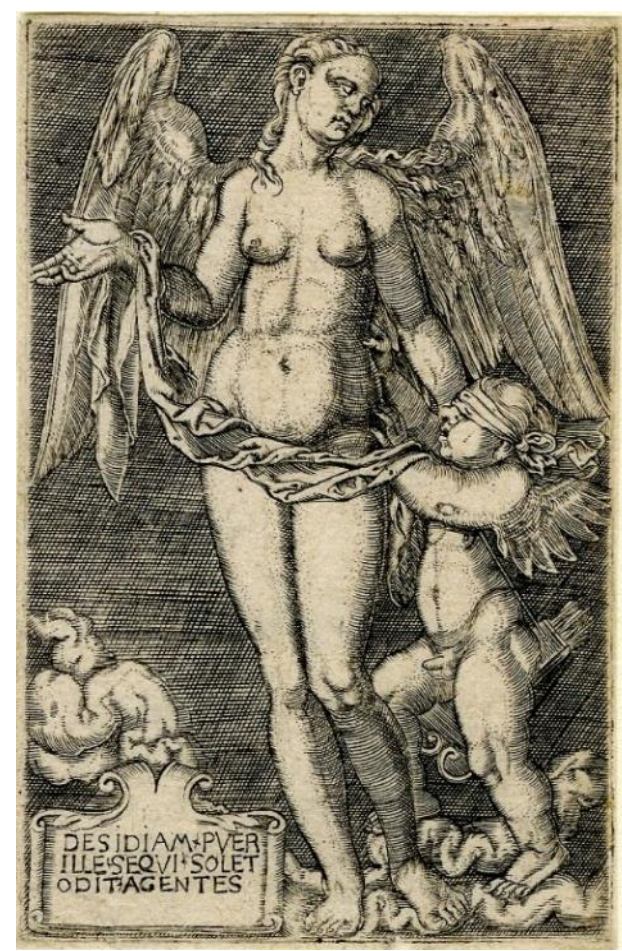

238. Sebald Beham. Venus. 1518-1580.

Museo Británico. Londres (ReinoUnido).

154; PAULI, G., Hans Sebald Beham; EinKritisches Verzeichniss seiner Kupfertiche Radirungen und Holzschnitte, Strasbourg Heitz, 1901, nº 93, p. 102; HOLLSTEIN, F. W. H., German engravings..., nº 93, p. 64. 


\section{Diego de Urbina \\ Bautismo de Cristo \\ Ca. 1564 \\ Catedral \\ Burgo de Osma (Soria)}

Cristo sumerge su cuerpo hasta los tobillos (fig. 239). Se le representa cubierto por un paño de pureza, un trozo de tela anudado en torno a la cintura ${ }^{515}$. Aparece de pie en medio del río casi seco, mientras Juan vierte el agua bautismal sobre su cabeza. Siguiendo la iconografía más propia de los Países Bajos Juan utiliza su mano como una concha desde la cual deja caer las gotas de agua sobre la cabeza de Cristo ${ }^{516}$.

Para la escena del Bautismo de Cristo, situada en la girola de la catedral de El Burgo de Osma, es muy probable que tomase como referencia la figura de San Bartolomé, en la escena del Juicio Universal de Miguel Ángel (fig. 240), ya que muestra la misma postura de piernas que el San Juan Bautista, con la derecha doblada y apoyada en una roca y la izquierda estirada.

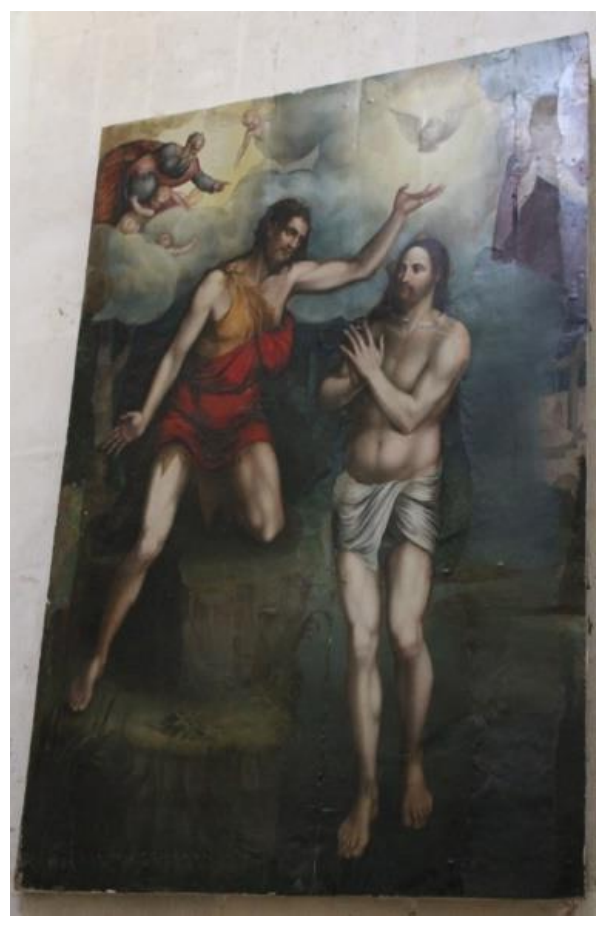

239. Diego de Urbina. Bautismo de Cristo. 1564. Catedral. Burgo de Osma (Soria).

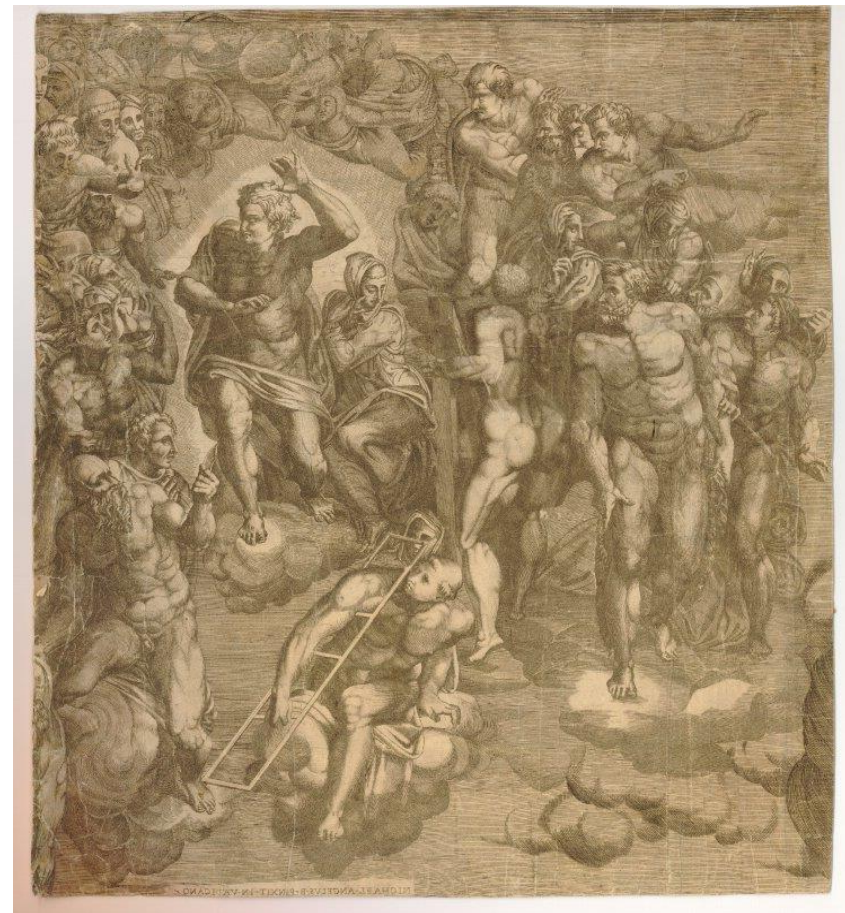

240. Giulio Bonasone. A partir de Miguel Ángel. Juicio Final. 1531-1576. Museo Británico. Londres

\footnotetext{
${ }_{516}^{515}$ COLLAR DE CÁCERES, F., "Diego de Urbina...”, pp. 126-127.

${ }^{516}$ REAU, L., op. cit., p. 312.
} 
En la misma composición, el santo que sostiene una cruz, apoyado sobre una nube, muestra una posición parecida (fig. 241). Sin embargo, Fernando Collar de Cáceres sostiene que podría estar inspirada en una de las figuras de Laocoonte $^{517}$ (fig. $242)^{518}$, concretamente en la central.

La expresividad y terribilitá del modelo miguelangelesco aparecen aquí más relajados. Además el canon de las figuras resulta menos musculoso y grandioso, con extremidadades más alargadas y delicadas. Es interesante resaltar el uso de colores estridentes propies del manierismo y la creación de un atmósfera mística a través de las nubes y de los tonos azulados vaporosos del fondo.

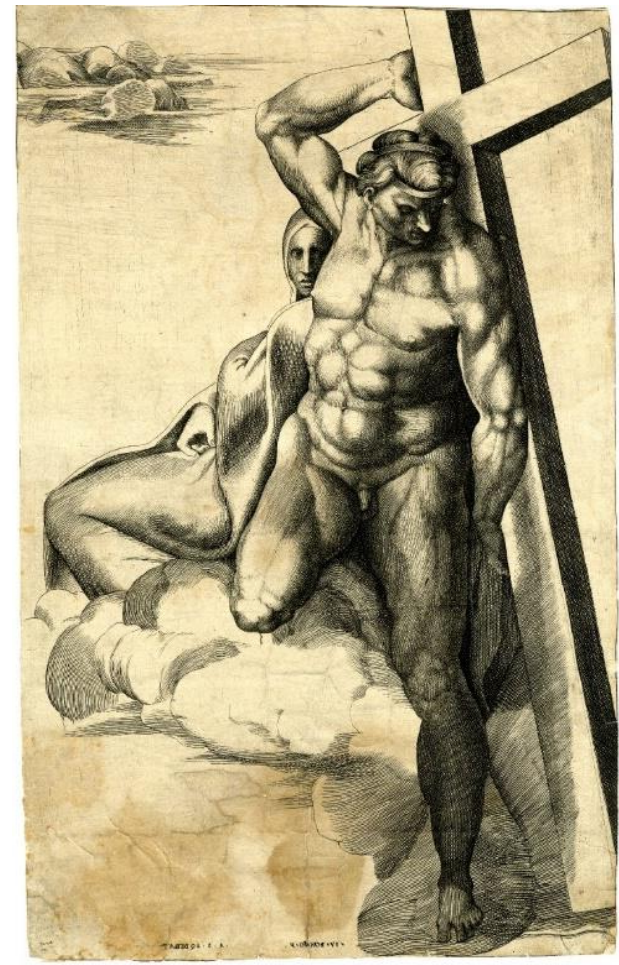

241. Giulio Bonasone. A partir de Michelangelo. Juicio Final. 1546-1550. Museo Británico. Londres (ReinoUnido).

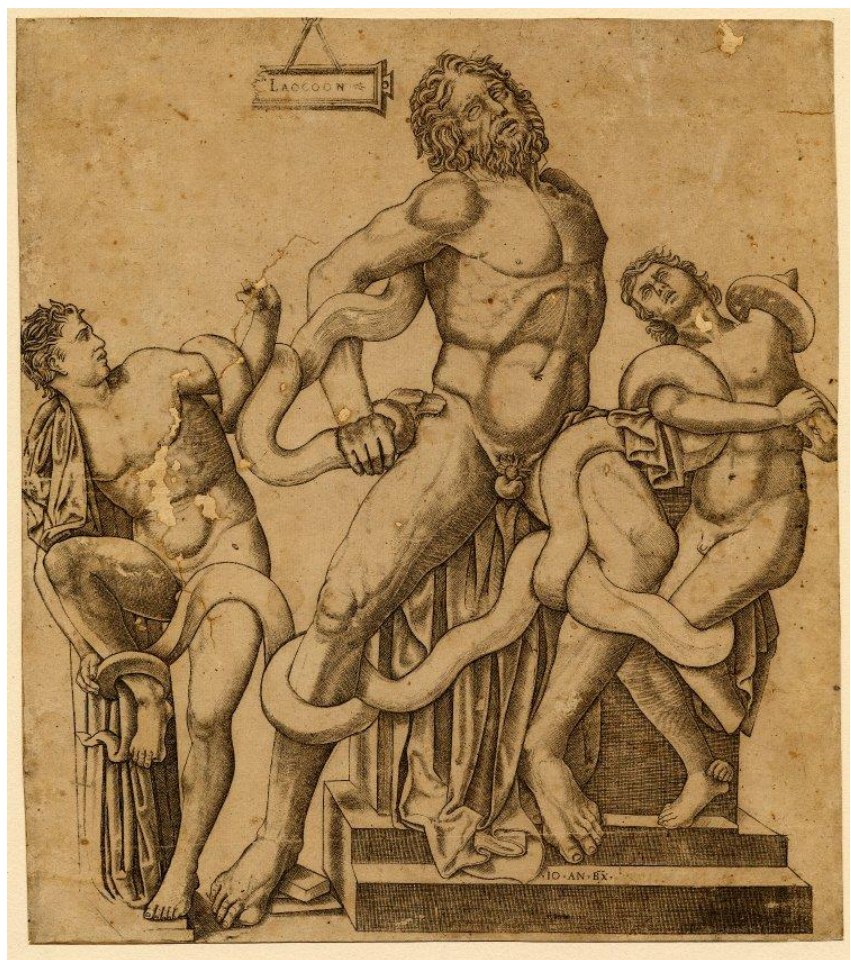

242. Giovanni Antonio Da Brescia. Laocoonte. 1506-1520.

Museo Británico. Londres (ReinoUnido).

\footnotetext{
${ }^{517}$ COLLAR DE CÁCERES, F., “Diego de Urbina...”, p. 127.

${ }^{518}$ Estampa disponible en:

http://www.britishmuseum.org/research/collection_online/collection_object_details.aspx?objectId=13467 41\&partId=1\&searchText=laocoon\&images=true\&page $=1$

BARTSCH, A., op. cit., vol. XIII; p. 326; HIND, A. M., Early Italian engraving..., vol. V (parte 2), $\mathrm{n}^{\circ}$ 20, p. 43.
} 


\section{Juan de Juni \\ Resurrección \\ 1570 \\ Catedral \\ Burgo de Osma (Soria)}

Es una obra perteneciente a la última etapa de Juan de Juni ${ }^{519}$. El sentido trágico de su obra se ha cambiado por un sentido más decorativo, de origen manierista ${ }^{520}$.

Es probable que esta escultura fuera encargada junto con el retablo de la catedral (fig. 243). Es de carácter manierista y está llena de movimiento; por un lado, Cristo avanza con la pierna izquierda por delante de la derecha; por otro lado, el manto de color bermellón le cubre las espaldas y su desnudez, se enrolla en su brazo izquierdo y cae levemente sobre el hombro derecho.

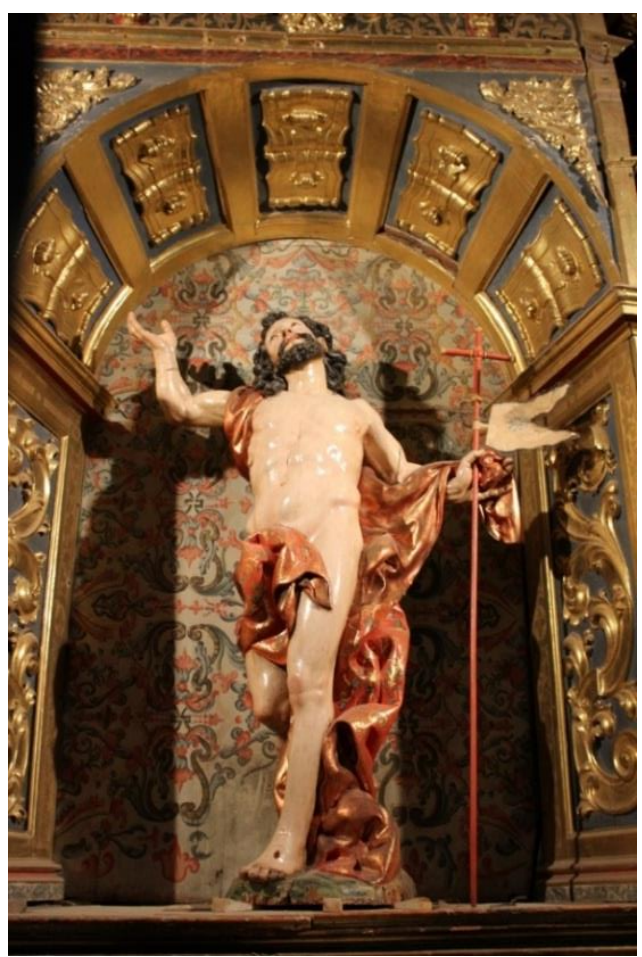

243. Juan de Juni. Resurrección. 1570. Catedral. Burgo de Osma (Soria).

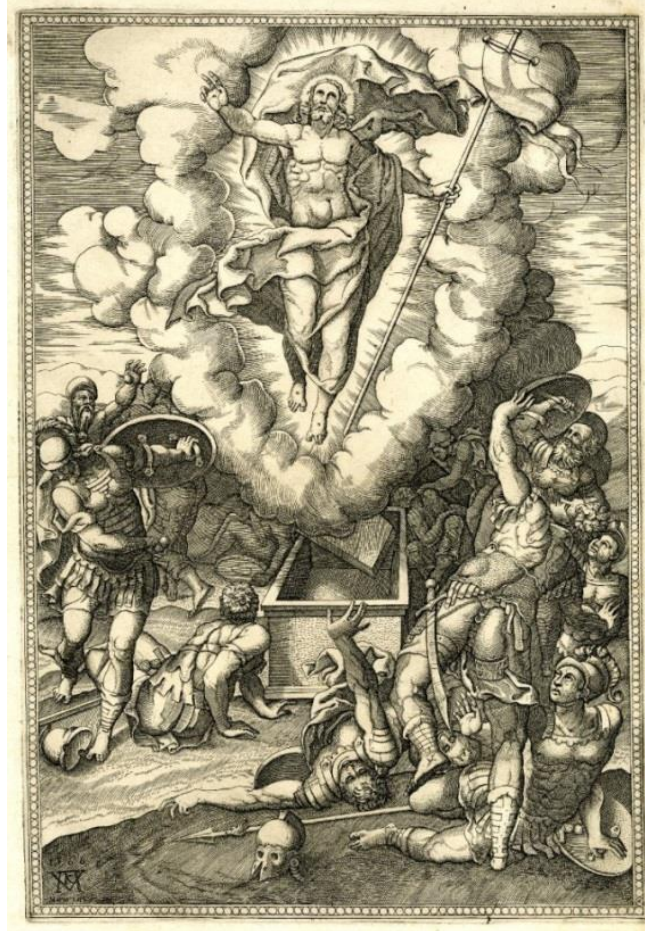

244. Mario Cartaro. Resurrección. 1566. Museo Británico. Londres (Reino Unido).

\footnotetext{
${ }^{519}$ WEISE, G., Spanische plastic aus sieben jahrhunderten, Renaissance and fruhbarock in altkastilien, die Renaissanceplastik der schulen von Palencia und Valladolid, vol. III-2Reutlingen: Gryphius, 1927, p. 332. FERNÁNDEZ DEL HOYO, M. A., Juan de Juni, escultor, Valladolid, Universidad de Valladolid, 2012, pp. 164-165; FERNÁNDEZ DEL HOYO, M. A., "Cristo resucitado", en Credo. Las Edades del Hombre, Valladolid, Fundación Edades del Hombre, 2013, nº 70, p. 256.

${ }^{520}$ MARTÍN GONZÁLEZ, J. M., Juan de Juni: vida., pp. 248-250; MARTÍN GONZÁLEZ, J. J., Juan de Juni y su época..., 1977, pp. 55-56.; "Cristo Resucitado", en La ciudad de seis piso. Las Edades del Hombre, Fundación Las Edades del Hombre, 1997, $\mathrm{n}^{\circ}$ 117, p. 219; MARTÍN GONZÁLEZ, J. J. Y CANO DE GARDOQUI, J. L., "Cristo resucitado", en El árbol de la vida. Las Edades del Hombre, Salamanca, Fundación Las Edades del Hombre, 2003, nº 6, pp. 438-429; FERNÁNDEZ DEL HOYO, M. A., "Cristo resucitado", en El contrapunto 2. 0., Salamanca, Fundación Las Edades del Hombre, 2019, p. 95.
} 
El manto cae sobre el suelo enrollándose sobre sí mismo. Para la escultura, que se encuentra dentro de la catedral soriana, es muy probable que Juni usara como modelo la estampa del mismo tema de Mario Cartaro (1566) (fig. 244) ${ }^{521}$, sobre todo en la postura, en el brazo izquierdo que sujeta el estandarte y en el paño ondeante lleno de pliegues.

El cuerpo de Cristo es musculoso y bien proporcionado, inspirándose probablemente en la estatuaria antigua, seguramente en el Laocoonte, aunque eliminando el sentido trágico de la escultura griega. Es una escultura encarnada a pulimento, lo que hace más visibles las cualidades visuales y táctiles de la obra.

\section{Juan de Arteaga y Francisco Rodríguez \\ Retablo mayor \\ Finales del siglo XVI \\ Iglaesia de Nuestra Señora del Castillo \\ Calatañazor (Soria)}

Este retablo mayor está compuesto por dos partes muy diferentes: el banco y el primer cuerpo son de finales del siglo XVI y principios del XVII, mientras que el resto es del segundo tercio del siglo XVII (fig. 245) ${ }^{522}$. La parte más antigua es obra de los escultores Juan de Arteaga y Francisco Rodríguez, aunque el dorado fue realizado por Tomás Ruiz de Quintana ${ }^{523}$.

El banco está compuesto por atalantes en los extremos, pilastras con altorrelieves de San Roque y San Sebastián, relieves de Cristo camino del Calvario y la Deposición y hornacinas de medio punto con las esculturas de San Andrés y San Bartolomé.

En el primer cuerpo hay imágenes de San Juan Bautista, Santiago Peregrino, San Pedro y San Pablo y relieves en casas de la Anunciación y Nacimiento. Cuenta también con otro banco en el cual hay relieves de ángeles en los laterales y en las casas centrales de Santa Cecilia, Santa Bárbara, la Huida a Egipto, San Joaquín y Santa Ana.

En el segundo cuerpo se encuentran imágenes de Santo Tomás Apóstol, San Juan Evangelista, Santo Domingo de Guzmán y San Felipe, además se observan

\footnotetext{
${ }^{521}$ Estampa disponible en:

http://www.britishmuseum.org/research/collection_online/collection_object_details.aspx?objectId=14575 58\&partId=1\&searchText=resurrection\&images=true \&people $=129933 \&$ page $=1$

BARTSCH, A., op. cit., vol. XV, p. 523.

${ }_{522}$ ALCOLEA BLANCH, S., op. cit., p. 72; REDONDO LAGÜERA, J. P., op. cit., 1998, p. 114.

${ }^{523}$ ARRANZ ARRANZ, J., La escultura romanista en la Diócesis...., pp. 70-75; VV. AA., Inventario artístico de Soria..., vol. II, pp. 170-171.
} 
relieves situados en casas relativos a la Presentación, Visitación y Nacimiento de la Virgen.

Por último, en el ático se hallan pilastras con las imágenes de San Simón, San Agustín, San Ambrosio y Santiago el Menor y dos relieves: uno de la Adoración de los pastores y otro de los Reyes Magos. En el hueco central se localiza la escultura de Cristo crucificado sobre un lienzo de la Jerusalén celeste.

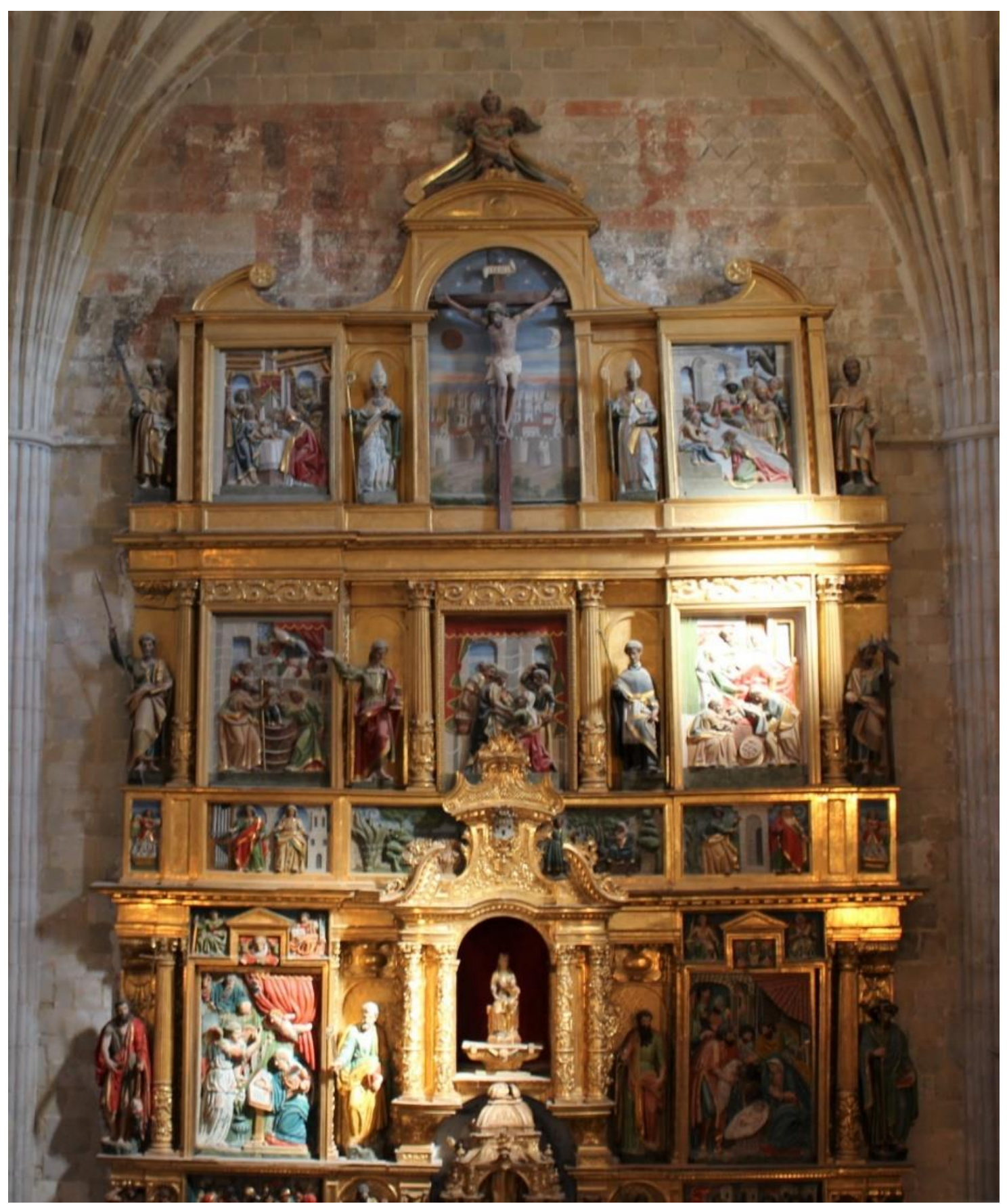

245.Juan de Arteaga y Francisco Rodríguez. Retablo mayor. Finales del siglo XVI. Iglesia de Nuestra Señora del Castillo. Calatañazor (Soria). 


\section{Anunciación}

Para el relieve de la Anunciación (fig. 246) probablemente se usó la estampa de Cornelis Cort (fig. 247) ${ }^{524}$, aunque adaptando sus dimensiones al espacio del retablo. La Virgen María muestra la misma postura, con los brazos en posición abierta: uno que avanza en dirección al ángel, y el otro está medio doblado, aunque en este caso la mano está medio cerrada, mientras que en en la estampa muestra la palma. También el ángel presenta una posición muy semejante, con la mano derecha levantanda y la otra sujetando la vara con la filacteria, que en la estampa es el ramo de azucenas. Como en el grabado, ha colocado el escultor una cortina en la parte derecha de la composición, dejando adivinar el lecho de la Virgen, que en el caso del relieve es levantada por un angelito. En la esquina superior izquierda vemos la figura de Dios Padre bendiciendo con una mano y con el globo terráqueo en la otra.

246. Juan de Arteaga y Francisco Rodríguez. Anunciación. Retablo mayor. Finales del siglo XVI. Iglesia de Nuestra Señora del Castillo. Calatañazor (Soria)

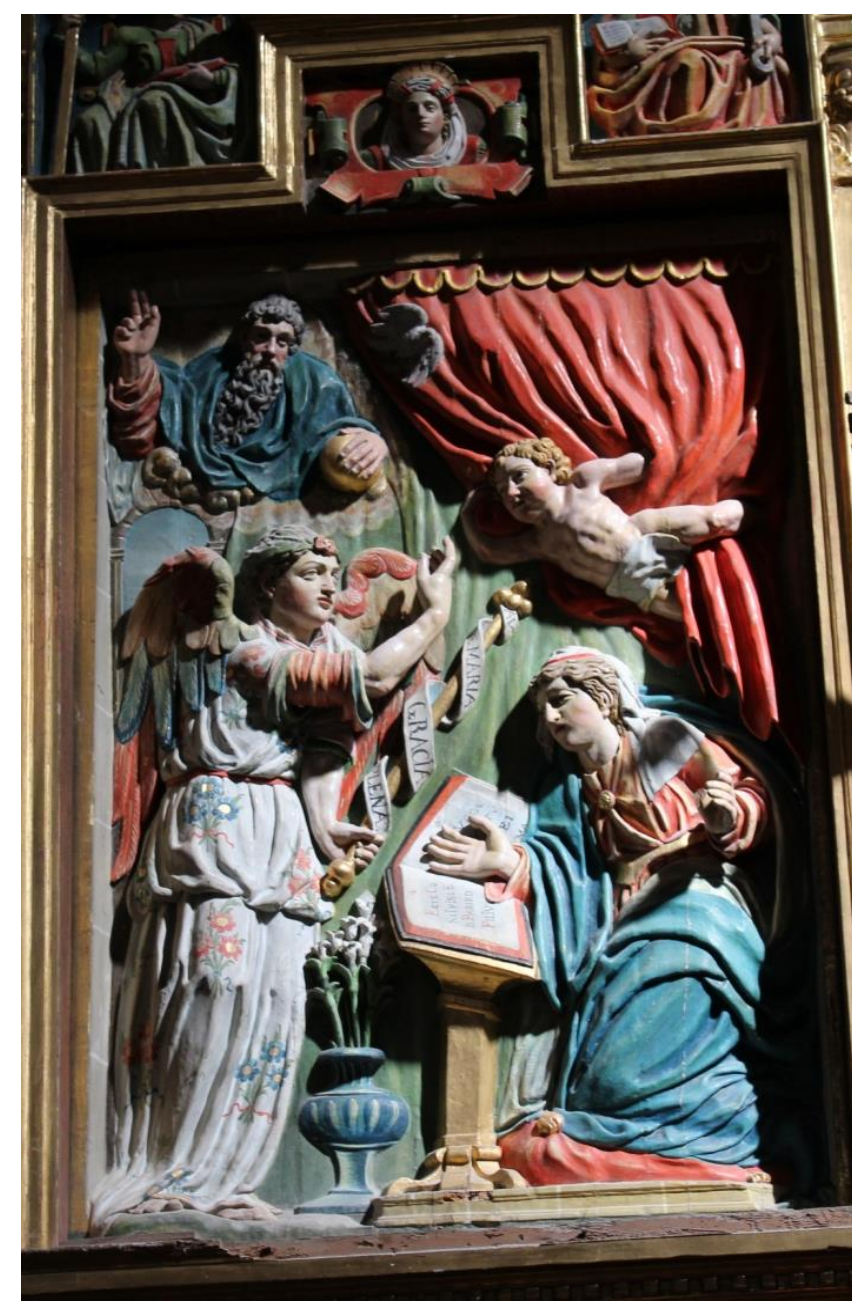

\footnotetext{
${ }^{524}$ Estampa disponible en: http://www.britishmuseum.org/research/collection_online/collection_object_details.aspx?objectId=30289 78\&partId=1\&searchText=annunciation\&images=true \&people $=128446 \&$ page $=1$ BIERENS DE HAAN, J. C. J., L'ouvre gravé de Cornelis Cort, graveur hollandais 1533-1578, nº 24, p. 48; HOLLSTEIN, F. W. H., The New Hollstein, Cornelius Cort, nº 23, III, vol. I, pp. 66-68.
} 
En el relieve el escultor muestra un manejo ciertamente torpe del espacio ya que las figuras parecen desproporcionadas y excesivamente constreñidas. En la estampa Cort muestra cierto interés por mostrarnos en perspectiva la estancia de la Virgen, con los muebles y el jarrón, en cambio en el relieve todo los elemento aparecen apiñados unos sobre otros. Las posturas también nos demuestran poca habilidad en especial en la representación de las manos y de los pliegues de las vestimentas del ángel. El relieve no logra captar adecuadamente la sensación de dinamismo que sí transmite la estampa en especial a través del ángel.

Todo el claroscuro que crea Cort en su composición a través de los fuertes contrastes entre la luz procedente del ángel y la oscuridad que domina la parte derecha de la estampa, se sustituye en el relieve por unos colores planos e intensos que contribuyen a dar a las figuras una escasa impresión de realismo.

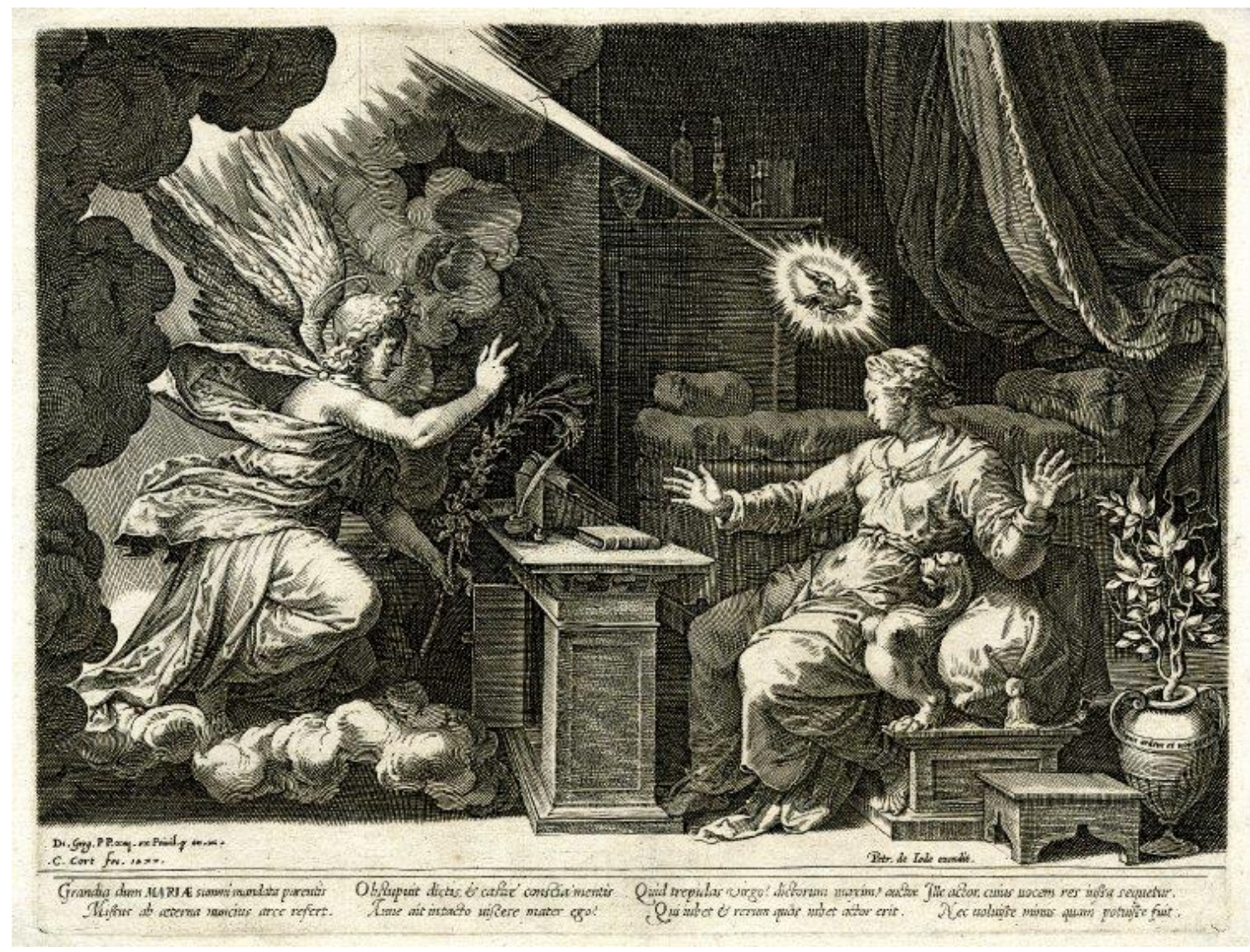

247. Cornelis Cort, Anunciación. 1577. Museo Británico, Londres (Reino Unido). 


\section{Juan de Baltanás (doc. 1561-1581) \\ Retablo mayor \\ Ca. 1561 \\ Iglesia de San Juan de Rabanera \\ Soria}

Es el retablo titular (fig. 248) ${ }^{525}$ de esta iglesia aunque se trasladó a la capilla primera del lado de la Epístola durante la restauración que se llevó a cabo mediados del siglo $\mathrm{XX}^{526}$. Está formado por un pequeño banco plateresco y dos cuerpos con tres calles, divididas por columnas de balaustre. En el banco se sitúan pilastras con hornacinas e imágenes de los Evangelistas y relieves de San Antonio y San Agustín, Santa Perpetua y Santa Felicitas ${ }^{527}$.

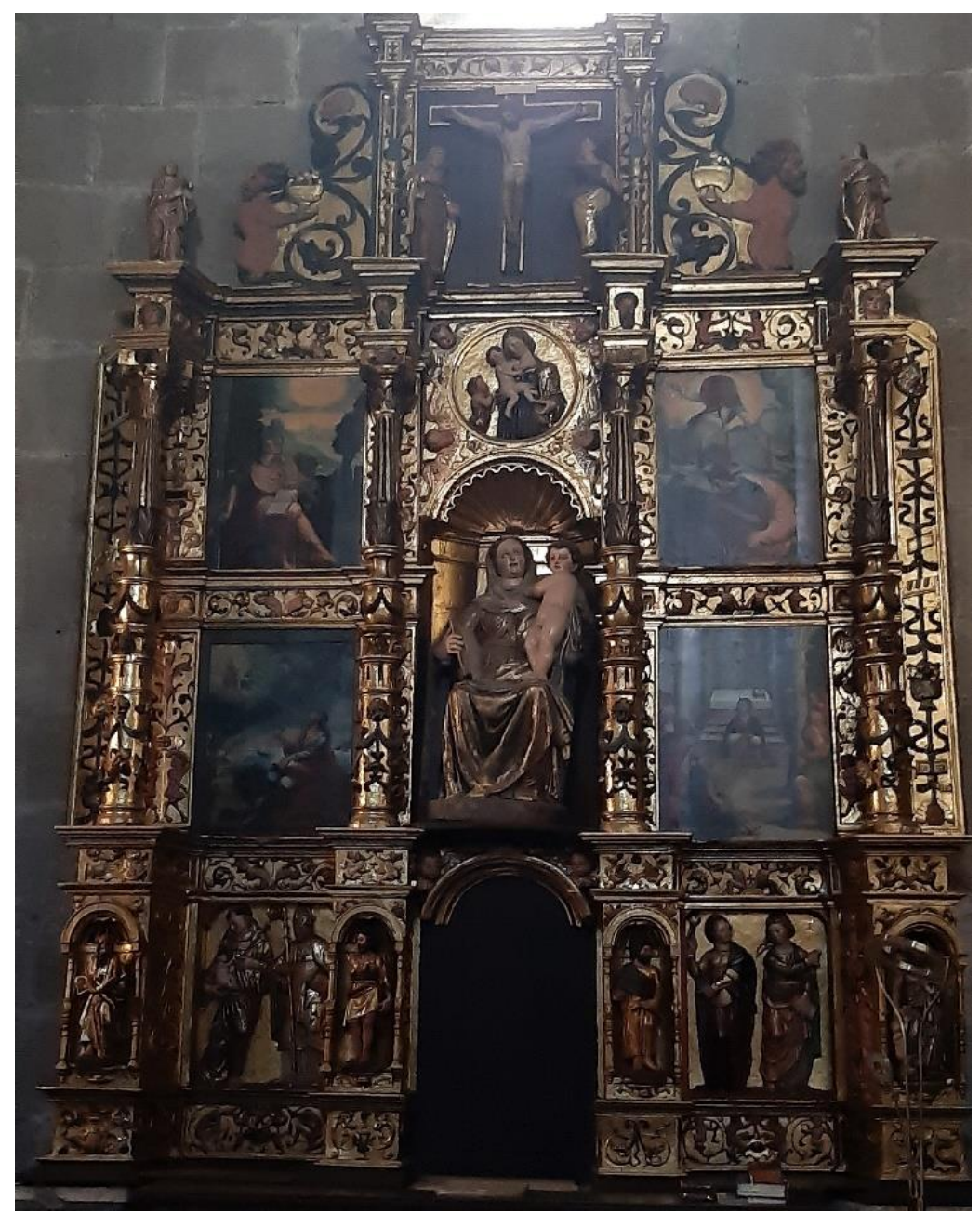

248. Juan de Baltanás. Antiguo retablo mayor. Ca. 1561. Iglesia de San Juan de Rabanera. Soria.

\footnotetext{
${ }^{525}$ Imagen procedente de ARRANZ ARRANZ, J., La escultura romanista en la diócesis..., p. 248. ${ }^{526}$ MARQUÉS DEL SALTILLO, LASSO DE LA VEGA Y LÓPEZ DE TEJADA (MARQUÉS DEL SALTILLO), M., Artistas y artifices sorianos de los siglos..., p. 44; ALCOLEA BLANCH, S., op. cit., p. 17. VV. AA., Inventario artístico..., vol. I, pp. 304-305.

${ }^{527}$ VV. AA., Inventario artístico..., vol. I, p. 305.
} 
Las columnas se apoyan sobre netos y sostienen a los cuatro Evangelistas en el frontal. Preside la calle central del segundo cuerpo la imagen de la Virgen María con el Niño Jesús. La misma escena se repite justo arriba, en un relieve en el que además aparece la imagen de San Juan Bautista Niño. En el ático se sitúa el Calvario, decorado con detalles de carácter plateresco. Las pinturas representan escenas de la Vida de San Juan Evangelista. El retablo es obra del escultor Francisco de Ágreda, mientras que la pintura se debe al soriano Juan Baltanás, que también se ocupó del dorado y estofado de las figuras ${ }^{528}$.

\section{San Juan Evangelista}

Para esta pequeña pintura (fig. 249) el artista podría haberse inspirado en la estampa del mismo tema de Schongauer (fig. 250) ${ }^{529}$, de la cual tomaría la postura de la figura sentada a la izquierda de la composición, mirando al cielo. No se adoptó la forma de las manos escribiendo, pero sí probablemente la pose de las piernas, aunque invertidas.

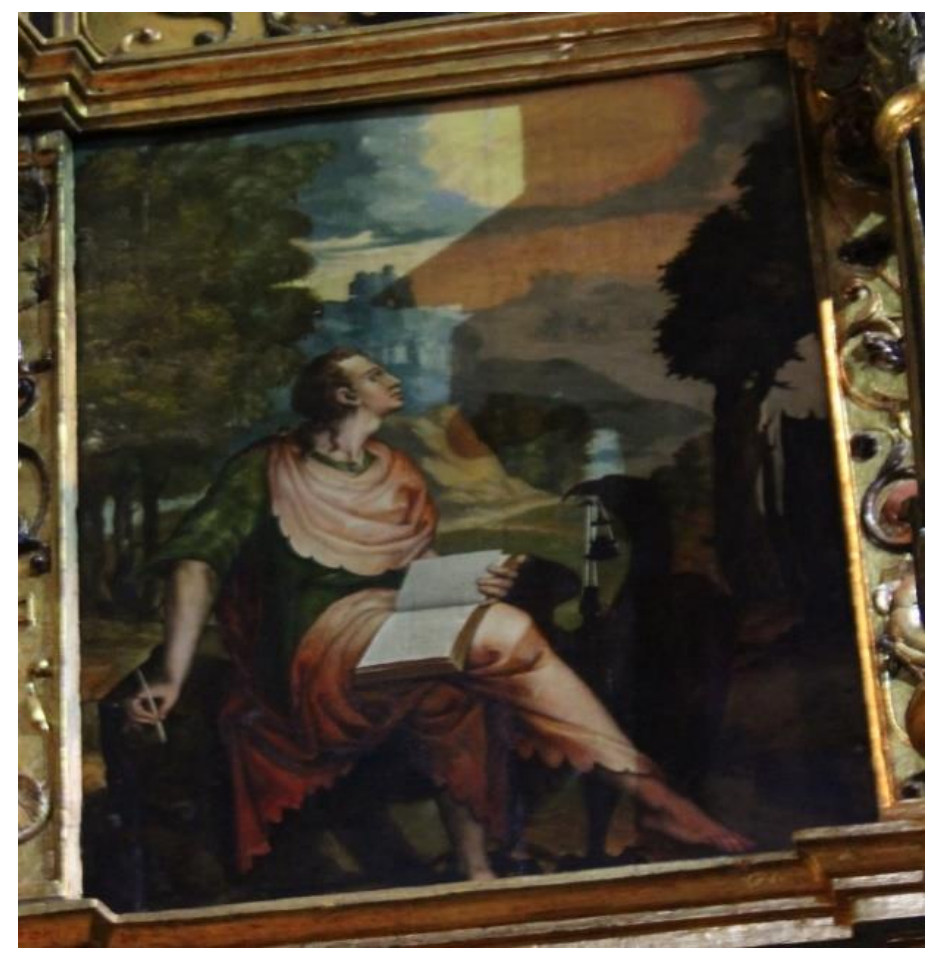

249. Juan de Baltanás. San Juan Evangelista. Ca. 1561.

Iglesia de San Juan de Rabanera. Soria

${ }^{528}$ MARQUÉS DEL SALTILLO, LASSO DE LA VEGA Y LÓPEZ DE TEJADA (MARQUÉS DEL SALTILLO), M., Artistas y artifices sorianos de los siglos..., p. 45.

${ }^{529}$ Estampa disponible en:

http://www.britishmuseum.org/research/collection_online/collection_object_details.aspx?objectId=14022 82\&partId=1\&searchText=saint + john\&images $=$ true \&people $=108158$ \&page $=1$

LEHRS, M., Geschichte und kritische ..., vol. IX, no 363, 1908, p. 295; HOLLSTEIN, F. W. L., German engravings..., $\mathrm{n}^{\circ}$ 60, vol. XLIX, pp. 140-141; STRAUSS, W. L., op. cit., vol. 8, parte 1, p. 60. 


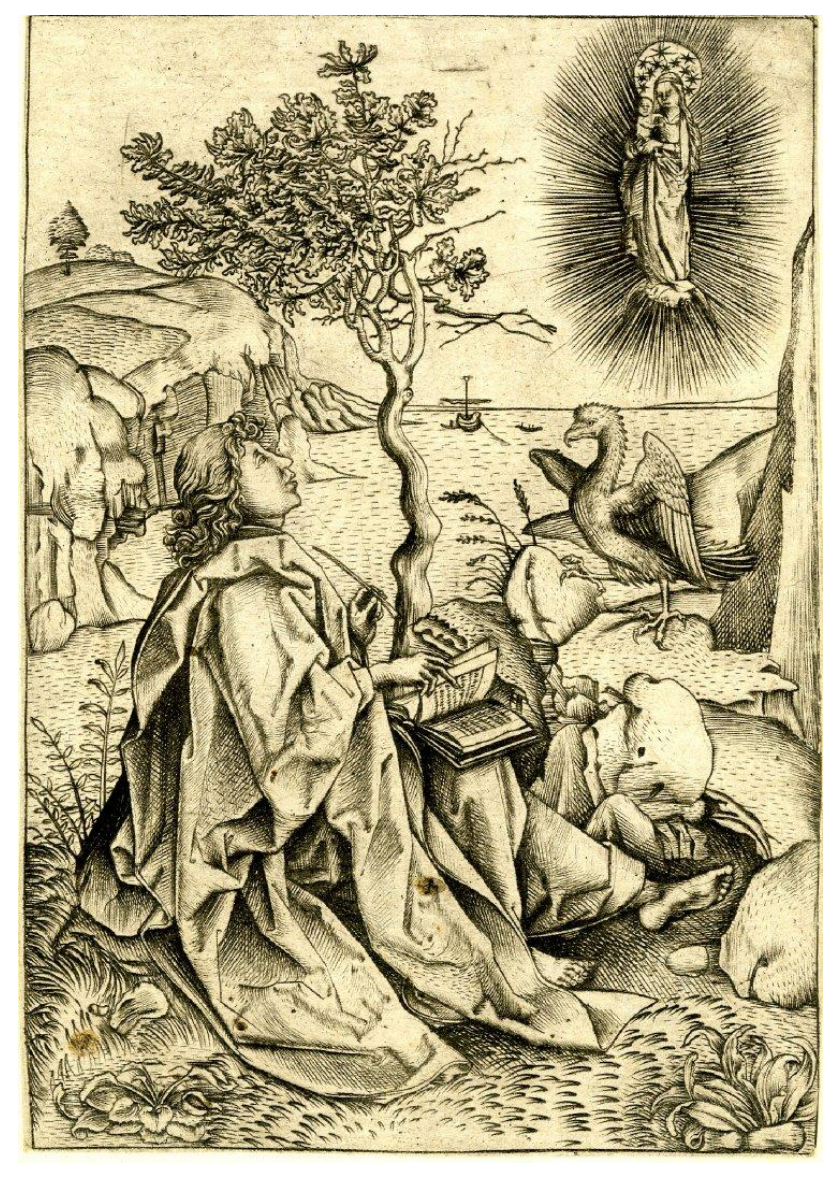

250. Martin Schongauer. San Juan Evangelista. 1469-1474. Museo Británico.

Londres (ReinoUnido).

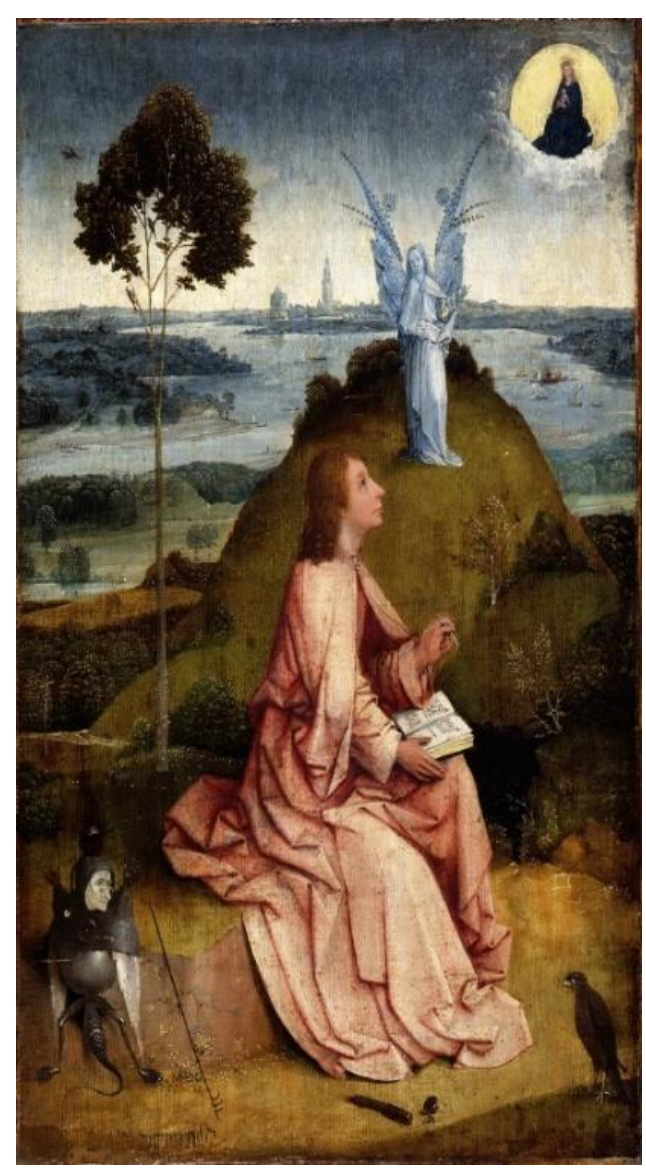

251. Hyeronimous Bosch. San Juan Evangelista. 1504-1505.

Gemäldegalerie. Berlín (Alemania).

El mismo modelo parece utilizarse algunas pinturas flamencas posteriores, como la del Bosco (1504-1505) (fig. 251) ${ }^{530}$ en la Gemälde Galerie de Berlín. El paisaje boscoso y marino del fondo también podría proceder de una estampa. Sin embargo sus vestimentas, sin esos pliegues tan marcados, no son propios del arte flamenco. El pintor ha creado cierta ilusión de espacio pintando los elementos lejanos de colores fríos como el azul, tal y como sucede en la pintura del Bosco.

\footnotetext{
${ }^{530}$ Imagen procedente de :

https://en.wikipedia.org/wiki/St. John the Evangelist_on_Patmos\#/media/File:Johannes_op_Patmos_Sai nt_John_on_Patmos_Berlin,_Staatlichen_Museen_zu_Berlin,_Gemaldegalerie_HR.jpg
} 


\section{Pedro del Cerro}

\section{Retablo mayor}

\section{Ca. 1585}

Iglesia de Santa María la Mayor

Pozalmuro (Soria)

La localidad de Pozalmuro se encontraba entre las diócesis de Osma, de la que formaba parte, y la de Tarazona. A ello se debe que el creador del retablo fuera maestro de ambas diócesis.

La primera noticia que tenemos al respecto es la de su tasación en 1608. El retablo había sido comenzado en 1585 . Su nombre sigue apareciendo en diferentes descargos hasta 1596. La pintura, el dorado y el estofado son obra de Francisco de Metelín, vecino de Tarazona, al cual se la había cedido a su vez Francisco Leonardo ${ }^{531}$.

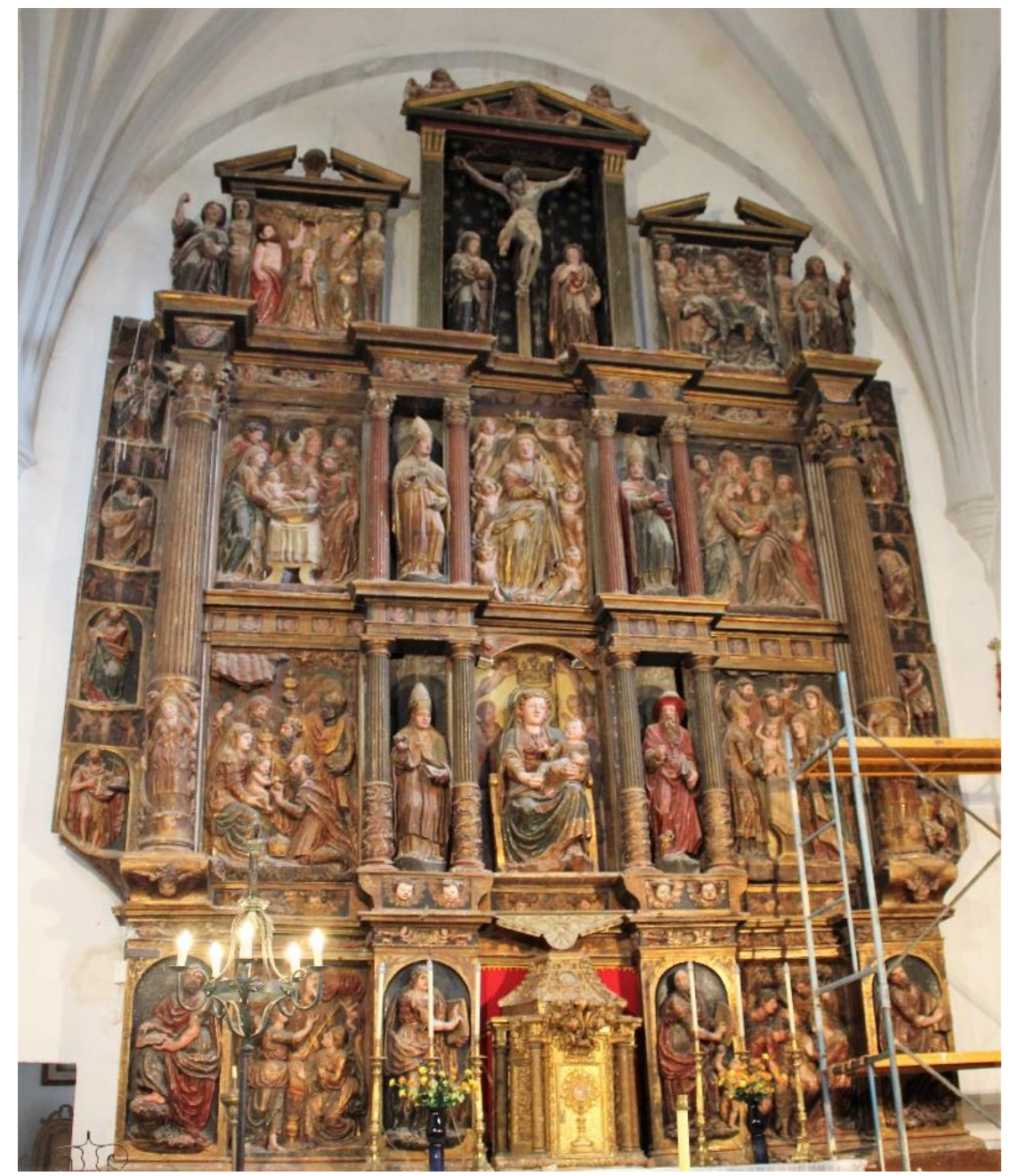

252. Pedro del Cerro. Retablo mayor. Ca. 1585.

Iglesia de Santa María la Mayor. Pozalmuro (Soria).

${ }^{531}$ ARRANZ ARRANZ, J., La escultura romanista ..., pp. 88-89. 
Fue realizado por el entallador y escultor Pedro del Cerro ${ }^{532}$. Es la única obra escultórica realizada enteramente por él. Era originario de Soria, donde desarrolló gran parte de su actividad, si bien también colaboró con otros maestros como Pedro Cicarte o Juan de Arteaga. Su obra es de un estilo romanista seco, sus composiciones son algo torpes, problema que normalmente soluciona colocando figuras simétricas. Llena todos los huecos con una auténtica acumulación de figuras. Las figuras, que suelen ser de gran tamaño, con cabezas desproporcionadas y ovaladas y poco expresivas.

El retablo parece inspirarse en el de Ólvega. Se compone de banco, dos cuerpos y ático (fig. 269). También se hicieron dos pequeñas polseras o guardapolvos que flanquean las dos columnas que unen los dos cuerpos. Su estructura aparece coronada por frontones partidos en las calles laterales y un frontón cerrado en la central. En ella se alberga la figura de Dios Padre y dos niños recostados.

Cada parte del retablo aparece separada por frisos. Los evangelistas del banco son de una gran expresividad de ecos miguelangelescos. Su obra se caracteriza por los mantos pesados y voluminosos que lucen sus figuras. El color es de tonalidad suave, no hay colores estridentes. El uso del dorado en algunas zonas como el fondo de oro del trono de la Virgen le confieren un cierto carácter aún gótico

\section{Presentación del Niño en el templo}

Esta escena representar la Circuncisión o la Presentación en el templo (fig. 253). Pedro del Cerro se inspiró para realizar esta escena del retablo en la estampa de Giulio Bonasone (fig. 254) ${ }^{533}$ del mismo tema. A la izquierda de la escena, aparece la Virgen con el Niño en brazos. Lo entrega al sacerdote que aparece en medio de la composición, ataviado con la misma indumentaria que en la estampa (la de un obispo), aunque con diversas variaciones, entre ellas la postura de las manos del sacerdote; si en el relieve parecen avanzar para sujetar al Niño, en la estampa se alzan mostrando las palmas.

\footnotetext{
${ }_{533}^{53}$ PÉREZ DE CASTRO, R., “Coronación de la Virgen”, pp. 519-522.

${ }^{533}$ Estampa disponible en:

http://www.britishmuseum.org/research/collection_online/collection_object_details.aspx?objectId=14451 29\&partId=1\&searchText=presentation+on+the+temple\&images $=$ true \&people $=131791$ \&page $=1$ BARTSCH, A., op. cit., vol. XV, p. 116; MASSARI, S., op. cit., p. 143.
} 


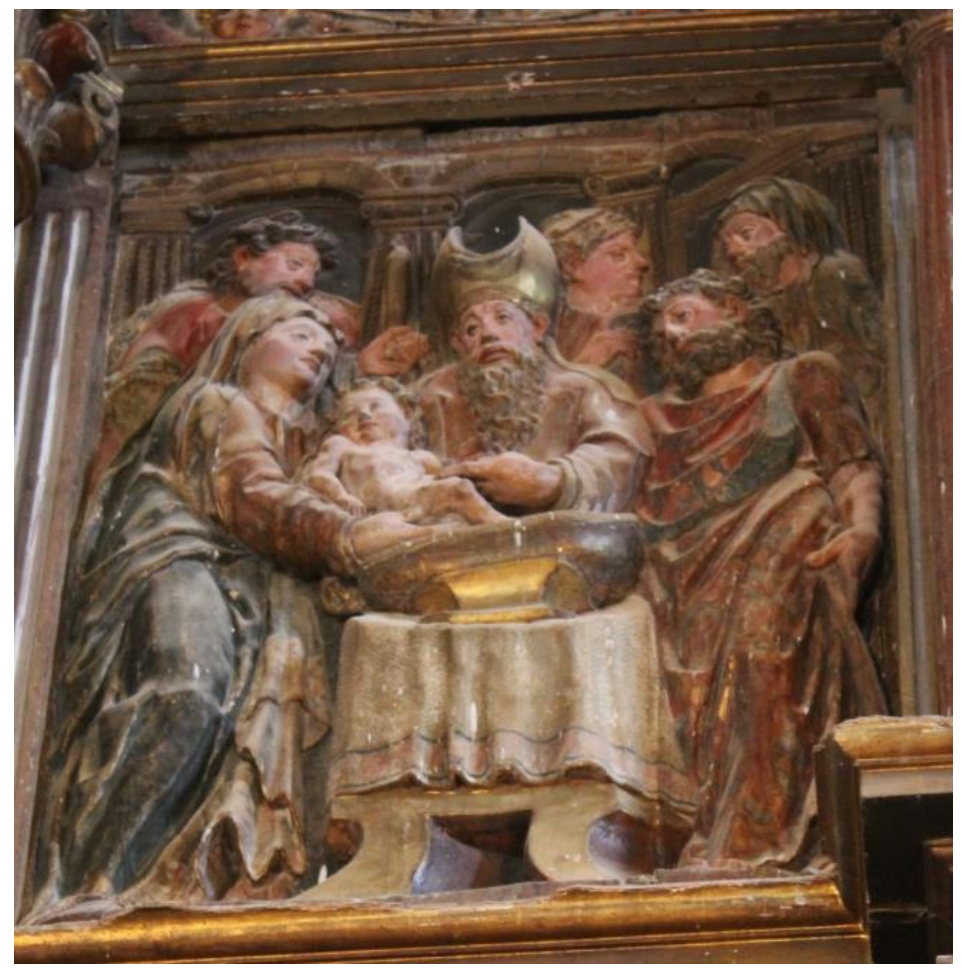

253. Pedro del Cerro. Presentación del Niño en el templo. 1585. Retablo mayor. Iglesia Santa María la Mayor. Pozalmuro (Soria).

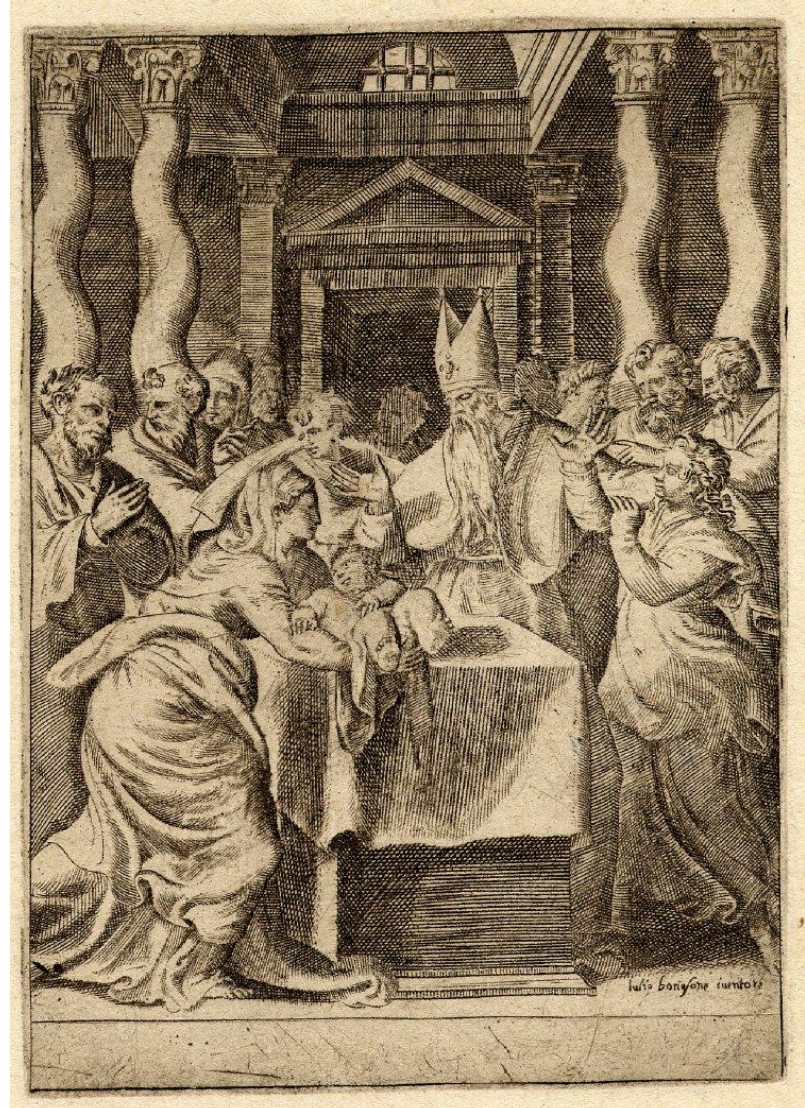

254. Giulio Bonasone. Presentación del Niño en el templo.

1547-1476. Museo Británico. Londres (ReinoUnido). 
Curiosamente encontramos algunos elementos coincidentes como puedan ser el rostro de un hombre situado al fondo a la derecha y que mira hacia el mismo lado. La postura del Niño que gira la cabeza en dirección a su madre también es similar, así como su monumentalidad y musculosidad. El fondo, que en la estampa está formado por cuatro columnas salomomónicas de capitel corintio y un frontón triangular en la entrada del fondo, en el relieve se basa en cuatro columnas estriadas de capitel jónico. El escultor ha simplificado el espacio y las poses de muchos de los personajes; no logra transmitir la sensación de dinamismo que sí transmite el grabado, a pesar de ello sí que logra emular parcialmente la disposición espacial del mismo.

\section{Coronación de la Virgen}

En este relieve Pedro del Cerro podría haber utilizado varios grabados nórdicos, si bien esta forma de representación forma parte de la tradición iconográfica (fig. 255). La Virgen aparece en el centro arrodillada, siendo coronada por Dios Padre, a la derecha de la escena, y Dios Hijo, a la izquierda. Las estampas podrían ser las de Lucas de Leyden (fig. 256) ${ }^{534}$ y Alberto Durero (fig. 257), donde Dios Padre y Dios Hijo aparecen representados de manera muy semejante, alzando los brazos por encima de la cabeza de la Virgen ${ }^{535}$. La diferencia es que en el relieve Cristo no aparece coronado ni luciendo un manto, su torso aparece desnudo y cubierto de cintura para abajo por un paño que llega hasta el suelo. Respecto a la Virgen, ésta aparece tal y como es en la estampa de Van Leyden, arrodillada, con amplios ropajes y con las manos unidas en pose de oración. Esta es la representación habitual de esta escena. Bajo su manto vemos aparecer sus ondulados cabellos, que en el grabado están sueltos. Por otro lado, en la estampa de Durero ${ }^{536}$ de la Vida de la Virgen, los dos coronadores aparecen representados de manera más parecida al relieve, si bien la Virgen no tiene las manos colocadas en posición de oración, sino cruzadas sobre el pecho.

\footnotetext{
${ }^{534}$ Estampa disponible en:

http://www.britishmuseum.org/research/collection_online/collection_object_details.aspx?objectId=13374 50\&partId=1\&searchText=coronation + of + the+virgin\&images $=$ true\&people $=117232 \&$ page $=1$ HOLLSTEIN, F. W. H., The New Hollstein..., Lucas van Leyden, $\mathrm{n}^{\circ}$ 285, pp. 212-213.

${ }^{535}$ PÉREZ DE CASTRO, R., "Coronación de la Virgen”, pp. 519-522.

${ }^{536}$ Estampa disponible en:

http://www.britishmuseum.org/research/collection_online/collection_object_details.aspx?objectId=13394 71\&partId=1\&searchText=coronation+of+the+virgin\&images=true\&people=127877\&page $=1$

BARTSCH, A., op. cit., vol. VII, p. 132; DODGSON, C., Catalogue of Early German and Flemish Woodcuts...., vol. I, $\mathrm{n}^{\mathrm{o}}$ 107, p. 300; MEDER, J., op. cit., $\mathrm{n}^{\circ}$ 206, p. 179; SCHOCH, R., op. cit., vol. II, ${ }^{\circ}$ 184, pp. 274-276.
} 


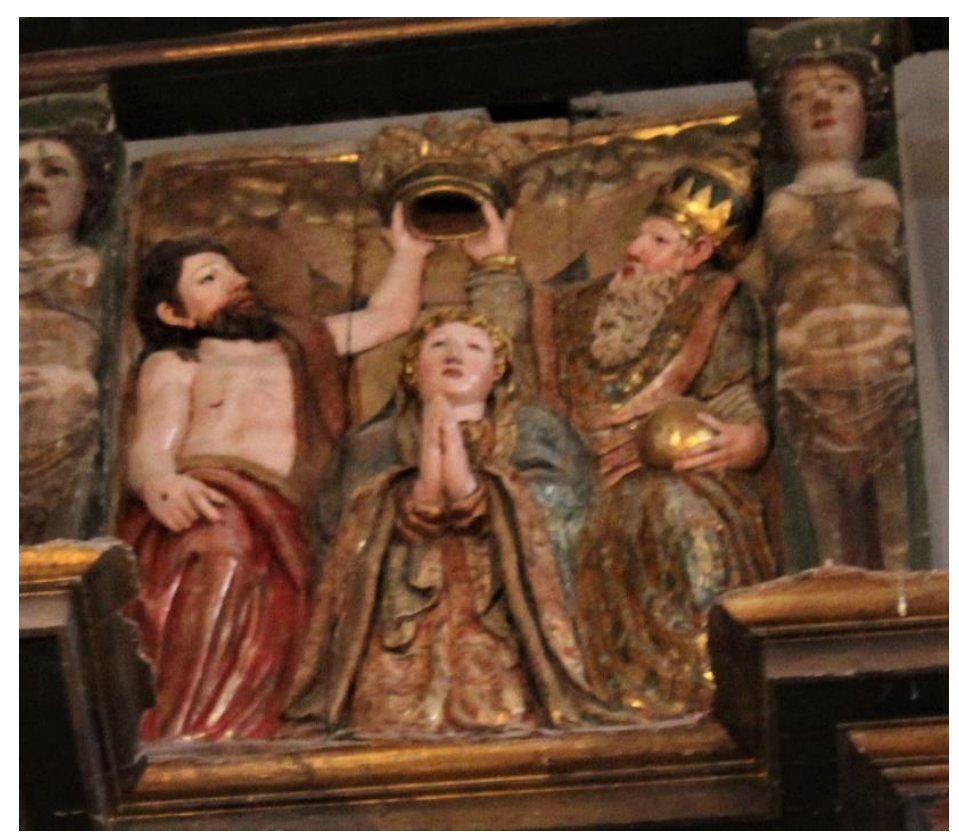

255. Pedro del Cerro. Coronación de la Virgen. Finales del siglo XVI. Retablo mayor. Iglesia de Santa María la Mayor. Pozalmuro (Soria).

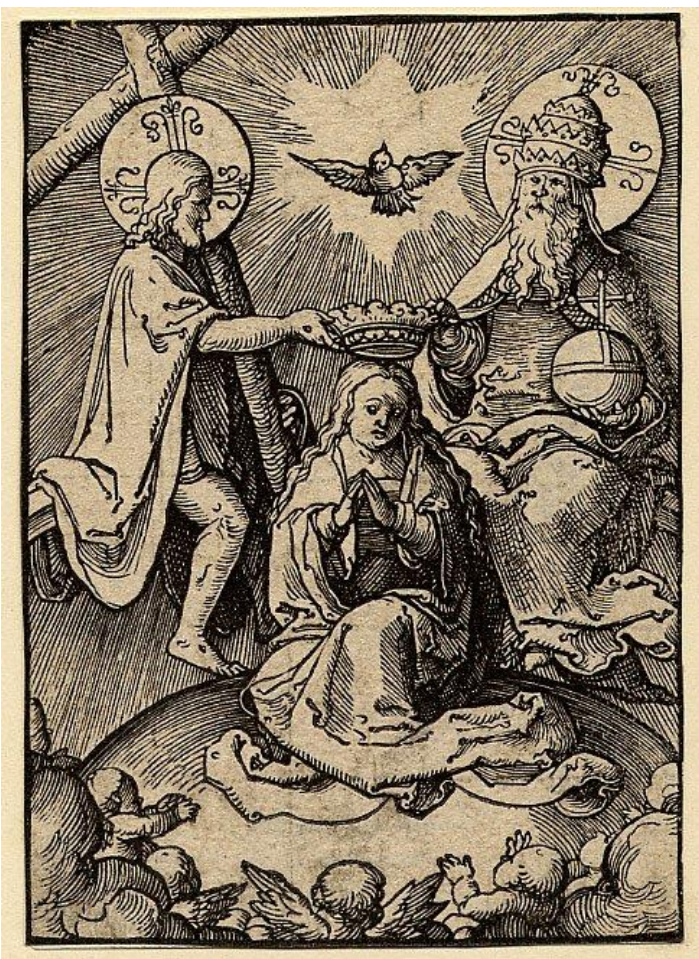

256. Lucas de Leyden.

Coronación de la Virgen. 1520

Museo Británico. Londres (ReinoUnido).

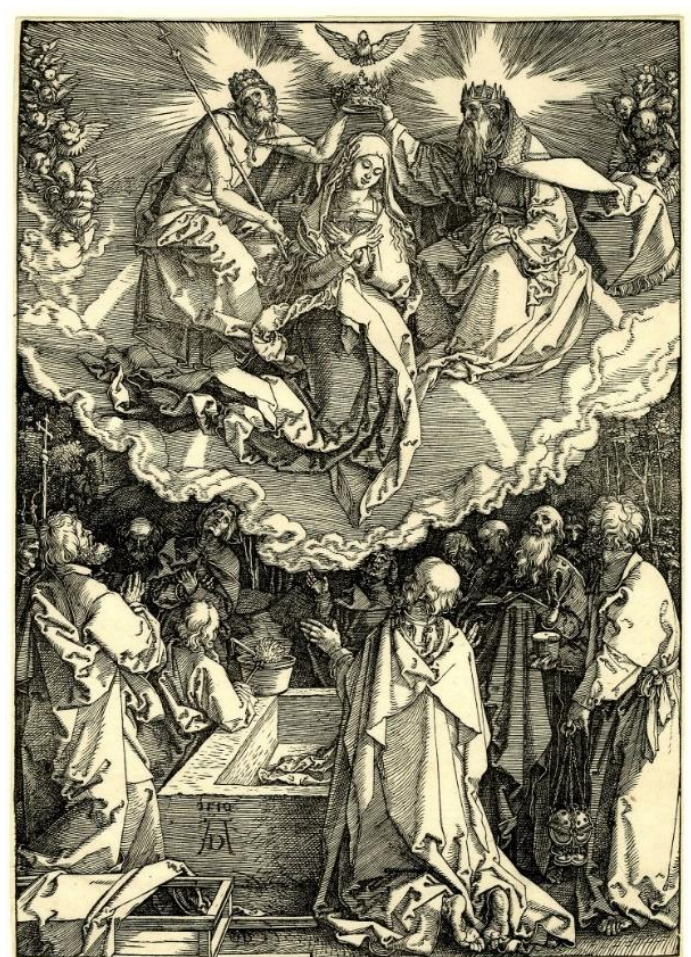

257. Alberto Durero.

Coronación de la Virgen. 1510.

Museo Británico. Londres (ReinoUnido). 


\section{Pedro del Cerro \\ Retablo mayor \\ Hacia 1575 \\ Iglesia de Santa María la Mayor \\ Ólvega (Soria)}

La localidad de Ólvega estaba ubicada en la diócesis de Tarazona durante el Renacimiento. Este retablo se considera anterior al retablo de Pozalmuro, aunque inferior en calidad ${ }^{537}$. Es uno de los retablos de mayores dimensiones de toda la diócesis $^{538}$. La obra parece ser que se realizó en torno a los años 70 del siglo XVI (fig. 258).

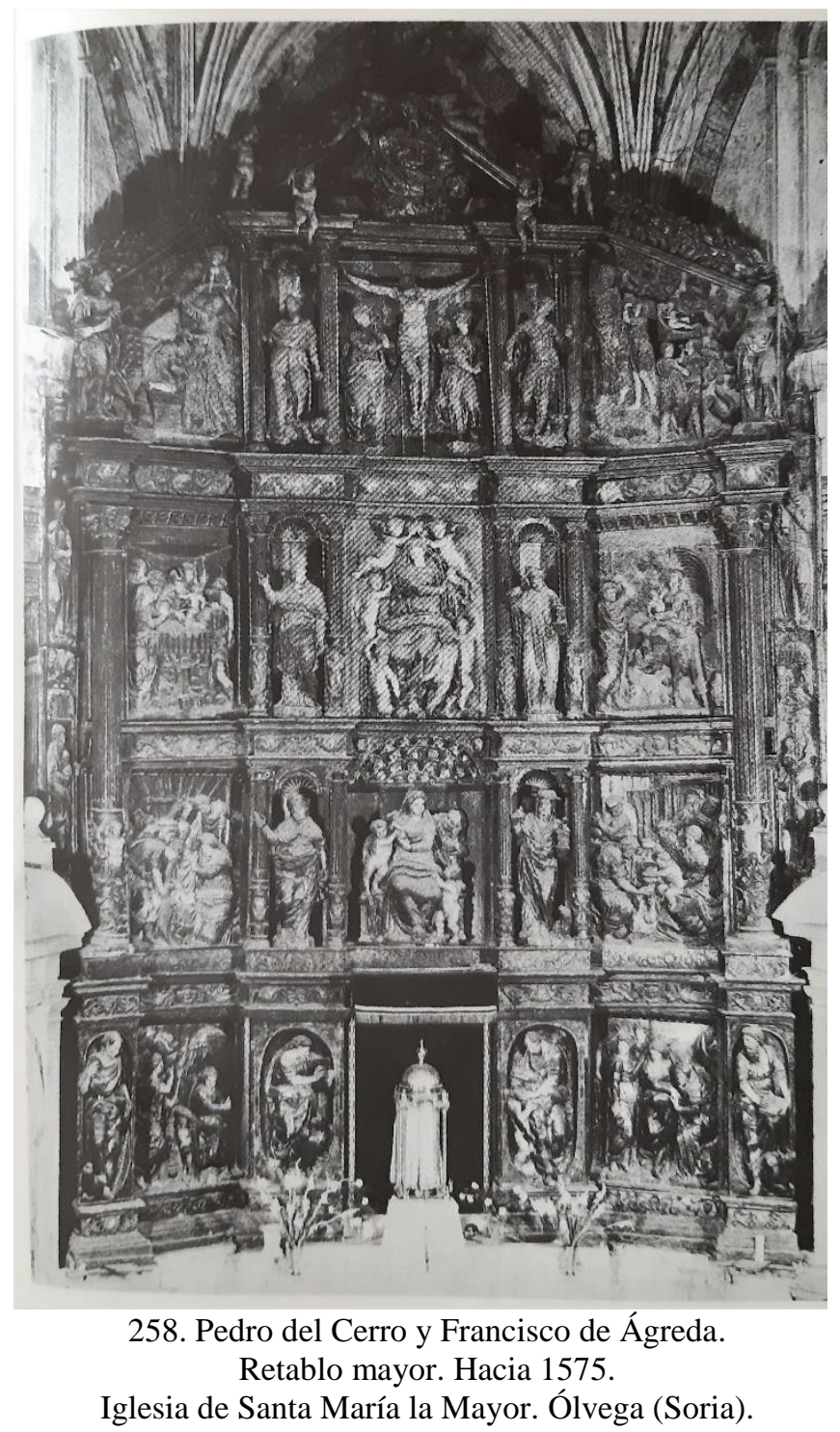

${ }^{537}$ PEÑA GARCÍA, M., Ólvega: historia, arte, folclore, Ólvega: Ayuntamiento, vol. I, 1982, pp. $273-$ 286; ARRANZ ARRANZ, J., La escultura romanista en la diócesis..., pp. 270-271; REDONDO LAGÜERA, J. P., op. cit., p. 115; PÉREZ DE CASTRO, R., "Sacrificio de Isaac", op. cit., pp. 56-57. ${ }^{538}$ Imagen disponible en ARRANZ ARRANZ, J., El Renacimiento en la Diócesis..., p. 640. 


\section{Anunciación}

Para la escena de la Anunciación (fig. 259) de este retablo romanista de finales del Renacimiento es probable que el escultor se basase en la ya citada estampa de Marco de Ravena (fig. 260) ${ }^{539}$, aunque cambiando algunos aspectos de la composición. El atril de la Virgen aparece situado a la izquierda en vez de a la derecha, y ésta muestra una extraña postura aferrándose con el brazo derecho al marco de la escena. Por otro lado, la cama con doseles que aparece al fondo de la escena es idéntica a la del grabado. El ángel es también muy parecido en su pose, aunque mucho más hierático que en la estampa.

El escultor no ha captado la delicadez ni armonía de las figuras del grabado, que aparecen aquí sustituidas por formas de canon mucho más potente y musculoso. El fondo dorado de la composición, sin ningún elemento espacial, contribuye a dar a la misma un carácter arcaico.

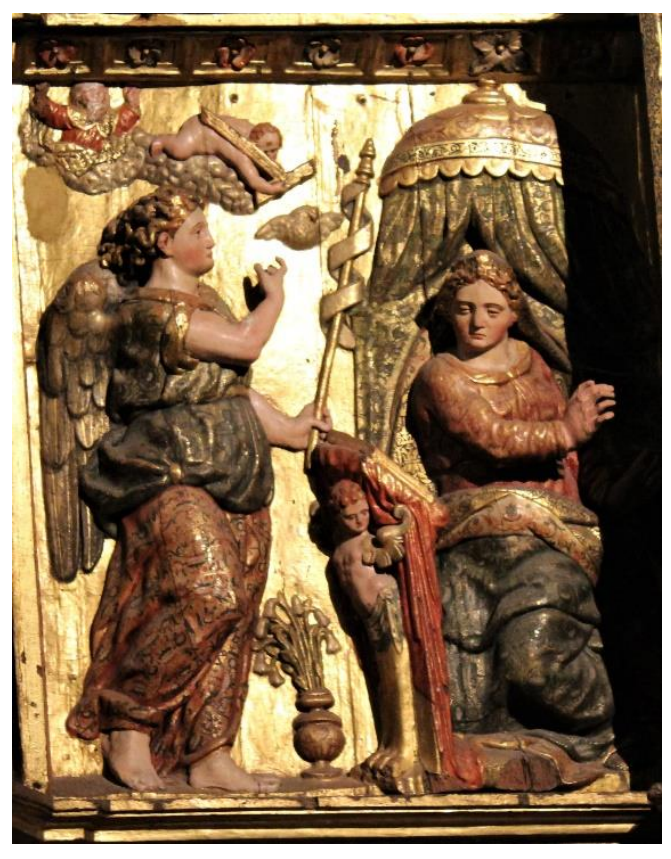

259. Pedro del Cerro. Anunciación. Retablo mayor. Hacia 1575. Iglesia de Santa María la Mayor. Ólvega (Soria).

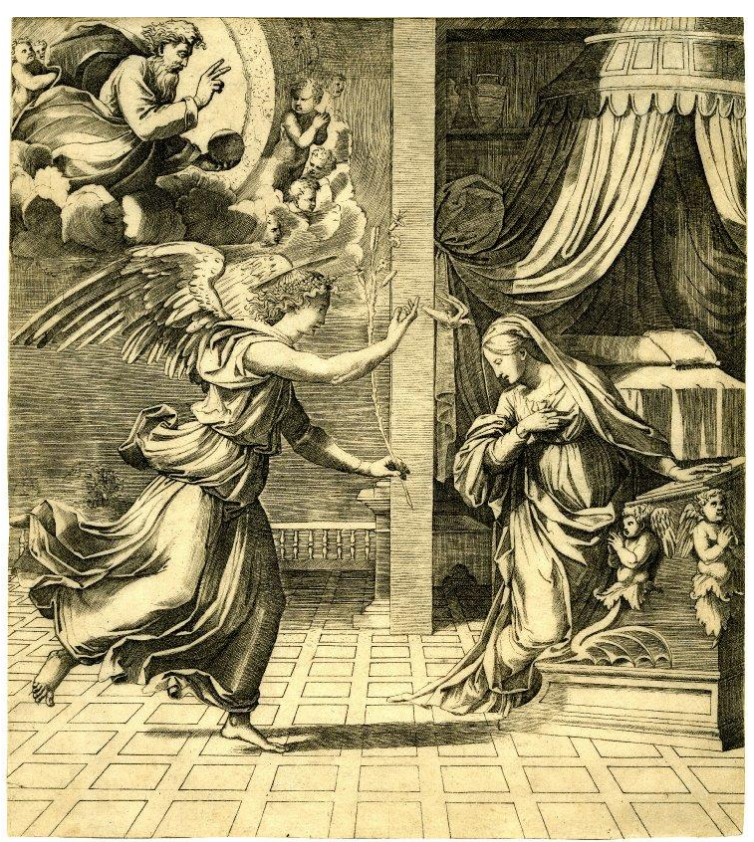

260. Marco de Ravenna. Anunciación. 1519-1517.

Museo Británico. Londres (ReinoUnido).

\footnotetext{
${ }^{539}$ Estampa disponible en:

http://www.britishmuseum.org/research/collection_online/collection_object_details.aspx?objectId=14389 58\&partId=1\&searchText=annunciation\&images $=$ true \&people $=115894 \&$ page $=1$

BARTSCH, A., op. cit., vol. XIV; p. 16.
} 


\section{San Juan Evangelista}

San Juan aparece en esta escena colocado de lado, con el rostro de perfil, situado en el estrecho espacio de la hornacina del retablo (fig. 261). La figura está inspirada en la estampa de Agostino Veneziano del 1518-1520 en el Museo Británico (fig. 262) ${ }^{540}$ con la que comparte la postura del santo de cintura para arriba, con el cuerpo inclinado hacia la derecha; sujeta el libro con la mano izquierda, mientras escribe con la derecha. Sin embargo, la parte inferior de la escena es muy diferente al grabado. En la estampa, San Juan aparece sentado sobre las alas extendidas del águila que parece planear entre un lecho de nubes, mientras que en el retablo San Juan está de pie, aunque con la pierna derecha semiflexionada como ocurre en la estampa, mientras que la izquierda aparece recta. Además, su pie derecho se apoya contra el borde de la hornacina. La figura del águila es mucho más pequeña que en la estampa, y aparece situada a la derecha de la escena, junto a los pies del santo. Debido al estrecho espacio en el que se ubica la figura, ésta no posee la misma complexión anatómica ni gracia que la original de la estampa, ocultándose algunas partes de su anatomía como puedan ser las piernas, que en la estampas se muestran desnudas.

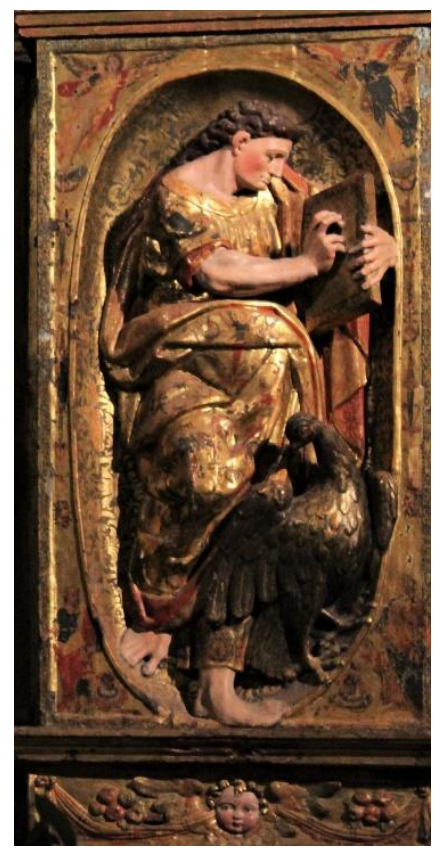

261. Pedro del Cerro. San Juan Evangelista. Hacia 1575. Iglesia de Santa María la Mayor. Ólvega (Soria).

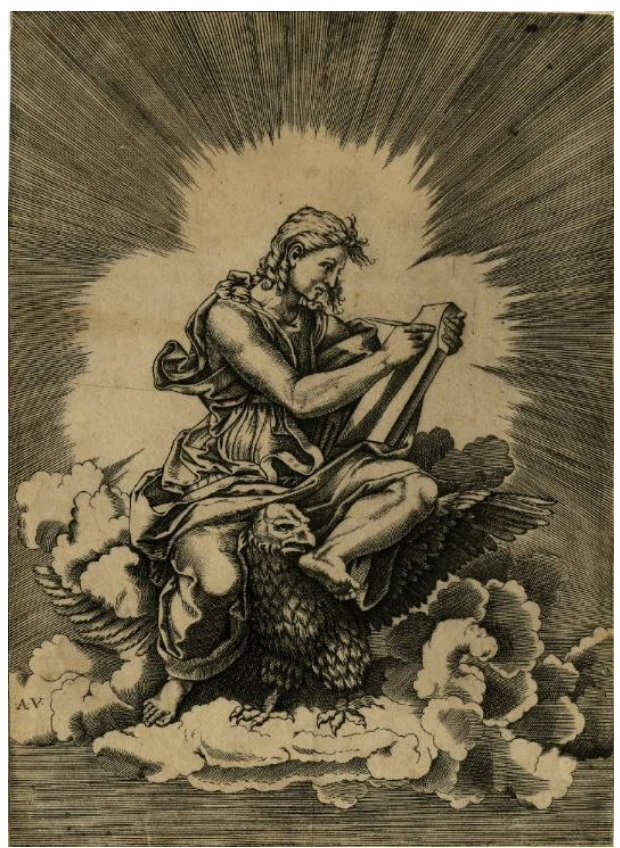

262. Agostino Veneziano.

San Juan Evangelista. 1518-1520. Museo Británico. Londres (ReinoUnido).

${ }^{540}$ Estampa disponible en:

http://www.britishmuseum.org/research/collection_online/collection_object_details.aspx?objectId=15197 02\&partId=1\&searchText=saint+john\&images=true \&people $=134723 \&$ page $=1$

BARTSCH, A., op. cit., vol. XIV, p. 83. 


\section{Gabriel de Pinedo \\ Retablo mayor \\ 1596 \\ Iglesia de Nuestra Señora de la Muela \\ Monteagudo de las Vicarías (Soria)}

Este retablo se halla colocado en el ábside de la iglesia, ocupando toda su altura $\mathrm{y}$ anchura $^{541}$. Está formado por un banco, dos cuerpos, un ático, tres calles y dos entrecalles. Los nichos en que se albergan las figuras son de forma rectangular. Es un retablo de aspecto rico y muy ornamental. Entre los elementos decorativos que se utilizan en el mismo destacan por un lado las columnas corintias de fuste estriado que separan las calles, y los grutescos que decoran los frisos. La traza es la característica de finales del siglo XVI. El uso de los frontones se limita al ático.

En cuanto al programa escultórico se basa en relieves que representan diversas escenas de la Vida de la Virgen. Por un lado, los apóstoles se representan individualmente en vertical, y son figuras llenas de vitalidad y energía, en sintonía con el estilo romanista del momento ${ }^{542}$. Los temas representados en las escenas son: $E l$ abrazo ante la Puerta Dorada, la Visitación, la Coronación de la Virgen, la Natividad de la Virgen, la Ascensión de la Virgen, la Anunciación, la Epifanía, la Presentación de Jesús en el templo, la Adoración de los pastores y el Calvario. Además, entre ellas se distribuyen las figuras de los cuatro evangelistas, así como figuras de las Virtudes y otros santos.

\section{Asunción de la Virgen}

Para la escena de la Asunción de la Virgen (fig. 264), Gabriel de Pinedo se inspiró probablemente en el grabado homónimo de Domenico Campagnola (1517) (fig. $265)^{543}$. En la figura de la Virgen con las manos en posición orante que miran hacia la izquierda mientras el rostro se yergue hacia el cielo implorante. Otra estampa que es aún más parecida es la atribuida a Cesare Vecellio (ca. 1520-1580) (fig. 266) ${ }^{544}$. Además

\footnotetext{
${ }^{541}$ ALCOLEA BLANCH, S., op. cit., p. 118-119; REDONDO LAGÜERA, J. P., op. cit., p. 115.

${ }^{542}$ MARTÍNEZ FRÍAS, J. M., “Gabriel de Pinedo...”, p. 338.

${ }^{543}$ Estampa disponible en:

http://www.britishmuseum.org/research/collection_online/collection_object_details.aspx?objectId=13548 64\&partId=1\&searchText=assumption\&images $=$ on \&page $=1$ BARTSCH, A., op. cit., vol. XIII, p. 381; HIND, A. M., Early Italian engraving..., vol. 5, no 3. I, p. 211. $;{ }^{544}$ Estampa disponible en: http://www.britishmuseum.org/research/collection_online/collection_object_details.aspx?objectId=16372 $\underline{48 \& \text { partId=1\&searchText=assumption\&images }=\text { true \&people }=104408 \& \text { page }=1}$ PASSAVANT, J. D., op. cit., vol. VI, p. 233.
} 
podría haberse inspirado en algunos de los angelitos que ocultan su rostro tímidamente bajo el manto de la Virgen.

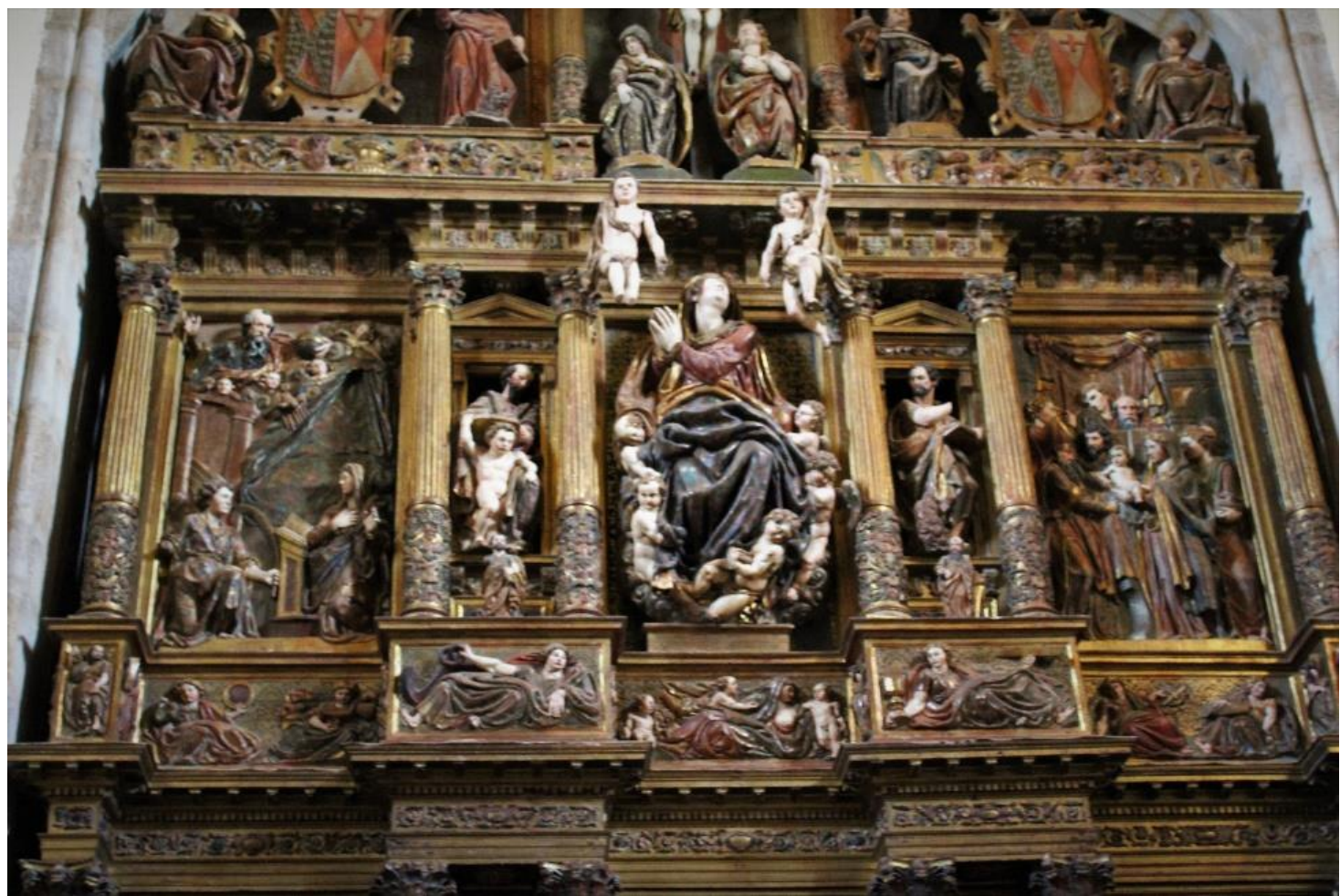

263. Gabriel de Pinedo. 1596.

Detalle del primer cuerpo del retablo mayor. Iglesia de Nuestra Señora de la Muela Monteagudo de las Vicarías (Soria).

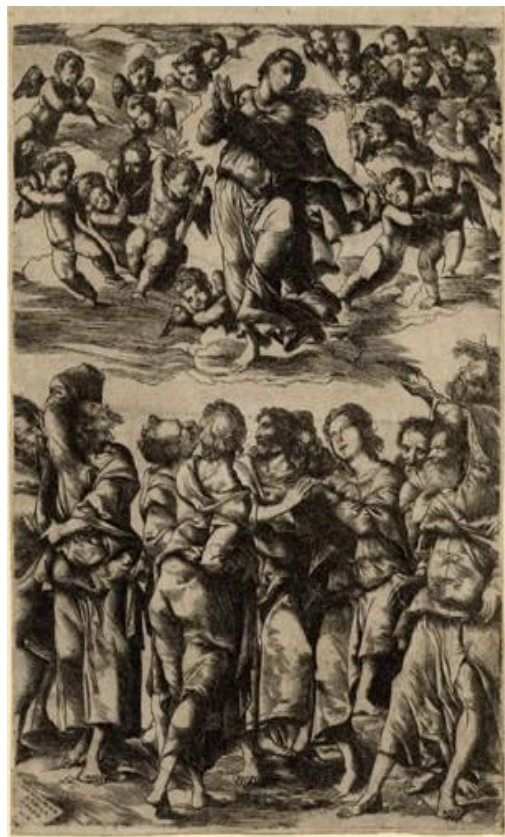

264. Domenico Campagnola. Asunción de la Virgen. 1517. Museo Británico. Londres (Reino Unido).

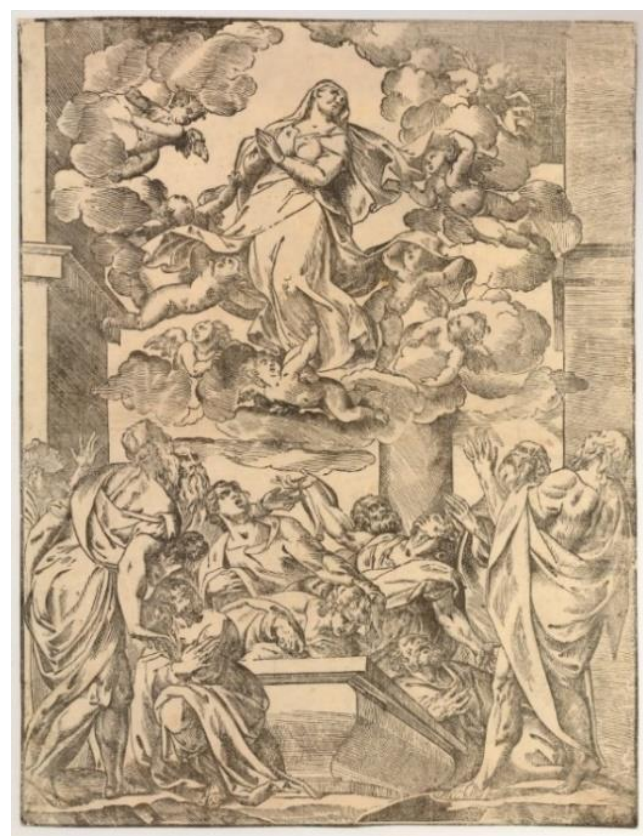

265. Cesare Vecellio. Asunción de la Virgen. Ca. 1520-1580. Museo Británico. Londres (Reino Unido). 


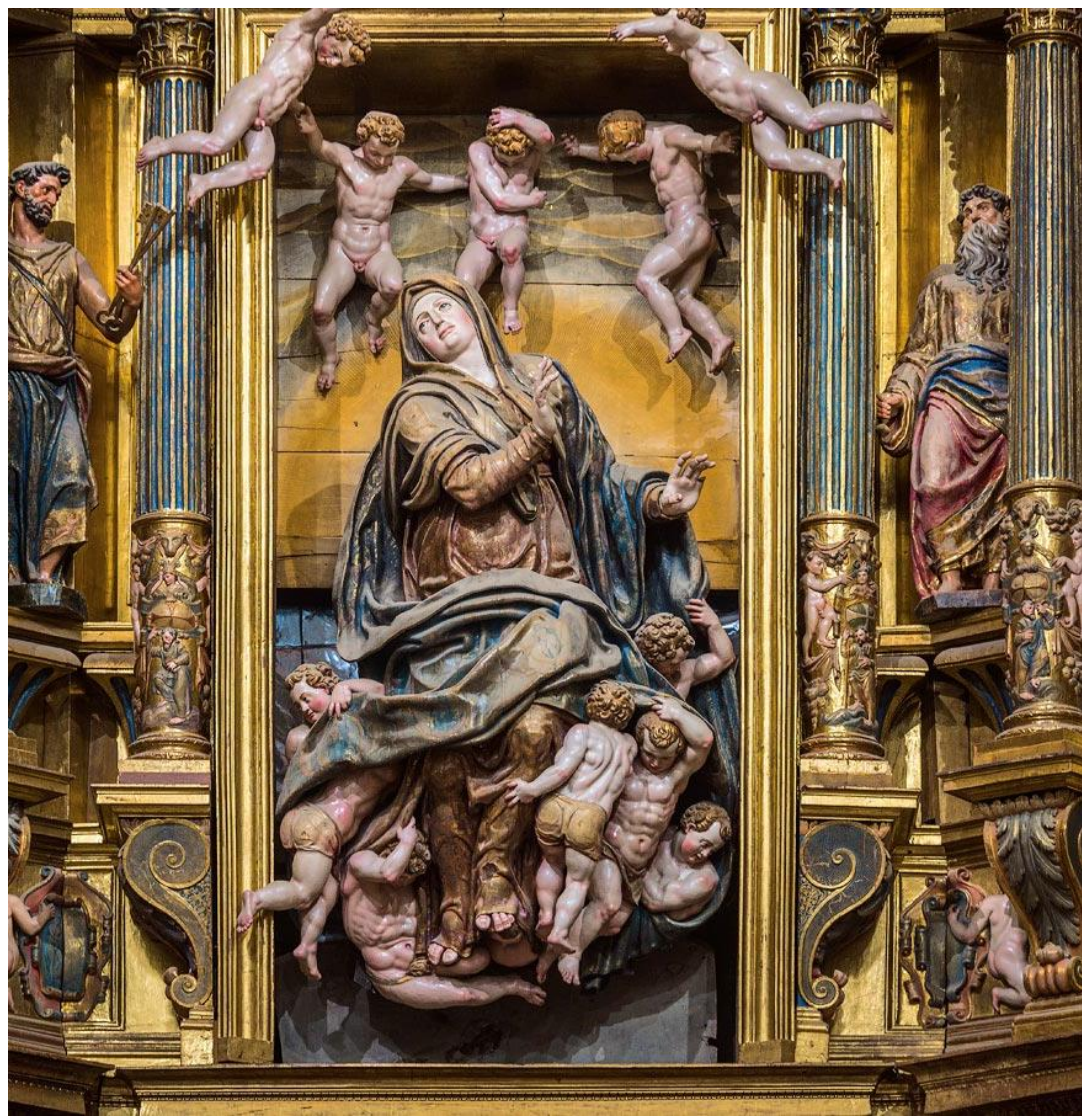

266. Gaspar Becerra. Asunción de la Virgen. Desde 1558.

Retablo mayor.

Catedral. Astorga (León)

Otra fuente importante para la escultura podría haber sido el retablo mayor de la Catedral de Astorga (1559) muy semejante en la forma de representar el espacio y el grupo de ángeles que rodean a la Virgen (fig. 266), si bien la forma de representar sus manos es diversa. La figura de Pinedo resulta menos dinámica y expresiva que la de las de las estampas, debido en especial al hecho de que los cabellos y el manto de la Virgen no ondean.

\section{Bartolomé de Ávila \\ Ecce Homo \\ Ca. 1597 \\ Retablo mayor \\ Iglesia de Nuestra Señora de la Asunción Pinilla del Campo (Soria)}

El retablo está formado por dos cuerpos con tres calles separadas columnas corintias estriadas y un banco (fig. 267) ${ }^{545}$. En el primer cuerpo se encuentran las escenas de la Adoración de los magos, la Huida a Egipto y un altorrelieve de la

\footnotetext{
${ }^{545}$ ARRANZ ARRANZ, J., "Renacimiento y Barroco", p. 425. MANRIQUE MAYOR, M. A., op. cit., pp. 69-70.
} 
Asunción de la Virgen. En el segundo las pinturas de Anunciación, la Adoración de los pastores y el un relieve Calvario. Entre dichas escenas aparecen las figuras de los cuatro evangelistas. El retablo se remata con un frontón curvo. En el banco además aparecen las escenas de la Última Cena, la Oración en el Huerto, la Flagelación y el Camino del Calvario.

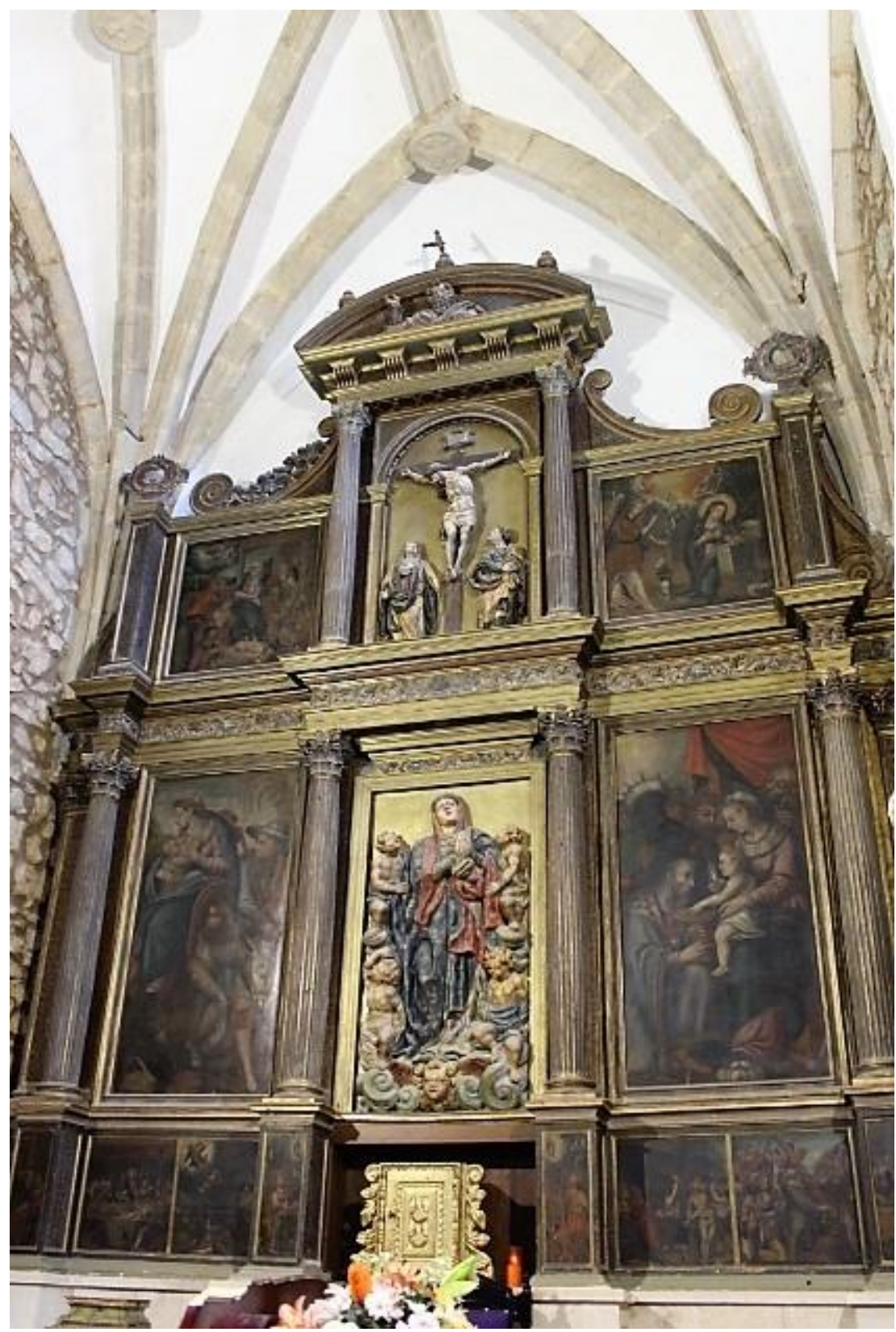

267. Bartolomé de Ávila. Retablo mayor. Iglesia de Nuestra Señora de la Asunción. 1597. Pinilla del Campo (Soria). 


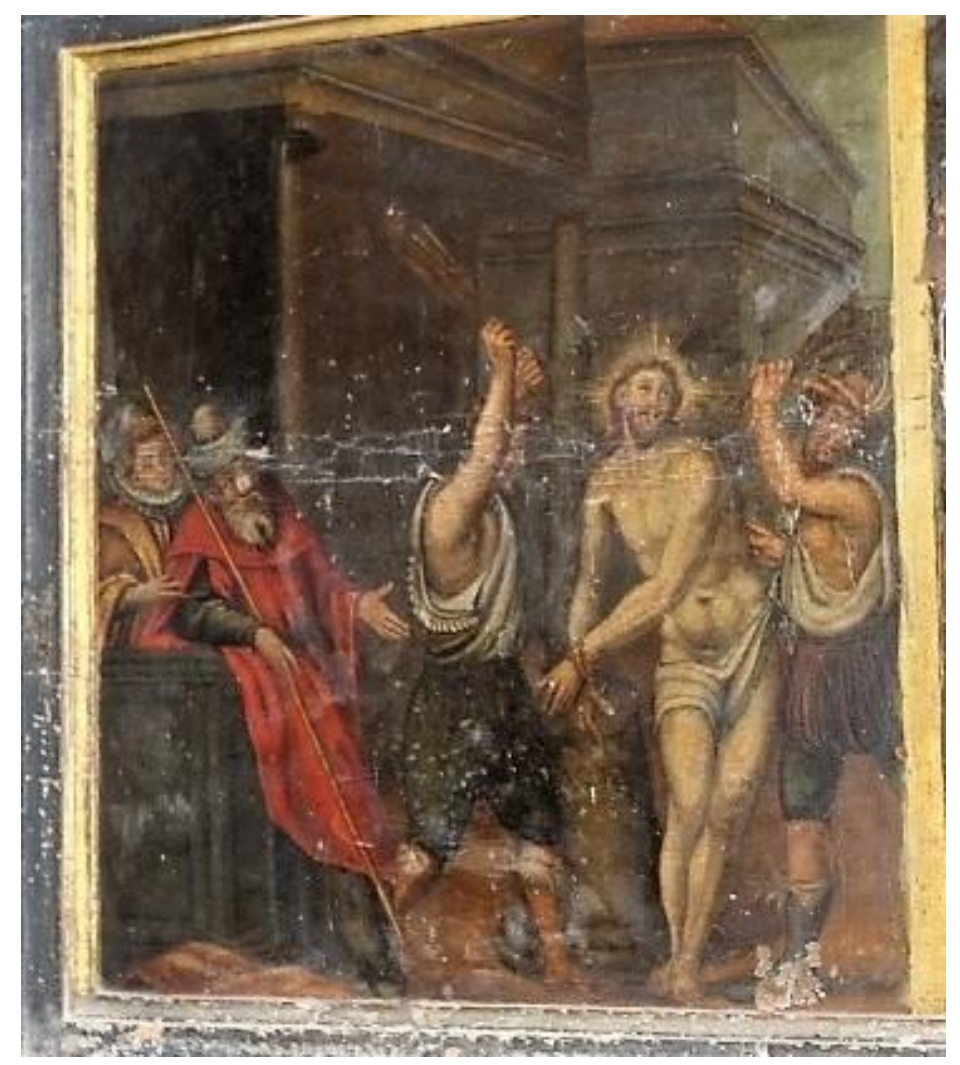

268. Bartolomé de Ávila. La Flagelación. 1597. Retablo mayor. Iglesia de Pinilla del Campo (Soria).

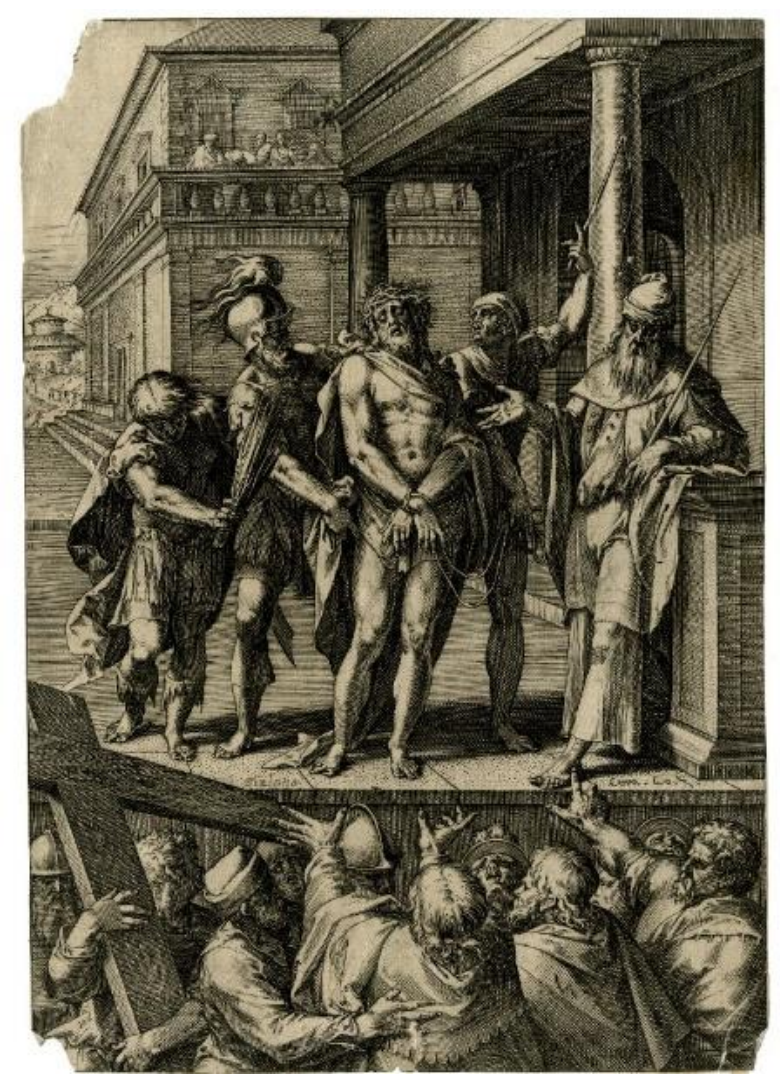

269. Cornelis Cort (a partir de Etienne Dupérac). Ecce Homo. 1572. Museo Británico. Londres (Reino Unido). 
Para esta escena del banco del retablo mayor de la parroquia de Pinilla del Campo (fig. 268), Bartolomé de Ávila se inspiró en la estampa del mismo tema de Cornelis Cort (fig. 269) ${ }^{546}$. Se basó especialmente en la figura de Pilatos, que, situado en la zona izquierda de la composición, señala con su mano izquierda a Cristo, mientras que con la derecha sujeta su bastón. Las vestimentas del personaje son así mismo idénticas a las del grabado (la túnica que cubre su cuerpo y su curioso sombrero). Además, Ávila ha copiado la estructura y las formas de los dos edificios palaciegos situados a la izquierda, detrás de Pilatos: el pórtico con columnas debajo del cual se cobija el gobernador romano, y el edificio situado un poco más adelante, y que tiene una especie de balcón en la zona superior.

El pintor, no parece haberse inspirado, sin embargo, en las figuras de Cristo y de los dos sayones que lo acompañan ${ }^{547}$. Es interesante el afán de Ávila por crear un espacio semejante al de la estampa con el fin de lograr cierta perspectiva. Por otro lado, la figura de Pilatos resulta mucho más achatada y sencilla que la de la estampa, hecho debido también a que el pintor la ha situado sentada.

\section{Anónimo \\ Retablo de la Anunciación \\ Finales del siglo XVI \\ Iglesia de San Pedro Apóstol \\ Las Cuevas de Soria.}

En la cartela neoclásica dorada podemos leer "este cuadro dio Lope de Morales del Espino año de 1527. Hizo el retablo la Iglesia año de 1759",548. En realidad, el cuadro no pudo ser donado en esta fecha ya que la pintura se inspira en modelos mucho más tardíos. No existen noticias al respecto del cuadro en los libros de fábrica. Sólo se hace referencia a la construcción de un nuevo retablo y al dorado de la tarjeta en el libro de fábrica de la data de $1760^{549}$.

Lope de Morales (? -1643) era un noble soriano perteneciente al linaje de los Morales, uno de los linajes troncales de Soria. Nació en las Cuevas de Soria y fue

\footnotetext{
${ }^{546}$ Estampa disponible en:

http://www.britishmuseum.org/research/collection_online/collection_object_details.aspx?objectId=30290 06\&partId $=1 \&$ searchText=ecce + homo\&images $=$ true \&people $=128446 \&$ page $=1$

BIERENS DE HAAN, J. C. J., L'ouvre gravé..., no 82, pp. 94-95; HOLLSTEIN, F. W. H., The New Hollstein..., Cornelis Cort part 1, $\mathrm{n}^{\mathrm{O}}$ 60, pp. 206-209.

${ }^{547}$ PÉREZ DE GRACIA RODRÍGUEZ, M. V., op. cit., pp. 49-50.

${ }^{548}$ ARRANZ ARRANZ, J. M., El Renacimiento en la Diócesis..., p. 364; BRASAS EGIDO, J. C., "La pintura en la diócesis...", pp. 193-194.

${ }_{549}$ AHDOS, Libro carta-cuenta, cuentas de los años 1729 a 1898, Signatura actual 1072, Signatura antigua 258/12, Descargos 21 de junio de 1760.
} 
procurador por Soria en la Cortes de 1614, así como oidor del Consejo de Navarra y finalmente fue promovido a la Cancillería de Valladolid y a la Fiscalía del Consejo de las Órdenes con el hábito de Santiago, trasladándose poco después al consejo de Castilla $^{550}$.

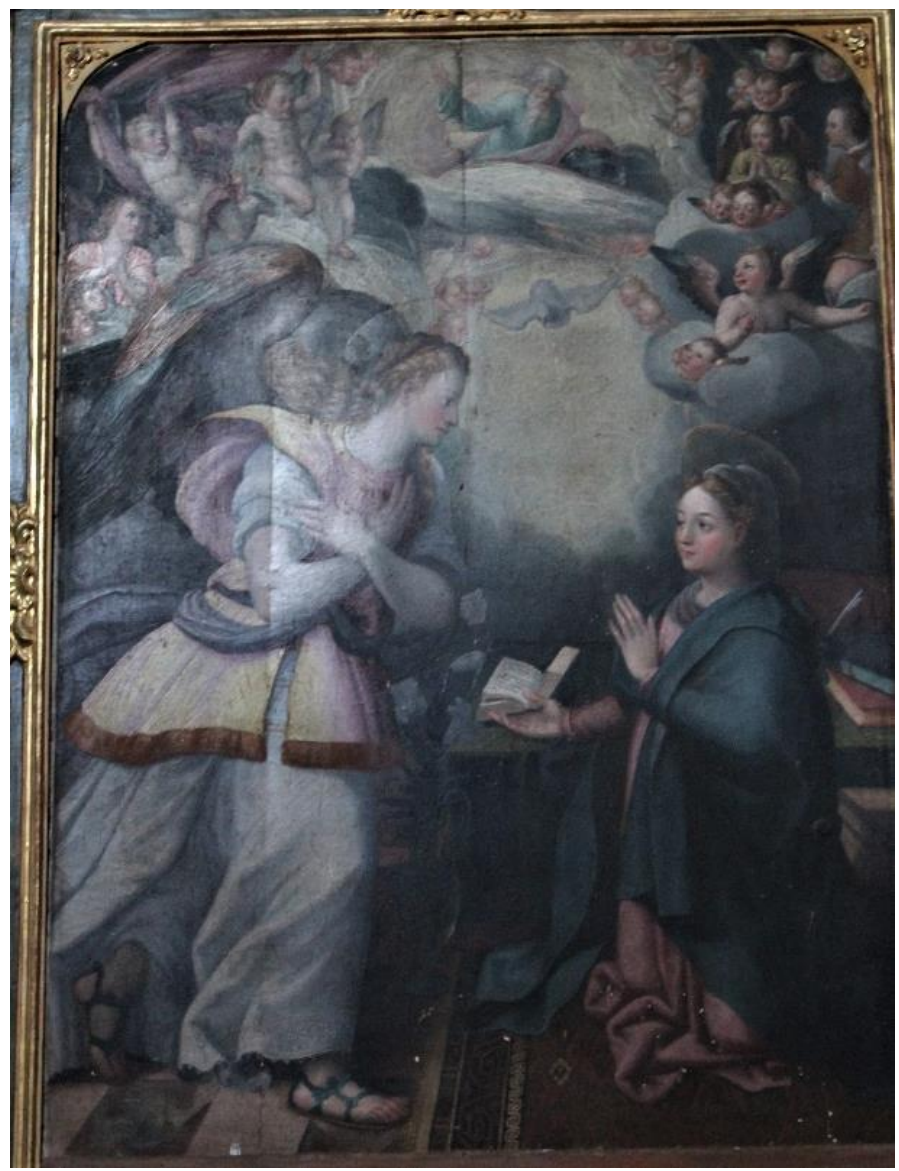

270. Anónimo. Anunciación. Finales del siglo XVI.

Iglesia de San Pedro Apóstol. Las Cuevas de Soria.

De en torno al último decenio del siglo XVI podemos considerar esta pintura de la Anunciación de las Cuevas de Soria, que sigue el estilo de la Bella Maniera italiana y se inspiró en dos estampas italianas (fig. 270) La primera es una estampa de Federico Barocci (1584) (fig. 271) ${ }^{551}$ de la cual toma la postura y la posición de las manos de la Virgen María, con la izquierda levantada y la otra apoyada en la mesa junto a un libro

\footnotetext{
${ }^{550}$ LOPE DE MORALES "Adiciones y nuevas advertencias para más inteligencia y claridad de estos discursos", en Relación del material del legado de Florentino Zamora depositado en la Biblioteca pública de Soria, inédito.

${ }_{551}$ Estampa disponible en:

http://www.britishmuseum.org/research/collection_online/collection_object_details.aspx?objectId=14530 28\&partId $=1 \&$ searchText $=$ annunciation\&images $=$ true \&people $=133291$ \&page $=1$

BARTSCH, A., op. cit., vol. XVII, p. 2.
} 
abierto, también el manto de la Virgen y el estudio de los pliegues de las vestimentas de la Virgen son muy semejantes.

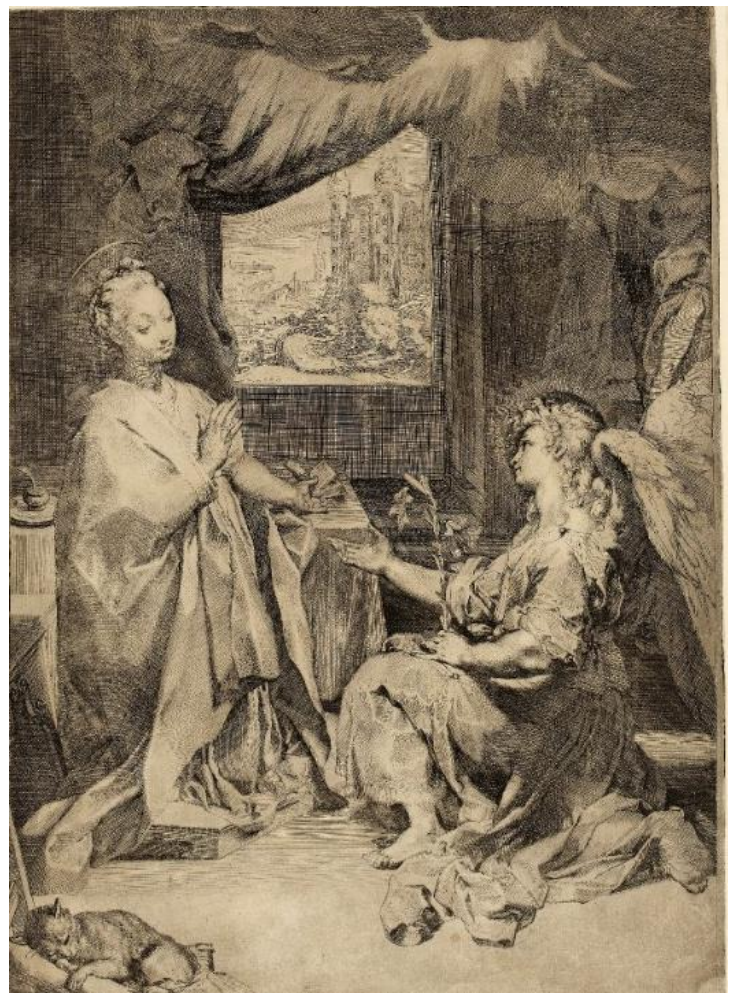

271. Federico Barocci. Anunciación. Ca. 1584. Museo Británico. Londres (Reino Unido).

Sin embargo, para la imagen del ángel se basó en otra estampa de otro maestro italiano anónimo, que copiaba una pintura de Tiziano (fig. 272) ${ }^{552}$, en la cual aparece el ángel entrando por la izquierda con las manos cruzadas sobre el pecho. El pintor ha copiado la colocación de los brazos y de las piernas. La figura entra con el pie derecho, mientras que el izquierdo está levantado en el aire. En la parte superior izquierda del cuadro podemos observar que el pintor también copió las figuras de dos angelitos que aparecen volando de la estampa, uno de los cuales aparece sujetando una especie de paño con las dos manos. En conjunto la escena parece más similar a la de Tiziano, ya que no muestra interés por el tema de la perspectiva, como es el caso de la estampa de Barocci, en la cual vemos una ventana por la que se observa un paisaje.

Cortes Arrese ${ }^{553}$ considera que la pintura está vinculada a modelos italianos como Miguel Ángel (monumentalidad de las figuras) o Rafael (delicadeza de manos y rostros). Además, resalta el carácter contrarreformista de la obra, en la cual se destaca especialmente el papel intermediador de María. Por otro lado, vincula la obra al círculo

\footnotetext{
${ }^{552}$ Biblioteca Nacional. Signatura, INVENT/5078, aguafuerte

553 CORTÉS ARRESE, M., "Pintura de la Anunciación", en Las Edades del Hombre. El arte de la iglesia de Castilla y León, Fundación las Edades del Hombre, 1988, n 144, pp. 248-249.
} 
artístico de Alonso Berruguete. También podría vincularse con la obra del pintor Gregorio Martínez con la que comparte algunas similitudes ${ }^{554}$.

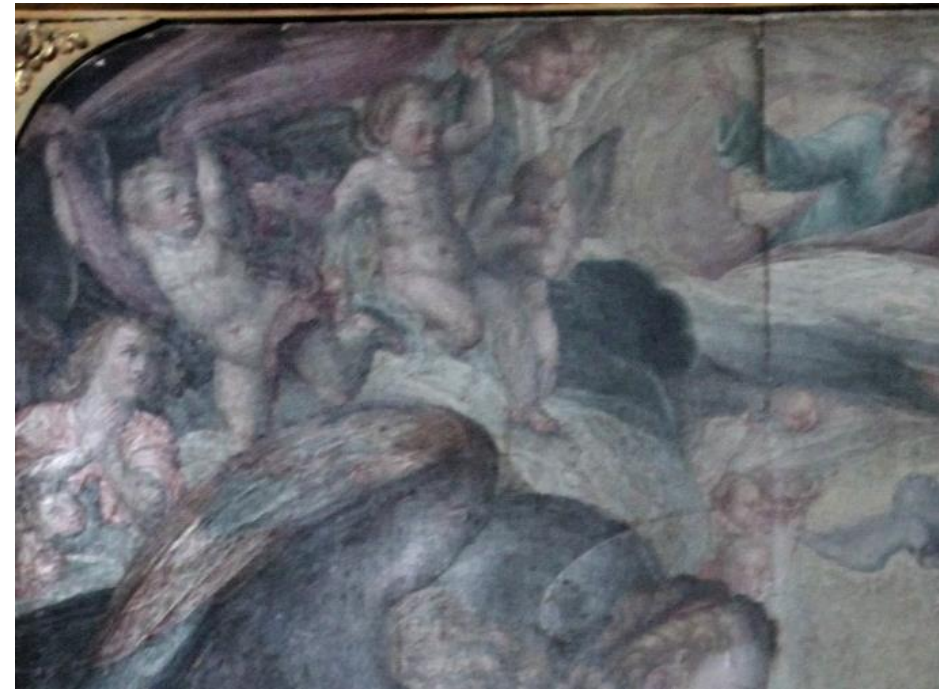

272. Detalle de la fig. 270.

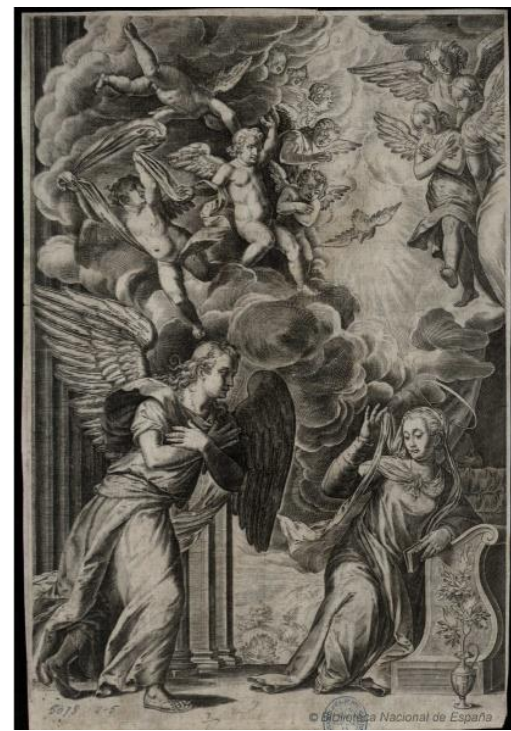

273. Anónimo italiano. Anunciación. 1570-1600. Biblioteca Nacional. Madrid.

\section{Juan Sanz y Juan de Orihuela \\ Retablo mayor \\ Finales del siglo XVI \\ Iglesia de de Santa María de Calatañazor. \\ Almazán (Soria)}

La advocación de esta iglesia responde a la población procedente de Calatañazor que repobló Almazán durante el reinado de Alfonso VII ${ }^{555}$. Hay constancia de su existencia desde principios del siglo XIV. La iglesia pertenecía a la Diócesis de Sigüenza. El templo fue reconstruido en varias ocasiones desde finales del siglo XVI y hasta el siglo XIX, habiendo perdido por el camino gran parte de su carácter románico original. Está situado en el ábside gótico.

Este retablo es considerado uno de los últimos retablos de talla del siglo XVI; su estilo enlaza con el siglo XVII (fig. 274). Se lo puede considerar como tardorromanista

\footnotetext{
${ }^{554}$ COLLAR DE CÁCERES, F., "El tríptico de Leoni...,", pp. 183-207.

${ }^{555}$ DEL HUERTO, J. y FRÍAS, T., Guía de Almazán, Artes Gráficas Egido, Almazán (Soria), 1991, pp. 26-28; REDONDO LAGÜERA, J. P., op. cit., p. 113; ECHEVERRÍA GOÑI, P. L Y VÉLEZ CHAURRI, J. J., "Santa Cecilia" y "San Mateo", en Paisaje interior. Las Edades del Hombre, Soria, 2009, Valladolid, Fundación Las Edades del Hombre, 2009, no 188 y 233, pp. 310-311, 359-360; PARRADO DEL OLMO, J. M., “Ángel recogiendo la sangre del cordero", en Eucharistia. Las Edades del Hombre, Fundación de Las Edades del Hombre, 2014, n 50, p. 242.
} 
y deudor de la obra de otros escultores como Gabriel de Pinedo o Pedro de Monje ${ }^{556}$. Es uno de los de mayores dimensiones de toda la Diòcesis. Tiene forma de medio hexágono, y está formado por un banco, dos cuerpos con cinco calles y un ático con tres. Las esculturas del retablo están todas realizadas en relieve, excepto las tallas de San Pedro y San Pablo que son exentas. Las escenas corresponden a la infancia y Pasión de Cristo junto a varias figuras de santos y virtudes. En el banco, y de izquierda a derecha, podemos observar la Fortaleza, la Oración del Huerto, San Miguel y la Justicia, la Flagelación, San Sebastián y la Caridad, la Magdalena, San Pedro y San Pablo, la Adoración de los Reyes, San Mateo y San Miguel, el Nacimiento, la Justicia con Santo Domingo de Guzmán, la Coronación de Espinas, Santa Bárbara con el ángel de la Anunciación, Jesús Camino del Calvario y la Esperanza.

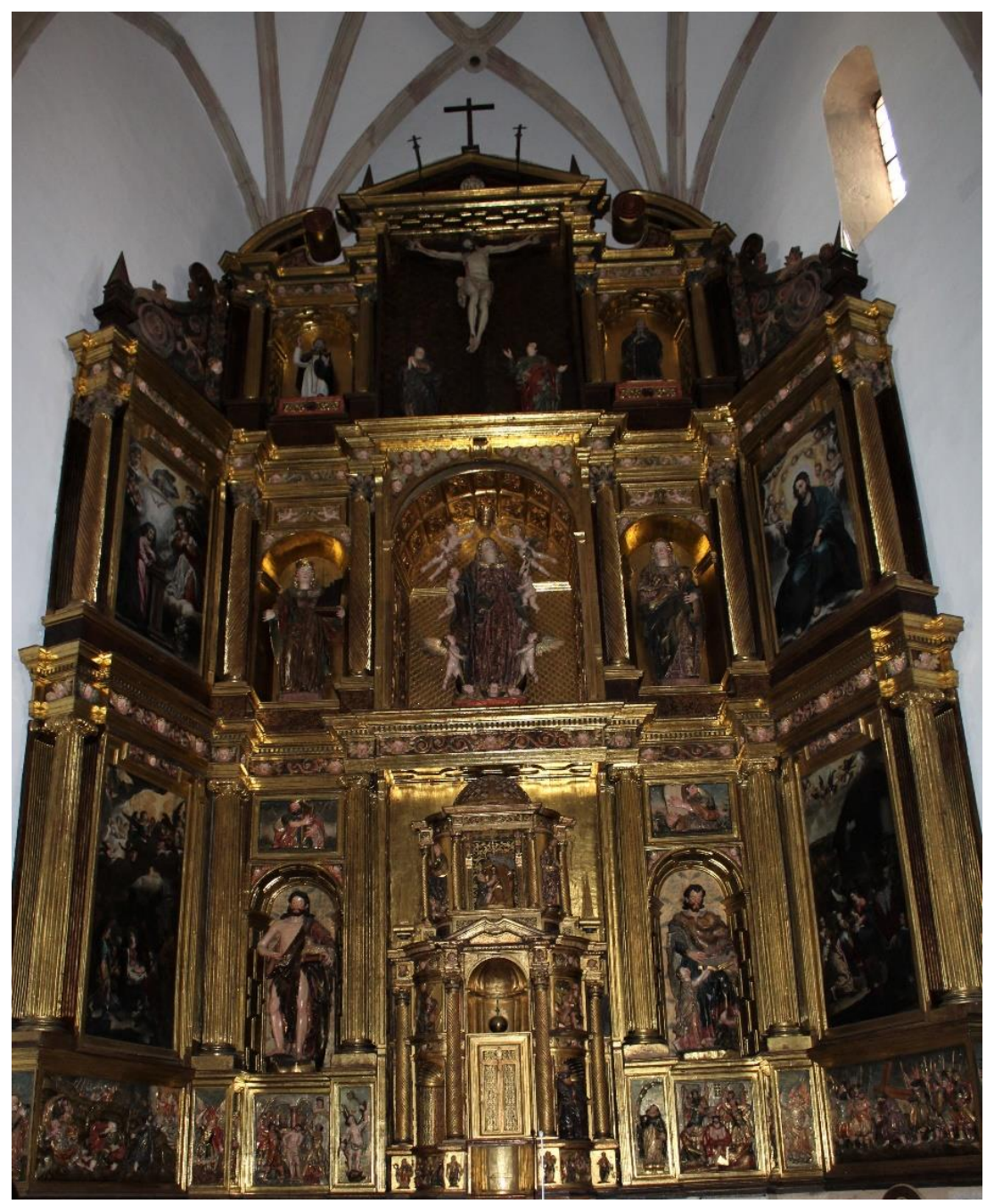

274.Juan Sanz y Juan de Orihuela. Retablo mayor. Finales del siglo XVI. Iglesia de Santa María de Calatañazor. Almazán (Soria).

${ }^{556}$ ECHEVERRÍA GOÑI, P. L Y VÉLEZ CHAURRI, J. J., “Santa Cecilia”, p. 310. 
En el primer cuerpo se localizan las representaciones de David, Moisés, el Cordero y Santa Lucía y en los extremos laterales San Juan Bautista y San Mateo. En el segundo cuerpo está ocupado por Santa Cecilia, la Coronación de la Virgen y Santa Lucía; en el ático se sitúan Santo Domingo, el Calvario y San Francisco.

\section{San Sebastián}

Para este relieve que representa el martirio de San Sebastián (fig. 275) el escultor podría haberse inspirado en el grabado homónimo (fig. 276) de Ludwig Krug $(1510-1532)^{557}$ con el que comparte la misma postura de los brazos y las piernas, si bien plasmadas de manera más torpe en el relieve y de forma invertida.

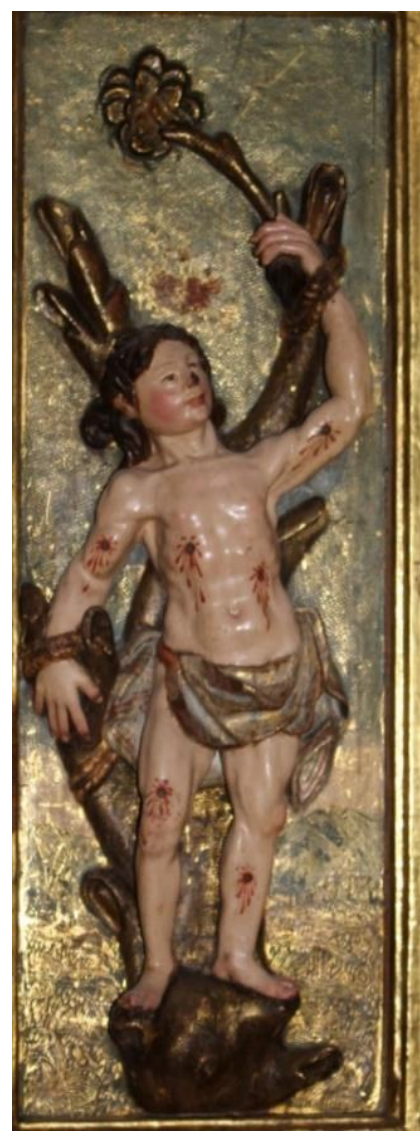

275. Juan Sanz. Martirio de San Sebastián. Finales del siglo XVI. Iglesia de Nuestra Señora de Calatañazor. Almazán (Soria).

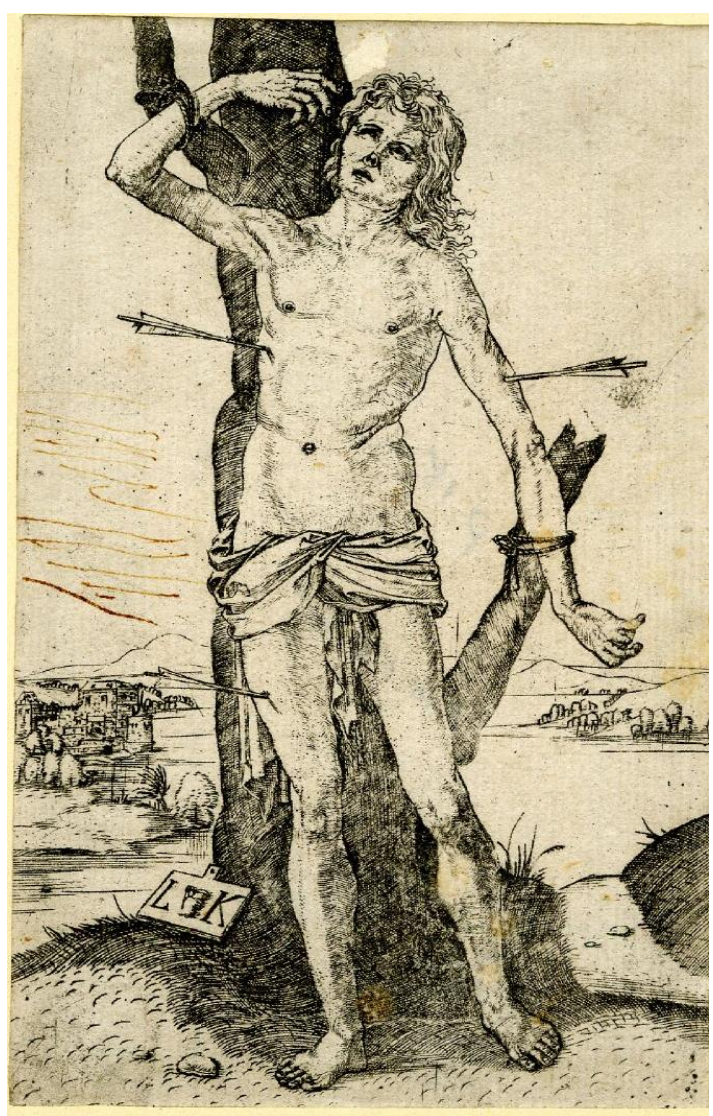

276. Ludwig Krug. Martirio de San Sebastián. 1510-1532. Museo Británico. Londres (Reino Unido).

${ }^{557}$ Estampa disponible en:

http://www.britishmuseum.org/research/collection_online/collection_object_details.aspx?objectId=14465 96\&partId=1\&searchText=saint+sebastian\&images=true \&people $=118575 \&$ page $=1$

Bibliografía: HOLLSTEIN, F. W. H., German engravings ..., $\mathrm{n}^{\circ}$ 15, p. 15. 
La misma anatomía angulosa marca el cuerpo delicado y fibroso del joven San Sebastián. El brazo izquierdo se alza, doblado por el codo a la altura de la cabeza. El derecho reposa más comodamente sobre el tronco del árbol en la escultura que en la estampa, donde aparece ligeramente girado.

Un detalle importante son las cuerdas que atan sus brazos al tronco y las ramas del árbol, que muestran un gran parecido con el grabado (figs. 277, 278, 279 y 280). El escultor ha omitido todo detalle del fondo, limitándolo a un tono azul pálido mientras que en la estampa está ocupado por un paisaje montañoso, así como una especie de lago o río. En el relieve se observan seis heridas que San Sebastián habría recibido, aunque sin mostrar las flechas, mientras que el grabado se ven tres con sus correspondientes flechas.

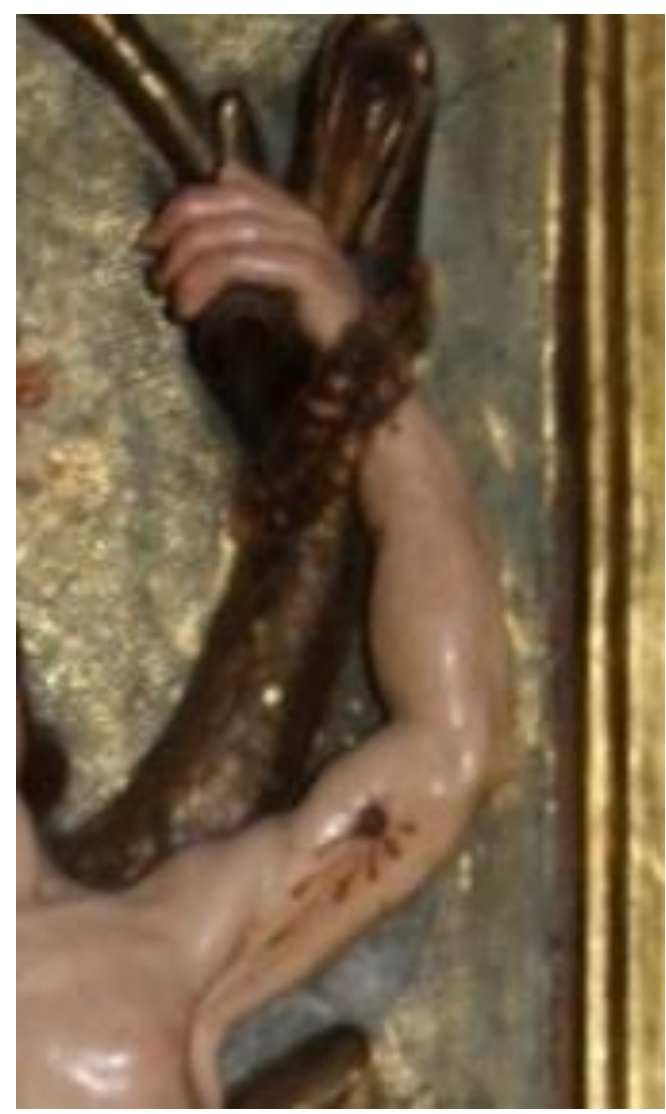

277. Detalle de la fig. 275.

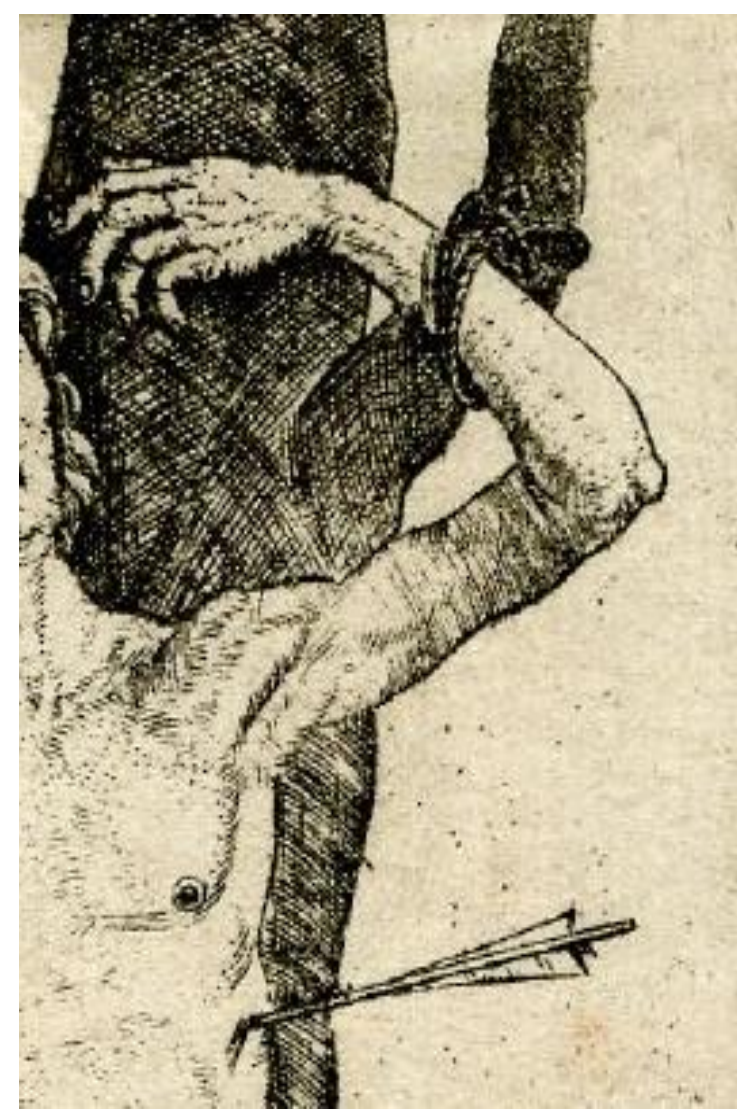

278. Detalle de la fig. 276. 


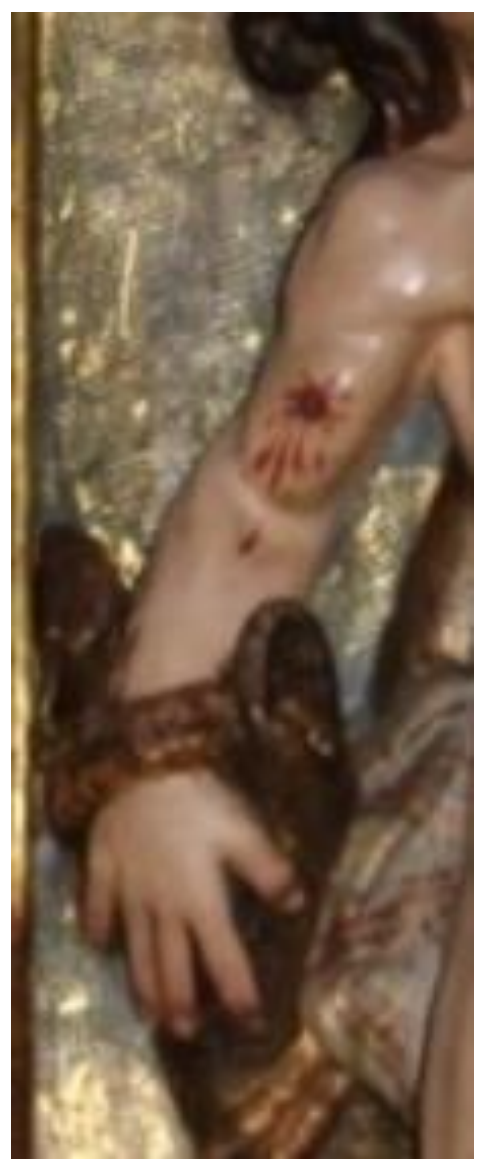

279. Detalle de la fig. 275.

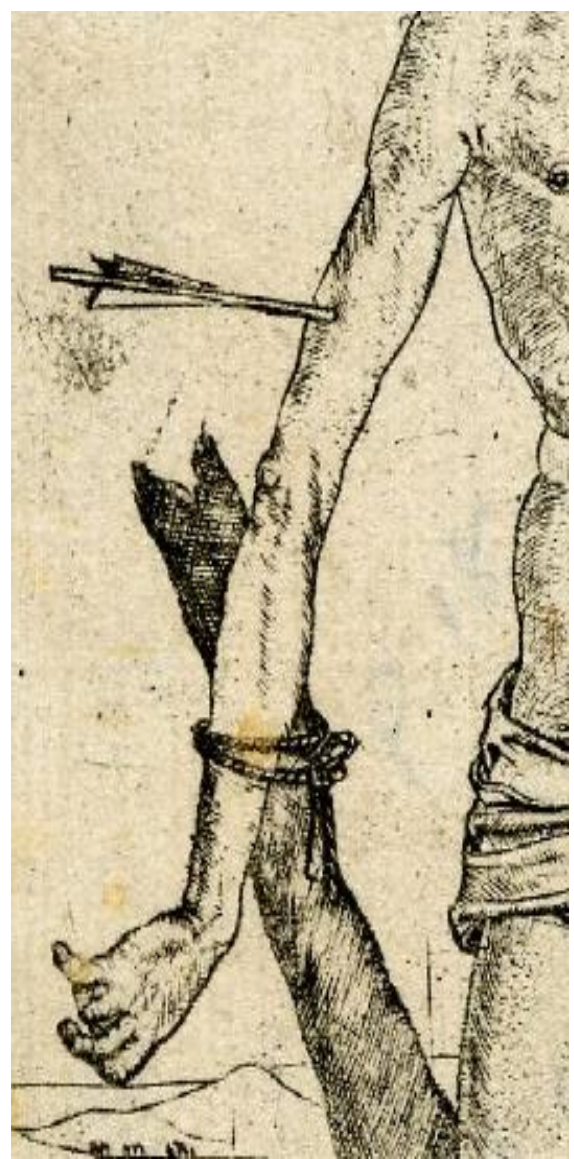

280. Detalle de la fig. 276.

\section{San Miguel}

En el relieve de San Miguel venciendo al demonio (fig. 281) el escultor podría haberse inspirado en el grabado del mismo tema de Jacopo Caraglio (1520-1560) (fig. $282)^{558}$. Ambos lucen la misma posición con el brazo derecho, que alza la espada sobre su cabeza en posición de ataque. Sin embargo, el izquierdo sujeta otra espada en la estampa y se apoya en una especie de garrote en el relieve. La postura de sus piernas también es similar, así como la vestimenta de San Miguel:indumentaria de soldado romano con coraza, botas y piernas desnudas.

El escultor ha simplificado las figuras, tanto la de San Miguel como la del demonio, el cual en la estampa adquiere una postura mucho más dinámica y compleja que en el relieve.

\footnotetext{
${ }^{558}$ Estampa disponible: https://research.britishmuseum.org/research/collection_online/collection_object_details.aspx?objectId=16 45924\&partId=1\&searchText=caraglio + saint + michael\&page $=1$
} 


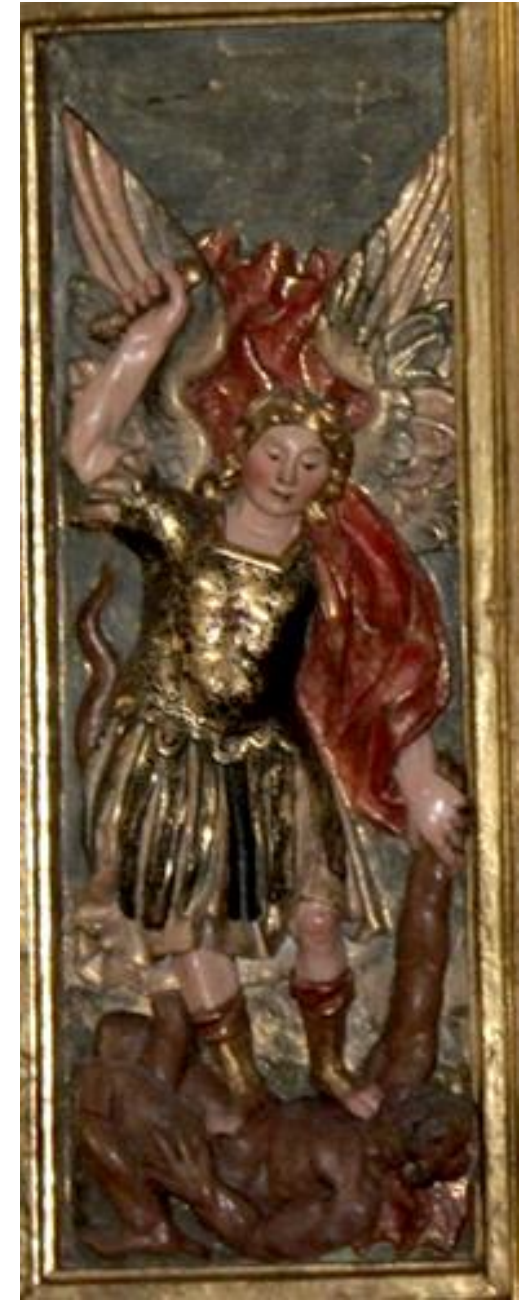

281. Juan Sanz, San Miguel venciendo a los demonios. Finales del siglo XVI Iglesia de Nuestra Señora de Calatañazor. Almazán (Soria).

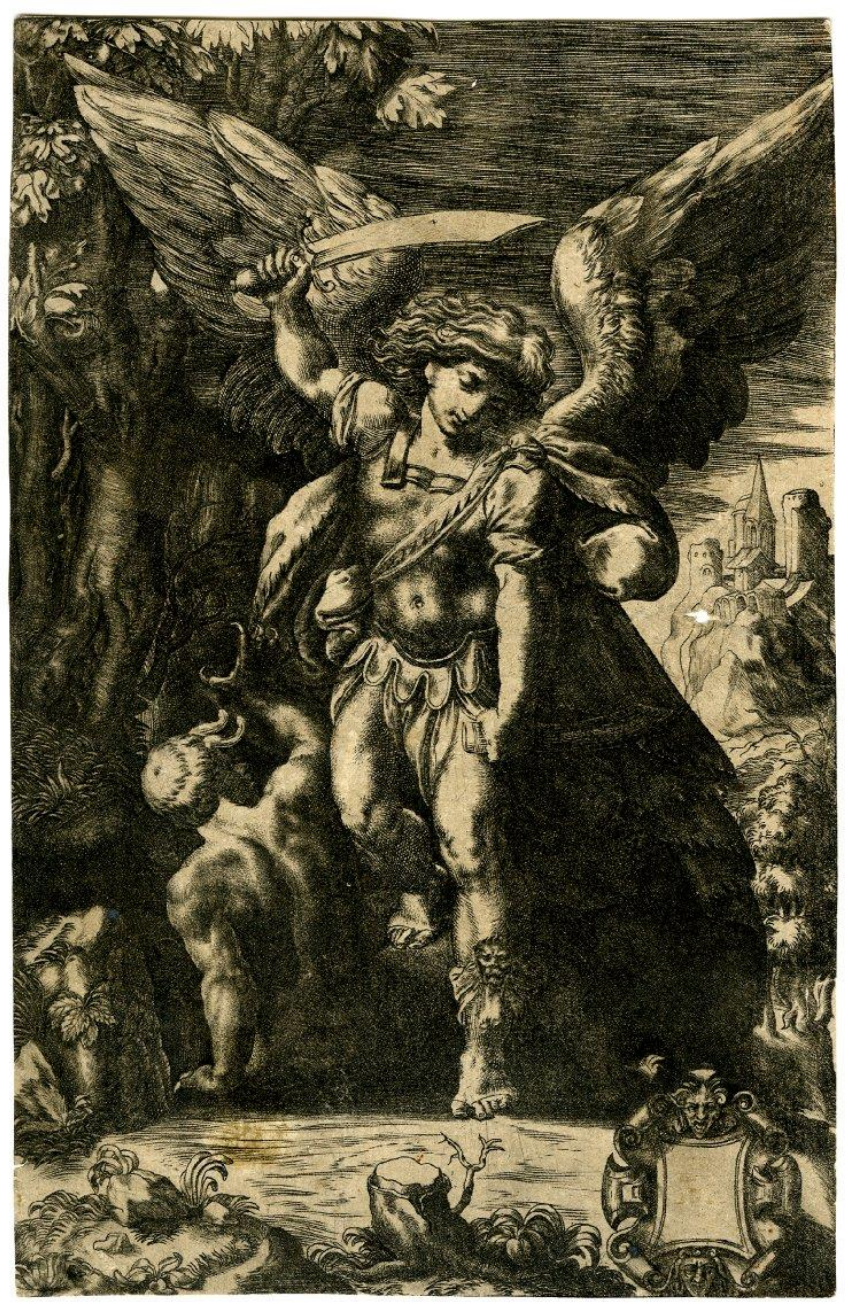

282. Jacopo Caraglio. San Miguel venciendo a los demonios. 1520-60. Museo Británico. Londres (Reino Unido).

\section{Anunciación}

Para esta escena anónima del retablo mayor de la iglesia de Santa María de Calatañazor (fig. 283), el pintor pudo haberse basado en un grabado de la Anunciación, de finales del siglo XVI, obra de Cornelis Cort (fig. 285) ${ }^{559}$.

En concreto, el artista parece haber tomado como modelo para su composición la figura de la Virgen María, que apoya la mano izquierda sobre su pecho, mientras que la derecha aparece más extendida en dirección al atril (fig. 284).

\footnotetext{
${ }^{559}$ Estampa disponible: RAMAIX, I., The Illustrated Bartsch, vol. 71, parte 1, Raphael Sadeler I, Abaris Books, Nueva York, 1999, p. 17.
} 


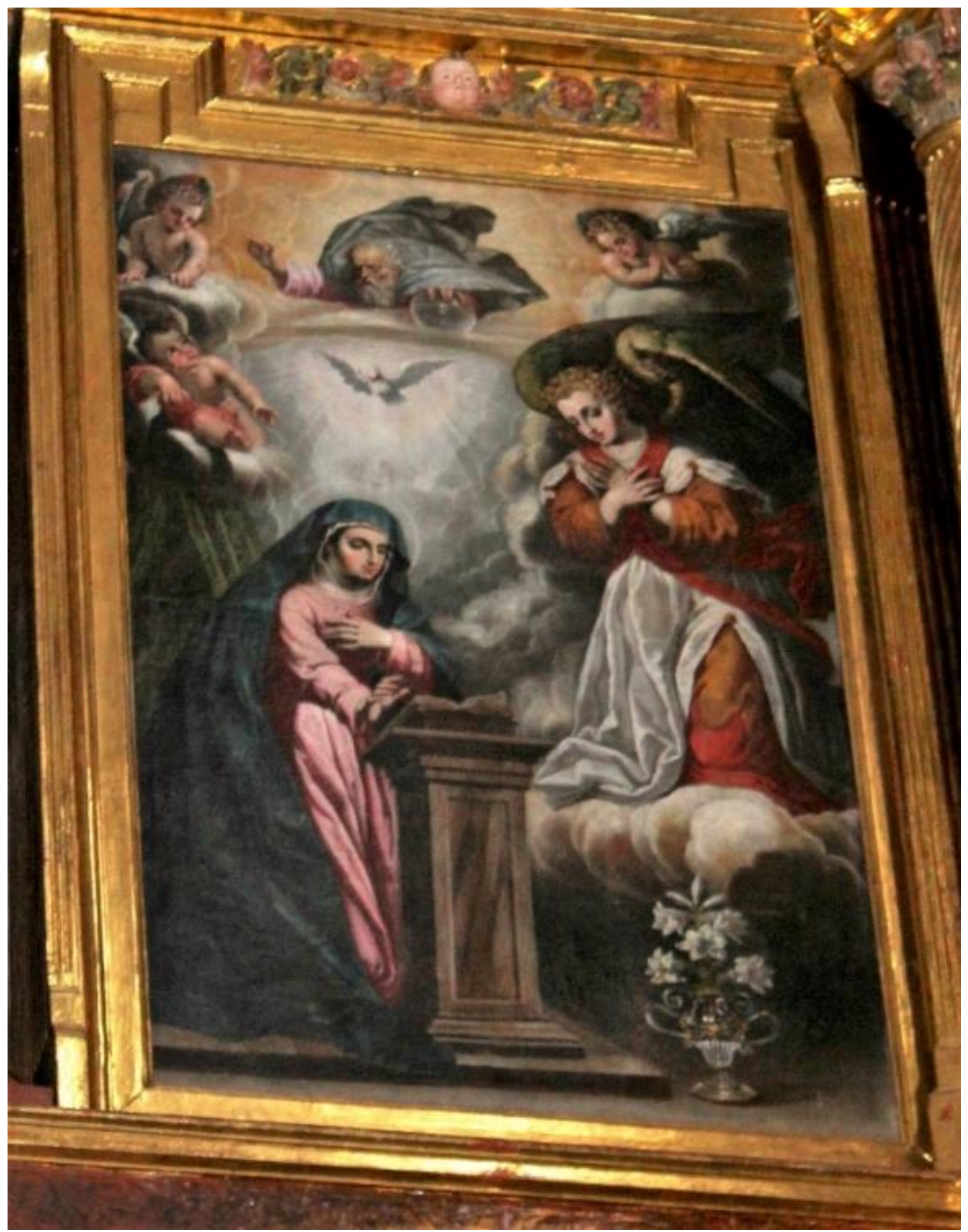

283. Anónimo. Anunciación. Finales del siglo XVI. Retablo mayor de Santa María de Calatañazor. Almazán (Soria), 


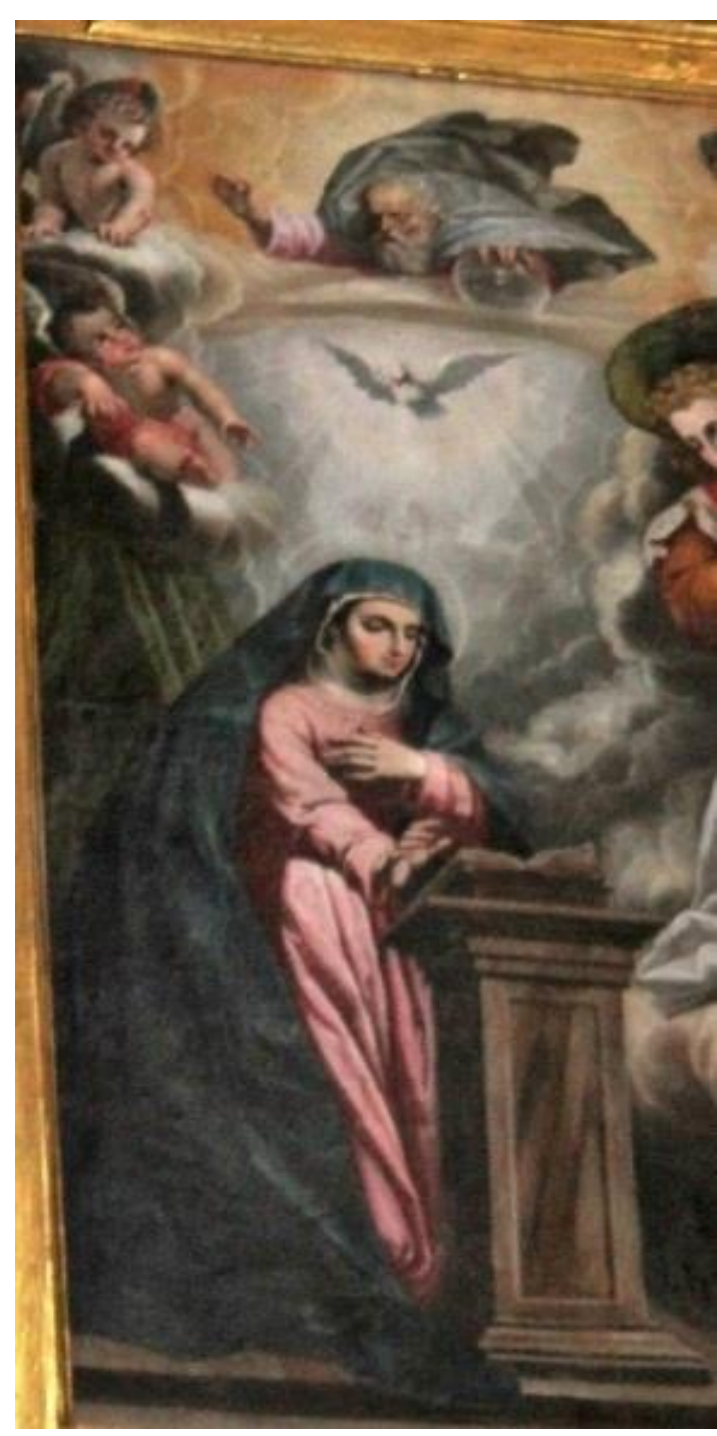

284. Detalle de la fig. 283.

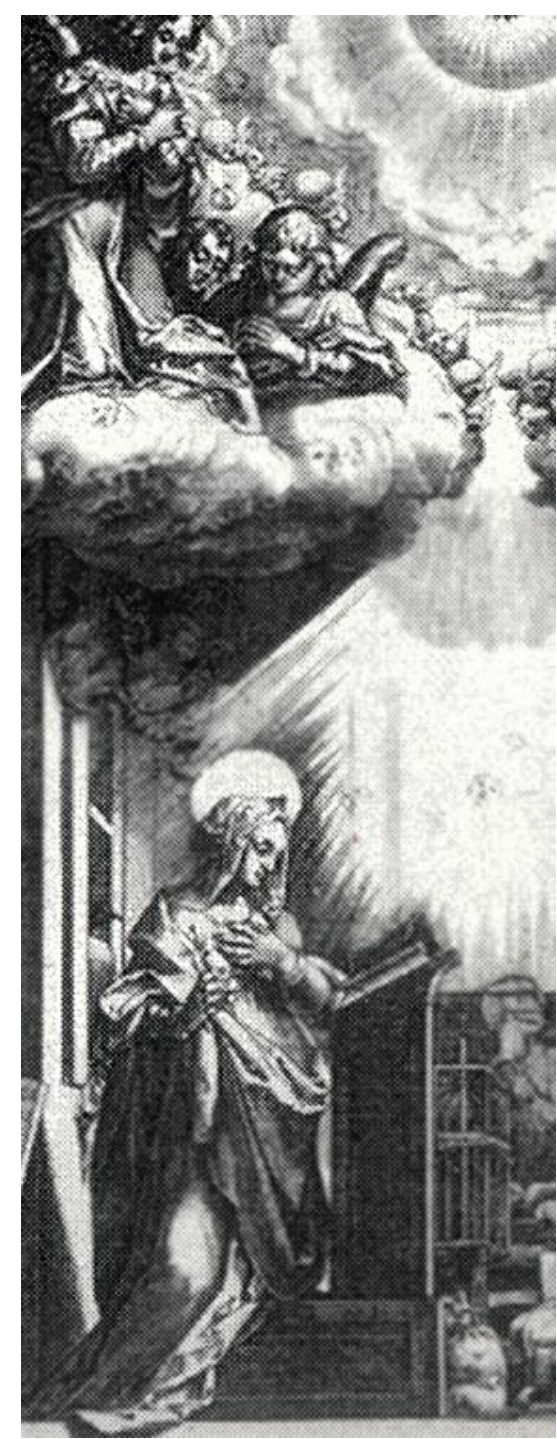

285. Raphael Sadeler (a partir de Cornelis Cort). Anunciación. 1580

Fine Arts Museum . San Francisco.

Para la figura del ángel, sin embargo, parece haber tomado como modelo el ángel situado sobre las nubes, por encima de la Virgen, y que aparece inclinado sobre una nube con los brazos cruzados sobre el pecho (figs. 286 y 287).

A pesar de que existen algunas diferencias como son la posición de las manos, que en el caso de la pintura están invertidas, podemos observar como las vestimentas del ángel son muy parecidas. También la parte superior, en la cual aparece Dios Padre rodeado de ángeles y nubes, podría haber sido tomada de la estampa. A pesar de ello el pintor ha reducido el número y magnificencia de la composición de Cort dado el estrecho espacio del retablo. Sin embargo si que logra captar parte del dinamismo y la vitalidad que desprenden las figuras y que preludia el Barroco. 
El pintor ha renunciado ha representar toda la magnificencia y complejidad de la parte superior del cuadro, simplificandolo a la figura de Dios Padre y de cuatro ángeles.

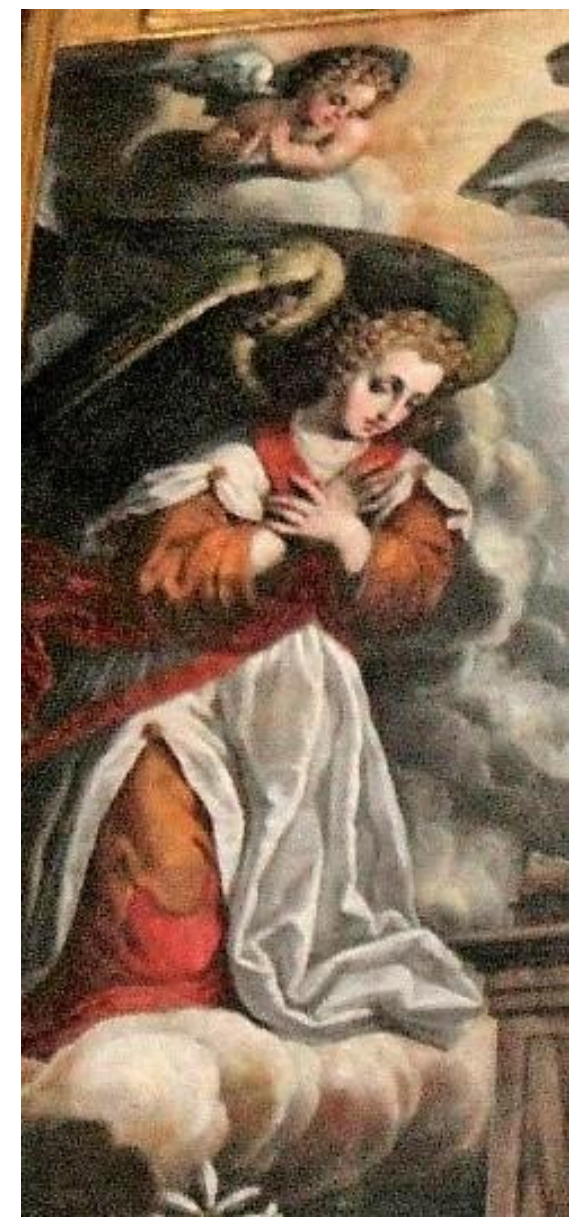

286. Detalle de la fig. 283.

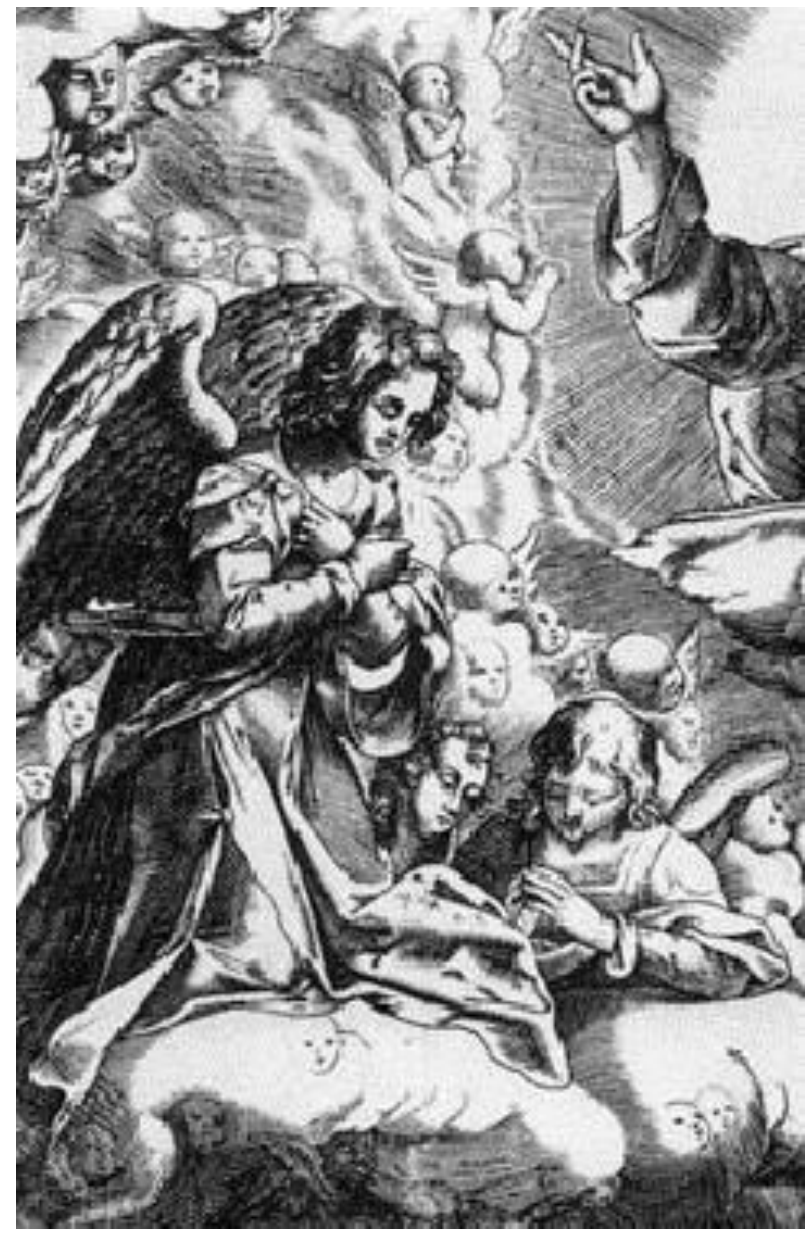

287. Detalle de la fig. 285 


\section{OBRAS IMPORTADAS}

\section{Anónimo \\ San Jerónimo Penitente \\ 1553 \\ Museo Diocesano \\ Burgo de Osma (Soria).}

En opinión de Arranz Arranz esta tabla podría relacionarse con Marinus van Reymerswal $^{560}$. Se encuentra en el Museo Diocesano, insalado en la Catedral oxomense (fig. 288). Se podría vincular a algunos modelos nórdicos de representación sobre el tema, como es el San Jerónimo Penitente de Albrecht Altdorfer . El pintor ha situado la escena en un entorno oscuro, entre lo que parecen unas ruinas. $\mathrm{Al}$ fondo observamos un paisaje montañoso, en el que predominan los tonos pardos, amarillentos, verdes y azulados para el fondo. San Jerónimo aparece en el centro mismo de la composición; su cuerpo es delgado, y muestra los típicos signos de la vejez, aunque se ha remarcado la musculatura de su torso. El león apenas aparece en la escena, mostrando tan sólo su cabeza asomando a la izquierda del vano situado al fondo.

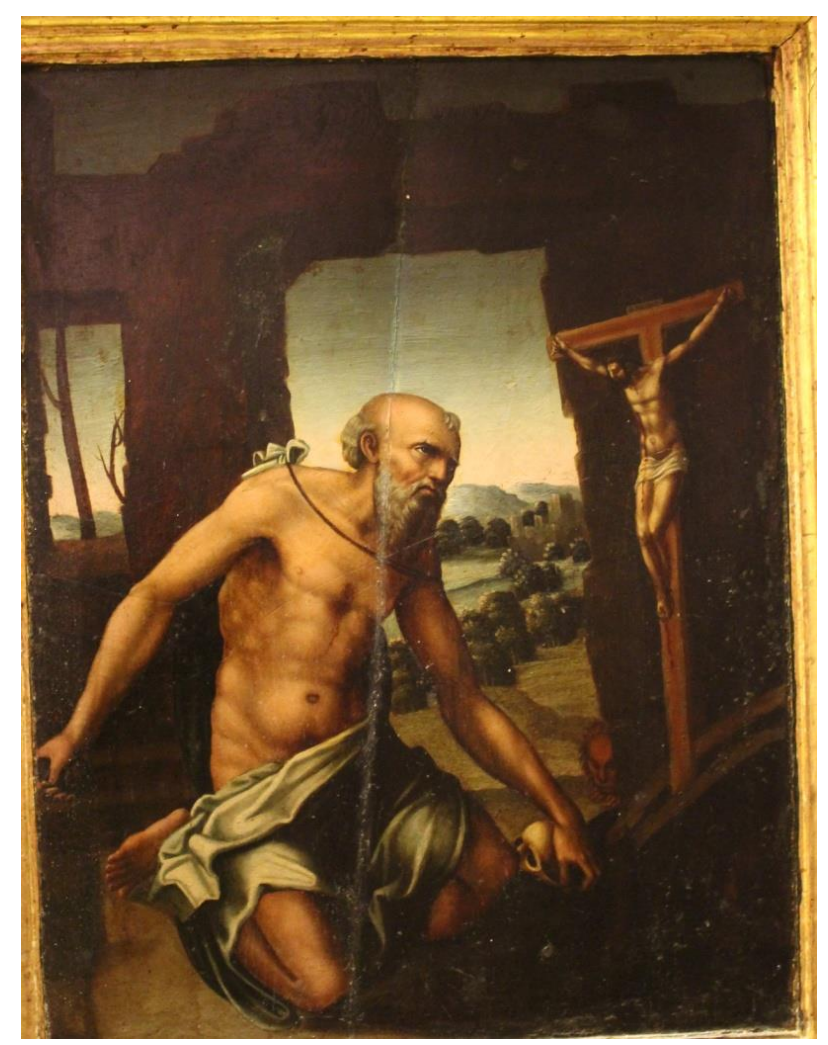

288. Anónimo. San Jerónimo Penitente. 1553. Museo Diocesano Burgo de Osma.

${ }^{560}$ ARRANZ ARRANZ, J., El Renacimiento en la Diócesis..., p. 392. 
Es muy posible que el pintor se inspirase por una parte en la estampa de Raimondi (fig. 289), donde San Jerónimo presenta la misma pose del brazo derecho estirado hacia atrás ${ }^{561}$. Sin embargo, en el grabado de Raimondi el personaje alza su mano izquierda hacia la cruz, mientras que en la pintura apoya la misma contra la calavera que se encuentra en el suelo. Además, sus piernas aparecen unidas, mientras que en la estampa aparecen separadas. También hay influencia de la estampa del grabador alemán Hans Baldung Grien (fig. 290) ${ }^{562}$ con la que comparte tanto la postura de las piernas como la del brazo izquierdo estirado hacia adelante.

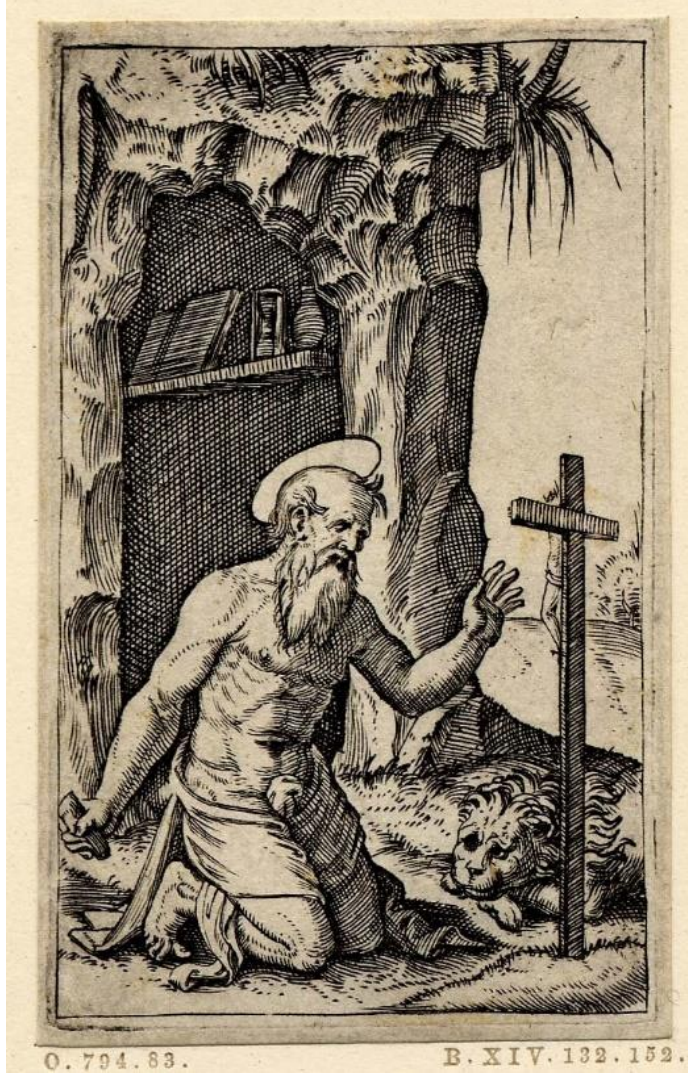

289. Marcantonio Raimondi.

San Jerónimo Penitente. 1500-1527. Museo Británico. Londres (Reino Unido).

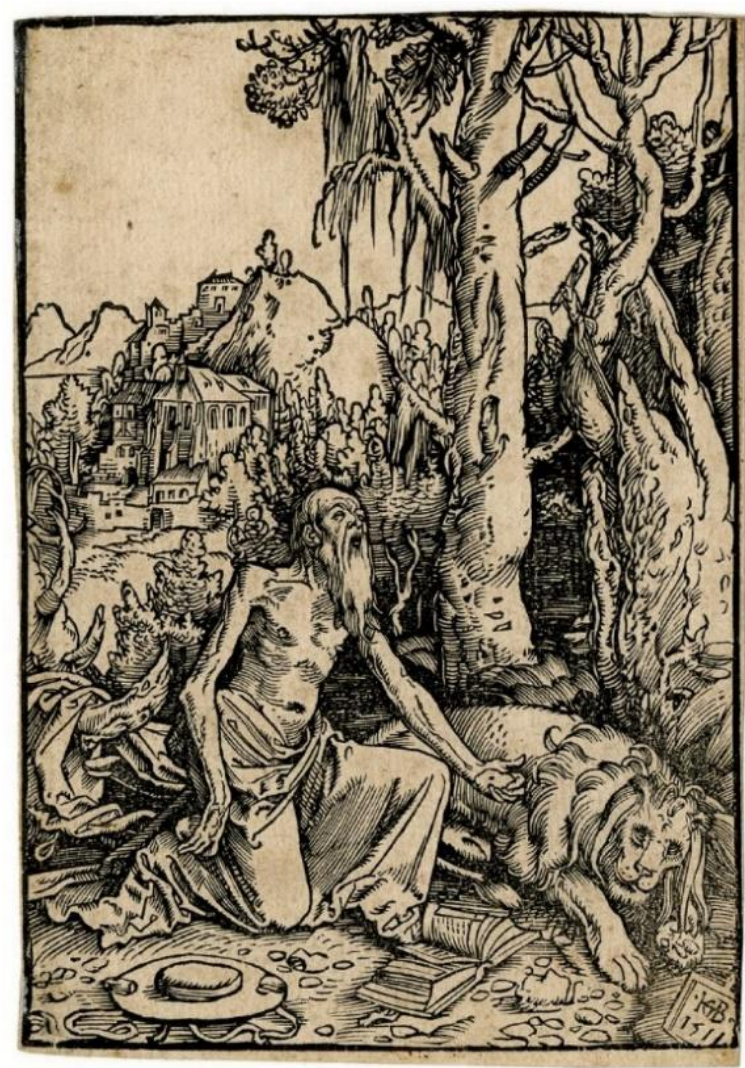

290. Hans Baldung.

San Jerónimo penitente. 1511.

Museo Británico. Londres (Reino Unido).

${ }^{561}$ Estampa disponible en:

http://www.britishmuseum.org/research/collection_online/collection_object_details.aspx?objectId=14339 $\underline{48 \& \text { partId }=1 \& \text { searchText }=\text { saint }+ \text { jerome \&images }=\text { true \&people }=115934 \& \text { page }=1}$

BARTSCH, A., op. cit., vol. XIV, p. 132; DELABORDE, H., op. cit., n 75, p. 130.

${ }^{562}$ Estampa disponible en:

http://www.britishmuseum.org/research/collection_online/collection_object details.aspx?objectId=14248 68\&partId=1\&searchText $=$ saint + jerome \&images $=$ true \&people $=133539 \&$ page $=1$

BARTSCH, A., op. cit., vol. VII, p. 312. 


\section{Pieter Pourbus el Viejo \\ Camino del Calvario \\ 1559}

\section{Concatedral de San Pedro}

(Soria)

Se trata de la escena del Camino del Calvario (fig. 291) ${ }^{563}$ de un tríptico flamenco para el cual el pintor Pourbus el Viejo se basó en el famoso modelo del Camino del Calvario de Durero ${ }^{564}$ (fig. 292) ${ }^{565}$. El tríptico procedía de la iglesia de San Nicolás (Soria) y está actualmente ubicado en la Concatedral de San Pedro ${ }^{566}$. En especial se ha basado en las posturas de Cristo y de María Magdalena. El primero aparece apoyando su mano derecha sobre una roca, mientras con la izquierda sostiene la cruz. En el caso de la segunda sólo se ha tomado las postura y la silueta arrodillada ante Cristo; sin embargo ni las vestimentas ni el tocado de la figura son parecidos. Por detrás de la Magdalena apreciamos el parecido de otros personajes con la estampa. Es el caso de los rostros de María y de Juan que aparecen muy juntos, casi tocándose. La cabeza de María se cubre con un manto. Respecto al fondo de la composición, en la cual se observa la ciudad de Jerusalén, podría proceder de modelos de estampas nórdicas de la época. Es el caso de algunos grabados del alemán Sebald Beham (fig. 293 y 294) ${ }^{567}$ En ellos apreciamos una serie de torres cubiertas con cúpulas.

563 Imagen procedente de: LA HOZ, L., “Tríptico: Camino del Calvario-Calvario-Resurrección”, en Paisaje interior. Las Edades del Hombre, Fundación Las Edades del Hombre, 2009, n 125, pp. 462-464.

${ }^{564}$ MARTÍNEZ FRÍAS, J. M., "Tríptico: Camino del Calvario-Calvario-Resurrección", en Kyrios. Las Edades del Hombre, Fundación las Edades del Hombre, 2006, nº 164, pp. 352-354; LA HOZ, L., op. cit., pp. 462-464.

${ }^{565}$ Estampa disponible en:

https://research.britishmuseum.org/research/collection_online/collection_object_details.aspx?objectId=14 39782\&partId=1\&searchText=calvary \&from=ad\&fromDate=1510\&to=ad\&toDate $=1515 \&$ page $=1$

BARTSCH, A., op. cit., vol. XIV, p. 404.

${ }^{566}$ ALCOLEA BLANCH, S., op. cit., p. 46; MARTÍNEZ FRÍAS, Concatedral de Soria, León, Edilesa, 1992; TARACENA Y AGUIRRE, B. y TUDELA DE LA ORDEN, J., op. cit., p. 127; DÍAZ PADRÓN, M., "Una pintura de Pierre Pourbus atribuida a Bernaert de Ryckere en la iglesia de San Martín de Courtrai", Archivo Español de Arte, tomo 57, no 226, 1984, p. 188; "Un tryptique inédit de Pierre Pourbus. La Passion du Christ dans la cathédrale de Soria (Espagna)", Revue belge d'archeologie et d'histoire de l'art, $\mathrm{n}^{\mathrm{o}}$ 77, 2008, pp. 75-89; ALONSO ROMERO, J., op. cit., p. 85-87; MARTÍNEZ FRÍAS, J. M., “Tríptico...”, pp. 352-354; LA HOZ, L., op. cit., pp. 462-464.

${ }^{567}$ Estampas disponibles en:

https://www.britishmuseum.org/research/collection_online/collection_object_details.aspx?objectId=1427 $136 \&$ partId=1\&searchText=jerusalem \&images $=$ true $\&$ from $=$ ad $\&$ fromDate $=1500 \&$ to $=$ ad $\&$ toDate $=1560 \&$ page $=1$

https://www.britishmuseum.org/research/collection_online/collection_object_details.aspx?objectId=1427 $195 \&$ partId=1\&searchText $=$ jerusalem $\&$ from $=$ ad $\&$ fromDate $=1500 \&$ to $=$ ad $\&$ toDate $=1560 \&$ page $=1$

BARTSCH, A., op. cit., vol. VIII, $\mathrm{n}^{\circ}$ 1-73, p. 230; DODGSON, Catalogue of Early german..., vol. 1, $\mathrm{n}^{\circ}$ 34, pp. 446-449. 
El pintor ha simplificado la escena, reduciendo el número de personajes que aparecen al fondo, y que en la estampa resultan mucho más grotescos y violentos ya que la mayoría aparece portando armas con gesto amenazador

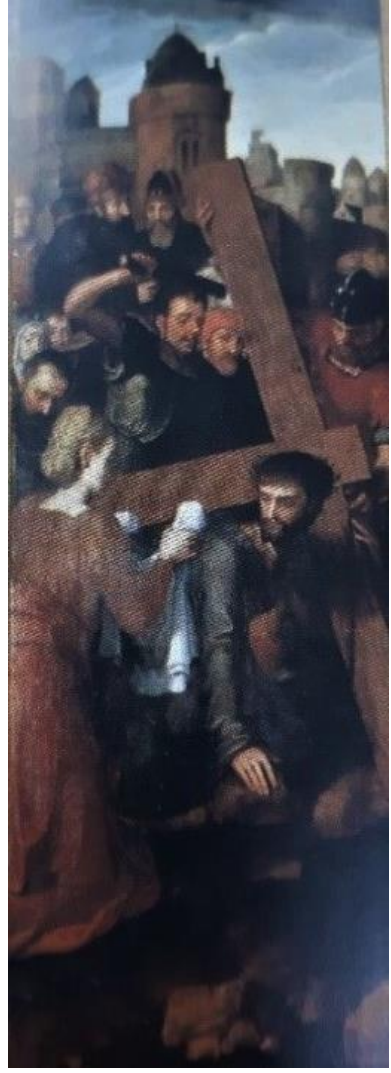

291. Pourbus el Viejo. Camino del Calvario (Tríptico flamenco). 1559.

Concatedral de San Pedro. Soria.

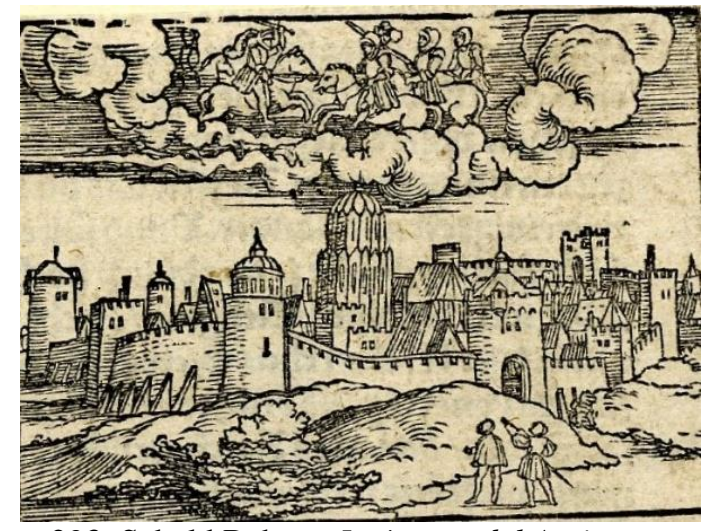

293. Sebald Beham. Imágenes del Antiguo Testamento. 1533. Museo Británico. Londres (Reino Unido).

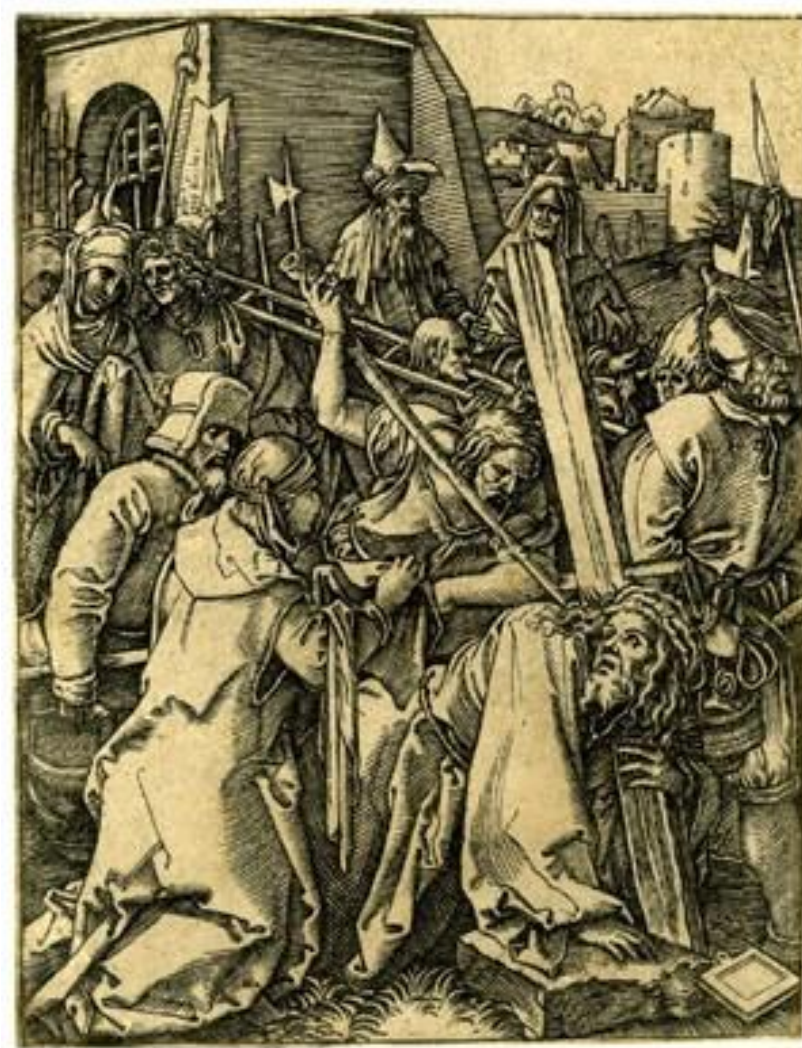

292. Marcantonio Raimondi (a partir de Alberto Durero) Camino del Calvario. 1510-1515. Museo Británico. Londres (Reino Unido).

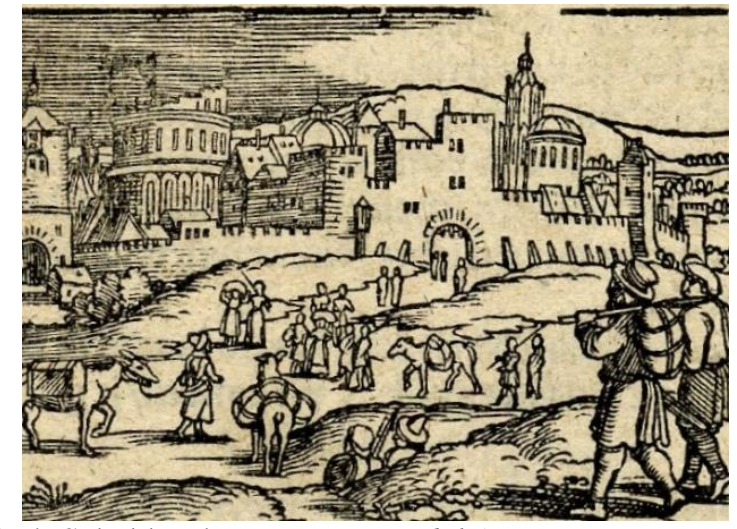

294. Sebald Beham. Imágenes del Antiguo Testamento. 1533. Museo Británico.

Londres (Reino Unido). 


\section{TABLAS}

A continuación se presentan una serie de tablas en las que se reflejan las sucesivas influencias entre grabados, pinturas y esculturas. Aparecen ordenadas siguiendo el orden cronológico de las estampas.

Se organizan teniendo en cuenta la obra emisora, su autor y fecha y la obra receptora, el autor, la fecha, la ubicación y la localidad. 


\begin{tabular}{|c|c|c|c|c|c|c|}
\hline 层 & 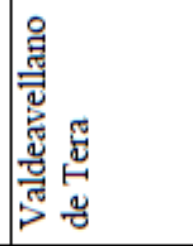 & 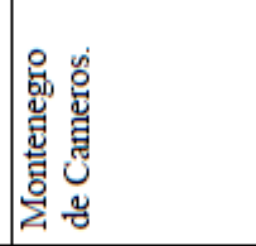 & 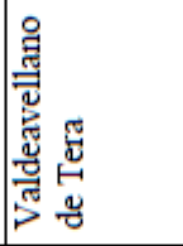 & 唯 & 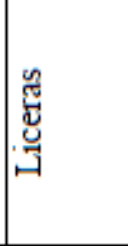 & 䓤 \\
\hline 号 & 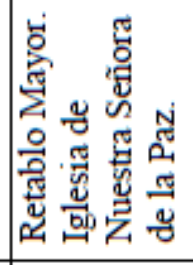 & 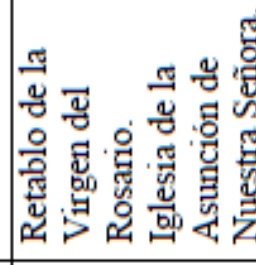 & 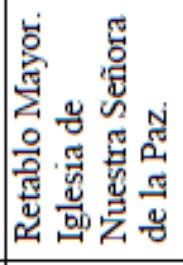 & 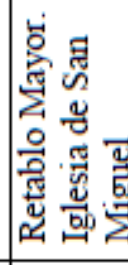 & 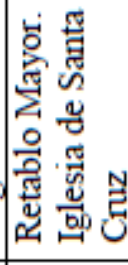 & 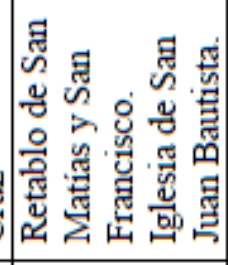 \\
\hline 良 & 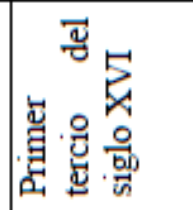 & 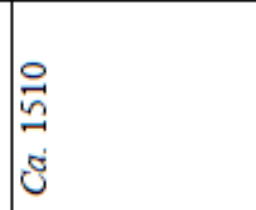 & 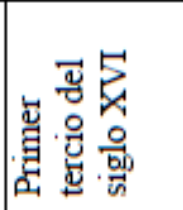 & 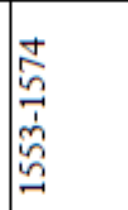 & 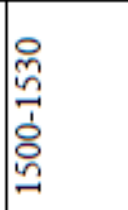 & 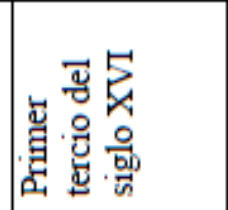 \\
\hline 啪 & 臱 & 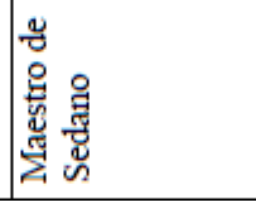 & 禀 & 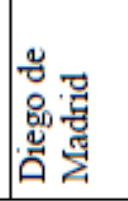 & 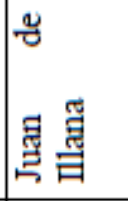 & 夏 \\
\hline 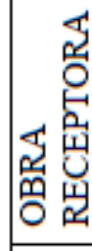 & पूँ & & 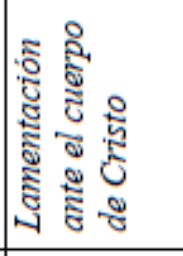 & & "ृ: & 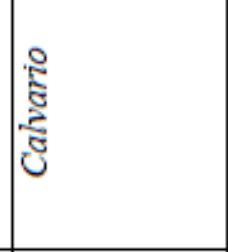 \\
\hline 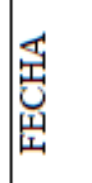 & 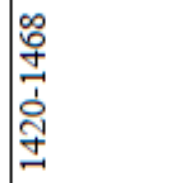 & & 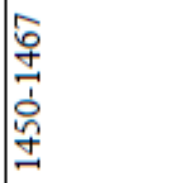 & & 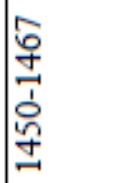 & 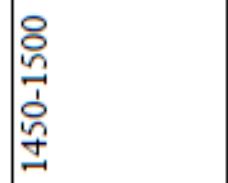 \\
\hline 舀 & 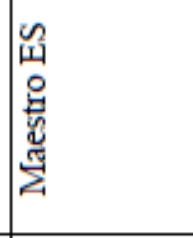 & & 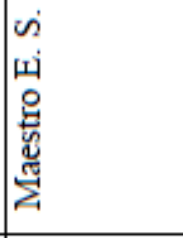 & & 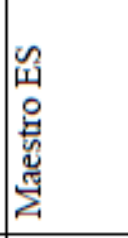 & 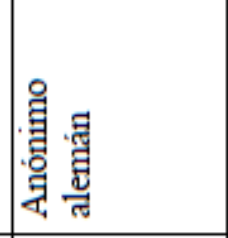 \\
\hline 㝵 & 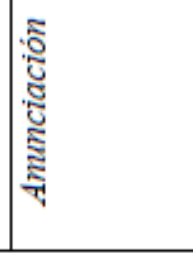 & & 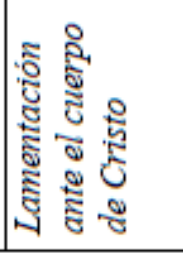 & & 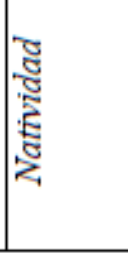 & 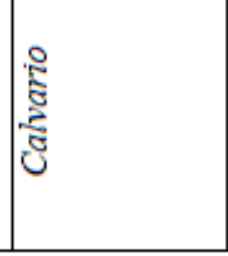 \\
\hline
\end{tabular}




\begin{tabular}{|c|c|c|c|c|c|}
\hline 离 & 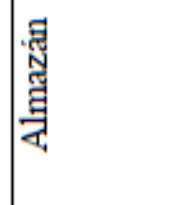 & 㺃 & 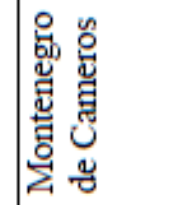 & 䍃 & 嵒 \\
\hline 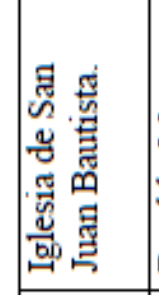 & 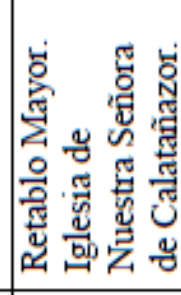 & 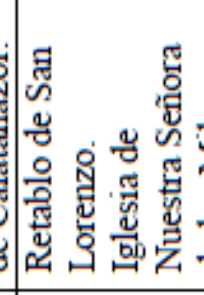 & 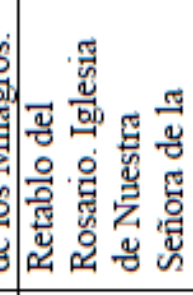 & 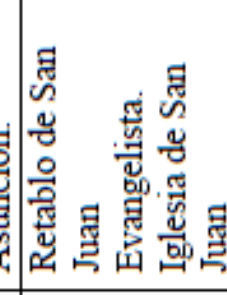 & 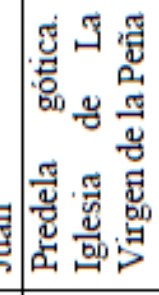 \\
\hline 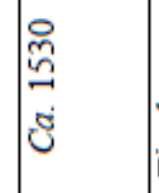 & 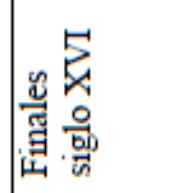 & $\begin{array}{l}0 \\
0 \\
0 \\
8\end{array}$ & 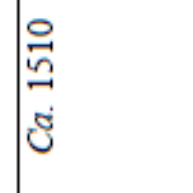 & $\begin{array}{l}\overrightarrow{0} \\
0 \\
0 \\
0\end{array}$ & 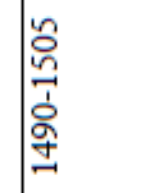 \\
\hline 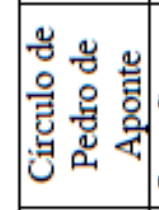 & 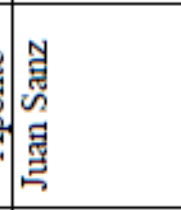 & 亭 & 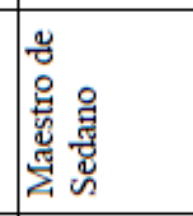 & 墨墨 & 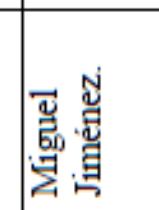 \\
\hline 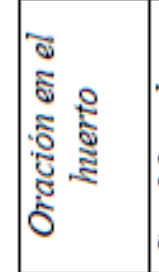 & 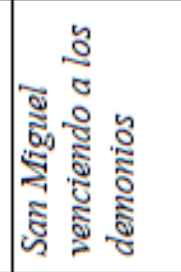 & 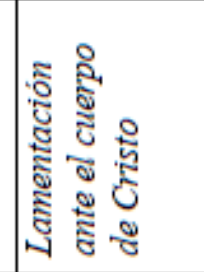 & 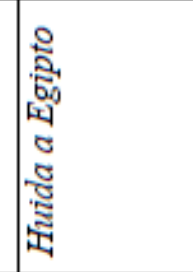 & 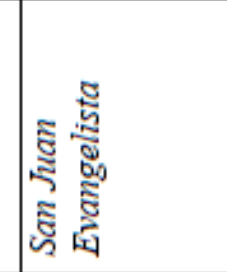 & 愛 \\
\hline 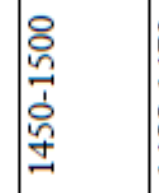 & 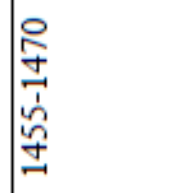 & 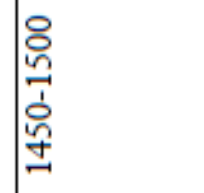 & 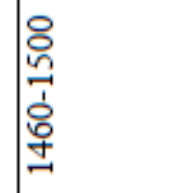 & 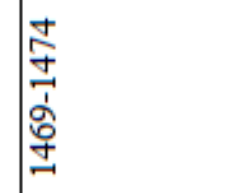 & 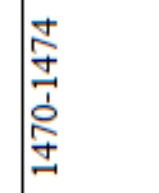 \\
\hline 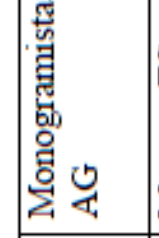 & 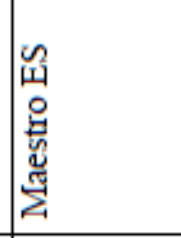 & 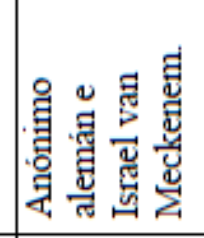 & 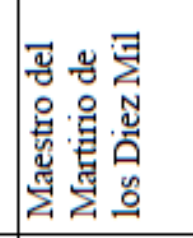 & 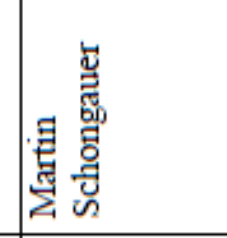 & 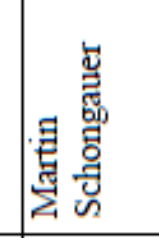 \\
\hline 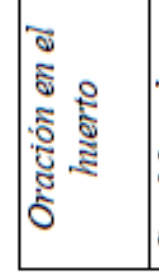 & 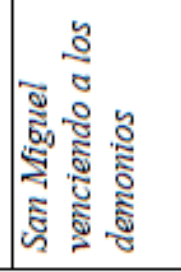 & 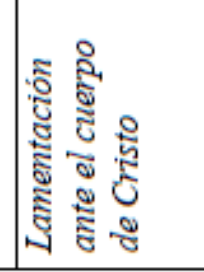 & 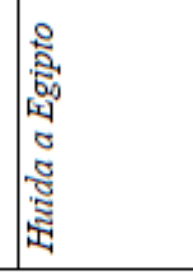 & 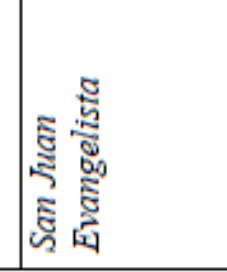 & | \\
\hline
\end{tabular}




\begin{tabular}{|c|c|c|c|c|}
\hline 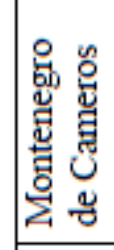 & 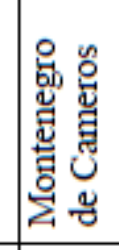 & 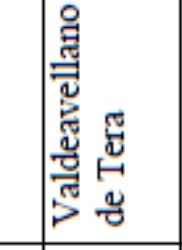 & 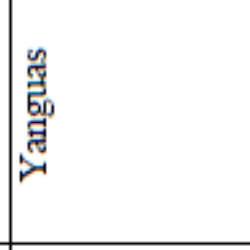 & 葴 \\
\hline 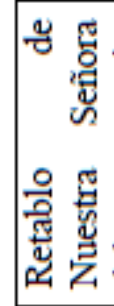 & 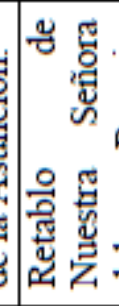 & 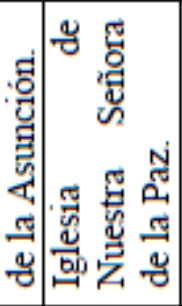 & 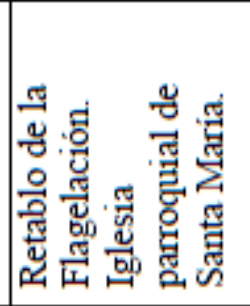 & 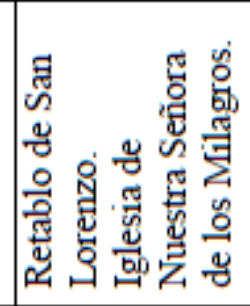 \\
\hline 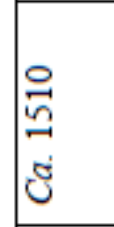 & $\begin{array}{l}\stackrel{8}{\hat{n}} \\
-3 \\
\tilde{c}\end{array}$ & 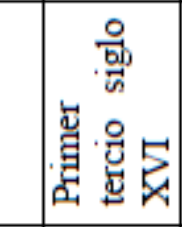 & 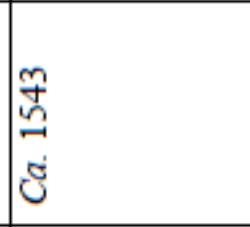 & 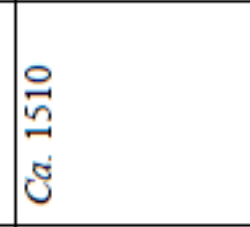 \\
\hline 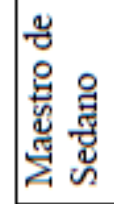 & 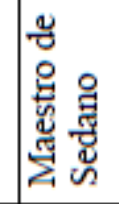 & 道 & 悬 & 毫 \\
\hline "ू & 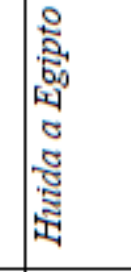 & 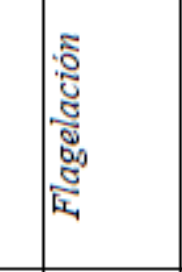 & 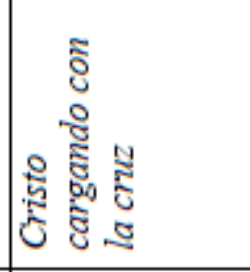 & 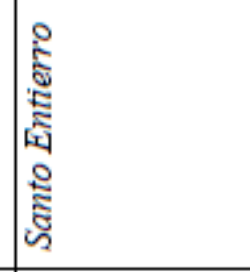 \\
\hline 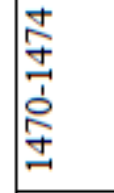 & 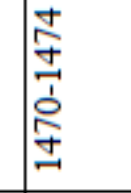 & 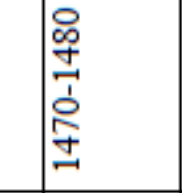 & 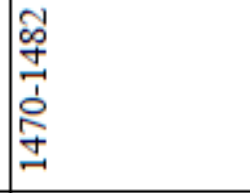 & 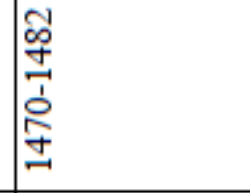 \\
\hline 晨 & 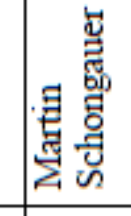 & 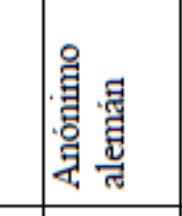 & 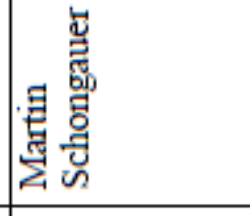 & 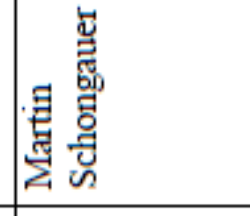 \\
\hline 宽 & 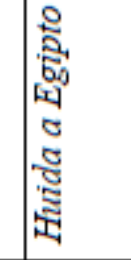 & 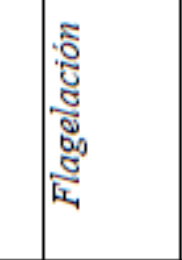 & 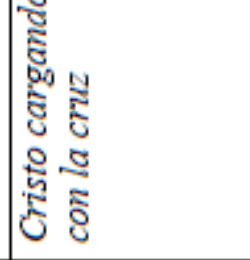 & 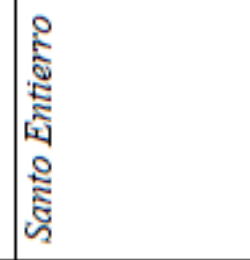 \\
\hline
\end{tabular}




\begin{tabular}{|c|c|c|c|c|c|}
\hline 㺃 & 袧 & 㺃 & 呇 & 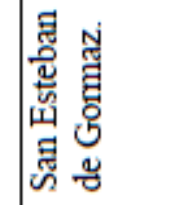 & 焉 \\
\hline 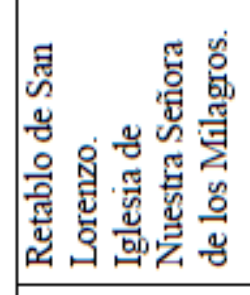 & 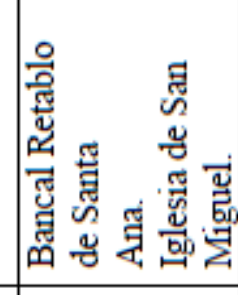 & 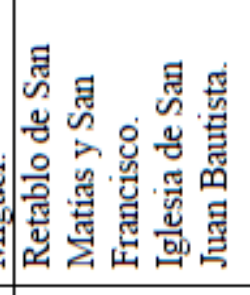 & 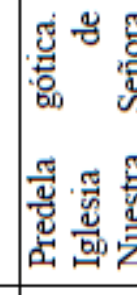 & 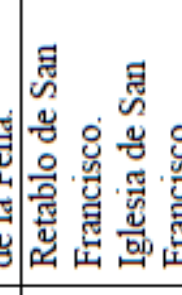 & 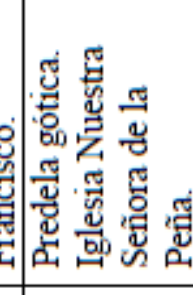 \\
\hline 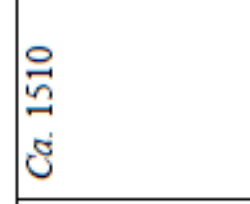 & 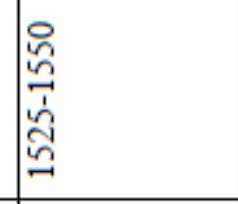 & 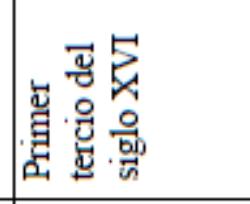 & 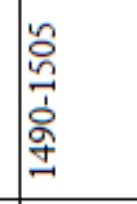 & 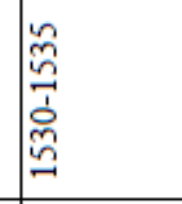 & 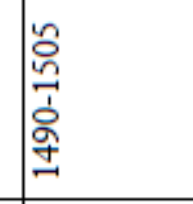 \\
\hline 亶 & 瞎 & 亶 & 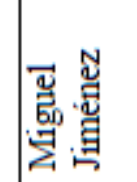 & 櫋 & 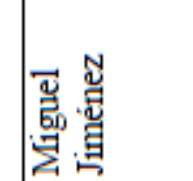 \\
\hline : & & 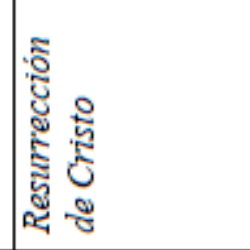 & $\mid$ & 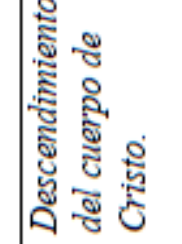 & 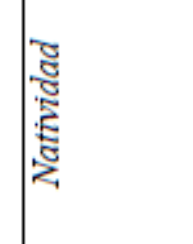 \\
\hline $\mid$ & & 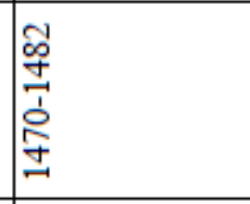 & 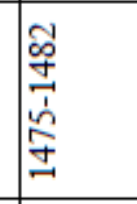 & 密 & 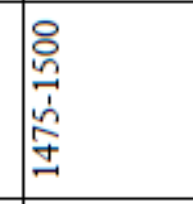 \\
\hline 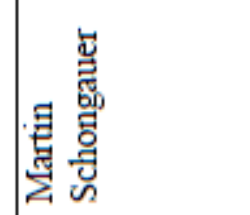 & & 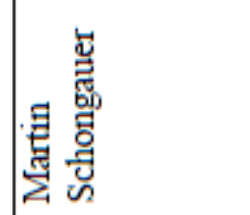 & 总 & 总总 & 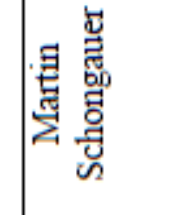 \\
\hline 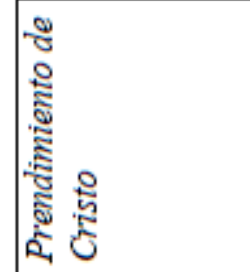 & & ช్ & 密 & 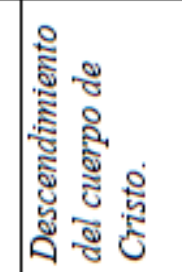 & 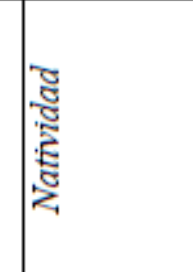 \\
\hline
\end{tabular}




\begin{tabular}{|c|c|c|c|c|c|}
\hline 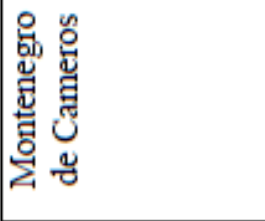 & 㞼 & 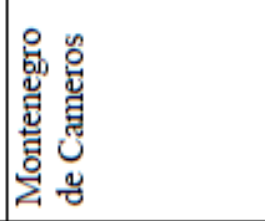 & 丞 & 总 & 总 \\
\hline 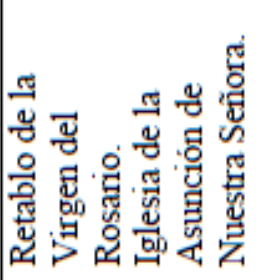 & 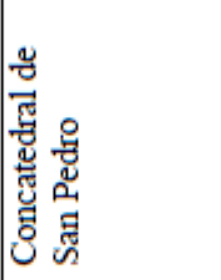 & 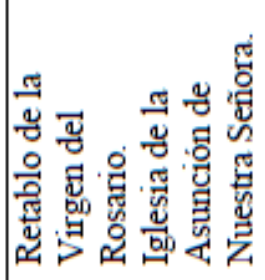 & 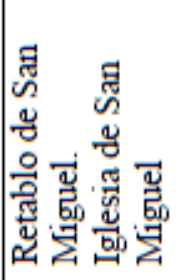 & 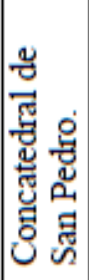 & 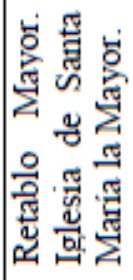 \\
\hline 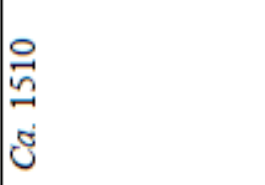 & 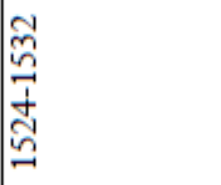 & $\begin{array}{l}\text { 음 } \\
\text { - } \\
8 \\
0\end{array}$ & $\underset{\sim}{\sim}$ & 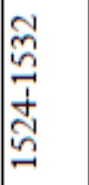 & 岕 \\
\hline \multirow[t]{5}{*}{ 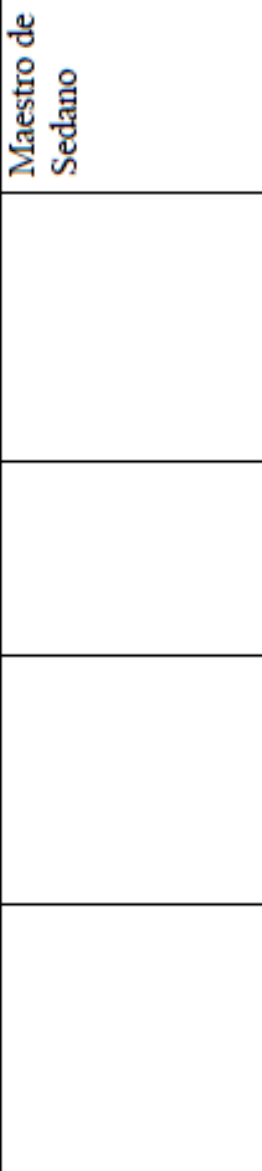 } & 急 & 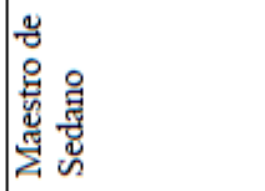 & 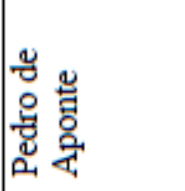 & 急 & 『ี \\
\hline & 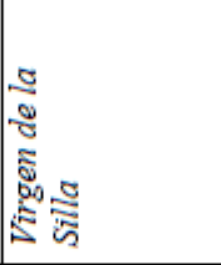 & 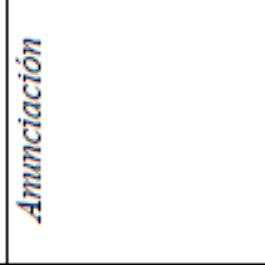 & 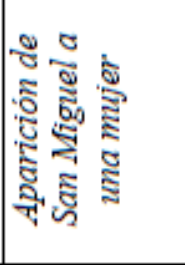 & 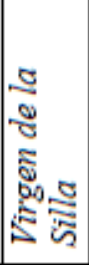 & 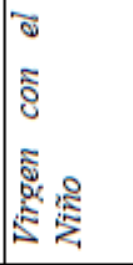 \\
\hline & 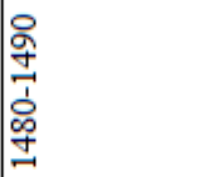 & \multicolumn{2}{|l|}{ 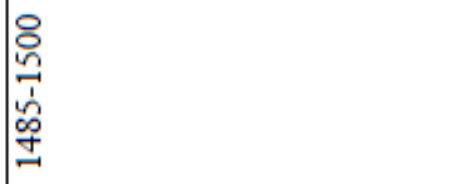 } & \multicolumn{2}{|l|}{ 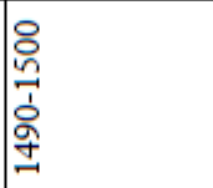 } \\
\hline & 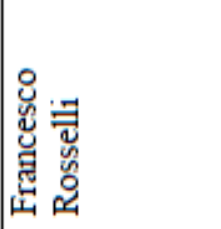 & \multicolumn{2}{|l|}{ 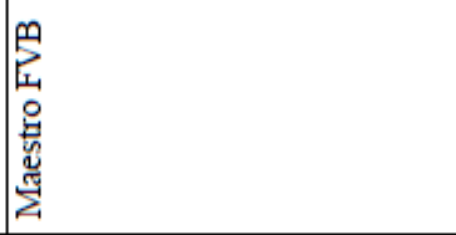 } & \multicolumn{2}{|l|}{ 咅。 } \\
\hline & 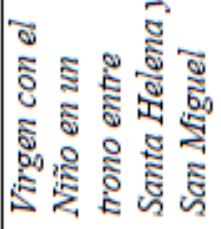 & \multicolumn{2}{|l|}{ 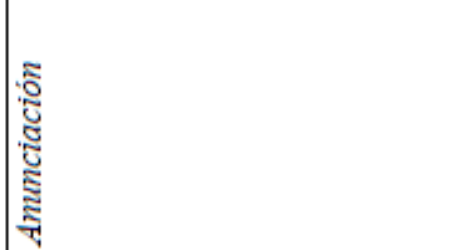 } & \multicolumn{2}{|l|}{ 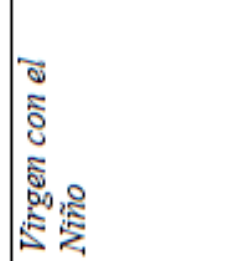 } \\
\hline
\end{tabular}




\begin{tabular}{|c|c|c|c|c|}
\hline 㺃 & 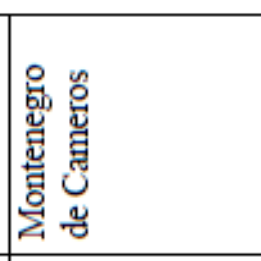 & 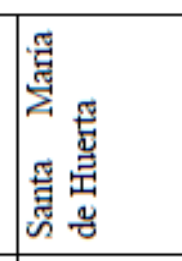 & 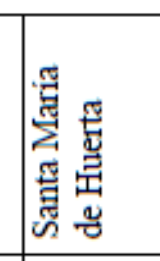 & 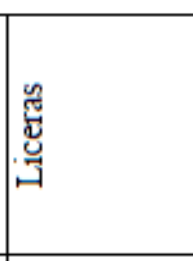 \\
\hline 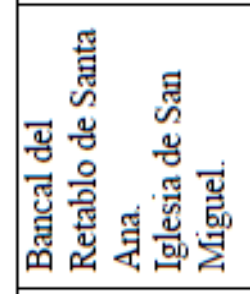 & 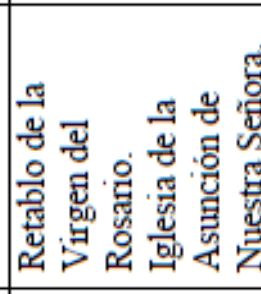 & 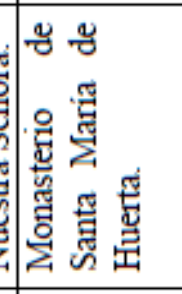 & 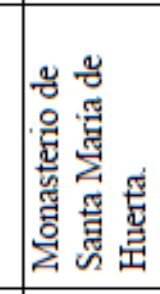 & 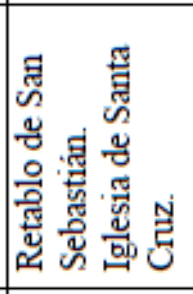 \\
\hline 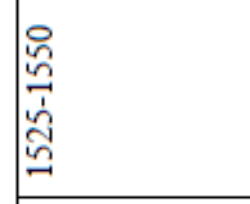 & \begin{tabular}{|l}
0 \\
0 \\
0 \\
0 \\
0
\end{tabular} & 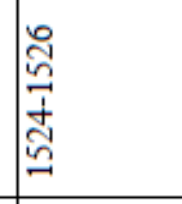 & 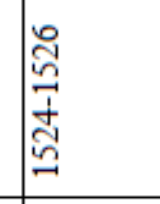 & 总 \\
\hline 道 & 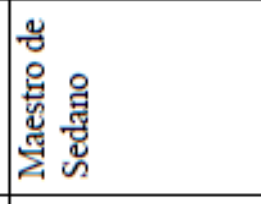 & 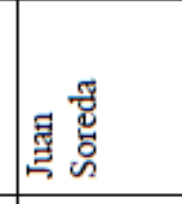 & 急总 & 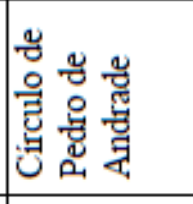 \\
\hline 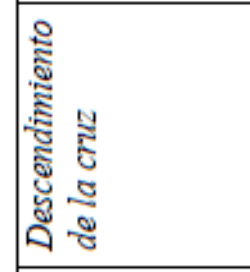 & "ू & 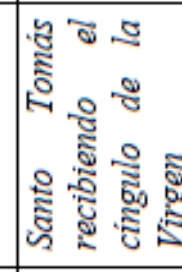 & 跣 & 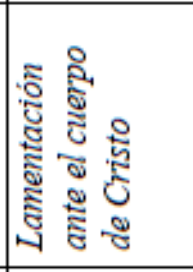 \\
\hline 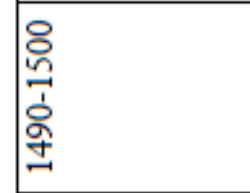 & 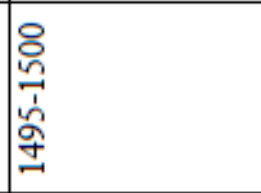 & 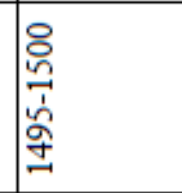 & 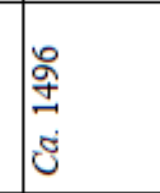 & 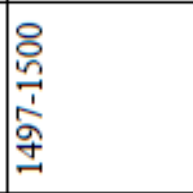 \\
\hline 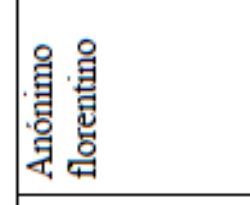 & 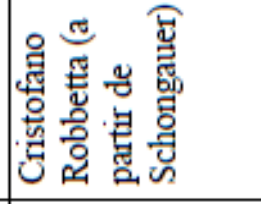 & 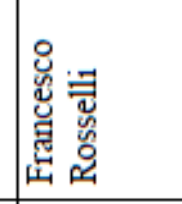 & 㝵递 & 善鄫 \\
\hline 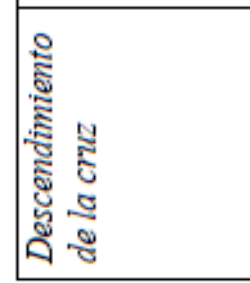 & 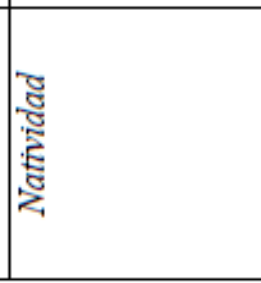 & 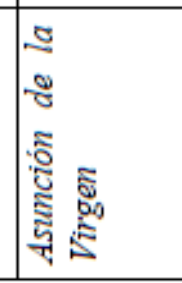 & 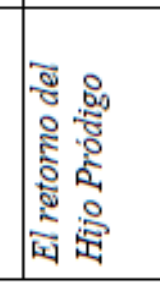 & 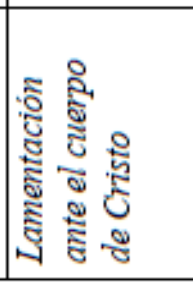 \\
\hline
\end{tabular}




\begin{tabular}{|c|c|c|c|c|}
\hline 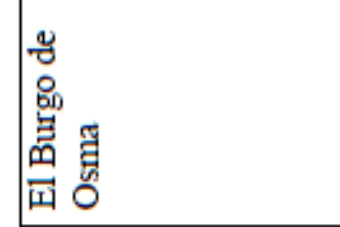 & 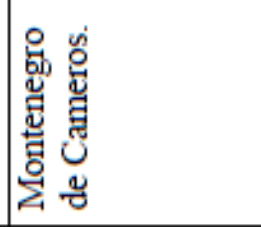 & 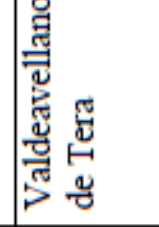 & 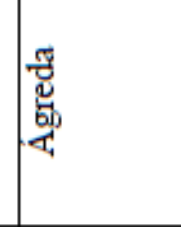 & 㺃 \\
\hline 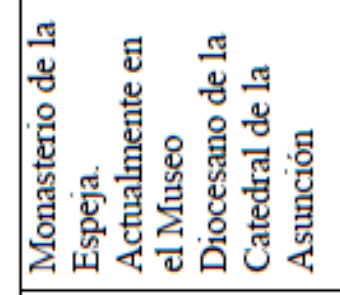 & 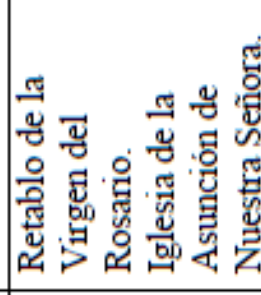 & 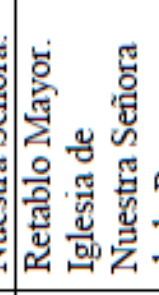 & 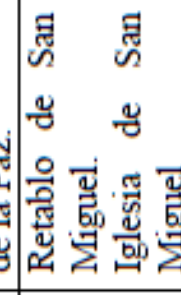 & 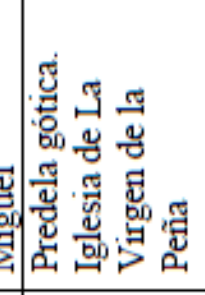 \\
\hline 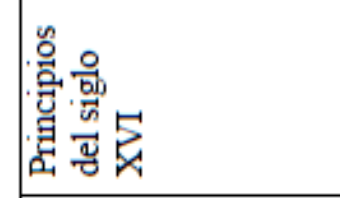 & 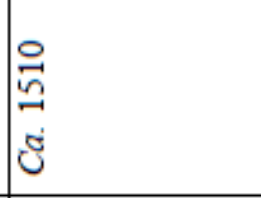 & 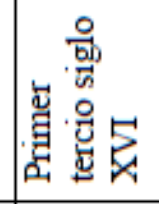 & $\begin{array}{l}\tilde{\pi} \\
\tilde{\mathscr{C}} \\
\tilde{\delta}\end{array}$ & 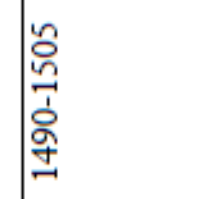 \\
\hline 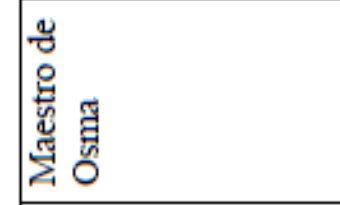 & 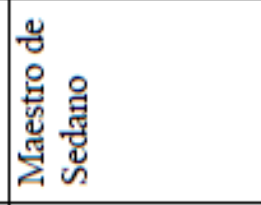 & 兽 & 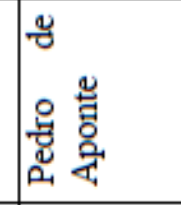 & 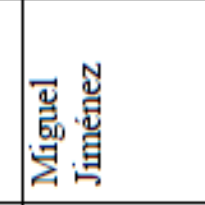 \\
\hline 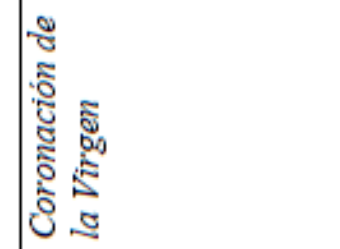 & 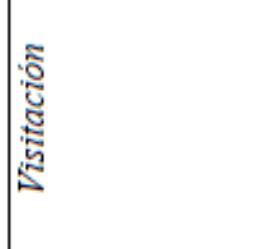 & 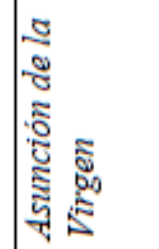 & 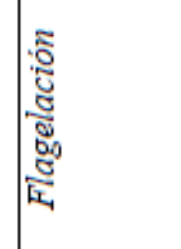 & |气 \\
\hline 㱚 & 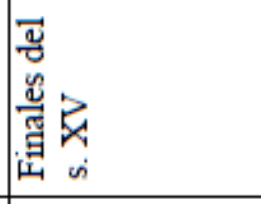 & 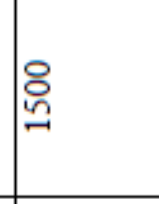 & 总 & 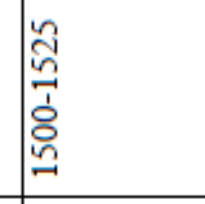 \\
\hline 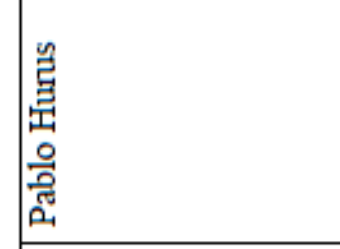 & 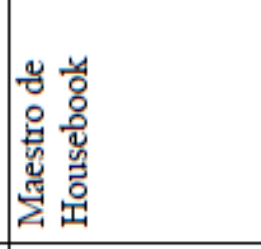 & 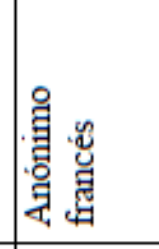 & 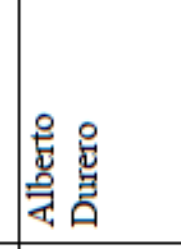 & 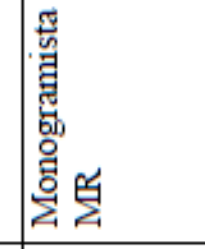 \\
\hline 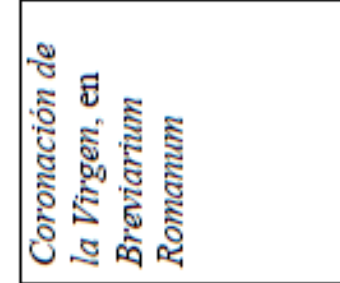 & 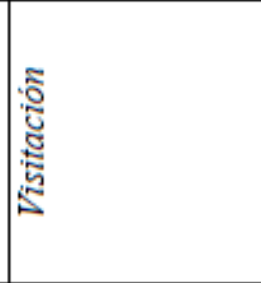 & 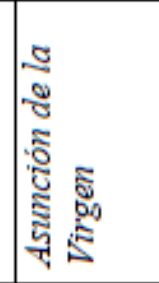 & 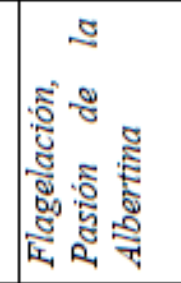 & 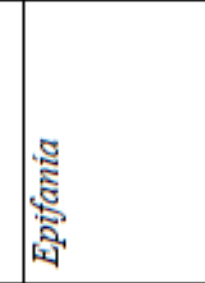 \\
\hline
\end{tabular}




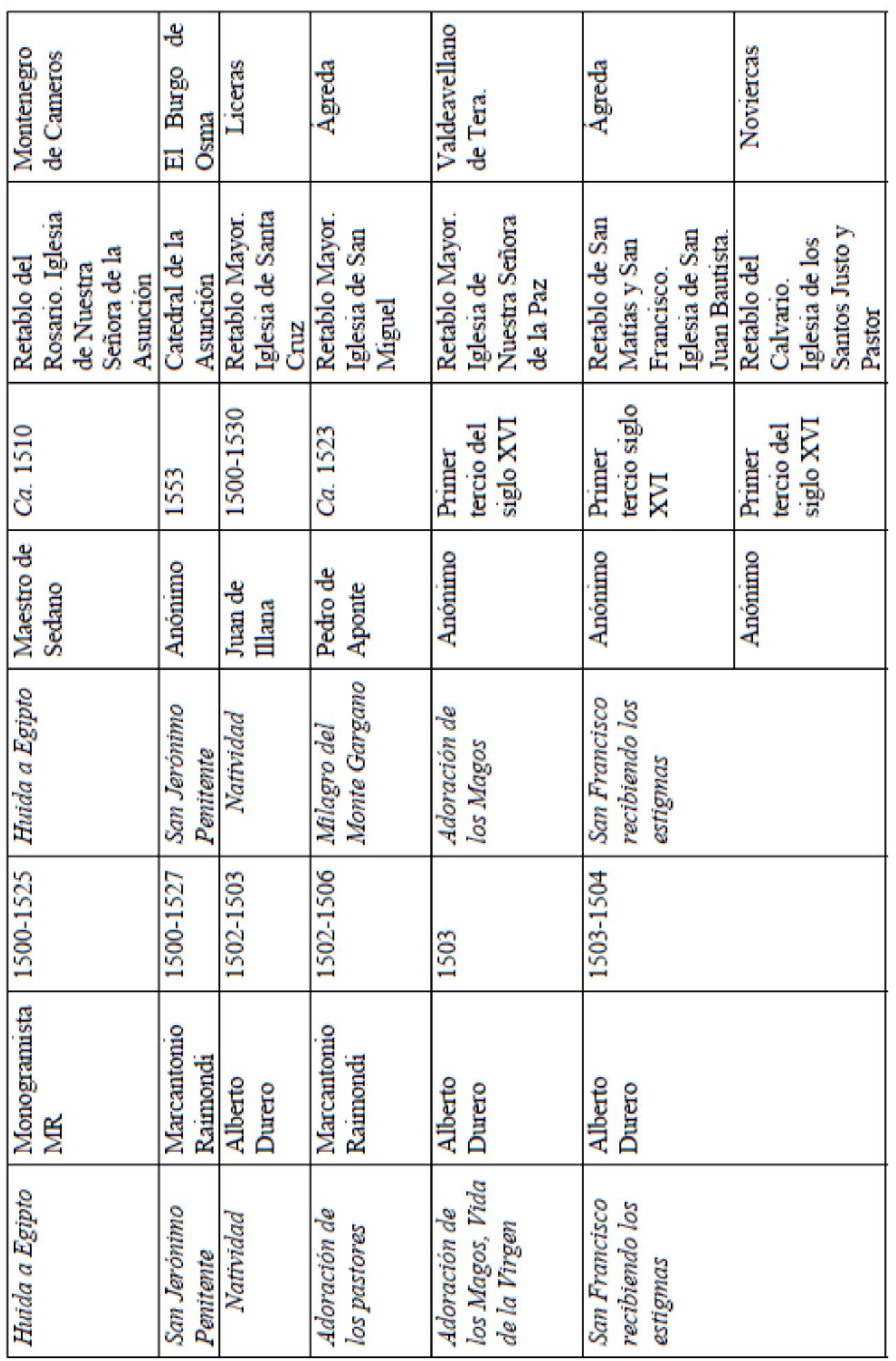




\begin{tabular}{|c|c|c|c|c|c|}
\hline 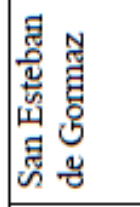 & 莺 & 莴 & 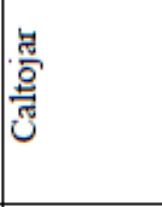 & 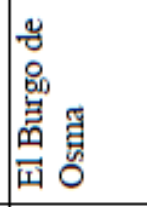 & 苟 \\
\hline 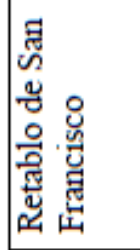 & 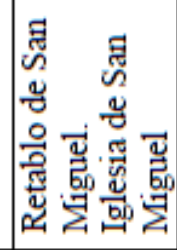 & 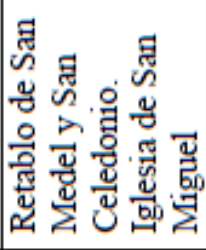 & 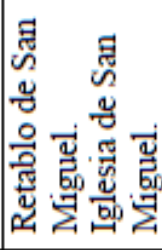 & 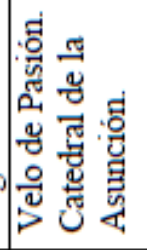 & 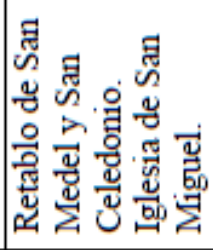 \\
\hline $\begin{array}{l}\stackrel{0}{n} \\
\\
8 \\
\delta\end{array}$ & 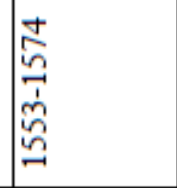 & 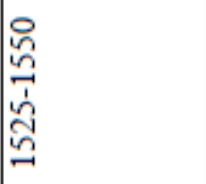 & 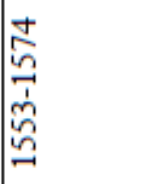 & $\tilde{n}$ & 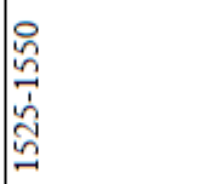 \\
\hline \multirow[t]{5}{*}{ 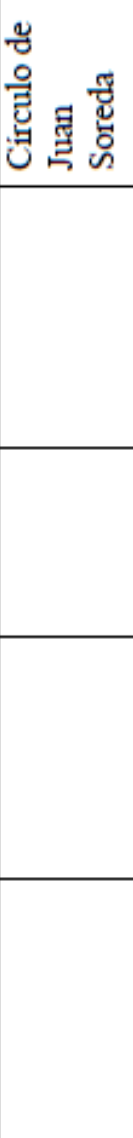 } & 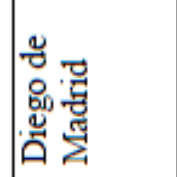 & 禀惢 & 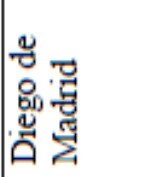 & 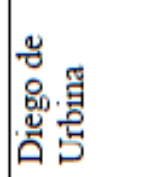 & 貫 \\
\hline & & 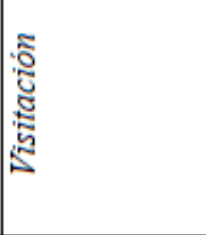 & & 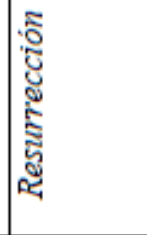 & 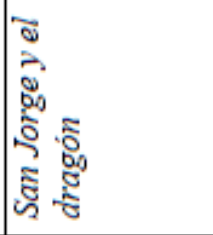 \\
\hline & & 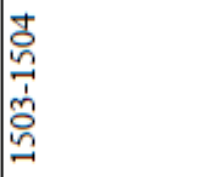 & & 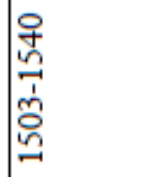 & 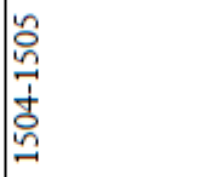 \\
\hline & & 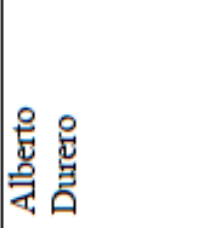 & & 首 & $\begin{array}{l}\text { 壱 올 } \\
\text { 究 }\end{array}$ \\
\hline & & 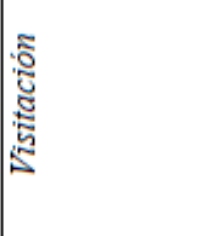 & & 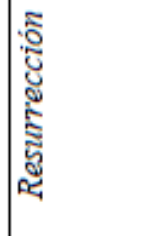 & 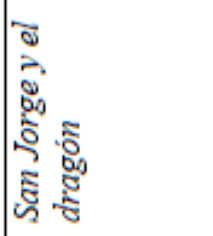 \\
\hline
\end{tabular}




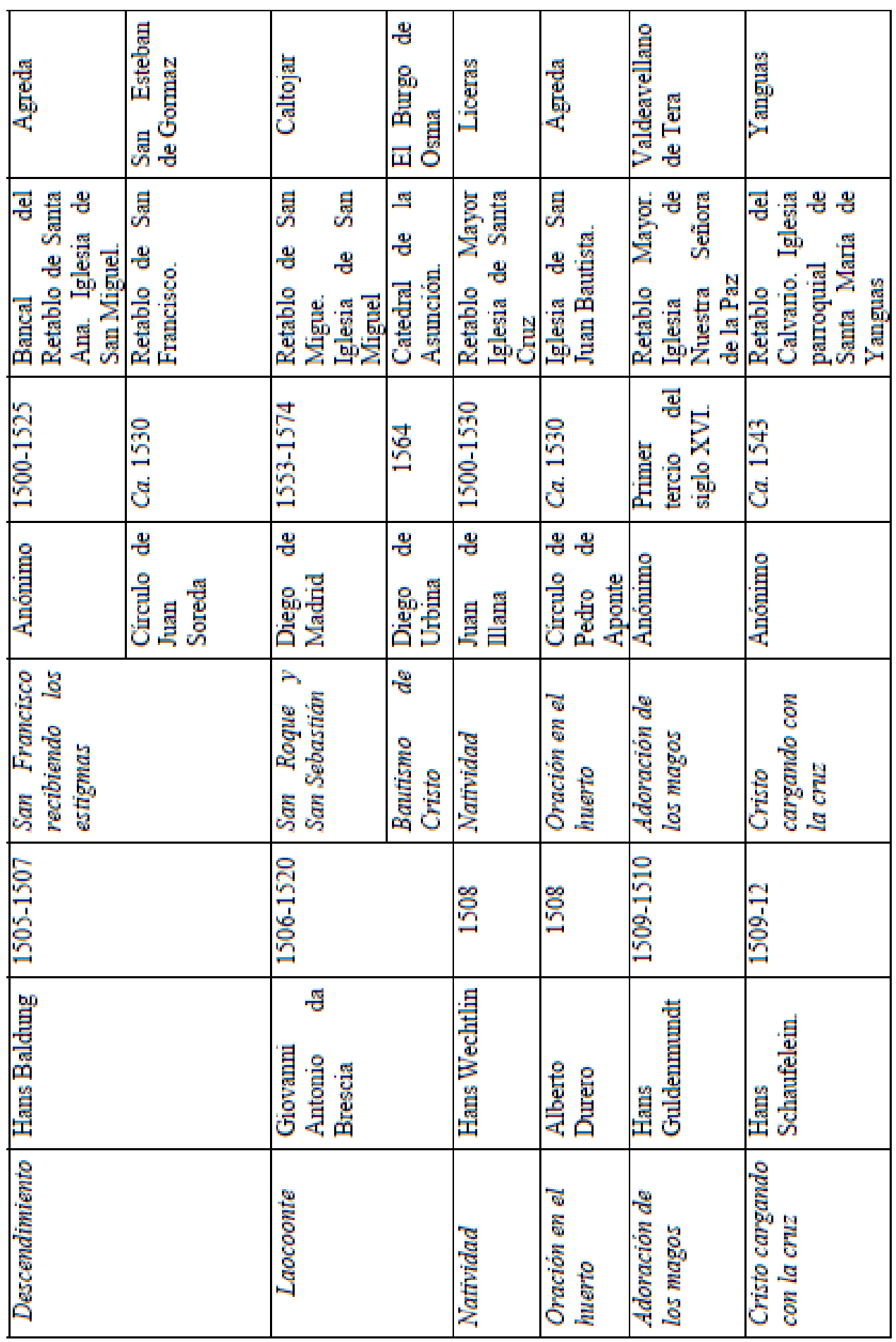




\begin{tabular}{|c|c|c|c|c|c|}
\hline 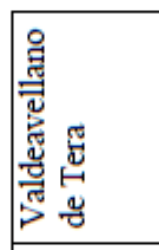 & 䍃 & 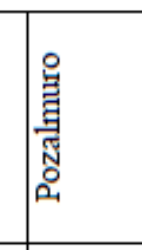 & 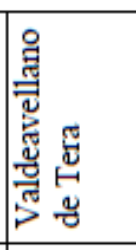 & 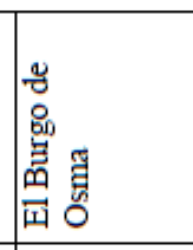 & |: \\
\hline 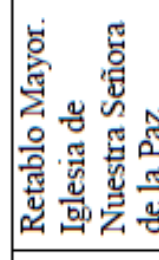 & 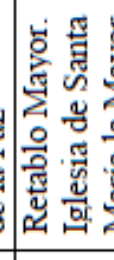 & 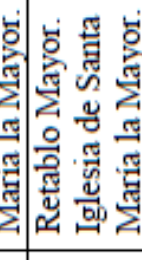 & 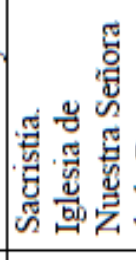 & 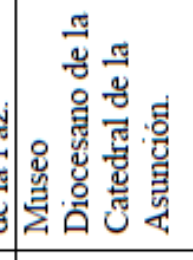 & 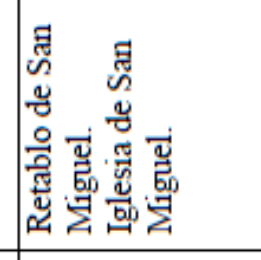 \\
\hline 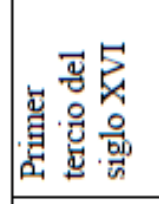 & 蒙 & 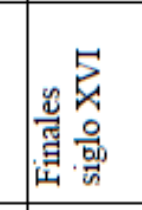 & 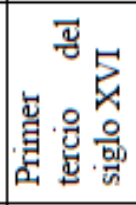 & $\overrightarrow{0}$ & 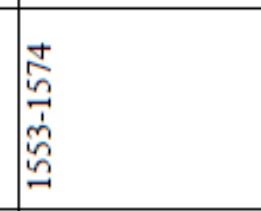 \\
\hline 悬 & 壪 & 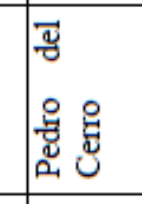 & 直 & 毫 & 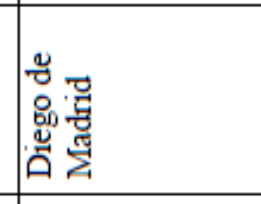 \\
\hline & & 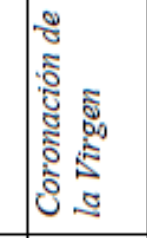 & 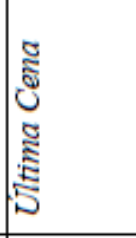 & 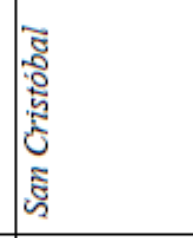 & 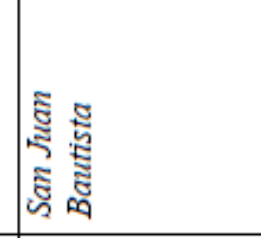 \\
\hline 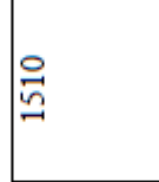 & & $\ddot{D}$ & $\stackrel{2}{2}$ & 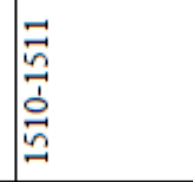 & 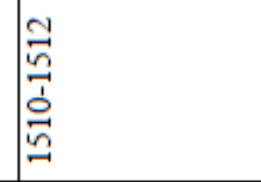 \\
\hline 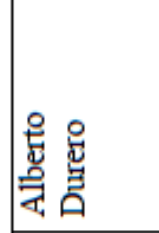 & & 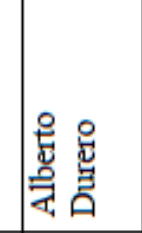 & 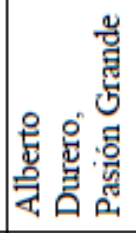 & 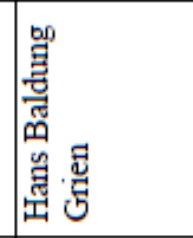 & 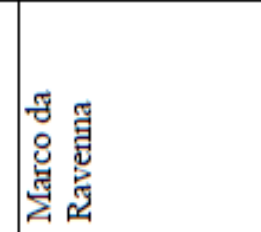 \\
\hline 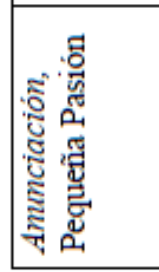 & & 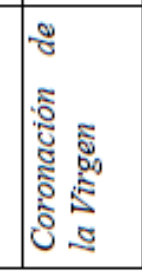 & 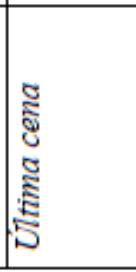 & 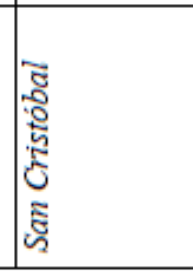 & 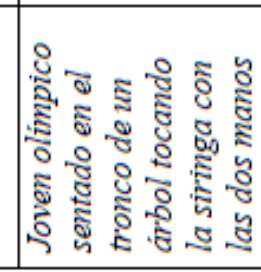 \\
\hline
\end{tabular}




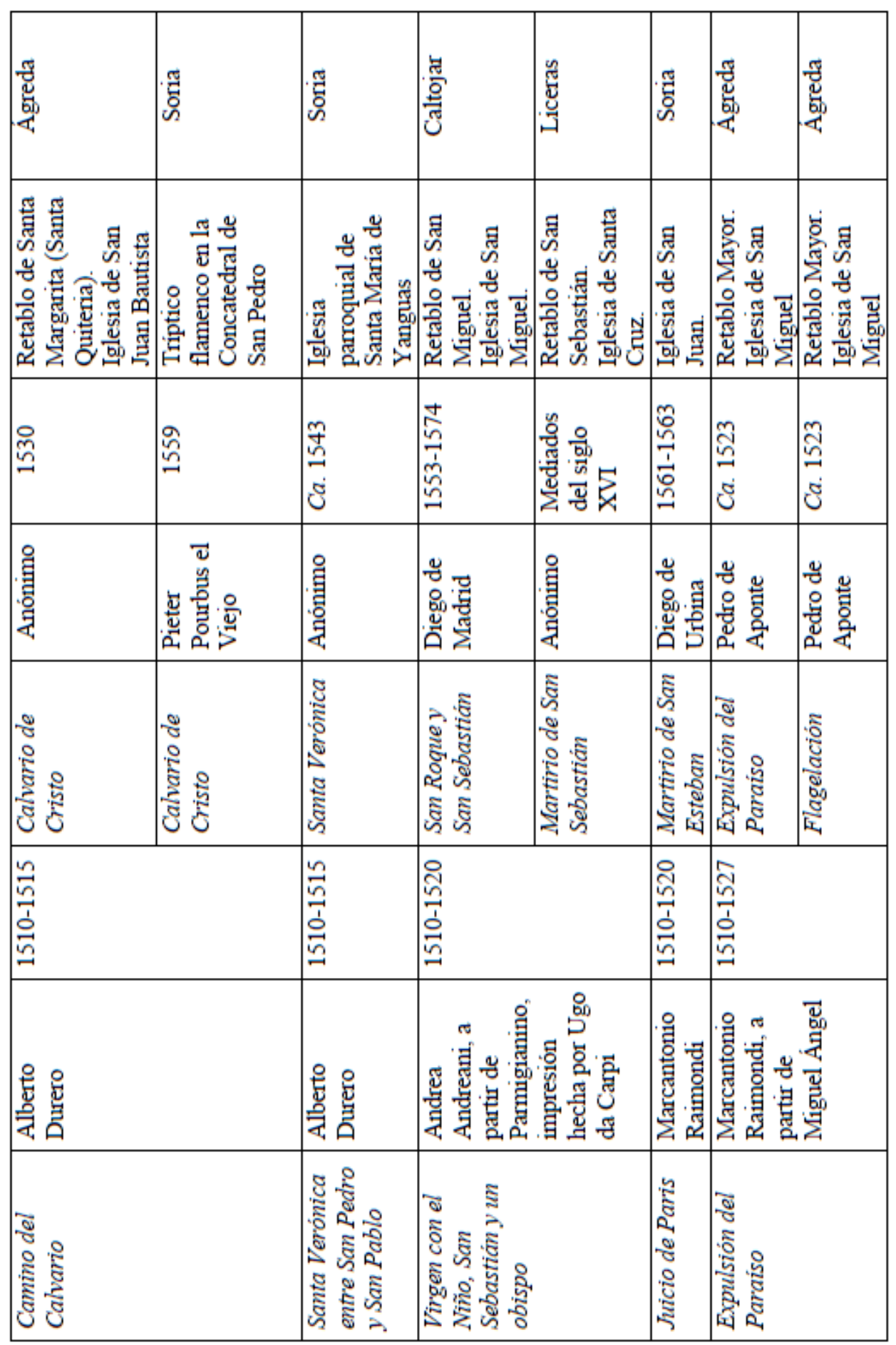




\begin{tabular}{|c|c|c|c|c|c|c|c|}
\hline 茞 & 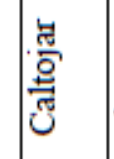 & & 䓤 & 骂 & 菏 & 㺃 & 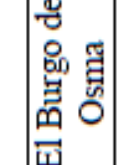 \\
\hline 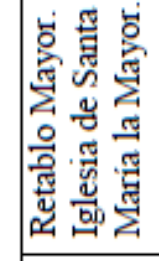 & 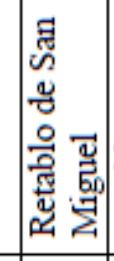 & 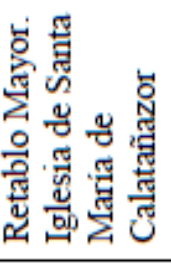 & 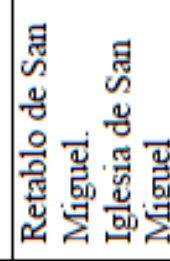 & 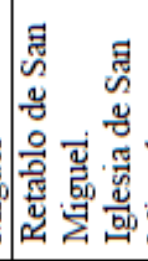 & 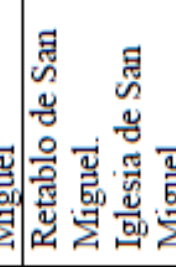 & 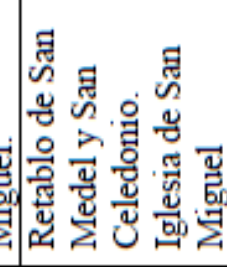 & 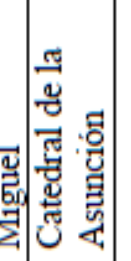 \\
\hline 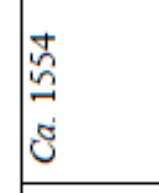 & 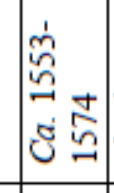 & 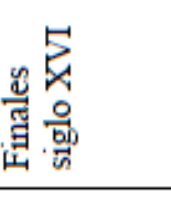 & 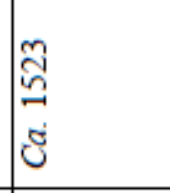 & 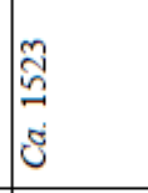 & 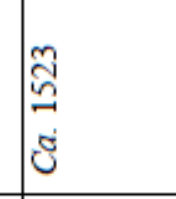 & 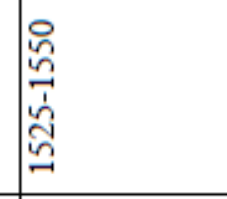 & 饍 \\
\hline 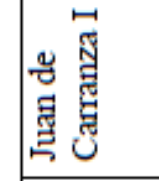 & 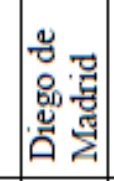 & & 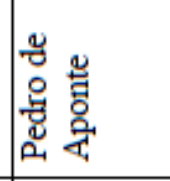 & 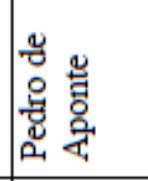 & 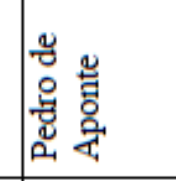 & 毫 & 夏 \\
\hline 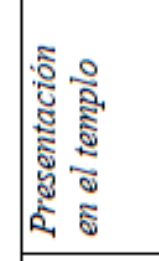 & 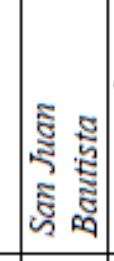 & 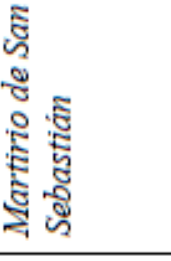 & 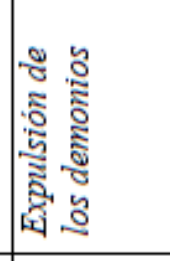 & 愘 & 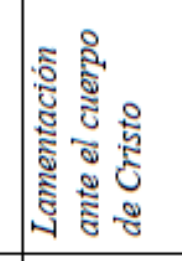 & 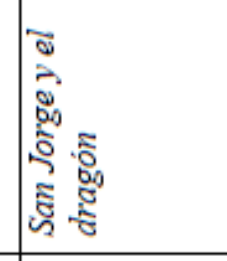 & 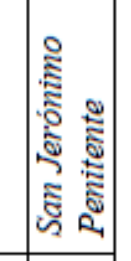 \\
\hline & 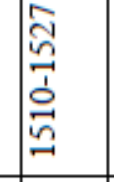 & & $\overrightarrow{\vec{n}}$ & $\overrightarrow{\vec{n}}$ & $\overrightarrow{\vec{I}}$ & $\overrightarrow{\vec{I}}$ & $\overrightarrow{\tilde{\sigma}}$ \\
\hline 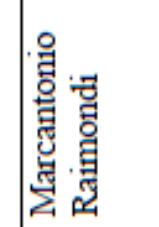 & 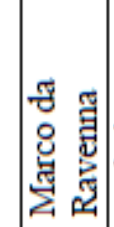 & & 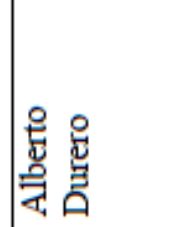 & 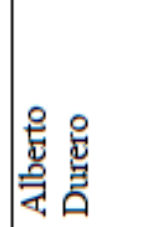 & 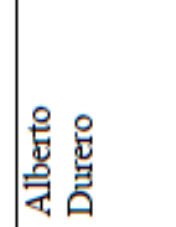 & 离 & 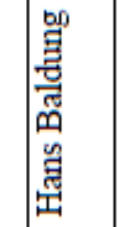 \\
\hline 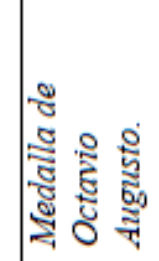 & 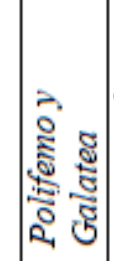 & 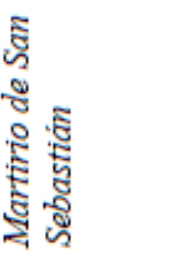 & 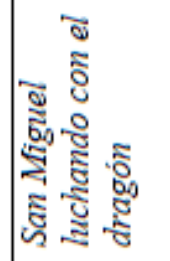 & |0 & हूँ & 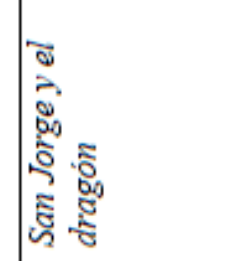 & 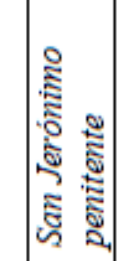 \\
\hline
\end{tabular}




\begin{tabular}{|c|c|c|c|c|c|c|}
\hline 总 & 戀 & | & 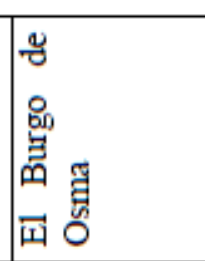 & 䍃 & 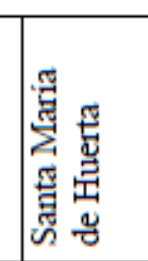 & 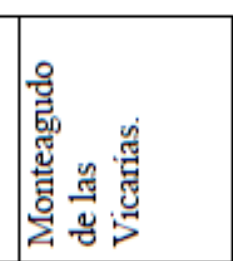 \\
\hline 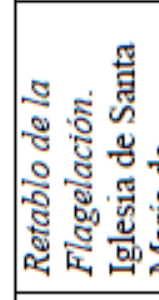 & 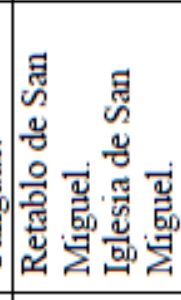 & 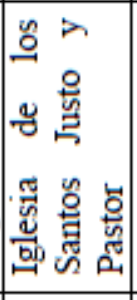 & 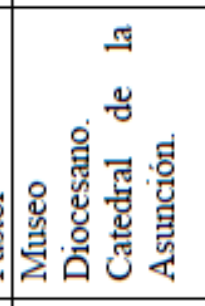 & 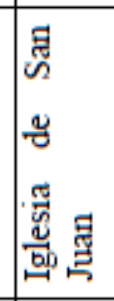 & 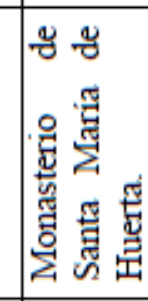 & 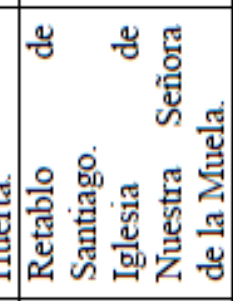 \\
\hline 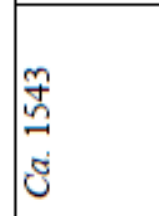 & 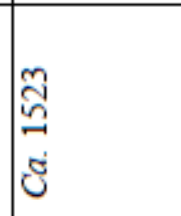 & 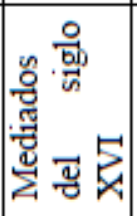 & $\overrightarrow{0}$ & 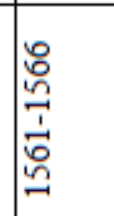 & 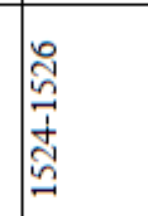 & 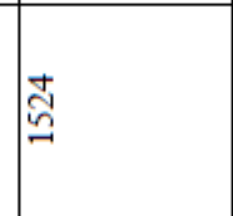 \\
\hline 皦 & 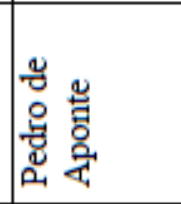 & 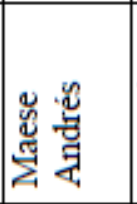 & 臬 & 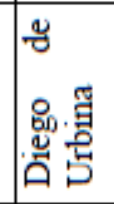 & 恚惫 & 景 \\
\hline 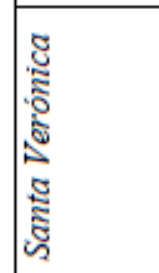 & 范 & & 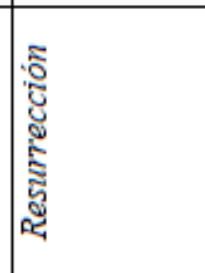 & 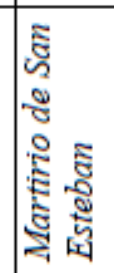 & 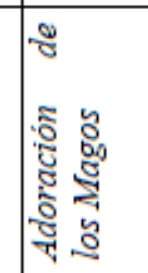 & 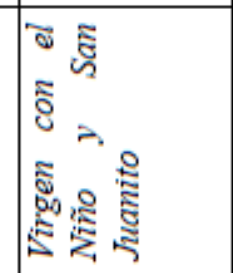 \\
\hline 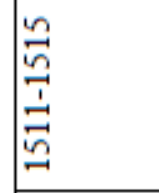 & 곰 & & $\stackrel{ }{\tilde{n}}$ & 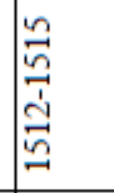 & $\frac{m}{\underline{\Omega}}$ & $\frac{m}{n}$ \\
\hline 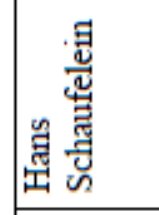 & 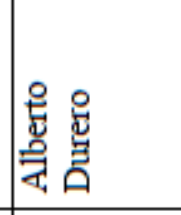 & & 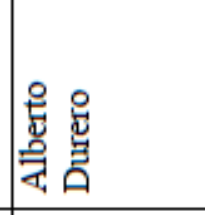 & 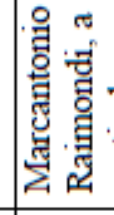 & 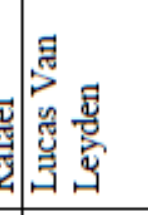 & 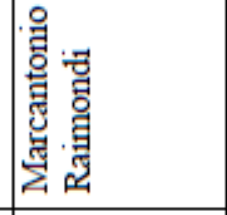 \\
\hline 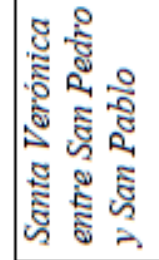 & 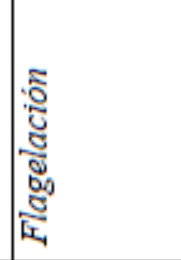 & & 䓂 & 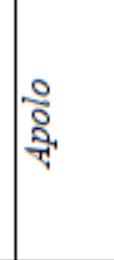 & 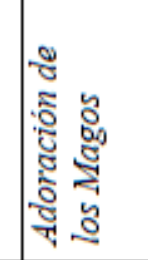 & 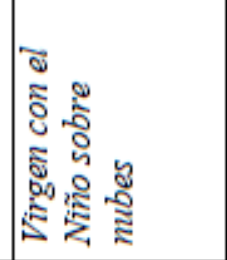 \\
\hline
\end{tabular}




\begin{tabular}{|c|c|c|c|c|c|}
\hline 㺃 & 営 & 愛 & 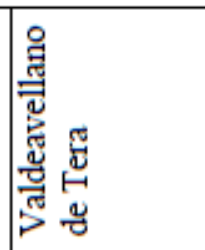 & 䔍 & | \\
\hline 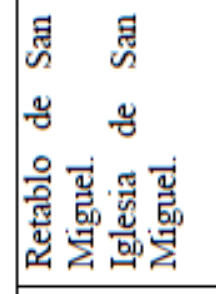 & 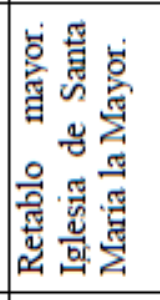 & 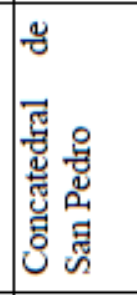 & 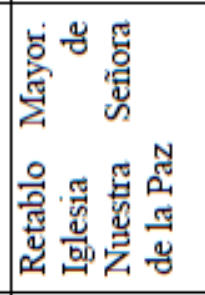 & 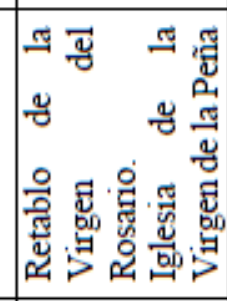 & 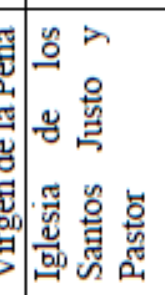 \\
\hline 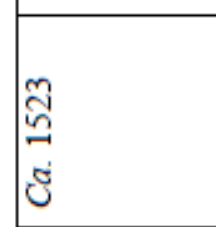 & 莒 & 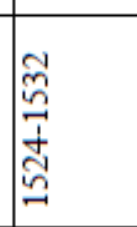 & 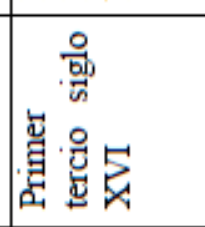 & 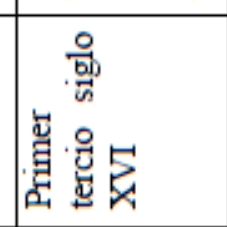 & 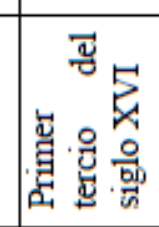 \\
\hline 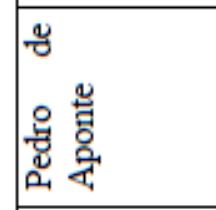 & 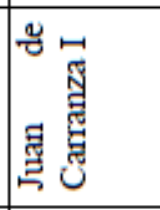 & 慰营 & 氈 & 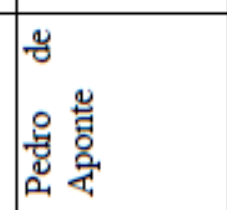 & 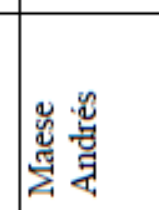 \\
\hline 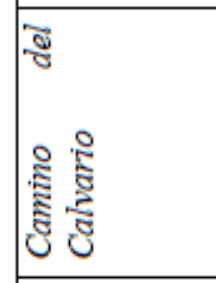 & 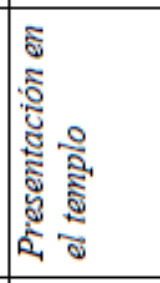 & 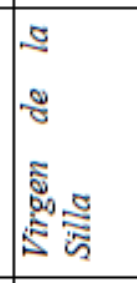 & 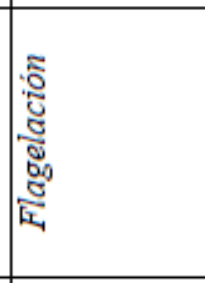 & 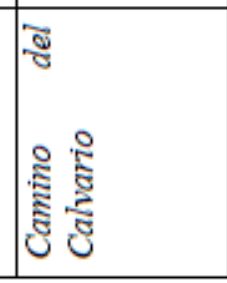 & 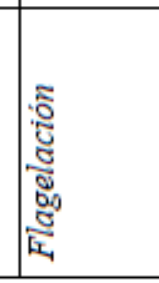 \\
\hline 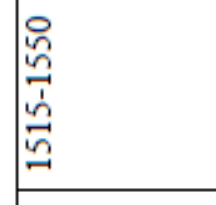 & 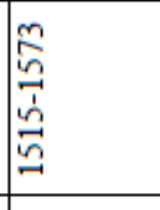 & 足 & $\hat{\vec{\prime}}$ & & \\
\hline 量量 & 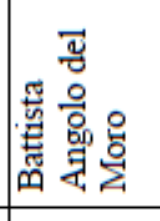 & 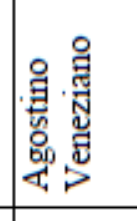 & 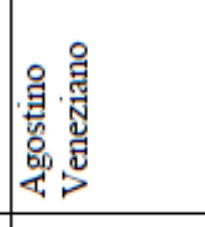 & & \\
\hline 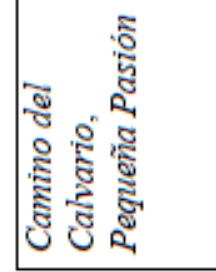 & 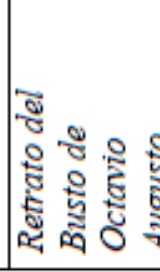 & 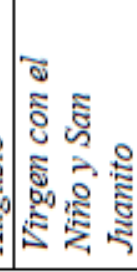 & 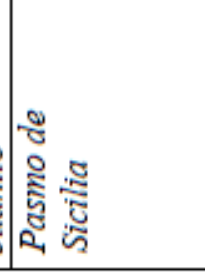 & & \\
\hline
\end{tabular}




\begin{tabular}{|c|c|c|c|c|c|c|}
\hline 㢣 & 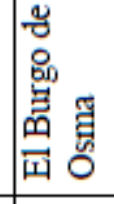 & 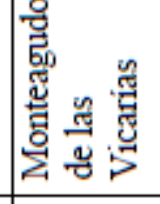 & 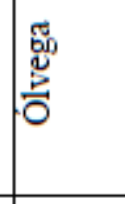 & $\mid$ & 总 & 崫 \\
\hline 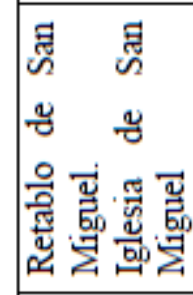 & 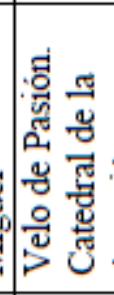 & 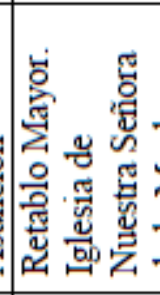 & 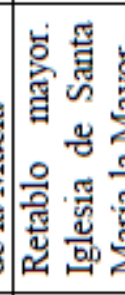 & 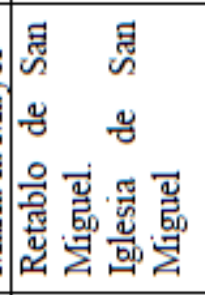 & 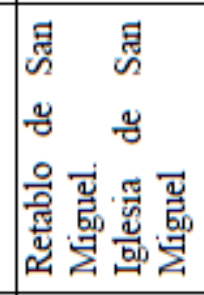 & 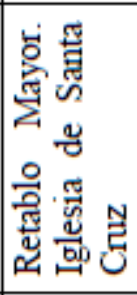 \\
\hline 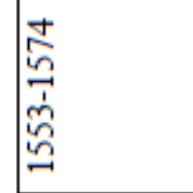 & 会 & 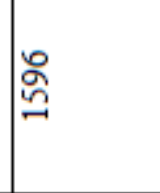 & 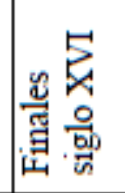 & 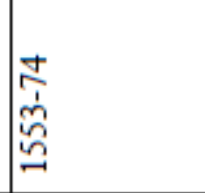 & 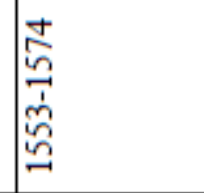 & 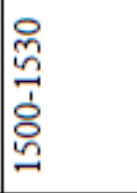 \\
\hline 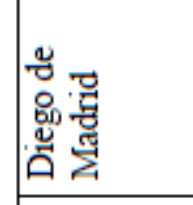 & 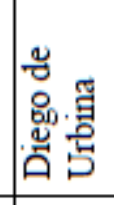 & 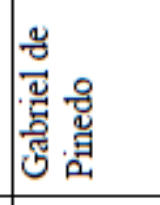 & 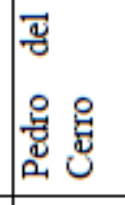 & 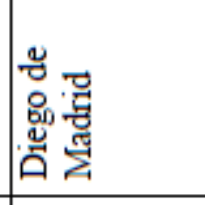 & 亭 & 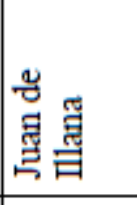 \\
\hline 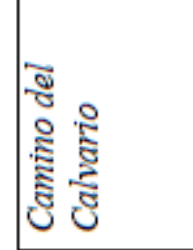 & 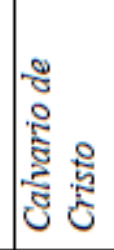 & 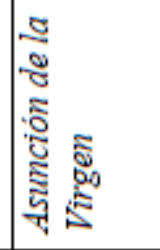 & 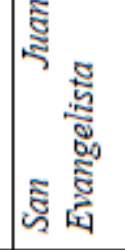 & 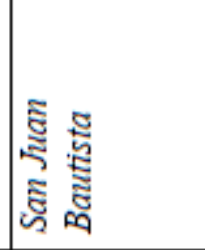 & 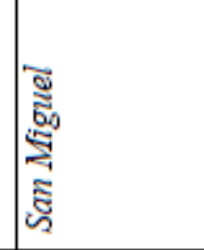 & 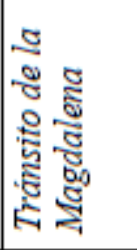 \\
\hline & & $\hat{\tilde{\Xi}}$ & 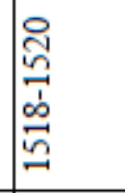 & 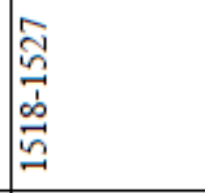 & 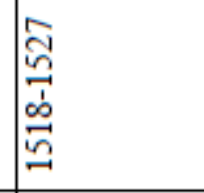 & 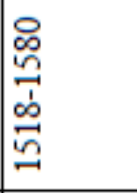 \\
\hline & & 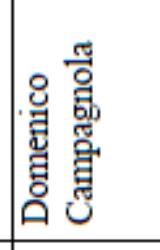 & 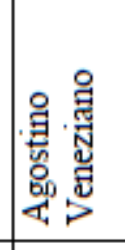 & 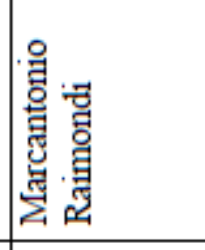 & 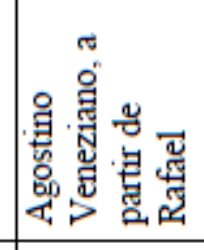 & 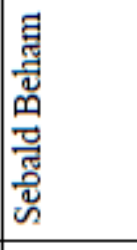 \\
\hline & & 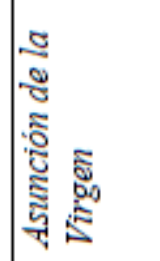 & 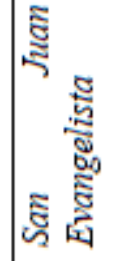 & 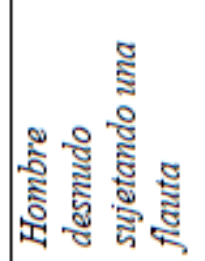 & 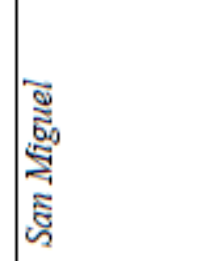 & : \\
\hline
\end{tabular}




\begin{tabular}{|c|c|c|c|c|c|c|c|}
\hline 遌 & 葋 & 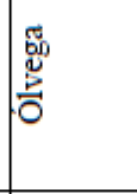 & 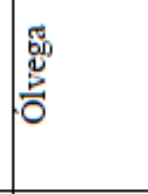 & 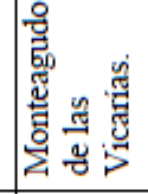 & 蝟 & 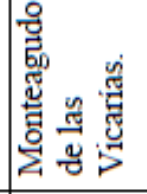 & 鄫 \\
\hline 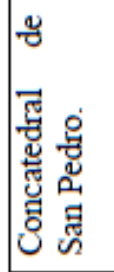 & 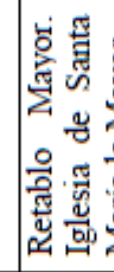 & 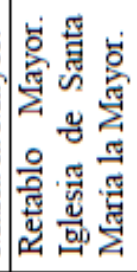 & 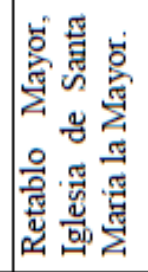 & & 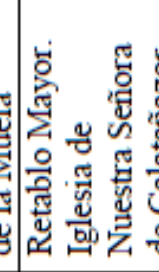 & 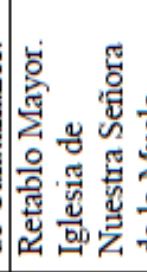 & 苟 \\
\hline$\frac{1}{\square}$ & 蒙 & 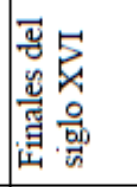 & 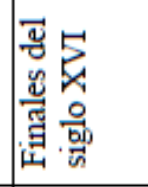 & 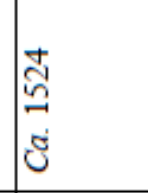 & 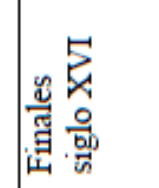 & 然 & 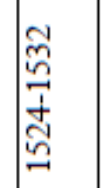 \\
\hline 恶营 & 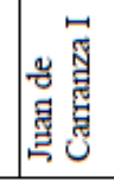 & 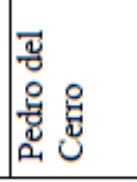 & 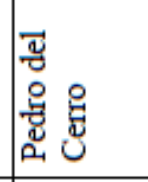 & 管 & 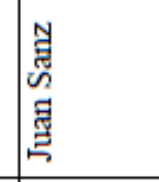 & 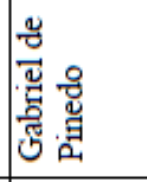 & 量婄 \\
\hline & & & 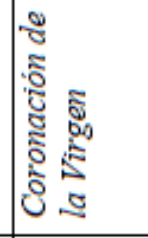 & 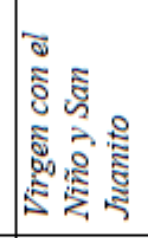 & 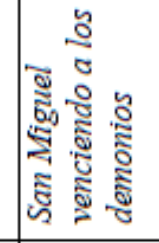 & 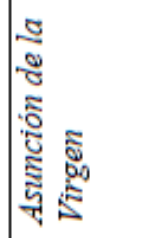 & 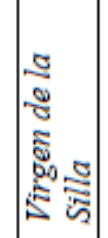 \\
\hline & & & స్రి & 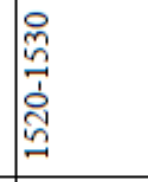 & 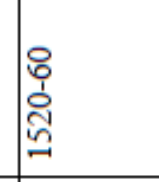 & 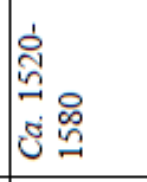 & $\begin{array}{l}0 \\
0 \\
0 \\
0 \\
\end{array}$ \\
\hline 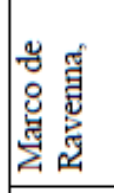 & & & 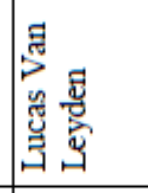 & 譄: & 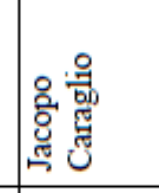 & 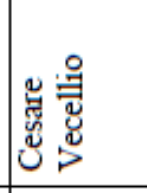 & 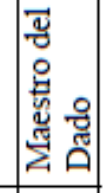 \\
\hline & & & 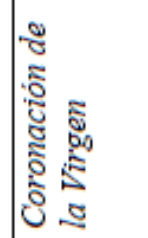 & 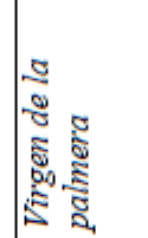 & 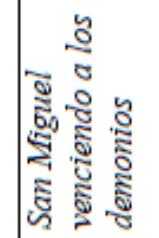 & 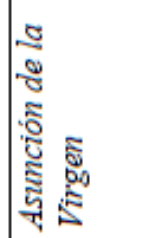 & 害 \\
\hline
\end{tabular}




\begin{tabular}{|c|c|c|c|c|c|c|c|}
\hline & 孚 & 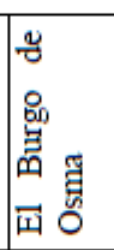 & . & 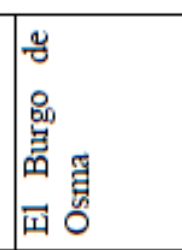 & 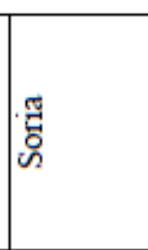 & 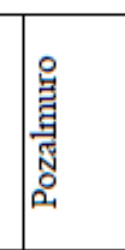 & 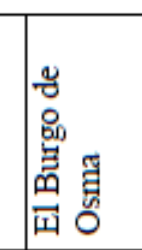 \\
\hline 䔅: & 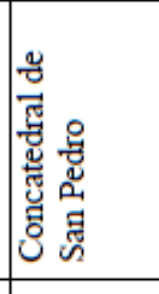 & 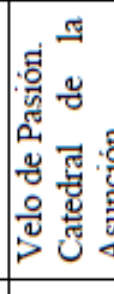 & 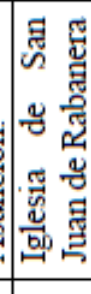 & 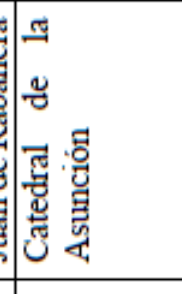 & 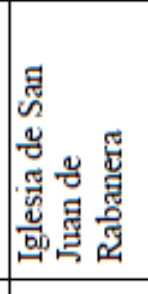 & 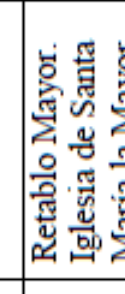 & 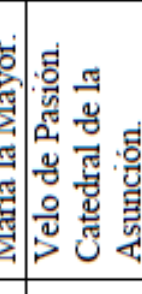 \\
\hline 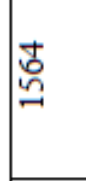 & 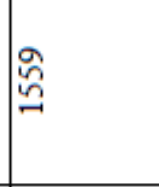 & 苔 & 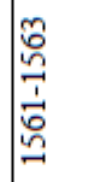 & 营 & 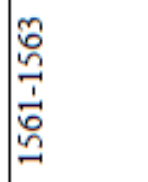 & 岕 & 总 \\
\hline 8 & 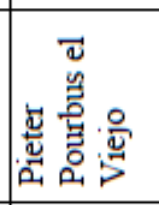 & 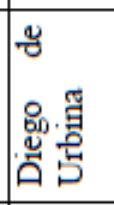 & 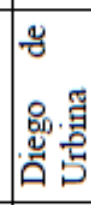 & \begin{tabular}{|l|l} 
\\
8 \\
8 \\
8
\end{tabular} & 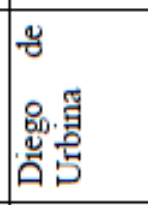 & 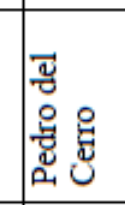 & 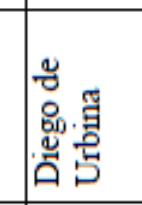 \\
\hline & 童密 & 量递 & 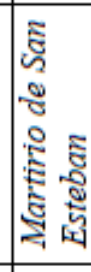 & 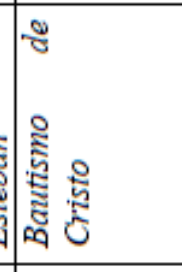 & 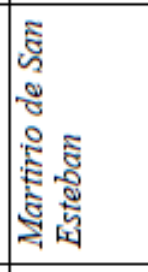 & 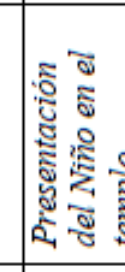 & 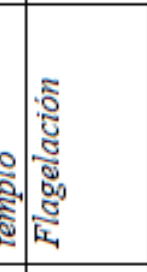 \\
\hline 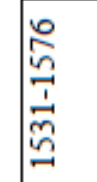 & 䬰 & 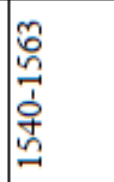 & 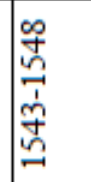 & 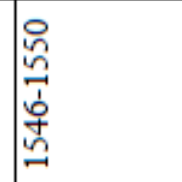 & 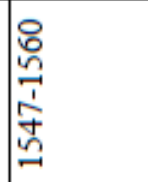 & 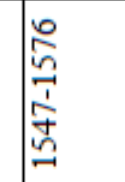 & 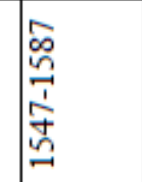 \\
\hline 呅 & & 总 & 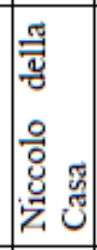 & 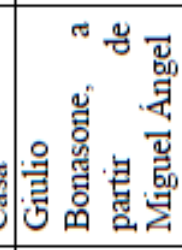 & 圎 & 這善 & 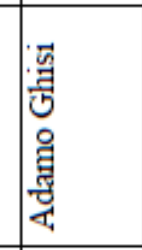 \\
\hline 结 & 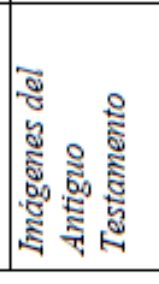 & 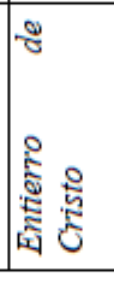 & 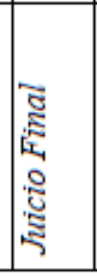 & 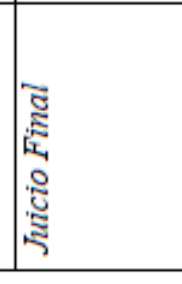 & 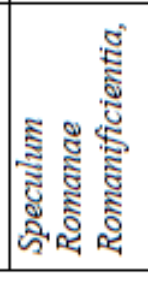 & 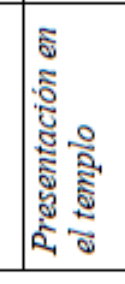 & 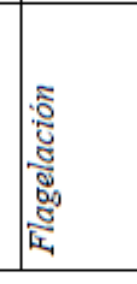 \\
\hline
\end{tabular}




\begin{tabular}{|c|c|c|c|c|c|}
\hline 㖞 & 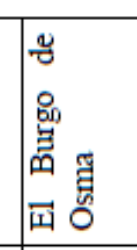 & 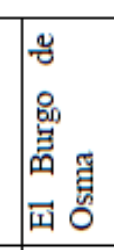 & | & 㺃 & 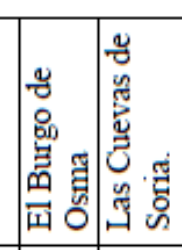 \\
\hline 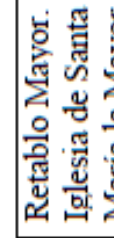 & $\begin{array}{l}0 \\
0 \\
0\end{array}$ & 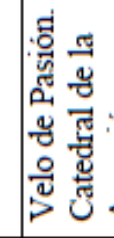 & 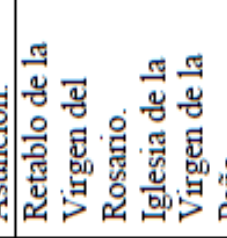 & 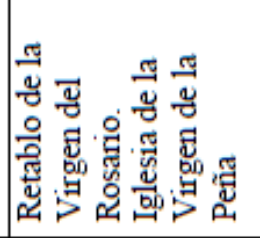 & 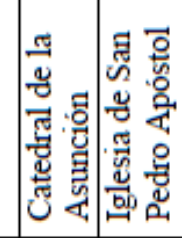 \\
\hline 蒿 & $\tilde{\tilde{n}}$ & $\tilde{\tilde{n}}$ & 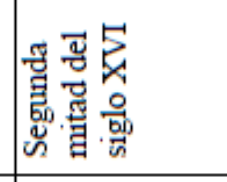 & 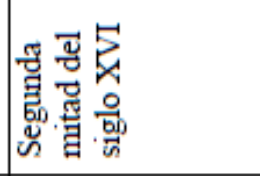 & 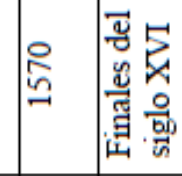 \\
\hline 舃 & 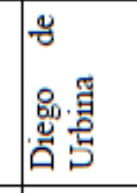 & 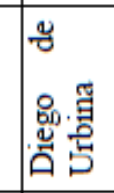 & 亭 & 䆃 & 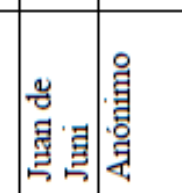 \\
\hline 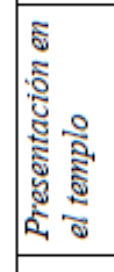 & 彦 & 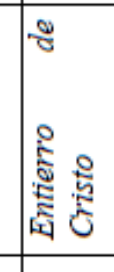 & 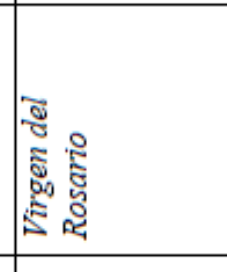 & 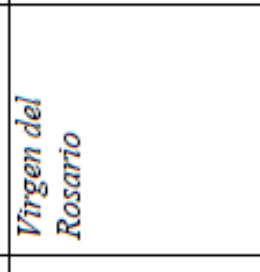 & 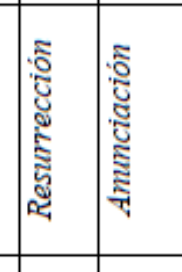 \\
\hline$\left[\begin{array}{l}n \\
2\end{array}\right.$ & 㗊 & 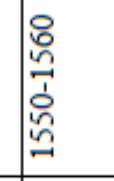 & 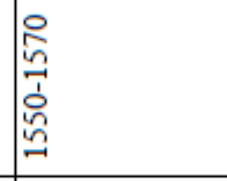 & 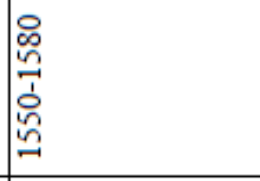 & 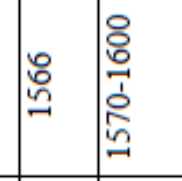 \\
\hline $3 n$ & 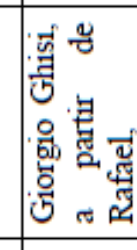 & 总 & 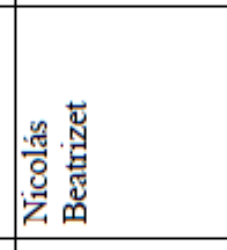 & 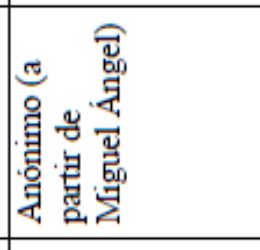 & 惑 \\
\hline 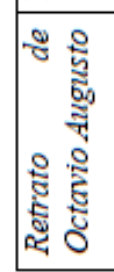 & : & 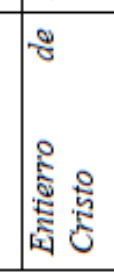 & 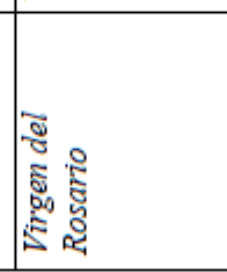 & 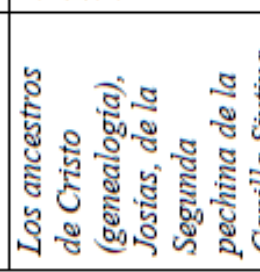 & 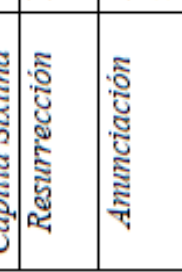 \\
\hline
\end{tabular}




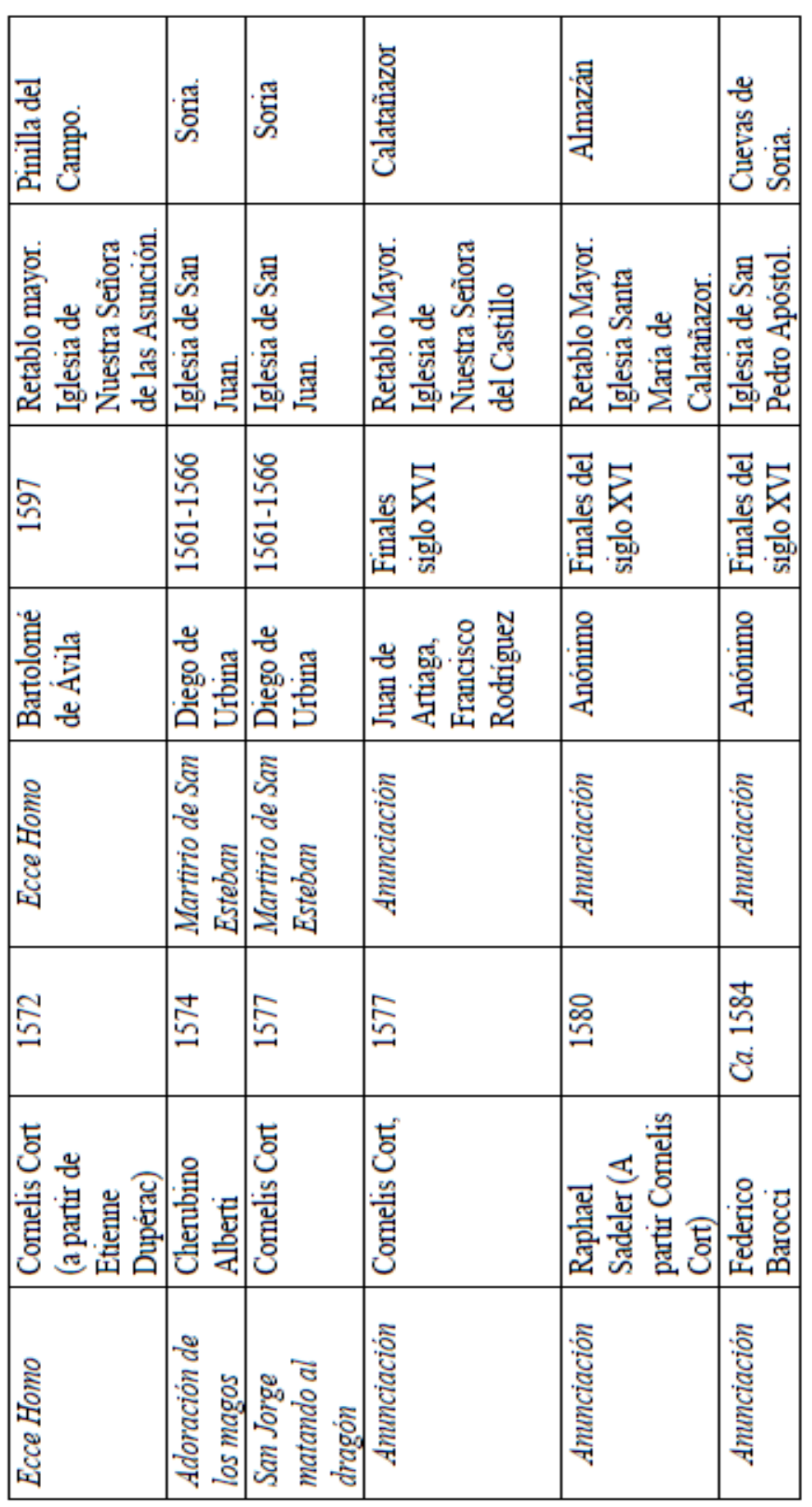




\section{CONCLUSIONES}

A modo de conclusión, podríamos decir que la influencia de las estampas en la actual provincia soriana se extendió desde los albores del siglo XVI hasta los últimos años del mismo. El tema ha sido tratado en relación a otras zonas de España como pueden ser Andalucía y Aragón. En estas provincias podemos observar que se sigue un orden semejante a la hora de usar grabados, sobre todo en el caso de Aragón (según han estudiado Carmen Lacarra y Carmen Morte), con el que la provincia de Soria compartía ciertas semejanzas a la hora de utilizar las estampas debido a su cercanía.

Comenzó en la zona de Ágreda, especialmente en obras de carácter aún gótico que se vieron influenciadas por las obras de grabadores generalmente alemanes de finales del siglo XV. Ejemplo de ello sería el banco de Nuestra Señora de la Peña o el retablo de San Lorenzo en la iglesia de Nuestra Señora de los Milagros. Así pues, podemos decir que este influjo entró en primer lugar en la zona a través de Aragón, cuyas imprentas eran famosas por sus artistas alemanes. Sin dejar de lado Ágreda, son importantes así mismo algunos ejemplos que se localizan al norte de la provincia, como el caso de Montenegro de Cameros, muy cercano a la Rioja, y donde también predominaba la influencia nórdica, debido al comercio. Otro ejemplo situado al norte sería el de Valdeavellano de Tera, en el cual también se observa la huella de grabados alemanes como los de Durero o el Maestro E. S. Además, el Maestro de Osma, uno de los pintores más importantes de la zona a principios del siglo XVI, también hizo uso de estampas, como se puede observar en algunas miniaturas (Monasterio de la Espeja).

Esta influencia culminó a finales del siglo XVI con obras pictóricas como la de Las Cuevas de Soria, o escultóricas en los retablos de las parroquias Almazán, Ólvega, Monteagudo de las Vicarías o Pozalmuro. Si se observan los ejemplos, se puede afirmar que el uso de estampas se ha extendido por toda la provincia, aunque curiosamente se encuentran al final del siglo más ejemplos escultóricos que pictóricos. Probablemente esto sea debido a que hasta finales de siglo no se comenzaron a construir los primeros retablos romanistas. Durante estos últimos años predominó la influencia italiana sobre la nórdica, aunque todavía se usaron con bastante frecuencia las estampas de maestros como Durero.

En cuanto a los grabados más utilizadas, en general son las de Schongauer, a finales del siglo XV y principios del siglo XVI, si bien su uso se extendió a veces hasta mediados del siglo. De Schongauer fue especialmente importante la estampa de la 
Natividad, que aparece en lugares tan dispares como Ágreda y Montenegro de Cameros, o la del Prendimiento de Cristo, la cual es usada en dos ocasiones en Ágreda. Posteriormente predominaron las de Alberto Durero y Marcantonio Raimondi, ya desde las primeras décadas del siglo XVI. En el caso de Alberto Durero, sus composiciones más frecuentes son por un lado San Francisco recibiendo los estigmas, que se dio en lugares como Ágreda, San Esteban de Gormaz o Noviercas, o la Anunciación, que ha sido muy utilizada en localidades como Valdeavellano de Tera o en Soria capital, en el Retablo de Santa María la Mayor, así como su Camino al Calvario, en sus distintas versiones, con ejemplos como el Retablo de Santa Quitería o de San Miguel, ambos en Ágreda, o el Tríptico flamenco de la Concatedral de San Pedro.

Otro grabador muy influyente fue Marcantonio Raimondi, cuyo influjo comienza en Valdeavellano de Tera, en la tabla de la Flagelación, y que culminó en obras como la pintura de El martirio de San Esteban en la parroquia de San Juan en Soria. Sus obras más importantes son El Pasmo de Sicilia inspirado en la pintura de Rafael o sus Vírgenes con el Niño, de las cuales a muchas versiones Además, en cuanto a grabadores italianos es reseñable también la estampa de Marco Dente de la Anunciación que fue utilizada en varias ocasiones.

En algunos casos hay documentación que testifica que realmente los artistas poseían estampas (Juan Soreda, Juan de Juni, Juan Sanz, Bartolomé de Ávila, Gabriel de Pinedo), sin embargo, hay otros sobre los que hay grandes lagunas documentales y es imposible saber con certeza si las poseían o no.

La mayoría de las veces los grabados se usaron para plasmar de manera íntegra la escena, o al menos algunos de los personajes principales. Tan sólo algunas pocas se utilizaron con la intención de basarse en algunos detalles o en la arquitectura o el paisaje.

Como se deduce de la tabla, los grabados más utilizados fueron en primer lugar el Pasmo de Sicilia, el cual se empleó para cinco composiciones diferentes. Comenzó su uso a principios del siglo XVI en obras como las pinturas de la iglesia de Nuestra Señora de la Paz de Valdeavellano de Tera y culminó a mediados de siglo con su empleo en el Velo de Pasión de la Catedral de Burgo de Osma. Se trata de una obra, originalmente de la mano de Rafael, muy difundida tanto de manera íntegra, como tomando tan sólo algunas de las figuras. De especial importancia ha resultado la figura que tira de Cristo con una cuerda y que aparece de espaldas. Otros elementos muy 
copiados son las figuras que aparecen al fondo de la composición, tanto los caballos, como los soldados que aparecen portando un estandarte.

Otra de las estampas más usadas fue la de San Francisco recibiendo los estigmas de Durero. Al igual que la anterior, su uso se inició a principios del siglo XVI, finalizando casi en el último tercio del siglo XVI. Fundamentalmente se empleó para la figura del santo con una rodilla flexionada y mostrando las palmas de las manos. En otros casos, la estampa sirvió de inspiración para la otra figura que aparece dormitando a la izquierda de la composición, o incluso para el paisaje boscoso que rodea la escena.

En tercer lugar, podríamos colocar la Anunciación de Marco de Rávena, también utilizada en tres casos. Su empleo se desarrolló durante todo el siglo. Se trata de una composición que sirve de modelo tanto para las figuras del ángel o de la Virgen, como para la composición del interior en el cual se desarrolla la escena. Especial relevancia tiene en este sentido la cama con doseles redondeados junto a la cual se sitúa la Virgen.

Por su origen, los primeros grabados en emplearse son los alemanes del siglo XV (Maestro E. S. y Schongauer), iniciándose su uso a partir de inicios de siglo hasta casi mediados de siglo. Junto a estos grabados alemanes aparecieron las primeras estampas italianas, en este caso las primeras en llegar son las florentinas del siglo XV, como las de Francesco Rosselli.

Un poco más tarde, se difundieron los primeros grabados de Durero. Junto con los de Marcantonio Raimondi y Schongauer fueron éstos los más utilizados. Las estampas de Durero comenzaron a ser usadas a partir de la década de 1520 extendiéndose su uso hasta la década de 1560 aproximadamente. También en esta época comenzaron a llegar los de Marcantonio Raimondi, Marco de Ravenna o Lucas de Leyden.

Durante los últimos decenios del siglo XVI predominaron los italianos, especialmente de grabadores como Parmigianino, Giorgio Ghisi o Giulio Bonasone. En estas últimas décadas también destaca la figura de Cornelis Cort, que dentro de los grabadores flamencos fue el más manejado.

Como ya se ha señalado anteriormente quedan muchas lagunas y obras por investigar debido a la gran cantidad de patrimonio desconocido. Sin duda esta Tesis contribuye un poco a iniciar un camino de investigación que podría ampliarse muchísimo más. La ausencia de un inventario sistemático de obras de la provincia soriana dificulta mucho la búsqueda de pinturas y esculturas que pudieran estar inspiradas en grabados. 
De hecho, aunque esta Tesis esté dedicada al siglo XVI, con toda seguridad el fenómeno prosiguió y dejó ejemplos en los siglos posteriores. Los siglos XVII y XVIII, aunque menos abundantes en su producción artística, resultarían también sin duda atractivos para ser investigados desde el punto de vista de la influencia de las estampas.

Por último se debería señalar la relevancia de recuperar y poner en relieve muchas de las obras que aparecen en esta Tesis, muchas de las cuales son prácticamente desconocidas y cuya importancia debería ser señalada. 


\section{BIBLIOGRAFÍA GENERAL Y RELACIONADA}

ABAD ZAPATERO, J. G., y ARRANZ ARRANZ, J., La Catedral de Burgo de Osma. Guía Turística, Soria, 1981.

Las iglesias de Aranda, Burgos, Caja de Ahorros Municipal de Burgos, 1989.

AGUERRI, F., La Catedral de Tarazona. Plan director y restauración: catálogo de la exposición semipermanente en el claustro, Tarazona, Fundación Tarazona Monumental, 2012.

ÁlVAREZ CLAVIJO, M. T., Logroño en el siglo XVI. Arquitectura y urbanismo, Logroño, Instituto de Estudios Riojanos, 2003.

ANGUlO IÑÍGUEZ, D., Pintura del Renacimiento, en Ars Hispaniae, vol. XIII, Madrid, Plus-Ultra, 1954.

ARIAS MARTÍNEZ, M., “A propósito de Juan de Juni y las estampas de Baccio Bandinelli”, Boletín de la Real Academia de Bellas Artes de la Purísima Concepción de Valladolid, $\mathrm{n}^{\circ}$ 48, 2013, pp. 27-34.

"La fortuna de los grabados de Sadeler en el ámbito leonés. Algunos ejemplos de su seguimiento en escultura y pintura entre los siglos XVI y XVII", De Arte, Vol. I, 2002, pp. 89-106.

"Revisando a Juan de Juni en San Marcos de León. Fuentes y modelos", Boletín de la Real Academia de Bellas Artes de la Purísima Concepción de Valladolid, $\mathrm{n}^{\circ}$ 43, 2008, pp. 9-34.

ARIAS MARTÍNEZ, M. Y HERNÁNDEZ REDONDO, J. I., Juan Picardo (1506-c. 1576), Medina del Campo, Fundación Museo de las Ferias, 2016.

AZCÁRATE, J. M., Arte gótico en España, Ediciones Cátedra: Madrid, 1990.

Escultura del siglo XVI, Ars Hispaniae, vol. 13, Madrid, Plus-Ultra.

ÁVILA PADRÓN, A., “A propósito de un Descendimiento del Maestro de Becerril y su modelo gráfico", Boletín del Seminario de Arte y Arqueología, t. 55, 1989, pp. 385-391.

"La Virgen con el Niño y las almas del purgatorio de Pedro Machuca y su vinculación italiana", Archivo Español de Arte, t. LXXXV, n 338, 2012, pp. 125146.

"Repercusión de la batalla de Cascina en la pintura española del primer Renacimiento", Goya. Revista de Arte, no 190, 1986, pp. 194-201.

BALAGUER SÁNCHEZ, F., "Pintores zaragozanos, en protocolos notariales de Huesca", Seminario de Arte Aragonés, n 6, 1954, pp. 77-89.

BARRIO LOZA, J. A., Escultura romanista en la Rioja, Madrid, Ministerio de Cultura, 1981.

BARTRUM, G., German Renaissance Prints, 1490-1550, Londres, BMP, 1995.

BENÍTEZ MORIANA, S., "Historia de la imprenta en Aragón”, 2014. Disponible en http://digital.csic.es/bitstream/10261/107569/1/Benitez_Historia\%20de\%201a\%20 imprenta\%20en\%20Arag\%C3\%B3n.pdf (consultado en 6/12/19). 
BIERENS DE HAAN, J. C. J., L'ouvre gravé de Cornelis Cort, graveur hollandais 1553-1578, La Haya, 1948.

BOORSCH, S., y SPIKE, J., The Illustrated Bartsch. 31, Italian artists of the sixteenth century, New York, Abaris Books, 1978.

BOSCH CANTALLOPS, M., Contribución al estudio de la imprenta en Valencia en el siglo XVI, Tesis Doctoral inédita defendida en la Universidad Complutense, 1989.

BRASAS EGIDO, J. C., "La pintura en la diócesis de Osma-Soria”, en Arte e Historia en la Diócesis de Osma, Burgo de Osma, Ayuntamiento de Burgo de Osma, 1990, pp. 183-204.

BRASAS EGIDO, J. C., "Pintura", en VV. AA., Historia del Arte de Castilla y León, t. V: Renacimiento y Clasicismo, Valladolid: Consejería de Cultura y Turismo, 1996,

CAMÓN AZNAR, J., La pintura medieval español, Summa Artis, vol. 22, Madrid, Espasa Calpe, 1966.

La pintura española del siglo XVI, Summa Artis, vol. 2, Madrid, Espasa Calpe, 1966.

CARMONA MUELA, J., Iconografía de los santos, Ediciones Istmo, Madrid, 2003.

CARRETE PARRONDO, J., El grabado en España: siglos XV al XVIII (Summa Artis, tomo XXXI), Madrid, Espasa Calpe, 1987.

CASTILLEJO BENAVENTE, A., La imprenta en Sevilla en el siglo XVI: (1521-1600), Sevilla: Editorial Universidad de Sevilla, 2019.

CASTILlÓN, J. F., La Catedral de Calahorra: un baptisterio para un martirio, Trobajo del Camino, Edilesa, 2000, p. 27.

CEÁN BERMÚDEZ, J. A., Colección lithográphica de cuadros del Rey de España el Señor Don Fernando VII. Obra dedicada a S: M. lithographiada por hábiles artistas bajo la dirección de D. José de Madrazo, Madrid, 1826.

COLLAR DE CÁCERES, F., "El Apocalipsis cum figuris en la sillería de Santa María de El Parral”, Boletín del Seminario de Arte y Arqueología, t. 66, 2000, pp. 217247.

CORTÉS, S., Y ESTELLA, M., "Los retablos documentados de Fuenlaencina y Auñón, y noticias sobre los de Pozuelo del Rey y Renera", Archivo Español de Arte, n ${ }^{\circ}$ 246, 1989, pp. 131-155.

CRIADO MAINAR, J., "Juan de Varaiz y la pintura de Tarazona en el último cuarto del siglo XVI”, Turiaso, vol. XVIII, 2005-2007, pp. 43-99.

DÁVILA FERNÁNDEZ, M. P., Los sermones y el arte, Valladolid, Universidad de Valladolid, 1980.

DELABORDE, H., Marc Antoine Raimondi: Etude Historique et Critique suivie d'un catalogue raisonné des ouvres du maitre, París, Librairie de l'art, 1888.

DIAGO HERNANDO, M., "Mercaderes italianos en Soria durante el siglo XVI", Celtiberia, $\mathrm{n}^{\circ}$ 107, 2013, pp. 195-242. 
DIAGO HERNANDO, M., "Relaciones comerciales entre Castilla y Aragón en el ámbito fronterizo soriano a fines de la Edad Media", Aragón en la Edad Media, $\mathrm{n}^{\circ}$ 9, 1991, pp. 179-202.

DÍAZ PADRÓN, M., "Una pintura de Pierre Pourbus atribuida a Bernaert de Ryckere en la iglesia de San Martín de Courtrai", Archivo Español de Arte, t. 57, n 226, 1984.

DODGSON, C., Albrecht Dürer, The Medici Society, 1926.

Catalogue of early German and Flemish woodcuts: preserved in the Department of Prints and Drawings in the British Museum, London, British Museum Trustees, 1903.

DUPLESSIS, G., Histoire de la gravure en Italie, en Espagne, en Allemagne,dans le Pays-Bas, en Angleterre et en France, París, Librairie Hachette, 1880.

ECHEVERRÍA GOÑI, P. L., y VÉLEZ CHAURRI, J. J., "Las fuentes gráficas de las pinturas barrocas de los padres de la iglesia de Mendiguren (Álava) y la Cerca (Burgos). Fortuna de una invención de Pieter de Witte”, Brocar, $\mathrm{n}^{\mathrm{o}}$ 38, 2014, pp. 163-178.

EISENSTEIN, E., La revolución de la imprenta en la Edad Moderna europea, Madrid: Akal Ediciones, 1994.

ESTEVE BOTEY, F., Historia del grabado, Madrid, Clan, 1993.

FLECHSIG, E., Schongauer, Strasboug, Heitz, 1944

FRÍAS BALSA, J. V., "Nuevos datos sobre el escultor Juan Picardo, autor de la Magdalena del Trascoro de la Catedral de Osma (Soria)", Celtiberia, n 98, 2004, pp. 267-284.

GAETA, L., Juan de Borgoña e gli altri: relazioni artistiche tra Italia e Spagna nel'400, Galatina, Mario Congedo, 2012.

GALLEGO, A., Historia del grabado en España, Madrid, Cátedra, 1979.

GARCÍA CHICO, E., "Artistas que trabajaron en la catedral de Burgo de Osma (siglo XVI)", Celtiberia, no 11, 1956.

Juan de Juni, Valladolid, Ediciones de la Escuela de Artes y Oficios Artísticos de Valladolid, 1949.

“Los grandes imagineros de Castilla: Juan Picardo", BSAA, t. 23, 1957, pp. 41-53.

GARCÍA CUADRADO, M. D., "San Cristóbal: significado iconológico e iconográfico", Antigüedad y cristianismo. Monografías históricas sobre la Antigüedad tardía, n 17, 2000, pp. 343-366.

GARGAllO SANJOAQUín, M., Breve historia de Tarazona, Tarazona, Centro de Estudios Turiasonense de la Institución Fernando el Católico, 1979.

GARRIGA RIERA, J., "Diestros en el contra açer de la vista...: La perspectiva lineal y los talleres de pintores hispanos en el siglo XVI", en REDONDO CANTERA, María José (coord.), El modelo italiano en las artes plásticas de la Península Ibérica durante el Renacimiento, Universidad de Valladolid, Servicio de Publicaciones, 2004, pp. 131-152. 
"Geometría espacial en la pintura de Pedro Berruguete en Castilla", Actas simposium internacional: Pedro Berruguete y su entorno, Palencia: 24, 25 y 26 de abril de 2003, Diputación de Palencia, 2004,

GIORGI, R., Santos, Barcelona, Electa, 2002.

GONZÁLEZ DE ZÁRATE, J. M., "De la difusión de modelos iconográficos. De Miguel Ángel a Juan de Anchieta", Goya, no 307-308, 2005, pp. 225-228.

"Durero y los hieroglyphica. Tres estampas y una pintura. Némesis (La Gran Fortuna), La justicia, Melancolía I, Cristo ante los doctores", Archivo Español de Arte, t. 79, $\mathrm{n}^{\mathrm{o}} 313,2006$, pp. 7-22.

GONZALO SÁNCHEZ-MOLERO, J. L., "La Biblioteca de Honorato Juan (15071566), Maestro de Príncipes y Obispo de Osma”, Pliegos de Bibliofilia, $\mathrm{n}^{\circ} 9$, primer trimestre 2000, p. 33-54.

GRIFFIN, C., Oficiales de imprenta, herejía e Inquisición en la España del siglo XVI, Madrid: Ollero y Ramos, 2009.

HANSEL, S., "Las Humanae Salutis monumenta de Benito Arias Montano y el problema de una iconografía contrarreformista de la Historia Sagrada" Cuadernos de Arte e iconografía, t. 6, $\mathrm{n}^{\circ}$ 11, 1993, pp. 497-506.

HIND, A. M., Andrea Mantegna and the Italian Pre-Raphaelite Engravers, Londres, Heinemann, 1911.

Early italian engraving, a critical catalogue, Londres, William Cloves and Sons, 1938.

Marcantonio and Italian engravers and etchers of the sixteenth century, New York, Fredk A. Stokes Company, 1912.

HOLLSTEIN, F. W. H., German engravings etchings and woodcuts, c. 1400-1700, Amsterdam, Menno Hertzberger, 1954.

The New Hollstein: Dutch and Flemish etchings, engravings and woodcuts 14501700, Amsterdam, Sound \& Visions Publishers, 2014.

HUIDOBRO, C., Durero grabador, Madrid, Electa, 1999.

"El grabado en la Europa de Erasmo: un arte nuevo", en Erasmo en España. La recepción del humanismo en el primer renacimiento español, 2002, pp. 140-157.

HUIDOBRO, C. y TOMÉ VIRSEDA, C., Grabados flamencos y holandeses del siglo XVI; Madrid, Biblioteca Nacional, 2004.

KOCH, R., The Illustrated Bartsch. 14, Early German masters: Albrecht Altdorfer, monogrammists, New York, Abaris Books, 1978.

LE BLANC, C., Manuel de l'amateur d'estampes 1550- 1820, París, F. Vieweb, 1854.

LEHRS, M., Geschichte und kristicge Katalog des deutschen, niederländischen und französischen Kupferstichs im XV Jaharhundert, vol. 5, Viena, Kraus Reprint, 1969.

LEWIS, M. \& R. E., The Engravings of Giorgio Ghisi, Metropolitan Museum, New York, 1985.

LÓPEZ GUILLAMÓN, I., "Benito Arias Montano y la Biblioteca Escurialense", Revista de Estudios Extremeños, vol. 52, n 3, 1996, pp. 937-968. 
MARÍAS FRANCO, F., El largo siglo XVI. Los usos artísticos del Renacimiento español, Madrid, Taurus, 1989.

"La arquitectura del siglo XVI en la provincia de Soria", Celtiberia, n 50, 1975, pp. 175-206.

MARTÍ Y MONSÓ, J., Estudios histórico-artísticos relativos principalmente a Valladolid, basados en la investigación en diversos archivos, ed. facs., Valladolid, Ámbito, 1992.

MARTíN GONZÁLEZ, J. J., Juan de Juni, Madrid, Instituto Diego de Velázquez del Consejo Superior de Investigaciones científicas, 1954.

"El manierismo en la escultura española", Revista de Ideas Estéticas, n 72, 1960, pp. 11-22.

Juan de Juni. Vida y obra, Madrid, Ministerio de Cultura, 1974.

Juan de Juni. Jean natif de Joigny, H. Cohen, 1983.

"Con Juan de Juni en Joigny", Academia, no 59, 1984, pp. 247-259.

"El Laocoonte y la escultura española”, BSAA, t. 56, 1990, pp. 459-469.

MARTÍN ORTEGA, A., “Testamentos de pintores”, BSAA, nº 32, 1966, p. 433.

MATEO GÓMEZ, I., "Panorama de la pintura europea del Renacimiento. Influencia del grabado alemán en España”, en Grabados alemanes de la Biblioteca Nacional (siglo XV-XVI), t. I, Madrid, Biblioteca Nacional, 1997.

MAYER, A., La pintura española, Barcelona, Labor, 1929.

MEDER, J., Dürer Katalog, Viena, 1932.

MORTE GARCÍA, C., Aragón y la pintura del Renacimiento: (exposición) Zaragoza del 9 de octubre al 30 de noviembre de 1990, Zaragoza: Caja de Ahorros y Monte de Piedad de Zaragoza, Aragón y Rioja, 1990.

Damián Forment, escultor del Renacimiento, Zaragoza, Caja Inmaculada D. L., 2009.

"La colección de pinturas, tapices, dibujos, estampas y esculturas de Miguel Climent Gurrea, protonotario del consejo Supremo de Aragón y otros inventarios del siglo XVI", Boletín del Museo e Instituto Camón Aznar, nº 65, 1996, pp. 131164.

"La obra del pintor Pedro de Aponte o del Ponte en Navarra: los retablos de Santa María la Real de Olite y de San Juan Bautista de Cintruénigo", Príncipe de Viana. Anejo, Anejo no 2, 1986, pp. 565-590.

"La pintura aragonesa del Renacimiento en el contexto hispánico y europeo", en III Coloquio de Arte Aragonés, vol. 2, Teruel, 1985, pp. 277-302.

MOYA VALGAÑON, J. G., en Historia del Arte en la Rioja (coord. ARRÚE UGARTE, B.), t. III, El siglo XVI., Logroño, Fundación Caja Rioja, 2007.

MUÑOZ JIMÉNEZ, Arquitectura del Manierismo en Guadalajara, Guadalajara, Institución Provincial de Cultura "Marqués de Santillana", 1987.

NAGLER, J. K., Die Monogrammister, Munich, G. Hirth, 1858.

NAVARRETE PRIETO, B., La pintura andaluza del siglo XVII y sus fuentes grabadas, Madrid, Fundación de Apoyo a la Historia del Arte Hispánico, 1998.

NAVARRO TALEGÓN, J., Pintura de Toro. Obras restauradas, Toro (Zamora), 1985. 
ORTEGO FRÍAS, T., Ágreda. Bastión de Castilla hacia Aragón, Soria: Publicaciones de la Caja de Ahorros y Préstamos de la provincia, 1980.

ORTIZ VALERO, N., "Una tabla dedicada a Santa Bárbara. Taller del pintor Miguel Jiménez (1462-1505)", Ars \& Renovatio, n 1, 2013, pp. 267-279.

PACHECO, F. El arte de la pintura, Madrid, Cátedra, 1990.

PALLARÉS JIMÉNEZ, M. A., La imprenta de los incunables de Zaragoza en el comercio internacional del libro en el último tercio del siglo XV, Zaragoza, Institución Fernando el Católico, 2008.

PALOMINO, A., El Museo pictórico y escala óptica, Madrid, Aguilar, 1988.

PAULI, G., Hans Sebald Beham; EinKritisches Verzeichniss seiner Kupfertiche Radirungen und Holzschnitte, Strasbourg Heitz, 1901.

PAYO HERNANZ, R., "Bernal Sánchez y la escultura burgalesa de los años centrales del siglo XVI. Entre la tradición siloesco vigarniana y el influjo berruguetesco", en FERNÁNDEZ GRACIA, R. (coord.), PVLCHRVM Scripta varia in honorem $M^{a}$ Concepción García Gainza, Pamplona, 2011, pp. 624-632.

PAYO HERNANZ, R., y ALONSO ABAD, M" . P., "Notas sobre la influencia de Durero en la plástica burgalesa: Francisco Carrillo y el Antiguo Retablo mayor de Villazopeque (Burgos) y Cristóbal Ferrado y las pinturas de la iglesia de la Cartuja de Miraflores", Boletín de la Institución Fernán González, n 242, 2011, pp. 7-21.

PECES RATA, F. Gil., "Obispos de Sigüenza, mecenas de la imprenta seguntina", Memoria Ecclesiae, n 33, 2009, pp. 301-306.

PÉREZ VILLAMIL, P., "El Renacimiento español: Martín de Vandoma y su escuela", Arte Español, t. III, n 3, segundo cuatrimestre, 1916, pp. 193-216.

La Catedral de Sigüenza erigida en el siglo XII: con noticias nuevas para la Historia del Arte en España, sacadas de documentos de su archivo, Madrid, Tipografía Herres, 1899.

PORTELA SANDOVAL, F. J., La escultura del Renacimiento en Palencia, Palencia, Diputación de Palencia, 1977.

"Un grabado de Marcantonio Raimondi y su reflejo en el arte español del siglo XVI", Archivo Español de Arte, t. 55, n 217, 1982, pp. 80-83.

POST, C. R., A History of Spanish Painting, t. XIII, Harvard-Radcliffe Fine Art Series, Milwood: Reprint, 1966.

RAMAIX, I., The Illustrated Bartsch, vol. 71, parte 1, Raphael Sadeler I, Nueva York, Abaris Books, 1999.

REAU, L., Iconografía del arte cristiano, Iconografía de la Biblia. Nuevo Testamento, Barcelona, Ediciones de Serbal, 2000.

ROBERT DUMESNIL, A. P. F., Le Peintre-Graveur Français ou Catalogue raisonné des estampes gravées par les peintres et les dessinateurs de l'ecole français, París, G. Wareé, 1835-1871.

ROSENBERG, A., Sebald and Barthel Beham, zwei Maler der deutscher Renaissance, Leipzig, Verlag von E. A. Seemann, 1875. 
SAÉNZ PASCUAL, R., "La influencia del grabado en la pintura manierista: el ejemplo de las tablas de Añes (Álava)", Revisión del Arte del Renacimiento, en Ondare, Cuadernos de artes plásticas y monumentales, $\mathrm{n}^{\circ}$ 17, 1998, pp. 447-452.

SAINZ MAGAÑA, E., El taller de Herreros. Trazas y estampas rescatadas del olvido, Caja Duero, Soria, 2009.

SÁNCHEZ CANTÓN, F. J., Durero en España, Museo de Pontevedra, LXVII Exposición: "Alberto Durero", 1471-1528, Diputación Provincial de Pontevedra, 1972.

SÁNCHEZ RIVERA, J. A., "La huella y la forma. Influencia del grabado español en el arte español de la Edad Moderna", Grabado y edición: Revista especializada en grabado y ediciones de arte, $\mathrm{n}^{\circ} 26,2010, \mathrm{pp} .16-22$.

"La huella y la forma. Influencia del grabado español en el arte español de la Edad Moderna (II)", Grabado y Edición.: Revista especializada en grabado y ediciones de arte, $\mathrm{n}^{\mathrm{o}}$ 26, 2010, pp. 6-12.

SCHREIBER, W. L., Handbuch der Holz und Metalschnitte des XV Jahrhunderts, 8 vols, Leipzig, Verlag Karl W. Hiersemann, 1926.

SERRANO Y SANZ, M., "Documentos relativos a la pintura en Aragón durante los siglos XIV y XV”, Revista de Archivos, Bibliotecas y Museos, t. XXXI, 1914, pp. 433-458.

SILVA MAROTO, P., "Influencia de los grabados nórdicos en la pintura hispanoflamenca", Archivo Español de Arte, n 243, 1988, pp. 271-289.

"Notas para un mejor conocimiento de la pintura burgalesa de fines del siglo XV y el primer tercio del XVI", La ciudad de Burgos, Burgos, 1984, pp. 883-889.

Pintura hispanoflamenca castellana: Burgos y Palencia, Valladolid, Consejería de Cultura y Bienestar Social, 1990.

SCHOCH, R., Albrecht Dürer, das druckgraphische Werk, Munich, Prestel, 2001.

SOLER I FABREGAT, R., "Libros de arte en bibliotecas de artistas españoles (siglos XVI al XVIII): aproximación y bibliografía", LOCUS AMENUS 1, 1995, pp. 154-158.

STRAUSS, W. L., y WOLFF, M., Illustrated Bartsch, German and Netherlandish Masters of the Fifteenth and Sixteenth Centuries, t. 23, New York, Abaris Books, 1985.

TARIFA CASTILLA, M. J., "El comercio de estampas entre Roma y España a finales del siglo XVI: el caso del mercader italiano Antonio Pisano", Archivo Español de Arte, t. 90, nº 357, 2017, pp. 49-66.

TORRALBA, F., Catedral de Tarazona, Zaragoza: Institución Fernando el Católico, 1974.

VEGA GONZÁLEZ, J., La imprenta en Toledo: Estampas del Renacimiento, 15001550, Ollero y Ramos Editores: Madrid, 2010.

VILLASEÑOR SEBASTIÁN, F., "Préstamos e influencias extranjeras en la miniatura hispanoflamenca castellana: 1450-1500", en XII Jornadas Internacionales de Historia del Arte. El arte foráneo en España. Presencia e influencia, Madrid, 
Departamento de Historia del Arte, Instituto de Historia, CSIC, 2005, pp. 227235.

VV. AA., Angeli. Las Edades del Hombre, Valladolid, Fundación las Edades del Hombre, 2019.

VV. AA., Credo. Las Edades del Hombre, Valladolid, Fundación Edades del Hombre, 2013.

VV. AA., El árbol de la vida. Las Edades del Hombre, Salamanca, Fundación Las Edades del Hombre, 2003.

VV. AA., El contrapunto 2. O., Salamanca, Fundación Las Edades del Hombre, 2019.

VV. AA., El grabado. Historia de un arte, Barcelona, Carroggio, 1981.

VV. AA., El Siglo de Oro de la pintura española, Madrid, Mondadori, 1991.

VV. AA., Juan de Juni y su época, exposición conmemorativa del IV centenario de la muerte de Juan de Juni, Madrid, Ministerio de Educación y Ciencia, 1977,

VV. AA., Kyrios. Las Edades del Hombre, Valbuena de Duero, Fundación de las Edades del Hombre, 2006.

VV. AA., La música en la iglesia de Castilla y León: (música impresa): polifonía y órgano. Las Edades del Hombre, Valladolid, Gráficas Andrés Martín, 1991.

ANGULO, E. et alii, "Las estampas de los Sadeler como transmisoras de modelos iconográficos en la pintura flamenca del siglo XVII", Goya, no 251, 1996, pp. 265-275.

VV. AA., Reconciliare. Las Edades del Hombre, Valladolid, Fundación Edades del Hombre, 2017.

VV. AA., The Illustrated Bartsch, German 15th century: Master E. S., Master FVB, Schongauer, Mair Von Landshut, vol. 8, New York, Abaris Books, 1980.

VV. AA., The Illustrated Bartsch, vol. 12, Hans Baldung Grien, Hans Springinklee, Lucas Van Leyden, Nueva York, Abaris Books, 1981.

VV. AA., Time to hope. Tiempo de la esperanza, Valbuena de Duero, Fundación Las Edades del Hombre, 2002.

WEISE, G., Spanische plastic aus sieben jahrhunderten, Renaissance and fruhbarock in altkastilien, die Renaissanceplastik der schulen von Palencia und Valladolid, Vol. III-2, Reutlingen: Gryphius, 1927.

WETHEY, H. A., "Escaleras del primer Renacimiento español”, Archivo Español de Arte, t. XXXVII, no 148,1964 , pp. 295-306.

ZUCKER, M. J., The Illustrated Bartsch, vol. 25, Early italian masters, OPAL Publishing Corporation, 1980.

\section{BIBLIOGRAFÍA ESPECÍFICA}

AINAUD, J., Miniatura, grabado y encuadernación, col. Ars Hispaniae, t. XVIII, Madrid, Plus Ultra, 1954. 
ALCALDE CRESPO, G., Ágreda: Soria, Ayuntamiento de Ágreda, 2005.

ALCOLEA BLANCH, S., Soria y su provincia, Barcelona, Aries, 1964.

ALONSO ROMERO, J., La concatedral de Soria. Al rumor del Duero, Trobajo del Camino: Edilesa, 2003.

ANTONIO SAÉNZ, T., "Diego de Urbina, pintor de Felipe II", Anales de Historia del Arte, $\mathrm{n}^{\circ} 1,1989$, pp. 141-158.

Pintura española del último tercio del siglo XVI en Madrid. Juan Fernández de Navarrete, Luis de Carvajal y Diego de Urbina, Tesis Doctoral, Madrid, Universidad Complutense de Madrid, 1987.

ARCO GARAY, R., "El pintor cuatrocentrista Pedro de Aponte", Arte Español, no 3, 1914, pp. 106-125.

"Pedro del Ponte o Aponte, pintor del Rey católico", BSAA, t. 9, 1942-1943, pp. 59-77.

ARRANZ ARRANZ, J., El Renacimiento en la diócesis de Osma-Soria, Burgo de Osma (Soria), Obispado de Osma-Soria, 1979.

La escultura romanista en la diócesis de Osma-Soria, Burlada (Navarra), I. G. Castuera, 1986.

"Renacimiento y Barroco", en Historia de Soria, Ingrabel, Almazán (Soria), 1985, pp. 439-442.

ATERIDO FERNÁNDEZ, A. y ZOLLE BETEGÓN, L., "Pintura y Letras: Hernando de Ávila, su biblioteca y su herencia" en Anuario del Departamento de Historia y Teoría del Arte, no 11, 1999, p. 145-168.

ÁVILA PADRÓN, A. "El pintor Juan Soreda. Estudio de su obra”, Goya, no 153, 1979, pp. 136-145.

"Influencia de la estampa en la obra de Juan Soreda", Boletín del Museo e Instituto Camón Aznar, nº 6 y 7, 1981, pp. 81-93.

"Influencia de Rafael en la pintura y escultura españolas del siglo XVI a través de estampas", Archivo español de Arte, t. LVII, n 225, 1984, pp. 58-88.

"Juan Soreda y no Juan Pereda. Nuevas noticias documentales e iconográficas", Archivo Español de Arte, t. LII, no 208, 1979, pp. 405-424.

BARTSCH, A., Le peintre graveur, Vol. 6, Viena, J. V. Degen, 1803.

BONAFÉ VALDUÉRTELES, B., Yanguas, Soria. Guía histórico artística, Sevilla, Grupo CG Inmakor, 2016.

BUFFA, S., The Illustrated Bartsch: Italian Masters of the Sixteenth Century: Barocci, de Santis, Facchetti, Potenzano, Scarsellino, Passari, Riccio, Casolani, Alberti, Nueva York, Abaris Books, t. 34, 1978.

CAMPOS SÁNCHEZ BORDONA, M. D., "Melior Traiano, Felicitor Augusto, Medallas y medallones al servicio de la propaganda e imagen imperial de Carlos V", La impronta humanística (ss. XV-XVIII): saberes, visiones e interpretaciones (coord. A. Castro Santamaría y J. García Nistal), Palermo, Officina di Studi Medievali, 2013, pp. 377-392. 
CAPILLA DE BLAS, J. M., "Velos de pasión, jirones olvidados", Arévacos, no 29, 2007, pp. 2-6.

CARDONA JIMÉNEZ, V., "El retablo de los Santos Emeterio y Celedonio de Ágreda (Soria): estudio iconográfico y estilístico" en Memoria final de Restauración del Retablo de San Emeterio y San Celedonio de la Iglesia de San Miguel Arcángel. Iglesia de San Miguel Árcangel, Ágreda, Soria, Albarium S. L, Abril 2008. URL: URL: https://issuu.com/proyectourdimbre/docs/memoria_final_san_emeterio_i

La pintura gótica en Ágreda (Siglo XV), Valladolid, Junta de Castilla y León, 2006.

CASTRO SANTAMARÍA, A., "La imagen de César en los libros de medallas del siglo XVI. A propósito del medallón del claustro" en La impronta humanística (ss. XVXVIII): saberes, visiones e interpretaciones (coord. A. Castro Santamaría y J. García Nistal), Palermo, Officina di Studi Medievali, 2013, pp. 393-412.

COLLAR DE CÁCERES, F., "Diego de Urbina (1516-95). Pintura y mecenazgo antes de 1570", Anuario del Departamento de Historia y Teoría del Arte, Vol. 22, 2010, pp. 103-136.

"El tríptico de Leoni y otras obras de Gregorio Martínez" en Goya, n 348, 2014, pp. 183-207.

COZAR DEL AMO, J. M., y GARCÍA LÓPEZ, A., "El pintor seguntino Diego de Madrid: Noticias sobre su obra artística en la segunda mitad del siglo XVI", Anales Seguntinos, nº 9, 1993, pp. 219-243

DEL HUERTO, J. y FRÍAS, T., Guía de Almazán. Centro de iniciativas y turismo, Artes Gráficas Egido, Almazán (Soria), 1991.

DÍAZ PADRÓN, M., "Un tryptique inédit de Pierre Pourbus. La Passion du Christ dans la cathédrale de Soria (Espagna)", Revue belge d'archeologie et d'histoire de l'art, $\mathrm{n}^{\mathrm{o}} 77,2008$, pp. 75-89.

ECHEVERRÍA GOÑI, P. L., "Los Ocio y su patronazgo artístico en el siglo XVI. Juan Carranza I y el retablo de la Anunciación de Treviana (La Rioja)", BSAA arte, $\mathrm{n}^{\circ}$ 77, 2011, pp. 69-92.

Policromía del Renacimiento en Navarra, Gobierno navarro, Departamento de Educación y Cultura: Pamplona, 1990.

FERNÁNDEZ DEL HOYO, M. A., El escultor Juan de Juni, en Conocer Valladolid: II curso de patrimonio cultural (coord. DELIBES DE CASTRO, G.,), 2009, pp. 109-120.

FIZ FUERTES, I., "El retablo mural del antiguo convento de San Francisco en San Esteban de Gormaz (Soria). Análisis iconográfico y filiaciones estilísticas", Estudios de Historia del Arte. Homenaje al profesor de la Plaza Santiago (coord. J. M. PARRADO DEL OLMO y F. GUTIERREZ BAÑOS) 2009, pp. 93-96.

GARCÍA VEGA, B., El grabado del libro español (siglos XV-XVI-XVII), Valladolid, Institución Cultural Simancas, t. I, 1984.

GONZÁLEZ BLASCO, P., Notas sobre Valdeavellano de Tera (Soria), Madrid, S M, 1998.

GÓNZALEZ DE ZÁRATE, J. M., Artistas grabadores de la edad del Humanismo, Pamplona, Liber Ediciones, 1999. 
GONZÁLEZ GARCÍA, J. L., "La colección, librería y relicario de D. Francisco Hurtado de Mendoza, Primer Marqués de Almazán (1532-1591)”, Celtiberia, Año 48, no 92, 1998, p. 193-228.

GUDIOL RICART, J., Pintura gótica, col. Ars Hispaniae, vol. 9, Madrid, Plus-Ultra, 1955.

Pintura medieval en Aragón, Institución Fernando el Católico, Zaragoza, 1971.

IBÁÑEZ RODRÍGUEZ, S., "La Diócesis de Calahorra a mediados del siglo XVI según el libro de visita del Licenciado Martín Gil”, Brocar. Cuadernos de investigación, $n^{\circ} 21,1998$, p. 135-184.

JANKE, R. S., "Algunos documentos sobre Pablo Hurus y el comercio de libros a fines del siglo XV”, Príncipe de Viana. Anejo. Año XLVII, Anejo 2, 1986.

LACARRA DUCAY, M. C., "Huella de Martin Schongauer en los primitivos aragoneses", Archivo Español de Arte, t. LII, no 207, 1979, pp. 345-350.

"Influencia de Schongauer en la pintura gótica aragonesa, nuevas reflexiones", Artigrama, $\mathrm{n}^{\mathrm{o}} 32,2017$, pp. 4170.

"Influencia de Martin Schongauer en los primitivos aragoneses", Boletín del Museo e Instituto “Camón Aznar”, no. XVII, 1984, pp. 15-39.

"Tendencia europea en la pintura altoaragonesa de la segunda mitad del siglo XV”, Serrablo, no 100, 1996, pp. 74-75.

LASSO DE LA VEGA Y LÓPEZ DE TEJADA (MARQUÉS DEL SALTILLO), M., Artistas y artífices sorianos de los siglos XVI y XVII: (1509-1699), Madrid, Imprenta y editorial Maestre, 1948.

LOPE DE MORALES “Adiciones y nuevas advertencias para más inteligencia y claridad de estos discursos", en Relación del material del legado de Florentino Zamora depositado en la Biblioteca pública de Soria, inédito.

LOPERRAEZ CORVALÁN, J., Descripción histórica del obispado de Osma, Madrid, Imprenta real, 1788.

MANRIQUE MAYOR, M. A., Las artes en Soria durante el siglo XVII. Estudio documental y artístico, Tesis Doctoral inédita, Universidad de Zaragoza, 1987.

MARCO MARTÍNEZ, J. A., El retablo barroco en el Antiguo Obispado de Sigüenza, Torrejón de Ardoz (Madrid), Diputación Provincial de Guadalajara, 1997.

MARTÍNEZ FRÍAS, J. M., Concatedral de Soria, León, Edilesa, 1992.

"Gabriel de Pinedo, escultor y tracista", Boletín del Seminario de Estudios de Arte y Arqueología, t. XILX, 1983, pp. 331- 343.

MARTÍN GONZÁLEZ, J. J., "Las bibliotecas de artistas: una aplicación de la estadística", Boletín de la Real Academia de Bellas Artes de San Fernando, n 61, 1985, pp. 123-144.

MINGHELlA y ARNEDO DE LAS MERCEDES, T., Historia de la Diócesis de Sigüenza y sus obispos, Madrid, Tipografía de la Revista de Archivos, Bibliotecas y Museos, Vol. II: desde principios del siglo XIV hasta comienzos del siglo XVII, 1912. 
MORTE, C., Aportaciones al estudio de la pintura de Aragón durante el siglo XVI, Tesis Doctoral inédita defendida en la Universidad de Zaragoza, 1981.

"Huella de Durero en un retablo aragonés del siglo XVI", Seminario de Arte Aragonés, $\mathrm{n}^{\circ} 27-28,1978$, pp. 55-63.

"La personalidad artística de Pedro de Aponte a partir del retablo de San Miguel de Ágreda (Soria)" en Actas del Primer Coloquio de Arte Aragonés, Teruel, 1978, pp. 219-234.

"Las artes figurativas del Renacimiento aragonés: revisión historiográfica y nuevas perspectivas", Actes del I, II i III coloquis sobre art i cultura a l'epoca del Renaixement a la Corona d'Aragó, Tortosa, 1996-1999, pp. 33-72.

"Los artistas de Aragón y sus proyectos en el Renacimiento: los proyectos figurativos", en El esplendor del Renacimiento en Aragón, Museo de Bellas Artes de Bilbao y Museo de Zaragoza, 2009, pp. 54-79.

MUNTADA TORRELlAS, A., Cantorales del Monasterio de San Jerónimo de Espeja: Catedral del Burgo de Osma, Catedral del Burgo de Osma, Cabildo S. I., 2003.

NAVAL MAS, A., Pedro del Ponte (Aponte), memoria de Licenciatura leída el 12 de diciembre de 1975 en la Universidad Complutense de Madrid, publicada en el Sitio de Antonio Naval Mas el 4 de noviembre de 2016. URL: http://www.antonionavalmas.net/spip.php?article88.

NÚÑEZ MARQUÉS, V., Guía de la catedral de Burgo de Osma y breve historia del obispado de Osma, Madrid, Gráficas Onofre Alonso Tetuán, 1949.

NUÑEZ MOTILVA, M. M., Proyecto de restauración del retablo de Santa Margarita (O Santa Quiteria) de la iglesia de San Juan Bautista (Ágreda), ALBARIUM, S. L, 2008.

ORICHETA GARCÍA, A., "Grabados alemanes y flamencos: los modelos de Juan de Juni y su escuela en León”, Academia: Boletín de la Real Academia de Bellas Artes de San Fernando, no 83, 1996, pp. 316-358.

PAYO HERNANZ, R. J. y ECHEVERRÍA GOÑI, P. L., “Aportaciones al conocimiento de la escultura castellana en los años centrales del siglo XVI. Juan de Carranza I y el retablo mayor de Soria", Anales de Historia del Arte, vol. 26, 2016, pp. 73-101.

PEDRAZA GRACIA, M. J., "El traspaso de la imprenta de Pablo Hurus: aportación documental para el estudio de la imprenta incunable zaragozana", Boletín del Museo e Instituto Camón Aznar, nº 68, 1997, pp. 131-142.

PEÑA GARCÍA, M., Ágreda: Santa María de los Milagros: libro del peregrino: oracional, arte, historia, Soria: Unión Gráfica, 1979.

Historia y Arte de Ágreda: compendio, Burgos, Montecarmelo, 2004.

Ólvega: historia, arte, folclore, Ólvega: Ayuntamiento, Vol. I, 1982.

PÉREZ DE GRACIA RODRÍGUEZ, M. V. "Noticias sobre los pintores Bartolomé de Ávila y Francisco Leonardo de Chavaçier”, De Arte, n 17, 2018, pp. 43-58.

RAMOS GÓMEZ, F. J., Juan Soreda y la pintura del Renacimiento en Sigüenza, Guadalajara, Diputación Provincial de Guadalajara, 2004. 
"Documentos sobre pintores seguntinos (II). 1535-1575. Pedro de Villanueva, Francisco de Pelegrina, Diego de Madrid, Pedro de Andrade y Juan de Illana", Wad Al-Hayara, 2005, n 31-32, p. 219-240.

SÁNCHEZ DONCEL, G., "La imprenta, en Sigüenza", Anales Seguntinos, Revista de Estudios Seguntinos, vol. I, n I, 1984, pp. 107-120.

STRAUSS, W. L., The Illustrated Bartsch, Sixteenth Century German Artists, vol. 10, Nueva York, Opal Publishing Corporation, 1980

The Illustrated Bartsch. Vol. 31. Italian Masters of the Sixteenth Century [15-4] G. B Ghisi, G.Ghisi, A. Ghisi, D. Ghisi, Monogrammists, Reverdino, Pomedello, L. De Musi, Sannuti, G. De Musi, Cartaro, Lulmus, Nueva York, Abaris Books, 1978.

TARACENA Y AGUIRRE, B. y TUDELA DE LA ORDEN, J., Guía artística de Soria y su provincia, Soria, Diputación Provincial de Soria, 1962.

VELASCO GONZÁLEZ, A., “Aportaciones a los catálogos de pinturas de Miguel Ximénez (doc. 1462-1505) y Martín Bernat (doc. 1450-1505), pintores de Zaragoza", Ars \& Renovatio, no 3, 2015, pp. 192-232.

VICENTE GARCÍA, M., Descripción de la Villa de Montenegro, Madrid, Imprenta de Don Francisco de la Parte, 1818.

VV. AA., Arte e Historia en la Diócesis de Osma, X Curso Universitario de Verano, Burgo de Osma: Ayuntamiento de Burgo de Osma, 1998

VV. AA., Castilla y León: Soria, Editorial Mediterráneo, Madrid, 1994.

VV. AA., El retablo de San Miguel de Ágreda (Soria). Historia y restauración, Valladolid, Caja Salamanca y Soria, 1997.

VV. AA., Inventario artístico de Soria y su provincia, vol. I, Madrid, Ministerio de Cultura, 1989

VV. AA., Las Edades del Hombre. La ciudad de seis pisos, Burgo de Osma, Fundación Las Edades del Hombre, 1997.

VV. AA., Las Edades del Hombre, paisaje interior, Soria, Fundación Las Edades del Hombre, 2009.

VV. AA., Llena de Gracia. Iconografía de la Inmaculada en la Diócesis de OsmaSoria, Editorial Ochoa, El Burgo de Osma (Soria), 2005.

VV. AA., Real Colección de Estampas de San Lorenzo del Escorial, GONZÁLEZ DE ZÁRATE (Ed.), Vitoria-Gasteiz, Instituto Municipal de Estudios Iconográficos Ephialte, 1992-1996.

ZAMORA LUCAS, F., La imprenta en el Burgo de Osma, Madrid, Tipografía de la revista de Archivos, Bibliotecas y Museos, t. XII, nº 2, 1956.

ZERNER, H., The Illustrated Bartsch 32: Italian Masters of the 16th Century: Parmigianino, Master F. P., Meldolla, Schiavone, Titian, Marconi, Tintoretto, Bresciano, Franco, P.Farinati, H.Farinati, del Moro, Fontana, Valentinis, Nueva York, Abaris Books, 1979.

The illustrated Bartsch. 33, Italian artists of the sixteenth century school of Fontainebleau: Rota, Palma, Primaticcio, Davent, Mignon, Heuy, New York, Abaris Books, 1978. 


\section{WEBGRAFÍA}

Biblioteca Nacional. Colecciones Grabados.

URL: http://www.bne.es/es/Colecciones/Grabados/

British Museum

URL: https://www.britishmuseum.org/research.aspx

Metropolitan Museum of Art

URL: https://www.metmuseum.org/art/collection 


\section{ÍNDICE TOPONÍMICO}

Ágreda (Soria): 4, 8, 12, 17, 19, 38, 39, 40-42, 46-48, 58, 61, 65, 66, 76-79, 81-83, 85, 87, 89, 101-103, 105-107, 111, 137-154, 159-168, 180, 191, 238, 245

Iglesia de Nuestra Señora de la Peña: 39, 61, 76, 78, 291

Tablas predela gótica: 4, 39, 61, 76, 77

Retablo de Nuestra Señora del Rosario: 149, 150, 151, 154

Iglesia de Nuestra Señora de los Milagros: 4, 83, 85, 87, 89, 291

Retablo de San Lorenzo: 4, 39, 83-90

Iglesia de San Juan Bautista: 102-112, 112-118

Retablo de Santa Quiteria: 110, 112

Retablo de San Matías y San Francisco: 101-106, 180

Tabla Oración en el Huerto: 107, 108, 109

Iglesia de San Miguel

Retablo de San Miguel: 4, 48, 107, 141-149

Retablo de San Emeterio y San Celedonio: 162, 163

Alemania: 1, 24, 25, 27, 28, 32, 36, 37, 54, 57, 81

Almazán (Soria): 13, 16, 58, 71, 251, 258-262, 290

Iglesia de Santa María de Calatañazor: 71, 258-262

Amberes (Bélgica): 25, 44, 50, 56

Aragón (Soria): 8, 11, 17-89, 31, 36, 38, 54, 60, 61, 63, 65, 73, 77, 137, 291

Aranda de Duero (Burgos): 68, 70, 71, 219

Atienza (Soria): 62, 71

Barcelona: 18, 19, 24, 32, 33, 39, 54, 76,

Berlanga de Duero (Soria): 13, 16, 34, 61, 69, 189, 215

Retablo de la Colegiata de la capilla de los Coria: 61

Bolonia (Italia): 26, 48, 53, 67

Burgos: 8, 14, 16, 29, 33, 39, 62, 69, 71, 92, 102, 183, 200

Calahorra (La Rioja): 1, 8, 14, 91, 173

Calatañazor (Soria): 71, 234, 235, 236

Iglesia de Santa María del Castillo: 233-235

Retablo mayor: 233

Caltojar (Soria): 13, 41, 47, 49, 69, 70, 188, 191-200, 212, 215

Iglesia de San Miguel: 188-199

Retablo mayor: 188-199

Castilla: 4, 10, 12, 14, 16, 17, 18, 27, 33, 54, 55, 62, 63, 65,

Constanza (Suiza): 32

Coscurita (Soria): 71

Dalmacia: 52

El Burgo de Osma (Soria): 4, 6, 8, 10, 11, 16, 18, 19, 21, 22, 33, 34, 50, 51, 61, 63, 64, $65,67,70,73,156,201,214,230$,

Catedral. Museo Diocesano: 10, 71, 200, 214- 217, 265, 293

San Jerónimo: 265, 266

Velo de Pasión: 4, 19, 21, 22, 50, 51, 68, 200-210, 291

Resurrección de Cristo: 232, 233

Flandes: 14, 25, 27, 37, 50, 54, 57, 150

Florencia (Italia): 26, 48, 67

Fontainebleau (Francia): 21, 25, 26, 51

Francia: 25, 26, 51, 57, 147 
Guadalajara: 3, 6, 62, 69, 71

Herreros (Soria): 59

Huesca: 19,65

Italia: 3-8, 15-17, 18-20, 26, 28, 29, 30, 31, 32, 34, 35, 37, 40, 42, 46, 47, 48-51, 54-59, $61,62,64,66-75,91,122,130,131,134,140,143-146,152,163,164,166,169$,

170, 172, 187-189, 191, 200, 205, 220, 209, 225, 230, 237, 259, 264-266, 290, 291

La Espeja (Soria): 21, 73, 75

La Rioja: 8, 15, 20, 21, 70, 290

Las Cuevas de Soria (Soria): 253, 254, 290

Iglesia de San Pedro Apóstol

Tabla de la Anunciación: 253, 254

León: 4, 10, 64, 66, 73, 102, 124, 250,

Convento de San Marcos: 10, 66

Leyden (Holanda): 43

Liceras (Soria): 13, 212-214, 226, 227, 230

Iglesia de Santa Cruz: 225, 227, 220,

Retablo de San Sebastián: 212-214

Retablo mayor: 226-230

Logroño (La Rioja): 11, 14, 15, 33

Londres (Reino Unido): 7, 45

Lovaina (Bélgica): 25

Madrid: 52, 67, 69

Mantua (Italia): 50

Matalebreras (Soria): 16

Medina de Rioseco (Valladolid): 34, 66

Mezquetillas (Soria): 71

Miñosa (Soria): 71

Monteagudo de las Vicarías (Soria): 20, 71, 168, 170, 172, 249, 250

Iglesia de Nuestra Señora de la Muela

Retablo mayor: 71, 249, 250

Retablo de Santiago: 169-172

Montenegro de Cameros (Soria): 39, 62, 91-98, 291, 292,

Retablo de la Virgen del Rosario: 91-98,

Munich (Alemania): 80, 81, 146

Nápoles (Italia): 62, 126,

Navarra: 16, 17, 21, 33, 54, 65, 71, 146, 149, 254

Noviercas (Soria): 41, 177, 179, 180, 291

- $\quad$ Iglesia de los Santos Justo y Pastor: 177, 179, 180

Tabla de la Flagelación: 177, 178

Retablo del Calvario: 179, 180

Nuremberg (Alemania): 24, 25, 42, 43

Olivares de Duero (Valladolid): 63, 64

Ólvega (Soria): 12, 20, 70, 183, 241, 245-247, 290

Iglesia de Santa María la Mayor: 20, 70, 245-247

Retablo mayor: 20, 182, 241, 245-247

Padua (Italia): 49, 156

Países Bajos: 28, 57, 230

Palencia: 11, 16, 33, 34,

Palma de Mallorca (Mallorca): 62

Pamplona (Navarra): 33 
Pareja (Guadalajara): 60, 116, 136

Parma (Italia): 49, 50

Peñalba de San Esteban (Soria): 10

Pinilla del Campo (Soria): 250-252

Iglesia de Nuestra Señora de la Asunción 250-252

Retablo mayor: 250-252

Portugal: 13, 63, 68, 69

Pozalmuro (Soria): 20, 70, 240-245, 290

Iglesia de Santa María la Mayor: 20, 70, 241-246

Retablo mayor: 241-246

Roma (Italia): 11-14, 19, 20, 26, 27, 44, 48, 49, 50, 53

Salamanca: 4, 34

San Esteban de Gormaz (Soria): 41, 46, 156, 157, 159, 292

- Iglesia de San Francisco: 156-159

Retablo mural de San Francisco: 155-158

San Lorenzo de El Escorial (Madrid): 2, 6, 11, 26, 56, 57, 59, 68, 72, 218

Santa María de Huerta (Soria): 3, 64, 131, 133-136,

Monasterio cisterciense

Tablas de Juan de Soreda: 64, 132-135, 141

Santander (Cantabria): 70

Sevilla: $13,23,31,54$,

Segovia: 8, 31, 69, 200,

Sigüenza (Guadalajara): 1, 3, 8, 13, 14, 17, 21, 33, 62, 63, 69-71, 125, 188, 214, 256

Solanillos (Guadalajara): 71

Soria: 1, 3, 6, 8, 14, 17, 18, 33, 34, 37, 41, 42, 49, 54, 55, 60, 70, 71, 112, 162, 181, 186, 253, 254, 291,

Concatedral de San Pedro: 3, 11, 64, 124, 125, 129, 132, 267, 268, 291

Tablas de Juan Soreda: 124-131

Tríptico del Calvario: 267, 268

Iglesia de San Juan de Rabanera: 16, 69, 218 219-224, 237, 238

Retablo de San Esteban: 68, 218-225, 291

Retablo de San Juan Evangelista: 239, 240

Iglesia de Santa María la Mayor: 5, 16, 19, 69, 182-188, 291

Retablo mayor: 19, 69, 181-187

Tarazona (Zaragoza ): 1, 8, 12, 16, 17, 137, 240, 245

Toledo: 13, 25, 33, 63

Valdeavellano de Tera (Soria): 41, 112-122, 290-292

Tablas de la sacristía: $112-114$

Retablo mayor: 114-122

Valencia: $31-33,54,63,66,301$

Valladolid: 2, 5, 8, 17, 12, 33, 35, 54, 62, 63,

Vaticano: (Italia): 72

Venecia (Italia): 25, 26, 44-48, 51

Verona (Italia): 49

Yanguas (Soria): 8, 14, 15, 41, 172-176

- Iglesia parroquial de Santa María: 14, 173-177,

Retablo de la Flagelación: 173-177,

Yelo (Soria): 71

Zara (Dalmacia): 51

Zaragoza: 17, 29, 31, 32, 34, 54, 60, 65, 73, 77 


\section{ÍNDICE ONOMÁSTICO}

Alberti, Cherubino: 52, 64, 223, 224

Alberti, León Bautista: 11

Altdorfer, Albrecht: 37, 41, 43, 165, 167, 265

Arias Montano, Benito: 2, 26, 57

Ávila, Bartolomé de: 56, 70, 250-253, 291

Aponte, Pedro de: 4, 12, 13, 18, 36, 58, 65, 71, 113, 114, 142-149, 153, 154, 155

Bandinelli, Baccio: 5, 49, 67,

Becerra, Gaspar: 68, 200, 250

Berruguete, Alonso: 63, 200, 211, 256

Bonasone, Giulio: 52, 53, 70, 220, 230, 231, 242, 243, 292

Borgoña, Juan de: 18, 63, 66,

Bermejo, Bartolomé: 60

Bernat, Martín: 60, 77

Botticelli, Sandro: 45

Brescia, Giovanni Antonio da: 46, 50, 193, 194, 199, 231

Calderón, Constanza: 181

Calderón, Familia: 181, 183

Caraglio, Jacopo: 53, 54, 66, 74, 260

Carranza (el Viejo), Juan de: 5, 20, 69, 181-187

Carvajal, Bernardino: 13, 14, 64,

Castillo, Luis del: 56, 63

Cerro, Pedro del: 20, 50, 70, 240-247

Cock, Hyeronimus: 26, 44, 50,

Correggio, Antonio Allegri: 44, 51

Cort, Cornelis: 3, 25, 44, 53, 224, 223, 254, 253, 261, 262

Cranach, Lucas: 25, 26, 42, 65, 66,

Dado, Maestro del: 49, 54, 127, 128

Da Vinci, Leonardo: 44, 64, 64, 135, 165, 210

Dente, Marco: 18, 48, 49, 64, 66, 67, 291

Durero, Alberto: 3, 11, 18, 19, 23, 24, 25, 28, 32, 36, 37, 40-47, 58, 59, 60, 64, 65, 66, $102,103,107,110-113,117,119,122,123,132,133,140,141,143-145,148$, 
157, 166-168, 174, 175, 178, 180, 186, 187, 189, 191, 192, 213-216, 226, 227, 243, 244, 267, 268, 290-292

E. S., Maestro: 25, 37, 93, 121, 227

Enríquez, Alonso: 63

Forment, Damián: 65, 66, 141

Galle, Philippe: 26, 57

Ghisi, Giorgio: 51, 68, 208, 209, 292

González Manso, Pedro: 63

Guldenmundt, Hans: 123, 125

Herrera, Juan de: 58

Hurus, Pablo: 12, 29, 32, 34, 37, 39, 42, 54, 65, 70, 73 ,74, 76

Jiménez, Miguel: 17, 35, 60, 61, 76-82

Juni, Juan de: 5, 8, 10, 11, 19, 66, 67, 137, 232, 233, 253, 291

Lafreri, Antonio: 27, 50, 53

Leonardo, Francisco: 56, 241

Leyden, Lucas de: 43, 47, 58, 59, 64, 134, 135, 243, 244

Lippi, Filippo: 45

Loaysa y Mendoza: García de: 63

Madrid, Diego de: 4, 46, 69, 70, 188-196

Mantegna, Andrea: 26, 45-47, 65, 158, 159

Mazzuola, Francesco: 50

Meldolla, Andrea: 51

Miguel Ángel: 19, 20, 21, 44, 48, 50, 52, 53, 63, 67, 68, 139, 145, 152, 153, 219, 220, 230,255

Orihuela, Juan de: 71, 256, 258

Osma, Maestro de: 17, 70, 71, 73, 89, 91, 117, 166

Parmigianino (Francesco Maria Mazzola): 19, 20, 51, 52, 53, 68, 192, 193, 204-207, 212, 292

Perret, Pierre: 59

Piombo, Sebastiano del: 51, 52, 202

Plantino, Cristóbal: 26, 57

Pinedo, Gabriel: 16, 20, 56, 70, 248-251, 257, 291

Pontormo, Jacopo: 53

Pourbus “el Viejo”, Pieter: 267, 268, 295, 303 
Portugal, Fadrique de: 13, 63, 64

Rafael: 3, 17, 19, 20, 23, 26, 31, 36, 44, 46-50, 52, 53, 60, 63, 67, 126, 136, 178, 199, 200, 203, 208, 209, 222, 255, 291

Raimondi, Marcantonio: 18-20, 23, 26, 36, 42, 43, 47-49, 50, 52, 58, 59, 63, 65, 66-68, $70,115,125,139,142,144,145,153,170,172,178,184,194,196-198,221,222$, $266,268,291,292$

Rosselli, Francesco: 45, 63, 66, 126, 137, 136, 293

Rosex da Modena, Nicoletto: 66

Rustici, Giovanni Francesco: 66

Salazar, Esteban: 56, 71

Sanz, Juan: 71, 256-261, 291

Schongauer, Martin: 17, 18, 21, 23, 25, 30, 32, 33, 36-38, 43, 59, 61, 62, 65, 66, 77, 79. $80-82,84,85,89,90,93-95,99,100,104,105,118,145,160,161,175,176,238$, 239, 290, 292

Schaufelein, Hans: 42, 66, 174-176

Sedano, Alonso: 17, 18, 62, 90-95, 97, 99

Sarto, Andrea del: 67

Scultori, Adamo: 50, 53

Scultori, Giovanni Battista: 50, 53

Sinobas, Maestro de: 61

Soreda, Juan: 3, 4, 13, 14, 18, 48, 49, 56, 59, 62-64, 69, 117, 124-126, 128, 131-136, $155-158,161,189,191,194,200,213,212,219,226,228$

Urbina, Diego de: 4, 19, 47, 51, 53, 63, 67-68, 200-210, 218-219, 230.

Vandoma, Martín de: 20, 69, 188, 198, 214

Veneziano, Agostino: 48, 49, 63, 115, 127, 128, 154, 178, 195, 199, 200, 203, 247

Wolgemut, Michael: 23, 25,

Yáñez de la Almedina, Fernando: 63 